GUILHERME RECENA COSTA

\title{
Superior Tribunal de Justiça e recurso especial: análise da função e reconstrução dogmática
}

Dissertação de mestrado apresentada à Faculdade de Direito da Universidade de São Paulo para obtenção do título de Mestre em Direito.

Área de concentração: Direito Processual

Orientador: Prof. Doutor Paulo Henrique dos Santos Lucon

SÃO PAULO 
BANCA EXAMINADORA: 
Aos meus

próprios precedentes:

meu pai e meu avô RECENA

(este, in memoriam)

acima de tudo, pelo exemplo. 
"[L]aw is inherently respectful of persons as agents; it respects the dignity of voluntary action and rational self-control",

(JEREMY WALDRON)

"[T] he quest for a conformity to rules, for a recognizable pattern of action, for an 'ordo voluntatis', is nothing else than a quest for harmony and beauty"

(AleXANDER PEKElis) 


\section{RESUMO}

RECENA COSTA, Guilherme. Superior Tribunal de Justiça e recurso especial: análise da função e reconstrução dogmática. Dissertação (Mestrado em Direito) - Faculdade de Direito da Universidade de São Paulo, São Paulo, 2011.

O tema dos recursos excepcionais, direcionados às Cortes Supremas, é de enorme importância no processo civil contemporâneo. Esse trabalho busca definir, à luz da Teoria do Direito e do Direito Comparado, quais funções devem ser assinaladas ao Superior Tribunal de Justiça para, a partir disso, poder realizar uma reconstrução dogmática do procedimento do recurso especial. Não há dúvida de que, à luz dos princípios do Estado de Direito, aos Tribunais Superiores deve ser hoje asinalada uma função precipuamente prospectiva, voltada para a orientação dos juízes e jurisdicionados por meio do estabelecimento de precedentes, e não para os litigantes, de forma retrospectiva. A experiência comparada e a análise detida do funcionamento dos Tribunais Superiores demonstra que bons resultados só podem ser cumpridos mediante mecanismos que permitam selecionar os recursos com base na sua importância. Defende-se, por isso, a criação de um filtro para o recurso especial, à semelhança do que já conhece o recurso extraordinário brasileiro por meio da exigência de repercussão geral da questão constitucional debatida. Em face da função prospectiva do Superior Tribunal de Justiça devem ser interpretados todos os demais problemas que gravitam em torno do recurso especial e do acesso à Corte (distinção entre fato e direito, pré-questionamento etc.). 


\begin{abstract}
Appeals to Supreme Courts are an enormously important theme in modern civil procedure. This essay intends to define the function that should govern the practise of Brazil's "Superior Tribunal de Justiça", with support from legal theory and comparative law studies, so that the characteristics of the appeal ("recurso especial") directed to the Court may be rethought on solid grounds. There should be no doubt that, in light of the rule of law principles, Supreme Courts should be assigned a prospective, facing forward function of establishing solid precedents for the guidance of judges and citizens, instead of facing towards the single parties involved in litigation and the past. Comparative studies show that this may only be done if the Court has control over its docket. The essay proposes the adoption of such a mechanism for the "recurso especial", as has already been done for the "recurso extraordinário" through the requirement of general importance of the constitutional issue raised in the appeal. All other aspects regarding access of the parties to the "Superior Tribunal de Justiça" (such as the distinction between law and fact, the prior decision of the legal issue raised etc.) should be interpreted in light of the prospective function of the Court.
\end{abstract}




\section{AGRADECIMENTOS}

Muitas pessoas contribuíram, cada uma de sua forma, para que tivesse condições de realizar esse trabalho, desde o ingresso no mestrado até o dia da entrega da dissertação. Dito isso, devo agradecer:

- às duas SÔNIAS, minha MÃE e minha Vó, pelo carinho, pelo afeto e pelo cuidado materno de sempre;

- ao meu PAI, a quem a dissertação foi dedicada;

- à VANESSA, com amor e pelo amor;

- ao meu orientador, a quem muito devo, Prof. Paulo Henrique dos SAntos LUCON, pelos ensinamentos, pela liderança e pela amizade;

- aos Professores Carlos Alberto Alvaro de Oliveira e José Rogério Cruz e TUCCI, que me apoiaram desde que decidi candidatar-me ao mestrado na Universidade de São Paulo;

- aos amigos André Gustavo Orthmann, Daniel Mitidiero, Eduardo José DA Fonseca Costa e Renato Resende Beneduzi, pelo diálogo e, ainda, pela leitura e cuidadosa revisão do trabalho;

- aos amigos Atair Trindade (e à sua família), Bernardo Becker, CAmilo Couto, Daniel Báril, Dorival Pavan, Elias Razuk, Francisco Ostermann, José Maciel, Luis Felipe Spinelli, Mateus Maciel, Renato Pavan, Stheven Razuk e TOMÁs RosSETTO, que estiveram particularmente presentes ao longo desses últimos três anos;

- aos Professores Flávio LuIZ YARShell e ORESTE LASPRO, pelas sugestões na banca de qualificação. 


\section{SUMÁRIO}

§ 1 - CONSIDERAÇÕES INTRODUTÓRIAS.

1.1. O BINÔMIO "SUPERIOR TRIBUNAL DE JUSTIÇA - RECURSO ESPECIAL" (OU O TEMA, A SUA JUSTIFICATIVA E O MÉTODO)

1.2. NOÇÕES PREMILINARES: O RECURSO ESPECIAL NO QUADRO DOS MEIOS DE IMPUGNAÇÃO ÀS DECISÕES JUDICIAIS

1.2.1. Sobre a classificação dos recursos..........................................................................................5

1.2.2. Recursos excepcionais: função e estrutura

§ 2 - APROXIMAÇÃO HISTÓRICA AO SUPERIOR TRIBUNAL DE JUSTIÇA E AO RECURSO

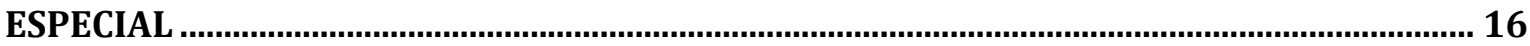

2.1. EVOLUÇÃO DO RECURSO EXTRAORDINÁRIO NO DIREITO BRASILEIRO. ..............................................16

2.1.1. Origens e criação do recurso pela Constituição de 1891....................................................16

2.1.2. Reforma de 1926 .....................................................................................................................18

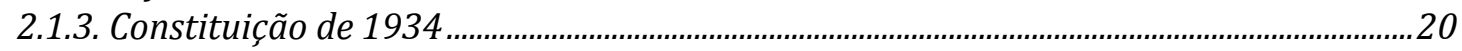

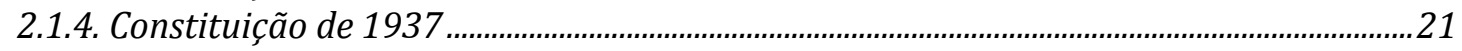

2.1.5. Constituição de 1946 .......................................................................................................21

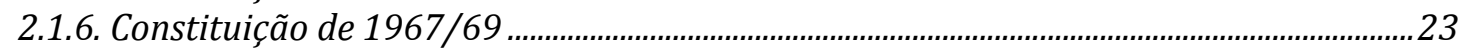

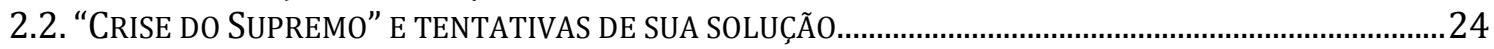

2.3. A CONSTITUIÇÃO DE 1988, o SUPERIOR TRIBUNAL DE JUSTIÇA E O RECURSO ESPECIAL....................26

§ 3 - INVESTIGAÇÃO DE DIREITO COMPARADO...................................................................... 32

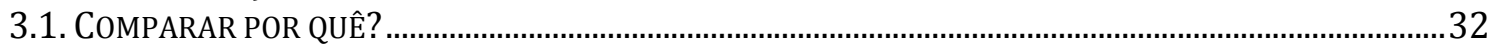

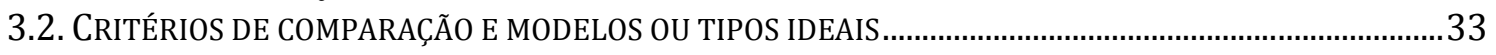

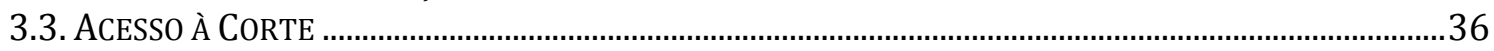

3.3.1. Possibilidade de seleção dos recursos....................................................................................36

3.3.2. Outros fatores que condicionam a admissibilidade dos recursos ou influem sobre o

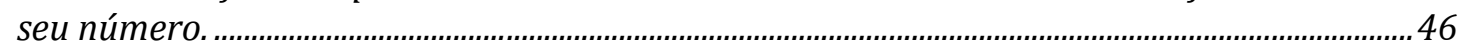

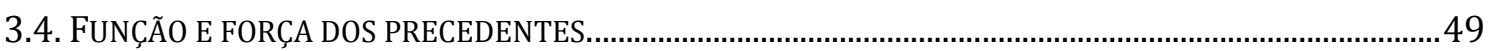

3.5. ÂMBITO DE ATUAÇ̃̃O E COGNIÇÃO DO TRIBUNAL ...............................................................................5

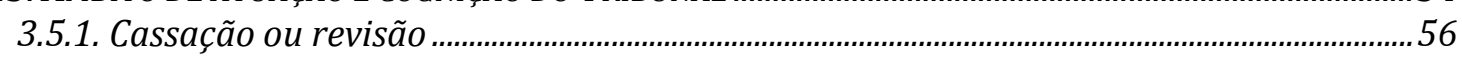

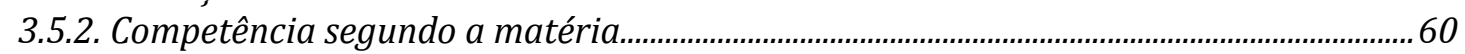

3.6. VALORAÇõES À LUZ DA PESQUISA REALIZADA......................................................................................61

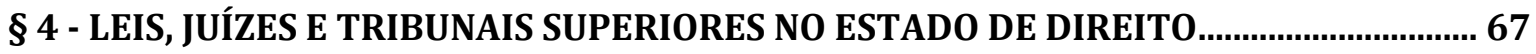

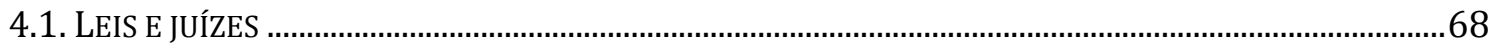

4.1.1. Texto e norma

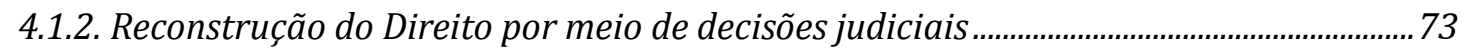

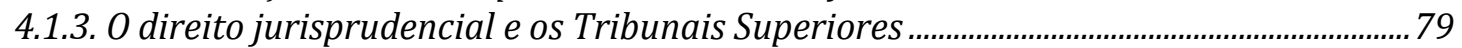

4.2. DIMENSÕES DO PRINCÍPIO DO ESTADO DE DIREITO..........................................................................

4.2.1. Igualdade perante a lei e uniformidade na aplicação do Direito........................................83

4.2.2. Segurança jurídica: estabilidade e previsibilidade da jurisprudência ................................86

4.2.3. Devido processo legal.............................................................................................................94

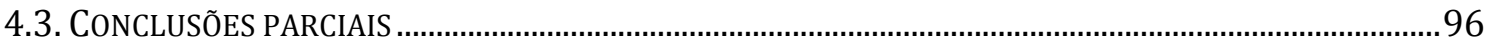

$\S 5$-COMPREENSÃO DA FUNÇÃO A SER DESEMPENHADA PELO SUPERIOR TRIBUNAL DE

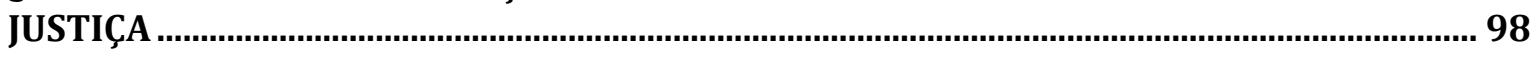

5.1. NOÇÕES INTRODUTÓRIAS............................................................................................................98

5.2. EVOLUÇÃO HISTÓRICA DOS TRIBUNAIS SUPERIORES E SENTIDO ATUAL DE NOMOFILAQUIA...............99

5.3. A PREVALÊNCIA DOS FINS (PÚBLICO OU PRIVADO) E A ATUAÇÃO DOS TRIBUNAIS SUPERIORES..... 107

5.3.1. Apresentação da tese em defesa da função subjetiva (ius litigatoris) ............................ 108

5.3.2. Defesa da prevalência da função objetiva (ius constitutionis)......................................... 110

5.3.2.1. A falácia da equivalência dos fins............................................................................... 110 
5.3.2.2. Promoção da igualdade e da segurança jurídica por meio dos precedentes............111 5.3.2.3. O paradoxo: a irracionalidade da defesa do "ius litigatoris" do ponto de vista dos litigantes

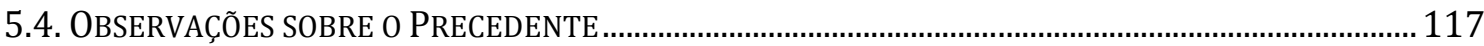

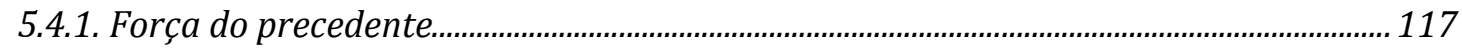

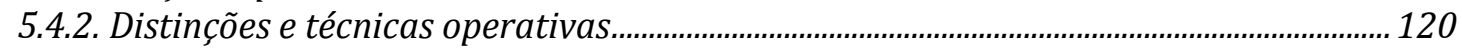

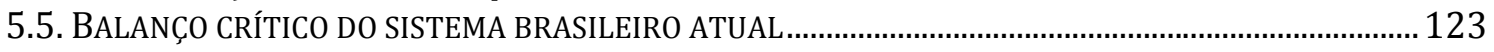

5.5.1. A falta de um mecanismo de seleção dos recursos e a "jurisprudência defensiva" ... 124

5.5.2. Avaliação crítica da Súmula da jurisprudência predominante......................................... 127

5.5.3. Julgamento de recursos especiais repetitivos ...................................................................... 129

5.5.4. Insegurança jurídica na jurisprudência do Superior Tribunal de Justiça ..................... 131

5.6. CONCLUSÕES FINAIS E SUGESTÕES DE REFORMA ………............................................................. 132

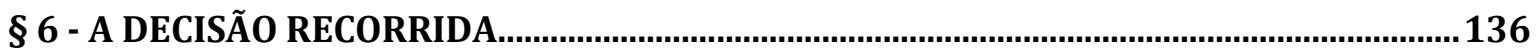

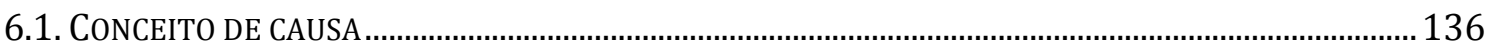

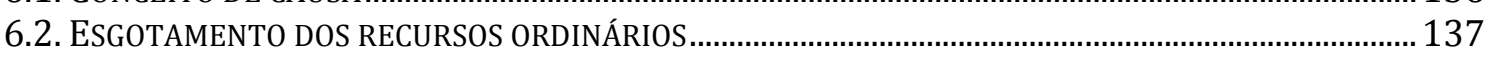

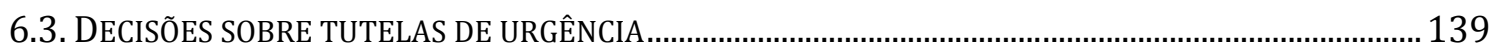

6.4. O PRÉ-QUESTIONAMENTO DA QUESTÃO FEDERAL.......................................................................... 141

6.4.1. Fundamento da exigência de pré-questionamento............................................................ 141

6.4.2. Definição: decisão da questão pelo Tribunal ................................................................... 143

6.4.3. Pré-questionamento "explícito" e "implícito"......................................................................... 146

6.4.4. Questão surgida e decidida no acórdão recorrido............................................................. 149

6.4.5. Segue: vício de procedimento concomitante ao acórdão recorrido................................. 151

6.4.6. Omissão judicial e embargos declaratórios........................................................................... 153

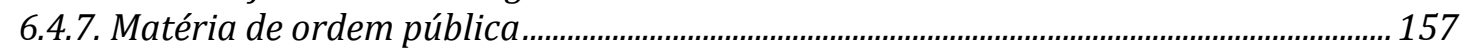

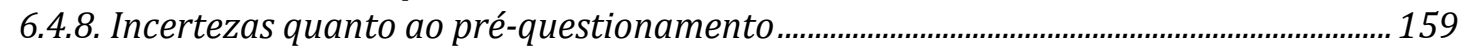

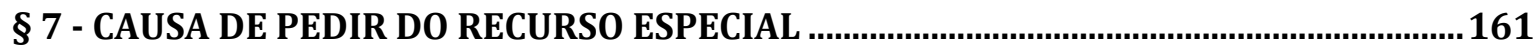

7.1. CAUSA DE PEDIR E PEDIDO (OU O OBJETO) DO RECURSO ESPECIAL ................................................... 161

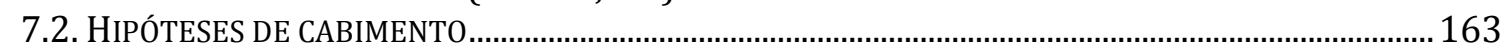

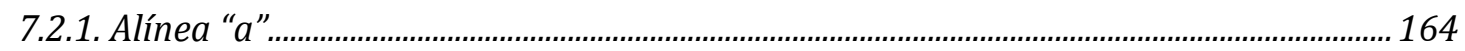

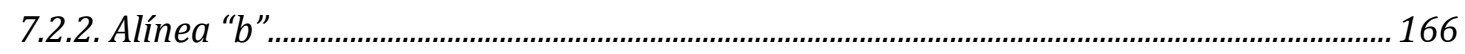

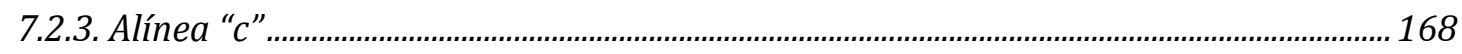

7.2.3.1. Cotejo analítico e "distinguishing" .............................................................................. 170

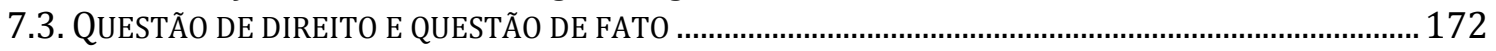

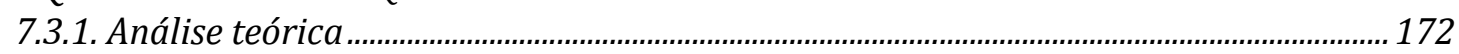

7.3.1.1. Uma distinção conceitual artificial............................................................................... 172

7.3.1.2. O sentido teleológico ou funcional da distinção.............................................................. 178

7.3.1.3. As chamadas "questões mistas" (mixed questions of law and fact): apreciação

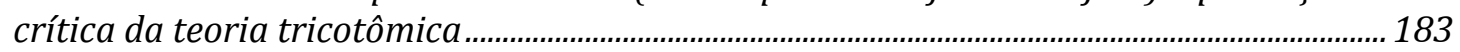

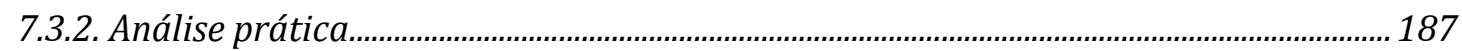

7.3.2.1. Simples reexame de prova (enunciado n. ${ }^{\circ} 7$ da Súmula/STJ) ...................................... 187

7.3.2.2. Qualificação jurídica de fatos, atos e negócios jurídicos................................................. 189

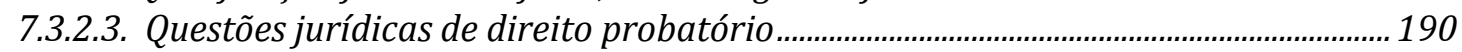

7.3.2.3.1. Segue: juízo de admissibilidade da prova........................................................................ 192

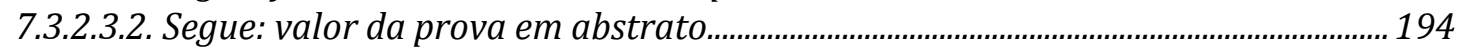

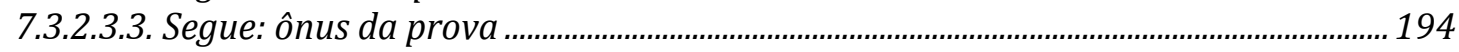

7.3.2.3.4. Segue: "standards" de convencimento judicial ............................................................ 196

7.3.2.3.5. Segue: presunções e máximas de experiência.................................................................. 197

7.3.2.3.6. Segue: controle sobre a motivação................................................................................ 200

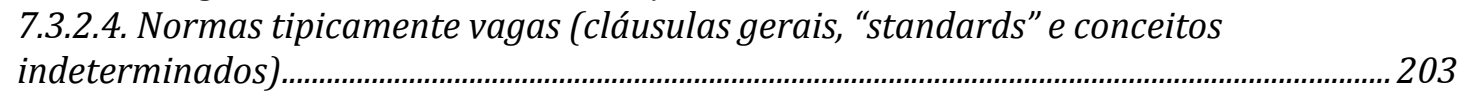

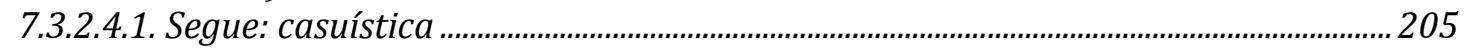

7.3.2.5. Interpretação de cláusulas de negócios jurídicos............................................................206

7.3.2.6. Padronização de valores (danos morais e honorários de advogado).......................... 208 
7.3.2.7. Acertamento das circunstâncias fáticas relativas a vício de procedimento cometido

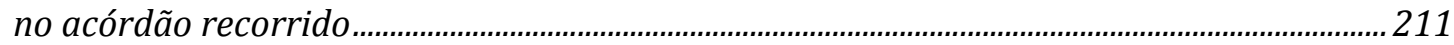

7.3.3. Conclusões parciais ............................................................................................................... 212

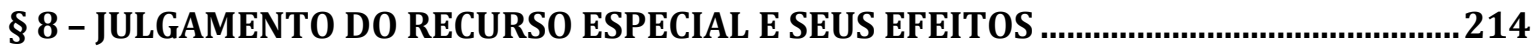

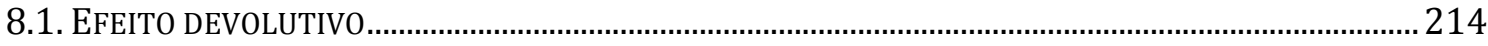

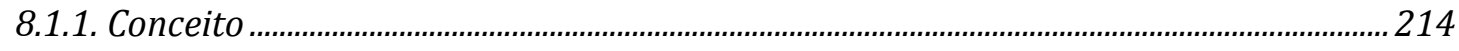

8.1.2. Princípio dispositivo e limitação do objeto do recurso especial à questão federal

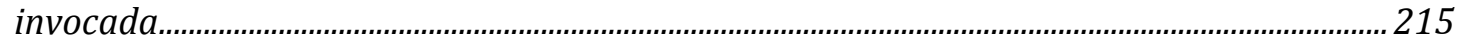

8.1.3. Tese contrária: efeito devolutivo amplo..........................................................................217

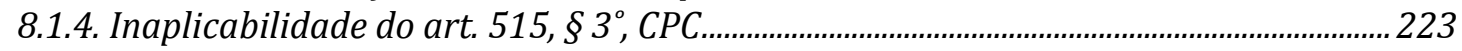

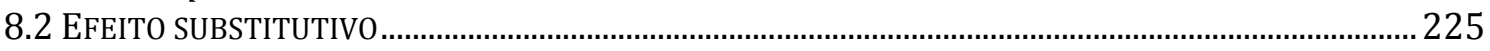

§ 9 - COORDENAÇÃO DO RECURSO ESPECIAL COM O RECURSO EXTRAORDINÁRIO ....229

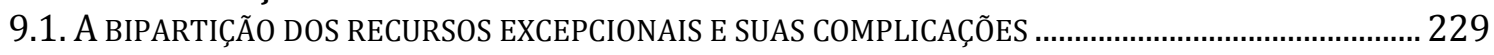

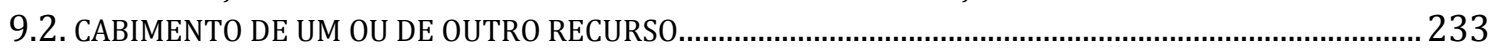

9.3. INTERPOSIÇÃO CONJUNTA DOS RECURSOS ESPECIAL E EXTRAORDINÁRIO .......................................... 235

9.4. LIMITES DO CONTROLE DE CONSTITUCIONALIDADE REALIZADO PELO SUPERIOR TRIBUNAL DE

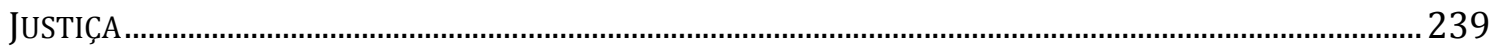

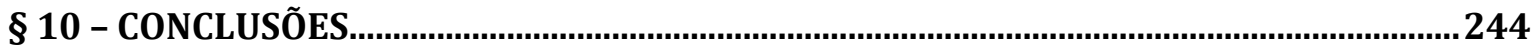

BIBLIOGRAFIA 


\section{$\S 1$ - CONSIDERAÇÕES INTRODUTÓRIAS}

\subsection{O BINÔMIO "SUPERIOR TRIBUNAL DE JUSTIÇA - RECURSO ESPECIAL" (OU O TEMA, A SUA JUSTIFICATIVA E O MÉTODO)}

Recurso especial e Superior Tribunal de Justiça. Eis aí um binômio interessante, cujo estudo se desdobra necessariamente em torno de dois temas centrais e complementares entre si: o do Superior Tribunal de Justiça, enquanto órgão do Poder Judiciário a que é acometida uma função específica, e o do recurso especial, enquanto meio de impugnação de decisões judiciais pelo qual se suscita a atuação daquela Corte. ${ }^{1} \mathrm{O}$ primeiro diz respeito a aspectos político-constitucionais relacionados à função típica do Tribunal na estrutura do poder estatal e na concretização e desenvolvimento do Direito; o segundo, a aspectos dogmático-processuais ligados à admissibilidade, à estrutura e ao arranjo procedimental do recurso. Recurso especial e Superior Tribunal de Justiça são, portanto, dois termos que guardam uma relação de complementaridade recíproca. ${ }^{2}$

Mas que enfoque deve ser dado a esse binômio? J. A. JoLOWICZ, embora escrevendo à luz das reformas do processo civil inglês (Woolf reforms), fez uma advertência plenamente aplicável à ciência processual e ao legislador brasileiros. Disse ele, basicamente, que a doutrina, nos últimos anos, concentrou muitos esforços no estudo das "engrenagens" do procedimento e nos problemas crônicos de sua demora e de seus altos custos, sem, entretanto, dar devida atenção às funções que devem ser perseguidas pelo nosso sistema de administração de justiça, como algo maior e por vezes distinto da mera eficiência na solução individual de conflitos. Há algo de errado, por isso, no próprio ponto de partida de muitas das discussões: em tempos de mudança (suave ou brusca), é intuitivo que as perguntas "o quê" e "por quê" precisam ser colocadas em vários níveis e com

\footnotetext{
${ }^{1}$ Embora tenha o Superior Tribunal de Justiça outras competências que não a de conhecer e julgar o recurso especial - i.e., competências originária e recursal ordinária (incisos I e II, respectivamente, do art. 105, CF) -, é esta a sua missão específica e a sua razão de ser ou o seu ethos dentro do sistema de administração da Justiça, razão pela qual a associação entre o recurso e o Tribunal é plenamente válida.

${ }^{2}$ De modo semelhante, a doutrina italiana destaca a recíproca influência da Corte e do recurso de cassação. Ver, nesse sentido, CALAMANDREI, La casación civil, tomo I, n. 2, p. 26 e também tomo II, n. 275, p. 368; CAlamandrei - Furno, "Cassazione civile", n. 1, p. 1054-1055; A. Pizzorusso, "Corte di Cassazione", n. 1.3, p. 2-3. Na doutrina espanhola, conferir JUAN MONTERO AROCA - JOSÉ Flors MATÍES, El recurso de casación civil, cap. 3, p. 260. Contra essa orientação, sem oferecer justificativa convincente, FERDINANDO MAZZARELLA, Analisi del giudizio civile di cassazione, p. 18-19, nota 8.
} 
referência a diversos institutos. Devemos buscar respostas não apenas para "como?" (e seus correlatos “quem?” e “onde?”), mas, em primeiro lugar, para “o quê?” e "por quê?” perguntas que precedem "como?", mas que comumente não são sequer colocadas. ${ }^{3}$

$\mathrm{O}$ alerta parece ser especialmente relevante em relação à competência recursal excepcional do Superior Tribunal de Justiça; no Brasil, tal como em outros lugares, há uma inegável ambigüidade impregnada tanto à atuação errática da Corte quanto aos discursos teóricos em torno dela desenvolvidos. ${ }^{4}$ Tendo isso em mente, aquela postura metodológica - que se poderia dizer funcional ou analítico-funcional - permeia, do início ao fim, o presente trabalho. Com efeito, é preciso preliminarmente identificar e bem compreender o papel a que é convocado o Superior Tribunal de Justiça - enquanto instituição na ordem constitucional brasileira -, para que se possa, somente então, reconstruir dogmaticamente o recurso por meio do qual a sua missão deve desempenhar-se.

Essa perspectiva - parece-me inegável - deve orientar tanto a interpretação do iure condito quanto, com maior razão, as propostas de iure condendo a respeito da matéria. ${ }^{5}$ Ao seu desenvolvimento devem concorrer diversos tipos de investigação. No trato aqui conferido ao problema, sobressaem, como campos do conhecimento jurídico que devem lançar luzes sobre a dogmática processual, sobretudo o Direito Comparado e a Teoria do Direito. Ultrapassada a fase de conquista de sua autonomia, cabe ao processo civil contemporâneo recuperar-se do isolamento por ele imposto a si mesmo.

À luz dessas considerações, a escolha do tema pode ser justificada por diversas razões. Uma delas é intuitiva em face do que já se disse e refere-se à ausência de formulação das perguntas "por quê?" e "o quê". Freqüentemente, passa-se a descrever diretamente "como" funciona o Superior Tribunal de Justiça. É inegável ter sabor de lugarcomum a afirmação de que a missão imediata dos recursos excepcionais é a defesa do direito objetivo, voltando-se tais impugnações apenas secundariamente para a tutela do interesse subjetivo dos litigantes. A associação é prontamente feita com o conceito de nomofilaquia, mais uma daquelas definições processuais apropriadas para todo o sempre pelo gênio incomparável de PIERo CALAMANDREI. Mas o termo, como tantos outros, é

\footnotetext{
${ }^{3}$ J. A. Jolowicz, On civil procedure, no prefácio, p. ix-x, e também na introdução, p. 1-8.

${ }^{4}$ É o tema central da conhecida coletânea de ensaios de MicheLE TARUFFo intitulada Il vertice ambiguo (trad. espanhola - El vértice ambiguo).

${ }^{5}$ Perspectiva metodológica exigida também pela doutrina italiana, à luz da Corte di Cassazione, $c f$. G. TARZIA, "Le impugnazoni civili tra disfunzioni e riforme", n. 5, p. 475-476.
} 
ambíguo. Por isso, é preciso parar e refletir sobre os diferentes sentidos atribuídos à função nomofilática, nem sempre coincidentes nos seus fins e, portanto, no modo por meio do qual é defendida a sua realização. Por vezes, diferentes setores da doutrina propõem formas completamente opostas de realizar aquela mesma missão. A conseqüência verificada, no mais das ocasiões, é um descompasso entre os fundamentos teóricos proclamados e as soluções práticas adotadas, com abalo da segurança jurídica e da previsibilidade do Direito. É certamente aplicável a nós a noção corrente na doutrina italiana de que o fundamento histórico e doutrinário da Corte de Cassação e o seu desenvolvimento concreto, à luz da práxis do órgão e da sua disciplina positiva, não coincidem, dando lugar a uma verdadeira "crise de identidade". ${ }^{6}$ Nesse quadro, este estudo está convicto de que é preciso resgatar (rectius: construir) o sentido prospectivo da jurisdição dos Tribunais de superposição e a força normativa dos seus precedentes. É essa a premissa teórica que se pretende aqui desenvolver para, a partir dela, reconstruir a dogmática do recurso especial.

Dito isso, o trato do tema parece ser relevante, talvez até mesmo necessário, ou, ao menos, oportuno em razão do momento em que nos encontramos.

Relevante, por ser inegável a crescente importância prática ligada à atuação do Superior Tribunal de Justiça no exercício de sua competência recursal excepcional. Disso dão conta não somente o volume incomensurável de recursos especiais endereçados àquela Corte - sede, portanto, em que são definitivamente resolvidos os conflitos no nosso cotidiano forense -, mas também os inúmeros dispositivos legais que conferem efeitos relevantes à jurisprudência dos Tribunais Superiores (v.g., arts. 285-A, 475, §3, $543-\mathrm{C}$, 544, $3^{\circ}, 557$, caput e $\S 1^{\circ}-\mathrm{A}$, etc., todos do Código de Processo Civil vigente). Essa constatação insere-se, aliás, numa tendência universal de crescente valorização do Direito tal como ele é concretizado pelos precedentes jurisprudenciais. ${ }^{7}$

Necessário, por não se poder ignorar a notória crise atravessada pelo Superior Tribunal de Justiça, órgão jurisdicional que não nega as suas origens e dá continuidade

\footnotetext{
${ }^{6}$ Cf. Michele TARUfFo, El vértice ambiguo, § 7, n. 2, p. 225; Elio FAZZAlari, Il giudizio civile di cassazione, p. 31-32 (ressaltando que a circunstância torna particularmente difícil a tarefa daqueles que buscam enfrentar o tema, obrigados a conciliar o modelo adotado com a prática e, ao mesmo tempo, buscar uma sistematização que vá além da disciplina positiva, tida largamente como insatisfatória).

${ }^{7}$ Tendência que pode ser aferida adequadamente à luz da investigação comparada. Entre nós, nesse sentido, ver, por último, LUIZ GUILHERME MARINONI, Precedentes obrigatórios, passim, bem como a obra, já clássica entre nós, de CRUZ E TUCCI, Precedente judicial como fonte de direito, passim.
} 
(com ainda maior intensidade) à igualmente notória "crise do Supremo". A mazela, na verdade, atinge todo o Poder Judiciário brasileiro e não se pode dizer estranha a outros sistemas de administração de justiça, como revela o estudo comparado. O número verdadeiramente assustador de recursos endereçados e decididos pela Corte impede o exercício adequado de sua função, ${ }^{8}$ gerando uma jurisprudência não uniforme, instável e imprevisível. O Superior Tribunal de Justiça muitas vezes é a causa, e não a solução, para o problema da insegurança jurídica. Por outro lado, há de recordar-se a chamada "jurisprudência defensiva", espécie de direito judicial formado ad hoc para proteger a Corte de um verdadeiro ataque de impugnações, fenômeno altamente prejudicial para a credibilidade da instituição e, antes de tudo, para os próprios litigantes. ${ }^{9}$

Oportuno, por fim, em razão do específico momento por que passa o direito processual civil brasileiro - objeto de incessantes reformas e inclusive de discussões em torno de um projeto de nova codificação. A construção de um novo sistema impõe, mais do que nunca, o debate em torno de temas de inegável relevância prática (eficácia dos precedentes, uso de filtros na seleção de recursos excepcionais, julgamento de lides repetitivas, aproximação entre o controle difuso e o controle concentrado de constitucionalidade etc).

No intuito de cumprir o objetivo de analisar o recurso especial à luz da função do Superior Tribunal de Justiça, o trabalho foi dividido em duas partes, correspondentes aos dois elementos destacados do binômio: a Corte e o recurso.

Na primeira delas, a atenção recai sobre o problema da função do Superior Tribunal de Justiça. O tema pressupõe uma aproximação histórica, que é realizada no $\S 2^{\circ}$ da dissertação. Em seguida, a investigação migra para o Direito Comparado $\left(\S 3^{\circ}\right)$ e para a

\footnotetext{
${ }^{8}$ Segundo pronunciamento do Presidente da Corte - Min. ARI PARGENDLER -, foram julgados, em 2010, mais de trezentos mil processos, o que significa uma média de mais de dez mil por julgador: "Recebemos 214.437 processos novos e julgamos 323.350. Fechamos o ano com uma vantagem de 108.913 processos!" (cf. reportagem veiculada no website da Corte em 17.12.2010: http://www.stj.gov.br/portal_stj/publicacao/engine.wsp?tmp.area=398\&tmp.texto=100283). A estatística chocante certamente não é algo a ser comemorado, mas uma denúnica, em verdade, da grave crise institucional instaurada.

${ }^{9}$ Essas afirmações parecem hoje dispensar qualquer demonstração empírica e, de resto, tais problemas de modo algum podem ser considerados recentes. Nesse sentido, v.g., basta recordar a conclusão já bastante antiga a que se chegou nas VI Jornadas Iberoamericanas de Derecho Procesal (Valencia - Venezuela, agosto de 1978) sob a rubrica "Presente y futuro de la Casación Civil": "Señala como principal defecto de la ordenación legal de la casación, exceso: a) de formalismo en los requisitos de admisión y en la limitación de los poderes de decisión del Tribunal y b) de lentitud en los trámites" (cfr. citação de ADOLFO GELSI BIDART, "Presentación comparativa de dos casaciones en Uruguay", RePro, 1980, vol. 17, n. 13, p. 122).
} 
Teoria do Direito $\left(\S 4^{\circ}\right)$, buscando recolher elementos para que se possa atribuir um sentido adequado ao conceito de nomofilaquia $\left(\S 5^{\circ}\right)$.

Na segunda parte, esboça-se uma tentativa de reconstrução dogmática do recurso especial e de sua praxe à luz dos fundamentos teóricos recolhidos na primeira parte do trabalho, buscando-se compreender a decisão de que se recorre $\left(\S 6^{\circ}\right)$, a causa de pedir do recurso $\left(\S 7^{\circ}\right)$ e os seus efeitos de seu julgamento $\left(\S 8^{\circ}\right)$, bem como coordenar a sua atuação com o recurso extraordinário $\left(\S 9^{\circ}\right)$. Brevíssimas conclusões ocupam o $\S 10^{\circ}$.

\subsection{NoÇões PREMILINARES: O RECURSO ESPECIAL NO QUADRO DOS MEIOS DE IMPUGNAÇÃO ÀS DECISÕES JUDICIAIS}

\subsubsection{SOBRE A CLASSIFICAÇÃO DOS RECURSOS}

Os mecanismos predispostos à impugnação de resoluções judiciais apresentam marcantes diferenças entre si: podem ser manejados dentro da mesma relação processual na qual foi proferida a decisão atacada ou por meio de ação autônoma; sua apreciação pode ser independente ou subordinada ao conhecimento de outro expediente; podem, ainda, impedir a formação da coisa julgada ou voltarem-se justamente contra tal autoridade; alguns requerem apenas o requisito da sucumbência para serem manejados, enquanto outros carecem de pressupostos ou motivos específicos, tipicamente previstos; consoante tais fundamentos, a cognição exercida pelo órgão ad quem e os efeitos de sua decisão também são variados.

À luz de tais elementos, diversas classificações dos meios de impugnação foram propostas pela doutrina. ${ }^{10} \mathrm{~A}$ aparente diversidade de resultados, contudo, decorre antes do emprego de critérios distintos à luz da mesma nomenclatura do que propriamente de discordância quanto aos contornos dos institutos objeto da classificação. Evidentemente, pouco importa o nomen iuris escolhido, desde que exista concordância em relação ao significado das expressões empregadas no discurso científico. Por isso, convém analisar as principais sistematizações sugeridas para optar por uma delas, fixando desde logo os conceitos adotados neste trabalho e o seu sentido.

\footnotetext{
${ }^{10}$ Ver, por todos, ARAKEN DE ASSIS, Manual dos recursos, n. 3, p. 50-54.
} 
Numa das possíveis aproximações ao tema - que se pode dizer corrente à luz da doutrina italiana ${ }^{11}{ }^{12}{ }^{12}$, são tidos por extraordinários os remédios (ditos também "recursos em sentido amplo") não impeditivos do trânsito em julgado da decisão ou voltados a atacar a res iudicata, configurando ações autônomas que dão origem, portanto, a uma nova relação jurídica processual. É o que se passa, v.g., com a nossa ação rescisória, na esteira da querela nullitatis surgida no direito intermédio. ${ }^{13}$ Seriam ordinários (ou "recursos em sentido estrito"), por sua vez, aqueles exercidos como um prolongamento da própria relação processual já instaurada, e que por isso mesmo impedem (ou retardam) a formação da res iudicata.

Percebe-se que o critério distintivo empregado ao discernir os recursos ordinários dos extraordinários reside, segundo essa primeira corrente, em saber se o remédio é manejado dentro ou fora da relação processual na qual se formou a decisão que se procura reformar ou anular, sendo a diferenciação calcada também na relação dos expedientes com a coisa julgada.

Dentro da categoria dos recursos ordinários ou em sentido estrito, seriam apartados, num segundo momento, de acordo com os seus pressupostos, aqueles meios de

${ }^{11} C f$. LUigi MonTESANO - GIOVANNI ARIETA, Diritto processuale civile II, n. 115, p. 265-266; entre nós, ver Alcides De Mendonça Lima, Introdução aos recursos cíveis, n. 135, p. 165; José CARLos Barbosa MoreIra, Comentários ao Código de Processo Civil, vol. 5, n. 134, p. 231. Cumpre lembrar, todavia, que o ricorso per cassazione (equivalente ao nosso recurso especial) era classificado como meio de impugnação extraordinário pelo revogado Código de Processo Civil italiano de 1865, o que parte da doutrina entende ser uma decorrência da extraordinariedade da própria Corte de Cassação e de sua posição particular no ordo iudiciorum, e não do recurso em si (cfr. FERDINANDO MAZZARELLA, Analisi del giudizio civile di Cassazione, p. 2-3).

${ }^{12}$ Mas não necessariamente à luz de outros ordenamentos europeus, consoante por vezes faz crer, de maneira equivocada, a doutrina pátria. Nesse sentido, a doutrina espanhola arrola como recursos somente os meios de impugnação que prolongam a relação processual já e ainda existente, compreendendo a expressão "meios de impugnação", em sentido amplo, os mecanismos voltados a atacar sentenças firmes, isto é, já transitadas em julgado (v. JUAN MONTERO AROCA - JOSÉ FlORS MATíES, El recurso de casación civil, p. 16-18), orientação que se aproxima daquela vigente no direito positivo brasileiro. Diferentemente de um e de outro caso (ou seja, da orientação italiana e da espanhola), no direito francês, sob a rubrica das voies extraordinaires de recours, colocam-se tanto expedientes utilizados no mesmo processo (v.g., o pourvoi en cassation, que, contudo, não obsta geralmente o trânsito em julgado) quanto aqueles voltados a desfazer uma decisão transitada em julgado (le recours en revisión, previsto nos arts. $593 \mathrm{e}$ ss. do NCPC). Tais meios de ataque às decisões judiciais têm em comum a exigência de fundamentação específica, prevista em lei, para que sejam admissíveis, consoante dispõe o art. 580, NCPC: "Les voies extraordinaires de recours ne sont ouvertes que dans les cas spécifiés par la loi". V., sobre a caracterização do pourvoi en cassation como recurso extraordinário, LOÏC CADIET, "El sistema de la casación francesa", n. I/3, p. 27.

${ }^{13}$ Ainda que, nas palavras de LIEBMAN (nas Notas a CHIOVENDA, Instituições de direito processual civil, São Paulo: Saraiva, 1965, v. 3, § 73, n. 378, nota 4, p. 204), a ação rescisória tenha "o corpo de uma ação, mas a alma de um recurso". Uma síntese da evolução e coordenação dos meios de impugnação das sentenças (apelação e querela de nulidade) pode ser encontrada na nota indicada (p. 200-204). 
impugnação de fundamentação livre (em que basta a sucumbência para que se recorra) daqueles de fundamentação vinculada (em que se exigem motivos específicos para recorrer). ${ }^{14}$ Haveria, assim, recursos ordinários classificados segundo pares conceituais variados: normais e especiais, de objetivo geral e de objetivo específico ${ }^{15}$ ou, ainda, ilimitados e limitados. ${ }^{16}$

Por esse prisma, os recursos especial e extraordinário (previstos nos arts. 102, III e 105, III, da Constituição, respectivamente) seriam recursos ordinários, porquanto usados “dentro da instância", ainda que manejados em via excepcional e portadores de caráter especial em relação aos demais recursos propriamente ditos. ${ }^{17}$ Justifica-se, nesse sentido, que a denominação de extraordinário teria servido apenas ao propósito de distinguir este particular recurso das apelações interpostas diante de sentenças dos juízes federais perante o Supremo Tribunal Federal e do recurso ordinário constitucional. ${ }^{18}$

Tornou-se assente em nossa doutrina, contudo, nomenclatura diversa da apontada. A expressão recurso é reservada para os meios de impugnação manejados na própria relação jurídica processual (categoria correspondente, como se viu, aos recursos ordinários da classificação tradicional), de modo a impedir a formação da coisa julgada. A dicotomia “ordinário-extraordinário" entra em cena apenas num momento seguinte, quando se repartem, dentro do gênero dos recursos, as respectivas espécies, segundo os seus pressupostos (função subjetiva ou objetiva, fundamentação livre ou vinculada, exame ilimitado ou limitado etc.).

\footnotetext{
${ }^{14}$ Nesse sentido, repudiando como distinção que, entre nós, "não tem relevância teórica nem prática" aquela feita entre recursos ordinários e extraordinários, prefere BARBOSA MOREIRA aludir simplesmente a recursos de fundamentação livre e de fundamentação vinculada (Comentários ao Código de Processo Civil, vol. 5, n. 142, p. 253-355).

${ }^{15}$ Cfr. JOSÉ AFONSO DA SILVA, Do recurso extraordinário no direito processual brasileiro, n. 34, p. 76 e ss. Para o autor, os recursos em sentido estrito (meios ordinários de impugnação), após serem agrupados segundo a via comum ou excepcional em que exercidos (segundo a estrutura que exijam para seu julgamento - normal ou de sobreposição, respectivamente), seriam divididos em normais e especiais: para aqueles, basta o pressuposto da sucumbência para recorrer; para estes, é necessário um plus indicado pela lei. Por fim, seriam de objetivo geral (reexame de fato e de direito) ou de objetivo específico (revisão in iure ou de questões fáticas restritas). À luz de tais sistematizações, o recurso extraordinário (e, hoje, o recurso especial) é, para o autor, um recurso ordinário (em sentido estrito) misto, especial e de objetivo específico (segundo a tabela de p. 85, constante do n. 35).

${ }^{16}$ É a sistematização preferida por ALCIDES DE MENDONÇA LIMA, Introdução aos recursos cíveis, n. 132, p. 159 e n. 139-141, p. 172-177. Confira-se, na mesma obra, o esquema contido no n. 139, p. 172.

${ }^{17}$ Cf. José Afonso DA SiLva, Do recurso extraordinário no direito processual brasileiro, n. 34, p. 76 e ss.

${ }^{18}$ Cf. José Afonso DA SILVA, Do recurso extraordinário no direito processual brasileiro, n. 36, p. 95.
} 
Os demais meios de impugnação - exercidos fora da relação processual na qual se formou a decisão e voltados, em regra, contra a coisa julgada já formada (ou seja, a categoria correspondente aos recursos extraordinários da classificação tradicional) - são referidos como ações impugnativas autônomas, e não como recursos. ${ }^{19}$

Compreende-se, do cotejo entre as duas propostas classificatórias, que aquilo que é tido como um recurso extraordinário para uma das correntes não o seja para a outra. A diferente nomenclatura empregada pelas duas classificações deve-se à utilização de critérios distintos para adjetivar um meio de impugnação como extraordinário: enquanto na doutrina tradicional a extraordinariedade está ligada ao modo de exercício do expediente, que se dá então por meio de ação autônoma, no direito brasileiro contemporâneo tal expressão é reservada às irresignações manifestadas dentro do mesmo processo, mas qualificadas por objetivos e fundamentos específicos.

O que se deve evitar, nesse ponto, é a importação de classificações incompatíveis com o direito pátrio, sob pena de utilizarem-se termos idênticos para designar realidades diferentes. Ignorar a terminologia do direito posto para criar esquema classificatório diverso - ligado ao direito e à doutrina estrangeiros - certamente não é o caminho mais aconselhável a seguir. Por isso, é preferível aludir a recursos, de um lado, e ações impugnativas, de outro, dividindo os primeiros em ordinários e extraordinários (ou excepcionais). Esta classificação guarda afinidade com o direito positivo brasileiro, conforme se depreende do art. 467, in fine, do CPC. ${ }^{20}$ A menção ali feita a recurso "ordinário ou extraordinário", cuja não-interposição é pressuposto do trânsito em julgado da decisão, indica claramente que o legislador pátrio emprega a terminologia para distinguir espécies de recursos em sentido estrito, segundo particularidades ligadas à sua fundamentação e ao seu objetivo.

No mesmo sentido, consagrou-se a exigência de esgotamento das vias "ordinárias" para que se interponham os recursos "extraordinários" (assim, os verbetes 281 da Súmula do Supremo Tribunal Federal e 207 da Súmula do Superior Tribunal de Justiça). A isso, pode somar-se a adesão da própria jurisprudência dos Tribunais de superposição, que

\footnotetext{
${ }^{19}$ Barbosa Moreira, Comentários ao Código de Processo Civil, n. 135, p. 232.

${ }^{20}$ Cf. ARAKEN DE ASSIS, "Introdução aos sucedâneos recursais", n. 1, p. 14-15; ID., Manual dos recursos, n. 3.1, p. 54 e n. 83 , p. 693.
} 
reconhece a natureza extraordinária dos recursos especial e extraordinário. ${ }^{21}$ Por fim, devese lembrar que a locução "recurso extraordinário", para designar espécie recursal manejada no próprio processo, é acolhida pelo texto constitucional (art. 102, III) e conta com o peso da tradição, remontando ao primeiro Regimento Interno do STF.

Portanto, no direito brasileiro, os recursos (divididos em ordinários e extraordinários ou excepcionais) têm como denominador comum o fato de constituírem remédios voluntários ${ }^{22}$ que impliquem "extensão do mesmo processo até então fluente". Todo o mais cai na vala das ações impugnativas autônomas (mandado de segurança, ação rescisória etc.). Contudo, a estas últimas não se pode atribuir a característica constante de atacar a coisa julgada já formada, sendo o mandado de segurança contra ato judicial exemplo suficiente a comprovar a falsidade da generalização. ${ }^{23}$ Desse modo, pode-se afirmar que todos os expedientes exercidos fora do processo originário são classificados como ações impugnativas, pouco importando o trânsito em julgado da decisão sob ataque.

\subsubsection{RECURSOS EXCEPCIONAIS: FUNÇÃO E ESTRUTURA}

$\mathrm{Na}$ esteira de outros modelos do processo continental, nosso sistema recursal visa a cumprir três propósitos básicos: reexaminar os fatos relevantes da controvérsia, revisar a intepretação/aplicação normativa e controlar a regularidade do procedimento. ${ }^{24}$ À luz da revisão das normas aplicadas, pode-se cogitar, ainda, de uma função prospectiva relacionada especificamente com o desenvolvimento e a unificação do Direito, o que "só é possível pela jurisprudência dos tribunais superiores". ${ }^{25}$

Guardando tais finalidades em mente e à luz da nomenclatura proposta no item anterior, os recursos deixam-se classificar em duas grandes categorias: ordinários e excepcionais.

${ }^{21}$ V.g., STJ, 5 $5^{\mathrm{a}}$ T., HC 97.447/MG, rel. Min. FELIX FISCHER, j. em 01.04.2008, DJe 23.06.2008.

${ }^{22}$ Fator que exclui do rol de recursos a remessa oficial.

${ }^{23}$ Cfr. José Carlos Barbosa Moreira, Comentários ao Código de Processo Civil, 14. ed., Rio de Janeiro: Forense, 2008, v. 5, n. 135, p. 232. Nesse sentido, ver o n. 268 da Súmula do STF.

${ }^{24} C f$. Peter L. MurRaY - Rolf STÜRNER, German civil justice, cap. 10(A), p. 367.

${ }^{25}$ Othmar JaUernig, Direito processual civil, §72/III, p. 362. Entendidos, no texto, como tribunais encarregados de uniformizar o Direito por meio de recursos excepcionais, lembrando-se que nem sempre os Tribunais Superiores atuam dessa maneira (v.g., o Superior Tribunal Militar, que, em relação à Justiça Militar da União, atua como instância de apelação). 
I) Nos recursos ditos ordinários - dos quais são arquétipos a apelação, o recurso ordinário em sentido estrito e o recurso "inominado" no âmbito dos Juizados Especiais -, o aspecto funcional está coordenado à proteção genérica dos interesses subjetivos dos litigantes (ius litigatoris) e, via de regra, a fundamentação é livre, bastando a sucumbência para que o recurso seja admitido. Em outras palavras, é suficiente que se alegue a injustiça da primeira decisão para que o processo seja renovado (i.e., a causa reexaminada) em segunda instância, na qual podem ser reexaminados os fatos relevantes, revisada a aplicação das normas e controlada a regularidade do procedimento. ${ }^{26}$

A apelação proporciona, nessa medida, um amplo reexame da prova já produzida pelas partes e dos aspectos jurídicos da causa, devolvendo ao Tribunal "todas as questões suscitadas e discutidas no processo, ainda que a sentença não as tenha julgado por inteiro", bem como eventuais fundamentos não acolhidos em primeiro grau (art. 515, $\S 1^{\circ}$ e $\left.2^{\circ}, \mathrm{CPC}\right)$.

Trata-se de manifestação da regra geral do duplo grau de jurisdição, que visa a proporcionar ao litigante a possibilidade de obter uma segunda decisão em relação aos fatos e ao direito, proferida por juiz diverso, que prevalecerá sobre a primeira. ${ }^{27}$ Embora questionável sob vários aspectos a regra do duplo grau, em geral entende-se que a experiência do primeiro julgamento - cuja atuação, nos dizeres de MACHADO GUIMARÃES, “já desbravou o terreno", entregando ao Tribunal uma lide "reduzida aos seus elementos essenciais" - contribui para a melhor qualidade da decisão tomada em segunda instância. ${ }^{28}$ Seja como for, por meio da apelação - recurso ordinário por excelência - devolve-se

\footnotetext{
${ }^{26}$ LUiZ MACHAdo GuimarÃES, "Efeito devolutivo da apelação", n. I, p. 216-217. Esclarece o autor que, ao contrário do que sucede com os recursos excepcionais, a apelação "não se trata de recurso tendente à reparação de um vício, mediante a rescisão da sentença, mas de recurso tendente à renovação (ou ao reexame) do precedente processo" (op. e loc. cit.).

${ }^{27}$ Ver ORESTE NESTOR DE SOUZA LASPRO, Duplo grau de jursdição no direito processual civil, n. 2.4, p. 27. As outras afirmações referidas no texto - de que a regra não tem caráter absoluto, não sendo uma garantia constitucional - também encontram apoio em lições do autor. V., na mesma obra cit., esp. n. 4.5, p. 93-97 e n. 8.1.2, p. 159. Ver, ainda, no mesmo sentido, BARBOSA MOREIRA, Comentários ao Código de Processo Civil, n. 138, p. 240; CÂNDIDO DINAMARCO, "O efeito devolutivo da apelação e de outros recursos", n. 81, p. 157161.

${ }^{28}$ LUIZ MACHADO GUIMARÃES, "Efeito devolutivo da apelação", n. II, p. 217. Em sentido semelhante, embora referindo-se especificamente ao uso de máximas de experiência, FRIEDRICH STEIN já salientara que o tribunal de segundo grau "pode aproveitar o ponto de vista do primeiro [i.e, do juiz de primeira instância] como um meio de conhecimento; a posição do segundo tribunal em relação a esse ponto de vista é a mesma que tem em relação a um ditame pericial" (El conocimiento privado del juez, § 7, p. 125). Sobre os prós e contras da regra do duplo grau, consultar, por último, ARAKEN DE Assis, Manual dos recursos, n. 5, p. 70 e SS.
} 
imediatamente o (re)exame da controvérsia ao juízo ad quem, tanto no que diz respeito às questões fáticas quanto no que concerne ao direito aplicável, excluídas, no entanto, novas provas e alegações. $^{29}$

II) Algo muito diferente se passa com os recursos extraordinários ou excepcionais (gênero a que pertencem, em nossa sistemática, tanto o recurso extraordinário em sentido estrito quanto o recurso especial, bem como o recurso especial no âmbito eleitoral e a revista trabalhista). Isso porque não entra em cena, no estudo dos recursos excepcionais, a regra do duplo grau de jurisdição, pertinente apenas aos recursos ordinários. ${ }^{30}$

Pelo contrário, os recursos ditos excepcionais são caracterizados por uma específica função, que transcende os interesses individuais dos litigantes. Esta função é dita nomofilática, e consiste em atribuir unidade ao Direito, uniformizando a jurisprudência. ${ }^{31}$ Costuma-se dizer, nesse sentido, que os recursos excepcionais tutelam o direito objetivo e só reflexa, secundária ou mediatamente o direito das partes, que é colocado a serviço daquele interesse geral. ${ }^{32-33}$

O texto constitucional consagra justamente isso, regulando o cabimento do recurso especial contra as "causas decididas" por tribunais de segunda instância, devendo para tanto alegar-se a violação de uma questão federal infraconstitucional (art. 105, III, CF).

\footnotetext{
${ }^{29}$ O que torna a apelação brasileira uma revisio prioris instantiae e não um novum judicium, de acordo com opção feita já pelo Código de 1939 ( $c f$. LUIZ MACHADO GUIMARÃES, "Efeito devolutivo da apelação", n. VIII, p. 224-225), e mantida pelo Código de 1973 ( $c f$. ANTÔNIO CARLOS DE ARAÚJO CINTRA, "Apontamentos sobre os fatos da causa e a apelação", esp. n. 2, p. 100-102).

${ }^{30}$ MatTiRolo, Trattato di diritto giudiziario civile italiano, vol. 1, n. 81, p. 73.

${ }^{31}$ O clássico quanto ao tema é a obra monumental de CALAMANDREI, La casación civil, esp. tomo III, n. 1077 , p. 41-180.

${ }^{32}$ Nesse sentido, entre muitos outros, CRUZ E TUCCI, Precedente judicial como fonte do direito, São Paulo: RT, 2004, cap. VIII, n. 2.1.2, p. 266; SERGIO BERMUDES, "O procedimento dos recursos extraordinário e especial no juízo recorrido”, n. 2., p. 198-199; ID., Introdução ao processo civil, p. 184; ARAKEN DE ASSIS, Manual dos recursos, n. 3.1, p. 55; ATHOS GUSMÃO CARNEIRO, Recurso especial, agravos e agravo interno, n. 2, p. 8; ADA PELLEGRINI GRINOVER, "Litisconsórcio necessário e efeito devolutivo do recurso especial", n. 2.2, p. 29; RoDOlFo DE CAMARGO MANCUSO, Recurso extraordinário e recurso especial, cap. 5, n. 2.2, p. 153 e ss.

${ }^{33}$ Sem prejuízo da validade da afirmação feita no texto, é necessário reconhecer que o Superior Tribunal de Justiça também exerce - ao lado da sua típica função nomofilática, mediante a qual outorga unidade ao Direito e uniformiza a jurisprudência - uma função de controle sobre a regularidade do processo e de fiscalização do regular exercício da competência jurisdicional. Isso ocorrerá quando o recurso trouxer como causa de pedir, respectivamente, um error in procedendo ou a violação de normas de competência. Ainda nesses casos, contudo, o Superior Tribunal contribuirá para a outorga de unidade ao Direito e para a uniformização da jurisprudência, julgando e, conseqüentemente, sinalizando - por meio de seus precedentes - o entendimento a respeito de tais questões. Para o direito italiano, ver CALAMANDREI - FURNO, “Cassazione civile", n. 1, p. 1055 e n. 22, p. 1070.
} 
Segundo a conhecidíssima fórmula de PONTES DE MIRANDA, o recurso extraordinário - e hoje também o recurso especial, acrescento - têm por finalidade assegurar "a inteireza positiva, a validade, a autoridade e a uniformidade de interpretação" do Direito federal. ${ }^{34}$

Da função, como sempre, deve-se passar à estrutura. Nesta, a finalidade específica dos recursos excepcionais acarreta, como conseqüência, uma série de restrições. Há, com efeito, uma limitação aos poderes do Tribunal ad quem, aspecto decorrente diretamente da fundamentação vinculada exigida para a interposição dos recursos excepcionais. Ou seja, da requisição de determinados motivos específicos - além do requisito básico da sucumbência (condição, no entanto, suficiente para o manejos dos recurso ordinários) para que seja admissível a impugnação, decorrem limitações ao âmbito do julgamento. ${ }^{35}$

Se por um lado o duplo grau e os remédios a ele atrelados permitem uma revisão da causa em toda a sua amplitude (in iure e in facto), o recurso excepcional ou "de estrito direito", por outro, não se presta a provocar novo reexame, mas apenas uma revisão parcial (in iure) da própria decisão impugnada. A explicação para essa restrição cognitiva é singela: se os recursos excepcionais estão vocacionados à tutela objetiva do Direito, então é natural e desejável que a atenção do julgamento deva voltar-se especificamente para o problema jurídico, sem que considerações com as minúcias do caso concreto difícultem uma adequada reflexão sobre uma questão de alcance geral. ${ }^{36}$ Como foi bem colocado por CALAMANDREI, o erro quanto aos fatos - justamente em razão de derivar de circunstâncias próprias da lide individualmente considerada - é incapaz de constituir um precedente capaz de ser seguido por outros juízes. Mas o erro concernentee ao direito - porquanto passível de generalização - configura exemplo "facilmente contagioso", capaz, por isso mesmo, de ser seguido e repetido numa série de relações similares futuras. ${ }^{37}$

A sua fundamentação vinculada faz com que o recurso especial veicule uma pretensão típica, porquanto fundada necessariamente em uma causa de pedir arrolada de

\footnotetext{
${ }^{34}$ Comentários ao Código de Processo Civil (de 1973), tomo VIII, p. 38-39.

35 Alcides DE MENDONÇA LIMA, Introdução aos recursos cíveis, n. 133, p. 159-161. Algo nesse sentido, FLÁvio CHEIM JoRGE, Teoria geral dos recurso cíveis, n. 4.1, p. 39.

36 J. A. JOLOWICZ, “Appeal and review in comparative law: similarities, differences and purposes”, p. 635; DANILO KNIJNIK, O recurso especial e a revisão da questão de fato..., n. 2.4, p. 108. Contra, ALEJANDRO BUENDÍA CÁNOVAS, La casación civil, cap. IV, p. 208-210 (entendendo as restrições quanto à cognição de fatos e reexame da prova como obstáculos desnaturalizadores do juízo jurisdicional).

${ }^{37}$ CALAMANDREI, La casación civil, tomo III, n. 38, p. 93-94.
} 
forma taxativa pela lei processual. ${ }^{38}$ Entretanto, é um engano confundir recursos de fundamentação vinculada com recursos excepcionais. ${ }^{39}$ Ainda que aquela característica se faça presente nestes, a associação contrária nem sempre é verdadeira. A classe dos recursos de fundamentação vinculada é mais abrangente, abarcando, além dos excepcionais, todas as modalidades recursais em que há tipicidade legal das críticas passíveis de serem dirigidas contra a decisão, a exemplo do que ocorre também com os embargos declaratórios (art. 535, CPC) - que, no entanto, são espécie ordinária de recurso. ${ }^{40}$

Outras associações e descrições feitas pela doutrina são também indevidas. Nesse sentido, v.g., é mencionado o juízo bipartido de admissibilidade como traço típico dos recursos extraordinário e especial. Ora, tal sistemática é contingente e não diz com a essência dos mesmos, sendo encontrada em outras modalidades recursais. ${ }^{41}$ Ademais, pode ser suprimida pelo legislador ou abrandada em seu alcance (tal como ocorreu, por exemplo, quanto à avaliação da repercussão geral do recurso extraordinário, tarefa acometida com exclusividade ao Supremo Tribunal Federal). Por outro lado, é também desatualizada a antiga lição de que o caráter extraordinário do recurso portador desse nome deve-se ao fato de que, por ocasião de sua criação, a sua interposição ocorria de uma justiça autônoma (estadual) para outra distinta (federal), sem que se pudesse vislumbrar vínculo hierárquico entre os órgãos a quo e ad quem. ${ }^{42}$ Isso porque os recursos excepcionais (extraordinário e especial) são julgados por Tribunais de superposição nacionais, abrangendo tanto a Justiça Federal como a dos Estados-membros. Cumpre desfazer, ademais, a associação dos recursos excepcionais com o federalismo: a necessidade de recursos excepcionais - instrumentos por meio dos quais os Tribunais Superiores devem conferir unidade ao Direito - não é exclusiva dos Estados instituídos sob a forma federativa (ou com uma dualidade de justiças), impondo-se também àqueles organizados de forma unitária.

\footnotetext{
${ }^{38}$ Trata-se, aqui, de uma tipicidade das causae petendi dos recursos, previstas taxativamente na legislação processual, tal como ocorre na ação rescisória (art. 485, CPC), o que permitiria o seu enquadramento como pretensões típicas. Sobre o tema, examinando a ação rescisória e propondo a tipicidade desta ação como decorrência da previsão taxativa de suas possíveis causas de pedir pela lei processual, ainda que esta seja relativa diante da abertura permitida pela cláusula de violação a dispositivo de lei, v. FLÁvio YARSHELL, Tutela jurisdicional, n. 4.8-4.9, p. 74-80.

${ }^{39}$ Confusão a que, salvo engano, não escapou SANDRO KOZIKOSKI, Manual dos recursos cíveis, p. 131.

${ }^{40}$ ARAKEN DE Assis, Manual dos recursos, n. 3.1-3.2, p. 54-56.

${ }^{41}$ LeOnidas Cabral AlbuQuerque, Admissibilidade do recurso especial, n. 3.1, p. 78.

${ }^{42}$ Matos Peiхото, Recurso extraordinário, Rio de Janeiro: Freitas Bastos, 1935, p. 170.
} 
Deixadas essas questões menores de lado, importa ainda reter, para os fins desse trabalho, que os recursos excepcionais ou de cassação foram construídos formalmente como ações impugnativas, na esteira da querela nullitatis do direito estatutário italiano e do direito comum. ${ }^{43}$ Assemelham-se, assim, à ação rescisória, remédio sabidamente ligado à antiga querela de nulidade. ${ }^{44}$ Não por acaso, os vocábulos "cassar" e "rescindir" guardam certa correspondência semântica e os recursos excepcionais, sob o aspecto de sua estrutura, são frequentemente comparados à ação rescisória. ${ }^{45}$

Por isso, ao contrário da apelação (e mesmo de alguns recursos de fundamentação vinculada, como os embargos infringentes), os recursos excepcionais não submetem a causa a um reexame imediato de fato e de direito; neles, inversamente, o reexame é obtido apenas de forma mediata, já que o Tribunal deve antes rescindir o julgado recorrido (juízo rescindente) - à luz da alegação de uma das causae petendi tipificadas na lei (questões jurídicas) - para somente então reexaminar a controvérsia (juízo rescisório). ${ }^{46} \mathrm{O}$ juízo de mérito, em outras palavras, é bipartido, apresentando-se, tal como ocorre na ação rescisória, tanto o iudicium rescindens quanto o iudicium rescisorium.

Portanto, a revisão efetuada pelo Superior Tribunal de Justiça tem por objeto o próprio julgamento recorrido; trata-se de um “juízo sobre um juízo", e não de um reexame da causa. Paradoxalmente, os Tribunais Superiores - embora situados no vértice do

\footnotetext{
43 Ver, resumidamente, CALAMANDREI, La casación civil, tomo II, n. 277, p. 373-375; CALAMANDREI FuRNO, "Cassazione civile", n. 5, p. 1058. Entre nós, seguiu, em largas linhas, esta exposição ALFREDO BuZAID, "A crise do Supremo Tribunal Federal", n. 1-2, p. 121-123. Isso é verdade ainda que se tenham, em alguma medida, esfumaçado os contornos entre recursos e ações impugnativas autônomas, nos dizeres de LUIZ MACHADO GUIMARÃES, "Efeito devolutivo da apelação", n. IV, p. 220, e nota 11.

${ }^{44}$ A ponto de justificar a afirmação de LIEBMAN no sentido de que "a querela nullitatis sobrevive, com o nome de ação rescisória" ("Institutos de direito comum no processo civil brasileiro", n. 12, p. 58);

${ }^{45}$ Ver, nesse sentido, FLÁVIO LUIZ YARSHELL, Ação rescisória: juízos rescindente e rescisório, n. 2, p. 24-25 e n. 3, esp. p. 29 (destacando a correspondência semântica entre cassar e rescindir e contrastando recursos excepcionais e ação rescisória).

${ }^{46}$ Com inteira razão, NELSON NERY JR., "Questões de ordem pública e o julgamento do mérito dos recursos extraordinário e especial: anotações sobre a aplicação do direito à espécie (STF 456 e RISTJ 257)", n. 2, p. 967. $C f$., ainda, na doutrina italiana, CALAMANDREI - FURNO, "Cassazione civile”, n. 14-18, p. 1063-1065; PROTO PISANI, Lezioni di diritto processuale civile, p. 503; ClAUDIO CONSOLO, Il processo di primo grado e le impugnazione..., p. 481-482; na doutrina espanhola, VICENTE GIMENO SENDRA, Derecho procesal civil, vol. 1, n. 32(I), p. 623; na doutrina portuguesa, CASTANHEIRA NEVES, O instituto dos 'assentos'..., cap. 2, p. 87 (destacando que, "se pode dizer-se que é a decisão recorrida o objecto imediato de revista, o certo é que o objecto mediato e fundamental é bem claramente o caso jurídico")
} 
ordenamento judiciário - são assim os órgãos com menor âmbito de competência jurisdicional, não conhecendo nem diretamente da causa nem da integralidade dela. ${ }^{47}$

Das observações feitas nessa primeira aproximação ao recurso especial (espécie do gênero dos recursos excepcionais), podem ser destacadas três características fundamentais.

A primeira concerne à missão específica desse recurso no quadro dos meios de impugnação às decisões judicias. Em nosso direito, cabe a ele conferir unidade ao Direito federal infraconstitucional. O escopo, como procurarei demonstrar, não se confunde e, em boa dose, coloca-se em confronto com o interesse particular dos litigantes que prepondera no recurso de apelação.

Da particularidade funcional decorre diretamente a segunda característica. Diz ela respeito à fundamentação vinculada dos recursos excepcionais: sua interposição depende da invocação de causae petendi tipicamente previstas, envolvendo a alegação de uma questão de direito federal. A distinção fato-direito, como será visto, é, na melhor das hipóteses, uma noção teórica "escorregadia", como colocou certa vez a Suprema Corte norte-americana. ${ }^{48}$ No entanto, a assimilação da causa de pedir a uma questão de direito quer significar que os Tribunais Superiores devem ocupar-se com resolução de problemas normativos, e não com os acontecimentos históricos ou as peculiaridades individuais de uma causa isolada. A medida em que tais oportunidades devem ser reconhecidas na aplicação de standards, cláusulas gerais, conceitos indeterminados, normas sobre direito probatório etc., é tema da maior relevância.

Por fim, visto que o seu fundamento é uma "causa decidida" pela instância a quo, é certo que o recurso especial se apresenta como um meio de impugnação do tipo rescisório, na medida em que realiza um juízo sobre o próprio acórdão impugnado (dito por vezes um "metajuízo", para significar um juízo feito sobre outro juízo), e não um reexame de novo da causa. ${ }^{49}$ Essa estrutura explica a exigência forense do pré-questionamento e o efeito devolutivo limitado do recurso especial.

\footnotetext{
${ }^{47} C f$. JuAn Montero ArocA - José Flors MatíES, El recurso de casación civil, cap. I, n. 2, p. 22.

${ }^{48}$ Thompson v. Keoane, 516 U.S. 99, 111 (1995).

${ }^{49}$ LuIGI MONTESANO - GIOVANNI ARIETA, Diritto processuale civile II, n. 117, p. 267 (distinguindo recursos rescindentes e susbtitutivos).
} 


\section{§ 2 - APROXIMAÇÃO HISTÓRICA AO SUPERIOR TRIBUNAL DE JUSTIÇA E AO RECURSO ESPECIAL}

O recurso especial, como é sabido por todos, é um desmembramento do recurso extraordinário. Com a criação - pelo constituinte de 1988 - do Superior Tribunal de Justiça, esta Corte assumiu a parcela de competência recursal extraordinária antes enfeixada pelo Supremo Tribunal Federal relativa ao direito federal infraconstitucional. É impossível compreender o recurso especial sem a referência à evolução anterior do recurso extraordinário e, particularmente, à notória "crise do Supremo". Sendo assim, passa-se a examinar, ainda que muito brevemente, tais temas.

\subsection{EVOLUÇÃO DO RECURSO EXTRAORDINÁRIO NO DIREITO BRASILEIRO.}

\subsubsection{ORIGENS E CRIAÇÃo DO RECURSO PELA CONSTITUIÇÃo DE 1891.}

Embora alguns autores - como JOÃO BONUMÁ - tenham filiado o recurso extraordinário imediatamente à antiga revista e, de forma mediata, à suplicação do direito lusitano, pode-se dizer que aquele encontrou inspiração literal no writ of error norteamericano, previsto no Judiciary Act de $1789 .{ }^{50}$ Aliás, ao romper com o regime unitário imperial e estabelecer a forma federativa de Estado, os autores do projeto de Constituição optaram por importar - na medida do possível - o modelo americano de Poder Judiciário,

\footnotetext{
${ }^{50}$ JosÉ AFONSO DA SILVA, Do recurso extraordinário no direito processual brasileiro, n. 8, p. 27. Adiante, esclarece o autor, após afirmar que a formulação original do recurso extraordinário era uma tradução quase literal do Judiciary act norte-americano: "Desprezou-se o recurso de revista do Direito luso-brasileiro, que a Constituição Política do Império acolhêra no seu art. 164, n. 1, quando estipulou que, ao Supremo Tribunal de Justiça, criado no art. 163, competia conceder ou denegar revistas nas causas e pela maneira que a lei determinasse". Também distinguiu, nos seguintes termos, o recurso extraordinário e a revista, DE PLÁCIDO E SILVA, comentando a legislação então vigente: "E, aliás, teve o mérito de fazer distinção entre o recurso de revista, anteriormente adotado pelo regime imperial, que se fundava, precìpuamente, na manifesta nulidade e na injustiça notória. enquanto o recurso extraordinário, além da condição de julgados manifestamente nulos e notòriamente injustos, fundados exclusivamente e diretamente em preceitos constitucionais, tem a finalidade relevante de fazer prevalecer a lei federal, impondo a uniformidade de aplicação em todo território da República" (Comentários ao Código de Processo Civil, vol. 5, n. 2.169, p. 281). Muitas páginas foram dedicadas ao writ of error, em nossa doutrina, por OSMAR MENDES PAIXÃo CÔRTES, Recurso extraordinário, n. 2.3.4-2.3.5, p. 152-186. Cabe lembrar que o antigo writ of error inglês foi substituído, há mais de um século, por um appeal, bastante diferente daquele, mas que nos Estados Unidos, o appeal ainda guarda alguma relação com o velho writ, sendo baseado numa apreciação restrita do record (cf. J. A. JOLOWICZ, On civil procedure, cap. 15, p. 309-310).
} 
sequer considerando ou discutindo as vantagens e desvantagens de experiências passadas ou dos recursos de cassação e revisão europeus. ${ }^{51}$

Tal orientação não ficou imune a críticas. A semelhante função exercida pelo antigo recurso de revista - voltado também para a proteção do "direito objetivo" ou, como se dizia então, do "direito em tese" - levou JoSÉ AFONSO DA SILVA a afirmar a existência, em nossa tradição, de um remédio que poderia muito bem ter sido adaptado para transformarse no atual recurso extraordinário. A solução, segundo o autor, teria evitado "os azares da incompreensão" derivados do "transporte mecânico e material", levado a cabo "sem aquela adaptação natural e reelaboração psicológica", da normativa anglo-americana. ${ }^{52}$ Reconheceu, contudo, que já à sua época o recurso extraordinário era mais parecido com a velha revista do que com o writ anglo-saxão. ${ }^{53}$

Seja como for, o recurso extraordinário teve por finalidade primitiva assegurar a supremacia do Direito federal sobre as judicaturas locais. Foi inicialmente previsto embora ainda sem essa denominação, que apareceria pela primeira vez somente no Regimento Interno do Supremo Tribunal Federal, de 26 de fevereiro de 1891 (art. 102) pelo projeto do Governo Provisório, no art. 58, $\S 1^{\circ}$, do Decreto ${ }^{\circ} .^{\circ} 510$, de 22 de junho de 1890, que teve vigência apenas parcial. Logo em seguida, em 11 de outubro de 1890, a matéria foi regulada pelo Decreto n. ${ }^{\circ} 848$, em seu art. $9^{\circ}$, par. único, em "tradução, quase ipsis litteris, dos textos americanos sôbre o writ of error". ${ }^{4}$

A Constituição republicana de 1891 admitiu o recurso para as decisões das Justiças dos Estados; reprisou, em largas linhas, no seu art. 59, $\S 1^{\circ}$, a redação do Decreto n. ${ }^{\circ} 510$, inserindo hipótese de cabimento de menor relevo prático (relativa a espólio de estrangeiro)

\footnotetext{
${ }^{51}$ Nesse sentido, informa ALFREDO BUZAID que "tais problemas eram realmente importantes e não se sabe porque não mereceram a atenção dos ilustres constituintes e dos membros do Govêrno Provisório". Seja como for, a organização do Poder Judiciário deu-se "sob os moldes americanos" ("A crise do Supremo Tribunal Federal", in Estudos de direito, São Paulo: Saraiva, 1972, v. 1, n. 11, p. 138). Em verdade, o que se sabe é que a Suprema Corte americana, nos seus primórdios, tinha como prioridade de suas atenções justamente o fortalecimento do federalismo e da relação entre União e estados-membros ( $c f$. LAWRENCE BAUM, The Supreme Court, cap. 2, p. 21), de modo que, ao instituir o Estado federal entre nós, o mais provável é que tenham nossos constituintes mirado também positivamente essa atuação do órgão judicial estadunidense. Como foi acentuado por BARBOSA MOREIRA, "não foi por acaso que o importamos [o recurso extraordinário], após a proclamação da República, do direito norte-americano" (Comentários ao Código de Processo Civil, vol. 5, n. 317, p. 584).

52 José AFONSO DA SILVA, Do recurso extraordinário no direito processual brasileiro, n. 10, p. 29-30.

53 JOSÉ AFONSO DA SILVA, Do recurso extraordinário no direito processual brasileiro, n. 53, p. 150.

54 JosÉ AFONSO DA SILVA, Do recurso extraordinário no direito processual brasileiro, n. 10, p. 31.
} 
como novidade no art. $61, \S 2^{\circ}{ }^{55}$ Rezava aquele primeiro dispositivo, cuja essência foi mantida, de um modo geral, nas sucessivas Constituições (até 1967) ${ }^{56}$ :

"Art. 59, § $1^{\circ}$ - Das sentenças das Justiças dos Estados, em última instância, haverá recurso para o Supremo Tribunal Federal:

a) quando se questionar sobre a validade, ou a aplicação de tratados e leis federais, e a decisão do Tribunal do Estado for contra ela;

b) quando se contestar a validade de leis ou de atos dos Governos dos Estados em face da Constituição, ou das leis federais, e a decisão do Tribunal do Estado considerar válidos esses atos, ou essas leis impugnadas".

O recurso nasce, pois, atrelado ao federalismo, ainda que esse tenha padecido "de equilíbrio estrutural congênito" em favor das fontes normativas federais, porquanto fruto do desmembramento de um Estado unitário e não de um pacto. Seja como for, reconhecese, já à luz desse texto, a tríplice função da Corte (nessa época composta por quinze Ministros, à luz do art. 56, CF-1891), que perdurou até a Constituição de 1988: exercer o controle de constitucionalidade, garantir a uniformidade de aplicação e preservar a supremacia do Direito federal. ${ }^{57}$

\subsubsection{REFORMA DE 1926}

Com a Reforma de 1926, foi suprimida a hipótese supérflua do art. 61, §2º, mantendo-se as demais (alíneas $a$ e $b$ do art. 59, $\S 1^{\circ}$ ) e acrescentando-se as alíneas $c$ e $d$, que tratavam, respectivamente, do cabimento diante de divergência de interpretação verificada entre tribunais (importante inovação que reforçara a função de uniformização jurisprudencial acometida ao Supremo Tribunal Federal) e de questões de direito criminal ou civil internacional. ${ }^{58}$

\footnotetext{
55 José AfONSO DA SILVA, Do recurso extraordinário no direito processual brasileiro, n. 10, p. 32.

${ }^{56} C f$. AlCidES DE MENDONÇA LiMA, "Recurso extraordinário e recurso especial”, p.136.

${ }^{57} C f$. ARAKEN DE ASSIS, Manual dos recursos, n. 81, p. 685-686 e n. 89, p. 771.

${ }^{58}$ Esta última, na verdade, uma mera transposição da letra $h$ do art. 60 da Constituição de 1891 (cf. JOSÉ AfOnso DA SILVA, Do recurso extraordinário no direito processual brasileiro, n. 12, p. 35).
} 
A alínea $a$, por sua vez, sofreu alteração, substituindo-se a locução "e a decisão fôr contra ela" pela expressão "e a decisão do tribunal lhes negar aplicação". Narra-se que tal emenda tinha por objetivo afastar as dúvidas surgidas em torno do sentido exato do art. 59, $\S 1^{\circ}$, de modo a desautorizar o entendimento - defendido por ninguém menos do que RUY Barbosa, João Mendes Jr. e Pedro Lessa - de que se negava aplicação, nos termos do permissivo, não apenas nos casos em que se deixava formalmente de aplicar uma norma, mas também quando esta havia sido interpretada e aplicada de modo equivocado. ${ }^{59} \mathrm{Com}$ efeito, à luz do texto do art. 59, § $1^{\circ}$, da CF-1891, houve intensa discussão acerca do sentido e do alcance da revisão permitida ao Supremo Tribunal Federal: mais precisamente, em torno do que significaria "questionar sobre a validade, ou a aplicação" das leis. ${ }^{60}$ Por esse prisma, não deixa de causar estranheza o fato de que - ao mesmo tempo em que limitou o cabimento pelas letras $a$ e $b-$ o legislador constitucional inseriu novas hipóteses de admissibilidade do recurso (alíneas $c$ e $d$ ). ${ }^{61}$

Ainda no que toca ao texto constitucional de 1926, é interessante notar que, pela então recém introduzida alínea $c$ (divergência ou dissídio jurisprudencial), estavam legitimados a interpor o recurso também os tribunais envolvidos e o Procurador Geral da

\footnotetext{
${ }^{59}$ Cfr. José Afonso DA SILVA, Do recurso extraordinário no direito processual brasileiro, n. 12 , p. 34 . O autor entende que a intenção da emenda foi acertada, na medida em que visava a afastar "aquela interpretação exagerada que os dispositivos da Constituição não facultavam", considerando-a coerente ao criar, para os problemas de interpretação, a hipótese da letra $c$ (nota 57). Em verdade, contudo, a divergência jurisprudencial é apenas um reforço ao cabimento pela letra $a$, na medida em que esta serve para o controle não apenas da validade das normas, mas também da sua melhor interpretação e aplicação ao caso concreto.

${ }^{60}$ Em síntese precisa da doutrina da época, MATOS PEIXOTO (Recurso extraordinário, p. 137-138) mapeou as diversas posições doutrinárias como segue: "I - os termos validade e applicação do art. n. 59 § 1 da Constituição de 1891 são synonymos e o juiz julga contra ella quando considera a lei revogada; portanto, somente nessa hypothese é admissivel o recurso extraordinario (LUCIO DE MENDONÇA); II - Ditos termos são synonymos e o recurso tem cabimento sempre que a justiça estadual tem a lei federal por invalida, e não somente no caso de consierá-la revogada (JOÃo MONTEIRO); III - As expressões validade e applicação enunciam cada qual conceitos distinctos: o recurso extraordinario tem lugar não só quando a justiça estadual julga invalida a lei federal, mas ainda quando, embora julgando-a valida, deixa de applicá-la; a justiça local é, entretanto, soberana no modo de fazer essa aplicação (CARVALHO DE MENDONÇA, JOÃO BARBALHO, EPITACIO PESSOA, LAFAYETTE); IV - O recurso extraordinario legitima-se quando a justiça local recusa applicar a lei federal e tambem, por importar no mesmo, quando ella julga contra a sua expressa e terminante disposição (AQUinO DE CASTRO, CANDIDO DE OlIVEIRA); V - O recurso extraordinario destina-se a manter a unidade do direito substantivo; não ha causa, fundada em lei federal, em que não se questione sobre a interpretação e applicação della; da decisão da justiça local sobre esse ponto cabe sempre o recurso extraordinario, quer ella declare a lei inapplicavel, quer a interprete ou applique erroneamente (RUY BARBOSA, LAFAYETTE (antiga opinião), JOÃO MENDES); VI - A Constituição, art. 59 § 1 exprime por outras palavras o mesmo que a alinea $c$ do paragrapho único do art. 9 do dec. N. 848, de 1890: consequentemente, desde que a parte invoca uma lei federal para amparar o direito pleiteado e o juiz deixa, por qualquer motivo, de applicar essa lei, tem todo o cabimento o recurso extraordinario (PEDRO LESSA)".
}

${ }^{61}$ Menciona-o Alfredo BuZAID, “A crise do Supremo Tribunal Federal”, n. 13, p. 141. 
República, ${ }^{62}$ e não somente as partes, em sistemática que se aproximava do "recurso no interesse da lei" conhecido em partes da Europa.

\subsubsection{CONSTITUIÇÃo DE 1934}

De seu turno, a Constituição de 1934 (art. 76, III) trouxe alguns pontos dignos de nota, a começar pela menção - pela primeira vez a nível constitucional ${ }^{63}$ - da alcunha recurso extraordinário e pela mudança da denominação do órgão judicial para "Corte Suprema" (que teve vida curta).

Inovou, ademais, ao incluir novo permissivo na letra $a$ - consagrando explicitamente o cabimento do recurso quando houver "decisão contrária a literal disposição de tratado ou lei federal, sobre cuja aplicação se haja questionado" -, excluindo, assim, o anterior entendimento de que somente quando declarada inválida a lei seria possível recorrer ao Supremo Tribunal Federal. ${ }^{64}$ As demais alíneas foram remanejadas, sendo removida do rol a anteriormente mal localizada hipótese que versava "questões de direito criminal ou civil internacional".

Na mesma ocasião, o Tribunal teve sua composição alterada de quinze para onze Ministros (art. 73), ficando autorizada a divisão da Corte em turmas ou seções, às quais seriam distribuídos os feitos $\left(\operatorname{art.} 73, \S 2^{\circ}\right){ }^{65}$

\footnotetext{
${ }^{62}$ Nesse período, o recurso de ofício era facultativo; com o Dec. $n^{\circ} 23.055$, de 9.8 .1933 , tornou-se o recurso ex officio obrigatório, cabendo a sua interposição ao Presidente do Tribunal local ou da Câmara julgadora. Manteve-se o recurso (novamente facultativo) na Constituição de 1934 (art. 76, p. único), que foi, contudo, a última Carta a prever a hipótese.

${ }^{63}$ Cabe lembrar que, até então, o nomen iuris "recurso extraordinário", embora já consagrado em doutrina, havia sido empregado apenas pela Lei n. ${ }^{\circ} 221$, de 1894 (art. 24), que, contudo, designava a impugnação também por "apelação" (arts. 54, IV e 58 - erro corrigido apenas pelo Dec. n. ${ }^{\circ} 1.939 / 1908$ ) pelo Dec. n. ${ }^{\circ}$ 3.084/1898 e, antes de tudo, pelo primeiro Regimento Interno do Supremo Tribunal Federal (de 1891).

${ }^{64} C f$. EduARDo Ribeiro de Oliveira, "Recurso especial - algumas questões de admissibilidade", n. 1, p. 179; Matos PeiXoto, Recurso extraordinário, p. 169.

${ }^{65}$ Consoante destacado por ALFREDo BuZAID, tal orientação "obedecia à política legislativa do Govêrno Provisório, que em 3 de fevereiro de 1931 reduzia a onze o número de ministros (Dec. no 19.656, art. $\left.1^{\circ}\right)$ ".
} 


\subsubsection{CONSTITUIÇÃo DE 1937}

Na subseqüente Constituição de 1937 - restaurado o tradicional nome "Supremo Tribunal Federal" -, a matéria relativa à sua competência recursal extraordinária passou para o art. 101, III, sem alterações relevantes.

É interessante lembrar, entretanto, que na vigência dessa Carta foram promulgados os Códigos nacionais de processo (civil e penal), concretizando-se assim a competência legislativa atribuída à União pela Constituição de 1934 (art. 5º XIX) para regular matéria processual. Como é de fácil intuição, a federalização do direito processual ampliou as hipóteses de cabimento do recurso extraordinário, impactando a Corte com um crescente número de irresignações. ${ }^{66}$ A organização centrípeta da Federação brasileira - não será demais relembrar - é fator importante a ser considerado no acúmulo de serviço dos Tribunais de superposição.

\subsubsection{CONSTITUIÇÃo DE 1946}

A Constituição de 1946 prescreveu, em seu art. 101, III, o cabimento do remédio em relação às "causas decididas em única ou última instância por outros tribunais ou juízes", ampliando, assim, as redações anteriores, que faziam menção apenas às "justiças locais" (Constituições de 1934 e de 1937). O constituinte de 1946 explicitou, ademais, o cabimento em casos de violação ao próprio texto constitucional (letra $a$ ), dando fim a discussões esparsas travadas diante das Constituições anteriores.

Com a criação do Tribunal Federal de Recursos (previsto no art. 103, CF-46) aliviando-se o Supremo Tribunal Federal de suas atribuições de segunda instância para os juízes federais (previstas, anteriormente, nos arts. 76, 2, II, $a$, CF-34, e 101, II, 2, $a$, CF-37) $-{ }^{67}$ passou a ser pertinente o recurso extraordinário não apenas em relação às Justiças dos

\footnotetext{
${ }^{66}$ É conhecida a opinião restritiva sobre o cabimento do recurso extraordinário sustentada por MATOS Pегхото; escrevendo nessa época (1935), afirmou o autor que, do contrário, "quasi todos os feitos propostos perante a justiça estadual iriam ter, mediante recurso extraordinario, ao Supremo Tribunal, pois rara é a causa que não se funda em dispositivo da lei federal. O Supremo Tribunal não poderia, com a organização que se lhe deu, dar vasão à avalanche de feitos vindos da justiça local" (Recurso extraordinário, p. 139). O alerta agravado ainda mais pela superveniência da legislação processual federal - foi, sem dúvida, comprovado pela crise institucional que seguiria.

${ }^{67}$ Ver, sobre isso, Ilmar Galvão, "Poder Judiciário. Reforma de 1988...”, p. 84; OSMAR Mendes PaIXão CÔRTES, Recurso extraordinário, n. 3.2.5, p. 222.
} 
Estados, mas também diante da Justiça Federal. Buscou-se, nessa medida, assegurar por meio de um recurso excepcional também a uniformidade das decisões tomadas por tribunais e juízes federais, ampliando-se assim a função jus-unitária do recurso extraordinário. ${ }^{68}$ A alteração foi sem dúvida acertada: sobre não se justificar a atuação, em grau ordinário, do Supremo Tribunal Federal em todas causas em que for parte a União, é evidente que a necessidade de certificar unidade ao Direito não é própria e exclusiva das Federações (sendo equivocada a necessária associação, feita por muitos autores pátrios, do recurso extraordinário ao federalismo e à dualidade judiciária), mas também diz respeito aos Estados organizados sob formas unitárias (basta recordar a existência dos recursos de cassação europeus). Por igualdade de razões, semelhante competência há de ser reconhecida em face das decisões tomadas por juízes pertencentes ao mesmo ente da federação a que se liga o Tribunal de superposição.

É importante destacar que a Carta de 1946 silenciou, em parte, quanto à locução "questionar" (empregada de variadas maneiras pelos textos anteriores), extirpando-a da letra $a$. A alínea previa o cabimento simplesmente "quando a decisão for contrária a dispositivo desta Constituição ou à letra de tratado ou lei federal'. O fato - interpretado como um silêncio eloqüente (inclusive porquanto permaneceu a alusão ao questionamento no permissivo da letra $b$ ) - levou parte da doutrina a afirmar a supressão da exigência do chamado pré-questionamento, ${ }^{69}$ tese, no entanto, que jamais chegou a consolidar-se.

Ponto digno de nota na história do Supremo Tribunal Federal foi a criação - em 1963, sob a liderança do Min. ViCTOR Nunes LeAL -, da Súmula da Jurisprudência Predominante, por força da Emenda Regimental aprovada em 28 de agosto daquele ano. ${ }^{70}$ Com o expediente, buscou-se de alguma maneira debelar a sobrecarga de processos, mediante a dispensa de referência a outros julgados (assim dispunha, v.g., o art. 98, $\S 5^{\circ}$, RISTF-70), de modo que a inclusão de tese na Súmula chegou a ter relevância no próprio cabimento e conhecimento do recurso extraordinário. ${ }^{71}$ A edição dos enunciados foi feita

${ }^{68}$ Cf. Pontes de Miranda, Comentários ao Código de Processo Civil (de 1973), t. VIII, p. 17-18 e p. 39.

${ }^{69}$ Nesse sentido, mencionando também as outras circunstâncias apotadas no texto: JOSÉ AFONSO DA SILVA, Do recurso extraordinário no direito processual brasileiro, n. 16, p. 38-39.

70 Sobre as circunstâncias históricas em meio às quais nasceu o instituto - voltado para a afirmação da autoridade do Supremo Tribunal Federal, em época em que se encontrava particularmente debilitado o Poder Judiciário -, v. BOTELHO DE MESQUITA, "A súmula da jurisprudência predominante no Supremo Tribunal Federal”, Teses, estudos e pareceres de processo civil, São Paulo: RT, 2005, v. 2, n. 5, p. 220-222.

${ }^{71} C f$. BARBosa Moreira, "Súmula, jurisprudência, precedente: uma escalada e seus riscos", n. 2, p. 300. O Regimento Interno de então previa a possibilidade de se "mandar arquivar o recurso extraordinário ou o 
com grande entusiasmo inicial: até o final de 1964, já havia sido publicado o verbete de n. 472.

Ainda nessa época, nova alteração do número de Ministros componentes da Corte ocorreu por meio do Ato Institucional de $\mathrm{n}^{\circ} 2$ de 1965, que o elevou de onze para dezesseis, sendo três dos Ministros aposentados, ulteriormente, com base no Ato Institucional n. ${ }^{\circ}$ 5/1968. O número de onze Ministros, antecipa-se, foi restabelecido pelo Ato Institucional n. ${ }^{\circ}$ 6/1969, sendo mantido pela Constituição vigente.

\subsubsection{CONSTITUIÇÃO DE 1967/69}

A Constituição de 1967, com a Emenda n. ${ }^{\circ}$ 1, de 1969, previu o cabimento do recurso extraordinário no art. 119, III. ${ }^{72}$ Pelo já mencionado Ato Institucional n. ${ }^{\circ}$ 6/1969, desapareceu a menção anterior a "tribunais e juízes", o que levou à edição do enunciado n. 527 da Súmula/STF, no qual ficou estabelecido não caber o recurso extraordinário de decisões proferidas por juiz singular. ${ }^{73}$

Nessa época, passa o Supremo Tribunal Federal a ter competência para estabelecer, por meio de seu Regimento Interno, a indicação das causas referidas pelas alíneas $a$ e $d$ (art. 119, III, $\left.\S 1^{\circ}, \mathrm{CF} 67 / 69\right)$ e "o processo e o julgamento dos feitos de sua competência" (art. 119, $\S 3^{\circ}, c, \mathrm{CF}-67 / 69$ ), revestindo-se as disposições regimentais de força de lei. ${ }^{74} \mathrm{~A}$ atribuição de poder normativo à Corte possibilitou o ulterior desenvolvimento da argüição de relevância, a que se faz referência no tópico seguinte.

\footnotetext{
agravo de instrumento, indicando o correspectivo número da súmula" (art. 15, IV).

${ }^{72} \mathrm{Na}$ redação original do dispositivo, o recurso era cabível nas "causas decididas, em única ou última instância, por outros tribunais ou juizes", o que implicava a possibilidade de seu manejo contra decisões tomadas em primeira instância. Pelo Ato Institucional n. 6, suprimiu-se a cláusula final, restrição mantida pela Emenda de 1969. Antes da Emenda 1/69, a competência era prevista no art. 114, III (CF-67).

${ }^{73}$ Cf. ARAKEN DE Assis, Manual dos recursos, n. 81, p. 691.

${ }^{74}$ Alfredo BUZAID, "Nova conceituação do recurso extraordinário na Constituição do Brasil", n. 16-18, p. 198-201.
} 


\section{2. “CRISE DO SUPREMO” E TENTATIVAS DE SUA SOLUÇÃo.}

Sem perder o fio da evolução legislativa, cabe salientar que o desenvolvimento ulterior do recurso extraordinário, bem como do ordenamento judiciário brasileiro como um todo, só podem ser compreendidos a partir da notória "crise do Supremo", fenômeno que marcou profundamente a história da Corte. ${ }^{75} \mathrm{O}$ tema, foi dito recentemente, "não saiu da ordem do dia [e] nela permanece há mais de meio século". ${ }^{76}$

A ela já se referia doutrina, em termos alarmantes, sob a égide da Constituição 1946. ${ }^{77}$ Como se viu, a implementação da Súmula da Jurisprudência Predominante, em 1963, denotava justamente uma preocupação com o número excessivo de recursos endereçados à Corte, buscando, acima de tudo, racionalizar a tomada de decisões. Antes mesmo disso, em verdade, as inúmeras discussões doutrinárias (à luz da primitiva regulação do recurso pelo art. 59, $\S 1^{\circ}, \mathrm{CF}-1891$ ), bem como as intervenções legislativa buscando restringir o cabimento recursal às hipóteses de estrita negativa de vigência da lei, já tinham à sua base uma inquietação quanto à possibilidade do aumento desmesurado do âmbito de atuação do Tribunal e dos números correlatos.

O verbete n. $^{\circ} 400^{78}$ da Súmula/STF, publicado em 1964, pode ser visto como uma primeira tentativa séria de solução da crise do Supremo. ${ }^{79}$ Nasceu do pressuposto de que apenas a interpretação aberrante da letra da lei ensejaria o recurso extraordinário, passando ao largo do controle do Supremo Tribunal Federal o entendimento razoável. Buscava-se, em alguma medida, fechar a válvula aberta pela Constituição de 1934, que admitia, ao

\footnotetext{
${ }^{75}$ Veja-se AlFredo BUZAID, “A crise do Supremo Tribunal Federal”, passim.

${ }^{76}$ Helcio AlVES de AsSUMPÇÃo, “Recurso extraordinário...”, n. 1, p. 260.

${ }^{77}$ Por todos, JOSÉ AfONSO DA SILVA, Do recurso extraordinário no direito processual brasileiro, esp. n. 206216 , p. 446-461 (descrevendo a "crise do Supremo" e oferecendo uma proposta de solução que veio a consagrar-se com a criação do Superior Tribunal de Justiça pela Constituição de 1988).

${ }^{78}$ Assim redigido: "Decisão que deu razoável interpretação à lei, ainda que não seja a melhor, não autoriza recurso extraordinário pela letra "a" do Art. 101, III, da Constituição Federal".

79 Antes, foram concebidos outros mecanismos, de menor alcance ( $c f$. HELCIO ALVES DE ASSUMPÇÃO, "Recurso extraordinário...", n. 1, p. 261-262, reportando-se a ensaio de CALMON DE PASSOS). Primeiro: a triagem dos recursos pela instância local (Lei n. $\left.{ }^{\circ} 3.396 / 1958\right)$. Segundo: a Súmula da jurisprudência predominante (implantada em 1963), já mencionada no texto. Terceiro: emenda regimental permitindo que os relatores convocassem as partes litigantes no procedimento do recurso extraordinário pendente há mais de dez anos, a fim de se pronunciarem sobre o interesse no seu andamento.
} 
contrário dos textos anteriores, a impugnação sempre que se contrariasse o texto legal, sem que se tivesse necessariamente de declará-lo inválido. ${ }^{80}$

A tendência iniciada com a "Súmula 400" desembocou no instituto da argüição de relevância. ${ }^{81}$ Como visto, o mecanismo foi fruto do poder normativo atribuído à Corte pelas regras da Constituição de 1967/69. Inicialmente, esta representava um obstáculo casuístico à admissão do recurso extraordinário, por meio da enumeração, no Regimento Interno, das hipóteses em que a impugnação não seria conhecida. Assim, a partir de 1970, o Regimento Interno do Supremo Tribunal Federal passou a indicar causas em que ficava afastado o cabimento do recurso, atendendo à sua natureza, espécie e valor pecuniário (art. 308), ressalvada a "ofensa à Constituição ou [a] discrepância manifesta da jurisprudência predominante no Supremo Tribunal Federal'.

De acordo com o poder constitucionalmente previsto (originariamente, no parágrafo único do art. 119, CF-67/69 ${ }^{82}$ ), a Emenda Regimental n. 3 , de 12.06.1975, introduziu e disciplinou a relevância da questão federal como requisito de admissibilidade do recurso extraordinário, a ser argüida nas hipóteses indicadas (art. 308, RISTF). A expressão foi alçada ao texto da Constituição pela Emenda Constitucional n. ${ }^{\circ} 7 / 77$ (outorgada com o pacote de abril); o art. 119, III, $\S 1^{\circ}$, CF 67/69, passou a prescrever, então, que as causas referidas nas letras $a$ e $d$ seriam “indicadas pelo Supremo Tribunal Federal, que atenderá à sua natureza, espécie, valor e relevância da questão federal". O rol de casos em que o recurso não era conhecido foi ampliado sucessivamente, operando a relevância como forma de exclusão do impedimento regimental.

Sobreveio nova alteração regimental (com a Emenda n. ${ }^{\circ}$ 2, de 04.12.1985, que passou a vigorar a partir de $\left.01^{\circ} .02 .1986\right)$, acompanhada de alteração na técnica de seleção dos recursos: ao invés de indicar as situações de inadmissibilidade, o texto arrolou hipóteses de cabimento (ao longo de dez incisos), conjugadas com uma negativa geral. Manteve, no entanto, no inc. XI, uma abertura para os demais feitos em que viesse a ser

\footnotetext{
${ }^{80}$ EDUARDo RIBEIRO DE OlIVEIRA, “Recurso especial - algumas questões de admissibilidade”, n. 1, p. 180181 .

${ }^{81}$ Cf. ARRUDA AlVIM, “O antigo recurso extraordinário e o recurso especial...”, n. III. p. 153.

82 "Parágrafo único. As causas a que se refere o item III, alíneas a e d, dêste artigo, serão indicadas pelo Supremo Tribunal Federal no regimento interno, que atenderá à sua natureza, espécie ou valor pecuniário". Com a Emenda 7/77 à Constituição, o texto recebe nova redação e é alocado no $\S 1^{\circ}$ : "As causas a que se fere o item III, alíneas a e d, deste artigo, serão indicadas pelo Supremo Tribunal Federal no regimento interno, que atenderá à sua natureza, espécie, valor pecuniário e relevância da questão federal".
} 
reconhecida a relevância. Esta última funcionava como uma "válvula de escape" voltada a afastar os óbices regimentais, inspirada no writ of certiorari americano. ${ }^{83}$ Ficou marcada a passagem de um "critério negativo específico" para um "critério positivo extremamente restrito, e negativo geral". ${ }^{84} \mathrm{O}$ art. $317, \S 1^{\circ}$, RISTF, atribuía poder discricionário aos Ministros para decidir acerca da relevância - "considerados os aspectos morais, econômicos, politicos e sociais da causa". A deliberação a seu respeito era realizada em sessão secreta, o que atraiu veementes críticas da doutrina. Talvez por isso, a vida da argüição de relevância foi interrompida, bruscamente, pela obra do constituinte de 1988.

\subsection{A Constituição de 1988, o Superior Tribunal de Justiça E o recurso ESPECIAL.}

A Constituição da República de 1988 efetuou significativas mudanças em todo o ordenamento judiciário brasileiro. Assim, v.g., extinguiu o antigo Tribunal Federal de Recursos, criando, no seu lugar, os atuais Tribunais Regionais Federais. No plano específico dos Tribunais Superiores, retirou a competência regimental da Corte Suprema para "legislar" em matéria processual afeta à sua órbita de julgamento, extinguindo de um só golpe a argüição de relevância. E, no que aqui interessa de perto, repartiu a competência recursal extraordinária do Supremo Tribunal Federal, delegando a apreciação das impugnações versando temas de direito federal infraconstitucional ao recém instituído Superior Tribunal de Justiça, composto pelo número mínimo de trinta e três ministros.

Trata-se, possivelmente, da "solução [...] mais radical da história do recurso extraordinário" ao problema da crise do Supremo. ${ }^{85}$ A grande inovação, como é de conhecimento geral, atendeu a uma sugestão doutrinária de JOSÉ AFONSO DA SILVA, autor que preconizara, em 1963, a criação de "um Tribunal Superior correspondente ao TSE e ao TST para compor as estruturas judiciárias do direito comum”, denominando-o, em sua obra, "Tribunal Superior de Justiça", e batizando de "recurso especial" a respectiva

\footnotetext{
${ }^{83} C f$. NELSON NeRY JR., Teoria geral dos recursos, n. 2.3.4.4, p. 100 e ss.; BARBosa MoreIRA, “A Suprema Corte norte-americana: um modelo para o mundo?", n. 8, p. 248-250.

${ }^{84}$ ARruDA AlVIM, "O recurso especial na Constituição Federal de 1988 e suas origens", n. 1.4, p. 29. Ver, ainda, ARAKEN DE AsSIS, Manual dos recursos, n. 84.1.4, p. 708; HeLCIO ALVES DE ASSUMPÇÃO, "Recurso extraordinário...”, n. 1, p. 263.

${ }^{85}$ Helcio AlVES DE ASSUMPÇÃo, “Recurso extraordinário...”, n. 1, p. 263.
} 
impugnação. ${ }^{86}$ A idéia foi reafirmada, poucos anos depois, em mesa redonda reunida na Fundação Getúlio Vargas. ${ }^{87}$

Instalado em sete de abril de $1989,{ }^{88}$ o Superior Tribunal de Justiça foi criado, pelo constituinte de 1988, na esperança de "desafogar" o Supremo Tribunal Federal de "pletoras de processos" que ali chegavam, buscando concentrar as tarefas deste último em torno da guarda da Constituição, aproximando-o do plano de uma verdadeira Corte Constitucional. ${ }^{89}$ Nessa linha, as impugnações voltadas a discutir problemas atinentes à aplicação do direito federal comum (e não daquele consubstanciado na Constituição) passaram a ser de competência do novo Tribunal, por meio do recurso especial (art. 105, III, CF), reservado ao Supremo o impropriamente chamado contencioso constitucional (art. 102, III, CF). Foi instaurada, assim, uma bifurcação recursal, sendo cabíveis, muitas vezes, os dois recursos (especial e extraordinário) de uma mesma decisão dos tribunais de apelação (calcada que seja em fundamento infraconstitucional e constitucional), sistemática que, como será visto, não fica imune a perplexidades e dificuldades as mais diversas.

A Constituição vigente seguiu o projeto assinado pela Comissão Provisória de Estudos Constitucionais (“Comissão de Notáveis”), atribuindo ao novel Superior Tribunal de Justiça competências originária, recursal ordinária e recursal extraordinária. Com relação a esta última - e excluída, por óbvio, a matéria constitucional -, o art. 105, III, CF, reproduziu, com apenas pequenas diferenças de redação, textos constitucionais das Cartas de 1967 (na versão originária), 1946, 1937 e 1934. ${ }^{90}$ Assim sendo, a Corte possui competência para julgar as causas decididas, "em única ou última instância", por tribunais estduais, distrital e regionais federais "quando a decisão recorrida a) contrariar tratado ou lei federal, ou negar-lhes vigência; b) julgar válido ato de governo local contestado em face de lei federal; c) der à lei federal interpretação divergente da que lhe haja atribuído

\footnotetext{
${ }^{86}$ Do recurso extraordinário no direito processual brasileiro, n. 212, p. 454-457.

${ }^{87}$ Consoante narra, entre outros, RICARDO ARNALdo MALHEIROS FIUZA, "Superior Tribunal de Justiça: 'guardião do direito federal comum,", n. 2, p. 315-316.

${ }^{88}$ Composto, inicialmente, de vinte e seis Ministros, aos que se somaram, no dia 18 de maio de 1989, mais sete, atendendo ao quorum mínimo de trinta e três. A composição inicial é referida, na íntegra, por RICARDO ARnAldo MALheiros FiUZA, “Superior Tribunal de Justiça: 'guardião do direito federal comum”, n. 4, p. 319-320.

${ }^{89}$ ALCIDES DE MENDONÇA LiMA, "Recurso extraordinário e recurso especial”, p. 138-139.

${ }^{90}$ ALCIDES DE MENDONÇA LIMA, "Recurso extraordinário e recurso especial”, p. 141.
} 
outro tribunal" (art. 102, III, CF, com a redação dada pela EC 45/04).

A nova Corte inseriu-se na tradição da antiga: aplicou e aplica, com certa constância, os enunciados sumulares do Supremo Tribunal Federal, mormente no que se relaciona com a admissibilidade do recurso especial. É essa uma circunstância natural do desmembramento deste do extraordinário. Não deixou o Superior Tribunal de Justiça, todavia, de lançar-se também com vigor na atividade normativa em questão; exercendo competência sobre conflitos compreendendo todo o direito federal comum, fixou, em dezembro de 2010, nada menos que o verbete de . $^{\circ} 470$ da sua própria Súmula.

Se num primeiro momento comentários dos mais otimistas puderam ressaltar "a surpreendente celeridade nos julgamentos pelo Superior Tribunal de Justiça", 91 não tardou para que se manifestassem novamente os velhos problemas ligados ao volume excessivo e à lentidão dos processos, agravados pela massificação dos litígios e pelo crescimento da população. A crise passou a ser referida no plural, atingindo, agora, não apenas um, mas ambos os Tribunais de superposição (o velho e o novo).

Suprimiram-se, consoante já anotado, os óbices regimentais antes existentes para o recurso extraordinário (argüição de relevância) - objeto das mais acirradas críticas doutrinárias -, que, assim, não chegaram a conviver lado a lado com o recurso especial. ${ }^{92}$ Entretanto, a plena tomada de consciência da função objetiva acometida ao Supremo Tribunal Federal - aliada à nova crise (ou ao perdurar de um estado constante de crise) levou à instituição, por meio da Emenda Constitucional n. ${ }^{\circ} 45 / 2004$, da repercussão geral da questão constitucional, como requisito sui generis de admissibilidade do recurso extraordinário (art. 102, § $3^{\circ}, \mathrm{CF}$; art. 543-A, CPC). O mecanismo inspira-se, em boa dose,

\footnotetext{
${ }^{91}$ CÂNDIDO DINAMARCO, "Superior Tribunal de Justiça e acesso à ordem jurídica justa", n. 3, p. 253. Outros, entretanto, corretamente vaticinaram o contrário: "tenho para mim que vai ocorrer com o tempo, sensível congestionamento no âmbito do Superior Tribunal de Justiça, como resultado dessa transposição de competências. Teremos, sem dúvida, um Tribunal agigantado, com os seus inconvenientes" (DJACI FALCÃO, "O Poder Judiciário e a nova Carta Constitucional", n. 5, p. 205). Para Helcio Alves DE AssuMPÇÃO, "[d]ecorridos mais de 17 anos da vigência da Carta de 1988, parece lícito dizer que a realidade não confirmou qualquer otimismo que a reordenação empreendida possa ter alimentado" ("Recurso extraordinário...”, n. 1, p. 264).

92 Tais óbices regimentais - resultantes, no dizer de ALCIDES DE MENDONÇA LIMA, de "esdrúxula competência" ("Recurso extraordinário e recurso especial", p. 139) inserida no art. 119, $\S 1^{\circ}$, da CF-67 pela Emenda n. ${ }^{\circ} 7 / 77$ - não foram, segundo o Min. COSTA LEITE, "jamais assimilados pela consciência jurídica nacional" ("Recurso especial: admissibilidade e procedimento", p. 191).
} 
na antiga argüição de relevância (e nas figuras análogas encontradas no Direito estrangeiro; v., infra, $\left.\S 3^{\circ}\right) .{ }^{93}$

Os critérios para sua aferição podem envolver pontos de vista econômicos, políticos, sociais, ou jurídicos (art. 543-A, CPC). Alega-se não se tratar de apreciação discricionária, até porque as decisões a seu respeito deverão, ao contrário da antiga argüição de relevância, ser motivadas. ${ }^{94}$ Entretanto, é difícil negar que a liberdade conferida aos Ministros na apreciação do que sejam "questões relevantes do ponto de vista econômico, político, social ou jurídico, que ultrapassem os interesses subjetivos da causa" é enorme. E não poderia ser diferente, já que a decisão apresenta cunho marcadamente político (no sentido próprio do termo), ${ }^{95}$ à semelhança do writ of certiorari norteamericano (criado em 1925 e, hoje, peça fundamental do controle exercido pela Suprema Corte sobre o seu docket). Trata-se de margem de liberdade (ou discricionariedade, a depender dos contornos conferidos a esse conceito) positiva e indispensável ao bom cumprimento da função da Corte, e não de instituto arbitrário, como parece a alguns.

Até o momento, não há mecanismo semelhante previsto para o Superior Tribunal de Justiça. É interessante notar que, com a atual sistemática dos recursos excepcionais, se inverteu a exigência de importância da questão debatida: a antiga argüição de relevância dizia respeito justamente às questões de direito federal infraconstitucional, porquanto o recurso extraordinário fundado em contrariedade a preceito da Constituição era admissível sem qualquer outro requisito; a atual repercussão geral (art. 102, § 3, $\mathrm{CF}$; art. 543-A,

\footnotetext{
${ }^{93}$ Embora alguns busquem negar qualquer assimilação. Segundo ARAKEN DE ASSIS, não se deve identificar a atual repercussão geral com o antigo instituto da argüição de relevância. A um, porque esta atuava como óbice ao conhecimento de questões federais, excluída do seu âmbito a ofensa à Constituição, enquanto a repercussão geral diz respeito justamente à matéria constitucional. A dois, porquanto a argüição de relevância era um mecanismo de inclusão, ao passo que o novel instituto funciona como elemento de exclusão da admissibilidade do recurso. A três, há sensíveis dessemelhanças no que tange ao procedimento: a argüição configurava incidente próprio, subordinado à iniciativa da parte recorrente; já a repercussão geral é demonstrada como preliminar recursal, situada no âmbito de admissibilidade da impugnação. A quatro, diante das diferentes previsões constitucionais em relação à publicidade e motivação das decisões, tais exigências eram dispensadas no regime anterior, sendo de rigor atualmente. Por fim, a argüição de relevância dependia do voto de quatro ministros, preponderando a opinião da minoria, enquanto a repercussão só será negada diante do pronunciamento de dois terços (oito) dos integrantes da Corte (Manual dos recursos, $\mathrm{n}$. 84.1.4.1, p. 709-710). Algo nesse sentido, LuIZ GUILHERME MARINONI - DANIEL MitidiERo, Repercussão geral no recurso extraordinário, n. 2.1, p. 30-31; HelCIO ALVES DE ASSUMPÇ̃̃O, "Recurso extraordinário...", n. 2.5, esp. p. 294-295; BRUNO DANTAS, Repercussão geral, n. 5.3, p. 249-250.

94 Nesse sentido, CRUZ E TUCCI, “A 'repercussão geral' como pressuposto de admissibilidade do recurso extraordinário", n. 2, p. 433, que destaca, adiante (op. cit., n. 4, p. 436-437), a necessidade de fundamentação adequada.

${ }^{95} C f$. ARrudA AlviM, “A EC n. ${ }^{\circ} 45$ e o instituto da repercussão geral”, p. 64.
} 
$\mathrm{CPC}$ ), pelo contrário, restringe-se ao fundamento constitucional e, pois, ao atual recurso extraordinário.

Trata-se de uma distinção absolutamente incoerente: a ser aplicado um mecanismo de seleção dos recursos com base na relevância das questões constitucionais discutidas, com maior razão isso deve ser feito com relação a temas de direito infraconstitucional. As normas constitucionais - justamente por sua posição hierárquica no ordenamento - são, ao menos presumidamente (embora uma inferência geral seja colocada em xeque pelo caráter pródigo e analítico da Constituição), mais importantes do que a legislação complementar ou ordinária e do que outros tipos de atos normativos - medidas provisórias, regulamentos etc. Evidentemente, não se está a defender a extinção da repercussão geral, mas $\operatorname{sim}-\mathrm{e} a$ fortiori - a criação de filtro análogo para o recurso especial, à luz da função específica do Superior Tribunal de Justiça no ordenamento judiciário.

Fora a instituição da repercussão geral, o panorama dos recursos excepcionais no direito constitucional brasileiro manteve-se, em síntese, inalterado sob a vigência da Constituição de 1988, com exceção da redistribuição de uma das hipóteses originais de cabimento do recurso especial (antigo art. 105, III, $b$ ) - versando conflito entre lei local e lei federal -, que passou, com a Emenda Constitucional 45/04, a integrar o rol de permissivos do recurso extraordinário (novo art. 102, III, b). No plano infraconstitucional, o procedimento a ser observado no julgamento dos recursos foi detalhado pela Lei $\mathrm{n}$. 8.038/90 (arts. 26/29), passando, depois, integralmente ao Código de Processo Civil (arts. $541 / 546$ ), este pontualmente retocado pelas Leis n. ${ }^{\circ} 8.950 / 94$ e n. ${ }^{\circ} 10.352 / 01$. Alterações mais significativas instituíram o regime de retenção (art. 542, $\S 3^{\circ}, \mathrm{CPC}, c f$. Lei n. ${ }^{\circ}$ 9.756/98) e o julgamento de recursos especiais repetitivos (art. 543-C, CPC, $c f$. Lei n. ${ }^{\circ}$ 11.672/08), bem como o procedimento da repercussão geral para o recurso extraordinário (arts. 543-A e 543-B, CPC, $c f$. Lei n. $\left.{ }^{\circ} 11.416 / 06\right)$.

Ademais, os anos após a Constituição de 1988 testemunharam a introdução de uma série de dispositivos outorgando maior peso e importância às decisões dos Tribunais de superposição, tomadas agora como precedentes judiciais dotados, em alguma medida, de força normativa (v.g., arts. 518, $\S 1^{\circ}, 557$, caput e $\S 1^{\circ}$-A, 475, $\S 3^{\circ}$, e $555, \S 1^{\circ}, 285-\mathrm{A}$, todos do CPC). ${ }^{96}$ Tema análogo, objeto de acirradas discussões, é o da súmula vinculante,

\footnotetext{
${ }^{96}$ Ver, sobre o ponto, CRUZ E TUCCI, Precedente judicial como fonte de direito, cap. VIII, n. 2.1.1, p. 259 e ss.
} 
instituída também pela EC 45/04 (art. 103-A, CF). Com base no poder que the foi outorgado pela Constituição, o Supremo Tribunal Federal pode (por meio do procedimento previsto pela Lei n. $\left.{ }^{\circ} 11.417 / 06\right)$ "aprovar súmula que, a partir de sua publicação na imprensa oficial, terá efeito vinculante em relação aos demais órgãos do Poder Judiciário e à administração pública direta e indireta".

Essa, em brevíssimas linhas e reduzida aos seus termos mais simples, é a aproximação histórica ao tema objeto de estudo: Superior Tribunal de Justiça e recurso especial. 


\section{§ 3 - INVESTIGAÇÃO DE DIREITO COMPARADO}

\subsection{COMPARAR POR QUÊ?}

“Perché sì, e tanto basti”, respondeu VINCENZO VigORITI. ${ }^{97}$

Em que pese a afirmação categórica e a autoridade do jurista citado, é necessário justificar a opção aqui feita por enveredar pela investigação comparada. E parece fácil dar razões de sobra para tanto. No seu estágio atual, a ciência processual civil não deve preocupar-se apenas com uma interpretação estanque do direito positivo nacional, mas também - principalmente em tempos de intensa reforma (e, a fortiori, de verdadeira recodificação) - com a busca de novos modelos que possam contribuir tanto para a melhor compreensão do direito vigente quanto para a alteração e para o aperfeiçoamento do sistema de administração da justiça. ${ }^{98}$

Avulta a importância, nesse contexto, dos estudos de Direito comparado, sobretudo diante da crescente aproximação entre culturas e da constatação da existência uma série de problemas que se podem dizer comuns a praticamente todo e qualquer sistema jurídico ocidental contemporâneo. A comparação - quando bem feita - força a reflexão a partir de ângulos diferentes, amplia o diálogo teórico e contribui para uma valoração realista das próprias instituições.

Frente a tal necessidade, mesmo soluções adotadas por famílias jurídicas tradicionalmente contrapostas apresentam grande utilidade como objeto de investigação e parâmetro de valoração. É certo que juízes, legisladores e professores ocupam posições diferentes nos dois modelos, ${ }^{99}$ mas a ninguém é dado ignorar que a clássica summa divisio

\footnotetext{
97 "Sul metodo comparativo", n. 2, p. 862.

98 "Jurisprudence is not just the science of interpreting national laws, statutes, legal principles, rules and standards. It should comprise the search for models of preventing and solving social conflicts within a worldwide society. In looking what has been done beyond the own borders comparative law offers incentives and a broader scope of models of solving a problem that could be and have been developed within national boundaries. Lawyers of all legal systems of the world are by far more imaginative than one lawyer could think up within his short life. Comparative law thus may be an 'ecole de verite', enrich the 'stock of possible solutions', and moreover offer the chance to find better solutions for the particular time and the particular country than by restricting to local or national doctrinal disputes" (PETER GOTTWALD, "Comparative civil procedure", n. 1, p. 23).

${ }^{99}$ R. C. VAN CAENEGEM, Juizes, legisladores e professores, cap. 1, p. 37 e ss.; ARTHUR T. VON MEHREN JAMES R. GORDLEY, The civil law system, cap. 16, p. 1146-1148, p. 1150: “o juiz é o herói do common law,
} 
feita entre civil law e common law - baseada no papel decisivo atribuído, respectivamente, à lei (lex) ou ao precedente (ius) no quadro das fontes do Direito ${ }^{100}-$, perdeu hoje bastante do seu sentido. ${ }^{101-102}$

A influência estrangeira é, ademais, uma constante na tradição do direito brasileiro; o próprio recurso extraordinário, como se viu, nasceu de instituto análogo do direito norteamericano (writ of error). ${ }^{103} \mathrm{Nada}$ impede - e tudo aconselha, em verdade - que se busquem subsídios no direito comparado, mantendo-se sempre, é claro, os cuidados que todo esforço de comparação exige. ${ }^{104}$

\subsection{CRITÉRIOS DE COMPARAÇÃO E MODELOS OU TIPOS IDEAIS}

No que interessa para os fins do presente trabalho, cabe utilizar a investigação comparada para valorar o papel desempenhado pelos Tribunais Superiores no cenário

enquanto o legislador e o grande comentarista são os heróis do civil law" ["the judge is the hero of the common law, whereas the legislator and the great commentator are the heroes of the civil law"].

${ }^{100} \mathrm{O}$ direito inglês, como se sabe, manteve-se imune aos influxos da recepção do direito romano-canônico ocorrida no continente europeu nos séculos XII e XIII através do estudo do Corpus Iuris Civilis, inclinandose, desde o início, por uma metodologia de invocação de precedentes (case law) como fontes do Direito. V., sobre isso, CRUZ E TUCCI, Precedente judicial como fonte do direito, cap. VI, n. 1, p. 149-154.

${ }^{101}$ Nesse sentido, entre muitos outros, ver MiCHELE TARUFFO, "Precedente e giurisprudenza", n. 1, p. 796; ALESSANDRO PIZZORUSSO, "Le sentenze dei giudici costituzionali tra diritto giurisprudenziale e diritto legislativo", p. 551 e ss.; GUY CANIVET, “Activisme judiciaire et prudence interprétative”, p. 9 e ss.; JERZY WRÓBLEWSKY, "Problems of judicial reasoning in civil law and common law systems", p. 188.

102 O que não implica, todavia, desconhecer outros pontos de contraste: "A diferença entre o common law e o Direito continental vai muito além disso: eles não apenas foram desenvolvidos por órgãos diferentes, mas sua própria substância era diferente, sendo um deles tradicional, nativo e feudal e o outro novo, estrangeiro e romano. Um sistema jurídico baseado em princípios feudais, apesar de adaptado e modernizado no decorrer dos séculos, e um sistema jurídico baseado nas doutrinas e princípios nada feudais do Direito romano e neorromano estão a mundos de distância, não apenas nas suas várias técnicas de legislação, mas nas suas próprias fundações" (R. C. VAN CAENEGEM, Juizes, legisladores e professores, cap. 3, p. 79 e ss.).

$103 \mathrm{O}$ direito público brasileiro buscou desde cedo subsídios no mundo anglo-saxão (em especial, no federalismo norte-americano), ao passo que o direito privado e o direito processual mantiveram-se, em boa dose, fiéis ao direito continental europeu, dando lugar a um "convívio sui generis" entre civil e common law que "iria marcar toda a posterior evolução do ordenamento pátrio" ( $c f$. BARBOSA MOREIRA, "A importação de modelos jurídicos", n. 3, p. 260). Entretanto, o direito processual vem recebendo crescente influência dos modelos de common law, tema no qual devem ser lembradas novamente as observações de BARBOSA MOREIRA ("O processo civil brasileiro entre dois mundos", esp. n. 5-11, p. 44-52) no sentido de destacar que o processo brasileiro e o norte-americano "se distanciam em aspectos capitais" (sobretudo no campo probatório), sem negar, contudo, "o peso do universo anglo-saxônico" entre nós; v., ainda, LEONARDO GRECO, "Paradigmas da Justiça contemporânea e acesso à justiça", n. 1.1, p. 4-5; CÂNDIDO DINAMARCO, "O futuro do processo civil brasileiro", n. 45, p. 128-131.

104 Tal como adverte CÂNDIDO DINAMARCO, "Processo civil comparado", n. 66-71, p. 168-177. 
jurídico contemporâneo, como ponto de partida para a reflexão sobre a função do Superior Tribunal de Justiça.

Nesse campo, algumas perguntas invariavelmente vêm à mente do pesquisador: como funcionam essas Cortes? Como é possível ao litigante chegar até elas? Que papel desempenham na sociedade em que estão inseridas? Visam sobretudo à uniformização da jurisprudência por meio de seus precedentes ou voltam-se para um controle amplo da legalidade das decisões emanadas dos órgãos inferiores? Que mecanismos utilizam para realizar de maneira ótima as suas atividades? Qual é o escopo de seus julgamentos? Como se enquadram no ordenamento judiciário de seu país?

Numa tentativa de resumir essas indagações debaixo de alguns poucos critérios, reduzindo os problemas aos seus termos mais simples e imprimindo assim alguma unidade à pesquisa, parece adequado analisar três pontos principais São eles, em síntese: I) a sistemática de admissibilidade dos recursos excepcionais - i.e, existe um direito subjetivo da parte ao conhecimento do recurso ou pode o Tribunal, de alguma forma, filtrar e escolher os casos em que deve atuar?; II) que tipo de função é acometida à Corte (de orientação ou de controle dos demais juízes) e qual é o valor de suas decisões enquanto precedentes (vinculantes, persuasivos ou nenhum)?; III) uma vez admitido o recurso, como se dá a atuação do Tribunal Superior (cassa a decisão e reenvia o processo ou aplica ele mesmo o direito à espécie) e qual é o seu âmbito material de competência à luz da Constituição e dos atos administrativos?

Estabelecido o tertium comparationis, é possível antecipar a existência de três grandes modelos de Cortes Supremas e de seus respectivos recursos excepcionais. São eles a cassação, a revisão e o appeal. ${ }^{105}$

Evidentemente, estamos a lidar com tipos ideais, ou seja, categorias aproximadas que não se reproduzem, concretamente, em um dado sistema positivo. Por isso, é duvidoso contrapô-las como espécies mutuamente excludentes. Melhor será compreender a relação entre elas existente como um continuum, de modo que um dado sistema jurídico pode inserir-se em algum ponto do espectro de acordo com o número maior ou menor de características que ostenta perante cada um dos tipos.

\footnotetext{
${ }^{105} C f$., entre outros, MiCHAL BOBEK, "Quantity or quality? Reassessing the role of Supreme Jurisdictions in Central Europe", n. I, p. 38-39.
} 
Num dos extremos fica o modelo de cassação, cujos traços fundamentais consistem no âmbito limitado de julgamento (apenas anulam a decisão recorrida) e na asseguração do meio de impugnação como um direito subjetivo do litigante (sem o uso de mecanismos de seleção). As Cortes de Cassação são organismos de grande porte, por vezes com centenas de magistrados, que conhecem e julgam dezenas de milhares de recursos por ano (algo perto de trinta mil). ${ }^{106}$ Os exemplos mais marcantes dessa experiência são a Itália e a França, países cuja doutrina, apesar da filiação anglo-saxônica do recurso extraordinário brasileiro (inspirado no writ of error estadunidense), exerceu e continua a exercer grande influência sobre nós.

$\mathrm{Na}$ outra ponta está o modelo do appeal, próprio dos países de common law. Os traços anteriormente apontados agora se invertem: às Supreme Courts (dos Estados Unidos e da Inglaterra) é dado julgar o caso diretamente. Mais importante do que isso, lhes é conferido um larguíssimo poder discricionário na escolha dos recursos a serem apreciados, i.e, no controle de sua docket. Em razão disso, contam elas com poucos magistrados - são nove os Justices da Suprema Corte norte-americana, por exemplo - e julgam menos de uma centena de casos por ano.

Entre os dois modelos já apontados, flutuam as Cortes de revisão. Nelas, capitaneadas pelo Bundesgerichtshof (BGH) alemão, podem ser visualizadas características intermediárias entre a cassação e o appeal, ainda que, em tempos recentes, seja nítida a aproximação com esse último modelo. Hoje, a maior parte dos Tribunais de Revisão pode julgar imediatamente a causa e é beneficiada por um mecanismo de filtragem, ainda que a seleção dos recursos seja feita com base em critérios legais objetivamente estabelecidos. Portanto, a discricionariedade é menor em comparação com aquela acolhida no common law, o que obriga algumas Cortes, segundo certos autores, a oferecer uma argumentação bastante complicada a respeito da inadmissão de um recurso. ${ }^{107}$ Há, no entanto, um certo domínio sobre a carga de trabalho: o órgão alemão, $v . g .$, julga, em média, três mil causas por ano. ${ }^{108}$

106 Segundo informações da própria Corte (http://www.cortedicassazione.it/ Documenti/StatisticaAGCIVILE2010.pdf), em 2009 foram: I) recebidos 28.418 e II) julgados 31.253 recursos, ficando pendentes ainda 96.233 impugnações.

${ }^{107} \mathrm{O}$ que leva esses mesmos autores a sugerir a dispensa de motivação em tais casos. V., nesse sentido, à luz do sistema tcheco - que segue justamente o modelo de revisão -, no qual o Tribunal gasta a maior parte do tempo arrazoando as decisões de inadmissão (destino reservado a cerca de $90 \%$ dos recursos interpostos), MiCHAL BOBEK, "Quantity or quality? Reassessing the role of Supreme Jurisdictions in Central Europe", 


\subsection{ACESSO À CORTE}

\subsubsection{POSSIBILIDADE DE SELEÇ̃̃o DOS RECURSOS}

O primeiro e mais importante fator para a compreensão da função deferida a um Tribunal Superior é revelado pelo equacionamento feito entre a posição jurídica do litigante e o controle de admissibilidade dos recursos pela Corte. Uma primeira análise pode diferenciar os sistemas jurídicos segundo os três modelos de recursos já mencionados: appeal, cassation e Revision. ${ }^{109}$

Por um lado, predomina a noção de que as Cortes Supremas detêm ampla discricionariedade para escolher, dentre os recursos a ela endereçados, aqueles que merecem ser julgados, segundo seu juízo de conveniência e oportunidade (i.e, segundo a sua sound judicial discretion). Assim, de fato, é no procedimento de appeal, típico do common law (v.g., Estados Unidos da América e Inglaterra).

Já nos países de civil law - com algumas exceções e ressalvada a atual tendência em sentido contrário -, prepondera a orientação segundo a qual os litigantes têm um verdadeiro direito subjetivo ao recurso excepcional, como poder integrante da própria noção de devido processo legal. O Tribunal Superior atuaria, assim, não apenas (ou não predominantemente) no desenvolvimento do Direito, mas sobretudo na correção de erros específicos em casos concretos. É o que ocorre no modelo cassacional (sobretudo, França e Itália).

American Journal of Comparative Law, 2009, vol. 57, n. II, p. 49-50. O autor argumenta que "o tempo e os recursos da Corte não seriam então gastos em argumentação inútil de por que a revisão não é admissível, mas ao invés disso canalizados para uma análise mais profunda dos casos que são admissíveis", o que aproximaria o sistema do modelo de appeal. Noticia, ainda, que semelhante alteração legislativa foi realizada no ano de 2000, mas a dispensa de motivação nas decisões de inadmissão da revision foi considerada inconstitucional pela Corte Constitucional de seu país (op. cit., p. 50). Lá, a Corte julga em média 3000 processos por ano (op. cit., n. II, p. 48, nota 42).

108 Informações obtidas no website do Bundesgerichtshof, que disponibiliza uma cartilha em inglês, referentes a 2009 e anos anteriores.

109 Cf. MiCHAL BOBEK, "Quantity or quality? Reassessing the role of Supreme Jurisdictions in Central Europe”, n. I, p. 38-39. O autor destaca, entretanto, que tais são apenas tipos ideias, não vigentes, via de regra, de forma "pura" na realidade concreta. Há, por isso, um vasto número de sistemas classificados como híbridos (assim, v.g., o sistema adotado em 1991 na República Tcheca, que misturava características do modelo de revisão - como a seleção de casos de acordo com critérios objetivados na lei - e de cassação como a ausência de poder para substituir a decisão recorrida, sendo obrigatória a anulação com reenvio. $C f$. op. cit., n. II, p. 47). No mesmo sentido, J. A. JolOwICZ, On civil procedure, p. 320 e 325 (destacando a impureza dos sistemas e um espectro de posições intermediárias). 
Numa situação intermediária, conquanto bem mais próxima hoje ao direito anglosaxão, fica o modelo germânico da Revision, em que se busca conferir grande medida de liberdade ao Tribunal, embora isso seja feito por meio da positivação de critérios objetivos de acesso (v.g., Alemanha, Japão e a experiência recente da repercussão geral do nosso próprio recurso extraordinário).

Cabe analisar, isoladamente, os principais sistemas a esse respeito.

I) Sabe-se que, em relação à seleção dos recursos a serem julgados, os modelos de common law se caracterizam por um amplo poder discricionário das Cortes Supremas, do que resulta um número muito reduzido de recursos admitidos e julgados no mérito. Em verdade, a idéia de seletividade anda de mãos dadas com a tradição do stare decisis, em que a importância do precedente é acentuada. ${ }^{110}$ A justificativa para tanto é muito simples: a Corte deve julgar apenas os casos mais importantes, devotando a eles tempo e atenção suficientes para cumprir adequadamente a sua missão de unificação e desenvolvimento do Direito, o que não seria possível se tivesse de julgar as milhares de impugnações a ela dirigidas, por vezes sem qualquer relevância a transcender a causa e o interesse dos litigantes individuais.

Varia, contudo, o órgão a que é atribuído o poder de escolha, sendo conferida a competência por vezes ao Tribunal ad quem (modelo americano), por vezes ao Tribunal $a$ quo (modelo inglês). Na primeira hipótese, outras confrontações também podem ser feitas: a competência da Corte Suprema pode ser exercida ao longo de um procedimento único (i.e, em que a parte apresenta, desde logo, em um pedido formalmente único, as razões para a concessão da permissão e as razões para a reforma da decisão recorrida no mérito $^{111}$ ) ou por meio de atos postulatórios distintos. Neste último caso, deve haver uma primeira manifestação da parte voltada tão-somente para conseguir a permissão para recorrer, de modo que, na eventualidade da concessão desta, a interposição do recurso ocorrerá apenas num segundo momento (tal como ocorre, v.g., no certiorari norteamericano e no mecanismo nele inspirado adotado na Eslovênia ${ }^{112}$ ).

\footnotetext{
${ }^{110}$ Ugo Mattei - TeEmu Ruskola - Antonio Gidi, Comparative law, cap. 6(d), p. 509.

${ }^{111}$ É o que ocorre, v.g., no nosso recurso extraordinário, em que a repercussão geral tem de ser argüida como preliminar no recurso, e na nossa revista trabalhista, em que há o requisito da transcendência (art. 896-A, CLT).

${ }^{112}$ ALEŠ GALIČ, "The role of the Supreme Court in creating precedents in Slovenian civil procedure”, n. II, p.
} 
A Suprema Corte norte-americana possui ampla discricionariedade na seleção dos recursos a serem julgados. Por isso, ainda que exista a previsão legal da "certificação" da questão por uma Court of Appeals, essa prerrogativa não é exercida na prática, entendendo-se que a Supreme Court deve ser soberana na sua avaliação e no controle sobre o seu próprio docket.

Isso se deve à petition for writ of certiorari, remédio que representa dois dos cinco tipos de procedimentos para os quais é competente a Suprema Corte norte-americana. ${ }^{113}$ Trata-se mecanismo por meio do qual o acesso é tornado altamente restrito: em 2007, v.g., das quase oito mil petições endereçadas à Supreme Corte, esta decidiu conceder certiorari e consideração integral a apenas noventa. Sabe-se que o writ of error - previsto pelo Judiciary Act de 1789 - foi substituído pelo appeal na regulação prevista pelo Judiciary Act de 1925. À luz dessa legislação, passaram a conviver o appeal - cujo conhecimento era obrigatório (as a matter of right) - e o writ of certiorari, cuja admissão depende de apreciação discricionária pela Suprema Corte (segundo sua sound judicial discretion), de acordo com a "regra dos quatro", que estabelece o quorum mínimo para que se conheça da irresignação. A partir de nova alteração em 1988, no entanto, o writ of certiorari tornou-se, na prática, a única via de provocação da Suprema Corte. ${ }^{114}$

A Suprema Corte não está obrigada a motivar as decisões que inadmitem o writ of certiorari. Para a comunidade jurídica norte-americana, é natural que seja assim: “de modo algum pode-se esperar da Suprema Corte que dê razões para por que ela não analisa cada um dos milhares de casos por ano que ela declina revisar". ${ }^{115}$ Apesar da ausência de

266 (referindo o art. 367.b, CPA).

${ }^{113}$ Um panorama das competências da Suprema Corte pode ser consultado em HAZARD JR. - TARUFFO, American civil procedure - an introduction, cap. 9, p. 184-186. Em grosseira síntese, a U.S.S.C. possui I) competência originária (original jurisdiction) para hipóteses absolutamente restritas, como conflitos entre Estados-membros e demandas em que embaixadores estrangeiros estão diretamente envolvidos, o que representa apenas um ou dois casos julgados por ano pela Corte. No âmbito de sua competência recursal, é raro o II) recurso direto (direct appeal) de decisões de Cortes Federais de primeira instância, limitado aos casos de reapportionment of state legislative electoral districts. Também tem escassa verificação a III) certificação de uma questão de importância por uma das Federal Court of Appeals (órgão a quo), na medida em que estas reconhecem, na prática, a competência da própria Suprema Corte para escolher, de maneira discricionária, os casos a serem decididos. O grosso do trabalho da U.S.S.C. envolve, justamente, as petitions for a writ of certiorari, tratadas no texto, oriundas IV) de decisões de uma das Federal Courts of Appeal ou v) de julgamentos finais emitidos pela jurisdição de um Estado-membro (State Courts), desde que, nessa última hipótese, esteja em jogo uma questão de direito federal.

${ }^{114} \mathrm{Na}$ doutrina brasileira, o certiorari é analisado por BARBosa MoReIRA, Comentários ao Código de Processo Civil, n. 316, p. 581; ID., "A Suprema Corte norte-americana: um modelo para o mundo?”, n. 4, p. 242-244; e por ADHEMAR FERREIRA MACIEL, "Restrição à admissibilidade dos recursos na Suprema Corte dos Estados Unidos e no Supremo Tribunal Federal do Brasil”, esp. n. 2, p. 34-37.

${ }^{115}$ FREDERICK SCHAUER, Thinking like a lawyer, n. 9.2, p. 175. Mas, em algumas ocasiões, alguns justices 
motivação, a doutrina é firme em reconhecer que a concessão ou não do certiorari de modo algum é aleatória. ${ }^{116}$ A Rule 10 das Supreme Court Rules indica uma série de atributos a serem considerados: importantes questões de direito federal não apreciadas ainda pela Corte, divergência entre Tribunais inferiores ou entre a decisão recorrida e a jurisprudência da Corte ou erros grosseiros de procedimento. Um fator principal parece ser a divergência entre os Tribunais inferiores (Circuit Courts), a reclamar uma intervenção da Suprema Corte de modo a uniformizar a jurisprudência. ${ }^{117}$ Também a importância da matéria debatida é um elemento chave para a concessão do certiorari: questões jurídicas que não apresentem transcendência e que digam respeito apenas à justiça do caso são normalmente desconsideradas; por outro lado, tópicos de ampla repercussão merecem a atenção da Corte, que assim pode desempenhar relevante papel no desenvolvimento do Direito e de políticas públicas (enquanto policymaker). ${ }^{118}$

Exemplificativamente, a Rule 10 das Supreme Court Rules (SCR 2010) ${ }^{119}$ enuncia que a Corte poderá acolher a petition for certiorari em certas hipóteses. Em resumo, podem dar ensejo ao acolhimento do certiorari: I) a constatação de divergência jurisprudencial (entre decisões de diferentes Courts of Appeals, entre estas e as mais altas State Courts ou entre estas últimas), ii) a verificação de erro procedimental grave, de modo a recomendar o exercício da competência de supervisão da USSC, iii) a decisão de uma questão particularmente importante que ainda não foi, mas deveria ser, solucionada pela USSC ou, ainda, iv) a contradição com precedentes anteriores da Corte.

manifestam seus votos dissidentes, usualmente para tornar explícito que a rejeição do certiorari não implica aprovação da decisão recorrida (cf. LAWRENCE BAUM, The Supreme Court, cap. 3, p. 89).

${ }^{116}$ Cf. LAWRENCE BAUM, The Supreme Court, cap. 3, p. 90.

${ }^{117}$ LAWRENCE BAUM, The Supreme Court, cap. 3, p. 91.

${ }^{118}$ LAWRENCE BAUM, The Supreme Court, cap. 3, p. 92-93.

119 "Rule 10. Considerations Governing Review on Certiorari. Review on a writ of certiorari is not a matter of right, but of judicial discretion. A petition for a writ of certiorari will be granted only for compelling reasons. The following, although neither controlling nor fully measuring the Court's discretion, indicate the character of the reasons the Court considers: (a) a United States court of appeals has entered a decision in conflict with the decision of another United States court of appeals on the same important matter; has decided an important federal question in a way that conflicts with a decision by a state court of last resort; or has so far departed from the accepted and usual course of judicial proceedings, or sanctioned such a departure by a lower court, as to call for an exercise of this Court's supervisory power; (b) a state court of last resort has decided an important federal question in a way that conflicts with the decision of another state court of last resort or of a United States court of appeals; (c) a state court or a United States court of appeals has decided an important question of federal law that has not been, but should be, settled by this Court, or has decided an important federal question in a way that conflicts with relevant decisions of this Court. A petition for a writ of certiorari is rarely granted when the asserted error consists of erroneous factual findings or the misapplication of a properly stated rule of law". 
Em solo britâncio, a antiga House of Lords (em seu Appellate Comitte) foi substituída pela nova Supreme Court para o Reino Unido, cuja atuação se iniciou em $1^{\circ}$ de outubro de 2009. Essa transferência de competência para o novo órgão deu-se por meio do Constitutional Reform Act 2005 (Parte 3) e buscou garantir maior independência dos magistrados, separando a cúpula do Poder Judiciário do Legislativo e Executivo. ${ }^{120}$

Tal como nos Estados Unidos, há um escrutínio rigoroso dos appeals apreciados pela mais alta jurisdição inglesa. É necessário obter permissão (ou leave) para recorrer, na qual o "futuro recorrente deve demonstrar que o seu caso levanta um ponto de direito passível de discussão de importância pública geral". ${ }^{121}$ A Supreme Court, na esteira do que fazia a House of Lords, ocupa-se apenas com os temas jurídicos de vital importância.

Entretanto, ao contrário do sistema norte-americano, a apreciação dessa questão cabe normalmente às instâncias inferiores no ordenamento judiciário inglês. Por isso, a permissão para recorrer deve ser endereçada - ressalvados os casos de leapfrog appeal (isto é, de recurso direto ou per saltum à Suprema Corte) - à Court of Appeals (Corte de segunda instância), no prazo de 28 dias da prolação do julgado, sendo então decidida por um painel de ao menos três Justices. Sendo recusada a permission to appeal pelo órgão a quo, uma application semelhante pode ser endereçada à Supreme Court. ${ }^{122}$

A prática do certiorari (ou de um correlato leave to appeal), com exceção da Dinamarca, ${ }^{123}$ é bastante difundida na Escandinávia. ${ }^{124}$ Com efeito, na Finlândia, a Suprema Corte "pode selecionar casos de importância para um julgamento substancial e direcionar os seus recursos para as questões de maior importância". ${ }^{125}$ A permissão para recorrer pode ser concedida quando o julgamento da questão possa ter um efeito de precedente, de modo a uniformizar a jurisprudência, ou quando razões graves (ligadas à constatação de um erro de procedimento ou à particular importância do caso para o

\footnotetext{
${ }^{120}$ O'HARE - BROWNE, Civil litigation, n. 45.001, p. 740.

${ }^{121}$ O'HARE - Browne, Civil litigation, n. 45.001, p. 741.

122 J. A. Jolowicz, On civil procedure, cap. 14, p. 217, nota 4 (destacando o princípio geral de que a leave pode ser concedida seja pela corte $a$ quo seja pelo tribunal ad quem e o fato de que, às vezes, a Court of Appeals recusa a permissão para permitir que a House of Lords - hoje Supreme Court - decida ela mesma sobre a admissão).

${ }^{123}$ Cf. HenRIK LindBlom, “The role of the Supreme Courts in Scandinavia”, n. 4, p. 359.

124 Chase-Hershroff-Silberman-Taniguchi-Varano-Zuckerman, Civil litigation in comparative context, cap. 7, n. II, p. 330-331; MICHELE TARUFFO, "Institutional factors influencing precedents", n. 2.2, p. 446.

${ }^{125}$ AULIS AARNIO, "Precedent in Finland", n. I.1(c), p. 70.
} 
recorrente) assim recomendarem. As decisões de admissão ou inadmissão não são motivadas e apenas algo em torno de dez por cento dos recursos são admitidos. ${ }^{126}$

A Suprema Corte sueca julga algo em torno de 130 a 160 casos por ano. Não por acaso, tem o poder discricionário de conceder ou não certiorari. Deve fazê-lo, contudo, apenas quando for importante estabelecer um precedente de modo a fixar uma regra geral ou se houver razões fortes para tanto, tais como um erro particularmente grave cometido pela instância a quo. Ademais, cabe à própria Suprema Corte estabelecer quais precedentes serão relatados na íntegra na coletânea oficial (Nytt Juridiskt Arkiv). A criação de um precedente depende, assim, da iniciativa das partes conjugada à decisão da Corte de julgar o recurso. $^{127}$

Algo semelhante ocorre na Noruega, onde a Suprema Corte também tem o poder discricionário de conceder ou não permissão para recorrer, de acordo com o seu entendimento acerca da existência ou não de significação geral da questão jurídica de alguma outra razão que reclame a sua intervenção extraordinária. ${ }^{128}$

II) A influência do modelo de appeal sobre variados outros países ligados à tradição de civil law é evidente: Alemanha, ${ }^{129}$ Argentina, ${ }^{130}$ Áustria, ${ }^{131}$ Brasil, $^{132}$ Espanha, ${ }^{133}$ Estônia, ${ }^{134}$ Holanda, ${ }^{135}$ Japão ${ }^{136}$ - todos esses países consagraram algum tipo de mecanismo de filtragem controlado pelos tribunais inferiores ou pelo próprio Tribunal Superior.

A lei de reforma do processo civil (Zivilprozessreformgesetz), de 27 de julho de 2001, trouxe importantes modificações ao sistema recursal alemão. No que toca à Revision,

\footnotetext{
${ }^{126}$ Ver, ainda, AUlis AARNIO, "Precedent in Finland", n. I.1(c), p. 71.

${ }^{127}$ GunNar BergholtZ - AleKSANDER PeCZENIK, "Precedent in Sweden”, n. 1, p. 293-295.

${ }^{128}$ SVEIN ENG, "Precedent in Norway", n. I.1(c), p. 192.

${ }^{129}$ Ver $\S 543$, ZPO (com a reforma de 2001).

${ }^{130}$ Ver art. 280, CPC de la Nación.

${ }^{131}$ Ver $\S 502$, ZPO.

${ }^{132}$ Refiro-me à repercussão geral prevista no art. 103-A, CF.

${ }^{133}$ Ver art. 477, LEC-2000.

${ }^{134}$ Michal BoBEK, "Quantity or quality? Reassessing the role of Supreme Jurisdictions in Central Europe", n. II, p. 46 , nota 35 .

${ }^{135}$ Ver art. 81 da Lei de Organização Judicial.

${ }^{136}$ Ver art. 318, CPC japonês.
} 
a principal mudança se refere à admissibilidade do recurso: neste ponto, o processo alemão migrou de um recurso que, acima de determinado valor da causa (60.000 DM), era visto como um direito subjetivo das partes para um sistema discricionário de seleção das causas de acordo com a sua importância. A finalidade da reforma é clara: permitir que o BGH "concentre suas na sua responsabilidade fundamental de render a construção autoritativa, interpretação e unificação do direito". ${ }^{137}$

\section{A significação fundamental (grundsätzliche Bedeutung) da questão, o} desenvolvimento do Direito ou a exigência de intervenção da Corte para garantir a uniformidade da jurisprudência são requisitos para a admissão do recurso. Falta, em regra, a significação diante de regras jurídicas antigas cujo sentido é já incontroverso ou de conclusões baseadas em aspectos individuais e fáticos do caso. Por sua vez, a oportunidade de desenvolver o Direito envolve o estabelecimento de princípios gerais em matérias não reguladas com precisão ou a colmatação de lacunas. ${ }^{138} \mathrm{O}$ último requisito (dissídio jurisprudencial), noticia a doutrina, tem ele sido interpretado de maneira bastante restrita pelo BGH: não basta a constatação de um erro material ou procedimental; deve haver frontal divergência com a jurisprudência ou o real perigo do julgado recorrido servir como precedente para casos futuros. ${ }^{139}$

À semelhança do sistema inglês (e contrariamente ao certiorari norte-americano), no direito alemão cabe ao tribunal inferior decidir sobre a admissibilidade recursal. A

\footnotetext{
${ }^{137}$ Ver Peter L. MURray - Rolf StÜRner, German civil justice, cap. 10(E), p. 387; CHASE-HershKofFSilberman-TANIGUCHI-VARANO-ZUCKERMAN, Civil litigation in comparative context, cap. 7, n. II, p. 336. Ambas as fontes destacam que o BGH desfruta, hoje, de poder discricionário análogo à Supreme Court norteamericana, tendo havido nítida inspiração no writ of certioraria. Contra, i.e, negando discricionariedade, sem oferecer uma razão convincente, HANS PRÜTTING, "Estudio introductorio al Código Procesal Civil alemán", cap. 5(V), p. 129. Cumpre salientar que, já na sistemática anterior, as causas abaixo da alçada de 60.000 DM seriam conhecidas apenas se apresentassem importância. Entretanto, o Tribunal Constitucional alemão entendeu (49 BVerfGe 148 (1979)) que semelhante discriminação - consistente em prever um mecanismo de seleção apenas para determindas controvérsias - violava o devido processo, permitindo ao BGH utilizar o antigo $\S 554 \mathrm{~b}$ apenas para rejeitar recursos claramente infundados. Nesse sentido, destaca PETER GOTTWALD que a reforma de 2001 "contém uma verdadeira decisão política de estabelecer acesso igualitário à Suprema Corte Federal", de modo que tanto as causas de alto quanto de baixo valor podem ser apreciadas, desde que apresentem significância fundamental ("Review appeal to the German Federal Supreme Court after the reform of 2001", n. I, p. 89).

${ }^{138}$ Sobre ambos os aspectos referidos no texto (significação fundamental e desenvolvimento do Direito), ver Peter GotTWALd, "Review appeal to the German Federal Supreme Court after the reform of 2001", n. II, p. 90-91. Substancialmente no mesmo sentido, à luz da regulação anterior, HANS PRÜTTING, "A admissibilidade do recurso aos Tribunais alemães", p. 159.

${ }^{139}$ Cf. Peter L. Murray - Rolf StÜRner, German civil justice, cap. 10(E)(1), p. 390 (indicando julgados do BGH nesse sentido); PETER GotTwald, "Review appeal to the German Federal Supreme Court after the reform of 2001", n. II, p. 92.
} 
decisão do tribunal recorrido que reconheça a possibilidade de interposição do recurso de revisão vincula o $\mathrm{BGH}$ (ex $\S 543,1, \mathrm{ZPO})$. Geralmente, tal constatação é feita no próprio julgado de que se recorrerá; silenciando este, a parte pode requerer que o órgão então se pronuncie. Não sendo concedida a permissão pela instância a quo, no entanto, pode-se levar a irresignação ao BGH por meio de um recurso contra o indeferimento de permissão (Nichtzulassungsbeschwerde). Essa impugnação (prevista no $\S 544, \mathrm{ZPO}$ ) recebe decisão sumária, motivada somente na extensão em que a Corte entenda necessário orientar os advogados acerca dos critérios utilizados para a admissão da revisão. Positiva que seja a apreciação, o caso prossegue como recurso de revisão, sendo apresentadas então as razões pelas partes. ${ }^{140}$

Também na Áustria, com a reforma de 2002, foi introduzida a exigência de uma "importante questão de direito" para os recursos excepcionais em casos de direito do trabalho e da seguridade social, reafirmando a tendência de dar ênfase à função de conferir unidade ao Direito e fortalecer o valor dos precedentes. ${ }^{141}$

$\mathrm{Na}$ Argentina, cujo recurso extraordinário - tal como o nosso - tem origem no writ of error norte-americano, também se outorgou (por meio da Lei n. ${ }^{\circ}$ 23.774/1990) competência à Suprema Corte para que esta selecione, segundo sua "sana discreción", as impugnações a serem conhecidas, descartando aquelas que não apresentem transcendência (conceito indeterminado a ser concretizado mediante raciocínio tópico). O método seletivo tem assento no art. 280 do Código Procesal Civil y Comercial de la Nación. ${ }^{142}$ Operou-se, com isso, uma "profunda reforma" no sistema, tendo sido a influência do certiorari norteamericano notória. A razão da mudança, como não poderia deixar de ser, estava no excesso de recursos, com desvirtuação da função da Corte e deterioração da qualidade de seus julgados. $^{143}$

\footnotetext{
${ }^{140}$ Ver, sobre esses e outros aspectos do procedimento, PETER L. MURRAY - ROLF STÜRNER, German civil justice, cap. 10(E)(1), p. 387-389.

${ }^{141}$ Ver Chase-HershKoff-Silberman-Taniguchi-VARANO-ZuCKerman, Civil litigation in comparative context, cap. 7, n. II, p. 337.

${ }^{142}$ No original: "La Corte, según su sana discreción, y con la sola invocación de esta norma, podrá rechazar el recurso extraordinario, por falta de agravio federal suficiente o cuando las cuestiones planteadas resultaren insustanciales o carentes de trascendencia".

${ }^{143}$ Ver, sobre o "certiorari argentino", Augusto M. MoRello, La nueva etapa del recurso extraordinario el "certiorari", esp. cap. 1-3, p. 1-38 e cap. 7-8, p. 91-133.
} 
A Espanha conhece, tradicionalmente, dois recursos extraordinários: um por violação de normas de direito material; outro por infração processual. No regime atual (LEC-2000), ao primeiro cabe a denominação casación, cabível diante de infrações de "normas aplicables para resolver las cuestiones objeto del proceso"; ao segundo, recurso extraordinario por infracción procesal. ${ }^{144}$ Naquele primeiro - excetuadas as infrações a direitos fundamentais (frise-se: de natureza material, e não processual ${ }^{145}$ ) ou em causas cujo valor transcenda a 150.000 euros, em que a relevância do recurso é presumida (ex art. $477.2,1^{\circ}$ e $2^{\circ}$, respectivamente, da LEC) -, há de apresentar-se um interesse transcendente para que seja admissível a cassação. Trata-se do requisito do interés casacional (art. 477.2.3 $3^{\circ}$ LEC), manifestado quando a decisão recorrida contrariar a doctrina legal do Tribunal Supremo (ou, se o direito invocado for local, de algum Tribunal Superior de Justicia, que será então competente para o julgamento), quando houver jurisprudência contraditória das cortes de apelação ou, ainda, quando a norma denunciada estiver em vigor a menos de cinco anos e inexistir jurisprudência aplicável a ela (ou a uma norma anterior do mesmo teor). ${ }^{146}$

\footnotetext{
${ }^{144}$ A coordenação entre os dois recursos é extremamente confusa e merece uma advertência dirigida ao leitor. Isso ocorre, em especial, porque o regime inicialmente previsto na LEC-2000 - que desvinculava nitidamente as duas impugnações (quanto ao procedimento, quanto ao órgão ad quem etc.), a ponto de considerá-las incompatíveis entre si (art. 466) - não se concretizou devido à rejeição da reforma da LOPJ (Ley Orgánica del Poder Judicial), de cuja aprovação dependia em razão de alterações de competência. São inaplicáveis, por ora, os arts. 466, 468, 472, 476.4, 488, 489 e 490-493 da LEC. Os recursos são atualmente regulados, por isso, por um regime transitório desenhado nas disposições finais da LEC (n. 16), que não corresponde à proposta inicial: é diferente a atribuição de competência para julgamento, bem como o processamento, tendo a cassação e o recurso por infração processual deixado de ser incompatíveis para tramitarem em conjunto (seguindo diferentes arranjos segundo a cassação venha fundada em normas de direito comum ou de direito local). Sobre tudo isso, criticamente, ver JUAN MONTERo AROCA - JosÉ Flors MATíES, El recurso de casación civil, cap. 1, p. 25-34; VICENTE GIMENO SENDRA, Derecho procesal civil, vol. 1, n. 31(II)-(IV), p. 606 ss.

145 Já que, na Espanha, para denunciar errores in procedendo cabe exclusivamente o recurso extraordinario por infracción procesal.

${ }^{146}$ O requisito do interés casacional foi objeto de regulamentação pela Sala Primera del Tribunal Supremo, na Junta celebrada em 12.12.2000, restringindo-se mais ainda a admissibilidade dos recursos. No referido acordo, ficou assentado que os três supostos de recorribilidade são mutuamente excludentes e que as sentenças proferidas em juicio ordinario ou verbal em razão da matéria, bem como nos diversos procedimentos especiais, somente são passíveis de admissão por meio da averiguação do requisito de interesse cassacional. Isso exclui da via da cassação, em qualquer caso, os processo ordinários e verbais em razão de quantia inferiores à summa gravaminis (ou, tecnicamente, summa cassationis) de 150.000 euros. Ver, amplamente, sobre a orientação jurisprudencial na matéria, JUAN MONTERO AROCA - JOSÉ FLORS MATíes, El recurso de casación civil, cap. 3(V), p. 392 ss.; AlejANDRo BuENDía CÁNOVAS, La casación civil, cap. 5, n. 6, p. 335 e ss. (criticando a orientação restritiva do Tribunal Supremo e acusando-a de ser manifestamente contra legem); J. NIEVA FeNOLL "La relevancia social de la casación”, n. 5, p. 112-113 (também criticando com veemência a interpretação jurisprudencial, que entende ser contra legem).
} 
Sua introdução, repetindo o ciclo universal, visou a combater a crise causada pelo excesso de recursos. ${ }^{147}$ Em atenção à função específica do Tribunal Supremo, i.e, “a unidade do Direito, material e processual, a nível interpretativo", questões que não apresentem disparidade jurisprudencial estão, em princípio, excluídas da cassação. ${ }^{148}$ Por outro lado, o curto tempo de entrada em vigor da lei e a inexistência de pronunciamentos a respeito de sua inteligência apresenta à Corte uma oportunidade de desenvolver o Direito, fixando pautas gerais para orientar particulares, administração pública e outros órgãos do Poder Judiciário em relação a normas novas, em torno das quais não há ainda divergência.

No art. 318 do Código de Processo Civil japonês, exige-se que - ressalvados os casos de questões constitucionais ou de erros de procedimento graves enumerados pelo Código (art. 312, 1 e 2) - a questão sobre a qual se baseia o recorrente seja de particular importância, nova, contrária a um precedente ou, ainda, que apresente oportunidade para a alteração de um entendimento anterior da Suprema Corte, cabendo a esta determinar a admissão ou não do recurso quando a decisão recorrida for final (jôkoku). Sendo a decisão interlocutória (kôkoku), a certificação cabe à própria Corte recorrida. Tais mudanças noticia-se - ocorreram diante da "quase impossível" sobrecarga da Corte, que, composta por quinze juízes, recebeu em 1995 cerca de três mil e quinhentos processos (a afirmação de uma "sobrecarga" causa certamente assombro ao jurista brasileiro), apesar de alguma oposição do órgão de classe dos advogados daquele país. ${ }^{149}$

III) A experiência do modelo cassacional é inteiramente diversa. Na França, v.g., o pouvoir de cassation é visto como um direito do litigante, fundado em "princípios gerais" do sistema. Não há, assim, espaço para uma seleção pela Corte dos recursos que deve julgar, o que acaba transformando a Cour de Cassation numa terceira instância. ${ }^{150}$

\footnotetext{
${ }^{147}$ JuAn MONTERO AROCA - José Flors MATÍES, El recurso de casación civil, cap. 1, p. 26, nota 8.

${ }^{148}$ ViCENTE GIMENO SENDRA, Derecho procesal civil, vol. 1, n. 32(IV), p. 637.

${ }^{149}$ Cf. TANIGUCHI, “The 1996 Code of Civil Procedure of Japan - a procedure for the coming century?”, n. 4, p. 779-780; CHASE-HERSHKOFF-SILBERMAN-TANIGUCHI-VARANO-ZUCKERMAN, Civil litigation in comparative context, cap. 7, n. VII, p. 362-363.

${ }^{150}$ Nesse sentido, LOÏC CADIET - JACQUES NORMAND - SORAYA AMRANI MEKKI, Théorie générale du procès, n. 283, p. 942; LOÏC CADIET, "El sistema de la casación francesa", n. II/1, p. 29; MICHEL TROPER CRISTOPHe GrZEgORCZYK, "Precedent in France", n. I.1(a), p. 104.
} 
Também é assim na Itália, onde o direito de recorrer em cassação é assegurado constitucionalmente (art. 111, Cost.), exigindo-se, por isso, uma reforma da Constituição para que se possa adotar um filtro baseado na importância da questão. ${ }^{151}$

O direito brasileiro, como se sabe, é hoje bipartido: o acesso ao recurso especial é franqueado sem restrições (art. 105, III, CF); o mesmo não ocorre com relação ao recurso extraordinário, brindado com a repercussão geral (art. 103-A, CF).

\subsubsection{OUTROS FATORES QUE CONDICIONAM A ADMISSIBILIDADE DOS RECURSOS OU INFLUEM SOBRE O SEU NÚMERO.}

Há outros fatores que condicionam a admissibilidade dos recursos e que funcionam, assim, como sucedâneos do poder de seleção das impugnações pela Corte ou, ao menos, como forças que impactam ou visam a manejar o número de recursos julgados. Em grosseira síntese, podem ser destacados: I) o papel dos advogados; II) os custos inerentes ao processo; III) alguns mecanismos de agilização procedimental.

I) Em primeiro lugar, pode ser mencionado o papel desempenhado pelos advogados. Em muitos países, é necessária uma habilitação especial para atuar perante os Tribunais Superiores. Essa idéia de especialização é particularmente desenvolvida na Alemanha, onde, para os feitos cíveis, apenas 41 advogados (a situação é a de junho de 2010) estão habilitados a advogar perante o Tribunal Federal de Justiça, exigindo-se inscrição no Rechtsanwaltskammer beim Bundesgerichtshof. São requisitos de admissão ao menos cinco anos de prática na advocacia e 35 anos de idade, bem como a indicação por um comitê específico composto pelo Presidente do Tribunal, pelos Presidentes das respectivas Turmas e por representantes da Ordem dos Advogados e nomeação pelo Ministro da Justiça. Ademais, tais advogados podem advogar apenas perante o BGH.

Na França, existe também um específico corpo de advogados habilitado a atuar perante as Cortes Supremas (avocats au Conseil d'État et à la Cour de Cassation), cujo número é hoje em torno de noventa, sendo a representação por algum deles obrigatória (art. 973, NCPC). Segundo consta, cerca de trinta por cento dos recursos não chegam à Cour

${ }^{151}$ Cf. G. TARZIA, "Le impugnazoni civili tra disfunzioni e riforme", n. 7, p. 484; GiovanNi Verde, "In difesa dello jus litigatoris...", n. 4, p. 6. 
em razão de consultas negativas que a situação de monopólio permite a esse corpo qualificado de patronos. ${ }^{152}$ É semelhante a situação na Bélgica (art. 478).

II) Em segundo lugar, podem ser mencionados os custos, as sanções ou outros desestímulos de natureza econômica ligados à interposição dos recursos excepcionais.

O custo alto para alcançar a Suprema Corte na Inglaterra não pode ser olvidado como um "impedimento de tipo econômico", obrigado o recorrente a prestar caução elevada e a dispender honorários consideráveis. ${ }^{153}$

Há também sanções pecuniárias. O sistema francês prevê uma multa, bem como a possibilidade de uma indenização a ser paga pelo recorrente ao seu adversário, em caso de recursos de cassação abusivos. ${ }^{154}$ Também pode ser multado aquele que abusa do direito de recorrer em cassação, com culpa grave, na Itália (art. 385, c.p.c.).

A ausência de efeito suspensivo do recurso excepcional também serve freqüentemente como desestímulo e é adotada a nível geral, bastando assimilar duas experiências de tipos ideais opostos (cassation e appeal). Na França, em verdade, não só o recurso em cassação não possui efeito suspensivo, como o cumprimento da decisão recorrida é, via de regra, pressuposto para a sua admissão, a teor do art. 1009-1, $1^{\text {a }}$ alínea, NCPC. Com esse mecanismo, buscou-se reforçar a autoridade das decisões de segunda instância, bem como evitar recursos meramente procrastinatórios. ${ }^{155}$ Em terras inglesas, o appeal para a Supreme Court não inibe ou suspende a eficácia da decisão recorrida; aquele Tribunal sequer se ocupa de tais questões, sendo de competência da corte inferior a

\footnotetext{
${ }^{152}$ CADIET - NORMAND - MEKKI, Théorie générale du procès, n. 290, p. 953.

${ }^{153}$ ELISABETTA SILVESTRI, "La selezione dei ricorsi in Cassazione: um problema per la riforma del processo civile", n. $4 b$, p. 498.

${ }^{154}$ Cf. o art. 628, NCPC: "Le demandeur en cassation qui succombe dans son pourvoi ou dont le pourvoi n'est pas admis peut, en cas de recours jugé abusif, être condamné à une amende civile dont le montant ne peut excéder 3000 euros et, dans les mêmes limites, au paiement d'une indemnité envers le défendeur".

${ }^{155}$ LoḮ CADIET, "El sistema de la casación francesa", Los recursos ante Tribunales Supremos en Europa (coord. Manuel Ortells Ramos), Madrid: Difusión Jurídica, 2008, n. II/1, p. 35-36. Eis a redação do dispositivo mencionado no texto: "Hors les matières où le pourvoi empêche l'exécution de la décision attaquée, le premier président ou son délégué décide, à la demande du défendeur et après avoir recueilli l'avis du procureur général et les observations des parties, le retrait du rôle d'une affaire lorsque le demandeur ne justifie pas avoir exécuté la décision frappée de pourvoi, à moins qu'il ne lui apparaisse que l'exécution serait de nature à entraîner des conséquences manifestement excessives".
} 
eventual concessão de efeito suspensivo (stay of execution), nos termos do art. 37 das Supreme Court Rules (SCR). ${ }^{156}$

III) Por fim, podem ser observados mecanismos que procuram simplificar o procedimento pelos Tribunais Superiores, enquanto meios de agilização procedimental. Semelhantes expedientes não são estranhos, de modo algum, ao Direito brasileiro: basta lembrar os extensos poderes conferidos aos Ministros relatores, bem como a técnica de julgamento por amostragem de recursos especiais ditos repetitivos, entre outras medidas, empregadas especificamente no âmbito dos Tribunais de superposição. Em verdade, a situação em outros países, nesse ponto, é bem mais tímida.

Assim, v.g., é a experiência francesa, em que há um colegiado reduzido responsável por conhecer, preliminarmente, dos recursos não-criminais. Trata-se de uma formation restreinte. Esse órgão, em que votam apenas três (e não os usuais cinco) juízes, na sua feição original, visava a apenas excluir da apreciação da Corte recursos manifestamente infundados ou inadmissíveis (reforma legislativa de 1979); em virtude de ulteriores alterações, a competência da formation restreinte passou a albergar também o julgamento de casos de fácil solução. ${ }^{157}$ De acordo com a atual sistemática (art. L.431-1, COJ; art. 1.014, NCPC), as formations d'admission podem rejeitar sumariamente recursos inadmissíveis ou que não seja fundados em moyens sérieux de cassation, por meio de uma decisão de fundamentação reduzida, em que as partes saberão os motivos da rejeição de sua impugnação ao consultar uma ficha padronizada e sucinta.

O mesmo ocorre na Itália com os julgamentos tomados em camera di consiglio, por meio dos quais se pode "dichiarare l'inammissibilità del ricorso principale e di quello incidentale eventualmente proposto" (art. 375, 1, c.p.c.) ou "accogliere o rigettare il ricorso principale e l'eventuale ricorso incidentale per manifesta fondatezza o infondatezza" (art. 375, 5, c.p.c.). Segundo a reforma de 2009, o recurso será declarado inadmissível quando a decisão recorrida for conforme à jurisprudência da Corte ou, ainda,

\footnotetext{
${ }^{156}$ O'Hare - Browne, Civil litigation, 14. ed., London: Sweet \& Maxwell, 2009, cap. 45, n. 45.001, p. 741.

157 Chase-Hershroff-Silberman-Taniguchi-Varano-Zuckerman, Civil litigation in comparative context, St. Paul: Thomson/West, 2007, cap. 7, n. II, p. 330; LOḮ CADIET, "El sistema de la casación francesa", Los recursos ante Tribunales Supremos en Europa (coord. Manuel Ortells Ramos), Madrid: Difusión Jurídica, 2008, n. I/2, p. 24; G. TARZIA, "Le impugnazoni civili tra disfunzioni e riforme”, n. 7, p. 483. Anterioremente às formations restreintes, havia a Chambre des requêtes, que desempenhava a função de filtro dos recursos que seriam conhecidos pela Cour de Cassation, mas tal sistemática foi abolida em 1947.
} 
quando é "manifestamente infundada a censura relativa à violação dos princípios reguladores do justo processo" (novo art. 360 bis, c.p.c.). ${ }^{158}$

Deve-se ter em mente, todavia, que embora estes mecanismos simplifiquem o procedimento - porventura abreviando tempo e custos na apreciação de cada recurso individualmente considerado -, eles em nada afetam a quantidade de recursos a serem apreciados. Não podem servir, assim, como filtros adequados para direcionar a atuação da Corte aos casos de importância geral ou como uma resposta para a crise gerada pelo elevado número de recursos. Sobre isso, estão de acordo a doutrina italiana e francesa. ${ }^{159}$

\subsection{FUNÇÃO E FORÇA DOS PRECEDENTES.}

O tema do peso das decisões dos Tribunais Superiores, enquanto verdadeiros precedentes, a vincular os demais juízes e orientar com segurança os indivíduos, está intimamente relacionado com o problema anterior. Trata-se, em boa medida, de uma decorrência da opção tomada diante das possibilidades de seleção ou de admissão irrestrita de recursos ou, em outros termos, de atribuição de uma função predominantemente pública ou privada à Corte.

Pouco precisa ser dito a respeito da função dos precedentes no mundo do common law, em que predomina o stare decisis. A observância dos precedentes é "um dos pilares do ordenamento jurídico norte-americano"160 e a Suprema Corte exerce uma notória atividade de lawmaking e de formulação da public policy. ${ }^{161}$ Cabe salientar, no entanto, que as decisões que rejeitam o certiorari não tem efeito de precedente. ${ }^{162}$

\footnotetext{
${ }^{158}$ ClaUdio CONSOLO, Il processo di primo grado e le impugnazioni..., p. 513-517.

${ }^{159}$ Michele TARUFFo, “Una reforma de la casación civil?", n. 7, p. 544; CADIET - NORMAND - MEKKI, Théorie générale du procès, n. 288, p. 951; LOÏC CADIET, "El sistema de la casación francesa", n. II/1, p. 34.

${ }^{160}$ BARBosa MoreiRA, “A Suprema Corte norte-americana: um modelo para o mundo?”, n. 6, p. 246.

${ }^{161}$ Ver ARTHUR T. VON MEHREN - JAMES R. GORDLEY, The civil law system, cap. 16, p. 1152 e ss. (analisando como o common law norte-americano é o sistema mais propício para que o juiz formule políticas públicas). Daí a correta afirmação de que as funções da Suprema Corte americana se aproximam mais às do Legislativo, "facing forward as lawgivers" (HAZARD JR. - TARUFFO, American civil procedure - an introduction, cap. 9, p. 184).

${ }^{162}$ Teague v. Lane, 489 U.S. 288, 296 (1989).
} 
Na Inglaterra, a vinculação às decisões anteriores da Corte é ainda mais rígida: até a mudança inserida pelo Practice Statement de 1966 (pronunciado pelo Lord GARDINER, em 26 de julho daquele ano), ${ }^{163}$ a House of Lords, consentânea com o princípio estabelecido em London Tramways, ${ }^{164}$ considerava-se absolutamente adstrita aos seus precedentes, não podendo superá-los em qualquer hipótese. Apesar da flexibilização mencionada, por meio da qual se permitiu à própria House afastar-se - sem descuidar de situações já consolidadas - de seus julgados anteriores, são raríssimos os casos de overruling e as cortes inferiores estão sempre formalmente vinculadas às decisões dos órgãos superiores. Trata-se, assim, de uma vinculação horizontal qualificada. ${ }^{165}$ Nessa linha de raciocínio, a sua principal preocupação está em "produzir decisões que sejam de valor para o futuro do Direito", ocupando-se, como já afirmado, apenas de temas jurídicos de vital importância e funcionando como uma Corte de precedentes para o Reino Unido. ${ }^{166}$

Essa é também a realidade dos países escandinavos, especialmente da Suécia e da Finlândia. Neste último, embora o juiz esteja submetido à lei e dela devam ser extraídas as soluções para os conflitos, é reconhecido o valor argumentativo significativo dos precedentes, que, na prática, só são superados por meio de uma fundamentação substancial de peso. Coerentemente, uma turma da Suprema Corte pode rever um precedente apenas por meio do prévio envio da questão ao órgão plenário. ${ }^{167}$

${ }^{163}$ É esta a parte mais relevante do Statement: "Their Lordships regard the use of precedent as an indispensable foundation upon which to decide what is the law and its application to individual cases. It provides at least some degree of certainty upon which individuals can rely in the conduct of their affairs, as well as a basis for orderly development of legal rules. (...) Their Lordships nevertheless recognise that too rigid adherence to precedent may lead to injustice in a particular case and also unduly restrict the proper development of the law. They propose therefore, to modify their present practice and, while treating formal decisions of this house as normally binding, to depart from a previous decision when it appears to be right to do so. (...) In this connection they will bear in mind the danger of disturbing retrospectively the basis on which contracts, settlement of property, and fiscal arrangements have been entered into and also the especial need for certainty as to the criminal law. (...) This announcement is not intended to affect the use of precedent elsewhere than in this House"

${ }^{164}$ London Tramways Co. v London City Council [1898] AC 375.

${ }^{165}$ ZenOn BANKowSKI - NeIL MacCormick - GeOFFrey Marshall, "Precedent in the United Kingdom", n. II.1, p. 326 e n. II.5, p. 329.

166 J. A. Jolowicz, On civil procedure, p. 272; "The business of the House of Lords is with the law itself; its role is to act as the source of the most authoritative precedents known to the law of England and, indeed, of the United Kingdom as a whole" (JOLOwICZ, "Appeal and review in comparative law: similarities, differences and purposes", p. 628).

${ }^{167}$ AULIS AARNIO, "Precedent in Finland", n. I.7, p. 83 e n. II.1, p. 86; HENRIK LINDBLOM, "The role of the Supreme Courts in Scandinavia”, n. 3.4.1, p. 339 (destacando uma prevalência nítida da função pública de formar precedentes na Suécia e na Finlândia e, embora em menor medida, também na Noruega e na Dinamarca). 
Na Noruega, a Suprema Corte aprecia as suas decisões anteriores como argumentos a serem levados necessariamente em consideração, de modo que, embora não sejam estritamente vinculantes do ponto de vista formal, apresentam força inegável. Cortes inferiores, por sua vez, consideram precedentes da Suprema Corte como determinantes do resultado do caso, cabendo falar de uma vinculação vertical, não havendo espaço para overrulings. ${ }^{168}$

Vários exemplos podem ilustrar a força dos precedentes nos sistemas da tradição de civil law. O direito alemão é particularmente rico nesse aspecto. Nele, o precedente (Präjudiz) desempenha papel importante, embora somente decisões do Tribunal Constitucional (Bundesverfassungsgericht) sejam formalmente dotadas de eficácia vinculante e, em alguns casos, de força de lei (Gesetzkraft). Dificilmente haverá, entretanto, uma decisão das Cortes Superiores que não faça referência a julgados anteriores, especialmente se houver uma jurisprudência reiterada sobre o assunto (ständige Rechtsprechung). Enquanto sistema de direito codificado, a importância dos precedentes será tanto maior nos casos em que não houver um dispositivo legal regulando o conflito ou houver discussões interpretativas a seu respeito. ${ }^{169}$

Na jurisprudência específica do BGH, em atenção aos princípios da certeza jurídica e da proteção da confiança, tende-se a reconhecer uma eficácia vinculante prima facie dos precedentes, de modo que apenas razões absolutamente convincentes e excepcionais contrárias à aderência ao julgado anterior permitem a sua superação. Há, inclusive, decisões responsabilizando o advogado por danos ao cliente se tiver negligenciado a jurisprudência do $\mathrm{BGH}^{170}$

Cabe lembrar, ainda, que a Constituição alemã, em face das várias justiças especializadas existentes, consagra a remessa de uma questão controversa comum a um órgão colegiado das diversas Cortes Supremas Federais. Ou seja, quando houver pretensão de desviar-se da jurisprudência de uma das outras Cortes Supremas (do Trabalho, Fiscal etc.), a divergência tem de ser apresentada ao Painel Comum das Cortes Supremas Federais (Gemeinsamer Senat der obersten Gerichte des Bundes). ${ }^{171}$ Sendo a divergência

\footnotetext{
${ }^{168}$ SVEIN ENG, "Precedent in Norway", n. II.1, p. 199.

${ }^{169}$ ROBERT ALEXY - RALF DREIER, "Precedent in the Federal Republic of Germany”, n. I.6-7, p. 23-24.

${ }^{170}$ ROBERT ALEXY - RALF DREIER, "Precedent in the Federal Republic of Germany”, n. II.1, p. 30-31.

${ }^{171}$ Sobre isso, consultar BRUNO SASSANI, "Tra 'consapevolezza culturale' e 'buona volotà organizzativa"”, n.
} 
interna à Corte $(\mathrm{BGH})$, cabe remeter ao Großer Senat, em conformidade com o $§ 132(2)$ ZPO. $^{172}$

Na Espanha, a infração da doutrina legal (doctrina legal) do Tribunal Supremo é fundamento para o reconhecimento de interés casacional na interposição do recurso (art. 477.2.3, LEC), demonstrando a importância da jurisprudência reiterada da Corte no quadro das fontes de direito. ${ }^{173}$ Com essa orientação, a nova lei espanhola reforçou "o caráter público da cassação, (...) que tende a cumprir de modo prevalente uma função de salvaguarda do Direito objetivo e a propiciar a unificação da jurisprudência a fim de lograr a uniformidade na interpretação e aplicação da norma (defesa do ius constitutionis)", em especial nos recursos fundados no interesse cassacional, "não atendendo tanto à justiça do caso concreto quanto à unificação da interpretação jurisprudencial da lei, cumprindo uma função de segurança jurídica". ${ }^{174}$

Por sua vez, na Itália, a reforma de 2006 - em que pese ter sido enormemente criticada pelo seu trato incoerente da matéria - foi toda pensada visando a assegurar e a promover a função nomofilática da Corte. ${ }^{175}$ Hoje, quando uma Sezione semplice (órgão colegiado menor) pretende desviar-se de um entendimento da Sezione unite (órgão colegiado maior), deve obrigatoriamente remeter a este último órgão a decisão do recurso (art. 374, 3, c.p.c.).

O direito francês oferece um exemplo radical de aversão aos precedentes. Predomina um forte apego à lei e praticamente inexistem referências a outras decisões na

5, p. 274-275 (defendendo que semelhantes previsões não implicam nenhuma ofensa à norma, também prevista na Constituição alemã - § 97, que vincula os juízes à lei).

${ }^{172}$ Esssa prática é antiga e remonta ao anterior Reichsgericht, cf. ERNST J. COHN, "Precedents in Continental Law", p. 368 (relatando, contudo, que o Reichsgericht firmara algumas orientações para evitar, na prática, o custoso procedimento de envio, tendência caricaturalmente apelidade de horror pleni).

${ }^{173}$ Sobre a doctrina legal e as discussões sobre sua natureza e eficácia prática, v. VICTOR FAIRÉN GUILLÉN, "La doctrina legal y el control de los hechos en la casación civil y laboral española", n. 4, p. 1033-1043.

174 JuAN MONTERo AROCA - JOSÉ Flors MatíES, El recurso de casación civil, cap. 3, p. 273; no mesmo sentido, VICENTE GIMENO SENDRA, Derecho procesal civil, vol. 1, n. 32(I), p. 625.

${ }^{175}$ O Dlgs. 40/2006 teve por objetivo expresso promover "Modifiche al codice di procedura civile in materia di processo di cassazione in funzione nomofilattica". Boa parte da doutrina, entretanto, entendeu que a reforma não foi adequada ao seu fim. Para uma crítica das alterações, ver SERGIO CHIARLONI, "Un singolare caso di eterogenesi dei fini...", n. 6, p. 851 e ss. (destacando que as reformas acabaram por inflacionar a corte e tornar ainda mais difícil o cumprimento da função nomofilática); MichELE TARUFFO, "Precedente e giurisprudenza", n. 6, p. 809 (criticando a obrigatoriedade de pronúncia, em todos os casos, do principio di diritto, o que impossibilita a atuação seletiva da Corte); ID., "Una reforma de la casación civil", n. 7, p. 545 (criticando em geral a reforma); "Las funciones de las Cortes Supremas", n. 4, p. 664; ANDREA PROTO PISANI, "Crisi della Cassazione", passim. 
motivação dos julgamentos: mais do que isso, decisões fundadas na citação de precedentes ou da jurisprudence, sem desenvolvimento de razões para o caso específico, tendem a ser consideradas inválidas sob o ponto de vista de sua motivação. ${ }^{176}$

Entretanto, as cortes inferiores, na prática, quase sempre seguem os precedentes da Cour de Cassation, algo que decorre naturalmente da hierarquia judicial ("vinculação de facto"). Os precedentes desempenham, assim, um papel significativo na interpretação dos textos legais e no desenvolvimento do direito (v.g., no âmbito da responsabilidade civil). ${ }^{177}$

Mesmo no sistema francês, ademais, há mecanismos outros voltados a assegurar a segurança jurídica e a estabilidade da jurisprudência. Assim, v.g., ocorre em relação à saisine pour avis de la Cour de Cassation, mediante a qual um juízo ordinário, identificando uma questão de direito que apresente uma dificuldade séria e repita-se em muitos casos, remete a questão para a Corte de Cassação, que então emite, dentro de três meses, uma opinião (arts. L441-1/L441-4, COJ; arts. 1.031-1/1.031-7, NCPC). Embora (e de maneira até contraditória) esta não seja formalmente vinculante para o juízo a quo, é nítido que este procedimento tem por finalidade promover, de um lado, a segurança jurídica e, de outro, a maior celeridade no julgamento dos feitos. Não há como negar, portanto, que o instituto considera relevante a definição da questão jurídica por meio de uma espécie de leading case ${ }^{178}$ Dentro da Cour de Cassation, devem ser destacadas ainda as chambres mixtes, responsáveis por prevenirem divergências interna corporis entre as chambres comuns, e a atuação da assemblée plénière, convocada obrigatoriamente quando o tribunal de reenvio persiste na solução dada pelo seu antecessor, após uma primeira cassação (hipótese em que a solução do segundo recurso é vinculante no caso específico) ou, de maneira facultativa, quando o recurso envolver questão de princípio, especialmente se houver divergência entre os juízes de mérito ou entre estes e a jurisdição suprema. ${ }^{179}$

\footnotetext{
${ }^{176}$ Michel TROPER - CRISTOPHE GRZEGORCZYK, "Precedent in France”, n. II.1, p. 115-116.

${ }^{177}$ MiChel TROPER - CRISTOPHE GRZEGORCZYK, "Precedent in France”, n. I.7, p. 112-113 e n. II.1, p. 118; NEIL MACCORMICK - ROBERT SUMMERS, "Further general reflections and conclusions", n. 1, p. 532.

178 LOÏC CADIET, "El sistema de la casación francesa”, n. I/3, p. 29 (destacando que o saisine pour avis insere-se numa visão que privilegia a função normativa da Corte de Cassação, representando, historicamente, mais uma conquista desta frente ao legislador e ao référé legislatif, ao consgrar sua missão interpretativa); MiCHEL TROPER - CRISTOPHE GRZEGORCZYK, "Precedent in France", n. I.5, p. 111-112.

${ }^{179}$ LOḮ CADIET, "El sistema de la casación francesa", n. I/2, p. 24-25. Ver os arts. L431-5 e L431-6, COJ (Code de l'organisation judiciaire).
} 
Pode-se concluir, neste tópico, pela crescente autoridade dos precedentes (ou da jurisprudência), em geral, nos diferentes sistemas jurídicos: acentuadíssima no common law e no mundo escandinavo, muito mais fraca na experiência francesa, é verdade, mas sempre presente em alguma medida. Às decisões judiciais dos Tribunais Superiores deve ser atribuída, ao menos, uma presunção de correção, fazendo recair sobre o opositor um ônus argumentativo particularmente elevado e a imposição de razões substanciais que justifiquem a superação. ${ }^{180}$

Ou seja, não se pode esquecer, em última análise, que a vinculação será também o resultado do poder de convicção das razões (Überzeugungskraft ihrer Gründe). Há que se ter constantemente em mente, por isso, o alerta de R. C. VAN CAENEGEM: "o direito produzido pelo juiz será tão bom quanto os juízes que o produziram (dificilmente poderia ser melhor)". 181

\section{5. ÂMBITO DE ATUAÇ̃̃o E COGNIÇÃO DO TRIBUNAL}

De um modo geral - e ressalvadas as Cortes escandinavas, bem como a antiga experiência espanhola de cassação por motivo de infração de lei relativo a erro de fato, hoje sepultada ${ }^{182}$ - os Tribunais Superiores revisam apenas questões de direito, não reexaminando os fatos acertados ou a convicção sobre a prova manifestada pelas instâncias inferiores. É assim - ao menos teoricamente e desconsideradas eventuais "impurezas", inevitavelmente presentes diante da artificialidade da distinção -, v.g., na Argentina, ${ }^{183}$ Alemanha, ${ }^{184}$ Bélgica, Espanha, ${ }^{185}$ França, ${ }^{186}$ Itália $^{187}$ e, como se sabe, também no Brasil. $^{188}$

\footnotetext{
${ }^{180}$ Robert Alexy - RALF DReIER, "Precedent in the Federal Republic of Germany”, n. II.1, p. 31.

${ }^{181}$ Juizes, legisladores e professores, cap. 4, p. 91.

${ }^{182} \mathrm{O}$ controle quanto ao erro de fato na apreciação da prova, diante de documentos ou atos autênticos, era uma particularidade da cassação espanhola surgida com a LEC-1881 (a título de curiosidade histórica, podese consultar o relatório de VICTOR FAIRÉN GUILLÉN, "La doctrina legal y el control de los hechos en la casación civil y laboral española", esp. n. 12-17, p. 1063-1076). Tal fundamento foi revogado pela Ley 10/1992 e não foi reproduzido na vigente LEC-2000.

${ }^{183}$ Ver o art. 14, Ley 48, embora alguma incursão fática seja possibilitada pela doutrina da sentencia arbitraria o del absurdo ( $c f$. AUGUSTO M. MORELLO, "Recursos extraordinarios: visión comparada brasileña y argentina", n. 4, p. 17).

${ }^{184}$ Ver o $\S 546$, ZPO. Cf. OTHMAR JAUERnIG, Direito processual civil, §72/II, p. 361; HANS PRÜTtING, “A admissibilidade do recurso aos Tribunais alemães superiores", p. 154.
} 
No common law, a distinção entre fato e direito sustenta todo o sistema recursal: via de regra, nos appeals - mesmo aqueles dirigidos aos tribunais de segunda instância só se discutem questões de direito, revisando juízos fáticos apenas em hipóteses excepcionais (como a insuficiência do standard of evidence ou o juízo fático clearly erroneous). ${ }^{189}$

É impossível não mencionar, ao referir o tema, as conhecidas dificuldades da distinção fato-direito e, nessa medida, as bases frágeis sobre as quais é delimitada a cognição das Cortes. Deixado o aspecto de lado, por ora, basta constatar que tanto numa quanto noutra das grandes famílias jurídicas, os recursos às Cortes Supremas só podem envolver questões de direito, excluída a revisão dos fatos, entendidos estes como as particularidades históricas do caso.

A primeira diferença que se coloca, nessa sede, diz respeito à atuação do Tribunal Superior, uma vez verificado um error iuris in iudicando no julgamento do recurso. A alternativa dá-se entre decidir, desde logo, o mérito da causa ou, pelo contrário, limitar o julgamento superior a um mero juízo rescindente da decisão recorrida, sendo de rigor o reenvio a um tribunal da instância inferior para a definição do litígio. A este último modus operandi correspondem as Cortes de cassação; àquele, os Tribunais de revisão (ou review). ${ }^{190}$ No fundo, a escolha reflete uma resposta ao dilema sobre qual órgão jurisdicional possui o poder (ou o "direito") de decidir o caso. ${ }^{191}$

\footnotetext{
${ }^{185}$ Ver o art. 477.1, LEC. VICENTE GIMENO SENDRA, Derecho procesal civil, vol. 1, n. 32(I), p. 623

${ }^{186}$ Falando a legislação na "non-conformité du jugemet qu'il ataque aux règles de droit" (art. 604, NCPC), lembrando-se, entretanto, a aproximação aos fatos por meio das doutrinas de défaut de motifs, manque de base légale e dénaturation.

${ }^{187}$ Ver Ferdinando MAZZARELla, Analisi del giudizio civile di cassazione, cap. 3, n. 1, p. 83 e ss., devendo recordar-se, no entanto, que alguma incursão fática é realizada por meio do controle da motivação (art. 360, 5, c.p.c.).

${ }^{188}$ Vejam-se, v.g., os enunciados nn. ${ }^{\circ} 5$ e 7 da Súmula/STJ.

189 Chase-Hershroff-Silberman-Taniguchi-VARAno-Zuckerman, Civil litigation in comparative context, cap. 7, n. IV, p. 346.

${ }^{190}$ Embora os países de common law empreguem, indistintamente, o termo "appeal" para designar suas formas recursais, é necessário distinguir, no plano teórico, entre estruturas de appeal puro (ou appeal by rehearing) e procedimentos de review (ou appeal by review), cf. CHASE-HERSHKOFF-SILBERMAN-TANIGUCHIVARANO-ZUCKERMAN, Civil litigation in comparative context, cap. 7, n. III, p. 342; J. A. JOLOWICZ, On civil procedure, cap. 15, p. 299.

${ }^{191}$ Nesses termos, J. A. Jolowicz, On civil procedure, cap. 15, p. 320-323 (destacando a tendência de atribuir a decisão ao órgão ad quem).
} 
A segunda diz respeito à matéria sobre a qual é chamado a atuar o Tribunal Superior: sua competência, nesse sentido, pode ser maior ou menor segundo realize ele mesmo o controle de constitucionalidade das leis e dos atos administrativos ou tais poderes sejam atribuídos a outros órgãos.

\subsubsection{CASSAÇÃo OU REVISÃo}

Hoje, praticamente inexiste - a ressalva é a Grécia, que mantém uma cassação pura (a denominada Areios Pagos) ${ }^{192}$ - sistema no qual ao Tribunal Superior não sejam outorgados, em qualquer hipótese, poderes para julgar diretamente o mérito da causa. Embora esse seja um traço marcante do modelo de cassação, foi ele abandonado pelos diversos países do grupo por meio de reformas legislativas.

Veja-se o exemplo francês: desde a reforma ocorrida em 1979, pode haver cassação sem reenvio, isto é, substituição da decisão recorrida por uma decisão de um dos painéis da Cour de Cassation, que define assim o litígio. Isso pode passar-se em duas hipóteses: quando o teor da decisão dispensar um novo julgamento da causa (v.g., decisões de irrecevabilité ou de incompétence), o que parece óbvio, ou, ainda, quando os fatos, tais como soberanamente definidos pela jurisdição ordinária, permitirem à Corte aplicar a regra de direito apropriada ao caso (arts. 621 e 627, NCPC, respectivamente). ${ }^{193}$ A inovação visou a eliminar o burocrático e lento procedimento de reenvio, justificando-se como medida de aprimoramento da administração da justiça em tempo razoável. ${ }^{194}$ Semelhante modificação ocorreu em 1990 na Itália, dando-se nova redação ao art. 384 do c.p.c., de forma a permitir o julgamento da causa quando ulteriores esclarecimentos fáticos fossem desnecessários.

\footnotetext{
${ }^{192}$ Segundo noticiam Ugo MAteI - TeEmu RuSKola - ANTONIO Gidi, Comparative Law, cap. 6(d) p. 514, nota 34 (destacando, embora, que a Corte tinha o poder de julgar sem reenvio no período entre 1957 e 1993).

${ }^{193}$ Art. 627, NCPC: “La Cour de cassation peut casser sans renvoi lorsque la cassation n'implique pas qu'il soit à nouveau statué sur le fond. (...) Elle peut aussi, en cassant sans renvoi, mettre fin au litige lorsque les faits, tels qu'ils ont été souverainement constatés et appréciés par les juges du fond, lui permettent d'appliquer la règle de droit appropriée". No mesmo sentido, o art. L. 411-3 do Código de Organização Judiciária. Antes de 1979, tal prerrogativa era conferida apenas à Assemblée Pleniére (que se reunia em segunda cassação), embora fosse inexistente, em todos os casos, previamente a 1967.
}

${ }^{194}$ Cf. CADIET - NORMAND - MEKKI, Théorie générale du procès, n. 292, p. 958. 
Cabe lembrar que esse resultado já era atingido, em alguns casos, pela "correção dos motivos" da decisão recorrida (art. 620, NCPC; art. 384, 2, c.p.c), hipótese em que, embora o Tribunal rejeitasse formalmente o recurso, corrigia a sua motivação, contribuindo para a formação da pronúncia final, que seria, então, subjetivamente complexa. $^{195}$

À luz dessa radical mudança, a diferença teórica antes existente entre o modelo de cassação e de revisão teve seu sentido diminuído, embora muitos autores acentuem, ainda, a sobrevivência de uma "ideologia" da cassação, que conduz, na prática, ao escasso uso dos julgamentos sem reenvio. Assim, ainda que atendidas as condições previstas para tanto (i.e., desnecessidade de ulteriores esclarecimentos fáticos), constata-se verdadeira discricionariedade por parte da Corte na substituição da decisão recorrida, mecanismo ainda pouco utilizado. ${ }^{196}$ A regra geral ainda é, portanto, a anulação com o subseqüente reenvio, sendo a decisão do Tribunal Superior a respeito da regra de direito vinculante para o juízo a quo na primeira (art. 384, c.p.c., Itália) ou segunda cassação (art. L431-4, 2, COJ, França). ${ }^{197-198}$ Há, inclusive, quem entenda que o reenvio favorece o diálogo entre os órgãos judiciais, na medida em que a resistência ou rebelião dos juízes de fundo pode conduzir à formação de uma assemblée plénière para que se decida o segundo recurso,

\footnotetext{
${ }^{195}$ Ver, sobre a eficácia da decisão de correção da motivação pela Corte de Cassação italiana, que inclusive poderia contribuir para a formação do giudicato, dando origem a um pronunciamento complexo, LIEBMAN, "Limiti ed effetti della 'correzione in diritto' della sentenza in sede di cassazione", p. 313 e ss.; ID., Manual de derecho procesal civil, p. 528. J. A. JoLOwiCZ destaca como a correção de motivos já insere um "elemento de impureza" no modelo da cassação (On civil procedure, cap. 15, p. 311).

${ }^{196}$ Assim, "[i]n practice, the difference will probably last for a few more decades. Progress in the area of cassation without remand will probably come painfully slow, but in inevitable" (UGO MATEI - TEEMU RuSKOLA - ANTONIO GIDI, Schlesinger's Comparative Law, cap. 6(d), p. 516). Segundo os autores, em 2008, enquanto apenas $3 \%$ do total dos recursos interpostos foram julgados sem reenvio, 19\% foram remetidos novamente às instâncias ordinárias; quanto ao resto, $24 \%$ foram desprovidos e $54 \%$ inadmitidos (op. cit., p. 515). Também salientando que, na prática, prevalece o reenvio, SOFIE M. GEEROMS, "Comparative law and legal translation: why the terms cassation, revision and appeal should not be translated”, p. 207.

${ }^{197}$ O juízo de reenvio italiano foi sempre mais restrito que o reenvio francês. Neste, há uma verdadeira renovação de uma fase do processo, com um retorno ideal do procedimento ao estado anterior à sentença cassada, com a possibilidade de serem argüidos novos motivos e consideradas novas provas em um novo juízo (ex. arts. 631/634 e 638, NCPC); na Itália, não se desconhece o julgado recorrido e cassado, realizandose apenas aquilo que é necessário e considerando-se preclusas as demais questões. Há, nisso, alguma aproximação com o modelo da Revision alemã, de modo que já foi dito do reenvio italiano ser ele "o momento intermediário de uma parábola ideal" entre o modelo francês originário e o modelo alemão (ver, sobre isso, EDOARDO RICCI, "La cassazione civile italiana e il divieto di pronuncia sul caso concreto", n. 4-8, p. 718 e ss.; a citação transcrita é da p. 727).

198 Essa é a regra geral na França (art. L.431-4, COJ), embora, em alguns casos, a atuação da assembée pléniaire pode ocorrer já na primeira cassação (art. L.431-6, COJ), sendo então desde logo vinculante a decisão da Corte ao tribunal de reenvio. Algo semelhante ocorre na Bélgica (arts. 1119 e 1120, Code Jud.).
} 
permitindo, com o tempo, uma maturação da orientação jurisprudencial. ${ }^{199}$ Outros manifestaram sua preocupação com o direito de defesa das partes e com a ambigüidade das cláusulas que autorizam o julgamento direto do mérito. ${ }^{200}$ A tendência, contudo, é de um progressivo aumento do uso da cassação sem reenvio, com aproximação, nesse ponto, ao modelo de revisão. ${ }^{201}$

Na Revision, como se sabe, o paradigma é outro: a Corte pode não apenas cassar, mas julgar ela própria o mérito da causa (ius rescissorium). Em relação ao $\mathrm{BGH}$, tal previsão é feita no $\S 563.3, \mathrm{ZPO}$, que prescreve o julgamento direto da causa quando esta se encontre em estado de ser decidida. Em caso contrário, ocorre o reenvio a um tribunal inferior, que deve ajustar-se à interpretação dada pelo BGH. Esta, segundo parte da doutrina, é a prática comumente observada. ${ }^{202}$ A substituição dos motivos da decisão recorrida é naturalmente possível, havendo previsão expressa no $§ 561$.

Na Espanha, o Tribunal Supremo atua não só cassando (ius rescindens), mas também rejulgando o mérito da causa (ius rescisorium). ${ }^{203}$ Cabe fazer um parêntese a fim de prevenir um equívoco: apesar do seu nome, a "cassação" espanhola evoluiu de forma a distanciar-se de maneira relevante da originária cassação francesa; desde muito cedo, v.g., atuou de maneira positiva, não somente cassando a decisão recorrida, mas julgando ela mesma a causa. ${ }^{204}$ Aliás, a doutrina espanhola esforça-se para demonstrar a originalidade de sua casación: embora influenciados em alguma medida pela doutrina da separação de poderes, os constituintes de Cádiz de 1812 criaram o Supremo Tribunal de Justicia (ulteriormente, Tribunal Supremo) já como órgão jurisdicional situado ao vértice da

\footnotetext{
${ }^{199}$ CADIET - NoRMAND - MEKKI, Théorie générale du procès, Paris: PUF, 2010, n. 292, p. 957.

${ }^{200}$ VITTORIO DENTI, "The Court of Cassation as a court on the merits", p. 194-195. Mas, deve-se confrontar esta posição com Elio FAZZALARI, "Rescissionary rulings from the Court of Cassation", p. 201-202 (entendendo não haver ofensa ao direito das partes, que podem fazer suas alegações de antemão).

${ }^{201}$ Nesse sentido, Claudio Consolo, Il processo di primo grado e le impugnazione..., p. 480.

202 "Por regla no ejerce un iudicium rescisorium y reenvía la causa" (HANS PRÜTTING, "Estudio introductorio al Código Procesal Civil alemán”, cap. 5(V), p. 128).

${ }^{203}$ VICENTE GIMENO SENDRA, Derecho procesal civil, vol. 1, n. 32(I), p. 625

${ }^{204} C f$. VICTOR FAIRÉN GUILLÉN, "La doctrina legal y el control de los hechos en la casación civil y laboral española”, n. 1, p. 1027-1030, que refere o Código de Comércio de 1820, o Decreto Real de 30 de janeiro 1855 e a LEC-1855 em abono; também JUAN MONTERO AROCA - JOSÉ FlORS MATíES, El recurso de casación civil, cap. 3, p. 266: "significa nada menos que el Tribunal Supremo español tuvo desde entonces jurisdicción positiva en la infracción de ley (...) si estimaba el recurso primero casaba la sentencia recurrida y luego entraba a decidir de manera firma el caso planteado, sin devolver la causa al tribunal de apelación".
} 
hierarquia judicial, e não como órgão político ligado ao Poder Legislativo e à sua proteção frente aos juízes. ${ }^{205} \mathrm{~A}$ associação, portanto, deve ser feita com o tipo ideal da revisão.

Diferentemente do que ocorre entre nós, a Suprema Corte americana não costuma embora possa fazê-lo - julgar ela mesmo a causa de maneira definitiva, substituindo por uma decisão sua o julgado recorrido. Muito pelo contrário, os estudiosos daquela Corte apontam que "ela quase sempre reenvia (manda de volta) o caso para a corte inferior para 'ulteriores procedimentos de acordo com essa decisão", ${ }^{206}$ Nenhum impedimento existe, por outro lado, a que a decisão recorrida seja mantida por outros motivos, já que a opinion é destacada do judgment (parte dispositiva) e somente o erro prejudicial dá lugar à reforma. ${ }^{207}$ Também na Argentina, embora exista a previsão legal (art. 16, $2^{\mathrm{a}}$ parte, Lei n. ${ }^{\circ}$ 48), a Corte Suprema decide o mérito da causa apenas excepcionalmente. ${ }^{208}$

A pesquisa, nesse ponto, revela que a inequívoca jurisdicionalização dos Tribunais Superiores, bem como a economia processual, impõem hoje como solução praticamente universal a atribuição do poder de decidir a causa diretamente a tais instâncias. Há certo consenso de que a aplicação do direito à espécie pelo próprio Tribunal Superior (e não por um juiz de reenvio) traz vantagens não somente do ponto de vista da eficiência (tempo e dinheiro), mas também na medida em que a solução é dada pelo próprio magistrado que enunciou a solução jurídica aplicável. ${ }^{209}$

Entretanto, e o ponto é de grande importância, a Corte nem sempre deve fazê-lo, pois - ao contrário do que, entre nós, é comumente afirmado (à luz, v.g., do verbete n. 456 da Súmula/STF) -, em muitos casos será ainda adequado o reenvio em nome do direito das partes e da preservação da função objetiva do Tribunal.

\footnotetext{
${ }^{205}$ Ainda que só se possa falar de uma "verdadeira cassação" a partir de 1838 (e não desde o aparecimento do instituto diverso do recurso de nulidad em 1812) e, com maior razão, à luz da regulação definitiva na LEC1855. Sobre o assunto, amplamente, VICTOR FAIRÉN GUILLÉN, "La recepción en España del recurso de casación francés (1812-1813)", p. 197 e ss.; JOSÉ LUIS VÁSQUEZ SOTELO, "El modelo español de casación", n. III, p. 369 e ss.; de maneira abrevida, JuAN MONTERo AROCA - José Flors MatíEs, El recurso de casación civil, cap. 3, p. 260-266.

${ }^{206}$ Lawrence Baum, The Supreme Court, cap. 6, p. 188; Ugo Matei - TeEmu Ruskola - Antonio Gidi, Schlesinger's Comparative Law, cap. 6(d), p. 516.

${ }^{207}$ Cf. J. A. Jolowicz, On civil procedure, cap. 15, p. 313.

${ }^{208}$ Cf. Barbosa Moreira, Comentários ao Código de Processo Civil, vol. 5, n. 324, p. 604, nota 59; CÂNDIDO DINAMARCO, “A função das Cortes Supremas na América Latina”, n. 410.2, p. 785.

${ }^{209} C f$. ANDRÉ TUNC, "La Cour suprême idéale”, p. 435.
} 


\subsubsection{COMPETÊNCIA SEGUNDO A MATÉRIA}

Em países que seguem o modelo austríaco de controle de constitucionalidade como a Alemanha, a Bélgica, a Espanha, a Itália, a Polônia, bem como os países, em geral, do Leste Europeu (antigas repúblicas soviéticas) ${ }^{210}$-, convivem, lado a lado, um Tribunal Supremo (responsável pelo julgamento, em última instância, das demandas e por conferir unidade ao Direito) e um Tribunal Constitucional (cuja missão é especificamente relacionada ao controle de constitucionalidade das leis e de outros atos normativos). A articulação entre os dois órgãos pode ser bastante complexa e problemática. ${ }^{211}$ Evidentemente, no entanto, mesmo onde existe uma Corte Constitucional específica, os demais juízes e Tribunais devem aplicar o direito infraconstitucional à luz da Constituição, interpretando a legislação de acordo. ${ }^{212}$

Já na tradição norte-americana, o controle de constitucionalidade (judicial review) é realizado (de maneira incidental) pelo mesmo órgão responsável pela unificação do direito federal, centralizadas ambas as funções na Suprema Corte. Essa a tendência predominante também nos países escandinavos. ${ }^{213}$

Entre nós, como se sabe, o controle de constitucionalidade consiste num sistema híbrido e, em boa medida, sui generis: ao Supremo Tribunal Federal cabe declarar, em abstrato, a (in)constitucionalidade das leis e atos normativos (art. 102, I, $a, \mathrm{CF}$ ); entretanto, todos os juízes e tribunais (art. 97, CF) devem realizar um exame de compatibilidade das leis com a Constituição. ${ }^{214}$ A competência recursal excepcional, por sua vez, é bipartida entre os dois Tribunais de superposição - o Supremo Tribunal Federal (art. 102, III, CF) e o Superior Tribunal de Justiça (art. 105, III, CF) -, de acordo com a natureza constitucional ou infraconstitucional dos fundamentos invocados, distinção por vezes confusa que complica a sistemática dos dois recursos.

\footnotetext{
${ }^{210}$ MiCHAL BOBEK, "Quantity or quality? Reassessing the role of Supreme Jurisdictions in Central Europe", n. II, p. 46.

${ }^{211}$ Ugo Mattei - Teemu Ruskola - Antonio Gidi, Comparative law, cap. 6(d), p. 505.

${ }^{212}$ Michele TARUFFo, “Institutional factors influencing precedents", n. 1.3, p. 443.

${ }^{213} C f$. Michele TARUFFo, "Institutional factors influencing precedents", n. 1.3, p. 442-443; AULIS AARNIO, "Precedent in Finland", n. I.1(a), p. 66.

${ }^{214}$ Segundo classificação de ALESSANDRo PiZZORUSSO, tal sistema pode ser classificado como dual, já que prevê tanto o controle concentrado e abstrato quanto o difuso e concreto, diferenciando-se de sistemas mistos, em que o controle é incidental, mas concentrado em um só órgão ("Le sentenze dei giudici costituzionali", $\mathrm{n}$. 4, p. 564)
} 
Cabe salientar, ainda, a existência de outras divisões de competência segundo a matéria. Na Europa, a Corte de Justiça da Comunidade Européia é responsável pela interpretação do direito comunitário e a Corte Européia de Direitos Humanos pode conhecer de alegações de violação ao devido processo legal pelo procedimento adotado nos países signatários e impor a eles condenações. ${ }^{215}$ Por fim, naqueles países que adotam o sistema de contencioso administrativo - como França e Itália - os conflitos envolvendo o indivíduo e a Administração são resolvidos dentro de uma estrutura autônoma, que culmina num órgão de cúpula também apartado (Conseil d'État, Consiglio di Stato). Mas também outras repartições de competência segundo a matéria, nesse campo, são conhecidas: na Alemanha, v.g., o Bundesgerichtshof (BGH), equivalente ao nosso Superior Tribunal de Justiça, fica situado no vértice da Justiça comum, convivendo com quatro Justiças especiais (trabalhista, administrativa, da seguridade social e fiscal), cada uma das quais com seu Tribunal Superior respectivo. ${ }^{216}$

\subsection{VALORAÇõES À LUZ DA PESQUISA REALIZADA}

Há uma crise generalizada dos Tribunais Superiores. Ela é lamentada em toda parte. Entre nós, é notória a história da "crise do Supremo". Mas de semelhante problema queixaram-se mesmo países aparentemente distantes da nossa realidade jurídica: a República Tcheca, a Eslovênia e o Japão são exemplos claros dessa ubiqüidade. ${ }^{217}$

A Corte di Cassazione italiana é paradigmática desse colapso: o número de processos julgados (cerca de 30.000 por ano) levou a doutrina daquele país a considerá-la "um monstrum do qual um jurista estrangeiro tem dificuldade para compreender sua existência", ${ }^{218}$ muito embora a afirmação seja quase uma piada de mau gosto para o processualista brasileiro, acostumado com estatísticas na casa das centenas de milhares.

\footnotetext{
${ }^{215}$ Daí a dificuldade que alguns autores encontram em reconhecer a Cassation francesa como verdadeira "Corte Suprema" (CADIET - NORMAND - MEKKI, Théorie générale du procès, n. 293, p. 960-961; LoÏC CADIET, "El sistema de la casación francesa", p. 22.)

${ }^{216}$ Consultar Peter L. MURRAY - Rolf StÜRnER, German Civil Justice, cap. 3, p. 37 e ss.

${ }^{217}$ Respectivamente, MiCHAL BOBEK, "Quantity or quality? Reassessing the role of Supreme Jurisdictions in Central Europe", n. I, p. 34; ALEŠ GALIČ, "The role of the Supreme Court in creating precedents in Slovenian civil procedure", n. II, p. 264-265; TANIGUCHI, "The 1996 Code of Civil Procedure of Japan - a procedure for the coming century?", n. 4, p. 779-780.

${ }^{218}$ Michele TARUfFo, “Una reforma de la casación civil?”, n. 1, p. 518.
} 
Ainda assim, na Itália, alguns chegam ao ponto de dizer haver ela perdido sua conotação de Suprema Corte. ${ }^{219}$ A quantidade, como não pode deixar de ser, repercute também sobre a qualidade das decisões e sobre a duração (não razoável) dos processos naquela sede. ${ }^{220}$ Isso se deve, grosso modo, tanto à inexistência de filtros nas Cortes de Cassação (diante, sobretudo, do obstáculo do art. $111,7^{\circ}$, da Constituição) quanto, em alguma medida, à própria cultura jurídica que impregna o sistema cassacional, em que os recursos excepcionais são vistos como direitos subjetivos dos litigantes e como uma fase usual e complementar de praticamente todo e qualquer processo. ${ }^{221}$

A experiência comparada evidencia, por outro lado, o funcionamento muito mais adequado dos modelos de revisão e de appeal. Isso é indicado pelo volume compreensível de recursos julgados (aspecto estrutural) e pelo relativo prestígio das decisões prolatadas (aspecto funcional). Qual é o segredo dessas Cortes?

A meu ver, buscando ao mesmo tempo fazer um apanhado geral e responder à pergunta, são duas as principais conclusões a serem extraídas do estudo comparativo.

I) Seleção dos recursos - a primeira é a tendência de utilizar um mecanismo de seleção dos recursos. A carga de trabalho é, por vezes, insuportável e não deixa dúvidas quanto a isso: os sistemas sem filtros efetivos (Itália e França) são exemplos ineficientes de administração de justiça, criticados intensamente pela doutrina daqueles países.

O critério há de recair sobre a importância (ou relevância, repercussão, transcendência etc.), a nível geral, da questão. As Cortes mais prestigiadas tendem a ser aquelas que decidem poucos, mas importantes casos. Alçadas ligadas ao valor da causa ou ao valor do prejuízo sofrido pelo recorrente devem ser repelidas, porquanto atentam contra

\footnotetext{
${ }^{219}$ ELIO FAZZALARI, "La cassazione civile: stato atuale e possibili misure", n. 1, p. 893. A idéia de que há uma crise funcional e "de identidade" do instituto da cassação é generalizada: GIOVANNI VERDE, Profili del processo civile, vol. 2, cap. 8, n. 7, p. 277; FEDERICO CARPI, "Una novità francese per frenare i ricorsi in Cassazione dilatori", p. 79; ClaUdio Consolo, Il processo di primo grado e le impugnazioni..., esp. p. 517518; ANDREA PROTO PISANI, “Crisi della Cassazione”, p. 262-263.

${ }^{220}$ Já em 1965, o problema da excessiva duração dos processos em fase de cassação era acentuado pela doutrina italiana, que relatava uma duração média que atingia "recorde impressionante de 1073 dias", ou seja, de quase três anos (CAPPELLETI, "Parere iconoclastico sulla riforma del processo civile italiano", n. 3, p. 115). No artigo referido, o autor faz uma proposta ousada de abolição dos juízos de apelação e do reexame dos fatos, por meio da qual passariam os tribunais de segunda instânica a atuar como Cortes de Cassação, cabendo a uma Cassação central a resolução de eventuais divergências.

${ }^{221}$ Cf. Chase-Hershroff-Silberman-Taniguchi-Varano-Zuckerman, Civil litigation in comparative context, p. 331.
} 
a igualdade e negligenciam questões jurídicas importantes passíveis de surgirem em causas de valor inestimável ou até mesmo de baixo valor.

Quanto ao modo de realização desse controle, parece preferível deixar ao próprio Tribunal Superior a admissão do recurso excepcional, seja porque isso garante uma uniformidade na aplicação de critérios de concessão da permissão, seja porque é ele mesmo quem conhece melhor os seus limites e a capacidade de sua atuação. ${ }^{222}$

II) Força dos precedentes - é certo que uma tradição fundada no "legalismo lógico" (ideal de vinculação estrita à lei) fez com que não se desse grande importância (ao menos formalmente) aos precedentes judiciais como exemplos de julgamentos de situações concretas na formação histórica dos sistemas de direito continental. ${ }^{223}$ Entretanto, a idéia de que apenas nos países de common law os precedentes teriam importância parece ter sido desmentida em grande medida; hoje, parece tranqüila a afirmação contrária de que os precedentes gozam de prestígio também nas jurisdições de tradição de civil law. ${ }^{224}$ Muitos autores, por isso, ressaltam a vinculação de facto, senão de iure, das decisões emanadas por Cortes Superiores no sistema continental, ainda que a expressão se sujeite a críticas. ${ }^{225}$

Portanto, quando o tema é a força normativa dos precedentes, dificilmente se pode falar numa verdadeira dicotomia: o que há, antes, é um continuum. ${ }^{226}$ Se é certo que na Inglaterra e nos Estados Unidos, o precedente - isoladamente considerado - possui grande força, os países continentais, como a Itália, apegam-se, em boa medida, mais à quantidade do que à qualidade das decisões, conferindo peso a uma jurisprudência conforme e reiterada. $^{227}$

\footnotetext{
${ }^{222}$ Nesse sentido, ALEŠ GALIČ, "The role of the Supreme Court in creating precedents in Slovenian civil procedure", n. II, p. 268.

${ }^{223}$ MIRJAN DAMAŠKA, The faces of justice and state authority, cap. I, n. iv, p. 33.

${ }^{224}$ Nesse sentido, entre tantos outros, Michele TARUFFo, "Precedente e giurisprudenza", n. 1, p. 795; R. C. VAN CAENEGEM, Juizes, legisladores e professores, cap. 1, p. 28-29; CRUZ E TUCCI, Precedente judicial como fonte do direito, cap. I, n. 2, p. 18; ALESSANDRO PIZZORUSSO, "Le sentenze dei giudici costituzionali", n. 2, p. 555 e 557 (destacando a constitucionalização européia do séc. XX como fator de consolidação do direito jurisprudencial); ROBERT ALEXY, Teoría de la argumentación jurídica, p. 261-262.

${ }^{225}$ V.g., indicando a contradição na locução "binding 'de facto", ALEKSANDER PECZENIK, "The binding force of precedent", n. 1, p. 461 e esp. n. 3, p. 465-467.

${ }^{226}$ NeIL MACCORMICK - ROBERT SUMmERs, "Further general reflections and conclusions", n. 1, p. 531-535.

${ }^{227}$ Michele TARUfFo, "Precedente e giurisprudenza”, n. 3, p. 803.
} 
Variados fatores, por certo, influem na maior ou menor força de um precedente. Primeiramente, deve ser destacada a tendência geral das Cortes de seguirem os seus próprios precedentes, especialmente quando tomadas por órgãos colegiados maiores. Outros importantes indicativos a serem levados em conta são: I) pertencer ou não a decisão a um conjunto de decisões reiteradas naquele sentido (cabendo falar, em alguns casos, numa jurisprudência permanente - ständige Rechtsprechung); II) a hierarquia da Corte que pronunciou o acórdão; III) a solidez dos argumentos lançados na decisão; IV) o decurso do tempo desde o julgado; v) a existência ou não de crítica doutrinária acerca do julgamento; VI) eventuais mudanças no sistema jurídico ou nas circunstâncias sociais e econômicas; VII) a necessidade de certeza e uniformidade em determinadas áreas do Direito; VIII) o quorum atingido na votação (unânime ou com dissidências) etc. $^{228}$

Seja como for, é certo que há uma tendência visível a emprestar cada vez mais importância à jurisprudência uniforme (e uniformizadora) dos Tribunais Superiores.

A questão da possibilidade de uniformidade da jurisprudência está ligada não só à força dos precedentes, mas também a dados estruturais dos Tribunais Superiores. Uma Corte formada por um grande número de integrantes tende a gerar julgados contraditórios, i.e, divergências entre as suas diferentes Turmas, Seções ou quaisquer outros órgãos colegiados fracionados, com o conseqüente enfraquecimento de sua autoridade. Por isso, a ausência de uma teoria do stare decisis ou de uma vinculação consistente ao precedente na maioria dos países de civil law representa, em verdade, "a conseqüência lógica das diferenças estruturais-organizativas, processuais e de sociologia jurídica”. ${ }^{229}$

À luz disso, é possível reafirmar, a essa altura, as duas principais conclusões enunciadas: é crescente a autoridade dos precedentes e é visível que o acúmulo de trabalho das Cortes Supremas tem exigido, para o adequado cumprimento de sua função, a instituição de mecanismos de seleção de recursos. Como destacou Michele TARUfFo, longe de representarem fenômenos contrapostos, há uma dupla relação de conexão entre os precedentes e a seleção de casos a serem julgados pelos Tribunais Superiores: "a oportunidade de estabelecer um precedente pode justificar a seleção de um caso para

\footnotetext{
${ }^{228}$ AULIS AARNIO, "Precedent in Finland", n. II.3, p. 88-89; ROBERT ALEXY - RALF DrEIER, "Precedent in the Federal Republic of Germany", n. II.3, p. 34-36.

${ }^{229}$ MAURO CAPPELlETTI, Juízes legisladores?, n. 14, p. 117 e 122; MiCHELE TARUFFO, "Institutional factors influencing precedents", n. 2.3, p. 446-447.
} 
decisão; uma decisão de um caso selecionado em razão de sua importância provavelmente tornar-se-á um precedente". 230

O cuidado nas transposições - no mais, alerta sempre presente no estudo comparativo - evidentemente não pode ser negligenciado. É preciso observar as peculiaridades ainda arraigadas nas diferentes tradições. ANDRÉ TUNC, embora versando um tipo ideal de Corte Suprema, afirmou que um modelo universal não é concebível à luz das particularidades de cada sistema jurídico. ${ }^{231}$

Se, a nível de micro-comparação, a atuação dos Tribunais Superiores difere em razão da maior ênfase dada ao escopo privado ou público da instituição, no âmbito da macro-comparação, tais diferenças revelam visões inteiramente diversas a respeito da função jurisdicional (e da burocracia estatal - officialdom - como um todo). De um lado, há modelos hierárquicos, que valorizam o controle sobre as instâncias inferiores; de outro, há tipos que visam à coordenação entre os juízes, buscando uniformidade por meio dos precedentes (stare decisis). Como já se viu, nos países ligados ao direito continental (e, em parte, também nos países da antiga União Soviética) - sobretudo naqueles de modelo cassacional - a função dos Tribunais Superiores cinge-se tradicionalmente ao controle individual de legalidade das decisões recorridas, que não se sujeitam a uma seleção pela Corte, sem maiores preocupações com a formação de precedentes voltados para o futuro. De maneira contrária, a tradição do common law empresta às Supreme Courts um papel na formação e desenvolvimento do direito, destacando o componente prospectivo de sua atuação jurisdicional e deferindo-lhes ampla discricionariedade na seleção dos casos a serem julgados. Ademais, o raciocínio judicial no continente tende a ser deducionista, legalista e magisterial, desprezando em boa dose os aspectos fáticos do caso, enquanto no common law predominam decisões de estilo substancial, discursivo e personalizado, com ampla análise dos fatos. ${ }^{232-233}$

\footnotetext{
${ }^{230}$ MiCHELE TARUFFo, "Institutional factors influencing precedents", n. 2.2, p. 446.

231 "La Cour supréme idéale", p. 433.

${ }^{232}$ Trata-se da conhecida obra de MIRJAN DAMAŠKA, The faces of Justice and State authority: a comparative approach to the legal process, New Haven: Yale University Press, 1986, passim. Para uma aplicação de tais noções especificamente ao papel atribuído aos Tribunais Superiores, v. MicHAL BOBEK, "Quantity or quality? Reassessing the role of Supreme Jurisdictions in Central Europe", American Journal of Comparative Law, 2009, vol. 57, n. I, p. 42-44. Por essa ótica, o modelo de revisão apresentar-se-ia como híbrido. Aproxima-se do common law na medida em que os Tribunais Superiores lidam, em princípio, apenas com casos em que há uma questão de importância fundamental, necessidade de desenvolver o direito ou divergência entre as cortes inferiores. Mas mantém, via de regra, válvulas de escape para a revisão de
} 
Assim, por exemplo, um modelo abertamente discricionário de julgamento é difícil de ser assimilado no civil law, onde é exigida tradicionalmente do juiz, mesmo nos casos de maior abertura semântica da norma, uma eleição de critérios "objetivos", devidamente fundamentada. ${ }^{234}$ Não precisamos ir longe para averiguar o acerto da premissa. Disso faz prova a experiência brasileira, em que o instituto da argüição de relevância - privado de motivação e visto como uma outorga de poder decisório excessivamente ampla ao Supremo Tribunal Federal - não foi jamais assimilado pela consciência jurídica nacional (v., supra, cap. 2). Parecemos haver dado o primeiro passo no rumo certo, portanto, com a repercussão geral. Oxalá possamos fazer, com êxito, o mesmo em relação ao Superior Tribunal de Justiça em um futuro breve.

decisões individuais (sem importância geral) em que exista manifesta má aplicação da norma jurídica ou erros de procedimento graves (op. cit., p. 43). A quem quiser consultar uma rápida síntese das idéias de DAMAŠKA, v. LEONARDO GRECO, "Paradigmas da Justiça contemporânea e acesso à justiça", n. 1.1, p. 3: "Na civil law, que é o nosso sistema jurídico, a jurisdição tem sido estruturada preponderantemente com a finalidade de atuação do direito objetivo e por isso a administração da justiça adota o que Damaska denominou de modelo hierárquico, centralizador. Nesse sistema, os juízes são considerados a boca da lei, expressão usada por Montesquieu para justificar a idéia de que os poderes dos juízes decorrem da lei e à lei devem estar sempre subordinados. É imperioso que os juízes inferiores estejam rigidamente controlados pelos tribunais superiores para que se mantenham fiéis a essa missão de serem o instrumento de cumprimento da lei. Já no modelo de administração da justiça dos países da common law, a função da justiça é, de modo preponderante, a de pacificação dos litigantes. A paz social na civil law é um objetivo remoto. Já na common law, a paz entre os litigantes, a rearmonização, a reconciliação é o seu objetivo direto, imediato. Na common law, pouco importa se a pacificação dos litigantes vai dar-se à luz da lei ou de outro critério qualquer que seja mais adequado ao caso concreto. O importante é harmonizar os litigantes. Isso porque a justiça da common law tem um profundo enraizamento na vida da comunidade e tem por função primordial preservar a coesão e a solidariedade entre os seus membros, interdependentes entre si. Enquanto a justiça da civil law tem sido a justiça do rei, do soberano, do Estado, a justiça da common law é a justiça paritária, da comunidade". Trabalhando sobre outro eixo diferentes tipos ideais ou modelos processuais, na doutrina brasileira, DANIEL Mitidiero, A colaboração no processo civil, parte II, p. 63 e ss (desenvolvendo os modelos isonômico, assimétrico e cooperativo de processo).

${ }^{233}$ Especificamente em relação ao raciocínio judicial e ao estilo das decisões, ver NEIL MACCORMICK ROBERT SUMMERS, "Further general reflections and conclusions", n. 2, p. 536-542; ROBERT ALEXY - RALF DREIER, "Precedent in the Federal Republic of Germany", n. I.2, p. 21 (destacando, em relação à Alemanha, que o raciocínio tende a se tornar mais discursivo e substancial na medida em que problemas interpretativos na aplicação das leis se façam presentes); MICHELE TARUFFO, "Institutional factors influencing precedents", n. 3 , p. 448 e ss.

${ }^{234} C f$., ainda, LEONARDO GRECO, "Paradigmas da Justiça contemporânea e acesso à justiça", n. 1.2, p. 6. 


\section{$\S 4$ - LEIS, JUÍZES E TRIBUNAIS SUPERIORES NO ESTADO DE DIREITO}

Nos sistemas de civil law (ou nas áreas do common law governadas por statutes), o Direito é fruto de uma combinação de legislação e jurisdição. O legislador é responsável pela criação do enunciado de lei; o juiz, por sua vez, interpreta o texto no momento de aplicá-lo, reconstruindo o seu sentido e concretizando a norma. Ambos contribuem, em diferentes planos, para a criação e para o desenvolvimento do Direito. Por isso, é hoje insustentável uma teoria declarativa da função jurisdicional, como se a essa coubesse apenas descobrir um significado latente no texto ou declarar uma vontade prévia e abstrata da lei. Interpretação é escolha e o ato de interpretar carrega consigo uma dose inevitável de criatividade. "Por mais que o intérprete se esforce por permanecer fiel ao seu "texto" - já o dizia MAURO CAPPELLETTI -, "ele será sempre, por assim dizer, forçado a ser livre". 235 Ou seja, o texto de lei será necessariamente o ponto de partida da argumentação jurídica desenvolvida para que se chegue à decisão, mas o juiz deve realizá-lo em um contexto novo e diverso; está obrigado, portanto, a criar, em alguma medida, o Direito para o caso, complementando a tarefa do legislador. Sendo assim, é nas decisões judiciais que o ordenamento jurídico encontra seu "produto acabado": formulam-se normas que não apenas decidem o conflito individual (de maneira retrospectiva), mas que servem também para conferir unidade ao Direito e desenvolvê-lo como um todo, orientando - enquanto pautas gerais de conduta - o comportamento e as escolhas de cidadãos livres e responsáveis (de forma preponderantemente prospectiva). Em razão de sua posição hierárquica e de sua capacidade institucional, a função prospectiva de formulação do direito jurisprudencial é atribuída especificamente aos Tribunais Superiores, cuja missão é justamente a de zelar pela igualdade e pela segurança jurídica na aplicação Direito.

Contudo, a concretização desse conjunto de normas de conduta - criadas a partir da lei pela interpretação dos tribunais - não é suficiente, por si só, para garantir valores essenciais ao conceito de Direito. Em verdade, a juridicidade do ordenamento depende da observância de outras normas, que regulam a própria aplicação, a implementação e o desenvolvimento do Direito; sem elas, não se pode reconhecer um autêntico sistema

${ }^{235}$ Juizes legisladores?, n. 3, p. 22. 
jurídico. Trata-se de prescrições de natureza formal e procedimental, integrantes do sobreprincípio do Estado de Direito (rule of law). Atuam elas sobre as regras e princípios substanciais que estabelecem direitos e deveres (normas de primeira ordem ou de primeiro grau) e, por isso, são normas de segunda ordem ou de segundo grau. Pela perspectiva das decisões judiciais, sobretudo daquelas emanadas por Tribunais Superiores, cabe lembrar como fundamentais os princípios: I) da igualdade (unidade do Direito e uniformidade na sua aplicação); II) da segurança jurídica (certeza e estabilidade do ordenamento jurídico); e III) do devido processo legal (adequada tutela dos direitos e legitimação das decisões judiciais). A sua observância é condição necessária para legitimar o Direito enquanto Direito e, por isso, tais princípios conformam o exercício do poder pelo Estado e impõem deveres aos tribunais no desempenho da função jurisdicional.

\subsection{LEIS E JUÍZES}

\subsubsection{TEXTO E NORMA}

À suposição de que leis detalhadas e bem redigidas dispensariam a própria interpretação dos textos legais pelos juízes e possibilitariam, assim, uma aplicação mecânica e unívoca do Direito, independentemente dos fatos do caso ou das valorações do intérprete, poderíamos atribuir a denominação de "positivismo normativista", "legalista" ou "cartesiano". O marco teórico, tipicamente iluminista, teve pesada influência: foi ele defendido ferrenhamente por pensadores como MONTESQUIEU e BENTHAM; ademais, foi adotado como idéia central colocada à base do modelo originário da Cassação e do importante movimento da codificação. ${ }^{236}$ Entretanto, teve vida breve (se é que efetivamente se fez sentir algum dia na prática) e sua essência comprovou-se, com o passar do tempo, decididamente falsa. ${ }^{237}$

\footnotetext{
${ }^{236}$ Consoante destaca KARL ENGISCH, “a desconfiança que haviam chamado sobre si os juízes no período da justiça de arbítrio e de gabinete (...) e, por outro lado, a adoração da lei animada por um espírito racionalista, fizeram com que a estrita vinculação do juiz à lei se tornasse no postulado central" (Introdução ao pensamento jurídico, cap. VI, p. 206). Para uma apreciação desse modelo e do papel que atribuía aos juízes, ver CRUZ E TUCCI, Precedente judicial como fonte do direito, cap. VII, n. 2, p. 197-202.

${ }^{237}$ Nesse sentido, Arthur T. VON MEHREN - JAMES R. GORDLEy, The civil law system, cap. 16, p. 1129; ALEXANDER PEKELIS, "The case for a jurisprudence of welfare", n. 9, p. 617-618; FERDINANDO MaZZARElla, Analisi del giudizio civile di cassazione, cap. 1, n. 1, p. 9; CASTANHEIRA NeVES, "A distinção entre a questão-de-facto e a questão-de-direito...”, n. 1, p. 519-522; ID., O instituto dos 'assentos' e a função jurídica dos Supremos Tribunais, cap. 2, p. 166-167; NICOLA PICARDI, "A vocação do nosso tempo para a
} 
A má redação dos textos legais, a proliferação desenfreada de legislação, as lacunas e as contradições no ordenamento jurídico, o uso intencional de linguagem com maior grau de indeterminação semântica (ou a "textura aberta" que acompanha, em verdade, qualquer enunciado) e mesmo a constatação trivial de que as leis não podem prever as inúmeras complexidades da vida jurídica e as transformações da sociedade - são todos esses indicadores a demonstrar a insuficiência da lei e o papel fundamental da interpretação (em alguma medida criativa) dos textos normativos pelo seu aplicador.

Resulta clara a distinção fundamental entre texto e norma. O texto legal, ao menos nos sistemas de direito legislado, sem dúvida fornece o ponto de partida na busca da solução jurídica, enquanto fonte formal do Direito. Não se pode ignorar, ademais, que as suas palavras carregam algum sentido intrínseco a ser necessariamente considerado - em decorrência de convenções de linguagem e de um conhecimento comum que têm de ser pressupostos, funcionando como limite para o intérprete. ${ }^{238}$ Entretanto, a norma (e, $a$ fortiori, o Direito) não é o enunciado, mas o seu significado enquanto resultado da interpretação do texto no momento de sua aplicação ao caso concreto. ${ }^{239}$ Adiantando uma importante conclusão, pode-se dizer que "não há correpondência bi-unívoca entre dispositivo e norma"; por isso, é possível que uma norma seja reconhecida sem um dispositivo específico que lhe dê suporte, reconstruída a partir de vários textos conjugados ou, inversamente, que um único dispositivo dê ensejo à formulação de mais de uma norma ou não tenha nenhum conteúdo normativo. ${ }^{240}$

jurisdição", n. 1.6, p. 12; LUIGI MENGONI, "Diritto vivente", n. 3, p. 446-447; OvíDIO A. BAPTISTA DA SILVA, “Questão de fato' em recurso extraordinário", p. 498. A esse respeito, cabe lembrar que sequer o detalhadíssimo Código editado por Frederico o Grande (que continha mais de 17.000 artigos) logrou êxito na empreitada "normativista": tanto a codificação prussiana quanto a comissão especial a quem caberia precisar o sentido dos textos legais, bem como a conseqüente proibição de interpretação por parte dos juízes, são, nesse aspecto, considerados fracassos. Ver, sobre a experiência narrada e sobre as ilusões de clareza e completude dos textos legais, verdadeiros "folclores" na tradicional teoria do direito, JOHN HENRY MERRYMAN - ROGELIO PÉREZ-PERDOMO, The civil law tradition, cap. VII, p. 39 e p. 42-43.

${ }^{238}$ Há, inclusive, quem sustente a "primazia" do argumento baseado no sentido normal (ordinary meaning) dos textos legais sobre a interpretação teleológica. Nesse sentido, por todos, RoBERT SUMMERS, "The argument from ordinary meaning in statutory interpretation", p. 219 e ss., passim; ID., "A formal theory of the rule of law", n. II, p. 170-171.

239 RICCARDO GUASTINI, "Se i giudice creino diritto", n. II, p. 173; ID., "Una teoría cognoscitiva de la interpretación”, n. 2, p. 27-29; VEZIO CRISAFULLI, "Disposizione (e norma)", n. 5, p. 207; LUIGI MENGONI, "Diritto vivente", n. 5, p. 448.

240 Humberto ÁvilA, Teoria dos princípios, n. 2.1.1, p. 31 (demonstrando as asserções por meio de exemplos). 
Assim, embora possam existir casos mais facilmente resolvidos à luz de argumentos semânticos (easy cases), há hipóteses em que a mera literalidade do texto é insuficiente e não conduz a um resultado definitivo ou adequado. ${ }^{241}$ Os desafios interpretativos que então surgem - e que constituem os assim chamados hard cases podem ser basicamente de dois tipos. ${ }^{242}$

Em primeiro lugar, manifestam-se diante da indeterminação semântica ou vagueza da linguagem (fuzzy language). ${ }^{243}$ Trata-se, por um lado, de fenômeno comum na apreciação de "conceitos vagos" ou "indeterminados", "standards" e "cláusulas gerais". 244 São todos estes tipos normativos que empregam de modo deliberado expressões semanticamente vagas, buscando, por esse meio, tornar o texto adaptável à realidade cambiante. Por isso mesmo, precisam ser concretizados em seu sentido pelo intérprete/aplicador à luz de elementos extratextuais. Mas as dificuldades dessa ordem não se encerram aí. As regras "produzem cortes dicotômicos em fenômenos contínuos"; 245 por isso, mesmo aqueles conceitos jurídicos que podem ser considerados - por contraposição aos indeterminados - como sendo razoavelmente certos apresentam zonas de incerteza diante de situações limítrofes ou hipóteses inéditas. O contexto do caso concreto faz surgir, então, um problema semântico específico, ${ }^{246}$ a reclamar uma escolha que depende da ponderação de uma série de razões que vai muito além de meros argumentos lingüísticos. ${ }^{247}$ Costuma-se aludir, então, à textura aberta (open texture) latente em qualquer termo jurídico (mesmo naqueles prima facie determinados) para representar a sua

\footnotetext{
${ }^{241}$ ROBERT ALEXY, “Interpretação jurídica”, n. III/3, p. 71.

${ }^{242} C f$., detidamente, FrederiCK SCHAUER, Thinking like a lawyer, cap. VIII, esp. n. 8.2, p. 157 e n. 8.3, p. 163 e nota 31; en passant, JERZY WRÓBLEWSKY, "Problems of judicial reasoning in civil law and common law systems", n. I, p. 191.

${ }^{243}$ Explicando o conceito de fuzzy language dentro de uma tipologia semântica das linguagens (hard, soft e fuzzy), JERZY WRÓBLEWSKY, "Problems of judicial reasoning in civil law and common law systems", n. I, p. 190-191.

${ }^{244}$ Para extensa indicação de exemplos de "termos e expressões dotados de vagueza socialmente típica" no direito privado brasileiro, ver JUDITH MARTINS-COSTA, A boa-fé no direito privado, n. 4.2.1.3, p. 314.

${ }^{245}$ Richard PoSNer, Problemas de filosofia do direito, n. 1, p. 61.

${ }^{246}$ ANDREA BELVEDERE, "Linguaggio giuridico", n. 6, p. 561-562. Diz-se, por isso, que o caso concreto é que limita pragmaticamente a pesquisa semântica, que, de outro modo, seria ilimitada.

247 Aleksander PeCZeniK, On law and reason, n. 1.2.2, p. 21-24. Ponderação de razões na qual, como salienta BARBOSA MOREIRA, desempenham importante papel as regras de experiência ("Regras de experiência e conceitos jurídicos indeterminados", p. 61 e ss., esp. n. 3-4, p. 65-68).
} 
possível indeterminação diante de específicas hipóteses de aplicação (situadas numa zona de penumbra). ${ }^{248}$

Em segundo lugar, pode acontecer que o sentido normal atribuído às palavras do texto conduza a um resultado conflitante, em alguma medida, com a própria finalidade da regra ou com a unidade e consistência do sistema jurídico como um todo, oferecendo uma resposta aparentemente inadequada ou incoerente ao caso concreto (o que alguns referem como uma lacuna axiológica).

As regras - pelo só fato de serem regras e, portanto, prescrições gerais - levam em consideração apenas algumas propriedades em sua fattispecie, selecionando-as como relevantes para a sua aplicação. Mas as situações reais, em boa medida imprevisíveis, podem apresentar outras características relevantes, que escapam à generalidade da norma. Inevitavelmente, portanto, algumas regras incluirão situações não abarcadas pela finalidade a elas subjacente (overinclusiveness) e outras regras deixarão de compreender ocorrências que seriam atingidas pela aplicação direta da justificativa da norma (underinclusiveness). ${ }^{249}$

Isso quer dizer que haverá hipóteses excepcionais em que o julgador poderá afastar a conseqüência prevista textuamente pela lei, aplicando outra norma ao caso, ou, ainda, ajustar (ampliando ou restringindo) o âmbito da hipótese normativa, de modo a adequá-la a uma situação específica. ${ }^{250}$

A jurisprudência do Superior Tribunal de Justiça pode confirmar o que foi dito até agora. A demonstrar a textura aberta de alguns conceitos, pense-se, v.g., na discussão sobre subsumir-se ou não a arma de brinquedo ao conceito de arma para fins de aumento da pena no crime de roubo (ex art. 157, § $2^{\circ}, \mathrm{I}, \mathrm{CP}$ ): chegou a Corte a sumular o entendimento afirmativo (enunciado n. ${ }^{\circ}$ 174, Súmula/STJ), embora, depois, tenha adotado a posição contrária, cancelando o verbete. ${ }^{251}$ Também não são estranhas decisões que superam o sentido expresso de um texto legal, formulando normas inclusive contrárias à lei (contra

\footnotetext{
${ }^{248}$ Por todos, H. L. A. HART, The concept of law, cap. VII, n. 1, esp. p. 123 e ss.

${ }^{249}$ Ver, ainda, FREDERICK SCHAUER, Thinking like a lawyer, n. 2.3, p. $26-28$.

${ }^{250}$ Quando e como isso pode acontecer é bem explicado por HUMBERTo ÁvILA, Teoria dos princípios, $\mathrm{n}$. 2.4.9.3, p. 112 e ss.

${ }^{251}$ STJ, $3^{\text {a }}$ Seção, REsp 213054/SP, rel. Min. José ARNALDO da FonSECA, j. em 24/10/2002, DJ 11/11/2002, p. 148.
} 
legem) para o caso. Basta lembrar, nessa sede, os julgados reconhecendo que a proibição categórica de concessão de antecipação dos efeitos da tutela em casos de irreversibilidade dos efeitos práticos provimento (art. 273, § $2^{\circ}, \mathrm{CPC}$ ) não é absoluta, podendo ser afastada diante da chamada "recíproca irreversibilidade", cabendo apreciar, então, qual é o direito mais provável ou o bem jurídico mais relevante. ${ }^{252}$

Sinteticamente, portanto, pode-se dizer que a distinção fundamental entre texto e norma (e o conseqüente reforço do papel criativo desempenhado pela interpretação), embora sempre presente, se manifesta de modo especialmente relevante em algumas situações. Assim o faz, v.g., seja quando o texto não fornece uma resposta clara e objetiva, seja quando fornece uma resposta inadequada. Essas ocorrências são potencializadas pelos fenômenos contemporâneos da "decodificação", da "fuga para as cláusulas gerais" e da "inflação" ou "orgia legislativa", que inevitavelmente favorecem a multiplicação de soluções as mais variadas, bem como a verificação de antinomias e contradições dentro do mesmo ordenamento jurídico. ${ }^{253}$ Ademais, mas não menos importante, a tarefa de reconstrução do sentido do texto legal é hoje acompanhada do dever de interpretação conforme à Constituição, o que impõe uma contínua conformação da legislação ao texto constitucional. $^{254}$

Deve somar-se a isso, ainda, a possível variação no tempo dos valores envolvidos nos conflitos de interesses - reclamando então uma nova acomodação do direito vigente (interpretação evolutiva) - e o inexorável surgimento de novos problemas e categorias, estranhos aos desenhos legais preexistentes - a exigir uma atividade destacadamente criativa por parte do aplicador). ${ }^{255}$ A lei, como se sabe, começa a envelhecer a partir do momento em que promulgada e não pode ser alterada tão rapidamente quanto a dinâmica da vida social, o que transfere ao intérprete um trabalho de ininterrupta adaptação.

\footnotetext{
${ }^{252}$ V.g., STJ, 4a T., REsp 417005/SP, rel. Min. RUY Rosado DE AGUIAR, j. em 25/11/2002, DJ 19/12/2002, p. 368.

${ }^{253} C f$. NICOLA PICARDI, "A vocação do nosso tempo para a jurisdição", n. 1.3, p. 5-6; DANILO KNIJNIK, $O$ recurso especial e a revisão da questão de fato..., n. 1.3, p. 13 e ss. (abarcando tais traços do Direito contemporâneo sob o rótulo da chamada "causa hermenêutica").

${ }^{254}$ LUIZ GUILHERME MARINONI, Teoria geral do processo, n. 7.6-7.7, p. 94-97.

${ }^{255}$ Cf. John Henry Merryman - Rogelio Pérez-Perdomo, The civil law tradition, cap. VII, p. 43-47; MELVIN A. EISENBERG, The nature of the common law, cap. 2, p. 5.
} 


\subsubsection{RECONSTRUÇ̃̃O DO DIREITO POR MEIO DE DECISÕES JUDICIAIS}

Viu-se que texto e norma não se confundem; antes, situam-se em planos diferentes: esta corresponde ao resultado da interpretação daquele. Assim, diante da vagueza e da textura aberta da linguagem, diferentes intérpretes podem, partindo do mesmo texto de lei, aplicar distintas normas a casos essencialmente iguais. A sentença de um juiz, por isso, constitui uma decisão interpretativa, que escolhe um sentido dentre várias possíveis, o que confirma a idéia corrente de que interpretação e aplicação compõem um processo unitário e inseparável. ${ }^{256}$

Tendo isso em mente, a doutrina contemporânea, na sua quase totalidade, destaca o papel criativo das decisões judiciais, ${ }^{257}$ prática que dá lugar a um verdadeiro corpo de Direito, o que permite falar num "Direito jurisprudencial" ou, de maneira mais expressiva, num "Direito vivente" (living law, diritto vivente, lebendes Recht). Chegou-se a diagnosticar, por isso, estarmos atravessando uma "fase histórica" de revalorização do momento jurisprudencial do Direito. ${ }^{258}$ Essa afirmação - em que pese ser indiscutivelmente correta - precisa ser compreendida e explicada em sua devida perspectiva. Partindo dessa premissa, as perguntas a serem enfrentadas são basicamente as seguintes: quando, de que modo e em que grau há criação do Direito pelo juiz? Quais são as conseqüências dessa atividade criativa dos juízes, bem como as suas possíveis debilidades, para o estabelecimento e para o desenvolvimento do Direito?

Adiantando a resposta à primeira pergunta, pode-se dizer haver sempre alguma dose de criação do Direito pelas decisões judiciais, embora sua manifestação ocorra em

\footnotetext{
${ }^{256} C f$., entre muitos outros, LUIGI MENGONI, "Diritto vivente", n. 3, p. 448, nota 28; RICCARDO GUASTINI, "Una teoría cognoscitiva de la interpretación”, n. 2, p. 27-29

257 Esta é uma tendência comum tanto aos sistemas common law quanto aos de civil law (cf. MAURO CAPPELlETTI, Juízes legisladores?, n. 14, p. 116, 123 e 128). A comprovar o acerto dessa afirmação, entre muitos outros, ARTHUR T. VON MEHREN - JAMES R. GORDLEY, The civil law system, cap. 16, p. 1143; BRUNO SASSANI, "Tra 'consapevolezza culturale' e 'buona volotà organizzativa': considerazione sparse sulla deprecata funzione nomofilattica della Corte di Cassazione", n. 2, p. 270; MELVIN A. EINSENBERG, The nature of the common law, cap. 2, p. 4-7; FREDERICK SCHAUER, "Do cases make bad law?", n. I, p. 886-887; ALEXANDER PEKELIS, "The case for a jurisprudence of welfare", n. 1-2, p. 611-612; EROS GRAU, Ensaio $e$ discurso sobre a interpretação/aplicação do direito, p. 15-28 e 55-78. Contra o entendimento atual, a doutrina mais antiga (hoje, claramente ultrapassada) defendia uma função meramente declarativa da jurisdição, que apenas tornaria explícito o que já estava contido no preceito legislativo, v.g., LIEBMAN, "A força criativa da jurisprudência e os limites impostos pelo texto da lei” (trad. Teresa Wambier), p. 59-60.

258 NiCOLA PICARDI, “A vocação do nosso tempo para a jurisdição”, n. 1.5, p. 10 e ss. e, especificamente sobre o diritto vivente, n. 1.7, p. 22-23. Para uma ampla análise das causas da intensificação da criatividade jurisprudencial, ver MAURO CAPPELLETTI, Juizes legisladores?, n. 5-10, p. 31-69.
} 
diferentes graus. Ela é inegável e atinge patamar máximo diante de autênticas lacunas do ordenamento, ou seja, de hipóteses não reguladas pelo texto normativo (insufficiency gaps), em que uma norma nova deve ser cunhada, especificamente para o caso, sem o apoio de um preceito legal preexistente. ${ }^{259} \mathrm{O}$ assunto traz à mente o interessante dispositivo inserido no Código Civil suíço (art. $\left.1^{\circ}, 2\right),{ }^{260}$ segundo o qual, adotando-se uma perspectiva realista, o juiz deverá, na ausência de texto legal ou de costumes a regular a hipótese, julgar de acordo com a norma que estabeleceria caso fosse o legislador.

Também modificam claramente o Direito - e, nessa medida, são criativas - as sentenças proferidas no controle de constitucionalidade, tanto ao eliminar dispositivos reputados inconstitucionais do ordenamento jurídico quanto ao estabelecer um único sentido do texto, dentre vários outros também passíveis de reconstrução, como sendo conforme à Constituição. ${ }^{261}$

Pode-se falar, ainda, de atividade criativa num sentido mais fraco, embora também revelador de uma inafastável dose de liberdade (ou discricionariedade ${ }^{262}$ ) judicial. Assim, a técnica legislativa das cláusulas gerais pode ser entendida como uma delegação de função ao juiz, ${ }^{263}$ que deve buscar elementos estranhos ao texto legal para concretizar a

${ }^{259} C f$. Eugenio BULYGin, "Los jueces crean derecho?", n. 5, p. 17, para quem somente nos casos de lacunas normativas há verdadeira criação do Direito pelo juiz.

${ }^{260}$ No original: "A défaut d'une disposition légale applicable, le juge prononce selon le droit coutumier et, à défaut d'une coutume, selon les règles qu'il établirait s'il avait à faire acte de législateur". Há dispositivo semelhante no Código Civil de Portugal (art. 10, 3): "Na falta de caso análogo, a situação é resolvida segundo a norma que o próprio intérprete criaria, se houvesse de legislar dentro do espirito do sistema".

${ }^{261}$ RICCARDO GUASTINI, "Se i giudice creino diritto", n. III, p. 179; também destacando o alto grau de criatividade no campo da justiça constitucional, MAURO CAPPELLETTI, Juizes legisladores?, n. 10, p. 61 e ss., e n. 14, p. 126; LUIZ GUILHERME MARINONI, Teoria geral do processo, n. 7.9, p. 99.

${ }^{262}$ Sobre a idéia de discricionariedade judicial como "figura intermediária entre poder vinculado e poder absoluto" - admitida nas hipóteses de "conceitos-válvula" (ou cláusulas gerais), mas não de conceitos indeterminados -, ver NICOLA PICARDI, "A vocação do nosso tempo para a jurisdição", n. 1.7, p. 18 e ss. Em sentido semelhante, MAURO CAPPELLETTI, Juizes legisladores?, n. 4, p. 23-24. No entanto, como lembra KARL ENGISCH, o conceito de discricionariedade é "um dos conceitos mais plurissignificativos e mais difíceis da teoria do Direito" (Introdução ao pensamento jurídico, cap. VI, p. 214; para um amplo desenvolvimento da noção dos conceitos discricionários, inclusive no âmbito judicial, ver op. cit., cap. VI, p. 214-228), o que conduz a opiniões variadas sobre o assunto. Assim, v.g., contra a posição do texto, BEDAQUE, "Discricionariedade judicial", p. 187-195; TERESA ARRUDA ALVIM WAMBIER, Recurso especial, recurso extraordinário..., n. 7.2, p.186-193; BRUNO DANTAS, Repercussão geral, n. 5.5.1, p. 261 e ss. (todos negando a existência de discricionariedade judicial e admitindo apenas "liberdade para chegar-se a uma única decisão correta").

${ }^{263}$ ARTHUR T. VON MEHREN - JAMES R. GORDLEY, The civil law system, cap. 16, p. 1150-1151; FRIEDRICH STEIN, El conocimiento privado del juez, § 3, p. 51 e ss.; NICOLA PICARDI, "A vocação do nosso tempo para a jurisdição", n. 1.3, p. 7; BARBOSA MOREIRA, "As bases do direito processual civil", n. 6, p. 10; ALEXANDER PeKelis, "The case for a jurisprudence of welfare", n. 2, p. 612; CANOTILHO, Direito constitucional..., p. 258; KARL ENGISCH, Introdução ao pensamento jurídico, cap. VI, p. 213 (falando de "conceitos 'carecidos de um 
norma no caso. Alguns autores chegam a afirmar que, do ponto de vista material, esse fenômeno representa "um direito baseado no precedente camuflado por leis". ${ }^{264}$ É claro que, a partir da formulação gradativa de um catálogo de decisões (que funcionam como topoi ou loci argumentativos), formam-se vínculos cada vez mais estreitos a guiar e uniformizar a atividade judicial; entretanto, não se pode negar a experiência inédita e inovadora oferecida por cada um dos casos individuais nessa tarefa de progressiva concretização. ${ }^{265}$ No mesmo sentido, também tem semelhante dose de criatividade a tarefa do juiz ao aplicar princípios, porquanto ele - realizando a finalidade prevista na norma e resolvendo uma eventual colisão com outros princípios contrários - deve elaborar uma nova regra (dita "regra derivada") para o caso, estabelecendo uma relação de primazia hierárquica entre os princípios colidentes. ${ }^{266}$

Há, portanto, atividade autenticamente criativa na colmatação de lacunas, no controle de constitucionalidade e, ainda que em menor medida, também na concretização de cláusulas gerais e princípios jurídicos. Mas, como se viu, a contribuição do intérprete/aplicador é decisiva mesmo que apenas para preencher "espaços" deixados pela indeterminação semântica do texto (chamados indeterminacy gaps), ${ }^{267}$ escolhendo um dos significados possíveis para o dispositivo, restringindo ou ampliando o âmbito da norma etc. Em qualquer modalidade de interpretação, portanto, "está ínsito certo grau de criatividade"

preenchimento valorativo"'); HORST-EBERHARD HENKE, La cuestión de hecho..., § 3(I), p. 56. Não por acaso, este último autor salienta que "dando à lei uma formulação vaga (...), o legislador pode criar "lacunas intra legem', que dão lugar à interpretação (suplência) pelo juiz” (op. cit., §3(I), p. 58-59). O próprio CALAMANDREI já falara, ao comentar designações legais vagas ou elásticas, que, "para a melhor formulação de alguns conceitos jurídicos, o legislador deliberadamente se entregou à cooperação do juiz" (La casación civil, tomo III, n. 39, p. 97).

${ }^{264}$ Robert AleXY - RALF Dreier, "Precedent in the Federal Republic of Germany", n. I.8, p. 24-25. No original: "Some statutes contain very general clauses which must be concretized by a course of judicial decisions. From a formal point of view, this is statute law interpreted by the judges; from a material point of view, this is precedent-based law camouflaged by statutes".

${ }^{265} \mathrm{Na}$ doutrina brasileira, analisando a estrutura das cláusulas gerais e o raciocínio tópico utilizado na sua aplicação, ver, por todos, JUDITH MARTINS-COSTA, A boa-fé no direito privado, esp. n. 4.2.2.1, p. 329 e ss., e n. 4.4, p. 355 e ss.

${ }^{266}$ RICCARDO GUASTINI, “Se i giudice creino diritto", n. III, p. 179.

${ }^{267}$ Sobre os diferentes tipos de lacunas, destacando, além das lacunas de insuficiência (insufficiency gaps) e de indeterminação (indeterminacy gaps), lacunas de inconsistência (inconsistency gaps) e de cunho axiológico (axiological gaps), ver: ALEKSANDER PECZENIK, On law and reason, Dordrecht: Kluwer, 1989, n. 1.2 .3 , p. $24-26$. 
ou "de discricionariedade", não se podendo fazer uma oposição clara entre interpretação e criação do Direito, como se fossem operações nitidamente antagônicas. ${ }^{268}$

Estar-se-ia, por isso, em face de qualquer ato de interpretação, também diante de genuína criação do Direito? Parece-me que não. Nesses casos, na verdade, o intérprete/aplicador "cria" somente na medida em que atribui significados aos enunciados, sem que possa desconsiderar as regras legais existentes. Portanto, a resposta à pergunta formulada há de ser mesmo negativa, pois há relevantes diferenças entre as espécies já analisadas.

A interpretação de um texto legal pelo juiz - embora carregue sempre consigo uma dose de criatividade - não é, em definitivo, o mesmo tipo de atividade realizada pelo legislador. Este, como é sabido, formulou com bastante liberdade o próprio enunciado, fonte esta que funciona como ponto de partida e objeto do processo interpretativo. Daí estar o juiz, por sua vez, limitado, em maior ou menor medida, pelo texto primitivo. Sintomática dessa diferença é a exigência de motivação da decisão judicial. Ao contrário do ato legislativo, é parte integrante essencial da sentença a sua fundamentação, fator que revela justamente a menor margem de liberdade judicial em comparação com os vínculos que amarram o legislador (obrigado a observar, em princípio, apenas as regras de competência e limitações materiais da Constituição, sem ter de justificar-se a cada novo ato normativo). ${ }^{269}$

Além disso, é óbvio que não pode haver interpretação na ausência de um texto, que carrega em si alguma significação, a ser interpretado. ${ }^{270}$ Ou seja, o juiz - na normalidade dos casos - não cria a partir do nada: reconstrói a norma a partir do texto legislativo. $\mathrm{O}$ Direito nasce, portanto, da "combinação" entre dispositivo (elaborado pelo legislador) e norma (reconstruída através da interpretação/aplicação, normalmente por meio da atividade jurisdicional). ${ }^{271}$ Em outras palavras, "a função jurisdicional haverá de assumir cada vez

\footnotetext{
${ }^{268}$ MaURo CAPPELletti, Juizes legisladores?, n. 3, p. 20-23.

${ }^{269}$ EUGEnio Bulygin, “Los jueces crean derecho?”, n. 5, p. 21; LUIZ GUILHERME MARINONI, Teoria geral do processo, n. 7.13, p. 104.

${ }^{270}$ Até porque, segundo MELVIN A. EISENBERG, "seria um estranho tipo de interpretação o que permitisse ao intérprete reformular ou radicalmente reconstruir o texto", ainda que, para o autor, em alguns casos, seria essa a extensão dos poderes de um Tribunal ao lidar com um precedente no âmbito do common law (The nature of the common law, cap. 6, p. 51-52).

${ }^{271}$ RICCARDO GUASTINI, "Se i giudici creino diritto", n. III, p. 175. Ver, ainda, sobre a idéia de reconstrução de significados, HuMBERTO ÁviLA, Teoria dos princípios, n. 2.1.2, p. 33-35.
} 
mais uma tarefa concretamente complementar e análoga (normativo-intencionalmente do mesmo tipo) da do legislador, no desenvolvimento e constituição social do direito", ${ }^{272}$ sem, contudo, confundir-se com ela.

Deve ficar claro, no entanto, que essa intervenção da jurisprudência na aplicação do Direito não ocorrerá a todo momento, como se não existissem, previamente à sentença, normas a regular a conduta dos indivíduos. Com isso, quero sublinhar que reconhecer $o$ papel criativo dos juízes não implica a adoção de uma teoria unitária do ordenamento jurídico. Os destinatários das normas, na maior parte das vezes, interpretarão e aplicarão eles mesmos os textos legais (ou seguirão as normas formuladas em precedentes por eles conhecidos), sem que se tenha de recorrer a uma decisão autoritativa para tanto. É da essência do Direito, aliás, que ele seja observado espontaneamente. Desse modo, embora dependam de procedimentos adequados para a sua realização em face de hipóteses anômalas de seu descumprimento, não há como negar que os direitos subjetivos existem prévia e independentemente dos órgãos jurisdicionais. $\mathrm{O}$ adimplemento - já se disse - é a morte natural das obrigações. Quotidianamente, em uma massa indefinida de episódios, contratos são cumpridos, dívidas são pagas, direitos reais são respeitados etc., sem qualquer intervenção estatal, ${ }^{273}$ o que confirma o acerto da teoria da dualidade de planos do ordenamento jurídico.

\footnotetext{
${ }^{272}$ CASTANHeIRa NeVEs, O instituto dos 'assentos'e a função jurídica dos Supremos Tribunais, p. 138.

${ }^{273}$ Isso ocorrerá principalmente em relação aos easy cases, em que o cumprimento espontâneo das obrigações envolvidas é favorecido pela clareza das posições jurídicas das partes. São os chamados hard cases exatamente porque neles, em face da incerteza a respeito da regra aplicável ao caso, ambas as partes entendem ser titulares de uma posição de vantagem e acreditam, por isso, possuir uma chance razoável de vitória na hipótese de litígio -, que compõem o grupo de situações particularmente propensas a desembocarem no Judiciário. Esse fenômeno - que conduz a uma predominância, em sede judicial, de situações anômalas se comparadas ao conjunto todo das relações sociais - é conhecido pela doutrina norteamericana como efeito de seleção (selection effect). Ver FREDERICK SCHAUER, Thinking like a lawyer, n. 2.2, p. 22-23 (excetuando, entretanto, do âmbito do efeito de seleção, os casos criminais, em que a litigância é movida por interesses diversos, $c f$., na op. cit., n. 9.4, p. 184-185); RICHARD POSNER, Problemas de filosofia do direito, n. 1, p. 57 (destacando que os juristas por vezes esquecem os casos mais simples, pressupondo que todas as questões jurídicas são indeterminadas). É certamente questionável a medida em que o efeito de seleção se manifesta na realidade social e jurídica brasileira. Presumivelmente (i.e, sem apoio em dados empíricos, até porque não se tem notícia deles em relação ao problema enfocado), sua intensidade - embora não se possa negá-la - será menor do que no ambiente cultural norte-americano, particularmente propenso aos acordos extrajudiciais (settlements). Deve-se ter em vista, nesse sede, também a relativa ineficiência de nossas agências nacionais e de outras instituições correlatas, bem como a irresponsabilidade estatal em geral (ponto bem ilustrado pelo regime dos precatórios), fator que faz desembocar no Poder Judiciário uma gama enorme de insatisfações, não resolvidas por outras formas senão o litígio. Por fim, a morosidade e ineficiência do próprio aparato jurisdicional brasileiro pode criar - ao contrário da representação tradicional do efeito de seleção - um incentivo à litigância mesmo para aquele que sabe não ter razão.
} 
O equacionamento da relação entre legislação e jurisdição é evidentemente muito complexo. Em linhas gerais, pode-se afirmar que a função jurisprudencial complementa a atividade legislativa: esta, sem aquela, é incompleta e não ganha concretude. Entretanto, há uma primazia (relativa) da lei, inclusive em razão do princípio democrático e das competências reservadas ao Poder Legislativo pela Constituição. Desse modo - sem excluir a imposição da interpretação conforme à Constituição ou da averiguação da adequação da regra à sua finalidade -, o intérprete estará autorizado a afastar-se dos limites impostos pelo texto legal somente em casos excepcionais (juízo de eqüidade) ou quando houver inequívoca violação do ordenamento constitucional. ${ }^{274}$ Alguns neoconstitucionalismos (e neoprocessualismos deles derivados) freqüentemente desprezam esses limites, em favor de um subjetivismo ou decisionismo "principiológico" condenável.

Em síntese: colocada a questão em sua devida perspectiva, não se pode mais ignorar que a jurisprudência dos Tribunais - em maior ou menor medida - contribui para a própria criação e estabilização do Direito, sem que isso implique, contudo, negar o princípio da legalidade ou da separação de poderes, a submissão do juiz à lei ${ }^{275}$ ou mesmo a dualidade de planos do ordenamento jurídico (direito material e processo). ${ }^{276}$

${ }^{274}$ Cf. Humberto Ávila, “'Neoconstitucionalismo': entre a 'Ciência do Direito' e o 'Direito da Ciência”, n. 2, p. 195 e n. 4, p. 200-201; FREDERICK SCHAUER, Thinking like a lawyer, n. 8.4, p. 163-167. Confrontar a posição de CARlos AlBerto Alvaro DE OliveIRA, Do formalismo no processo civil, n. 26.5, p. 282-284 (defendendo a possibilidade de decisões contra legem, mas nunca contrárias ao Direito, de maneira um tanto mais flexível do que propugnado no texto). Contra o sentido do texto, CASTANHEIRA NEVES, defende que "a preferência pelo legislador cede perante a preferência pelo direito", definindo este "como expressão da justiça material tal como hoje juridicamente a entendemos: como expressão do próprio princípio normativo do direito, enquanto tal", e fazendo referência a uma suposta "consciência jurídica geral" como síntese $(O$ instituto dos 'assentos' e a função jurídica dos Supremos Tribunais, cap. 2, esp. p. 163-165 e 175 e ss.). É fácil perceber, por um lado, que o raciocínio empregado é circular: a preferência (que, segundo o autor, não pode ser da lei) é do Direito; este é, então, identificado com a justiça material, que, por sua vez, é definida como expressão... do Direito. Com isso, nada mais foi dito senão que "o direito é a justiça e a justiça é o direito", voltando-se ao ponto de partida sem recolher qualquer parâmetro útil. Por outro lado, é difícil compreender o que se quiser dizer, nos dias atuais, com a alusão vaga a uma "consciência jurídica geral, sabendo-se que a sociedade contemporânea é marcada justamente por opiniões radicalmente opostas em temas fundamentais".

${ }^{275}$ Nesse sentido, reportando-se ao princípio da submissão do juiz à lei, "exigência que evidentemente não impede a interpretação criativa do órgão judicial ou o preenchimento de lacunas legais", CARLOS ALBERTO Alvaro De OliveIRA, Do formalismo no processo civil, n. 9.6, p. 124-125. No mesmo sentido, KARL ENGISCH, Introdução ao pensamento jurídico, cap. VI, p. 207.

${ }^{276}$ Até porque o objetivo primordial do Direito é guiar a conduta e, nessa medida, o ideal perseguido é de cumprimento espontâneo (self application) das normas ( $c f$. JEREMY WALDRON, "The concept and the rule of law", n. V, p. 26-27). 


\subsubsection{O DIREITO JURISPRUDENCIAL E OS TRIBUNAIS SUPERIORES}

Tomar consciência do papel criativo dos juízes é fundamental para descrever, de maneira realista, a função jurisdicional e para compreender o papel desempenhado pelos Tribunais Superiores. Com efeito, devem ser descartadas como inaptas as visões declarativas da jurisdição, especulações teóricas plenamente "em desacordo com a realidade". ${ }^{277}$ Até aqui, no entanto, parece ter sido apenas afirmado o óbvio. Resta, ainda, o verdadeiro dilema: saber como tal atividade criativa deve enquadrar-se no quadro das atribuições da função jurisdicional, bem como os limites a que está sujeita e as eventuais debilidades que apresenta.

Consoante aponta MELvin Eisenberg, embora a função primordial da atividade jurisdicional seja a de aplicar o direito ao caso, resolvendo assim um conflito e pacificando as partes, não se pode ignorar o importante papel da jurisprudência no estabelecimento de regras a partir das quais outras pessoas que não os litigantes possam orientar a sua conduta. Tal escopo não deve ser visto apenas como um produto acidental da atividade de resolução de conflitos, mas como uma finalidade autônoma, a ser considerada em si mesma, ainda que subordinada àquela de várias maneiras (sobretudo pelas limitações impostas pelo devido processo legal; v.g., aquelas derivadas do princípio dispositivo em sentido material ou princípio da demanda, de modo que os juízes somente se pronunciam acerca do objeto litigioso tal como delimitado pelas partes). A atividade jurisdicional, assim, ostenta um caráter dúplice: ao decidir o caso específico, volta-se sobretudo para o passado e dirige-se às partes envolvidas (caracterizando uma atuação retrospectiva e individual); mas, ao mesmo tempo, estabelece um parâmetro para a decisão de casos futuros, orientando o comportamento da sociedade como um todo e unificando a jurisprudência (de maneira prospectiva e geral). ${ }^{278}$

\footnotetext{
${ }^{277}$ São palavras do Lord NichOLLS of BIRKENHEAD (in National Westminster Bank plc v Spectrum Plus Ltd [2005] UKHL 41 § 35).

${ }^{278}$ The nature of the common law, cap. 2, p. 4-7. O autor - após destacar duas funções autônomas desempenhadas pelas cortes: decidir conflitos (dispute resolution) e "enriquecer o manancial de regras jurídicas" (enrichment of the supply of legal rules) - defende dois modelos ou formas de encarar o estabelecimento de normas gerais pela jurisdição. Numa primeira aproximação (by-product model), esse resultado seria meramente ancilar e acidental em relação à solução da controvérsia trazida pelas partes; por outra perspectiva (enrichment model), mais adequada à realidade, as cortes conscientemente assumem o encargo de criar "corpos de Direito". Seria um engano entender que a defesa do segundo modelo - efetuada de maneira convincente por EISENBERG - é aplicável somente aos sistemas do common law: demonstrado o papel do intérprete/aplicador na reconstrução da norma a partir do texto legal, ela é certamente válida também no âmbito do civil law.
} 
Essa duplicidade é especialmente verdadeira para os Tribunais Superiores. Se as disposições legais podem receber diferentes interpretações, é necessário - em nome da igualdade perante a lei - que seja atribuída a um órgão de cúpula a competência de uniformizar os entendimentos jurisprudenciais. As Cortes Supremas têm por missão institucional justamente a de conferir unidade ao Direito e desenvolvê-lo por meio de seus precedentes (função objetiva, de orientação, prospectiva, pastoral etc.). ${ }^{279-280} \mathrm{~A}$ frase comumente repetida de que os recursos excepcionais "não se ocupam da justiça da decisão recorrida, mas sim da tutela do direito objetivo" significa que neles prepondera a função prospectiva de estabelecimento de regras (direito jurisprudencial). A relação entre as duas funções jurisdicionais, apontadas no parágrafo anterior, inverte-se: o interesse particular será apenas o móvel por meio do qual se serve o Tribunal para desenvolver e sedimentar o Direito. E, de fato, tais Tribunais Superiores são particularmente aptos a realizar tal escopo: primeiro, porque se situam no vértice do ordenamento judiciário, possibilitando unidade na estrutura; segundo, porque, em decorrência dessa convergência, estão em posição privilegiada para visualizar um grande número de casos análogos e para apreciar diferentes pontos de vista, podendo, assim, fazer uma análise empírica e proceder a uma reflexão necessárias para exercer a sua função de orientação.

Não se pode desconhecer, porém, uma série de implicações negativas e de enfermidades ligadas ao reconhecimento do Direito jurisprudencial e à sua uniformização. Em primeiro lugar, a doutrina dos tribunais, por ser essencialmente casuística, é de mais difícil acesso e compreensão pelos indivíduos, especialmente se as decisões são numerosas. Em segundo lugar, há uma inevitável tensão entre a atuação retrospectiva (ou a individualidade do caso concreto) e a atuação prospectiva (ou a generalidade das categorias de casos) da jurisdição, particularmente saliente no âmbito dos Tribunais Superiores. Em terceiro lugar, o ambiente judiciário apresenta certa inadequação estrutural para formular normas gerais: há um déficit de informação e de recursos materiais para valorar adequadamente alternativas políticas e conseqüências das decisões. Em quarto lugar, o

\footnotetext{
${ }^{279}$ PAUL LEMMENS, “Guidance by Supreme courts to lower courts on the requirements of the ECHR”, p. 305.

${ }^{280}$ Não se deve ignorar, entretanto, a função auxiliar desempenhada pela doutrina e a sua contribuição para uma "obra clarificadora". Já dizia CALAMANDREI que "doutrina e jurisprudência servem para aproximar os homens à certeza do Direito", restringindo e particularizando em regras cada vez mais precisas os contornos extremos dos desenhos legais ("La certeza del derecho y las responsabilidades de la doctrina", p. 128).
} 
Poder Judiciário carece, em alguma medida, da legitimação democrática própria ao Legislativo. $^{281}$

Os dois primeiros problemas dizem respeito ao princípio da segurança jurídica e, mais especificamente, à importância de cognoscibilidade e previsibilidade do Direito (v., infra, n. 4.2.2). A tensão entre justiça do caso e justiça geral é tema que preocupa à uniformidade das decisões ou à igualdade perante a lei (v., infra, n. 4.2.1). Por sua vez, a legitimação da atuação judicial na constituição do direito está intimamente ligada ao devido processo legal e, nomeadamente, à exigência de participação e efetiva influência das partes (e também de terceiros com interesses institucionais) na tomada das decisões (v., infra, n. 4.2.3). Os três princípios mencionados não estão isolados. Igualdade e segurança jurídica, de um lado, e devido processo legal, de outro, representam, respectivamente, as dimensões formal e procedimental do sobreprincípio do Estado de Direito, no qual estão integradas e articuladas.

\subsection{DIMENSÕES DO PRINCÍPIO DO ESTADO DE DIREITO}

O Direito é composto primariamente de normas de conduta (normas, como se viu, que resultam da combinação entre o texto legal e a sua interpretação/aplicação). A noção é mesmo intuitiva. Para coordenar os indivíduos na sociedade, são empregadas regras que prescrevem comportamentos como sendo lícitos ou ilícitos (ou, de forma mais precisa, proibidos, permitidos ou obrigatórios) ou que atribuem bens, poderes ou outras posições de vantagem aos sujeitos. Estas normas, por atuarem de maneira imediata e direta sobre as pessoas - seja para guiar efetivamente a sua conduta, seja como parâmetro na resolução de disputas quando não ocorre o seu cumprimento espontâneo - são chamadas normas de “primeira ordem" (ou "primeiro grau”).

A mera existência de tais normas de conduta, entretanto, é insuficiente para que se reconheça um sistema que possa, sem mais, ser adjetivado como genuinamente jurídico (law-like). O conceito de Direito reclama o sobreprincípio do Estado de Direito (rule of

${ }^{281}$ Esses quatro problemas são amplamente tratados por MAURO CAPPELLETTI, Juízes legisladores?, n. 12, p. 82 e ss. e n. 13, p. 92 e ss.; antes dele, já identificara tais objeções ALEXANDER PEKELIS, "The case for a jurisprudence of welfare", n. 8, p. 616-617. 
law), ${ }^{282}$ ou seja, a supremacia do Direito no exercício do poder, de modo a garantir, de um lado, uma esfera de liberdade e autonomia aos cidadãos e, de outro, a efetiva proteção de seus direitos. Diferentemente das normas de conduta, os princípios que compõem o Estado de Direito são normas de "segunda ordem" ou "segundo grau", ou seja, condições sistêmicas abrangentes no seu escopo, que limitam e dirigem a criação, a implementação e a aplicação de todas as normas de primeiro grau.

O Estado de Direito é melhor compreendido como um tipo ideal, ao qual os sistemas jurídicos reais podem aproximar-se em maior ou menor medida. Seus contornos, por isso, são variados e complexos, sujeitos, em alguma medida, a formulações diversas. ${ }^{283}$ No entanto, deixando de lado a discussão, que escapa do presente ensaio, é seguro apontar que as condições sistêmicas antes referidas abraçam, por um lado, prescrições de conteúdo formal que conferem legitimidade e consistência ao ordenamento jurídico (igualdade e segurança jurídica) e, por outro, normas de natureza procedimental que visam a garantir processos justos e instituições imparciais na aplicação do Direito (devido processo legal). ${ }^{284}$

À luz de tais dimensões do Estado de Direito, devem ser destacadas, dentre outras, as exigências de que as normas sejam: I) objeto de aferição segundo critérios de validade previamente conhecidos; II) gerais em seu alcance; III) minimamente claras e determinadas no seu sentido; IV) normalmente prospectivas nos seus efeitos; v) razoavelmente estáveis; VI) cognoscíveis e públicas; VII) aplicadas, mediante um processo justo, por tribunais

\footnotetext{
${ }^{282}$ JEREMY WALDRON, "The concept and the Rule of Law", n. III, p. 10-12, n. VII, p. 44-47.

283 Para uma análise aprofundada, ver RICHARD FALLON JR., “The Rule of Law' as a concept in constitutional discourse", n. II, p. 10 e ss. (descrevendo quatro modelos ou tipos ideais do Rule of Law: historicista, formalista, processual e substancial). Outra parte da doutrina destaca, ainda, as diferenças entre modelos do ponto de vista do Direito comparado, i.e, entre Rule of Law, Rechtsstaat, État légal etc. (v.g., CANotilho, Direito constitucional..., p. 93-97; Daniel Mitidiero, Processo civil e Estado Constitucional, parte I, n. 1.1, p. 15-23). Sem prejuízo dessa última corrente de autores, o conceito de Estado de Direito é, a meu ver, acima de tudo, um ponto de convergência dos sistemas jurídicos ocidentais fundados sobre um ideal de liberdade.

${ }^{284}$ ROBERT S. SUMMERS, “The principles of the rule of law", n. I, p. 1692, n. IV, p. 1701-1703 (defendendo o seu caráter formal), e n. V, p. 1703 e ss. (atribuindo-lhe o papel de conferir legitimidade ao Direito); ID., "A formal theory of the rule of law", n. IV, p. 174-178 (argumentando as vantagens de uma teoria relativamente formal); RICHARD FALLON JR., "“The Rule of Law' as a concept in constitutional discourse”, n. V, p. 53-54 (também acentuando a predominância de aspectos formais sobre aspectos substanciais no ideal do Estado de Direito); JEREMY WALDRON, “The concept and the Rule of Law", n. II, p. 7-8 e n. IX, p. 54 e ss. (destacando a importância da dimensão procedimental do Estado de Direito); LUIZ GUILHERME MARINONI - DANIEL MitiDiero, O projeto do CPC, n. 1, p. 15-16 (afirmando que do Estado Democrático de Direito decorrem, como diretrizes fundamentais, a igualdade, a segurança jurídica e o direito à participação no processo).
} 
acessíveis, independentes e imparciais; VIII) interpretadas de maneira uniforme pelos órgãos jurisdicionais; IX) objeto de debate e sujeitas à crítica pela opinião pública etc. ${ }^{285}$

Nos três tópicos seguintes, analisarei, muito brevemente, como tais exigências devem balizar a aplicação do Direito pelos juízes e, mais especificamente, como devem guiar a atividade essencialmente prospectiva dos Tribunais Superiores.

\subsubsection{IGUALDADE PERANTE A LEI E UNIFORMIDADE NA APLICAÇÃO DO DIREITO}

O princípio da igualdade manifesta-se de duas maneiras. De um lado, pode-se falar em igualdade perante a lei ou igualdade na aplicação do Direito (de caráter formal), de modo a garantir uniformidade de tratamento pelos juízes. De outro, pode-se tratar da igualdade na própria lei (de caráter material), como comando dirigido ao legislador para que não efetue discriminações injustificadas (proibição do arbítrio). ${ }^{286}$

Pela perspectiva aqui tratada - da jurisprudência dos Tribunais Superiores -, tem importância sobretudo a noção de igualdade na aplicação do Direito. Evidentemente, o Poder Judiciário, sobretudo por meio do Supremo Tribunal Federal, deve controlar a adequação das leis diante do princípio da igualdade material, declarando inconstitucionais aquelas que estabeleçam distinções arbitrárias. Mas essa função de controle deve ser conjugada com a necessidade de estabelecer um entendimento uniforme a respeito da matéria controvertida, sendo necessário que, uma vez aferida a igualdade na lei (o que pode requerer algum ajuste ou mesmo a invalidação de determinado dispositivo), seja assegurada a igualdade perante a lei, ou seja, o tratamento igualitário dos jurisdicionados, segundo a regra formulada pela Corte.

\footnotetext{
${ }^{285}$ ROBERT S. SUMMERS, “The principles of the rule of law”, n. II, p. 1693-1694 e n. III, p. 1697 e ss; ID., “A formal theory of the rule of law", n. II, p. 167-168.

${ }^{286}$ Cf. CASTANHeira Neves, O instituto dos 'assentos'e a função jurídica dos Supremos Tribunais, cap. 2, p. 120-121; CANotilho, Direito constitucional..., p. 426-427; Humberto ÁvILA, Teoria da igualdade tributária, n. 2.3.1, p. 74-75. O primeiro autor citado nesta nota, após referir a tradicional distinção entre as concepções formal e material, analisa três perspectivas assumidas pela igualdade em um sentido políticojurídico (denominada por ele igualdade perante o direito), destacando, ao lado da igualdade perante a lei e da igualdade social, a idéia de igualdade pela participação, a ser garantida não apenas nos corpos representativos, mas também no processo judicial (op. cit., cap. 2, esp. p. 125-126 e nota 267). A meu ver, essa exigência de participação liga-se diretamente à dimensão procedimental do Estado de Direito, representada pelo devido processo legal, consoante defendido no texto.
} 
A universabilidade (universalizability) das razões e, conseqüentemente, das decisões, constitui um dos preceitos fundamentais da argumentação jurídica. Trata-se, acima de tudo, de uma condição de racionalidade prática. O Direito é, por essência, geral no seu alcance (versando categorias de pessoas, e não indivíduos isolados), o que é bem representado pelos princípios de igualdade, legalidade e impessoalidade. ${ }^{287}$

As coisas não se passam de modo diferente no âmbito judicial, onde os textos legais ganham sua concretude. Do ponto de vista processual, a igualdade também desponta como elemento essencial ao valor justiça, que traduz a realização exata do Direito material e, portanto, exige a identidade de regulação para situações idênticas. ${ }^{288}$ A legitimidade das decisões judiciais - e o modo de compatibilizar sua inevitável função criativa com o ideal do Estado de Direito - depende, dentre outras coisas, de serem elas "predicadas sobre uma máxima capaz de adquirir a universalidade que caracteriza o Direito em seu sentido mais alto". 289

O problema não reside na afirmação de que casos iguais devem ser tratados de maneira igual. Quanto a isso, todos estão de acordo. Mas a realidade é a de que nenhum caso é idêntico, sob todos os aspectos, a outro. Diante disso, as dificuldades estão, por um lado, em determinar os critérios de comparação para aferir a similaridade entre conjunturas fáticas em alguma medida diferentes e, por outro, em saber até que ponto e com qual amplitude é desejável vincular situações concretas a uma regra geral comum. ${ }^{290}$ Nesse sentido, FREDERICK SCHAUER chama atenção para o fato de que "dar uma razão num caso particular é transcender justamente a particularidade daquele caso", ou seja, é declarar aplicável uma regra geral que abrange tanto a controvérsia atual como outras tantas da mesma categoria (atuais ou que possam vir a surgir). ${ }^{291}$

Tomo um exemplo a fim de ilustrar a idéia. O Superior Tribunal de Justiça decidiu que, “após a implementac ão da condic ão prevista no art. 4, " $d$ ”, do Decreto-Lei $n$. .

\footnotetext{
${ }^{287}$ Cf. ROBERT ALEXY, Teoría de la argumentación jurídica, n. 3.2.1.1, p. 79 e ss., n. 4.1, p. 186-187; JEREMY WALDRON, "The concept and the rule of law", n. V, p. 25; FREDERICK SCHAUER, Thinking like a lawyer, n. 1, p. 8; EUGENIO BULYGIN, "Los jueces crean derecho?", n. 5, p. 21; GUSTAV RADBRUCH, "El fin del derecho", p. 62.

${ }^{288}$ Cf. Carlos Alberto Alvaro de Oliveira, Do formalismo no processo civil, n. 8.1.1, p. 99-100.

${ }^{289}$ ALEXANDER PEKELIS, "The case for a jurisprudence of welfare”, n. 10, p. 618.

${ }^{290}$ NEIL DUXBURY, The nature and authority of precedent, cap. 5, n. 2, p. 174-175.

${ }^{291}$ Thinking like a lawyer, n. 9.2, p. 177; mais amplamente em "Giving reasons”, n. III, esp. p. 640 e ss.
} 
1.510/76 [i.e., alienação ocorrida após cinco anos da subscrição ou aquisição da participação societária], não incide o imposto de renda de pessoa física sobre o lucro de venda das ações, ainda que a Lei $n .^{\circ} 7.713 / 88$ tenha, ulteriormente, revogado a norma isentiva", motivando que se trata, no caso, de uma isenção onerosa e, por isso, insuscetível de ser suprimida em relação àqueles indivíduos que, previamente à sua derrogação, cumpriram as respectivas exigências. ${ }^{292} \mathrm{O}$ acórdão, além de decidir o caso concreto (da isenção amparada pelo Decreto-Lei n. ${ }^{\circ}$ 1.510/76 em relação à participação acionária vendida pela pessoa física recorrida), está ao mesmo tempo afirmando, como regra geral, que, após cumpridos os requisitos ou condições impostos pela lei para qualquer isenção onerosa, nenhuma legislação ulterior poderá alterá-la ou suprimi-la, pois, nessas circunstâncias, todos contribuintes que se enquadrarem nessa categoria têm o "direito adquirido" a não serem tributados.

Qualquer decisão judicial em sentido contrário à regra formulada pelo Superior Tribunal de Justiça, em relação a esses mesmos aspectos relevantes, violará a igualdade perante a lei. Daí a necessidade de respeito à jurisprudência dos Tribunais de superposição: ainda que sejam necessárias mudanças, é imprescindível que os jurisdicionados sejam tratados de maneira igualitária no plano estático. Fala-se, por isso, na contraposição entre divergência sincrônica e diacrônica: há necessidade de uniformidade num dado momento, embora seja admissível a mudança no tempo. ${ }^{293}$ A variação, todavia, deve ser devidamente justificada, reestabelecendo-se com a nova decisão uma pauta uniforme fundada em razões que se coloquem além do caso paradigmático; o leading case, com efeito, visa a fixar os parâmetros para uma jurisprudência constante. ${ }^{294}$ Parece claro que nada disso é possível se os juízes e tribunais inferiores não observam os precedentes dos Tribunais Superiores (vinculação em sentido vertical). Além do mais, a própria Corte Suprema deve ser consistente com suas decisões, pois "antes de se exigir o respeito dos demais, é necessário respeitar-se". 295

${ }^{292}$ STJ, $1^{\text {a }}$ T., AgRg no REsp 1182012/MG, rel. Min. Benedito GonçAlves, j. em 24/08/2010, DJe 31/08/2010.

${ }^{293}$ Vezio Crisafuldi, "Disposizione (e norma)", n. 5, p. 20; MiChele TARUfFo, El vértice ambiguo, $\S 3$, p. 120-121 e $\S 7$, n. 4, p. 232; ClaUdio CONSOlo, Il processo di primo grado e le impugnazioni..., p. 489; ARRUdA Alvim, "O recurso especial na Constituição Federal de 1988 e suas origens", n. 2.1, p. 33.

${ }^{294}$ Michele TARUfFo, El vértice ambiguo, § 3, p. 140-141 e § 7, n. 4, p. 233.

${ }^{295}$ LUIZ GUILHERME MARINONI, “Aproximação crítica entre as jurisdições de civil law e common law...”, p. 182; também nesse sentido, Teresa ARrUdA Alvim WAMBIER, "Estabilidade e adaptabilidade com objetivos do direito: civil law e common law", n. 6, p. 151. 
Tendo essa premissa em mente, no que é pertinente ao núcleo desse estudo, é importante perceber que os Tribunais Superiores, ao decidirem o caso atual, traçam parâmetros de decisão para casos futuros, cujas características, por vezes, não podem sequer ser previstas. Deve-se, por isso, fazer uma ponderação entre as vantagens de estabelecer um entendimento judicial amplo - que servirá como orientação para os jurisdicionados e para outros juízes e, nessa medida, vinculará a própria Corte, em uma série igualmente ampla de casos - com as vantagens da maior flexibilização resultante da opção contrária, isto é, de decidir o caso de maneira bastante restrita, estabelecendo um precedente para uma categoria bem menor de situações e deixando espaço em aberto para escolhas futuras. Uma decisão cujo escopo seja excessivamente amplo forçará o Tribunal a rever sua jurisprudência diante de um caso ulterior, por meio de distinções inconsistentes com a motivação anterior (perdendo-se coerência), e obrigará os juízes inferiores a aplicarem regras sub-ótimas aos casos particulares (gerando-se injustiça). Em suma, o julgador consciente sabe estar decidindo não apenas o caso de hoje, mas, em alguma medida, também o de amanhã, pois "toda vez que uma Corte dá razões para a sua decisão, ela necessariamente opina sobre casos diferentes daquele que se lhe presenta". ${ }^{296}$ Trata-se, em suma, de saber escolher entre decidir mais ou menos à luz do caso atual, fundamentando as decisões de acordo com essa ponderação.

\subsubsection{SEGURANÇA JURÍDICA: ESTABILIDADE E PREVISIBILIDADE DA JURISPRUDÊNCIA}

O ordenamento jurídico - visto como sistema - pressupõe em alguma medida coerência e consistência entre os seus termos, de modo que se possa compreendê-lo como um todo. Se, pelo ângulo estático (ou espacial), essa coerência é alcançada por meio da

\footnotetext{
${ }^{296}$ FREDERICK SCHAUER, Thinking like a lawyer, n. 9.3, p. 182 e n. 10.4, p. 199; ID.; "Precedent", n. IV, p. 589 e n. V, p. 591 (discutindo o tamanho das categorias utilizadas na decisão como decisivo do peso e do âmbito de aplicação do precedente); ID., "Do cases make bad law?", n. II, p. 900 (afirmando textualmente que "a court could, after all, reach the wrong result in the case before it in order to announce the right rule for future controversies. Or courts could recognize the nonrepresentativeness of the case before them and then either make less law than they would otherwise be inclined to do, or announce a rule narrower than or different from what would appear to flow out of the outcome in the particular case"). Nesse sentido, tamberm EMILY SHERWIN, "Judges as rulemakers", n. II, p. 923 (defendendo que os juízes devem optar por decisões restritas em seu escopo, de modo a evitar a propagação de regras amplas e errôneas; no original: "Judges should avoid broad-bush rulemaking and opt for narrow grounds of decision that minimize the harmful consequences of erroneous rules").
} 
igualdade perante as normas, pela perspectiva dinâmica (ou temporal), é o princípio da segurança jurídica que proporciona uma espécie de "consistência duradoura". 297

Em grosseira simplificação, o princípio da segurança jurídica pode ser visualizado por dois prismas, manifestando dois tipos de eficácias: I) estabilidade dos atos normativos (eficácia ex post); II) previsibilidade e calculabilidade das conseqüências jurídicas pelos destinatários das normas (eficácia ex ante). ${ }^{298}$ A distinção corresponde, grosso modo, aos elementos objetivos e subjetivos do princípio, estes últimos geralmente relacionados com a imposição de proteção à confiança. Trata-se, no fundo, de dois lados da mesma moeda: o sujeito confia na estabilidade do ordenamento jurídico, na medida em que "o homem necessita de segurança para conduzir, planificar e conformar autónoma e responsavelmente a sua vida". 299

Para realizar tais ideais, é preciso, em primeiro lugar, conhecer as normas jurídicas. Sem esse pressuposto, não se pode sequer falar em previsibilidade. Pior do que isso, sem saber o que é o Direito vigente, não há como cumpri-lo, o que significa anular a sua função de orientação das condutas em sociedade, ou seja, o seu escopo de coordenar (ao invés de suprimir) o agir responsável dos indivíduos e tratá-los com dignidade. ${ }^{300}$

Utiliza-se comumente a palavra cognoscibilidade. ${ }^{301}$ Antes de tudo, o requisito impõe que os textos normativos sejam redigidos de maneira clara e razoavelmente determinada, ${ }^{302}$ ainda que a maior ou menor determinação da legislação dependa, em

${ }^{297}$ TÉRCIO SAMPAIO FERRAZ JR., "Irretroatividade e jurisprudência judicial”, n. 1, p. 7 (destacando que a estabilidade da jurisprudência - sua "consistência duradoura" - permite ligar o passado ao futuro, servindo para orientar a ação por meio da proteção de legítimas expectativas); no mesmo sentido, FREDERICK SCHAUER, "Precedent", n. V, p. 596 (afirmando que igualdade e vinculação ao precedente são os ramos espacial e temporal do mesmo princípio da consistência).

${ }^{298}$ CANOTILHO, Direito constitucional..., p. 264.

${ }^{299}$ CANOTILHO, Direito constitucional..., p. 257.

300 JEREMY WALDRON, "The concept and the Rule of Law", n. V, p. 26-28 (afirmando que "O Direito é inerentemente respeitoso de pessoas como agentes; ele respeita a dignidade da ação voluntária e do autocontrole racional"; no original: "law is inherently respectful of persons as agents; it respects the dignity of voluntary action and rational self-control"). Por isso, a cognoscibilidade do Direito é um critério para a aferição de um sistema jurídico democrático (R. C. vAN CAENEGEM, Juizes, legisladores e professores, cap. 2, p. 54.)

${ }^{301}$ O termo "cognoscibilidade", segundo indica R. C. VAN CAENEGEM, foi cunhado por JEREMY BeNTHAM (Juizes, legisladores e professores, cap. 1, p. 33).

${ }^{302}$ CALAMANDREI arrolava a má redação das leis como uma "ameaça de fato" à certeza jurídica, seguindo a exposição de LOPEZ DE OÑATE ("La certeza del derecho y las responsabilidades de la doctrina", p. 123-124). 
muitos casos, dos fins concretos perseguidos pelo legislador. ${ }^{303}$ Mas uma legislação certa, por si só, é insuficiente. Já tendo sido estabelecido que texto e norma não se confundem, dando aquele margem a diferentes interpretações, e tendo em vista a "explosão legislativa" de tempos recentes, percebe-se claramente que, também no civil law, "a cognoscibilidade do Direito depende, em grande parte, da cognoscibilidade dos casos relevantes". ${ }^{304-305}$

Visto que o juiz contribui, em alguma medida, para a própria criação do Direito, não é preciso um grande esforço para reconhecer que a decisão judicial constitui uma expectativa normativa de que casos similares ao que foi objeto de julgamento sejam decididos da mesma maneira no futuro. ${ }^{306}$ Mais do que isso, se a norma não é o texto legal, mas a sua interpretação, “[a] lei, de per se, diz pouco ou nada ao cidadão e ao jurista; ocorre atender à interpretação e à aplicação por parte dos tribunais", 307

Daí a necessidade de precedentes com força de precedentes, i.e, de decisões dos Tribunais Superiores que possam ser identificadas, estudadas e assimiladas pela comunidade jurídica, articulando a dialética entre legislação e jurisprudência; e não um manancial desordenado e incoerente formado por milhares e milhares de julgados sem qualquer força argumentativa. ${ }^{308} \mathrm{~A}$ certeza gerada pelos precedentes permite aos ${ }^{303}$ Como já afirmado, as cláusulas gerais e outras formulações relativamente vagas funcionam como uma
delegação de função ao juiz, que deve, então, concretizar a norma à luz de elementos e informações variados,
ampliando-se a sua margem de liberdade/discricionariedade. Por isso, o grau de determinação dos preceitos
legais depende do equacionamento dado ao problema de distribuição de funçães entre o legislador e o juiz,
essencialmente contingente. Ver, entre outros, FREDERICK SCHAUER, Thinking like a lawyer, n. 10.3, p. 194-
196 (descrevendo a opção por regras ou standards como um tradeoff entre a alocação de poder decisório no
presente e no futuro); RICHARD POSNER, Problemas de filosofia do direito, n. 1, p. 59-60 (destacando a
tensão entre regras e standards); JUDITH MARTINS-COSTA, A boa-fé no direito privado, n. 4.2.1.3, p. 312
(referindo-se a uma "polaridade dialética que permeia todo o direito" entre "precisão e [...] imprecisão"). ${ }^{304}$ R. C. VAN CAENEGEM, Juizes, legisladores e professores, cap. 4, p. 113; nesse sentido, também LUIZ GUILHERME MARINONI, "Aproximação crítica entre as jurisdições de civil law e de common law...", p. 204206 (destacando que a expectativa do civil law de alcançar certeza por meio da ilusão absurda da vedação de interpretação da lei encobre a realidade com uma falsa perspectiva)

${ }^{305}$ Por isso, pode ser questionada e duramente criticada a afirmação de que no Brasil, país onde há uma reconhecida inflação legislativa, "dificilmente há necessidade de acrescentar normas jurisprudenciais às legais" (feita por ninguém menos que BARBOSA MOREIRA, "A importação de modelos jurídicos", n. 3, p. 264).

${ }^{306}$ MisABel DeRZI, Modificações da jurisprudência no direito tributário, cap. III, n. 10, p. 246-251 e n. 10.3, p. 266-267.; NELSON NERY JR., "Boa-fé objetiva e segurança jurídica - eficácia da decisão judicial que altera jurisprudência anterior do mesmo Tribunal Superior", n. 2, p. 77-82; CARL FULDA, "Prospective overruling of court decisions in Germany and the United States", p. 441.

${ }^{307}$ NICOLA PICARDI, "Notas sobre o precedente judicial", n. 5.2, p. 147-148; no mesmo sentido, ROBERT S. SUMMERS, "The principles of the rule of law", n. III, p. 1699.

${ }^{308}$ BRUNO SASSANI, “Tra 'consapevolezza culturale' e 'buona volotà organizzativa': considerazione sparse sulla deprecata funzione nomofilattica della Corte di Cassazione", n. 3, p. 271-272. Segundo o autor (op. cit., p. 274), trata-se de "um princípio de constituição material do Estado de direito baseado sobre o civil law (...), 
indivíduos saber de antemão as conseqüências de suas ações, de modo que possam planejálas e organizar os seus negócios. Esse tipo de consistência, não há como negar, traz um "benefício público considerável”. 309

Cognoscível que seja a norma (e, portanto, a decisão que a afirma), surge o problema de sua estabilidade. Esta qualidade - parece até desnecessário dizê-lo - é elemento essencial a qualquer ordenamento jurídico. Sem alguma permanência, o Direito não passaria de um capricho ou de uma frivolidade arbitrária. De nada adiantaria construir - já se disse - se o material usado não incorporasse a grande força do universo, qual seja, a inércia. $^{310}$

Por outro lado, é também banal que o ambiente social está naturalmente sujeito a alterações. O Direito, enquanto produto da cultura, deve buscar adaptar-se aos novos tempos, reagindo a novas idéias e acontecimentos e refletindo os valores políticos atuais da comunidade a que serve, ainda que não consiga acompanhar, passo a passo, o ritmo acelerado da dinâmica social ou dos avanços tecnológicos. Em muitos casos, poderá mesmo servir como instrumento precursor de transformações desejáveis.

Ora, adaptação - e, a fortiori, transformação - implicam necessidade de mudança. No entanto, como já vimos, o princípio do Estado de Direito e, mais especificamente, a sua manifestação por meio da segurança jurídica, exige estabilidade e permanência das normas. Há, por isso, um conflito evidente entre estabilidade e variação. Alguns autores chegaram a anunciar um "visível paradoxo" a que está exposto o Direito contemporâneo, vinculado à exigência de segurança, de um lado, e exposto à "natureza complexa e pluralista de nossa sociedade", de outro. ${ }^{311}$ Esse paradoxo é particularmente pronunciado no âmbito judicial, porquanto é a jurisdição - enquanto manifestação do poder habilitada a responder com maior agilidade à evolução social (i.e, antes do que a legislação) -, na maior parte das vezes, que é chamada a fazer a obra pioneira de atualização do fenômeno jurídico.

pelo qual se encarrega ao órgão de vértice (...) do Poder Judiciário a tarefa de garantir a correta dialética entre o momento legislativo e o judiciário, bem como entre as várias instâncias e níveis do próprio judiciário".

${ }^{309}$ NeIL DUXBURY, The nature and authority of precedent, cap. 5, n. 1, p. 162.

310 "Stability has an obvious social, political and moral value, which it would be foolhardy to deny. Builders would build in vain if the material they use did not embody the great force of this universe, inertia. Political and legal institutions of every people testify to the recognition of this force" (ALEXANDER PEKELIS, "The case for a jurisprudence of welfare", n. 11, p. 619).

311 OVÍDIO A. BAPTISTA DA SILVA, ““Questão de fato’ em recurso extraordinário”, esp. 488-493. 
No âmbito da jurisprudência, a tensão entre estabilidade e mudança manifesta-se quando o julgador atual entende que o precedente que seria aplicável é equivocado (ou desatualizado, em face de mudanças sociais) e que outro resultado deveria ser alcançado se a decisão fosse tomada pela primeira vez (ou simplesmente hoje, reconsiderados os dados envolvidos). Surge, então, a alternativa entre abandonar a orientação antiga, estabelecendo um novo entendimento, ou preservá-la, a despeito de não ser ela a melhor. É este último o fundamento do stare decisis (abreviação de stare decisis et non quieta movere), teoria que impõe a eficácia vinculante dos precedentes no common law. Na primeira opção, privilegia-se a correção substancial da decisão; na segunda, confere-se peso decisivo aos princípios formais do Estado de Direito.

Por óbvio, os Tribunais de superposição devem, acima de tudo, aplicar os seus entendimentos de maneira consistente. Isso quer dizer que, na maior parte das vezes, a orientação consagrada deve ser mantida, ainda que outra norma possa ser - do ponto de vista de uma completa reconsideração de razões substanciais (regras da experiência, considerações políticas, sociais, morais etc.) - entendida como mais adequada. Os valores formais ligados à segurança jurídica (e seus derivados: previsibilidade, certeza, cognoscibilidade etc.) e à igualdade sobrepõem-se, na normalidade dos casos, às razões substanciais subjacentes. ${ }^{312}$

No entanto, a opção por um ou por outro caminho não é absoluta e não deve ser feita a priori, como se houvesse uma única resposta adequada para quaisquer casos. É verdade que hoje todos sabem do importante papel desempenhado pelos precedentes. Entretanto, nenhum sistema jurídico defende, na atualidade, uma rigidez absoluta na sua aplicação. Mesmo na Inglaterra, em que o stare decisis ganhou seus contornos mais intransigentes, é hoje reconhecida a possibilidade da Supreme Court (antiga House of Lords) revogar os seus próprios entendimentos. Como é notório, o Practice Statement de 1966 permitiu essa relativa flexibilização, embora, na prática, sejam raríssimos os overrulings, sendo melhor falar, na verdade, de uma vinculação horizontal qualificada. ${ }^{313}$

O dilema, portanto, não reside em saber se, mas em determinar quando os precedentes podem ser revogados e qual eficácia deve ter a nova decisão, o que envolve

\footnotetext{
${ }^{312}$ Nesse sentido, MeLVIn A. EISEnBERG, The nature of the common law, cap. 6, p. 68.

313 Zenon Bankowski - Neil MacCormick - Geoffrey Marshall, "Precedent in the United Kingdom", n. II.1, p. 326 e n. II.5, p. 329.
} 
uma consideração ampla sobre as conseqüências da mudança de orientação, transcendendo em muito um mero exame de "certo ou errado" à luz do caso atual ou das opiniões pessoais do julgador. ${ }^{314}$

Em magnífico ensaio, escrito há mais de sessenta anos, AlEXANDER PeKELIS já afirmava com inteiro acerto que os "tribunais devem ser capazes de escapar ao dilema de ou operarem com aspereza retroativa ou eternizarem regras prejudiciais", sugerindo justamente a capacidade dos juízes de "colocarem de lado o precedente apenas para o futuro, aplicando ainda o Direito antigo ao caso em mãos". 315 Trata-se do prospective overruling ou, como é conhecida a técnica entre nós, modulação dos efeitos da decisão. Ela consiste, basicamente, em aplicar a regra jurisprudencial vigente ao caso, de modo a proteger as expectativas dos indivíduos, anunciando, contudo, uma alteração para o futuro. Segundo Ugo MatTeI, é um dos "mais interessantes instrumentos nomofiláticos da Supreme Court" dos Estados Unidos, que já o aplicou em variadas situações. ${ }^{316}$

Também na Inglaterra - embora a posição tradicional seja no sentido da retroatividade das mudanças de orientação judicial - a House of Lords (hoje Supreme Court) já sinalizou uma tendência a admitir julgamentos não-retroativos. No caso Spectrum, ${ }^{317}$ o Lord NiCHOLLS of BIRKENHEAD dedicou várias páginas ao instituto do prospective overruling, destacando amplamente seus prós e contras. ${ }^{318} \mathrm{O}$ problema, como deixou claro a decisão, toca o tema central da definição da função dos Tribunais, que, já vimos, não é apenas declaravia; na ocasião, o juiz citado afirmou que " a House [of Lords] esteve preparada para renunciar a uma interpretação estrita e estreita do papel judicante do Judiciário", já que "os próprios juízes têm uma função legítima de criação do Direito". 319

A dificuldade prática de maior relevo ligada a uma noção pura de prospective overruling reside na falta de estímulo para que o litigante busque modificar o entendimento que lhe é desfavorável: ainda que consiga convencer a Corte de mudar sua opinião, os

\footnotetext{
314 Mais uma vez, já antevia claramente o problema o gênio de ALEXANDER PEKELIS, "The case for a jurisprudence of welfare", n. 12, p. 619.

315 "The case for a jurisprudence of welfare", n. 12, p. 620.

316 "Precedente giudiziario e stare decisis", n. 15, p. 164.

${ }^{317}$ National Westminster Bank plc v Spectrum Plus Ltd [2005] UKHL 41.

${ }^{318}$ Spectrum, cit., [2005] UKHL $41 \S \S 26$ e ss. (destacando as dificuldades práticas e teóricas).

${ }^{319}$ Spectrum, cit., [2005] UKHL $41 \S \S 16$ e 32.
} 
efeitos da decisão não aproveitariam ao seu caso. Conseqüentemente, o desenvolvimento do Direito seria barrado. A alternativa apresentada é a técnica do selective overruling, pela qual apenas o recorrente vitorioso se beneficia com a nova orientação, sendo mantido o entendimento antigo em relação aos fatos pretéritos e causas pendentes. No entanto, essa própria solução geraria, por sua vez, problemas de desigualdade a discriminação entre os litigantes (privilegiando aquele que "chega primeiro" ou que tem condições financeira de arcar com um processo levado até os Tribunais Superiores).

Os argumentos a favor de tal modulação de efeitos, no entanto, são variados e de peso. Em síntese, pode-se dizer que ela protege a liberdade, a igualdade e a confiança legítima dos jurisdicionados. Ademais, a solução contrária esbarra na regra da irretroatividade das normas e no dever de boa-fé objetiva imposto aos órgãos jurisdicionais. Por fim, há de se ter presente que a estabilidade da jurisprudência contribui para a credibilidade do próprio Poder Judiciário.

Há, com efeito, necessidade de tutelar os comportamentos dos jurisdicionados que agiram em conformidade com a orientação jurisprudencial vigente, ainda que, ulteriormente, venha ela a ser modificada (princípio da proteção da confiança). A aplicação retroativa de uma norma é resultado intrinsecamente injusto, agredindo a própria “juridicidade" do Direito, porquanto ao indivíduo, nesses casos - por não conhecer de antemão os efeitos jurídicos ligados às suas condutas-, não é permitido agir em conformidade com a ordem normativa. Tolhe-se, nessa medida, a sua liberdade e dignidade de auto-determinação (self-direction) e, como conseqüência, o sujeito de direitos acaba sendo transformado em um objeto de comandos arbitrários. ${ }^{320}$ A norma aplicada a fatos pretéritos é de cumprimento impossível, ofendendo a função orientadora do Direito e até mesmo os cânones da lógica deôntica. ${ }^{321}$

\footnotetext{
${ }^{320}$ ROBERT S. SUMmers, “The principles of the rule of law", n. V, p. 1704-1705; JEREMY WALDRON, "The concept and the Rule of Law", n. II, p. 6.

${ }^{321}$ Nesse sentido, já assinalara PONTES DE MIRANDA: "Dizer que o fato do tempo A, que passou, tem de ser regido pela regra jurídica do tempo $\mathrm{C}$, equivale a admitir a reversão do tempo e regular relações interhumanas que já desapareceram" (Tratado de direito privado, tomo I, § 11, n. 3, p. 30). A alteração da jurisprudência de Tribunal Superior pode, em muitos casos, ser considerada como verdadeiro direito superveniente, a alterar, de alguma forma, a causa petendi da ação. Com base nesse raciocínio, v.g., o Superior Tribunal de Justiça já concedeu ordem a paciente que reiterara os mesmos motivos já alegados em habeas corpus anterior, considerando justamente a mudança de entendimento ocorrida no meio-tempo como razão a autorizar o conhecimento de matéria já apreciada no remédio passado. (STJ, 6a T., HC 137346/ES, rel. Min. Og Fernandes, j. em 21.09.2010, Dje 18.10.2010). No caso, o Tribunal modificou o entendimento anterior para assentar que a falta grave não interrompe o prazo de contagem para a obtenção dos benefícios
} 
O princípio da proteção da confiança, no entanto, exige uma apreciação das circunstâncias concretas, a demonstrar que as expectativas dos jurisdicionados na estabilidade da jurisprudência são legítimas ou plausíveis. A doutrina alemã destaca, v.g., que o princípio é enfraquecido se o julgado foi objeto de crítica severa por parte da doutrina e se já havia, por isso, tendências sinalizadas no sentido de uma mudança. ${ }^{322}$

O direito positivo brasileiro contém vários dispositivos vedando, em geral, a retroatividade. Em primeiro lugar, cabe lembrar o art. $5^{\circ}, \mathrm{XXXVI}, \mathrm{CF}$, resguardando o direito adquirido, o ato jurídico perfeito e a coisa julgada dos efeitos de lei superveniente. Analogamente, dispõe o art. $2^{\circ}$, XIII, da Lei n. ${ }^{\circ} 9.784 / 99$ (Lei do Processo Administrativo) ser "vedada [a] aplicação retroativa de nova interpretação" pela Administração.

Por certo, não pode ser a jurisdição a única função estatal considerada imune a tal vedação. Por muito tempo, é certo, o tema da irretroatividade das decisões judiciais foi negligenciado pela doutrina. Sob a ficção da teoria declarativa da função jurisdicional, escondia-se a falsa suposição de que uma mudança na orientação dos tribunais apenas revelaria o que havia sido desde sempre o Direito, corrigindo erros antes praticados. ${ }^{323}$ No entanto, se a definição da norma depende, em verdade, de sua interpretação/aplicação pelos juízes, pela mesma razão aplicada aos atos legislativos, deverá ser a jurisprudência prospectiva nos seus efeitos, sob pena de a irretroatividade ser uma garantia insuficiente e ilusória. Para CÂNDIDO DINAMARCO, o impacto de uma reviravolta jurisprudencial sobre os jurisdicionados é "em tudo e por tudo equivalente ao impacto que sobre suas respectivas esferas de direitos produziria uma alteração legislativa", devendo ser repelidos os efeitos da nova orientação sobre fatos consumados e pendentes sob a égide da anterior, sob pena de violação à regra da irretroatividade das leis (e, analogicamente, das decisões) e ao due process of law. ${ }^{324}$ Nessa linha, também o dever administrativo de agir conforme à boa-fé objetiva impede a aplicação retroativa da mudança de entendimento jurisprudencial. ${ }^{325}$

da execução penal.

322 Robert AleXY - RAlf DreIER, "Precedent in the Federal Republic of Germany", n. II.6, p. 39, citando BverfGE 84, 212 (227).

${ }^{323}$ Cf. ALEXANDER PEKELIS, "The case for a jurisprudence of welfare”, n. 12, p. 120.

${ }^{324}$ CÂNDIDO DinAmARCO, "Modulação dos efeitos da declaração de inconstitucionalidade", esp. n. 12, p. 62 65. O posicionamento incensurável do insigne Professor, reproduzido na passagem transcrita no texto, permite colocar em xeque a defesa extremada feita por ele da teoria dualista do ordenamento jurídico, confundida então com a atribuição de uma função meramente declarativa à jurisdição, na sua tese $A$ instrumentalidade do processo, n. 28.2, p. 230 e ss. (caracterizando a atividade do juiz como "típica função 
Tem sido defendida, em relação ao controle incidental de constitucionalidade realizado pelo Supremo Tribunal Federal, a aplicação da regra que prevê a modulação dos efeitos em sede de controle abstrato (art. 27, Lei n. ${ }^{\circ}$ 9.868/99). ${ }^{326}$ Semelhante extensão pode - e deve - ser realizada também em favor do Superior Tribunal de Justiça, quando proceda à alteração de sua jurisprudência. ${ }^{327}$

\subsubsection{DEVIDO PROCESSO LEGAL}

Para Mauro CAPPElletti, o ethos da função jurisdicional não está na sua substância, mas em características formais e procedimentais que regulam a sua atuação. Segundo ele, tanto o legislador quanto o juiz criam, substancialmente, o Direito (ambos atuam, em suas palavras, em law-making processes). Entretanto, é próprio da jurisdição conservar certas "virtudes passivas" essenciais, ou seja, observar restrições de ordem formal como a inércia, a vinculação a um caso (cases and controversies) e a imparcialidade, bem como depender da participação dos interessados para legitimar suas decisões. $^{328}$

O devido processo legal - previsto pela Constituição (art. $5^{\circ}$, LIV) - é que dá forma a essa atuação. ${ }^{329}$ Ele é um sobreprincípio que visa a promover um ideal de protetividade dos direitos, exercendo uma "função articuladora" de outras regras e princípios processuais

reveladora, equiparável à do técnico fotográfico"). Como procurei ressaltar, reconhecer a inegável criatividade judicial não significa, de modo algum, negar a dualidade de planos do ordenamento jurídico. No mesmo sentido, ROQUE CARRAZZA, "Segurança jurídica e eficácia temporal das alterações jurisprudenciais", n. 4.1, p. 48-49 e esp. n. 4.2, p. 54-59; NELSON NERY JR., "Boa-fé objetiva e segurança jurídica - eficácia da decisão judicial que altera jurisprudência anterior do mesmo Tribunal Superior", n. 4, p.94-96 e n. 6, p. 101; TÉRCIO SAMPAIO FERRAZ JR., "Irretroatividade e jurisprudência judicial", n. 2, p. 10-11;

${ }^{325}$ Destacando o assento constitucional da boa-fé objetiva no direito brasileiro, ver NELSON NERY JR., "Boafé objetiva e segurança jurídica - eficácia da decisão judicial que altera jurisprudência anterior do mesmo Tribunal Superior", n. 3, esp. p. 84-87.

326 GILMAR MENDES, "Limitação de efeitos no sistema difuso e a aplicação do art. 27 da Lei 9.868/99: algumas notas", n 2, p. 32. Possibilidade já reconhecida também na jurisprudência: STF, $2^{\text {a }}$ T., AgReg no RE 497403, rel. Min. CelSO DE Mello, j. em 13/02/2007, DJ 23/03/2007 p. 141.

${ }^{327}$ NELSON NERY JR., "Boa-fé objetiva e segurança jurídica - eficácia da decisão judicial que altera jurisprudência anterior do mesmo Tribunal Superior", esp. n. 6, p. 101-102; TÉRCIO SAMPAIO FERRAZ JR., "Irretroatividade e jurisprudência judicial", n. 7, p. 24.

${ }^{328}$ Juizes legisladores?, n. 11, p. 73 e ss.

${ }^{329}$ Entendido o formalismo, aí, no seu sentido amplo, ou seja, como fator de organização e delimitação de poderes e posições processuais e de previsibilidade do procedimento, tal como destacado, em passagem já clássica, por CARlos Alberto Alvaro de Oliveira, Do formalismo no processo civil, n. 2.4, p. 28. 
ligados à concepção de um processo justo. ${ }^{330} \mathrm{~A}$ noção pressupõe, ainda, a independência e a imparcialidade das instituições encarregadas de aplicar o Direito. ${ }^{331}$

A doutrina processual brasileira dedicou ampla atenção ao tema. ${ }^{332}$ Cabe, aqui, apenas sinalizar algumas das normas essenciais que compõem o modelo brasileiro de devido processo: I) inafastabilidade do controle jurisdicional (art. $5^{\circ}, \mathrm{XXXV}, \mathrm{CF}$ ); II) juiz natural e proibição de juízos de exceção (art. $5^{\circ}$, incisos LIII e XXXVII); III) imparcialidade dos juízes e independência do Poder Judiciário; IV) contraditório e ampla defesa (art. $5^{\circ}, \mathrm{LV}, \mathrm{CF}$ ); v) paridade de armas, como corolário da igualdade (art. $5^{\circ}$, caput); VI) motivação das decisões (art. 93, IX, CF); VII) duração razoável do processo (art. $5^{\circ}$, LXXVIII, CF); VIII) procedimento probatório adequado, com proibição de provas obtidas por meios ilícitos (art. $5^{\circ}, \mathrm{LVI}, \mathrm{CF}$ )

Diante de algumas objeções anteriormente formuladas - no sentido da inadequação estrutural e da carência de informações do Poder Judiciário para formular normas de alcance geral, bem como da sua natureza contramajoritária -, especial relevo deve ser conferido ao princípio do contraditório. Porquanto as partes serão afetadas pela decisão judicial, na condição de suas destinatárias, esta só será legítima na medida em que lhes for franqueada ampla oportunidade de influir sobre a formação do respectivo provimento. ${ }^{333}$ A própria definição de processo, enquanto instituição dialética, envolve a idéia de participação: trata-se de procedimento em contraditório. ${ }^{334}$

Entretanto, a tradicional noção de contraditório - adequada aos litígios individuais - deve ser ampliada diante de processos em que são tomadas decisões de alcance geral. Daí

\footnotetext{
${ }^{330}$ V. a síntese de PAULO Henrique dos SAntos LuCon, "Devido processo legal substancial", esp. p. 19-34.

${ }^{331}$ ARRUDA ALVIM, "O Estado-de-Direito e a função jurisdicional”, esp. n. 7-9, p. 226-231(destacando também a relação entre o acesso à jurisdição - imparcial e independente - como condição do Estado de Direito).

${ }^{332}$ Humberto Ávila, “O que é ‘devido processo legal'?”, n. 1.2, p. 54-58.

${ }^{333} C f$., na doutrina italiana, Nicolò Trocker, Processo civile e costituzione, cap. VI, n. 2, p. 378; NicolA PICARDI, "Audiatur et altera pars: as matrizes histórico-culturais do contraditório", passim, mas esp. n. 4.8, p. 141. Entre nós, Carlos Alberto AlVARo De Oliveira, "A garantia do contraditório", p. 227 e ss., passim; ANTONIO DO PASSO CABRAL, "Il principio del contraddittorio come diritto d'influenza e dovere di dibattito", esp. n. 3, p. 453 e ss.; CRUZ E TUCCI, Limites subjetivos da eficácia da sentença e da coisa julgada civil, n. 9, p. 106 e ss.; CÂNDIDO DINAMARCO, A instrumentalidade do processo, esp. n. 16, p. 159 e ss. É importante lembrar, todavia, que a garantia do contraditório não implica sempre a exigência de que ele seja prévio, podendo ser também "postecipado" ou "eventual" ( $c f$. OvíDIO A. BAPTISTA DA SILVA, Processo e ideologia, cap. VI, esp. n. 1-6, p. 151-159).

${ }^{334} C f$. Elio FAZZALARI, "Procedimento (teoria generale)", p. 827; ID., "Processo e giurisdizione”, p. 3-5.
} 
o fundamental papel hoje desempenhado pelo amicus curiae no julgamento, v.g., da repercussão geral do recurso extraordinário (art. 543-A, $\S 6^{\circ}, \mathrm{CPC}$ ), dos recursos repetitivos (art. 543-C, $\S 4^{\circ}, \mathrm{CPC}$ ) e das ações de controle abstrato de constitucionalidade.

\subsection{CONCLUSÕES PARCIAIS}

À luz do que foi dito, parece seguro afirmar a completa superação das teorias declarativas que buscam descrever a função jurisdicional como uma atividade meramente dedutiva de aplicação mecânica da lei. O texto não se confunde com a norma, que é o resultado de um processo interpretativo sempre permeado por alguma dose de criatividade. Isso não implica - foi demonstrado - uma negação da primazia da lei ou da dualidade de planos do ordenamento jurídico, mas impõe uma tomada de consciência quanto à natureza constitutiva das decisões judiciais. Deve-se perceber, a partir daí, que a jurisdição não atua apenas retrospectivamente, mas também de maneira prospectiva, o que é verdadeiro, sobretudo, para os Tribunais Superiores, situados no vértice do ordenamento e, por isso, encarregados de um processo tendencial e dialético de uniformização e estabilização do Direito.

A fim de compatibilizar o Direito jurisprudencial, suas deficiências e seus perigos com o ideal de juridicidade do ordenamento, devem ser observadas uma série de normas (de segundo grau), verdadeiras condições sistêmicas que delimitam a criação, a aplicação e a implementação daquelas outras regras (de primeiro grau). Essas normas compõem o princípio do Estado de Direito, que se desdobra, em síntese, em duas dimensões.

A primeira delas é predominantemente formal, abarcando, dentre outros ideais, a igualdade perante a lei e a segurança jurídica. A observância desses princípios é imposta em nome do requisito da consistência - estática e no tempo, respectivamente - do Direito. A igualdade pressupõe, acima de tudo, a universalização das razões de decidir; assim, o julgador consciente sabe estar definindo, em alguma medida, outros conflitos além do caso que tem em suas mãos, o que deve guiar o alcance com que formula a sua decisão. A segurança, por sua vez, busca garantir estabilidade e previsibilidade, noções que devem ser conjugadas com a necessidade oposta de desenvolvimento e adaptação do Direito. Surge, daí, a importância de proteger as expectativas legítimas dos jurisdicionados diante de alterações jurisprudenciais, já que a aplicação retroativa das normas agride a liberdade e a 
capacidade de auto-determinação dos indivíduos, sendo necessário, em muitos casos, atribuir eficácia prospectiva à decisão que altera um entendimento jurisprudencial consolidado. Trata-se do prospective overruling ou, como é conhecida entre nós, da técnica de modulação dos efeitos das decisões.

A outra dimensão do Estado de Direito é procedimental. Ela é representada pelo devido processo legal, sobreprincípio que visa a promover os ideais de protetividade dos direitos por meio de processos justos e de imparcialidade e independência das instituições judiciárias. Articula, para esse fim, princípios e regras processuais diversos. No contexto da função prospectiva dos Tribunais Superiores, ganha relevo sobretudo o princípio do contraditório, entendido como exigência de participação não só das partes, mas também de outros entes interessados (v.g., amici curiae) na solução de um problema normativo de alcance geral.

Para os fins desse estudo, basta fixar, como conclusão parcial, que, tomada plena consciência da função normativa-prospectiva dos Tribunais Superiores, estes devem zelar, antes de tudo, pela estabilidade de sua jurisprudência. Havendo substanciais razões para introduzir uma mudança nessa jurisprudência (procedendo-se, assim, a um overruling do precedente anterior), o Superior Tribunal de Justiça deverá analisar detidamente as conseqüências dessa alteração. Não raro (ou, talvez, até na maior parte das vezes), a única solução consentânea com o princípio do Estado de Direito será atribuir efeito ex nunc à nova norma judicial, modulando assim os seus efeitos. Seja como for, deverá garantir a mais ampla participação nos processos por ele decididos, sobretudo naqueles estruturalmente vocacionados para decisões de alcance geral. 


\section{§ 5-COMPREENSÃO DA FUNÇÃO A SER DESEMPENHADA PELO SUPERIOR TRIBUNAL DE JUSTIÇA}

\subsection{NOÇÕES INTRODUTÓRIAS}

No Brasil, assim como na Itália, a discussão em torno da função dos Tribunais Superiores e dos recursos excepcionais é marcada, desde a obra fundamental de CALAMANDREI, pelo conceito de nomofilaquia, conceito que polariza e atrai as especulações teóricas e a praxis.

A análise da nomofilaquia pode enveredar por dois caminhos diversos. Pelo primeiro, questiona-se a sua natureza e o seu objeto (ou "o que é nomofilaquia e o que ela protege"?). Pelo segundo, pergunta-se pelo seu escopo e pelo seu modo de implementação à luz dos interesses objetivos e subjetivos envolvidos (ou "como deve ser realizada a missão nomofilática"?). Cada uma dessas perguntas pode receber respostas diferentes, segundo as inclinações adotadas pelo seu destinatário.

Em relação à primeira indagação, pode-se adotar I) um marco teórico fundado em um racionalismo jurídico cartesiano, reconhecendo-se aos juízes um papel apenas declarativo (ou revelador) de um suposto sentido unívoco contido na lei. Conseqüentemente, aos Tribunais Superiores vai conferida a missão de uma defesa formal ou abstrata da legislação. Por outro lado, é possível manifestar-se II) a visão que reconhece um papel complementar e constitutivo desempenhado pela função jurisdicional no desenvolvimento e estabilização do Direito. Às Cortes Supremas caberia, então, escolher uma dentre várias interpretações possíveis, fixando uma tese jurídica à luz de problemas jurídicos concretos.

Diante da segunda questão, há quem I) coloque o acento nos interesses dos litigantes (ius litigatoris), sustentando que os Tribunais Superiores devem atuar retrospectivamente, corrigindo os erros e injustiças individuais de tantos casos quanto seja possível, não podendo recusar os recursos interpostos. Em sentido contrário, pode defender-se II) a predominância do interesse público (ius constitutionis), conferindo-se realce à atuação prospectiva das Cortes Supremas, cabendo a estas uniformizar e desenvolver o Direito por meio de precedentes. Entende-se possível, nessa visão, a seleção 
dos recursos com base na importância ou na repercussão geral das questões neles debatidas. A meio caminho, existem também III) teorias híbridas, que buscam acomodar ambos os fins, sustentando a sua equivalência.

É possível dizer que - embora não necessariamente em todas as tratativas doutrinárias - andam de mãos dadas, na ordem em que foram apontados, os entendimentos descritos: I) a defesa da função subjetiva e da justiça do caso liga-se, em regra, a um paradigma estritamente formalista, em que há uma única resposta correta; II) a defesa da função objetiva, por sua vez, valoriza o papel constitutivo da jurisprudência (ou melhor, dos seus precedentes) num processo de estabilização hermenêutica do Direito.

\subsection{Evolução histórica dos Tribunais Superiores E SENTIDo ATUAL de NOMOFILAQUIA}

A investigação sobre a natureza e o objeto da nomofilaquia representa, acima de tudo, uma investigação histórica, ligada à evolução das funções acometidas aos juízes e, mais especificamente, aos Tribunais de Cassação e de Revisão.

Costuma-se realizar uma periodização histórica dividida em três fases. Nesse sentido, CASTANHEIRA NEVES destaca que, I) num primeiro momento, representado pelo originário e revolucionário Tribunal de Cassation francês, tinha-se como objetivo apenas a defesa formal da lei, por meio de uma atuação estritamente negativa de um órgão colocado ao lado do Poder Legislativo, já que se acreditava numa onipotência e univocidade de sentido das leis. Com o reconhecimento da necessidade inevitável de interpretação dos textos legais pelos juízes, ingressa-se II) num segundo momento, em que se reconhece a sua natureza jurisdicional e o escopo passa a ser a uniformidade da jurisprudência na interpretação das leis, mas uma interpretação entendida ainda em acepção abstrata, ou seja, do ius in thesi e desvinculada do caso, "em ordem a averiguar se a intepretação enunciada na decisão recorrida é uma interpretação possível (ou válida em geral) do preceito legal", do que resultava apenas a cassação, com proibição de conhecer-se $d u$ fond des affaires. III) A terceira e atual fase dá um novo sentido à uniformidade da jurisprudência, relacionando a interpretação ao caso concreto, de modo que cabe aos Tribunais Superiores conferir 
unidade ao Direito no momento de sua aplicação, decidindo, em alguns casos, diretamente a controvérsia subjacente à decisão. ${ }^{335}$

A rigor, somente a partir do ambiente político e cultural inaugurado com a Revolução Francesa (i.e., a partir da idéia de Estado liberal burguês) é que os recursos excepcionais ou de estrito direito - dos quais é protótipo a cassação - ganham os seus contornos modernos. ${ }^{336}$ Não obstante a sua raiz revolucionária e o seu escopo político original, os contornos dessa criação jurídica verdadeiramente "poliédrica" - cuja compreensão adequada, já advertira CALAMANDREI, envolve a consideração de suas múltiplas facetas -, foram marcantemente influenciados por dois coeficientes. O primeiro é de cunho histórico, remontando tanto a elementos remotos - colhidos do direito romano e do direito comum/estatutário - quanto à situação imediatamente anterior do ancien régime. A segunda tem natureza doutrinal ou ideológica, assumindo posições destacadas: a concepção de separação dos poderes e o papel central atribuído à lei como fonte do direito. $^{337}$

Pelo prisma histórico, devem ser levados em consideração, antes de tudo, dois elementos constitutivos remotos, cujo nascimento e desenvolvimento autônomo podem ser identificados em períodos diversos: de um lado, a idéia romana da nulidade das sentenças portadoras de erros de juízo particularmente graves; de outro, a estrutura da querela nullitatis medieval. ${ }^{338}$ Depois, o fator de influência a ser considerado será a própria experiência institucional do antigo regime francês - representada pelo embate entre os Parlements e o Conseil des parties do Rei.

Ainda no direito romano, surgiu a noção de que a sentença que contivesse um erro de direito - e, mais especificamente, um erro contra o Direito em tese ou em abstrato -

335 CASTANHEIRA NEVES, $O$ instituto dos 'assentos'..., cap. 2, p. 79-87; periodização a que aderem LUIZ GUILHERME MARINONI - DANIEL MITIDIERO, Repercussão geral no recurso extraordinário, n. 1.1, p. 12-14.

${ }^{336}$ A "conclusão geral de todo o estudo histórico" desenvolvido, de modo insuperável, por CALAMANDREI, é a de que a "Cassação, em seus elementos essenciais, é instituto de origem genuinamente francesa, e que todas as tentativas de descobrir traços de sua origem for a de França não encontram nenhum fundamento na realidade histórica" (La casación civil, tomo II, n. 279, p. 376). No mesmo sentido, SERGI GUASCH FERNÁNDEZ, El hecho y el derecho en la casación civil, introd., p. 19.

${ }^{337}$ Cf. CALAMANDREI, La casación civil, tomo II, cap. XIX, n. 138-145, p. 15 e ss. e, no mesmo tomo, a síntese feita em n. 274-279, p. 367-377; na doutrina mais recente, aderem a essa exposição JUAN MONTERO AROCA - JosÉ FLORS MATÍES, El recurso de casación civil, cap. 3, p. 238 e ss.

338 Ver, resumidamente, CALAMANDREI, La casación civil, tomo II, n. 277, p. 373-375; CALAMANDREI FURNO, "Cassazione civile", n. 5, p. 1058. Entre nós, seguiu, em largas linhas, esta exposição ALFREDO BuZAID, “A crise do Supremo Tribunal Federal”, n. 1-2, p. 121-123. 
atentava contra a ordem jurídica de maneira mais grave do que aquela em que o juiz tivesse cometido um mero equívoco na apreciação dos fatos ou mesmo na aplicação da norma ao caso específico. O error, no primeiro caso, transcendia o caso particular (mero ius litigatoris) e ofendia as leis em sua generalidade (ius constitutionis), na medida em que o juiz desconhecia, em abstrato, uma norma jurídica existente, ignorando o Direito constituído ao decidir. Diante da particular gravidade dessa forma de injustiça, a sentença prolatada era considerada nulla - defeito que, no direito romano, era equivalente à inexistência do ato e que veio a consagrar-se, no antigo direito lusitano, por meio da expressão "sentença nenhuma"339 - e incapaz de tornar-se res iudicata, sendo por isso desnecessário impugná-la por meio de algum mecanismo específico. Equiparavam-se, assim, a sentença nulla por defeito de atividade e a sentença injusta por errores in iudicando particularmente danosos. ${ }^{340}$

No direito comum/estatutário, ocorre a mutação do conceito de nulidade, que passa então a ser entendido como um vício sanável da sentença. Por essa perspectiva, ele deveria ser denunciado, dentro de certo termo, sob pena de não poder ser invocado ulteriormente. Tem-se aí, na previsão de um meio de impugnação diverso da apelação, a origem da querela nullitatis - ação impugnativa tipicamente destinada a anular sentenças portadoras de errores in procedendo, cujo cabimento foi estendido a certos errores in iudicando de direito (error contra ius in thesi clarum). Sua estrutura, do ponto de vista processual, está à base do recurso de cassação francês e italiano, ainda que a função exercida pelo juiz superior não pudesse, em qualquer medida, ser equiparada à noção moderna de nomofilaquia (como unidade do direito por meio da uniformização da jurisprudência), peculiar à Cassação revolucionária e seus desenvolvimentos. ${ }^{341}$

\footnotetext{
339 É digna de nota a polêmica travada na doutrina brasileira sobre o significado da "sentença nenhuma" prevista nas Ordenações do Reino. PONTES DE MIRANDA sustentou que o direito lusitano já havia se livrado da noção romana de sentença nulla como sentença inexistente desde 1217, deslocando o problema para o campo da validade e ressaltando que as nulidades tinham de ser decretadas (Tratado da ação rescisória das sentenças e de outras decisões. 5. ed. Rio de Janeiro: Forense, 1976, p. 99-100). Criticando severamente tal orientação, MOACYR LOBO DA COSTA afirmou que, no Direito lusitano, a "assimilação da nulidade da sentença à inexistência do julgado é patente e inegável" (A revogação da sentença: gênese e genealogia. São Paulo: Ícone, 1995, p. 157-159). A discussão interessa de perto ao tema da querela nullitatis, um dos componentes que está à base da formação dos recursos excepcionais ou de estrito direito.

${ }^{340}$ Em profundidade, CALAMANDREI, La casación civil, tomo I, cap. II, esp. n. 16-22, p. 61-71.

${ }^{341}$ Novamente, o trato aprofundado deve-se CALAMANDREI, La casación civil, tomo I, cap. VIII, n. 53-58, p. 161 e ss. Ver, entre nós, Barbosa MoreIRA, Comentários ao Código de Processo Civil, n. 134, p. 230.
} 
Já em período histórico mais próximo, durante o ancien régime, a França conheceu a demande en cassation. Esta era um meio de impugnação de sentenças contrárias às ordenações e aos editos reais («contravention aux ordonnances»), proferidas pelos Parlements, que eram os órgãos judiciais de última instância, ligados à nobreza, dentre os quais ganhou grande notoriedade o de Paris. Dirigia-se a irresignação ao Conseil des Parties, seção destacada do Conselho do Rei. Antes disso, o poder de cassar («casser ») sentenças era exercido por própria iniciativa («de son propre mouvement ») do monarca, como forma de combater a rebeldia e a mediação de seu poder pelos mencionados ofícios jurisdicionais. ${ }^{342}$ A demande en cassation e o Conseil des Parties ofereceram, assim, o "esqueleto" da Cassação moderna, ${ }^{343}$ diferenciando-se, contudo, pela diferente função exercida: no ancien régime, a preocupação era própria de uma política absolutista e traduzia a luta entre o poder régio e os Parlamentos judiciais; com a Revolução francesa, o escopo passou a ser a defesa da lei contra as transgressões dos juízes e, ulteriormente, a unificação da jurisprudência. ${ }^{344}$

I) Feitas essas observações, deve-se ter em mente que a criação revolucionária, em 1790, do Tribunal de Cassation - órgão então estabelecido junto ao Poder Legislativo («auprès du corps législatif») com a função de proteger a lei de eventuais desmandos cometidos pelos juízes - só pode ser compreendida a partir da concepção então nascente do

\footnotetext{
${ }^{342}$ Os Parlements, compostos por pessoas ligados à nobreza, exerciam - ao lado de sua função jurisdicional os poderes de enregistrement (registro de disposições reais, que era requisito para sua aplicação) e de rémontrance (veto das mesmas disposições, antes de proceder ao seu registro) das ordenações do Rei, o que acarretava "uma efetiva mediação do poder do Rei absoluto" ( $c f$. EDUARDO GARCÍA DE ENTERRÍA, Revolución francesa y administración contemporanea, esp. p. 42-51; JUAN MONTERO AROCA - JOSÉ FLORS MATíES, El recurso de casación civil, cap. III, n. 1, p. 239; NICOLA PICARDI, "Introdução ao Code Louis (ordonnance civile, 1667)", n. 3.2.2, p. 85 e ss.). A monarquia, portanto, que havia se servido dos Parlements para afirmar sua autoridade sobre as jurisdições locais (feudais e baronais), acabou assistindo a uma transfiguração daqueles, no sentido de conquistar, "em boa substância, uma posição de forte autonomia paralegislativa, em concorrência com o rei". Tal desenvolvimento teria sido uma reação aos abusos praticados pelo monarca, que interferia no funcionamento da atividade jurisdicional dos Parlements por meio das lettres de justice (cf. GINO GIOIA, "Lo sviluppo storico del ricorso per cassazione, tra necessità e abusi", n. 2, p. 931932).

${ }^{343}$ Tanto que, no Decreto de 20 de outubro de 1789, a Assembléia Nacional ordenou que o Conseil des parties seguisse funcionando até a realização da reforma judicial, tendo a antiga instituição desaparecido justamente com a criação do Tribubal de cassation (cf. JUAN MONTERO AROCA - JosÉ FLORS MATíES, El recurso de casación civil, cap. 3, p. 247).

${ }^{344}$ Cf. CALAMANDREI - FuRno, "Cassazione civile", n. 8-9, p. 1059-1060; GinO GioIA, "Lo sviluppo storico del ricorso per cassazione, tra necessità e abusi”, n. 3, p. 933; JUAN MONTERO AROCA - JOSÉ FLORS MATÍES, El recurso de casación civil, cap. 3, n. 1, p. 240-241. Sobre a função exercida pelo Conseil des parties na monarquia fracesa, há amplo estudo de CALAMANDREI, La casación civil, tomo I, esp. cap. XVI, n. 11-114, p. 323-335 e cap. XVIII, n. 126-137, p. 377-421.
} 
Estado liberal burguês, preocupada com uma rígida separação dos poderes, na qual despontara, como elemento preponderante e fundamental da organização estatal, a lei. ${ }^{345}$

Parece ocioso dizer que no desenho institucional de poderes preconizado por MONTESQUIEU - diante da desconfiança nutrida pelos revolucionários em relação aos juízes, justamente por estes integrarem os antigos Parlements, representativos do ancien régime -, o juiz deveria ater-se a aplicar mecanicamente a norma ditada pelo legislador, servindo apenas como la bouche de la loi. O modelo cassacional pressupõe, nesse primeiro estágio, a idéia legalista consistente na defesa da possibilidade de aplicação de normas abstratas e desvinculadas dos fatos do caso concreto, sem necessidade de interpretá-las. ${ }^{346}$ Essa verdadeira "deificação da lei” levou à crença ingênua na onipotência, univocidade e completude dos Códigos, dando nascimento à Escola da Exegese. ${ }^{347}$

Da forma como foi criada, a Cassação não exercia função jurisdicional, atuando apenas como sentinela das leis, voltada a impedir a invasão do âmbito legislativo pelos juízes. ${ }^{348}$ Sua competência, em outras palavras, era puramente negativa: não detinha o poder de declarar o direito entre as partes, decidir o mérito da controvérsia ou mesmo estabelecer como o caso deveria ser decidido pelo juiz de renvoi; o Tribunal de cassation foi estabelecido apenas para cassar ou anular as sentenças judiciais prolatadas em desconformidade com os textos legais. Sequer se pronunciava, assim, sobre o mérito da causa (fond des affaires) e, a fortiori, não substituía a decisão do juiz por uma decisão sua (não "aplicava o direito à espécie", diríamos nós), cingindo-se a rescindir o julgado e a reenviar a causa para novo julgamento por um Tribunal inferior da mesma hierarquia que o primeiro. ${ }^{349}$ Em verdade, a Cassação não se pronunciava, de modo a substituir por uma

\footnotetext{
${ }^{345}$ Por isso, é correto o entendimento de que a cassação não foi a decorrência automática de uma separação qualquer dos três poderes, mas do predomínio que foi outorgado ao legislador na tripartição das funções estatais, em boa parte devido à doutrina de ROUSSEAU, que via na lei a vontade geral e soberana da nação ( $c f$. JOSÉ LUIS VÁSQUEZ SOTELO, "El modelo español de casación”, n. II/1, p. 358.)

${ }^{346}$ MIRJAN DAMAŠKA, The faces of justice and state authority, cap. I, n. IV, p. 35; FERDINANDO Mazzarella, Analisi del giudizio civile di cassazione, cap. I, n. 1, p. 9; GiovanNi Verde, Profili del processo civile, cap. 8, n. 7, p. 275; SERGI GUASCH FERNÁNDEZ, El hecho y el derecho en la casación civil, cap. 1, n. IV(1), p. 34-36.

${ }^{347}$ Cf. JuAn Montero Aroca - José Flors Matíes, El recurso de casación civil, cap. 3, p. 246.

${ }^{348}$ Contra, sustentando a natureza jurisdicional (e política) da Cassação desde os seus primórdios, FERDINANDO MAZZARELla, Analisi del giudizio civile di cassazione, cap. 1, n. 4, p. 22-24.

${ }^{349}$ Em conformidade com o que dispunha o art. $3^{\circ}$, item 3, do Decreto de 27 de Novembro $-1^{\circ}$ de Dezembro de 1790: "Sous aucun prétexte et en aucun cas, le Tribunal ne pourra connaître du fond des affaires. Après avoir cassé les procédures ou le jugement, il renverra le fond des affaires aux tribunaux qui devront en connaître, ainsi qu'il sera fixé ci-après".
} 
decisão sua o ato recorrido, sequer nos casos de decisões interlocutórias (jugements d'avant dire droit) ou de sentenças terminativas, ou seja, de decisões que não tratavam, propriamente, do mérito ou do fond des affaires. ${ }^{350}$

A cassação fundada em error in iudicando procedia apenas quando o juiz do mérito considerava inexistente uma lei vigente ou aplicava lei que não existia; não se adentrava, portanto, no âmago de questões relativas à interpretação ou à aplicação da norma ao caso. ${ }^{351}$ Cassada que fosse a sentença, o juiz do reenvio poderia julgar a causa em conformidade com a decisão recorrida, hipótese em que caberia, pelos mesmos motivos, uma segunda cassação. Se o juiz do segundo reenvio (i.e., o terceiro a julgar o mérito da causa) persistisse na tese repugnada pelo Tribunal de cassation, teria lugar o référé obligatoire ao Corps legislatif, por meio do qual era emanado um decreto interpretativo da lei, e somente então estaria vinculado o (quarto) juiz da causa. Nessa época, portanto, a Cassação não era órgão jurisdicional (ou judicial) e atuava de maneira puramente negativa, sequer se pronunciando frente aos juízes de mérito sobre a correta interpretação da lei, tarefa que caberia ao próprio legislador. ${ }^{352}$ Apenas nos casos de error in procedendo havia, de forma indireta, uma vinculação do juízo recorrido, que deveria retomar a marcha do processo a partir do primeiro ato anterior à invalidade praticada. ${ }^{353}$

Essa função meramente negativa do Tribunal de Cassação partia de um pressuposto metodológico específico e levava às últimas conseqüências a doutrina da separação dos poderes. Era amparada pelas noções de completude e de univocidade semântica da lei: sustentada pelas crenças de que os Códigos regulavam todas as possíveis situações de conflito e de que as disposições legais teriam um único sentido. Basicamente, pode-se dizer que se entendia possível aplicar a lei sem interpretá-la à luz do caso, ignorando-se (e, mais do que isso, repelindo-se) qualquer contribuição ao desenvolvimento do Direito por parte dos juízes. É sintomático, nesse sentido, o discurso radical proferido por ROBESPIERRE, em que ele afirmara: "em um Estado que tem uma constituição, uma

\footnotetext{
${ }^{350} \mathrm{Cf}$. EDOARDO RICCI, "La cassazione civile italiana e il divieto di pronuncia sul caso concreto", Rivista di diritto processuale, 1968, vol. 4, n. 2, p. 711 e n. 3, p. 714-715, respectivamente.

351 JuAn MONTERo Aroca - José Flors Matíes, El recurso de casación civil, cap. 3, p. 251.

${ }^{352}$ CALAMANDREI - FurNo, "Cassazione civile", n. 9, p. 1060-1061; JuAN MONTERo AROCA - JOSÉ Flors MATíES, El recurso de casación civil, cap. 3, p. 247-248 e, esp., p. 251-252; J. A. JOLOWICZ, "Appeal and review in comparative law: similarities, differences and purposes", p. 621; JOHN HENRY MERRYMAN Rogelio Pérez-Perdomo, The civil law tradition, cap. VII, p. 40. Contra, Ferdinando MazZarella, Analisi del giudizio civile di cassazione, cap. 1, n. 4, p. 22.

353 JuAn Montero ArocA - José Flors MatíES, El recurso de casación civil, cap. 3, p. 252-253.
} 
legislação, a jurisprudência dos tribunais não é outra coisa que a lei. A palavra jurisprudência deve ser excluída de nossa língua". 354

II) Apenas num segundo momento, ao longo de uma evolução gradativa, a Cassação passou a assumir funções verdadeiramente jurisdicionais, integrando-se à organização judicial. As mudanças começam pelo nome da instituição (que se altera, em 1804, de Tribunal para Cour), passam pelo modo de nomeação dos magistrados (antes, eram eleitos para mandatos temporários; a partir da Carta de 1814, são nomeados pelo Rei e inamovíveis) e pela ampliação dos fundamentos para recorrer (flexibilizando-se a rigidez da expressão "contravention expresse au texte de la loi », de modo a abranger também erros de aplicação e interpretação das normas), e terminam com uma verdadeira alteração das funções da Corte (de modo a abranger a unificação da jurisprudência) e com a supressão do « référé legislatif ${ }^{355}$

Constatou-se que, com o passar do tempo, a Corte de Cassação apresentou determinado grau de criatividade, desenvolvendo um corpo de jurisprudência próprio e assumindo uma função positiva de interpretação e de direção no desenvolvimento do Direito. Paralelamente, seu controle foi ampliado para abranger não apenas a «contravention expresse au texte de la loi », mas também a errônea interpretação da lei. ${ }^{356}$ Nessa evolução, aboliu-se o «référé obligatoire » dirigido ao Legislativo e a pronúncia da Corte, por meio de suas seções unidas, passou a ser vinculante ao juiz do segundo reenvio (lei de $1^{\circ}$-IV-1837).

III) As Cortes de Revisão (e, hoje, também as configurações contemporâneas dos Tribunais de Cassação) já se inserem noutro paradigma. A Revision alemã representa o passo final da "jurisdicionalização" dos Tribunais Supremos no direito continental. Enquanto, ao menos tradicionalmente, a Corte de Cassação se limitava a cassar a decisão recorrida e a pronunciar o princípio de direito aplicável, vinculando, em certas hipótese, o juízo de reenvio, a Corte de Revisão avançou a uma terceira fase: além de cassar e

\footnotetext{
${ }^{354}$ No original: "Dans un Etat qui a une constitution, une législation, la jurisprudence des tribunaux n'est autre chose que la loi. Le mot jurisprudence doit être effacé de notre langue" (ROBESPIERRE, Séance du 18 novembre 1790, Archives parlementaires, 1ère série, Tome XX, p. 516).

${ }^{355}$ Em largas linhas, JUAN MONTERo AROCA - José Flors MATíEs, El recurso de casación civil, cap. 3, p. 255-259; GINO GIOIA, "Lo sviluppo storico del ricorso per cassazione, tra necessità e abusi", n. 3, p. 936-937.

${ }^{356}$ CALAMANDREI - FuRno, "Cassazione civile", n. 10, p. 1061; ANDRÉ TunC, "La Cour suprême idéale", p. 438; BRUNO SASSANI, "Tra 'consapevolezza culturale' e 'buona volotà organizzativa': considerazione sparse sulla deprecata funzione nomofilattica della Corte di Cassazione”, n. 2, p. 270.
} 
enunciar a orientação jurídica correta, aplicava ela mesmo a norma ao caso, substituindo o julgado da instância inferior. ${ }^{357}$

É inquestionável que o racionalismo que inspirara a criação da Cassação francesa inclusive como órgão estranho ao Poder Judiciário - é insustentável. A idéia de uma exata aplicação da lei, desprovida dos fatos do caso, partindo de textos unívocos é inconsistente do ponto de vista teórico e prático (v., supra, $\S 4^{\circ}$ ). Daí a necessária releitura por que passou o conceito de nomofilaquia. O Tribunal Superior não é responsável por uma defesa formal da lei, mas por estabelecer, in concreto, o sentido dos textos legais. O fato do órgão ser único e situar-se no vértice do ordenamento judicial é que tende a gerar um efeito uniformizador da jurisprudência. ${ }^{358}$ Nessa medida, atribui-se-lhe, pela sua posição, a competência de fixar uma interpretação "vera" ou autêntica dos enunciados legais, numa obra constante de estabilização hermenêutica ou de "nomofilaquia tendencial", que não se confunde com a existência a priori de uma right answer ou com o mito da univocidade da lei. ${ }^{359}$ A origem etimológica da palavra corrobora essa posição, pois nómos, em grego, significara modo de vida ou comportamento, costume ou, em sentido amplo, direito. ${ }^{360}$ Seria impreciso, portanto, reduzir a nomofilaquia a uma defesa da lei formal.

\footnotetext{
${ }^{357}$ Ao tempo de Bismarck, já eram conhecidas as deficiências da Cassação de modelo francês. Ademais, a doutrina passara a aceitar a interpretação das leis como atividade inerente à função jurisdicional. À luz dessas considerações, "os alemães fizeram a coisa racional: eles criaram uma Suprema Corte com o poder de revisar as decisões das cortes inferiores", estabelecendo a interpretação jurídica correta e decidindo ela mesmo a controvérsia (John HENRY MERRYMAN - ROgeLIO PÉREZ-PERDOMO, The civil law tradition, cap. VII, p. 41).

${ }^{358}$ CASTANHEIRA NEVES, “A distinção entre a questão-de-facto e a questão-de-direito...”, n. 2, p. 527.

359 Cf. Vezio Crisafulli, "Disposizione (e norma)", n. 5, p. 209, nota 47; Michele TarufFo, El vértice ambiguo, $\S 3$, n. 4, p. 124 e ss., $\S 7$, n. 3, p. 226 (destacando, entre outros pontos, que a tese da right answer de DWORKIN não é mais convincente que os velhos argumentos do formalismo interpretativo); SERGIO CHIARLONI, "Un singolare caso di eterogenesi dei fini...", n. 6, p. 849. Sobre o conceito de nomofilaquia e o predicado "tendencial" ou "hermenêutica", v., em tom crítico, Ferdinando Mazzarella, Analisi del giudizio civile di cassazione, cap. 1, n. 3, p. 15-17, nota 7 (alegando que substituir a noção de nomofilaquia como defesa da interpretação exata pela idéia de uma escolha dentre significados plúrimos não passa de substituir um mito por outro). Entre nós, em sentido positivo, DANILO KNIJNIK, O recurso especial e a revisão da questão de fato..., n. 2.3, esp. p. 100-105.

${ }^{360}$ É o que informa MichaEL GAGARIN, Early greek law, em diversas passagens da obra - n. 1, p. 1, nota 1; n. 2 , p. 21 , nota 8 ; n. 3 , p. 53.
} 


\subsection{A prevalênCia dos fins (público ou privado) E a atuaÇão dos Tribunais SUPERIORES}

A discussão doutrinária sobre os fins do Superior Tribunal de Justiça (ou melhor, dos Tribunais Superiores como um todo) repousa hoje sobre outras bases. Se a nomofilaquia deve ser entendia em sentido "dialético", "tendencial" ou "hermenêutico", então a fixação da norma pelo Tribunal Superior depende de escolhas e valorações, o que significa que sua função pode ser realizada de modos diversos. ${ }^{361}$

O problema consiste, então, em saber se o seu escopo precípuo é concretizar a unidade do Direito (função pública ligada ao ius constitutionis), realizar a justiça no caso concreto (função privada conexa ao ius litigatoris), ou, ainda, o que equivale a esta última posição, promover uma concorrência simultânea necessária entre as duas finalidades, vistas como coincidentes sempre. $^{362}$

Por essa perspectiva, os Tribunais Superiores e a função nomofilática podem, segundo varie a opção pela predominância da função pública ou privada, ser entendidos, respectivamente, como vocacionados à formulação prospectiva de uma norma de alcance geral por meio da edição de um precedente ou voltados para o controle retrospectivo de legalidade da específica da decisão recorrida. ${ }^{363}$ No primeiro modelo, tendem a vigorar mecanismos de seleção dos recursos a serem julgados. A Corte lança mão de critérios objetivos ligados à importância das questões debatidas ou à oportunidade de estabilizar um entendimento a seu respeito. No segundo tipo ideal, os recursos são vistos como direitos subjetivos dos litigantes e tendem a ser empregados argumentos ligados à justiça do caso e às posições jurídicas das partes individualmente consideradas. À luz da investigação de Direito Comparado (supra, $\S 3^{\circ}$ ), é fácil assimilar o primeiro modelo ao appeal e à Revision, ligando o segundo à cassation.

\footnotetext{
${ }^{361}$ MiCHELE TARUFFO, El vértice ambiguo, § 7, n. 3, p. 227.

${ }^{362} C f$. CASTANHEIRA NEVES, “A distinção entre a questão-de-fato e a questão-de-direito...”, n. 2, p. 525-526.

363 Distinção feita de maneira insistente por MiCHELE TARUFFO, El vértice ambiguo, introd., p. 13-16, § 7, n. 3, p. 227 e ss.; ID., "Institutional factors influencing precedents", n. 2.1, p. 444-445; ID., "Las funciones de las Cortes Supremas", n. 1, p. 649-650; também Aulis AARNIO, "Precedent in Finland”, n. I.5, p. 80, noticiando este último autor que a Suprema Corte da Finlândia adota uma "função claramente prospectiva", no sentido de estabelecer um "precedente" para orientar decisões das cortes inferiores e, em alguma medida, suas próprias decisões.
} 


\subsubsection{APRESENTAÇÃO DA TESE EM DEFESA DA FUNÇÃO SUBJETIVA (IUS LITIGATORIS)}

A defesa do ius litigatoris (por alguns referida como a função dikelógica ${ }^{364}$ ) vê como um direito subjetivo da parte a apreciação do recurso por ela interposto. Por isso, a Corte deve focar as suas atenções sobre as particularidades dos casos - de todos os casos que chegam às suas mãos, visando sobretudo à justiça individual. Para os autores que a defendem, haveria uma falsa contraposição entre ius constitutionis e ius litigatoris. ${ }^{365}$

Por essa visão, o recurso especial representa garantia de acesso à justiça, constituindo mais um canal para que as partes busquem corrigir injustiças cometidas pelas instâncias locais - com exclusão apenas de questões fáticas e de direito local - de modo que o acesso ao Superior Tribunal de Justiça deveria ser suficientemente amplo, a ponto mesmo de permitir com que "todas as questões federais" lá sejam discutidas. ${ }^{366}$

Levando a concepção adiante, os autores defendem que os Tribunais de cúpula devem levar em consideração não apenas os "grandes temas", mas as questões "menores" ligadas especificamente ao interesse dos recorrentes. Pouco importa, assim, a transcendência ou repercussão geral da questão jurídica neles debatida. A idéia de um filtro ou de outro mecanismo de seleção é fortemente repelida. Argumenta-se que, se as Cortes Supremas não se ocupam de toda a gama de conflitos, não podem cumprir a função nomofilática, já que sua jurisprudência será escassa e de pouco valor, abrindo espaço para dissidências entre as decisões de segundo grau. ${ }^{367}$

Essa concepção, pois, pode ser assim resumida: para ter um real impacto sobre a sociedade, o Tribunal Superior deve julgar o número máximo de casos possíveis, controlando, uma a uma, as insatisfações que possam surgir na aplicação do Direito no país pelos tribunais inferiores. Não sendo assim, permite-se incerteza jurídica e distancia-se o Tribunal dos cidadãos. O ideal de uniformidade não é alcançado por meio de poucos precedentes, mas por meio de um controle retrospectivo abrangente, compreensivo e absoluto sobre as instâncias inferiores.

\footnotetext{
${ }^{364}$ BRUNO DANTAS, Repercussão geral, n. 2.3.2.1, p. 66 e ss.

${ }^{365}$ ALEJANDRO BUENDÍA CÁNOVAS, La casación civil, cap. IV, p. 208-210 e p. 371 (quarta conclusão).

${ }^{366}$ Nesse sentido, em ensaio já antigo, CÂNDIDO DINAMARCO, "Superior Tribunal de Justiça e acesso à ordem juridica justa", n. 2, p. 250-253 e n. 5, p. 255-257.

${ }^{367}$ J. NIEVA FENOLL "La relevancia social de la casación”, n. 3, p. 102-103, n. 6, p. 115.
} 
Em resumo: a Corte deve julgar muito (quantitativamente) para atuar bem (qualitativamente), sob pena de não proteger eficazmente o ordenamento jurídico. Nas palavras de NiEva FENOLL, "se o tribunal de cassação deve proteger o ordenamento jurídico, deve ocupar-se de todos os erros que vulneram dito ordenamento", sendo necessário dotá-los de infraestrutura capaz de lidar com todo esse volume. A sua sugestão - partindo-se da premissa que a grande maioria dos casos não demanda uma apreciação demorada - é a instalação de órgãos colegiados menores para conhecer dos casos fáceis e de aumento do número de juízes. ${ }^{368}$

Como se pode facilmente perceber, há forte repulsa em relação aos mecanismos de seleção dos recursos (certiorari, significância da questão, repercussão geral, interés casacional, general importance etc.). No Brasil, há quem defenda semelhante ponto de vista, acusando, inclusive, o instituto da repercussão geral de ser incompatível com o Estado Democrático de Direito. ${ }^{369}$

Outra variante da tese ataca a função nomofilática como sendo uma "visão centralizada e fortemente autoritária da justiça”. Caberia contentar-se com uma Corte que seja apenas e tão-somente um órgão de garantia da exata observância da lei, única função possível de ser cumprida, sendo "oportuno pensar uma Corte Suprema que se preocupa da nomofilaquia em função da justiça da decisão singular e não vice-versa". ${ }^{370}$ A isso, costuma somar-se uma defesa da falta de uniformidade da jurisprudência em razão do caráter pluralista da sociedade contemporânea, entendendo-se como arbitrária a supressão do dissenso por essa via. ${ }^{371}$

\footnotetext{
368 J. NIEVA FENOLL “La relevancia social de la casación”, n. 7, p. 120-121.

${ }^{369}$ ALEXANDRE BAHIA, Recursos extraordinários no STF e no STJ, n. 3.5, p. 174.

${ }^{370}$ Nesse sentido, GIOVANNI VERDE, "In difesa dello jus litigatoris...", n. 6, p. 10-11, embora, adiante, pareça o autor defender um ponto de vista essencialmente contingente, à luz das limitações do sistema italiano (sobretudo, dos obstáculos impostos pelo art. 111, $7^{\circ}$, da Constituição, que garante um direito subjetivo ao recurso em cassação), sinalizando, em tais circunstâncias (número excessivo de recursos, autoridade apenas relativa da Corte etc.) ser possível apenas uma "função nomofilática menor" voltada para a justiça do caso concreto, dando especial relevo ao controle da motivação (op. cit., n. 8, p. 18-19).

${ }^{371}$ ALEXANDRE BAHIA, "Os recursos extraordinários e a co-originalidade dos interesses público e privado no interior do processo...”, n. 2, p. 369, nota 10.
} 


\subsubsection{DEFESA DA PREVALÊNCIA DA FUNÇÃO OBJETIVA (IUS CONSTITUTIONIS)}

\subsubsection{A FALÁCIA DA EQUIVALÊNCIA dOS FINS}

Muitos autores argumentam ser um equívoco contrapor interesse público e interesse privado na consideração dos fins atribuídos aos Tribunais Superiores. Argumentam que os dois escopos coincidem e convivem de maneira hamônica na prática: tutelar o ius litigatoris é tutelar o ius constitutionis, segundo essa visão.

É essa uma conhecida falácia. É sabido que as funções objetiva e subjetiva não se confundem, ainda que não possam ser contrapostas senão como extremos de um contínuo, permitindo soluções intermediárias. Basta, para chegar-se a essa conclusão, considerar que os adeptos da primeira admitem e incentivam, como medida necessária, o poder conferido à Corte para selecionar os recursos a serem julgados, com base na importância da questão suscitada, solução reputada absolutamente inadmissível para os defensores da visão subjetiva. Em verdade, a tese da coincidência entre os escopos subjetivo e objetivo - i.e., a idéia de que por meio do controle individual de todas as decisões seria garantida a legalidade do ordenamento como um todo - não passa de uma variante da concepção subjetiva, procurando absorver nesta a tensão entre as duas finalidades. ${ }^{372}$

Já se disse, com inteiro acerto, que “o escopo é ou predominante público ou privado". ${ }^{373}$ De fato, a tentativa de conciliar, em pé de igualdade, a função pública com a função privada "nunca funciona", levando invariavelmente a uma submissão do escopo público diante do número alarmante de recursos conhecidos, que impedem o desempenho da verdadeira função do Tribunal Superior. ${ }^{374}$ Isso porque a função "jurisprudencial e normativa" dos Tribunais Superiores exige decisões bem fundamentadas sobre temas

\footnotetext{
${ }^{372}$ Michele TARUFFO, El vértice ambiguo, introd., p. 25-26 e $\S 5$, n. 3, p. 176. É importante perceber que "versão objetiva e versão subjetiva da garantia de legalidade não são dois modos diversos para indicar a mesma coisa, nem fenômenos equivalentes ou destinados a fundir-se, de alguma maneira, um com o outro. Representam, ao contrário, os pólos de um espaço conceitual diferenciado dentro do qual o problema de definir o conteúdo de semelhante garantia pode receber respostas muito diferentes" (op. cit., introd., p. 26). Além disso, variam os critérios e modos de interpretação segundo esta seja uma atividade destinada a controlar a aplicação da norma a um caso concreto - considerado em toda a sua individualidade, inclusive do ponto de vista do procedimento que conduziu até à decisão - ou voltada para um ponto de vista institucional consistente em considerar o caso com uma oportunidade para estabelecer um precedente (op. cit., § 5 , n. 3, p. 177).

${ }^{373}$ Michal BoBEK, "Quantity or quality? Reassessing the role of Supreme Jurisdictions in Central Europe", n. III, p. 57.

${ }^{374}$ Michal BobeK, "Quantity or quality? Reassessing the role of Supreme Jurisdictions in Central Europe", n. II, p. 48.
} 
especialmente relevantes, ao passo que a função "jurisdicional e disciplinar" impõe, de modo contrário, que sejam conhecidos todos os recursos interpostos. ${ }^{375}$

É claro que, uma vez conhecido o recurso, o Tribunal se ocupa do caso, escolhendo uma interpretação justa da lei. Mas o só fato de que, antes de passar ao exame do caso, há um escrutínio rigoroso de admissibilidade das impugnações (em alguma medida, inclusive nos sistemas de cassação e no nosso recurso especial, embora por meio de uma jurisprudência defensiva) demonstra que o interesse privado só é tutelado na medida em que o interesse público o imponha. Na visão conhecida de CALAMANDREI, o recurso de cassação serve a um fim público, embora aproveite e explore, para tanto, a iniciativa individual. Ao fim e ao cabo, faz a justiça do caso concreto "somente nos limites dentro dos quais isso possa servir para alcançar o seu escopo de unificação da jurisprudência". ${ }^{376}$

Dito isso, cabe passar a uma defesa da prevalência da função prospectiva dos Tribunais Superiores.

\subsubsection{Promoção da igualdade E DA SEguranÇA JURídica POR MEIO dos PRECEDENTES}

Como se viu, a teoria em defesa do ius litigatoris pressupõe uma análise particularizada do caso, em que se busque por meio do recurso excepcional "a justiça do caso concreto". Essa postura, no entanto, muitas vezes se choca com o ideal de uniformidade e com a lógica do precedente. Com efeito, "em uma posição em que cada caso faz história por si, porque é apreciado em sua irrepetível unicidade, não há espaço para a uniformidade de interpretação da lei: pois, enquanto existe, é vista como routine ou como um vínculo formalista". 377

Já os precedentes contribuem para a previsibilidade, a segurança jurídica, a uniformização da jurisprudência e a própria credibilidade do Poder Judiciário, podendo-se falar numa nomofilaquia por meio dos precedentes (ou seja, numa coordenação entre as

\footnotetext{
375 LOÏC CADIET, "El sistema de la casación francesa", Los recursos ante Tribunales Supremos en Europa (coord. Manuel Ortells Ramos), Madrid: Difusión Jurídica, 2008, n. I/3, p. 29-30.

${ }^{376}$ CALAMANDREI - FURNO, “Cassazione civile”, n. 3, p. 1056.

${ }^{377}$ MiCHELE TARUfFO, El vértice ambiguo, § 7, n. 4, p. 232.
} 
funções de controle de legitimidade da decisão recorrida e uniformização da jurisprudência) como escopo ideal dos Tribunais Superiores. Nessa medida, o respeito à lei não é garantido apenas em relação ao caso objeto de julgamento, mas antes de tudo pelo respeito (rectius, pela vinculação) dos demais juízes à interpretação dada pelo Tribunal Superior e pelas decisões tomadas pelos particulares com base no precedente. Os órgãos situados na cúpula do Poder Judiciário não existem apenas para solucionar conflitos jurisdicionalizados, mas também para orientar a sociedade como um todo, sinalizando o modo como as relações intersubjetivas devem ocorrer. ${ }^{378}$

Cabe, agora, refutar os argumentos contrários.

I) Em primeiro lugar, o argumento de que uma “defesa do ordenamento jurídico" só pode ser realizada mediante um controle de todas as decisões recorridas é falso. Basta lançar os olhos sobre as Cortes Supremas da common law ou o BGH alemão para ver que "é possível, para uma Corte Suprema, ter sob controle a legalidade global do sistema jurídico mesmo pronunciando um número de sentenças sumamente reduzido a cada ano", i.e, ditando precedentes pro futuro. ${ }^{379}$

Mais do que isso, em verdade, o destaque conferido ao ius litigatoris pela tese subjetiva conduz à impossibilidade prática de garantir-se uniformidade. Já se disse, com razão, que a "hipertrofia das leis" conduz à "distrofia ou mesmo [à] atrofia de muitas delas". ${ }^{380} \mathrm{O}$ mesmo pode ser dito dos precedentes. Um número excessivo de julgados, além de diminuir a sua autoridade, acaba por afetar a cognoscibilidade do ordenamento, pressuposto dos princípios da igualdade e da segurança jurídica (v., supra, $\S 4^{\circ}$ ). A apreciação de inúmeras e repetitivas questões de menor relevo - prática que ou conduz à reiteração desnecessária ou gera dissidências internas - impede um Tribunal Superior de desempenhar sua função institucional. ${ }^{381}$ Assim, a relação entre a força normativa das

\footnotetext{
${ }^{378}$ Nesse sentido, J. A. Jolowicz ressalta que são mais importantes as decisões tomadas fora dos Tribunais mas com base em seus entendimentos - do que propriamente a solução de conflitos. No original: "Far more important to the daily life os society are the 'decisions' which are made outside the courts, but on the basis of what is believed a court would decide if asked, than are the decisions actually made by the courts" ("Appeal and review in comparative law: similarities, differences and purposes", p. 636).

${ }^{379}$ Michele TARUfFo, "Las funciones de las Cortes Supremas", n. 2, p. 653 (referindo-se as Supreme Courts) e n. 3, p. 655-658 (destacando o atual modelo da Revision alemã).

${ }^{380}$ CALAMANDREI, "La certeza del derecho y las responsabilidades de la doctrina", p. 123-134.

${ }^{381}$ NeIL MACCORMICK - RoBeRt SUMMERS, "Further general reflections and conclusions", n. 4, p. 547; J. A. JOLOWICZ, "Appeal and review in comparative law: similarities, differences and purposes", p. 635.
} 
decisões e o seu número é de proporcionalidade inversa: quanto mais decisões sobre temas desimportantes ou repetitivos, maior é a inconsistência e menor é a cognoscibilidade do Direito jurisprudencial. $^{382}$

II) Ainda nesse âmbito, devem ser rechaçadas propostas que visem sobretudo (ou, $a$ fortiori, exclusivamente) ao aumento de juízes. O "gigantismo" da Corte leva ao problema da inconsistência de sua próprias decisões, mormente quando os mecanismos para a solução interna de divergências são ineficientes.

III) Outro argumento a ser combatido liga-se à suposta natureza refratária do Direito do nosso tempo à uniformização. É inegável que a sociedade contemporânea (para alguns, “pós-moderna") é essencialmente pluralista, não havendo nela consenso em torno de temas fundamentais. É também certo que o reflexo legislativo dessa característica, comumente referido como "decodificação" ou "inflação legislativa", se faz presente aos olhos de todos. Daí não se pode retirar, contudo, a conclusão de que se deve permitir (ou até mesmo incentivar) uma semelhante dispersão da jurisprudência, afastando a idéia de sua uniformização por meio de um Corte Suprema. Trata-se de uma verdadeira e crescentemente freqüente "tentativa de racionalizar a incoerência da jurisprudência"; no entanto, é justamente numa situação de tal gênero que o papel desempenhado por um órgão jurisdicional situado no vértice do ordenamento judiciário assume vital importância. ${ }^{383}$ Portanto, ao contrário do que é, em tempos recentes, comumente afirmado, numa sociedade complexa e pluralista como a nossa, mecanismos de justiça geral são imprescindíveis e regras - enquanto formas de solução prévia de conflitos e garantia de segurança jurídica e de estabilidade - essenciais. ${ }^{384}$

IV) Por fim, referindo-se sempre a obra de NiEVA FenOll para consulta, há quem entenda ser autoritária a vinculação aos precedentes. Contudo, é esse mesmo jurista quem defende a necessidade de uma cassação compreensiva (i.e, abrangente de todos os casos possíveis), de modo que o Tribunal Superior possa, acima de tudo, vigiar constantemente a

\footnotetext{
${ }^{382}$ Não por acaso, o excelente ensaio sobre a problemática das Cortes Supremas, de autoria de MICHAL BOBEK, traz na primeira parte do seu título a pergunta "quantidade ou qualidade?", primeira escolha a guiar a implantação de um modelo ("Quantity or quality? Reassessing the role of Supreme Jurisdictions in Central Europe").

383 Sergio Chiarloni, "Un singolare caso di eterogenesi dei fini...", n. 6, p. 850; G. TARZiA, "Le impugnazoni civili tra disfunzioni e riforme", n. 5, p. 477.

${ }^{384}$ Humberto Ávila, “'Neoconstitucionalismo': entre a 'Ciência do Direito' e o ‘Direito da Ciência’”, n. 3, p. 198
} 
atividade dos juízes inferiores, que devem ter, em alguma medida, "temor" de transgredir o ordenamento jurídico nas suas decisões. ${ }^{385}$ Deixada de lado a questão de que a idéia de um controle necessário pode conduzir a uma regressão ao infinito (quis custodiet ipsos custodes?), o que já enfraquece a validade teórica dessa concepção, é importante perceber que ela, ao invés de garantir uma atuação coordenada dos juízes, busca-se incutir neles o medo decorrente de uma estrutura hierárquica.

A idéia de um rígido controle por meio de recursos é, de fato, uma das características marcantes do modelo de processo hierárquico, consoante demonstrado por MIRJAN DAMAŠKA. Nesse tipo ideal, a etapa recursal é vista como um desenvolvimento natural de qualquer litígio, havendo uma revisão não só regular, como também compreensiva. Pouco valor é dado, assim, aos juízes de primeiro grau, meros burocratas cujo trabalho deve ser necessariamente revisado. Ao contrário, os sistemas que privilegiam o precedente costumam ter uma distribuição horizontal de autoridade. ${ }^{386}$ Portanto, a crítica de autoritarismo dificilmente poderia ser dirigida ao modelo do appeal (e, em geral, aos sistemas que consagram mecanismos de seleção dos recursos e a força dos precedentes), sendo antes cabível à cassation. Não por acaso e por paradoxal que possa parecer à primeira vista, ClAUdio CONSOLO refere o art. 111, $7^{\circ}$, da Costituzione italiana (ou seja, o dispositivo que garante o "acesso ilimitado" à Corte de Cassação daquele país) como uma “"totalitária' garantia constitucional". 387

\subsubsection{O PARADOXO: A IRRACIONALIDADE DA DEFESA DO "IUS LITIGATORIS" DO PONTO DE VISTA DOS LITIGANTES}

Uma garantia irrestrita de um terceiro grau de jurisdição, como bem reconhece a doutrina italiana, comparando o seu ordenamento com os sistemas estrangeiros, "é estranha à história, à função, à natureza e às possibilidades das Cortes de última instância", sendo

\footnotetext{
${ }^{385}$ Nesse sentido, com efeito, J. NIEVA FENOLL "La relevancia social de la casación”, n. 3, p. 103-104 (destacando a importância da "ameaça da futura cassação da sentença", sem a qual os juízes decidirão "sem temor algum").

${ }^{386}$ The faces of justice and state authority, esp. n. II(i), p. 48-49/

${ }^{387}$ Il processo di primo grado e le impugnazioni..., p. 487.
} 
suficiente, para garantir razoavelmente as exigências de justiça do caso individual, o respeito ao duplo grau. ${ }^{388}$

No entanto, mesmo que se escolhesse dar primazia aos interesses subjetivos dos litigantes (ius litigatoris), é duvidoso que esse objetivo seja alcançado por um acesso irrestrito ao Superior Tribunal de Justiça. Isso porque, do ponto de vista privado, a admissão do recurso excepcional só atende aos anseios da parte recorrente, i.e, da parte a quem desfavorece a decisão tomada pelo tribunal de segundo grau. Pelo contrário, a parte recorrida - vitoriosa nas instâncias ordinárias - será onerada com a pendência do processo e com o dano marginal que daí resulta. Só haverá, na prática, uma melhor tutela da "justiça do caso" quando o recurso for provido; em caso contrário, terá havido, em alguma medida, sacrifício dos interesses daquele litigante que tinha razão, sem qualquer melhora na situação de qualquer uma das partes.

Objetar-se-á, talvez, que essa avaliação ex post facto é inviável e distorcida. Antes da resolução definitiva da lide, a incerteza que marca a coisa litigiosa não permite que as partes saibam, de antemão, quem sairá vitorioso do processo. Como ambas são potenciais sucumbentes no julgamento de segunda instância, deixar em aberto, irrestritamente, um segundo recurso para corrigir a eventual injustiça da decisão pode representar um mecanismo no interesse de ambas.

Mas sequer essa defesa é justificada. Para aferir a consistência desse argumento e levá-lo a sério, ter-se-ia de aplicar ao problema algo como a noção de véu da ignorância e e posição original de RAWLS, de modo que, "sem saber como as várias alternativas afetarão o seu caso, [as partes] serão obrigadas a valorar princípios somente com base em considerações gerais". ${ }^{389}$ Colocada por essa nova perspectiva, a questão passa a ser basicamente a seguinte: sem que os litigantes possam saber em que posição se encontrarão após o julgamento da apelação (vencedor ou vencido), será no seu melhor interesse que seja garantido o acesso ao Tribunal Superior por meio de um recurso de admissibilidade irrestrita?

\footnotetext{
${ }^{388}$ BRUNO SASSANI, "Tra 'consapevolezza culturale' e 'buona volotà organizzativa': considerazione sparse sulla deprecata funzione nomofilattica della Corte di Cassazione", n. 4, p. 273.

${ }^{389}$ A theory of justice, p. 102 e ss., esp. p. 118-122 (a transcrição é do n. 24, p. 118).
} 
É preciso refletir pouco para perceber que a resposta positiva depende de que o porcentual de recursos providos pelo Superior Tribunal de Justiça seja significante, de modo que, em um número razoável casos, a existência de um "terceiro grau" de jurisdição efetivamente traga uma melhora para uma das partes. Em caso contrário, como se viu, a pendência do processo não traz ganho ao recorrente e impõe ao menos um dano marginal ao recorrido, com um resultado global negativo, mesmo pela perspectiva do ius litigatoris. Assim, mesmo que o litigante não possa saber se sairá vitorioso ou não, a predisposição do recurso só lhe será benéfica se, em boa parte dos casos, existir uma expectativa razoável de vitória. ${ }^{390}$

No entanto, as estatísticas demonstram - com sobra - justamente o contrário. Em 2009, do total de recursos julgados (impressionantes 328.178), foi dado provimento a apenas $21,24 \%$ deles. Quanto ao mais, a $56,79 \%$ foi negado provimento, $17,23 \%$ não foram conhecidos e $4,74 \%$ foram enquadrados na categoria "outros" (compreendendo decisões de homologação de desistência ou de acordo, julgamentos de conflitos de competência etc.). ${ }^{391}$ Ou seja, em termos aproximados, a atuação do Superior Tribunal de Justiça trouxe algum benefício para o interesse dos litigantes (ius litigatoris) em apenas um em cada cinco recursos; nos outros oitenta por cento dos casos, o ius litigatoris não foi favorecido.

Isso significa que a manutenção de um acesso irrestrito à Corte não é apenas contrária ao interesse público compreendido pela função prospectiva de orientação por meio dos precedentes; é também irracional do ponto de vista econômico das partes (e, portanto, do ius litigatoris), bem como de uma alocação racional de recursos pelo Poder Judiciário como um todo. Somem-se a isso, ainda, os argumentos fundados na paridade de armas - já que o acesso ao Superior Tribunal de Justiça tende a privilegiar os litigantes habituais, em detrimento dos litigantes eventuais - e na falta de qualquer garantia de que a decisão ad quem será qualitativamente (do ponto de vista da justiça) superior àquela proferida pelo tribunal local, e pouco ou nada fala em favor da atuação da Corte pelo ponto de vista do ius litigatoris.

A implementação de mais uma fase procedimental - como etapa necessária dentro de um processo já marcado pela sua morosidade -, desvinculada da importância da

\footnotetext{
${ }^{390}$ HeNRIK LindBLOM, "The role of the Supreme Courts in Scandinavia", n. 3.4.2, p. 341.

${ }^{391} C f$. o relatório estatístico de 2009 (disponível em http://www.stj.jus.br).
} 
questão a ser julgada, não pode justificar-se, portanto, nem pelo interesse das partes nem pelo interesse público. O recurso excepcional justifica-se apenas se, por meio dele, puder a Corte atuar de maneira prospectiva, promovendo a função de orientação e conferindo unidade ao Direito por meio de seus precedentes.

\subsection{ObSERVAÇões SObre O Precedente}

\subsubsection{FORÇA DO PRECEDENTE}

Para alguns autores, "é da própria previsão de tribunais com competência para dar unidade ao Direito e da necessidade de coerência como qualidade ínsita ao sistema jurídico que surge a necessidade de respeito aos precedentes". 392

São variadas as razões para conferir peso e, até mesmo, força vinculante aos precedentes dos Tribunais Superiores. ${ }^{393}$ De um lado, tais justificativas são de ordem normativa, concretizando princípios constitucionais ligados ao Estado de Direito (v., supra, $\S 4^{\circ}$ ), tais como a igualdade de tratamento, ${ }^{394}$ a segurança jurídica (permitindo previsibilidade e estabilidade do ordenamento) e a proteção da confiança; de outro, constituem considerações de natureza conseqüencial, ${ }^{395}$ como a eficiência decisional, o reforço da confiança depositada pela sociedade no Poder Judiciário, o desestímulo à litigância, o favorecimento de acordos e a redução de custos em geral. Ademais, o precedente judicial contribui, ainda que indiretamente, para a qualidade das decisões judiciais. Na medida em que os juízes pesquisam seriamente os precedentes pertinentes,

\footnotetext{
${ }^{392}$ MARINONI - MitidieRO, O projeto do CPC: críticas e propostas, São Paulo: RT, 2010, n. 1, p. 17. Algo nesse sentido, considerando tímida a introdução constitucional de eficácia vinculante apenas em relação aos julgados do STF sumulados na forma do art. 103-A (as chamadas súmulas vinculantes) e defendendo que tal poder deveria ter sido conferido também ao STJ e aos tribunais locais naquilo em que emitem a última palavra (i.e., direito federal e direito estadual/municipal, respectivamente), CÂNDIDO DINAMARCO, "Súmulas vinculantes", Fundamentos do processo civil moderno, 6. ed., São Paulo: Malheiros, 2010, t. I, n. 117, p. 216 e n. 126, p. 234.

${ }^{393}$ Sobre o ponto, ver, amplamente,

${ }^{394}$ NeIL DUXBURY, The nature and authority of precedent, cap. 5, n. 2, p. 174-175; ALEŠ GALIČ, "The role of the Supreme Court in creating precedents in Slovenian civil procedure”, n. IV, p. 272.

${ }^{395}$ NEIL DUXBURY, The nature and authority of precedent, cap. 3, n. 2, p. 92 e ss.
} 
são obrigados a confrontar grupos de casos, operação que permite uma ampliação do quadro de possibilidades fáticas e, assim, uma melhor formulação da regra na espécie. ${ }^{396}$

Contra a eficácia vinculante dos precedentes, geralmente são levantadas como objeções possíveis injustiças individuais (devidas a decisões sub-ótimas para o caso), bem como o risco estagnação do Direito, a ofensa à liberdade dos juízes e o desequilíbrio na separação de poderes. ${ }^{397}$

Uma ponderação de tais argumentos aponta claramente em favor de sua força normativa. Como se viu, a doutrina do precedente não impede a evolução e o desenvolvimento do Direito. Embora a prática de seguir os precedentes vise à estabilidade, não há hoje dúvida de que um Tribunal Superior pode rever os seus próprios precedentes, desde que razões particularmente fortes se façam presentes. Até mesmo na Inglaterra, onde a doutrina do stare decisis encontrou sua formulação mais rígida, a Supreme Court (antiga House of Lords) tem o poder de efetuar um overruling: embora essa posição radical tenha sido afirmada no final do século XIX pela House of Lords, ${ }^{398}$ o Practice Statement de 1966 (pronunciado pelo Lord Gardiner, em 26 de julho daquele ano) permitiu à Corte (e exclusivamente a ela, ou seja, sem afetar a vinculação das Corte inferiores) que superasse um entendimento anterior quando houvesse razões para tanto, sem descuidar de situações já consolidadas. ${ }^{399}$

Uma teoria dos precedentes permite o equilíbrio entre estabilidade e vinculação, de um lado, e mudança e adaptação, de outro; o precedente funciona, assim, como uma presunção forte, que só pode ser superada por razões contrárias particularmente graves. Há,

\footnotetext{
${ }^{396}$ EMILY SHERWIN, “Judges as rulemakers”, n. II, p. 926-927.

${ }^{397}$ Para uma defesa dessas posições, em linhas gerais, na doutrina brasileira, ver HUMBERTO THEODORO JR. DIERLE NunES - ALEXANDRE BAHIA, "Breves considerações sobre a politização do Judiciário e sobre o panorama de aplicação no direito brasileiro - análise da convergência entre o civil law e o common law e dos problemas da padronização decisória", n. 2.1.1, p. 29-30.

${ }^{398}$ London Tramways Co. v London City Council [1898] AC 375.

399 "Their Lordships regard the use of precedent as an indispensable foundation upon which to decide what is the law and its application to individual cases. It provides at least some degree of certainty upon which individuals can rely in the conduct of their affairs, as well as a basis for orderly development of legal rules. (...) Their Lordships nevertheless recognise that too rigid adherence to precedent may lead to injustice in a particular case and also unduly restrict the proper development of the law. They propose therefore, to modify their present practice and, while treating formal decisions of this house as normally binding, to depart from a previous decision when it appears to be right to do so. (...) In this connection they will bear in mind the danger of disturbing retrospectively the basis on which contracts, settlement of property, and fiscal arrangements have been entered into and also the especial need for certainty as to the criminal law. (...) This announcement is not intended to affect the use of precedent elsewhere than in this House"
} 
nessa medida, uma majoração do ônus argumentativo acometido a quem busca afastar-se da decisão anterior. ${ }^{400}$

Por outro lado, a sujeição do juiz à lei (por oposição, ao menos segundo o pensamento tradicional, a uma vinculação aos precedentes de Cortes Superiores) não implica liberdade de interpretação e aplicação das normas, "entendida como possibilidade para o juiz singular de reivindicar um status próprio de pensador livre". 401

Cabe acrescentar, ainda, que a força dos precedentes não depende estritamente de uma previsão legal expressa. Não obstante, é certo que a Constituição confere eficácia vinculante aos julgamentos tomados em controle abstrato de constitucionalidade (art. 102, $\S 2^{\circ}$ ) enunciados de Súmula editados em conformidade com o art. 103-A e que o Código de Processo Civil, em diversas passagens, faz alusões à jurisprudência dos Tribunais Superiores como pressuposto de determinadas decisões. Ainda que assim não fosse, podese dizer que a autoridade dos precedentes (e de outras fontes de Direito, em geral) costuma derivar de uma prática reiterada por parte da comunidade jurídica, de modo que o que antes era tido como meramente persuasivo torne-se, na prática, efetivamente vinculante. ${ }^{402} \mathrm{Em}$ outras palavras, a força obrigatória do precedente pode e deve ser reconhecida, ainda que não exista um dispositivo legal expresso nesse sentido.

\footnotetext{
${ }^{400}$ Entre outros, NEIL DUXBURY, The nature and authority of precedent, cap. 5, n. 3, p. 183; ROBERT ALEXY, Teoría de la argumentación jurídica, n. 2.5.1, p. 262-265; FREDERICK SCHAUER, Thinking like a lawyer, n. 4.3, p. 76; CRUZ E TUCCI, Precedente judicial como fonte de direito, cap. IX, n. 1, p. 295-302; LUIZ GuILHERME MARINONI, Precedentes obrigatórios, cap. 2, p. 103 e ss.; ALEŠ GALIČ, "The role of the Supreme Court in creating precedents in Slovenian civil procedure”, n. IV, p. 273. Contra, por todos, KARL LARENZ, Metodologia da ciência do direito, cap. 5, n. 5, p. 612-613 (defendendo que a necessidade de buscar a melhor decisão sobrepõe-se ao valor da segurança jurídica).

${ }^{401}$ BRUNO SASSANI, “Tra 'consapevolezza culturale' e 'buona volotà organizzativa': considerazione sparse sulla deprecata funzione nomofilattica della Corte di Cassazione”, n. 6, p. 276.

${ }^{402}$ Ver, v.g., Frederick SCHAUER, Thinking like a lawyer, n. 4.5, p. 81. Parece lícito afirmar que é exatamente esse o fenômeno que se está a verificar em relação ao alcance dos pronunciamentos do Supremo Tribunal Federal, tomados em sede de controle concreto, sobre a (in)constitucionalidade de leis. Em que pese a previsão constitucional da necessidade da "suspensão da execução, no todo ou em parte, de lei declarada inconstitucional por decisão definitiva do Supremo Tribunal Federal" pelo Senado (art. 52, X, CF), desenvolveu-se tendência contrária no sentido de dispensar, na prática, esse mecanismo, reconhecendo-se a eficácia erga omnes da decisão plenária independentemente de resolução legislativa. A questão está sendo atualmente debatida na Reclamação 4.335/AC, rel. o Min. GILMAR MENDES, em que se discute se a inconstitucionalidade do art. $2^{\circ}, \S 1^{\circ}$, da Lei $8.072 / 1990$ (dispositivo que veda a progressão de regime nos crimes hediondos), declarada incidente tantum em julgamento de habeas corpus pelo mesmo Supremo Tribunal Federal (Pleno, HC 82959, rel. Min. MARCO AURÉLIO, j. em 23/02/2006, DJ 01.09.2006, p. 18 - v. informativo 417/STF), teria alcance erga omnes independentemente da suspensão da lei pelo Senado e se ensejaria ou não, portanto, a possibilidade de reclamação contra eventuais julgados contrários.
} 
Independentemente de tais discussões, parece certo, enfim, que em qualquer sistema racional, o precedente deve possuir, ao menos, uma força presuntiva, de modo a inverter e majorar sensivelmente o ônus argumentativo de quem pretende superá-los. ${ }^{403}$ No fundo, a "ausência de respeito aos precedentes está fundada na falsa suposição, própria à civil law, de que a lei seria suficiente para garantir a certeza e a segurança jurídicas”. ${ }^{404}$

\subsubsection{DISTINÇÕES E TÉCNICAS OPERATIVAS}

Seria impossível desenvolver, nessa sede, um tratamento amplo das diversas distinções operativas e das complexas técnicas que regulam a aplicação do precedente. Numa breve aproximação ao tema, cabe salientar que se deve saber I) quando os precedentes vinculam e II) qual parte da decisão é vinculante.

I) A primeira questão diz respeito ao efeito vinculante das decisões, que pode ser compreendido no sentidos vertical e horizontal. Como premissa geral, há de se respeitar sempre o precedente de uma Corte superior, a menos que exista uma diferença relevante no caso atual (distinguishing). Mais do que isso, as próprias decisões também devem ser respeitadas, pois estão sujeitas apenas excepcionalmente ao overruling.

Por distinguishing, deve entender-se "o método de confronto [...] pelo qual o juiz verifica se o caso em julgamento pode ou não ser considerado análogo ao paradigma", o que tanto pode ser feito para ampliar, quanto para reduzir o âmbito de aplicação da decisão anterior. $^{405}$

Já o overruling implica a superação do precedente. Justamente por isso, não pode ser feito por uma corte inferior. A exceção é o chamado anticipatory overruling. Por meio dele, o juiz inferior deixa de aplicar um precedente formalmente válido da Corte Suprema, mas que já tenha sido implicitamente overruled. Ou seja, quando se puder inferir

\footnotetext{
${ }^{403}$ FredericK SCHAUER, "Precedent", n. II, p. 580, nota 18.

${ }^{404}$ LUIZ GUILHERME MARINONI, "Aproximação crítica entre as jurisdições de civil law e de common law...", p. 231. Note-se que a experiência desmentiu completamente o ideal de BENTHAM, ferrenho opositor do common law e defensor da codificação como meio de conferir certeza ao Direito.

${ }^{405}$ CRUZ E TuCCI, Precedente judicial como fonte de direito, cap. 6, n. 7, p. 174.
} 
seguramente que a Suprema Corte não mais aplicaria aquele precedente, o stare decisis não é baseado sobre a decisão atual, mas sobre um prognóstico de decisões futuras. ${ }^{406}$

II) Por outro lado, nem tudo que está no precedente é tido por vinculante. De fato, tem sabor de lugar-comum na doutrina a afirmação de que apenas a ratio decidendi de uma decisão anterior é vinculante e, por isso, considerada precedente. Todo o resto da fundamentação da decisão é tido como obiter dicta e, nessa linha, nunca mais do que uma autoridade meramente persuasiva para futuros casos. ${ }^{407}$ Por isso mesmo, obiter dictum significa algo dito ao lado ou de passagem, demonstrando não fazer parte do caminho percorrido para alcançar uma conclusão.

A distinção é importante em razão dos seus efeitos: como já foi dito, apenas a ratio é considerada vinculante. A razão para tanto basicamente consiste na verificação de que o obiter dictum, constituindo parte da decisão em alguma medida irrelevante para a solução do caso, foi afirmado sem uma consideração tão séria do caso. Além disso, recusar efeito vinculante aos dicta visa a limitar o poder dos juízes, evitando que criem, para o futuro, regras calcadas em proposições amplas e desnecessárias em relação às questões efetivamente decididas. ${ }^{408}$

Contudo, há pelo menos três aproximações metodológicas ao tema da definição da ratio decidendi ou holding contidos no precedente, ${ }^{409}$ e o problema está longe de uma solução pacífica.

Por um primeiro prisma, tido como minimalista, interessa tão-somente a parte da regra enunciada que decisivamente influiu sobre o desfecho do processo, ou seja, que foi estritamente necessária para o resultado e em cuja ausência a controvérsia teria sido decidida de maneira diversa. Todo o resto é tido como dicta e, por isso, não seria vinculante. $^{410}$

\footnotetext{
${ }^{406}$ UGO MATTEI, "Precedente giudiziario e stare decisis", n. 14, p. 161-162.

${ }^{407}$ V.g., RUPERT CROSS - J. W. HARRIS, Precedent in English Law, n. II(1), p. 39 e ss.

${ }^{408}$ RUPERT CROSS - J. W. HARRIS, Precedent in English Law, n. II(1), p. $42-43$.

${ }^{409}$ MeLVin A. EisenBerg, The nature of the common law, cap. 6, esp. p. 52-56.

${ }^{410}$ Ver, sobe essa aproximação e suas críticas, a descrição do teste de WAMBAUGH feita por LUIZ GUILHERME MARINONI, Precedentes obrigatórios, cap. 3, n. 2.1, p. 224.
} 
Em segundo lugar, há a aproximação centrada no resultado (result-centered approach), segundo a qual a ratio se determina pela análise do resultado da demanda à luz dos fatos materiais considerados pela Corte. Trata-se da conhecida explicação de GOODHART. $^{411}$

Por fim, maior peso pode ser dado ao que foi propriamente afirmado pela Corte anterior (announcement approach), dado que tal regra seja relevante às questões surgidas na demanda.

Em que pese contrariar a orientação tradicional, o último modelo parece ser o mais acertado ou, ao menos, predominante na prática dos Tribunais. Através dele, confere-se relevância à função prospectiva das decisões judiciais, podendo-se explicar, também, julgados de prospective overruling (algo similar à nossa modulação dos efeitos), em que a regra vinculante para o futuro será justamente algo não necessário (porque não aplicado) ao caso e que não representa o seu resultado. Ademais, é necessário lembrar que as razões invocadas para uma dada decisão são sempre mais amplas do que a questão a ser resolvida e, por isso, segundo a orientação tradicional, em alguma medida meramente dicta, porquanto não necessárias, em toda a sua extensão, para atingir o resultado alcançado. Entretanto, são justamente os fundamentos (reasons) do precedente que representam a sua essência e possibilitam a promoção de valores ligados à segurança jurídica, de modo que as teses minimalista e do resultado ignorariam, em boa dose, esta importância dos dicta nos futuros julgamentos. ${ }^{412}$

Por outro lado, os modelos minimalista e aquele centrado no resultado apresentam dificuldades práticas de não pouca relevância. $\mathrm{O}$ teste do fundamento necessário que está à base do esquema minimalista é falho quando a decisão repousa sobre dupla fundamentação, sendo cada um dos fundamentos autônomos suficiente a manter o resultado. Nesses casos, nenhum dos dois fundamentos pode ser visto como essencial ao resultado e, portanto, haveria apenas obter dicta, sem poder precisar-se a verdadeira ratio decidendi. ${ }^{413}$ Por outro lado, basta lembrar a crítica endereçada a GOODHART, no sentido de

\footnotetext{
411 "The ratio decidendi of a case", passim.

412 Parte da doutrina busca destacar, por isso, diferentes graus de importância dos obiter dicta, v.g., LUIZ GUILHERME MARINONI, Precedentes obrigatórios, cap. 3, n. 2.2, p. 239.

413 Cf. NeIL DuXBury, The nature and authority of precedent, cap. 3, n. 1, p. 76-78. Para o autor, é "certamente errado, por exemplo, definir a ratio decidendi como a proposição do julgamento que, acaso seu sentido fosse invertido, teria alterado a decisão" (op. cit., cap. 3, n. 1, p. 76). Sobre o problema do julgado
} 
que os chamados "fatos materiais" do caso anterior podem ser considerados em diferentes graus de generalidade, o que levaria à extração de diversas razões de decidir, para perceber também as limitações dessa teoria.

\subsection{BALANÇO CRÍTICO DO SISTEMA BRASILEIRO ATUAL}

Analisando-se a atual situação do Superior Tribunal de Justiça, é possível - embora de maneira muito otimista - dizer que há uma crescente valorização dos precedentes e, com isso, um progressivo caminhar na direção de uma Corte que desempenhe uma adequada função prospectiva. Disso dá conta, v.g., a sistemática de julgamento dos recursos repetitivos.

Com maior cautela deve ser vista a Súmula da jurisprudência dominante. Ainda que busque reforçar a autoridade do Tribunal e zelar pela igualdade, representa ela um caminho metodologicamente inadequado para tanto.

Seja como for, no entanto, o passo decisivo ainda não foi tomado. O Superior Tribunal de Justiça - ao contrário do Supremo Tribunal Federal, diferença da qual resulta uma incompreensível incoerência no sistema recursal brasileiro - não dispõe ainda de um mecanismo de seleção dos recursos com base na importância da questão neles discutida. Sem ele, sua missão não pode ser cumprida a contento, mesmo com o auxílio dos recursos repetitivos (que, vale lembrar, também encontram limites na sua aplicação), caindo-se na perigosa vala da "jurisprudência defensiva".

Por fim, outras duas críticas podem ainda ser endereçadas ao Direito brasileiro: de um lado, há ainda uma considerável insegurança na jurisprudência do próprio Tribunal; por outro, a aversão a um sistema racional de obediência aos precedentes no Brasil impede a uniformidade e a estabilidade, alimenta a litigiosidade e contribui para o agravamento da crise do Superior Tribunal de Justiça. 


\subsubsection{A FALTA de UM MECANISMO de SELEÇÃo dOS RECURSOS E A "JURISPRUDÊNCIA DEFENSIVA"}

Diante da falta de mecanismos idôneos a selecionar os recursos, os Tribunais de superposição, movidos por uma necessidade prática, foram desenvolvendo outros modos de controlar a sua carga de trabalho. Ou seja, na falta da atribuição de um poder legítimo para escolher, com base em critérios políticos ligados à importância da questão, os recursos a serem julgado, as Cortes engendraram outras formas - ilegítimas - de reduzir o número de impugnações.

É isso o que se veio a denominar "jurisprudência defensiva", prática que acentuou, drasticamente, o formalismo com que o juízo de admissibilidade recursal é realizado. Deve ser entendido o aspecto formal, aqui, como um "fetichismo da forma" ou "formalismo pernicioso", comparável quase às exigências do processo romano das legis actiones, no qual o mais leve descuido da parte no pronunciamento das palavras legais levava à sua derrota. $^{414}$

Poder-se-ia questionar se, em verdade, não é melhor assim. Ou seja, se não é preferível que os Tribunais Superiores, apesar de realizarem efetivamente um juízo prático sobre a conveniência e oportunidade de conhecer do recurso, mantenham essa atividade oculta, sem levar ao público, de maneira aberta, o debate, sob o disfarce de aplicarem - de maneira dedutiva e formal - supostos requisitos constitucionais e legais.

Esse dilema é já antigo no estudo da função judicial, sobretudo na temática da natureza declarativa ou constitutiva da atividade dos juízes. A esse respeito, AlEXANDER PEKELIS, após demonstrar a inegável função criativa (lawmaking) dos juízes, colocou a pergunta em termos muitos simples: "mesmo que os juízes saibam [que fazem escolhas criativas na aplicação do Direito], devem eles contar a história, [ou devem utilizar], como os velhos homens sábios costumavam fazer, os símbolos persuasivos da astrologia judicial"? A sua resposta, como não poderia deixar de ser, foi negativa: a necessidade de

\footnotetext{
${ }^{414}$ É um dos poucos pontos em que se pode concordar com J. NIEVA FenOLL ("La relevancia social de la casación", n. 5, p. 110-111), embora, consoante apontado no texto, a sua visão da função nomofilática seja justamente a causa do formalismo por ele mesmo criticado. Sobre o formalismo pernicioso, ou seja, o excesso da forma, ver CARLOS ALBERTO ALVARO DE OLIVEIRA, "O formalismo-valorativo no confronto com o formalismo excessivo", p. 149 e ss.
} 
declinar clara e explicitamente as suas razões é o pressuposto para uma jurisdição democrática, que permita a participação da opinião pública no exerício do poder. ${ }^{415}$

À mesma conclusão chegou MAURO CAPPELLETTI, em trecho que parece ter sido escrito com os olhos postos no problema aqui versado: “essas escolhas não devem ser ocultadas por meio de contorções lógicas e verbais, tornando-se-as assim mais responsáveis e democráticas, [já que] numa sociedade aberta e democrática devem ser patentes as reais razões de qualquer escolha judiciária e revelados os conflitos entre as várias soluções possíveis, evidenciando-se, de tal maneira, também os elementos de incerteza, abrindo-se caminho, se for o caso, para intervenções reparadoras do legislador". 416

O mesmo se passa em relação ao problema da admissibilidade dos recursos pelo Superior Tribunal de Justiça. Ao invés de ocultar "por meio de contorções lógicas e verbais" as razões que embasam as escolhas dos recursos - sob as roupagens de sutis e artificiais distinções acerca do que configura ou não o "pré-questionamento", do que se conforma a uma "questão de direito" ou a uma "questão de fato", do que basta ao "cotejo analítico" entre acórdãos supostamente divergentes dos tribunais a quo -, estas deveriam ser reveladas, possibilitando um controle intersubjetivo sobre o juízo de admissibilidade. Em um ambiente democrático, este juízo tem de ser público e motivado, tal como ocorre hoje na experiência do Supremo Tribunal Federal com o instituto da repercussão geral, mecanismo que justamente acentua a função pública do recurso extraordinário. ${ }^{417}$

Em face dessas considerações, a situação atual do Superior Tribunal de Justiça, parece evidente, é insatisfatória para todas as partes envolvidas: litigantes, procuradores e magistrados.

Os jurisdicionados são submetidos, regularmente, a mais um grau de jurisdição com os desgastes e custos inerentes ao prolongamento do processo - e à incerteza quanto ao resultado da lide, situação que, parece ocioso lembrar, prejudica sobretudo o litigante economicamente desfavorecido.

\footnotetext{
415 "The case for a jurisprudence of welfare", n. 16, p. 622-623.

${ }^{416}$ Juizes legisladores?, n. 15, p. 132.

${ }^{417}$ Luiz GUILHERMe MARINONI - DANIEL Mitidiero, Repercussão geral..., n. 1.2, p. 19-21; BrUNO DANTAS, Repercussão geral, n. 5.4, p. 257.
} 
Os advogados, por sua vez, são obrigados a caminhar por um autêntico campo minado, não sabendo nunca, com segurança, que tipo de cuidados devem tomar e qual argumentação devem desenvolver no recurso para que esse seja conhecido. São freqüentemente surpreendidos por requisitos inéditos impostos retroativamente pela jurisprudência e tachados de incompetentes quando suas petições são inadmitidas.

Por fim, o próprio Superior Tribunal de Justiça - desprovido das ferramentas adequadas para cumprir suas funções - manifesta descontentamento em atuar dessa maneira. Consciente do problema, o Min. HuMBerto GoMes DE BARros, comparando o jurisdicionado a um "passageiro de um vôo", disse que, sob a condução do Superior Tribunal de Justiça, "o avião [...] está extremamente perdido" e afirmou que o papel da Corte - são ainda suas as palavras -, tem sido "derrubar os jurisdicionados", tal como no popular "brinquedo em que uma enorme bóia, cheia de pessoas, é arrastada por uma lancha em alto mar" ${ }^{418}$ É muito pouco razoável, para dizer o mínimo, que se tenham de concentrar os esforços dos magistrados do mais alto escalão do ordenamento judiciário brasileiro - no julgamento de um agravo regimental em agravo de instrumento, por exemplo - na determinação de ser ou não inteiramente legível o carimbo do protocolo do recurso especial. ${ }^{419}$

Deve-se buscar, portanto, uma superação da jurisprudência defensiva pela instituição de um mecanismo de seleção de recursos. A proposta não é certamente novidade, tendo sido sugerida por muitos doutrinadores brasileiros ${ }^{420}$ e considerada, embora apenas em raríssimas ocasiões, em julgados do Superior Tribunal de Justiça. ${ }^{421}$

\footnotetext{
${ }^{418}$ As citações são do voto-vista proferido em STJ, $1^{\text {a }}$ Seção, AgRg no REsp 382736/SC, rel. p/ acórdão Min. FRANCISCO PEÇANHA MARTINS, j. em 08/10/2003, DJ 25/02/2004, p. 91. Em verdade, a manifestação dizia respeito à freqüente alteração de entendimentos que se verifica no Tribunal; no entanto, ela é inteiramente aplicável também ao juízo de admissibilidade dos recursos.

${ }^{419}$ Os julgados da Corte permitem, data venia, o exagero do texto: "1 - Cabe à parte agravante juntar cópia do recurso especial, com carimbo do protocolo legível, para fins de verificação da tempestividade do apelo nobre" (STJ, 4a T., AgRg no Ag 1308965/SC, rel. Min. RAUl ARAÚJO, j. em 05/10/2010, DJe 20/10/2010). Contam-se às centenas os julgados desse teor.

${ }^{420}$ V.g., OvíDIO A. BAPTISTA DA SILVA, “"Questão de fato’ em recurso extraordinário”, p. 493 e 503; ID., Processo e ideologia, cap. X, n. 11-18, p. 256-263 (fazendo também um reclamo à revitalização da "destruída" jurisdição de primeiro grau); ARRUDA ALVIM, "O antigo recurso extraordinário e o recurso especial...”, n. III, p. 153-154, esp. nota 17; NELSON NERY JR., Teoria geral dos recursos, n. 2.3.4.4, p. 104; RODOlFo De CAMARGo MANCUSO, Recurso extraordinário e recurso especial, 10. ed., São Paulo: RT, n. 2.1, p. 85; ID., "A realidade judiciária brasileira e os Tribunais da Federação - STF e STJ”, esp. n. 3, p. 1073 e ss.; Gleydson De OliveIRA, Recurso especial, n. 5, p. 386 e ss.; José RaIMUNDo GomeS DA CRUZ, "Admissibilidade dos recursos e efetividade do processo civil", n. 13.9, p. 201.

${ }^{421}$ De fato, apenas em isoladas ocasiões, o Superior Tribunal de Justiça têm levado em consideração o
} 


\subsubsection{AVALIAÇÃo CRÍTICA DA SÚMULA DA JURISPRUDÊNCIA PREDOMINANTE}

Cabe perquirir em que medida a prática dos Tribunais de superposição de "sumularem" entendimentos guarda conformidade com a função objetiva e prospectiva dos Tribunais Superiores, compreendida esta como o escopo de conferir unidade ao Direito e orientar os juízes e jurisdicionados por meio de precedentes.

É importante notar que o enunciado da Súmula não pode ser confundido com o precedente. Este, como se sabe, relaciona-se a um caso e às suas circunstâncias, e em face desses dados deve ser interpretado. É a motivação da decisão anterior que orienta a solução do caso atual. ${ }^{422}$ A tese da Súmula, por sua vez, é formulada como um texto de alcance geral e abstrato, ${ }^{423}$ e, embora possam (e devam) ser investigadas as decisões que lhe deram origem, isso raramente é feito na prática. A prática das Súmulas, portanto, pode ser questionada ao menos em três níveis.

Primeiro: pode-se discutir a própria legitimidade de o Poder Judiciário editar normas gerais e abstratas, desvinculadas dos casos (cases and controversies) a serem julgados. ${ }^{424}$ Não por acaso, a experiência das "diretivas" (equivalentes às "súmulas") é típica de regimes comunistas, exibindo um ranço autoritário. ${ }^{425}$

critério da relevância ou repercussão geral para afastar a sua "jurisprudência defensiva". Nesse sentido, o voto do Min. SÁlvio DE FIgUEIREdo TeIXEIRA, no qual opinou que "quando se apresenta um caso de relevância para a comunidade jurídica brasileira, pela sua importância, este Tribunal deve deixar de lado o rigor formal e conhecer do recurso (...)" (STJ, Corte Especial, Eresp 158.884/RS, rel. p/ ac. Min. HUMBERTO GOMES DE BARROS, j. em 01/02/2002, DJ 20/05/2002, p. 95). Há, por isso, quem considere aconselhável, de lege lata, fazer menção à relevância da questão jurídica no corpo da petição do recurso especial (RAFAEL BICCA MACHADO, Recurso especial p. 131).

${ }^{422}$ FREDECICK SCHAUER, Thinking like a lawyer, esp. n. 3.4, p. 52-54; CALAMANDREI FuRnO, "Cassazione civile", n. 3, p. 1057.

${ }^{423}$ Cf. MiCHELE TARUFFO, "Precedente e giurisprudenza", n. 2, p. 798 (contrapondo precedentes e máximas); CÂNDIDO DINAMARCO, "Modulação dos efeitos da declaração de inconstitucionalidade", n. 8, esp. p. 56 (destacando que sumular não é uma atividade propriamente jurisdicional, mas uma função normativa, responsável por inserir preceitos situados entre o plano abstrato da lei e o plano concreto das decisões judiciais); antes, já MAURO CAPPELLETTI, Juízes legisladores?, n. 11, p. 81.

${ }^{424}$ Ver Ovídio A. BAPTISTA DA Silva, Processo e ideologia, cap. X, esp. n. 15, p. 258-259; CASTANHEIRA NEVES, $O$ instituto dos 'assentos'..., passim.

425 Como nos países antes governados por regimes comunistas, como a Polônia, em que máximas ou súmulas, na forma de normas gerais e abstratas, eram publicadas oficialmente no Monitor Polski. Cabe notar que, desde 1989, com a queda do regime totalitário, a Suprema Corte polonesa não mais detém poder para editar tais súmulas ( $c f$. LECH MORAWSKI - MAREK ZIRK-SADOWSKI, "Precedent in Poland”, n. I.1(c), p. 223). No mesmo sentido, Michal BOBEK, "Quantity or quality? Reassessing the role of Supreme Jurisdictions in 
Segundo: não se compreende a justificativa para a sua existência, na medida em que, respeitados que sejam os precedentes, a regra jurídica deles extraída já cumpriria adequadamente a função de estabilização normativa e uniformização, tornando desnecessário o enunciado sumular. ${ }^{426}$ Com efeito, Súmula só apresenta utilidade naqueles ordenamentos em que os pronunciamentos dos Tribunais Superiores são muito numerosos e, por isso, pouco impactantes, ao contrário do que ocorre, v.g., nos países de common law. ${ }^{427-}$ Terceiro: a natureza geral e abstrata dos enunciados sumulares é mesmo incompatível com certos tipos de atividade jurisdicional. É sabido que no trato de normas vagas (cláusulas gerais e conceitos indeterminados), cuja precípua função normativa está justamente na possibilidade de sua concretização à luz das circunstâncias do caso, "os critérios de apoio para essa aplicação e determinação concretas das cláusulas gerais só podem ser oferecidos por uma 'comparação de casos' ou pela função exemplar de uma casuística de precedentes". ${ }^{428}$ Portanto, cristalizar em verbetes de súmula entendimentos sobre normas tipicamente vagas ou anula a sua função enquanto tais (quando se pretender extrair uma regra geral e abstrata do seu conteúdo) ou não serve a nenhum propósito prático relevante, sendo mera repetição da abertura já contemplada pela lei.

Exemplos dessa inadequação funcional das "súmulas" são variados. Parece difícil negar que contribui pouco, nada, ou mesmo vai contra o ideal de segurança jurídica um enunciado normativo tal como o contido no item n. ${ }^{\circ} 417$, Súmula/STJ: "Na execução civil, a penhora de dinheiro na ordem de nomeação de bens não tem caráter absoluto". De tal verbete, sem que se socorra o intérprete dos precedentes que estão à sua origem, não pode ser extraída qualquer conseqüência normativa.

Esses fatores trazem consigo, ainda, um problema prático de método: enquanto proposições gerais e abstratas, os enunciados da Súmula não são fundamentados e assemelham-se ao texto legal "frio", exigindo, tal como este, uma interpretação de seu sentido para reconstruir a norma e dando margem, com isso, à inseguranças. Definitivamente, portanto, o caminho das "súmulas" não é o mais adequado a seguir.

Central Europe", n. II, p. 45.

${ }^{426}$ Luiz GuILHERMe Marinoni, Precedentes obrigatórios, cap. 3, n. 1.3, p. 218.

${ }^{427}$ Já o destacara ANDRÉ TUNC, "La Cour suprême idéale”, p. 438-439, comentando a prática de alguns dos antigos países socialistas (como a Polônia) consistente em emitir "déclarations réglementaires" na forma de "resoluções contendo respostas a questões jurídicas" ou "diretivas para a administração da justiça e da prática judiciária".

${ }^{428}$ CASTANHeIRa NeVES, $O$ instituto dos 'assentos'..., cap. 2, p. 74, nota 151. 


\subsubsection{JULGAMENTO DE RECURSOS ESPECIAIS REPETITIVOS}

A possibilidade de julgar um recurso-piloto, cuja decisão servirá como paradigma para uma "multiplicidade de recursos com fundamento em idêntica questão de direito" (art. 543-C, CPC, cf. Lei n. ${ }^{\circ} 11.672 / 08$ ) é inovação positiva do processo civil brasileiro. Acentua, em boa medida, a função prospectiva do Superior Tribunal de Justiça, dando realce ao precedente (e aos princípios por ele prestigiados) e evitando uma irracional repetição de decisões no mesmo sentido.

A necessidade de conferir tratamento diferenciado às causas repetitivas ("litígios de massa", "macrolides", "pretensões isomórficas" etc.), molecularizando a tutela jurisdicional, decorre fundamentalmente dos princípios da igualdade perante a lei e da economia processual. ${ }^{429-430}$

A preocupação com a igualdade que norteia tais procedimentos abrange duas ordens de questões. Primeira: a imposição formal de conferir tratamento homogêneo a situações idênticas, buscando garantir a uniformização da jurisprudência e uma razoável previsibilidade, bem como a eliminação de custos desnecessários (economia processual). Segunda: a garantia da igualdade material das partes no processo, evitando o favorecimento de litigantes habituais - normalmente envolvidos em tais litígios de massa em face de litigantes eventuais, enfraquecidos pela sua atuação individual. ${ }^{431}$

É acentuada a função pública que motiva os recursos repetitivos, refletindo-se tal orientação na sua regulamentação prática, a ponto de afetar prerrogativas processuais normalmente disponíveis das partes. Assim, v.g., o Superior Tribunal de Justiça tem entendido que, uma vez afetada impugnação como caso-piloto, dela não poderá desistir o

429 CÂNDIDO DinAMARCO, "Súmulas vinculantes", n. 119, p. 219-221; SIDNEI AgostinHO BenETI, “Assunção de competência e fast track recursal", n. 1, p. 790-791 (contrastando a "lide individual clássica" e a "marcolide"); ANDRÉ ABBUD, "A repercussão geral dos recursos extraordinários e o julgamento por amostragem...", p. 311.

430 Entre os exemplos de mecanismos para julgamento de causas repetitivas, estão o incidente de uniformização (arts. 476/479, CPC), a assunção de competência (art. 555, § $1^{\circ}$, CPC), a suspensão de segurança de várias liminares (art. $4^{\circ}, \S 8^{\circ}$, Lei 8.437/1992 e art. 15, $\S 2^{\circ}$, Lei 12.016/2009), o pedido de uniformização da interpretação de lei federal nos Juizados Especiais Federais (art. 14, Lei 10.259/2001), o julgamento liminar de improcedência (art. 285-A, CPC) e o julgamento de recursos especiais repetitivos (art. 543-C, CPC) e da repercussão geral da questão constitucional (art. 543-B, CPC).

${ }^{431}$ V., nesse sentido, LEONARDO JOSÉ CARNEIRO DA CUNHA, “O regime processual das causas repetitivas", n. 2, p. 143-149. 
recorrente, em que pese a determinação expressa do art. 501, CPC. ${ }^{432}$ Entretanto, há de ser ressalvado que a previsão de que o Tribunal mantenha a decisão em sentido oposto ao julgamento do Superior Tribunal de Justiça (art. 543-C, $\S 8^{\circ}, \mathrm{CPC}$ ) contraria o espírito da reforma e, nessa medida, não é compatível com o interesse subjacente ao instituto.

Por outro lado, como qualquer instrumento, o mecanismo pode prestar-se a abusos. As preocupações fundamentais para que o mecanismo produza bons resultados residem na escolha do recurso-piloto, no correto sobrestamento das demais impugnações e na garantia de participação efetiva de todos os interessados (incluídos aí eventuais amici curiae). A eleição do recurso afetado para julgamento por amostragem é particularmente decisiva, até porque, contra tal decisão, não cabe recurso. ${ }^{433}$ Deve haver critérios a governar a oportunidade e conveniência da afetação de um recurso-piloto. Existirão casos, portanto, em que semelhante procedimento não será aconselhável, seja porque ausente prévia discussão e amadurecimento em torno da questão, seja porque o caso específico não pode ser considerado uma amostra adequada da controvérsia.

Nesse sentido, v.g., o Min. Herman Benjamin destacou em um de seus votos a sua "perplexidade político-processual" em torno do recurso especial afetado à Primeira Seção da Corte que versava o tema da assinatura básica de serviço de telefonia. ${ }^{434}$ Segundo o magistrado, a afetação "foi feita, quase que automaticamente, sem qualquer discussão prévia e amadurecimento, no âmbito interno de ambas as Turmas, das múltiplas questões novas e controvertidas", sendo "difícil negar que, no âmbito do STJ, a demanda não estava madura para, de cara, prolatar-se decisão unificadora e uniformizadora a orientar a Seção, suas duas Turmas e todos os Tribunais e juizos do Brasil'. Ademais, a escolha de uma ação individual, movida por litigante eventual de escassos recursos econômicos, acabou por inviabilizar uma participação efetiva dos consumidores na formação da decisão. Este fator se fez sentir pela ausência de sustentação oral e entrega de memoriais por parte da recorrida, ocasionando "verdadeiro monólogo dos maiores e melhores escritórios de advocacia do País" em nome das companhias recorrentes. Foi dito, na ocasião, que "a vitória das empresas de telefonia, que hoje se prenuncia, não é

\footnotetext{
${ }^{432}$ LUIZ FUX, "A desistência recursal e os recursos repetitivos", p. 12-13. LEONARDO JOSÉ CARNEIRO DA CunHA, "O regime processual das causas repetitivas", n. 7, p. 171-172.

${ }^{433}$ Vítor José DE MELlo MONTEIRO, “Julgamento por amostragem do recurso especial (Lei n. ⒒672/08)”, p. 408.

${ }^{434}$ STJ, $1^{\text {a }}$ Seção, REsp 911802/RS, rel. Min. José DELGADO, j. em 24/10/2007, DJe 01/09/2008.
} 
exclusivamente de mérito; é, antes de tudo, o sucesso de uma estratégia judicial, legal na forma, mas que, na substância, arranha o precioso princípio do acesso à justiça, uma vez que, intencionalmente ou não, inviabiliza o debate judicial e o efetivo contraditório, rasgando a 'ratio essendi' do sistema de processo civil coletivo em vigor".

Outro risco reside na inadequada assimilação de um recurso ao caso-piloto. Tal sobrestamento também tem de ser feito de forma cuidadosa, sob pena de uma aplicação equivocada da decisão (que não seria um precedent in point). Isso é tanto mais grave porquanto o Superior Tribunal de Justiça tem negado o cabimento de agravo de instrumento contra a decisão de sobrestamento do recurso especial na origem, ao argumento de que não se realizou ainda juízo de admissibilidade, não ostentando o pronunciamento, portanto, caráter decisório. ${ }^{435}$ Trata-se, no entender da Corte, de "decisão irrecorrivel". No entanto, a partir de outro julgamento, admite-se, a contrario sensu, a possibilidade de ser manejada medida cautelar voltada a destrancar o recurso cujo fundamento seja diverso da questão jurídica idêntica, desde que os recursos-piloto já tenham sido afetados pelo Ministro-relator. ${ }^{436}$

\subsubsection{INSEGURANÇA JURÍDICA NA JURISPRUDÊNCIA DO SUPERIOR TRIBUNAL DE JUSTIÇA}

Se a função dos Tribunais Superiores é conferir unidade ao Direito, então eles têm o dever funcional correlato de conferir estabilidade à sua jurisprudência, alterando seus entendimentos apenas diante de situações graves e motivadas. ${ }^{437}$

Essa não é, entretanto, a realidade brasileira. Alguns autores chegam a apontar que os precedentes do Superior Tribunal de Justiça sequer têm eficácia persuasiva, o que é revelado pelo fato de juízes inferiores não apenas não seguirem a sua orientação, mas fazerem isso sem motivação. ${ }^{438} \mathrm{O}$ problema, como se sabe, está relacionado à vinculação vertical do precedente; contudo, mesmo sob a perspectiva horizontal (stare decisis), há desrespeito das decisões tomadas pela própria Corte.

\footnotetext{
${ }^{435}$ STJ, $2^{\text {a }}$ T., AgRg no Ag 1223072/SP, rel. Min. HumBerto MARTins, j. em 09/03/2010, DJe 18/03/2010.

${ }^{436}$ STJ, $3^{\text {a }}$ T., MC 17.226/RJ, rel. Min. MASSAMI UYEDA, j. em 05/10/2010, DJe 17/11/2010.

${ }^{437}$ Michele TARUFFO, El vértice ambiguo, § 3, p. 120-121.

${ }^{438}$ LUIZ GUILHERME MARINONI, “Aproximação crítica entre as jurisdições de civil law e de common law...", p. 228.
} 
A preocupação com a falta de estabilidade da jurisprudência do Superior Tribunal de Justiça já foi manifestada publicamente por alguns de seus membros. Nesse sentido, aduziu com inteira correção o Min. Humberto Gomes DE BARros: "se nós - os integrantes da Corte - não observarmos as decisões que ajudamos a formar, estaremos dando sinal, para que os demais órgãos judiciários façam o mesmo. Estou certo de que, em acontecendo isso, perde sentido a existência de nossa Corte. Melhor será extingui$l a "{ }^{439}$ Diante de tão veemente afirmação, pouco ou nada mais precisa ser dito para que seja diagnosticada uma grave enfermidade em relação à função de orientação da Corte.

\subsection{CONCLUSÕES FINAIS E SUGESTÕES DE REFORMA}

É fora de dúvida que "o papel primacial do processo civil se está deslocando da simples solução de litígios para a geração de benefícios sociais - numerosos e variados, inclusive o desenvolvimento do direito por meio de decisões judicias". ${ }^{440}$ Disso resulta que os Tribunais Superiores acabam por exercer uma função acentuadamente prospectiva, e não meramente retrospectiva. Consiste ela na elaboração de precedentes a partir de casos selecionados em razão de sua importância e, assim, na coordenação entre a função legislativa e a função jurisdicional. É ultrapassada, por isso, a idéia de realizar uma nomofilaquia "particularista e analítica", mediante a intervenção da Corte em todos os casos em que se suscite um error iuris; seu resultado é perder de vista a função pública do Tribunal Superior. ${ }^{441}$

\footnotetext{
${ }^{439}$ STJ, Corte Especial, AgRg nos EREsp 228432/RS, rel. Min. Humberto Gomes DE BarRos, j. em 01/02/2002, DJ 18/03/2002, p. 163

${ }^{440}$ BARBosa Moreira, "O neoprivatismo no processo civil", Temas de direito processual - Nona série, São Paulo: Saraiva, 2007, n. 8, p. 99; no mesmo sentido, JolowICZ, "Appeal and review in comparative law: similarities, differences and purposes", in Melbourne University Law Review, 1986, vol. 15, p. 622. No mesmo sentido, afirmou-se que "o Judiciário não se presta exclusivamente para decidir conflitos concretos, mas ainda deve cuidar para que as suas decisões possam servir de orientação para casos futuros" (CRUZ E TUCCI, Precedente judicial como fonte do direito, São Paulo: RT, 2004, cap. I, n. 2, p. 25).

${ }^{441}$ Cf. Michele TARUFFo, “Una reforma de la casación civil?”, n. 2, p. 522-525. Também relacionam função nomofilática e precedente judicial, LUIGI MONTESANO - GIOVANNI ARIETA, Diritto processuale civile II, $\mathrm{n}$. 148, p. 331; CruZ E TUCCI, Precedente judicial como fonte do direito, São Paulo: RT, 2004, cap. I, n. 1, p. 17; HeNRIK LindBlom, "The role of the Supreme Courts in Scandinavia", n. 3.4.3, p. 344. Aleš Galič, "The role of the Supreme Court in creating precedents in Slovenian civil procedure", n. V, p. 274; ARRUDA ALVIM, "O recurso especial na Constituição Federal de 1988 e suas origens", n. 1.3, p. 34. Na doutrina mais antiga, v. CALAMANDREI - Furno, “Cassazione civile”, n. 2, p. 1056.
} 
É claro que, uma vez admitido o recurso, o Superior Tribunal de Justiça buscará estabelecer uma interpretação justa da norma. Mas, para que possa haver qualquer uniformização de jurisprudência, é necessário que a atividade desempenhada pelo Tribunal situado no vértice da organização judiciária seja limitada. Havendo uma limitação adequada, poderá o Tribunal Superior dedicar-se a estabelecer precedentes bem fundamentados a respeito de questões de interesse geral e de maior importância, sem descuidar, por outro lado, da solução adequada do caso individual por ele julgado. Tendo isso em vista, a tendência a realizar ao máximo o escopo privado dos recursos excepcionais e a consequente sobrecarga de processos acabam por anular aquela função, dando origem a um corpo de jurisprudência numeroso, mal fundamentado e divergente. ${ }^{442}$

Um aumento no número de Ministros também não se mostra adequado, já que não há comprovação de que uma ampliação dos quadros seja medida eficiente para equilibrar a proporção entre julgadores e recursos; em verdade, a experiência demonstra que a tendência é de um progressivo aumento de irresignações, com o que o problema se repete e o remédio torna-se apenas um paliativo. Segunda: um número elevado de juízes traz não apenas dificuldades administrativas (como o aumento do custo para a manutenção da Corte), mas também afeta o bom desempenho da função do Tribunal Superior. O gigantismo da Corte de Cassação italiana bem demonstra isso: a conseqüência inevitável dessa deformidade estrutural será a divergência interna de entendimentos. O Tribunal que deve uniformizar torna-se, nessa medida, ele mesmo um elemento desagregador.

Na melhor das hipóteses, portanto, a defesa do ius litigatoris pode ser considerada uma aspiração ingênua, que ignora as capacidades institucionais dos Tribunais Superiores em nome de um argumento irracional de justiça. Como já dissera STEIN, "do ponto de vista da parte prejudicada, todas as restrições da cassação constituem outras tantas injustiças", o que recomenda evitar o manejo do argumento ao absurdo ou a invocação de um apelo emocional ao sentimento do justo. ${ }^{443}$

Numa visão mais pessimista, pode-se dizer que a pretensão de analisar e responder de maneira fundamentada a todas as irresignações endereçadas ao Superior Tribunal de Justiça - independentemente de sua relevância ou repercussão geral - é, em verdade, uma

\footnotetext{
${ }^{442}$ Michal BoBeK, "Quantity or quality? Reassessing the role of Supreme Jurisdictions in Central Europe", n. I, p. 41.

${ }^{443}$ FRIEDRICH STEIN, El conocimiento privado del juez, § 7, p. 132.
} 
proclamação vazia e cínica. De que adianta assegurar um direito (de status constitucional) a um "terceiro grau" de jurisdição se, na prática, os jurisdicionados são reféns de uma jurisprudência defensiva imprevisível, excessivamente formalista e de decisões massificadas que, em razão justamente das capacidades institucionais limitadas do Tribunal, dispensam pouca ou nenhuma atenção ao caso concreto? Tal realidade serve apenas ao propósito de desvirtuar o Superior Tribunal de Justiça, impedindo que os Ministros atuem como verdadeiros guias da jurisprudência nacional.

A título de desfecho do capítulo, parece necessário assentar duas conclusões específicas em relação aos rumos do Superior Tribunal de Justiça.

I) Em primeiro lugar, parece certa, a esta altura, a necessidade de um mecanismo de seleção dos recursos a fim de permitir que o Superior Tribunal de Justiça desempenhe adequadamente a sua função. Nesse sentido aponta, como se viu (supra, § $3^{\circ}$ ), o Direito comparado.

Em países em que não há um filtro, os Tribunais Superiores acabam adotando uma postura excessivamente formalista na apreciação de requisitos de admissibilidade, visando a reduzir, por essa via torta e imprevisível, com sacrifício da transparência, a carga excessiva dos feitos. ${ }^{444}$ A tão criticada argüição de relevância, em verdade, revelava-se mais consentânea ao Direito do que a atual jurisprudência defensiva. Aquele sistema, embora muito criticado (sobretudo pela falta de motivação das decisões), "embora aleatório, não escondia a intenção de obstaculizar a utilização do recurso extraordinário. Depois da Constituição de 1988, porém, não podendo mais a Suprema Corte valer-se dos óbices regimentais, passou a utilizar mecanismos menos transparentes para obstar ao conhecimento dos recursos, gerando por vezes perplexidade nos operadores do direito". ${ }^{44}$

Como fazer essa seleção? Filtros ligados ao valor da causa - além de ofenderem a igualdade perante a lei - deixam de reconhecer que mesmo causas envolvendo interesses econômicos relativamente pequenos podem apresentar-se como uma oportunidade para a intervenção efetiva do Superior Tribunal de Justiça. ${ }^{446}$ Ademais, a consciência jurídica

\footnotetext{
${ }^{444}$ MiChAL BoBEK, "Quantity or quality? Reassessing the role of Supreme Jurisdictions in Central Europe", p. 34.

${ }^{445}$ CARlos Alberto CARMONA, "O sistema recursal brasileiro: breve análise crítica", n. 8, p. 45.

${ }^{446}$ Nesse sentido, ReNÉ DAVID, French law, p. 44; HANS PRÜTTING, "Estudio introductorio al Código Procesal Civil alemán”, cap. 5(V), p. 128.
} 
brasileira dificilmente assimilaria outros tipos de óbices, tais como a restrição do número de advogados habilitados a postular perante a Corte ou a imposição de depósitos recursais. Um aumento do número de Ministros, já se viu, também não é recomendável. Tais hipóteses devem ser descartadas como soluções.

Mais eficiente (e também mais democrático) é aferir a admissibilidade à luz do problema normativo levantado na impugnação da parte. A seleção dos recursos deve ser realizada com base na importância das questões debatidas, na sua repercussão geral, fundamental significação etc. O que o Tribunal deve ter em mente é a oportunidade para fixar uma pauta geral a orientar juízes e jurisdicionados por meio de seus precedentes. É esse também o exemplo deixado pela experiência recente da repercussão geral no recurso extraordinário. Seria uma grande incoerência que o sistema recursal brasileiro seguisse discriminando recurso especial e recurso extraordinário nesse quesito. ${ }^{447}$

II) Isso conduz à segunda conclusão. Ela é no sentido da necessidade de conferir à jurisprudência dos Tribunais de superposição o seu peso adequado no quadro das fontes ou “fatores” do Direito. Isso implica reforçar a vinculação vertical ao precedente, por um lado, e exigir do Superior Tribunal de Justiça o respeito aos seus próprios jugados, por outro.

447 TERESA ARRUDA AlVIM WAMBIER, "Estabilidade e adaptabilidade com objetivos do direito: civil law e common law", n. 6, p. 166. 


\section{§ 6 - A DECISÃO RECORRIDA}

\subsection{CONCEITO DE CAUSA}

A interposição do recurso especial é cabível apenas diante de "causas decididas, em única ou última instância, pelos Tribunais Regionais Federais ou pelos Tribunais dos Estados, do Distrito Federal e Territórios" (art. 105, III, CF). O conceito de causa compreende processos de natureza jurisdicional, tanto em sede de jurisdição contenciosa quanto no âmbito da jurisdição voluntária. Isso compreende, em alguns casos, o procedimento de dúvida, ${ }^{448}$ estando excluída, a princípio, a reclamação ${ }^{449}$ e não sendo, definitivamente, cabível recurso especial contra a decisão proferida no processamento de precatórios (enunciado n. ${ }^{\circ} 733$, Súmula/STF).

Pouco importa que o acórdão verse questões processuais ou de mérito: de acordo com o enunciado n. 86 da Súmula/STJ, "cabe recurso especial contra acórdão proferido no julgamento de agravo de instrumento". No entanto, da leitura do texto constitucional, I) exclui-se o cabimento do recurso especial diante de pronunciamentos em primeiro grau, ${ }^{450}$ dentre as quais se destacam as decisões colegiadas das turmas recursais de juizado especial

\footnotetext{
${ }^{448}$ Em relação ao procedimento de dúvida previsto pela Lei dos Registros Públicos, o entendimento majoritário é o de que a presença ou não de causa - a ensejar interposição de recurso especial, nos termos do art. 105, III, CF - depende dos sujeitos envolvidos no conflito. Assim, se houver apenas divergência entre o interessado e o oficial do registro, o recurso especial é afastado; mas, ocorrendo verdadeira "contenciosidade" entre os interessados, há causa e o recurso tem cabimento. Nesse sentido, v.g., "(...) se a dúvida se estabelece unicamente entre o interessado e o oficial do registro, não há causa, na acepção constitucional (art. 105, III, CF/88), descabendo o recurso especial; todavia, quando surge contenciosidade entre os interessados, no processo administrativo regulado pela Lei $n^{\circ}$ 6.015/73 (Lei dos Registros Públicos),

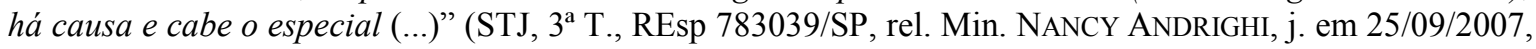
DJ 22/10/2007, p. 247).

449 "Em tema de reclamação, ou correição parcial, predomina a tese da inadmissibilidade do apelo extremo, salvo se na correição parcial houver sido apreciado 'algo pertinente ao mérito"' (ATHOS GUSMÃO CARNEIRO, Recurso especial, agravos e agravo interno, n. 6, p. 20).

${ }^{450}$ A Constituição, ao atribuir competência ao Superior Tribunal de Justiça, refere expressamente o cabimento de recurso especial contra decisões de Tribunais (art. 105, III, CF). Ao regular o recurso extraordinário, todavia, não impôs semelhante exigência (art. 102, III, CF). Da comparação entre os dois dispositivos resulta não caber recurso especial contra decisão em primeiro grau de jurisdição. Disso não há dúvida: é "manifestamente incabível" o recurso especial interposto diretamente contra a decisão de juiz singular (cf. STJ, $1^{\text {a }}$ T., EDcl no Ag 692519, rel. Min. TEORI ZAVASCKI, j. em 20/09/2005, DJ 03/10/2005, p. 138). Conseqüentemente, cabe recurso extraordinário (mas não especial) diante de decisões de Turmas Recursais dos Juizados Especiais (colegiado de juízes de primeiro grau) ou de sentenças proferidas em execuções fiscais de menos de cinqüenta OTN (nas quais cabem apenas embargos declaratórios e uma modalidade sui generis de embargos infringentes ao mesmo juiz). A distinção constitucional é questionável, mas faz parte do sistema recursal (Luiz Guilherme Marinoni - SÉrgio C. AREnhart, Processo de conhecimento, n. 2.10.1, p. 575).
} 
(verbete n. 203 , Súmula/STJ) ${ }^{451}$ e II) impõe-se o esgotamento das vias ordinárias (item n. 281, Súmula/STF), ou seja, a interposição prévia de qualquer outro recurso ordinário cabível antes do manejo da impugnação dirigida ao Superior Tribunal de Justiça.

\subsection{ESGOTAMENTO DOS RECURSOS ORDINÁRIOS}

Como já ressaltado, a interposição do recurso especial pressupõe o esgotamento das vias ordinárias (item n. ${ }^{\circ} 281$, Súmula/STF), ou seja, o manejo prévio de qualquer outro recurso ordinário cabível contra a decisão, antes que se intente ascender ao Superior Tribunal de Justiça. O Direito brasileiro, ao contrário de alguns sistemas estrangeiros, não acolhe um recurso excepcional per saltum (leapfrog appeal, Sprungrevision).

Para que se possa interpor recurso especial da parte não-unânime de acórdão que reforma a sentença apelada, é necessária - a fim de esgotar as vias ordinárias - a prévia interposição dos embargos infringentes (ex art. 530, CPC), tal como preconizado pelo enunciado n. ${ }^{\circ} 207$, Súmula/STJ; não o fazendo, a parte poderá recorrer apenas do capítulo unânime, operando-se preclusão quanto ao restante. Acaso interpostos, o prazo para manejos dos recursos excepcionais só se inicia a partir da intimação da decisão proferida nos embargos infringentes (art. 498, CPC), muito embora existam decisões que entendem não haver sobrestamento do prazo se este recurso vem a ser inadmitido. ${ }^{452} \mathrm{~A}$ doutrina, corretamente, destaca a necessidade de interposição do agravo interno (art. 532, CPC) contra eventual decisão de inadmissão do relator, mas ressalva pouco importar, para fins de recurso especial, se eram cabíveis ou não os infringentes. Com a providência do art. 532, $\mathrm{CPC}$, estaria preenchido o requisito do esgotamento das vias ordinárias. ${ }^{453}$ Deve lembrarse, ainda, que cabem embargos infringentes “contra acórdão, proferido por maioria, em agravo retido, quando se tratar de matéria de mérito" (n. 255, Súmula/STJ) e que, por outro lado, o recurso não é cabível frente a julgamento por maioria em reexame necessário

\footnotetext{
${ }^{451}$ É esta a posição atual do Superior Tribunal de Justiça (STJ, 3a T., AgReg no AI 1016894/SP, rel. Min. Ari Pargendler, j. em 21.08.2008, DJe 13.11.2008), que inclusive reviu a redação original do enunciado sumular de número 203, extirpando a cláusula "nos limites de sua competência". A doutrina entendeu correta a interpretação dada ao problema, na medida em que a solução contrária possibilitaria a interposição de numerosos recursos que questionassem a complexidade da causa, ressalvando embora a criação de mecanismo voltado a impor os endereços interpretativos fixados pelo Superior Tribunal de Justiça às Turmas Recursais, por meio de reclamação. Nesse sentido, CLÁUdio ANTÔNIO SOARES LEVADA, "A súmula 203 do STJ", n. 6, p. 39 e p. 41-43.

${ }^{452}$ STJ, $4^{\mathrm{a}}$ T., Ag. Reg. no AI 505.055/SC, rel. Min. Jorge SCARTEZZINI, j. em 14.09.2004, DJ 08.11.2004, p. 235.

${ }^{453} C f$. ARAKEN DE Assis, Manual dos recursos, n. 92.1.1, p. 778.
} 
(n. 390, Súmula/STJ) ou em apelação em mandado de segurança (ex art. 25, Lei 12.016/09).

O mesmo raciocínio anteriormente efetuado é aplicável em relação às decisões singulares dos relatores nos tribunais de segundo grau, tomadas com amparo no art. 557, CPC. É necessário manejar o agravo interno (art. 557, § $1^{\circ}, \mathrm{CPC}$ ) contra a decisão monocrática, provocando pronunciamento da Turma, a fim de que se preencha o requisito em apreço, esgotando as possibilidades recursais na instância $a$ quo.

Por sua vez, a mera possibilidade de oposição de embargos declaratórios (ressalvada a hipótese de omissão e de ausência de pré-questionamento) não exclui, por si só, o preenchimento do requisito de esgotamento dos recursos ordinários, de modo a inviabilizar a interposição de recurso especial. Se assim fosse, o manejo do remédio seria obrigatório em praticamente todos os casos, até porque, teoricamente, apenas estará isenta de quaisquer vícios a decisão perfeita. ${ }^{454} \mathrm{E}$, seguindo no raciocínio, será igualmente prescindível que se interponha, de eventual decisão monocrática que rejeita os embargos declaratórios, o agravo interno ex art. 557, CPC, para que seja cabível o recurso especial. Se a restrição não se impõe diante da possibilidade de opor o recurso, não se pode considerar presente, a fortiori, no caso de mera possibilidade de sua reiteração. A conclusão também se justifica porque tal espécie de decisão não encontra amparo no dispositivo mencionado, já que, pela regra especial do art. 537, CPC, os embargos aclaratórios devem ser apresentados em mesa na sessão subseqüente. ${ }^{455}$

Evidentemente, também os acórdãos de que caiba diretamente recurso ordinário ao Superior Tribunal de Justiça (v.g., em mandado de segurança de competência originária art. 105, II, $b, \mathrm{CF})$, não são passíveis de ataque via recurso especial.

Havendo incidente de uniformização de jurisprudência (art. 478, CPC), o recurso caberá não contra o incidente em si, mas contra a decisão do órgão que decidir a causa à luz daquela determinação. ${ }^{456} \mathrm{O}$ mesmo ocorre em relação ao incidente de declaração de

${ }^{454} C$ f. AdROALDO FURTADO FABRício, "Embargos de declaração: importância e necessidade de sua reabilitação", n. 3, p. 53-56. Com efeito, nas palavras do autor (op. cit., n. 3, p. 54): "As mais completas, claras e coerentes sentenças dos melhores juízes, mesmo elas, podem ser ainda suscetíveis de aperfeiçoamento em algum dos aspectos tratados, ou em mais de um".

${ }^{455}$ Sobre todas as conclusões do parágrafo do texto, ver ATHOS GuSMÃo CARNEIRO, "Os embargos de declaração e a Súmula 281 do Supremo Tribunal Federal", n. 10-13, p. 482-483.

${ }^{456}$ Cf. Barbosa Moreira, Comentários ao Código de Processo Civil, v. 5, n. 319, p. 591 
(in)constitucionalidade, ex arts. 480 e ss., CPC, consoante o enunciado n. ${ }^{\circ}$ 513, Súmula/STF.

Por fim, cabe lembrar a situação particular da remessa necessária. Já assinalara PONTES DE MiRANDA que "não pode usar de recurso extraordinário o que se conformou com a sentença de primeira instância". ${ }^{457}$ A pretensão esbarraria na vedação do venire contra factum proprium. Por isso - com base na preclusão lógica - já chegou a decidir o Superior Tribunal de Justiça não ser admissível o recurso especial interposto pela Fazenda Pública contra acórdão que confirmou, em reexame necessário, a sentença não apelada, reconhecendo a presença de fato impeditivo do poder de recorrer. ${ }^{458}$ Entretanto, há uma série de acórdãos mais recentes em sentido contrário, ${ }^{459}$ demonstrando, mais uma vez, a enorme instabilidade da jurisprudência da Corte, especialmente no que diz respeito à admissibilidade do recurso especial. A nova orientação é criticável: incentiva uma litigância irresponsável por parte da Fazenda, alarga ainda mais questionáveis privilégios processuais e conduz a uma completa desvalorização da jurisdição em primeiro grau.

\subsection{DECISÕES SOBRE TUTELAS DE URGÊNCIA}

Em síntese, o enunciado n. ${ }^{\circ} 735$ da Súmula do Supremo Tribunal Federal afasta o cabimento do recurso extraordinário diante do "caráter precário ou provisório da decisão liminar" (que se contenta com o mero fumus boni iuris do direito ameaçado), sujeita por isso à revisão a qualquer tempo, e da necessidade de proceder-se, em regra, ao reexame de

\footnotetext{
${ }^{457}$ Pontes de MiRanda, Comentários ao Código de Processo Civil (de 1973), t. VIII, p. 33.

${ }^{458}$ Nesse sentido, "Diante [...] da impossibilidade de agravamento da condenação imposta à fazenda pública, nos termos da Súmula 45/STJ, chega a ser incoerente e até mesmo de constitucionalidade duvidosa, a permissão de que os entes públicos rediscutam os fundamentos da sentença não impugnada no momento processual oportuno, por intermédio da interposição de recurso especial contra o acórdão que a manteve em sede de reexame necessário, devendo ser prestigiada a preclusão lógica ocorrida na espécie, regra que, segundo a doutrina, tem como razão de ser o respeito ao princípio da confiança, que orienta a lealdade processual (proibição do venire contra factum proprium). [...] Recurso especial não conhecido em razão da existência de fato impeditivo do poder de recorrer (preclusão lógica)" (STJ, 1 a Seção, REsp 904885/SP, rel. Min. Eliana CALMON, j. em 12/11/2008, DJe 09/12/2008).

${ }^{459}$ Veja-se: “(...) 2. A Corte Especial do STJ pacificou seu entendimento recentemente, afirmando que a Fazenda Pública pode opor recurso especial contra contra acórdão que, julgando reexame necessário, manteve a sentença de primeiro grau contrária aos seus interesses. Ficou assentado que o comportamento omissivo da Fazenda, ao não apelar, não configura a preclusão lógica em relação aos recursos dirigidos às instâncias extraordinárias. 3. Precedentes: REsp 905771/CE, Rel. Min. Teori Albino Zavascki, Corte Especial, DJe 19.8.2010; e EResp n. 1119666, Rel. Min. Eliana Calmon, julgado em 1.9.2010" (STJ, $2^{\text {a }}$ T., EDcl no REsp 1130900/ES, rel. Min. MAURo CAMPBell MARQUeS, j. em 07/10/2010, DJe 25/10/2010).
} 
prova para avaliar a presença do periculum in mora. Essa linha de raciocínio, como se sabe, é também a ratio decidendi de vários julgados do Superior Tribunal de Justiça, que invocam a proposição da Súmula para não conhecer recursos especiais voltados contra provimentos urgentes. ${ }^{460-461}$

A orientação encampada pelo enunciado n. 735 da Súmula/STF merece ser repensada, já que ambos os argumentos que estão à sua base não resistem a uma análise aprofundada. Em primeiro lugar, a precariedade atribuída às decisões liminares deve ser recebida cum grano salis: segundo a doutrina majoritária, ainda que provisório, o provimento antecipatório pode ser revogado somente se houver alteração das circunstâncias fáticas (a indicar ausência de perigo na demora) ou aprofundamento da cognição (ensejando ulterior juízo de verossimilhança negativo sobre o direito alegado). ${ }^{462}$ Não se pode desconsiderar, ainda nesse passo, a importância autônoma de tais decisões no processo civil contemporâneo e a sua freqüente definitividade de facto, senão de direito. Em segundo lugar, a revisão do juízo acerca do art. 273, CPC (ou outros dispositivos equivalentes) não implicará necessariamente reexame de matéria fática. As noções de verossimilhança, prova inequívoca e dano irreparável ou de difícil reparação são conceitos indeterminados como tantos outros encontrados em abundância nas leis contemporâneas; assim, na medida em que o Superior Tribunal de Justiça possa, por meio do julgamento do caso, desenvolver o Direito fixando pautas gerais a respeito de tais problemas normativos,

\footnotetext{
${ }^{460}$ V.g., entre os julgados mais recentes daquels Corte, STJ, $4^{\mathrm{a}}$ T., AgRg no Ag 1284086/MS, rel. Min. MARIA ISABEL GALLOTTI, j. em 21/10/2010, DJe 10/11/2010; os leading cases são acórdãos de relatoria do Min. TeORI Albino ZAVASCKI: STJ, $1^{\text {a }}$ T., AgRg no Ag 762.445/TO, j. em 21/09/2006, DJ 16/10/2006, p. 301; STJ, $1^{\text {a }}$ T., REsp 664.224/RJ, j. em 05/09/2006, DJ 01/03/2007, p. 230; e, em especial, STJ, $1^{\text {a }}$ T., REsp 765375/MA, j. em 06/04/2006, DJ 08/05/2006, p. 176. Na Itália, os provimentos que não são idôneos para decidir ou incidir sobre direitos subjetivos com possível força de coisa julgada também não estão sujeitos ao recurso de cassação. Contudo, reforma recente estabeleceu o cabimento, em tais casos, de um recurso no interesse da lei, de iniciativa do procurador geral, atribuindo à Corte o poder de pronunciar-se acerca de tais resoluções - ex art. 363, c.p.c. (cf. MICHELE TARUFFO, “Una reforma de la casación civil?”, n. 3, p. 528-529).

${ }^{461}$ Não deixa de causar espanto - como observou DAISSON FLACH - a posição "desconcertante" do Superior Tribunal de Justiça a esse respeito. Isso porque a sua jurisprudência, de um lado, é firme no sentido de que não devem submeter-se à retenção (ex art. $\left.542, \S 3^{\circ}, \mathrm{CPC}\right)$ os recursos especiais que veiculam matéria urgente (dada a evidente ineficácia de seu julgamento apenas ao final do procedimento ordinário); mas, de outro, são barradas as impugnações interpostas contra provimentos antecipatórios fundados em cognição sumária (A verossimilhança no processo civil, n. 3, p. 144-145, com indicação farta de precedentes em ambos os sentidos).

${ }^{462}$ Ver, nesse sentido, MÁRCIA FERNANDES BEZERRA, "O cabimento do recurso extraordinário contra acórdão que defere medida liminar e a súmula 735 do STF”, n. 3, p. 953-954.
} 
devem as respectivas questões ser consideradas passíveis de revisão in iure (v., infra, § $\left.7^{\circ}\right)^{463}$

Por fim, e mais importante, a renúncia ao desenvolvimento do Direito no âmbito das tutelas de urgência vai contra a função do Superior Tribunal de Justiça. Cabe lembrar não haver exigência de definitividade da decisão - em oposição ao seu caráter provisório ou temporário - no texto constitucional que regula o cabimento do recurso especial. A decisão deve ser definitiva apenas no sentido de não caber qualquer outro recurso de natureza ordinária. Nessa medida, "a orientação tomada pelo STJ traz como conseqüência, no limite, uma preocupante renúncia ao exercício da função paradigmática e construtiva do Tribunal, que consistiria em definir critérios de interpretação e operação do sistema das tutelas de cognição sumária" ${ }^{464}$ Essa renúncia é tanto mais grave quando se considera a crescente sumarização da justiça civil, fenômeno que revela, inclusive, uma tendência universal de autonomização dos juízos tomados com base em cognição sumária. ${ }^{465}$

\subsection{O PRÉ-QUESTIONAMENTO DA QUESTÃO FEDERAL}

\subsubsection{FUNDAMENTO DA EXIGÊNCIA DE PRÉ-QUESTIONAMENTO}

O termo "questionar" aparecia - seguindo a tradição do remédio norte-americano do writ of error $-{ }^{466}$ no texto constitucional de 1891 (art. 59, $§ 1^{\circ}$ ). Antes disso, em verdade, já o Dec. n. ${ }^{\circ}$ 848/1890 utilizava a locução "posta em questão". Aquele primeiro verbo foi mantido pela Reforma de 1926, perdurando a referência a tal "questionamento", de uma forma ou de outra, nas Constituições de 1934 e1937. Exigia-se, em conformidade com os dispositivos, o que veio a consagrar-se como o pré-questionamento (ou, mais comumente, com questionável acerto gramatical, prequestionamento) da questão.

${ }^{463}$ Cf. Luiz Guilherme Marinoni - SÉRgio C. Arenhart, Prova, n. 20.6, p. 340-342.

${ }^{464}$ DAISSON FLACH, A verossimilhança no processo civil, n. 3, p. 146. Também assim a passagem recolhida na p. 144: "Recusando o controle das decisões antecipatórias, os tribunais superiores deixam de realizar justamente aquela que é sua função primordial que é oferecer segurança e previsibilidade, mediante depuração de critérios de interpretação e aplicação do sistema".

${ }^{465}$ Sobre o ponto específico, permito-me referir o que escrevi no ensaio "Entre função e estrutura: passado, presente e futuro da tutela de urgência no Brasil", n. 4, p. 672 e ss.

${ }^{466} C f$. AlCides DE MENDONÇA Lima, "Recurso extraordinário e recurso especial", p. 140; MATOS PeiXoto, Recurso extraordinário, p. 91 e 98; EGAS MONIZ DE ARAGÃO, "Pré-questionamento", n. 2-3, p. 37-38. Também no direito alemão é exigido que a as alegações das partes se encontrem respondidas na sentença recorrida (art. 559, 1, ZPO). 
Alguns entenderam, em face da dicção expressa dos enunciados constitucionais mencionados, ser o pré-questionamento uma criação da jurisprudência à luz de tal regulamentação textual específica. ${ }^{467}$ Em decorrência disso, a partir da Constituição de 1946 - quando foi suprimida a anterior alusão a "questionar" na alínea $a$ do art. 101, III -, sustentou-se que sua imposição como requisito de admissibilidade do recurso extraordinário seria inconstitucional, mero "subterfúgio para não conhecer do recurso", sem possibilidade, pois, de sumular-se entendimento contrário. ${ }^{468}$ Há, inclusive, notícia de alguns poucos precedentes do Supremo Tribunal Federal nesse sentido. ${ }^{469}$

Prevaleceu, entretanto, a orientação contrária, que veio inclusive a ser sumulada naquela Corte, de acordo com os enunciados n. 282 : “É inadmissível o recurso extraordinário, quando não ventilada, na decisão recorrida, a questão federal suscitada"; e n. 356: "O ponto omisso da decisão, sobre o qual não foram opostos embargos declaratórios, não pode ser objeto de recurso extraordinário, por faltar o requisito do prequestionamento". Entende-se, em conformidade com a posição, de fluir o préquestionamento da própria finalidade do recurso e da verba constitucional, que fala em "causa decidida", posto que a sua exigência tenha de ser "escoimada (...) dos exageros do formalismo". 470

Certamente não é dado aos Tribunais de superposição criar requisitos de admissibilidade para os recursos excepcionais, uma vez derrogada a competência regimental antes existente para tanto. Não se pode ignorar, todavia, que, em muitas ocasiões, a suposta interpretação dos textos constitucionais e legais defendida pela chamada "jurisprudência defensiva" configura efetivamente a imposição de novas e descabidas exigências, não raro formuladas como autênticas armadilhas para os litigantes. Essa realidade forense - que, consoante foi repetidamente destacado, é sintomática de problemas institucionais graves ligados ao número excessivo de recursos e à falta de um

${ }^{467}$ JOSÉ FREDERICO MARQUES, Manual de direito processual civil, vol. 3, n. 647, p. 182.

468 Cf. GALENO LACERDA, "Críticas ao prequestionamento", n. 19-20, p. 80; JosÉ AfONSO DA SILVA, Do recurso extraordinário no direito processual brasileiro, n. 77, p. 198; BOTELHO DE MESQUITA, “A nova lei de recursos (lei 8.038/90)", n. 1, p. 190-191.

${ }^{469}$ São citados por ARAKEN DE ASSIS (Manual dos recursos, n. 81, p. 690), v.g.: STF, 2 ${ }^{\mathrm{a}}$ T., RE 6.363/RJ, rel. Min. Orosimbo NonAto, j. em 24.01.1947, RF 112/429; STF, $2^{\mathrm{a}}$ T., RE 4.772/PR, rel. Min. OrOSIMBO NONATO, j. em 28.01.1947, $R F$ 112/366.

${ }^{470}$ PAUlo RoBerto DA COSTA LeITE, “Recurso especial: admissibilidade e procedimento”, p. 192-193. No mesmo sentido, com inteiro acerto, EDUARDO RIBEIRO DE OLIVEIRA, "Recurso especial - algumas questões de admissibilidade", n. 2, p. 185 e ss.; RUY ROSADO DE AGUIAR JR., "Recurso especial: questão de ordem pública. Prequestionamento", n. 4, p. 274. 
filtro adequado para o Superior Tribunal de Justiça - é certamente responsável pela multiplicação de discussões e incertezas, acadêmicas e jurisprudenciais, em torno de algo que, não fosse a anomalia, seria apenas, quando muito, um falso problema.

Ressalvadas as demasias e as deturpações, a compreensão adequada do tema deve partir da idéia de pré-questionamento apenas como dado por meio do qual se manifesta o cabimento recursal, decorrente da expressão "causas decididas" empregada pelo texto constitucional. Por essa perspectiva, a exigência do pré-questionamento não é arbitrária; pelo contrário, tem fundamento (como não poderia deixar de ser) na Constituição Federal. Entretanto, em conformidade com as normas pertinentes (ou seja, a partir dos arts. 102, III e 105, III, CF), é legítima apenas a imposição da existência de decisão a respeito da questão federal no julgado recorrido, e nada mais.471

\subsubsection{DEFINIÇÃO: DECISÃO DA QUESTÃo PELO TRIBUNAL}

Discutiu-se amplamente, em doutrina e jurisprudência, a definição do préquestionamento. Dessa discussão aflorou, em síntese, uma tríade de opiniões. Reduzido aos seus termos mais simples, o panorama permite identificar o conceito em tela como a exigência de: I) prévia manifestação das partes a respeito da questão federal; II) pronunciamento judicial nesse sentido, independentemente de ter sido ou não levantada a matéria pelos litigantes; ou, ainda, III) de uma combinação dos dois elementos, sendo imprescindível que se apresentem ambos concomitantemente. ${ }^{472}$

$\mathrm{Na}$ esteira da corrente $s u b \mathrm{I}$ ), os precedentes que deram origem ao enunciado n. ${ }^{\circ} 282$ da Súmula/STF exigiam que a questão federal tivesse sido previamente suscitada pelos recorrentes, i.e, levantada nas suas razões recursais nas instâncias ordinárias; ${ }^{473} \mathrm{em}$

\footnotetext{
${ }^{471}$ Nesse sentido, CÂNDIDO DINAMARCO, "Fundamento constitucional da exigência de prequestionamento", n. 557, p. 1030-1031; NELSON NERY JR., "Ainda sobre o prequestionamento - os embargos de declaração prequestionadores", p. 855 e ss.; ID., Teoria geral dos recursos, n. 3.4.1.1, esp. p. 292; também apontando que a expressão "causas decididas" equivale ao "questionamento", CASSIO SCARPINELla BuENO, Curso sistematizado..., vol. 5, cap. 11, n. 2.1, p. 240; RAFAEL BICCA MACHADO, Recurso especial, cap. 2, n. 1, p. 67.

${ }^{472}$ Sobre isso, amplamente, José MigUEL GARCIA MEdinA,Prequestionamento e repercussão geral, n. 3.1.1, p. 112 e ss.

473 Nesse sentido, na jurisprudência do Supremo Tribunal Federal, v.g., "É requisito do recurso extraordinário que se tenha questionado previamente a aplicação do texto de lei federal que se alega ter sido infringido. Se se trata de questão externa ao acórdão, superveniente, e que só se manifestou na segunda
} 
reforço da tese, pode-se invocar argumento ligado ao significado literal do vocábulo, no qual se faz presente o prefixo de anterioridade ("pré”). ${ }^{474}$ Contudo, esta orientação - ligada à regra do tantum devolutum quantum apellatum e ao princípio dispositivo em sentido material - ignora que se devolvem ao juízo de apelação também outras questões além daquelas argüidas pelas partes, inclusive as cognoscíveis de ofício pelo órgão judicial. Ademais, a discussão semântica em torno da locução ou a busca abstrata pelo seu "sentido correto" são totalmente despropositadas e apenas geram confusão; como é sabido, convencionou-se utilizar a palavra para designar uma condição inerente ao cabimento dos recursos excepcionais, de modo que o importante é definir o que seja o requisito, e não o vocábulo em si, tomado fora de seu contexto.

Por essa perspectiva, é importante perceber que pode existir acórdão apoiado em fundamento não suscitado pelas partes e, ainda assim, haverá "causa decidida" (ou "préquestionamento", na linguagem corrente dos Tribunais) nos termos dos dispositivos constitucionais pertinentes (arts. 105, III e 102, III), sendo cabíveis os recursos excepcionais.

É irrelevante, portanto, que se faça presente a prévia manifestação das partes a respeito da questão, devendo ser descartadas as opiniões sub I) e III), que dela necessariamente dependem. Por certo, será a alegação anterior a regra, mas o fato de ter sido suscitado o tema pelas partes - embora determinante, à luz da regra da congruência, do que deve ser efetivamente julgado pelo tribunal de apelação, a fim de que não se incorra em error in procedendo -, não é suficiente, nem sequer necessário, para viabilizar o recurso especial calcado em error in iudicando. Qualquer outra interpretação atribui ao problema sentido incompatível com o texto constitucional, que demanda apenas a resolução da questão ("causa decidida"), silenciando quanto a todo o resto nesse aspecto. Logo, a manifestação prévia da parte será, por um lado, insuficiente (se, a despeito dela, não houver decisão) e, por outro, desnecessária (acaso tenha havido julgamento, ainda que não suscitada a matéria pelos litigantes) a fim de preencher o requisito. Por sua clareza, merece transcrição a definição doutrinária do Min. ATHOS GUSMÃo CARNEIRO: "a questão federal considera-se prequestionada quando decidida no acórdão, haja ou não sido,

instância, será então caso de ação rescisória" (STF, $1^{\text {a }}$ T., RE 58.405, rel. Min. BARROS MONTEIRO, j. em 16/04/1968, DJ 07-06-1968).

${ }^{474}$ Caminho percorrido por José Miguel Garcia Medina, Prequestionamento e repercussão geral, n. 3.1.1, p. 117-118. 
expressa ou implicitamente, suscitada pelo litigante. O prefixo 'pré' significa anterioridade com relação ao momento processual em que a parte manifesta o recurso extraordinário ou especial, e não ao momento em que prolatada a decisão irrecorrível". 475

O que interessa, então, é que a questão seja revelada no acórdão recorrido, tendo sido efetivamente decidida, pouco importando a atividade anterior das partes ou suas razões recursais em segundo grau. Segundo feliz metáfora, o Superior Tribunal de Justiça só pode julgar "o que estiver dentro do retângulo denominado acórdão", ou seja, somente poderá redecidir- exercendo então um metajuizo- o que já tiver sido anteriormente decidido. ${ }^{476} \mathrm{Na}$ atualidade, praticamente inexistem duas opiniões a esse respeito. ${ }^{477}$

Daí por que matérias não decididas - ainda que "de ordem pública" - não atendem ao requisito do pré-questionamento e, portanto, não podem ser levadas em consideração no julgamento do recurso especial.

\footnotetext{
${ }^{475}$ Recurso especial, agravos e agravo interno, 6. ed., Rio de Janeiro: Forense, 2009, n. 14, p. 50.

${ }^{476}$ NELSON NERY JR., "Questões de ordem pública e o julgamento do mérito dos recursos extraordinário e especial: anotações sobre a aplicação do direito à espécie (STF 456 e RISTJ 257)", n. 7, p. 974.

${ }^{477}$ CRUZ E TUCCI, A 'causa petendi' no processo civil, n. 4.27, p. 287-288; RUY RosAdo DE AGUIAR JR., "Recurso especial: questão de ordem pública. Prequestionamento", n. 2, p. 273-274; ADROALDO FURTADO FABRÍCIO, "Embargos de declaração: importância e necessidade de sua reabilitação", n. 5-6, p. 62-64; EGAS MONIZ DE ARAGÃO, "Pré-questionamento", n. 14, p. 47-48; CÂNDIDO DINAMARCO, "Fundamento constitucional da exigência de prequestionamento", n. 559, p. 1033; ARRUDA ALVIM, "O recurso especial na Constituição Federal de 1988 e suas origens", n. 1.3, p. 26; ID., "Recurso especial - fundamentação vinculada", n. 1.2, p. 23; ID., "O antigo recurso extraordinário e o recurso especial...”, n. II. p. 151; EDUARDO RIBEIRO DE OLIVEIRA, "Recurso especial - algumas questões de admissibilidade", n. 2, p. 186; ARAKEN DE Assis, Manual dos recursos, n. 84.1.2, p. 701;PAULO ROBERTO DA COSTA LEITE, "Recurso especial: admissibilidade e procedimento", p. 192-193; NELSON NERY JR., Teoria geral dos recursos, n. 3.4.1.1, p. 290-291; TERESA ARRUDA AlVIM WAMBIER, Recurso especial, recurso extraordinário e ação rescisória, $\mathrm{n}$. 12.5.1, p. 400; CASSIO SCARPINELla BUENO, Curso sistematizado..., vol. 5, cap. 11, n. 2.1, p. 241; FrEDIE DIDIER JR., "Alegação de prescrição e decadência em recurso extraordinário: notas ao Código Civil de 2002", n. 2, p. 118-119; RODOLFO DE CAMARGO MANCUSO, Recurso extraordinário e recurso especial, n. 6.1, p. 320; OSMAR MENDES PAIXÃo CÔRTES, Recurso extraordinário, n. 3.3.1, p. 254; JOÃO FRANCISCO NAVES DA FONSECA, Exame dos fatos nos recursos extraordinário e especial, n. 10, p. 41; ANGÉLICA ARRUDA ALVIM EDUARDO ARRUDA ALVIM, “Aspectos inerentes ao prequestionamento no recurso especial”, n. 2, p. 11511152; RAFAEl BICCA MACHADO, Recurso especial, cap. 2, n. 2, p. 69; Luís EDUARDO S. FERNANDES, Embargos de declaração, n. 22.5, p. 194. Também assim José Miguel GARCiA MEdinA, "Variações jurisprudenciais recentes sobre a dispensa do prequestionamento", p. 281-282, embora este autor diferencie, semanticamente, "prequestionamento" (como sendo, tecnicamente, atividade das partes) e a exigência constitucional de uma "causa decidida", ressaltando que apenas esta última é pertinente ao cabimento dos recursos excepcionais, sendo aquele irrelevante $\mathrm{O}$ resultado prático a que se chega, como se vê, é o mesmo, embora não se observe a nomenclatura ostensivamente consagrada pelos Tribunais de superposição.
} 


\subsubsection{PRÉ-QUESTIONAMENTO "EXPLÍCITO" E "IMPLÍCITO"}

Entende-se, em geral, por pré-questionamento "explícito" a exigência de que o acórdão recorrido não apenas decida a questão federal, mas também aponte - de maneira explícita - o dispositivo legal utilizado como fundamento. Inversamente, seria "implícito" o pré-questionamento quando, embora não indicando os textos legais, o acórdão trate inequivocamente da matéria discutida, aplicando ou deixando de aplicar as normas pertinentes. $^{478}$

A jurisprudência do Superior Tribunal de Justiça é hoje firme em contentar-se com o chamado pré-questionamento "implícito", ou seja, em entender como preenchido o requisito de admissibilidade sem que se tenha de, necessariamente, encontrar na redação do acórdão a menção expressa ao dispositivo legal. ${ }^{479}$ Em verdade, há julgados afirmando que “o prequestionamento do dispositivo legal pode ser explícito ou implícito, a tese jurídica é que deve ser sempre explícita", ${ }^{480}$ o que confirma a desnecessidade de indicação de artigos de lei pelo seu número.

\footnotetext{
${ }^{478}$ Há outros sentidos conferidos pela doutrina ao chamado "pré-questionamento implícito" (cf. pesquisa feita por ADROALDO FURTADO FABRícIO, "Embargos de declaração: importância e necessidade de sua reabilitação", n. 7, p. 68-69): alguns sustentam a sua relação com o tema do julgamento implícito e das questões prévias, de modo que, decidida a questão subordinada, a questão subordinante teria sido implicitamente pré-questionada; outros, semelhantemente, reconhecem que ele ocorre "quando a parte deseja fundar o recurso em matéria que o Tribunal tinha o dever de analisar, independente de provocação dos litigantes por estar tacitamente pré-questionada, mas sobre a qual não se expressou", o que exige a oposição dos aclaratórios (palavras de EGAS MONIZ DE ARAGÃO, "Pré-questionamento", n. 11.3, p. 44). Por sua vez, CASSIO SCARPINELLA BUENO defende que o pré-questionamento seria implícito diante de decisão obscura, que, embora julgando a causa, "não é tão clara quanto à sua conformação ou aos seus limites" (Curso sistematizado..., vol. 5, cap. 11, n. 2.1, p. 244; "De volta ao preqüestionamento - duas reflexões sobre o RE 298.695-SP”, n. 3, p. 74). Nenhuma das três versões, contudo, representa a acepção corrente, tal como versada no texto e discutida nos Tribunais: ao contrário do sustentado pela primeira, a questão prévia tem de ser enfrentada diretamente para que dela caiba recurso excepcional; a segunda peca por associar préquestionamento à atividade das partes e ao efeito devolutivo da apelação; a terceira, embora mais próxima ao que se defende no texto, peca por relacionar o pré-questionamento implícito à decisão obscura, o que não ocorre necessariamente. Isso porque o pré-questionamento será implícito quando a aplicação/interpretação da norma for objeto de decisão pelo Tribunal, ainda que o texto legal não seja identificado por um número de dispositivo, não havendo, contudo, nenhuma obscuridade - via de regra - nessa solução.
}

479 STJ, $4^{\mathrm{a}}$ T., Ag Reg no REsp 1052586/RS, rel. Min. JoÃo OtÁvio NoronHA, j. em 07.05.2009, DJe 18.05.2009; STJ, $2^{\text {a }}$ T., EDcl no Ag Reg no REsp 974877/PR, rel. Min. MAURO CAMPBELl MARQUES, j. em 21.05.2009, DJe 04.06.2009. Aliás, o Superior Tribunal de Justiça já decidiu ser, na verdade, explícito o préquestionamento, mesmo sem a indicação numérica do dispositivo violado: “(...) Considera-se explícito $o$ questionamento, quando o tribunal a quo, mesmo sem fazer referência expressa a dispositivos legais, nem declinar os números que os identificam no Ordenamento Jurídico, enfrenta as regras neles contidas" (STJ, Corte Especial, EREsp 155.358/SP, rel. Min. Humberto GOMES De BARROS, j. em 17.12.1999, DJ 28.02.2000, p. 29).

${ }^{480}$ STJ, $2^{\mathrm{a}}$ T., AgRgREsp 502.632/MG, rel. Min. Eliana CALmon, j. em 21/10/2003, DJ 24/11/2003, p. 264. 
Divergências terminológicas à parte, o importante, de fato, é que a questão tenha sido efetivamente decidida, e não que se tenha feito uma referência "numérica" ao texto legal utilizado como fundamento do acórdão. Como já foi demonstrado, texto e norma não têm correspondência bi-unívoca, sendo absolutamente despropositado que, identificada a norma aplicada (i.e., a questão federal decidida, a tese jurídica etc.), se exija a explicitação do dispositivo legal para fins de admissibilidade do recurso especial. A isso deve somar-se o argumento de que o cabimento do recurso, tal como regulado pela Constituição, exige apenas uma "causa decidida" e, ainda, o dado de que, sob a ótica do princípio iura novit curia, não há vinculação do juiz ao fundamento legal (ainda que essa possa existir, conforme o caso, em relação ao fundamento jurídico). ${ }^{481}$

Cabe salientar, contudo, que o Supremo Tribunal Federal - ao menos majoritariamente - reclama ainda o pré-questionamento explícito. ${ }^{482-483}$

Deve-se chamar atenção para duas questões neste sede. Primeira: não se considera pré-questionada a questão meramente ventilada no voto vencido (enunciado $\mathrm{n}^{\mathrm{o}}$. 320, Súmula/STJ), ${ }^{484}$ ainda que a consideração do voto dissidente possa facilitar a demonstração da questão decidida e dos fundamentos adotados pela maioria. ${ }^{485} \mathrm{O}$ mesmo raciocínio se

\footnotetext{
${ }^{481}$ Ambos argumentos são referidos e endossados por ADROALDO FuRTADO FABRícIO, "Embargos de declaração: importância e necessidade de sua reabilitação", n. 7, p. 69-70. Também sustentado que o texto constitucional não faz qualquer exigência de indicação do dispositivo legal para cabimento dos recursos excepcionais, entre muitos outros, CASSIO SCARPINELla BuENO, Curso sistematizado..., vol. 5, cap. 11, n. 2.1, p. 244.

${ }^{482} C f$. Rodolfo de CAMARGO MANCuSo, Recurso extraordinário e recurso especial, n. 6.1, p. 318. O autor menciona dois importantes julgados do STF nesse sentido: AgRg 253.566-6, DJ 03.03.2000; $1^{\text {a }}$ T., AI-AgR 492775-SP, j. em 17.10.2006, DJ 10.11.2006.

${ }^{483} C f$., v.g., na jurisprudência mais recente daquela Corte: STF, $1^{\text {a }}$ T., AI 804055 AgR, rel. Min. CÁRMEN LÚCIA, j. em 09/11/2010, DJe 24/11/2010; STF, 2 ${ }^{\mathrm{a}}$ T., AI 557130 AgR, rel. Min. Ellen GRACIE, j. 16/03/2010, DJe 08/04/2010.

${ }^{484}$ Muito embora já se tenha decidido em sentido contrário no âmbito do Supremo Tribunal Federal: "Recurso extraordinário: prequestionamento: irrelevância da ausência de menção dos dispositivos constitucionais atinentes aos temas versados. 1 . O prequestionamento para o $R E$ não reclama que o preceito constitucional invocado pelo recorrente tenha sido explicitamente referido pelo acórdão, mas, sim, que este tenha versado inequivocamente a matéria objeto da norma que nele se contenha. 2. É de receber-se com cautela a assertiva de que a fundamentação do voto vencido é irrelevante para a satisfação do requisito do prequestionamento: quando é patente a identidade das questões constitucionais resolvidas, de modo diametralmente oposto, pelo acórdão recorrido, de um lado, e pelo voto vencido, de outro, a invocação expressa pelo voto dissidente dos dispositivos constitucionais pertinentes às indagações que também o acórdão enfrentou e resolveu é a melhor prova de que a maioria do Tribunal não fez abstração de ditas normas, mas, sim, que lhes deu inteligência diversa (...)" (STF, Pleno, RE 141.788, rel. Min. SEPÚLVEDA PerTENCE, j. em 06/05/1993, DJ 18/06/1993, p. 12114).

${ }^{485}$ Cf. CAssio SCARpinella Bueno, Curso sistematizado..., vol. 5, cap. 11, n. 2.1, p. 242.
} 
aplica às menções feitas no relatório do acórdão. ${ }^{486}$ Segunda: não basta a mera indicação dos dispositivos. O pré-questionamento, em síntese, nada tem a ver com a menção expressa de dispositivos de lei, de modo que esta é desnecessária e, por outro lado, não é nem mesmo suficiente. ${ }^{487}$ No entanto, na prática, alguns autores recomendam que a parte, por precaução, busque sempre também a indicação explícita dos artigos legais. ${ }^{488}$

O Superior Tribunal de Justiça já decidiu, ademais, que a mera confirmação da sentença recorrida por seus próprios fundamentos- em acórdão com motivação per relationem -não configura pré-questionamento.489 Trata-se de orientação equivocada que contraria os deveres de colaboração e boa-fé do juiz, na medida em que - aceita como válida, na praxe, a motivação do acórdão que apenas "mantém a decisão por seus próprios fundamentos" - se penaliza o jurisdicionado por prática de duvidosa legitimidade adotada pelo próprio Poder Judiciário. Ademais, se a sentença de primeiro grau efetivamente decidiu a questão e, ulteriormente, tal decisão foi "incorporada" ao acórdão do Tribunal local, recebendo a sua total adesão, não há qualquer razão para não enxergar, aí, uma "causa decidida", tal como dispõe o texto constitucional.

Por outro lado, porém, a mesma Corte considerou existente o pré-questionamento quando, embora formalmente não conhecendo do recurso ordinário, o Tribunal a quo avançou no seu juízo e pronunciou-se sobre o mérito das questões argüidas pelo recorrente; nesse caso, o recurso especial com base em error in iudicando (e não meramente em error in procedendo) foi conhecido e provido, substituindo-se a decisão a quo. ${ }^{490}$

\footnotetext{
${ }^{486}$ Nesse sentido, v.g., "O pressuposto do prequestionamento é inerente às instâncias excepcionais. Para configurá-lo não basta a simples menção, no relatório do acórdão recorrido, dos dispositivos de lei federal apontados como ofendidos. Faz-se necessário que a instância revisora de segundo grau tenha expendido juizo de valor acerca das questões federais devolvidas ao STS" (STJ, 3 T., REsp 228934/SE, rel. Min. WALDEMAR ZVEITER, j. em 27/03/2000, DJ 29/05/2000, p. 151).

${ }^{487}$ ARRUDA ALVIM, "Recurso especial - fundamentação vinculada”, n. 1.2.3, p. 29.

${ }^{488}$ Nesse sentido, RAFAEL BICCA MACHADO, Recurso especial, cap. 2, n. 3, p. 75.

${ }^{489}$ STJ, $4^{\mathrm{a}}$ T., REsp 125127/DF, rel. Min. SÁlvio de FigueIREDo TeIXeIRA, j. em 22/09/1998, DJ 05/04/1999, p. 131.

${ }^{490}$ STJ, $3^{\text {a }}$ T., REsp 337094/MG, rel. Min. Humberto Gomes De BArRos, j. em 29/11/2005, DJ 19/12/2005, p. 393.
} 


\subsubsection{QUESTÃo SURGIDA E DECIDIDA NO ACÓRDÃO RECORRIDO}

Não pode ser descartado o surgimento de questão que não foi anteriormente suscitada e debatida pelas partes no julgamento prolatado pela segunda instância. O amplo efeito devolutivo da apelação (art. $515, \S \S 1^{\circ}$ e $2^{\circ}, \mathrm{CPC}$ ) dá ensejo à oportunidade para a apreciação de ofício das matérias de ordem pública (art. 267, § $3^{\circ}, \mathrm{CPC}$ ), bem como à possibilidade de julgamento imediato do mérito diretamente pelo órgão de segundo grau (art. 515, $\S 3^{\circ}, \mathrm{CPC}$ ). Decorrem daí decisões de temas não necessariamente "questionados" pelas partes nas peças recursais. A esse tipo de acórdão, convencionou-se chamar “julgamento com surpresa para a parte”. Não se pode ignorar, ainda, o amplo reexame realizado em segunda instância por ocasião da remessa necessária, em que não há adstrição aos limites de um recurso. As hipóteses, por fugirem à regra, podem gerar alguma confusão no que tange ao cabimento do recurso especial, razão pela qual merecem análise.

O pré-questionamento, como se viu, não se confunde com a prévia manifestação dos litigantes a respeito de um ponto, a fim de torná-lo controvertido; trata-se apenas da exigência de que a questão tenha sido enfrentada pelo acórdão do qual se pretende interpor recurso excepcional. No caso do julgamento "com surpresa", o próprio Tribunal erige, ex officio, um ponto em questão, sendo desde logo cabível o recurso especial. ${ }^{491}$ Por isso, é absolutamente infundada a cobrança de que a parte oponha, após o julgado manifestado "com surpresa", embargos declaratórios com a suposta finalidade de pré-questionamento: havendo decisão a respeito da matéria, está configurado - ipso facto - o seu préquestionamento, sendo dispensável e ilógica qualquer outra providência nesse sentido.

Deve-se ter em mente, ademais, que os embargos declaratórios são espécie de recurso de fundamentação vinculada, i.e., têm suas hipóteses de cabimento previstas taxativamente na lei. Só podem ser conhecidos diante da alegação de obscuridade, contradição ou omissão (art. 535, incisos I e II, CPC), não se podendo falar numa categoria sui generis dos "embargos pré-questionadores", desvinculada de tais motivos. O próprio Superior Tribunal de Justiça reconhece que "os embargos declaratórios, mesmo para fins

\footnotetext{
${ }^{491} C f$. Egas Moniz de Aragão, "Pré-questionamento", n. 7, p. 41. Também assim Pontes DE MiRAndA, Comentários ao Código de Processo Civil (de 1973), t. VIII, p. 35; JosÉ SARAIVA, Recurso especial e o STJ, n. 18.1.4, p. 276-277 (criticando de forma contundente a alteração ulterior da jurisprudência).
} 
de prequestionamento, só serão admissiveis se a decisão embargada ostentar algum dos vícios que ensejariam o seu manejo - omissão, obscuridade ou contradição". 492

Ora, ao julgamento que introduz uma questão nova (i.e., ao "julgamento com surpresa para a parte"), nenhuma omissão pode ser imputada: muito pelo contrário, o Tribunal local, nessa hipótese, acrescenta algo à decisão de primeiro grau, de modo que apenas esta última poderia ser porventura tachada de omissa. Também de obscuridade e contradição não se pode falar em termos que vinculem essencialmente esses vícios ao acórdão que supre a omissão da sentença recorrida ou decide de ofício matéria de ordem pública. É certo que tais deficiências poderão manifestar-se nessa ocasião de forma autônoma, mas não necessariamente atreladas ao julgamento da nova questão, a respeito da qual pode haver interesse em recorrer aos Tribunais de superposição. Daí a necessidade de admitir o recurso especial sem a irracional exigência de interposição prévia dos embargos declaratórios, que, nesses casos, "nenhuma função teriam a cumprir e nenhuma base legal poderiam encontrar, por ausentes seus pressupostos legais". 493

Entretanto, mais uma vez é necessário levar em conta a "jurisprudência defensiva" do Superior Tribunal de Justiça a esse respeito, de modo a destacar a predominância de julgados entendendo necessária a interposição de embargos declaratórios "préquestionadores", mesmo diante de vulnerações da lei federal surgidas no próprio acórdão recorrido. ${ }^{494}$ Constatada essa realidade, a cautela obviamente recomenda - mesmo contra a boa técnica e a razoabilidade - a oposição dos embargos de declaração também nessas hipóteses.

\footnotetext{
${ }^{492}$ STJ, $2^{\text {a }}$ T., REsp 874.531/SP, rel. Min. CASTRO MeIRA, j. em 21/08/2008, DJe 07/10/2008, citando precedentes. No mesmo sentido, mais recentemente, "Os embargos de declaração só se prestam a sanar obscuridade, omissão ou contradição porventura existentes no acórdão, não servindo à rediscussão da matéria já julgada no recurso" (STJ, 4a T., EDcl no AgRg no Ag 1008803/RS, rel. Min. MARIA IsABEL GALLOTTI, j. em 02/09/2010, DJe 16/09/2010).

${ }^{493}$ É a conclusão certeira de ADROALDO FURTADO FABRÍCIO, "Embargos de declaração: importância e necessidade de sua reabilitação", n. 6, p. 66.

${ }^{494}$ Nesse sentido, por último, STJ, $4^{\mathrm{a}} \mathrm{T}$., AgRg no Ag 1008785/RS, rel. Min. Fernando GonÇALVES, j. em 23/02/2010, DJe 08/03/2010. Os leading cases que deram origem ao entendimento são: STJ, Corte Especial, EREsp 99796/SP, rel. Min. EdUARDO RIBEIRO, j. em 16/06/1999, DJ 04/10/1999, p. 36, vencido o Min. Nilson NAVES; STJ, Corte Especial, EREsp 8285/RJ, rel. Min. Garcia VieIRA, j. em 03/06/1998, DJ 09/11/1998, p. 2, por apertada maioria.
} 


\subsubsection{SEGUE: VÍCIO DE PROCEDIMENTO CONCOMITANTE AO ACÓRDÃO RECORRIDO}

A orientação anterior do Superior Tribunal de Justiça dispensava, corretamente, a interposição de embargos declaratórios com finalidade de pré-questionamento quando o recurso especial tivesse por causa de pedir uma nulidade do próprio acórdão recorrido. ${ }^{495}$ Contudo, essa posição foi alterada pela Corte Especial, ${ }^{496}$ de modo a dificultar - por via oblíqua - o acesso ao Tribunal, exigindo-se a provocação ulterior,via embargos de declaração, da instância a quo sobre o error in procedendo por ele mesmo cometido.497 Passou-se a exigir, nesses termos, v.g., a manifestação do Tribunal recorrido acerca da violação da cláusula de reserva de plenário para a declaração de inconstitucionalidade de lei (arts. 480/482, CPC). ${ }^{498}$ É essa também a opinião de ARAKEN DE Assis: “ocorrendo error in procedendo no julgamento - recorde-se a inobservância do prazo previsto no art. $552, \S 1^{\circ}$-, nada se decidiu e, portanto, há necessidade de o interessado interpor embargos de declaração para obter pronunciamento a respeito, "prequestionando" (= obtendo decisão), no caso, a questão federal". 499

O posicionamento é de todo inaceitável, exigindo um "pré-questionamento" impossível ou, ao menos, incoerente. Primeiramente, desconsidera-se a natureza particular desse específico fundamento do recurso especial (vício formal - error in procedendo); ademais, entra em conflito com a finalidade do pré-questionamento e, ainda, com a natureza do recurso de embargos declaratórios. Trata-se de mais uma amostrada condenável jurisprudência defensiva dos Tribunais de superposição, que - na falta de expedientes adequados para controlar a sua agenda - criam, sem amparo constitucional ou legal, requisitos manifestamente ilegítimos de admissibilidade para os recursos excepcionais. Em razão disso, a doutrina majoritária, de forma apropriada, sustenta a

\footnotetext{
${ }^{495}$ V.g., STJ, $5^{\mathrm{a}}$ T., REsp 45.956-RJ, rel. Min. José FernANDES DANTAS, j. em 18.4.1994, DJU 2.5.1994, p. 10.020 .

${ }^{496}$ STJ, Corte Especial, EREsp 103746/CE, rel. Min. José ARNALDO DA FonSECA, j. em 15/09/1999, DJ 18/10/1999, p. 197; recentemente, STJ, 2 ${ }^{\text {a }}$ T., REsp 1027267/ES, rel. Min. Eliana CALMON, j. em 02/04/2009, DJe 29/04/2009. ${ }^{497}$ Sobre isso, com indicações de precedentes, ver: ATHOS GUSMÃo CARNEIRO, Recurso especial, agravos e
agravo interno, n. 17, p. 58-60; JOSÉ THEOPHILO FLEURY, Recursos especial e extraordinário, n. 5.3, p. 188-
193. Este último autor considera, em sentido diametralmente oposto ao texto, acertado o posicionamento dos
Tribunais de superposição, diante da possibilidade de serem invocadas, "em sede de embargos declaratórios,
nulidades absolutas da sentença ou, ainda, nulidades externas, como a ausência de intimação de advogado
para a pauta de julgamento" (op. cit., n. 5.3, p. 193-194).

${ }^{498}$ STJ, $2^{\mathrm{a}}$ T., REsp 663.562/RJ, rel. Min. CASTRO MEIRA, j. em 07/06/2005, DJ 05/09/2005, p. 367.

${ }^{499}$ ARAKEN DE Assis, Manual dos recursos, 2. ed., São Paulo: RT, 2008, n. 84.1.2, p. 705.
} 
desnecessidade de pré-questionamento e, a fortiori, deembargos "pré-questionadores" em tais hipóteses. 500

É necessário atentar para a diferente natureza dos errores in iudicando e errores in procedendo. Que se trata de duas espécies de erro, com diferentes características e repercussões no plano do julgamento dos recursos, não se pode negar. Basta lembrar que somente as irresignações fundadas em vício de juízo podem conduzir à irradiação do efeito substitutivo dos recursos, na medida em que a decisão eivada de vício de procedimento é, ao contrário, meramente anulada para que o processo seja reenviado ao juízo a quo (ressalvada, nos recursos ordinários, a aplicação do art. 515, §3, $\mathrm{CPC}$ ).

Nesta hipótese (error in procedendo), não há um juízo, no sentido próprio do termo - ou seja, decisão referida a um problema jurídico suscitado a partir de fatos que foram matéria de prova -, como objeto recursal, mas a análise de uma situação atual consubstanciada pelo próprio processo e que continua a desenvolver-se perante o Superior Tribunal de Justiça. ${ }^{501} \mathrm{O}$ fundamento não diz respeito ao conteúdo do acórdão recorrido, mas a um vício formal que o inquina. ${ }^{502}$

Disso decorre tanto a desnecessidade de pré-questionamento nos casos em que o vício de procedimento tenha surgido concomitantemente ao acórdão recorrido quanto a possibilidade de o Superior Tribunal de Justiça conhecer diretamente as circunstâncias fáticas a ele relativas (v., infra, $\S 7^{\circ}$ ). É pouco mais que evidente que, se o préquestionamento refere-se à presença de decisão a respeito da questão federal no julgado

\footnotetext{
${ }^{500}$ CruZ E TUCCI, $A$ 'causa petendi' no processo civil, n. 4.27, p. 288-9; EDUARDO RIBEIRO DE OLIVEIRA, "Recurso especial - algumas questões de admissibilidade", n. 2, p. 185; BARBOSA MOREIRA, Comentários ao Código de Processo Civil, v. 5, n. 324, p. 601, nota 47; AdROALdo FurTAdo FABRício, "Embargos de declaração: importância e necessidade de sua reabilitação", n. 6, p. 67-68 e nota 51. Contra, surpreendentemente, EGAS MONIZ DE ARAGÃO, "Pré-questionamento", n. 12, p. 45. Este autor defende, no entanto, que basta a mera apresentação dos embargos declaratórios, sendo possível recorrer aos Tribunais de superposição ainda que eles sejam rejeitados (op. cit., n. 13.3, p. 47), o que evidencia ser essa uma exigência formal despropositada e sem sentido.

${ }^{501} C f$., na doutrina italiana, em lição de todo aplicável ao recurso especial, MAZZARELLA, Analisi del giudizio civile di cassazione, p. 67 e ss., esp. nota 114; ID., "Cassazione: i) dirittoprocessualecivile”, n. 4.4, p. 5. Por isso, será equivocado generalizar de forma absoluta a idéia de que o recurso especial representa um "juízo sobre um juízo" (portanto, um metajuízo).

${ }^{502} C f$. FAZZALARI, "Ricorso per cassazione nel diritto processuale civile", n. 8, p. 588.
} 
recorrido, tal exigência não pode ser imposta aos recursos que não se voltam contra o conteúdo do acórdão, mas são fundamentados num vício de forma que o atinja. ${ }^{503}$

Ademais, ressalvada a hipótese de julgamento infra petita, a nulidade surgida por ocasião da prolação do próprio acórdão recorrido não dá lugar a omissão, obscuridade ou contradição, de modo que não configura hipótese de cabimento de embargos declaratórios (ex art. 535, CPC); esse mesmo recurso não se presta, além disso, a invalidar o julgado, ${ }^{504}$ mas sim a promover sua integração, esclarecimento ou complementação, ainda que, excepcionalmente, essas providências possam causar um efeito infringente indireto. A jurisprudência do Superior Tribunal de Justiça, como se viu, não admite - de forma correta, diga-se de passagem - o manejo dos embargos de declaração fora da relação numerus clausus de motivos; entretanto, ao exigir o pré-questionamento do vício surgido no acórdão (v.g., quando o juízo decidiu matéria estranha ao thema decidendum), a Corte cai em invencível contradição com aquela posição e comete grave equívoco técnico.

O entendimento do Superior Tribunal de Justiça, entretanto, já se disse, é no sentido contrário. $\mathrm{O}$ advogado diligente, portanto, manejará os embargos declaratórios.

\subsubsection{OMISSÃO JUDICIAL E EMBARGOS DECLARATÓRIOS}

Evidentemente, não se pode inovar no processo, i.e, trazer matéria nova, não suscitada oportunamente, por meio de embargos declaratórios ofertados à luz do acórdão de segundo grau. $505^{-506}$ Sendo este recurso voltado, no que aqui interessa, à integração de uma omissão, é necessário que a matéria omitida seja abarcada pelo objeto do processo, não podendo afigurar-se estranha às alegações das partes ou ao restrito elenco passível de análise de ofício pelo juiz. Essa constatação óbvia, em verdade, nada tem a ver com a

\footnotetext{
${ }^{503}$ Há que se fazer, todavia, aprofundando o quanto foi dito no parágrafo, uma importante distinção: se o vício de procedimento é anterior ao recurso ordinário interposto - ou seja, se tem origem na decisão de primeiro grau -, constitui fundamento que poderia ter sido examinado pelo Tribunal local em sede de agravo ou de apelação. Por isso, não será possível suscitá-lo, pela primeira vez, no recurso especial; nesse caso, a matéria estará preclusa. A dispensa de pré-questionamento refere-se, portanto, ao vício surgido por ocasião do julgado recorrido.

${ }^{504}$ Contra, Egas Moniz DE ARAGão, "Pré-questionamento", n. 12.2, p. 46.

${ }^{505}$ Entre muitos outros, OvídIO A. BAPTISTA DA SILVA, Curso de processo civil, vol.7, n. 17.4.4.3, p. 432; Egas Moniz DE ARAGÃo, "Pré-questionamento", n. 11.3, p. 45.

${ }^{506}$ Nesse sentido, é firme também a jurisprudência do Superior Tribunal de Justiça: “(...) 3. Ausentes os requisitos do art. 535 do CPC, incabivel inovar-se nos autos, em sede de Embargos de Declaração, apresentando-se tese jurídica estranha à lide. Caráter infringente dos embargos. 4. Embargos de declaração rejeitados" (STJ, 2a T., EDcl no REsp 281817/PR, rel. Min. Eliana CALMON, j. em 06/05/2003, DJ 02/06/2003, p. 243).
} 
natureza ou a finalidade dos recursos excepcionais; trata-se, antes, de projeção do efeito devolutivo do juízo de apelação e da normativa geral relativa à estabilização do objeto litigioso.

Ora, se a respeito de questão não levantada pelas partes nem conhecida de ofício pelo Tribunal local não se pode provocar tardiamente a manifestação judicial por meio de embargos de declaração, estes não serão cabíveis, a fortiori, visando a abrir caminho para a ulterior interposição de recurso especial ou extraordinário. A doutrina realça essa impossibilidade ao aludir que a hipótese criaria, na realidade, um autêntico "pósquestionamento", totalmente incompatível com o regramento dos recursos excepcionais. ${ }^{507}$

Há, no entanto, hipóteses em que o Tribunal a quo realmente incide em omissão relevante e, destarte, devem ser opostos os embargos declaratórios a fim de provocar sua decisão a respeito do tema pertinente. ${ }^{508}$ Nesses casos, deverá a parte manejar o recurso visando à integração do julgado, sob pena de não haver decisão a respeito da questão omitida e, portanto, inexistir o devido pré-questionamento. Sabe-se, porém, que os tribunais de apelação têm verdadeira repulsa ao embargos de declaração, rejeitando-os na esmagadora maioria das vezes. Era comum, ainda, a aplicação de multa ao recorrente em tais situações (ex art. 538, p. único, CPC). Essa aversão jurisprudencial das instâncias $a$ quo, aliás, foi o fator que levou à positivação do enunciado n. 98 da Súmula/STJ, consignando que os "embargos de declaração manifestados com notório propósito de prequestionamento não tem caráter protelatório", de modo a conciliar a prática com a orientação acolhida no juízo de admissibilidade efetuado pelo Superior Tribunal de Justiça.

Ainda assim, é comum (ou melhor, altamente provável) que seja negada a ocorrência de uma omissão pelo órgão prolator do acórdão, "rejeitando-se" (a falta de distinção entre admissibilidade e mérito é patente) os embargos declaratórios. Existem hoje duas orientações a respeito dessa situação de persistência da omissão diante do Tribunal $a$

\footnotetext{
${ }^{507}$ De modo que "os embargos com essa finalidade preparatória de recurso hão de ser pré-questionadores, e não pós-questionadores, como se dá quando o tema constitucional ou federal, na verdade, apenas vem agitado, ex novo, no bojo dos próprios embargos, assim propiciando, em modo anômalo, a criação, originária, de tal quesito de procedibilidade" (MANCUSO, Recurso extraordinário e recurso especial, 10. ed., São Paulo: RT, 2007, n. 6.1, p. 321).

508 Por outro lado, diante da possível intransigência dos Tribunais de superposição (nomeadamente, o Supremo Tribunal Federal) em relação à exigência do chamado "pré-questionamento explícito", casos há em que será interessante, na prática, obter uma (injustificada) pronúncia acerca dos artigos de lei, ainda que a questão constitucional seja perfeitamente identificável sem essa alusão numérica.
} 
$q u o::^{509}$ no Supremo Tribunal Federal, prepondera a noção de que, opostos os embargos de declaração, a questão omitida está pré-questionada, independentemente do resultado do julgamento, sendo possível interpor, desde logo, o recurso extraordinário quanto ao tema de fundo (verbete n. ${ }^{\circ} 356$, Súmula/STF); já no Superior Tribunal de Justiça, apenas sanada efetivamente a omissão - i.e, somente com o provimento dos declaratórios - estará preenchido o requisito do pré-questionamento, o que obriga a parte a interpor recurso especial voltado especificamente contra a violação ao art. 535, II, CPC (enunciado n. ${ }^{\circ} 211$, Súm./STJ). ${ }^{510-511}$

A divergência tem grande relevância prática, uma vez que o Superior Tribunal de Justiça exige a interposição do recurso especial fundado na violação ao art. 535, CPC. Mas não é só: essa mesma Corte, constatando a divergência de posições entre os Tribunais de superposição, não se considera competente para conhecer de recurso especial interposto com base no art. 535, CPC, nas hipóteses em que a omissão alegada seja de cunho constitucional. $^{512}$ Portanto, havendo sido interpostos embargos declaratórios com finalidade "pré-questionadora" voltados a sanar omissão a respeito de tema constitucional, deve-se interpor, desde logo, o recurso extraordinário alegando o error in iudicando (ou, por precaução, alegando também a ofensa ao art. $5^{\circ}$, LIV, CF), sem que se lance mão do recurso especial.

\footnotetext{
${ }^{509}$ Algo reconhecido pela próprio jurisprudência do Superior Tribunal de Justiça: "(...)1. O STF, no RE 219.934/SP, prestigiando a Súmula 356 daquela Corte, sedimentou posicionamento no sentido de considerar prequestionada a matéria constitucional pela simples interposição dos embargos declaratórios. Adoção pela Suprema Corte do prequestionamento ficto. 2. O STJ, diferentemente, entende que o requisito do prequestionamento é satisfeito quando o Tribunal a quo emite juizo de valor a respeito da tese defendida no especial(...)" (STJ, 2 a T., REsp 866482/RJ, rel. Min. EliANA CALMON, j. em 05/08/2008, DJe 02/09/2008).

510 Assim, "atualmente temos dois sistemas quanto aos embargos de declaração opostos a acórdão alegadamente omisso: o do Supremo Tribunal Federal, expresso na Súmula 356, e o do Superior Tribunal de Justiça, revelado na Súmula 211" (ATHOS GUSMÃo CARNEIRO, Recurso especial, agravos e agravo interno, 6. ed., Rio de Janeiro: Forense, 2009, n. 16, p. 56-7); $c f$, ainda, LuIZ GuILHERME MARINONI - SÉRGIO C. Arenhart, Processo de conhecimento, n. 2.10.1, p. 576; TERESA ARrudA AlviM WAMBIER, Recurso especial, recurso extraordinário e ação rescisória, n. 12.5.6, p. 416.

${ }^{511}$ Nesse sentido, v.g., STJ, 5a T., REsp 968378/RS, rel. Min. ARnAldo EsTEVES LiMA, j. em 19/11/2009, DJe 15/12/2009.

${ }^{512}$ Nesse sentido, destaca-se trecho de voto proferido em precedente daquela Corte (STJ, $2^{\mathrm{a}} \mathrm{T}$., AgRg no Ag 1113494/SP, rel. Min. CASTRO MEIRA, j. em 19.05.2009, DJe 29.05.2009): "No concernente à suposta omissão do acórdão recorrido, que não teria apreciado os mencionados dispositivos constitucionais, cediço é que a verificação de eventual omissão na análise de matéria constitucional, no âmbito desta Corte, importaria na usurpação da competência reservada ao Pretório Excelso, pois, para se emitir juízo a respeito da ocorrência ou não de tal mácula e da sua relevância no julgamento da causa, indispensável seria a análise, ainda que perfunctória, da questão constitucional". Com essa conclusão, não se pode concordar de jeito algum: a análise da violação ao art. 535, II, CPC, diz respeito a um error in iudicando, sendo, ao contrário do afirmado pelo julgado, absolutamente dispensável analisar a questão de fundo.
} 
A maior parte da doutrina entende correta a solução adotada pelo Superior Tribunal de Justiça, no sentido de ser imprescindível o provimento dos embargos declaratórios para que a matéria seja considerada pré-questionada. Sendo desprovidos, caberá apenas recurso especial fundado em violação ao art. 535 do Código de Processo Civil (ou, conforme o caso, o correlato recurso extraordinário fundado no art. $\left.5^{\circ}, \mathrm{LIV}, \mathrm{CF}\right) .^{513}$

Outros consideram o enunciado sumular $\mathrm{n}^{\circ} 211$ teoricamente exato, mas, dependendo do caso, reputam preferível que os Tribunais de superposição julguem desde logo o error in iudicando. Isso deverá ocorrer desde que se possa precisar qual foi a "causa decidida", ainda que essa identificação não ocorra de maneira absolutamente cristalina, reservando-se o expediente dos embargos de declaração para os casos de total omissão. ${ }^{514}$

Há de ser levado em conta, efetivamente, que as partes muitas vezes opõem os aclaratórios de maneira supérflua e apenas ad cautelam. ${ }^{515}$ Ademais, haverá casos em que a própria decisão que rejeita - apenas formalmente, diga-se de passagem - os embargos de declaração pode delimitar suficientemente a controvérsia jurídica para fins de interposição, quanto ao error in iudicando, do recurso especial. Com efeito, muitas vezes a decisão dos embargos declaratórios, embora "rejeitando-os" (a expressão é comumente empregada, mas imprecisa do ponto de vista técnico) acaba por trazer - no intuito, talvez, de justificar a adequação da tutela jurisdicional anteriormente prestada -, uma motivação superabundante (um obiter dictum, poderia dizer-se) em relação ao que se proclama como juízo de mera inadmissibilidade, adentrando, em verdade, o tema de fundo e, nessa medida, decidindo explicitamente (i.e, pré-questionando) a quaestio iuris. A anulação é

${ }^{513}$ CRUZ E TUCCI, "Recentes orientações em tema de prequestionamento", n. 2, p. 82-83; NELSON NERY JR., "Questões de ordem pública e o julgamento do mérito dos recursos extraordinário e especial: anotações sobre a aplicação do direito à espécie (STF 456 e RISTJ 257)", n. 5, p. 969; ARRUDA ALVIM, "Recurso especial fundamentação vinculada", n. 1.2.2, p. 25 e n. 1.2.3, p. 29; CASSIO SCARPINELLA BuENO, "Prequestionamento - reflexões sobre a súmula 211 do STJ", esp. n. 2, p. 63 e ss., e n. 4, p. 76 e ss.; ID., "Duas 'novidades' em torno dos recursos extraordinários em sentido lato", n. 3, p. 226; OSMAR MENDES PAIXÃO CÔRTES, "As nulidades acolhidas pelos Tribunais Superiores em recursos de natureza extraordinária - necessidade ou formalismo?", n. 3, p. 980 e n. 4, p. 981-982. O entendimento defendido é o de que apenas em relação a decisões comissivas (e não decisões "omissivas", ou seja, a respeito de matérias que deveriam ter sido ou que se entende terem sido tacitamente decididas) preenchem o requisito do cabimento dos recursos excepcionais (NELSON NERY JR., "Ainda sobre o prequestionamento - os embargos de declaração prequestionadores", p. 861-864).

${ }^{514}$ Egas Moniz DE ARAGão, "Pré-questionamento", n. 13, p. 46 e n. 13.2, p. 47.

515 "Por conta das exigências às vezes formalistas do Superior Tribunal de Justiça, esmeram-se os litigantes, quando encontram-se diante da expectativa de apresentar recurso especial, interpondo - por questão de segurança - embargos de declaração para prequestionar de modo expresso, claro, direto, pontual, a questão malversada na instância local" (CARLOS ALBERTO CARMONA, "O sistema recursal brasileiro: breve análise crítica", n. 7, p. 44). 
"contraproducente e inútil, devendo ser, na medida do que for praticamente possível, evitada". ${ }^{516}$ Ademais, não se devem agravar ainda mais os ônus do recorrente, comparáveis já ao trabalho de Sísifo. ${ }^{517}$

No entanto, diante do entendimento sumulado e da praxe da Corte, há a necessidade prática, no manejo do recurso especial, de fazê-lo também com fundamento no art. 535, II, CPC, caso os embargos declaratórios opostos não tenham sido acolhidos pela instância. Cumulam-se, então, os dois pedidos, alegando-se, preliminarmente, a violação ao art. 535, II, CPC e, para a eventualidade de considerar-se suprido o requisito do préquestionamento, a matéria de fundo como pedido subsidiário. Ou seja, do ponto de vista estritamente pragmático, a solução será recorrer tanto do error in procedendo (alegando violação ao art. 535, CPC, e pedindo a cassação), em caráter preliminar, quanto do error in iudicando (invocando a matéria de fundo e pedindo a revisão). Dessa forma, amarra-se o julgamento pelo Superior Tribunal de Justiça: ou se reconhece a violação ao art. 535, CPC, anulando o acórdão recorrido, ou se tem por pré-questionada a matéria, adentrando-se no juízo de mérito quanto ao erro de julgamento. ${ }^{518}$ A não ser, é claro, que por meio dos embargos declaratórios tenha o recorrente buscado introduzir, tardiamente, matérias que dependiam de sua alegação no momento processual oportuno, hipótese em que o tribunal de apelação não deveria mesmo tê-las apreciado.

\subsubsection{MATÉRIA DE ORDEM PÚBLICA}

O pré-questionamento, como já visto, é requisito constitucional ligado ao cabimento do recurso especial. Reflete, em verdade, a função dos Tribunais Superiores,

${ }^{516} C f$. PAUlo HenRiQue dos SANTOS LuCon, "Recurso especial: ordem pública e prequestionamento", n. 5, p. 737 (nota 21) e, ainda, n. 8.1, p. 738-9.

${ }^{517}$ Referindo-se à orientação consagrada pelo Superior Tribunal de Justiça, afirma ADROALDO FURTADO FABRíCIO: "É preciso que se tenha presente, também na perspectiva dos resultados práticos a que se volta o processo, que aquela primeira solução obriga o recorrente a rolar, mais uma vez, e quiçá mais outras, a sua pedra de Sísifo, que as condições atuais da prestação jurisdicional já tornam tão pesada" ("Embargos de declaração: importância e necessidade de sua reabilitação", n. 8, p. 73). Sísifo, como se sabe, fora um astuto mortal que, com suas artimanhas e indiscrições, despertara a ira de Zeus na mitologia grega; como castigo, após a sua morte, foi forçado a empurrar uma enorme rocha até o topo de uma montanha, mas, quando estava prestes a alcançar o cume, a pedra sempre rolava novamente montanha abaixo, obrigando-o a repetir, assim, a tarefa eternamente.

${ }^{518}$ Cf. Egas Moniz de ARAgão, "Pré-questionamento", n. 13.1, p. 47.ATHOS GuSMÃo CARNEIRO, Recurso especial, agravos e agravo interno, n. 16, p. 57; RODOLFO DE CAMARGO MANCUSO, Recurso extraordinário e recurso especial, n. 6.1, p. 325, nota 197; RAFAEL BICCA MACHADO, Recurso especial, cap. 2, n. 6, p. 87. 
chamados a efetuar um metajuízo sobre as decisões dos tribunais inferiores. Por isso, recurso que tenha por fundamento error in iudicando deve, necessariamente, apontar como causa de pedir -, a decisão errônea da questão federal. Pouco importa, para esse fim, a natureza da norma: mesmo as questões de ordem pública devem ter sido préquestionadas (i.e, decididas) para que possam ser apreciadas em sede de recurso excepcional.

Entretanto, existe grande polêmica a esse respeito. No Superior Tribunal de Justiça, há basicamente três entendimentos sobre a relação entre pré-questionamento e matéria de ordem pública: ${ }^{519}$ I) para alguns, a questão não pré-questionada não pode, em qualquer hipótese, ser apreciada; II) no outro extremo, embora não se veja a tese em nenhum acórdão recente, há quem admita sua apreciação independentemente de préquestionamento ou de se ter conhecido do recurso por outro fundamento, invocando-se argumento de justiça; ${ }^{520}$ III) por fim, numa posição intermediária, sustenta-se que a cognição é possível, desde que o recurso seja conhecido por outro fundamento.

Hoje, dentre as teorias, o objeto da disputa fica entre a primeira ("a questão não pré-questionada não pode, em qualquer hipótese, ser apreciada") e a terceira ("a cognição é possível, desde que o recurso seja conhecido por outro fundamento"). Como afirmado, a posição radical que admite apreciação de questões de ordem pública não pré-questionadas independentemente de se ter conhecido do recurso por outro fundamento não tem aceitação e, por isso, carece de relevância na discussão.

Disso decorre, desde logo, ao menos uma conclusão parcial: o recurso especial não pode trazer como única causa de pedir uma questão (ainda que de ordem pública) não préquestionada, i.e, não decidida pelo Tribunal a quo. Mesmo para aqueles que defendem uma ampliação da cognição do Superior Tribunal de Justiça a tais questões, o recurso há de ter sido conhecido com base em outra causa de pedir. A discussão desloca-se, assim, do âmbito específico da causa de pedir invocada no recurso (e, mais especificamente, do préquestionamento) para tornar-se, acima de tudo, um problema de delimitação do seu efeito devolutivo. Com efeito, a teoria ampliativa defende justamente uma dissociação entre causa de pedir e âmbito de devolução. Por isso - sem ignorar que o pré-questionamento

\footnotetext{
${ }^{519}$ Com as devidas indicações, RUY Rosado DE Aguiar JR., "Recurso especial: questão de ordem pública. Prequestionamento", p. 280 e ss.

${ }^{520}$ STJ, $3^{\text {a }}$ T., REsp 66.567/MG, rel. Min. WALDEMARZVEITER, j. em 25.03.1996, DJ 24.06.1996.
} 
está intimamente relacionado com a devolução propiciada pelos recursos excepcionais -, o tema, em suas linhas gerais, será tratado juntamente com os efeitos do julgamento do recurso especial (infra, $\left.\S 8^{\circ}\right)$

Por ora, cabe apenas ressaltar uma única exceção à conclusão parcial acima formulada: o vício concernente à falta de formação de litisconsórcio necessário pode ser reconhecido independentemente de pré-questionamento, na medida em que esse requisito de admissibilidade seria mesmo impossível de ser preenchido em tais casos. ${ }^{521}$ Isso deve-se ao caráter excepcional do defeito em questão, capaz de render inutilitur data a sentença proferida sem a integração do litisconsorte, na medida em que a unicidade da relação de direito material discutida ou a lei impõem que a declaração judicial só poderá ser praticamente eficaz se presentes todas as partes envolvidas naquela situação substancial. ${ }^{522}$ A sentença proferida em tais condições ofende a própria essência dialética do processo. Por isso mesmo, a invalidade jamais se convalida e, além de ser causa para a rescisão do julgado, será sempre possível invocá-la por meio da querela de nulidade (ou, ainda, como causa petendi de impugnação ao cumprimento da sentença). ${ }^{523}$

\subsubsection{INCERTEZAS QUANTO AO PRÉ-QUESTIONAMENTO}

Por paradoxal que possa parecer, os Tribunais de superposição - encarregados justamente da nobre função de zelar pela unidade do direito e pela uniformidade jurisprudencial - não logram consenso em torno do tema do pré-questionamento. As oscilações manifestam-se, num primeiro plano, entre o Supremo Tribunal Federal e o Superior Tribunal de Justiça. São dignos de nota, nesse sentido, os desacordos frontais em torno da necessidade ou não de indicação do dispositivo legal pelo acórdão recorrido ou,

\footnotetext{
${ }^{521}$ ADA PELLEGRINI GRINOVER, "Litisconsórcio necessário e efeito devolutivo do recurso especial", n. 3, p. 39; AleXANDRe Freitas CÂMARA, Lições de direito processual civil, vol. 2, n. 2.6, p. 133. O autor corretamente entende que o pré-questionamento será necessário também para a apreciação das ditas matérias de ordem pública, com a ressalva do recurso interposto pelo litisconsorte necessário preterido.

${ }^{522}$ M. ENCARNACIÓNDÁVILAMILLÁN, Litisconsorcio necesario, p. 49 e 62-67, com a ressalva de que, sem que a matéria seja argüida pelo interessado ou conhecida de ofício pelo juiz, a sentença proferida em tais condições produzirá efeitos na prática. Referida autora arrola os seguintes fundamentos do litisconsórcio necessário: respeito ao princípio do contraditório (audiência bilateral), natureza da relação jurídica material, evitar sentenças contraditórias e a impossibilidade jurídica da pronúncia, bem como a impossibilidade física do seu cumprimento (p. 52 e ss.).

${ }^{523}$ Ver, sobre isso, PAULO HENRIQUE LUCON - GUILHERME RECENA COSTA, "O processo de perda do mandato em razão de desfiliação sem justa causa...”, n. 6.1, p. 92-95.
} 
ainda, acerca de ser ou não imperativo o provimento dos embargos declaratórios, opostos diante do juízo a quo, a fim de viabilizar a interposição do recurso excepcional a respeito da matéria omitida. Quanto a esse último ponto, não há nada menos do que dois enunciados sumulados em sentido contraditório (verbetes 356 e 211 das Súmulas do STF e STJ, respectivamente).

Mas também internamente - ou seja, mesmo entre os órgãos fracionários de um único Tribunal - reinam divergências e, mais do que isso, não raro uma mesma Turma ou Seção manifesta juízos de admissibilidade inconsistentes com suas prévias decisões.

Por óbvio, a falta de uniformidade em relação a esse importante aspecto do cabimento dos recursos excepcionais prejudica sobretudo o jurisdicionado e o seu advogado, forçados a percorrer sempre o caminho mais longo e penoso, a fim de prevenir imprevistos, embora, em muitos casos, nem mesmo cautelas redobradas sejam suficientes a contornar julgados com surpresa para as partes.

Já se destacou, por isso, a necessidade veemente de uniformização em torno da matéria. Estando o cabimento de ambos os recursos excepcionais regulado inteiramente na Constituição, que é justamente o fundamento normativo do pré-questionamento, a tarefa é inegavelmente de competência do Supremo Tribunal Federal. ${ }^{524}$ Caberá ao Superior Tribunal de Justiça (e aos demais tribunais envolvidos), portanto, adotar o entendimento fixado por aquela Corte, conformando-se ao que for decidido. Seja como for, enquanto o ideal não se realize, seria de todo razoável que, ao menos, se adotasse uma regra de fungibilidade dos entendimentos sobre o pré-questionamento, permitindo um juízo de admissibilidade recursal positivo nas hipóteses de dúvida objetiva. ${ }^{525}$

\footnotetext{
${ }^{524}$ Algo nesse sentido, CASSIO SCARPINELLA BUENO, "De volta ao preqüestionamento - duas reflexões sobre o RE 298.695-SP”, n. 5, p. 81-83.

${ }^{525}$ É a sugestão feita por TERESA ARRUDA ALVIM WAMBIER, Recurso especial, recurso extraordinário e ação rescisória, n. 12.5.7, p. 416 e ss.
} 


\section{$\S 7$ - CAUSA DE PEDIR DO RECURSO ESPECIAL}

\subsection{CAUSA DE PEDIR E PEDIDO (OU O OBJETO) DO RECURSO ESPECIAL}

Sendo uma pretensão autônoma, ${ }^{526}$ ainda que exercida dentro do processo, o recurso especial apresenta elementos objetivos próprios: o I) pedido (de anulação ou reforma da decisão recorrida) e a II) causa de pedir (alegação de violação ao direito federal infraconstitucional cometida pelo acórdão de segundo grau). ${ }^{527}$

I) Quanto ao pedido, nenhuma particularidade existe em relação aos outros recursos: pede-se a reforma da decisão, quando alegado error in iudicando, ou a sua anulação, em hipótese de error in procedendo. A distinção entre vícios de julgamento e de procedimento costuma ser traçada à luz de dois critérios: a posição do juiz em relação à norma violada e a natureza desta. Por essa perspectiva, o error in procedendo ocorre quando o juiz deixa de observar norma (processual) de que ele mesmo era destinatário, porquanto reguladora da sua própria atividade no processo, tornando a decisão nula. Já no error in iudicando, o juiz deixa de aplicar ao caso a norma (de direito material) adequada, isto é, aquela endereçada ao conflito de interesse entre as partes, com o que comete uma injustiça. $^{528}$

A essa noção, um tanto quanto simplista, deve-se acrescentar que a inobservância de uma forma processual pelo juízo a quo (error in procedendo), uma vez tomada como motivo de recurso, será objeto de julgamento pelo juízo ad quem, que poderá então cometer um error in iudicando a seu respeito. Assim, v.g., quando o juiz de primeiro grau rejeita o requerimento de produção de prova relevante feito pela parte e decide em seu desfavor à luz da "ausência de provas", a ocorrência ou não de cerceamento de defesa será

\footnotetext{
${ }^{526}$ Nesse sentido, ARAKEN DE ASsis, Manual dos recursos, n. 2.2, p. 40-45 (invocando EMILIO BetTI, PETER Gilles, JAIME GUASP e RENZO PROVINCIALI). Se essa defesa é válida para os recursos, em geral, a fortiori é ela aplicável aos recursos excepcionais, construídos sobre a base de ações de impugnação.

${ }^{527}$ ViCENTE GIMENO SENDRA, Derecho procesal civil, vol. 1, n. 32(III), p. 628-629. Embora, diante de sua particular estrutura, o objeto dos recursos excepcionais seja claramente destacado, todos os recursos apresentam causa de pedir e pedidos próprios (i.e., distintos da ação originária, ainda que possa haver coincidência no caso de apelação total), o que autoriza, inclusive, atingir a conclusão de que têm natureza jurídica de pretensões (ou ações) autônomas, exercitadas em simultaneo processu, como prolongamento da mesma relação processual. Nesse sentido, ARAKEN DE ASSIS, Manual dos recursos, n. 2.2, p. 40-45.

${ }^{528}$ CALAMANDREI - FURNO, "Cassazione civile”, n. 22, p. 1070-1071; para um estudo mais aprofundado, ver CALAMANDREI, "Sulla distinzione tra error in iudicando ed error in procedendo", p. 285 e ss.
} 
objeto de julgamento pelo Tribunal de apelação, que decidirá a questão aplicando as normas de direito processual pertinentes (art. 330, I, CPC). Desse modo, eventual recurso especial interposto do acórdão que venha a confirmar a validade da sentença terá por fundamento imediato um error in iudicando do Tribunal, e não propriamente o error in procedendo originário cometido pelo juízo de primeiro grau. Tomando outro exemplo, se o Tribunal deixar de observar formalidade essencial (v.g., deixando de publicar a pauta contendo a data do julgamento e impossibilitando, com isso, a realização de sustentação oral), estará ele mesmo deixando de observar as normas que regulam a sua atividade e, assim, o recurso especial interposto terá como fundamento direto um vício de procedimento. As duas situações são, como visto, nitidamente diversas, ${ }^{529}$ ainda que em ambas o provimento do recurso especial leve à anulação da decisão recorrida: na primeira hipótese, cassado o acórdão, os autos devem retornar ao juiz de primeiro grau para que produza a prova requerida e julgue a causa novamente; na segunda, bastará que o Tribunal proceda ao novo julgamento, sem incorrer, desta vez, em vício de forma.

II) Deixando de lado a ampla discussão doutrinária sobre os contornos exatos da causa de pedir - especialmente diante da distinção comumente feita entre direito auto e heterodeterminado - é suficiente apontar, nessa sede, que toda pretensão deve ser fundada, e que a causa petendi representa justamente o fato ou conjunto de fatos a partir dos quais se extraem as conseqüências jurídicas almejadas. ${ }^{530}$

A causa de pedir do recurso especial - isto é, o fundamento de sua pretensão - é a questão de direito federal infraconstitucinoal nele suscitada. ${ }^{531}$ Consoante esteja à base de um pedido de reforma ou de anulação da decisão será representada, respectivamente, ao menos via de regra, por uma norma de direito material ou direito processual.

\footnotetext{
${ }^{529}$ Essa observação é de grande importância para que se compreenda corretamente a exigência de préquestionamento da questão federal. No caso de error in procedendo cometido pelo Tribunal, não há sentido em exigir que a questão veiculada como causa de pedir do recurso especial tenha sido decidida no acórdão recorrido, uma vez que diz respeito à própria validade do julgado, constituindo um elemento formal externo ao julgamento. Por outro lado, se foi o juiz em primeiro grau quem deu origem ao vício de procedimento, a questão teria de ser devolvida ao Tribunal por meio do recurso de apelação, cabendo exigir, nesse caso, que tenha sido decidida (i.e., pré-questionada) no acórdão recorrido.

${ }^{530}$ Nesse sentido, BARBosa MOREIRA, O novo processo civil brasileiro, p. 17; CRUZ E TUCCI, A causa petendi no processo civil, n. 1.3.3, p. 26 e n. 4.16, pp. 209-210; CARLOS AlBERTO AlVARO DE OLIVEIRA DANIEL MitidiERO, Curso de processo civil, vol. 1, § 36, p. 151.

${ }^{531}$ Por todos, CRUZ E TUCCI, A causa petendi no processo civil, n. 4.27, p. 285.
} 
Ao contrário do que tem sido afirmado por parcela da doutrina, ao Superior Tribunal de Justiça também é aplicável o princípio iura novit curia. Isso implica, na prática, que uma vez narrada a violação à questão de direito federal (ou a divergência atual entre julgados), o Tribunal não está adstrito ao permissivo constitucional invocado pela parte, quando entenda que o mesmo é equivocado, podendo conhecer o recurso por outro motivo. $^{532-533}$

Essa afirmação, contudo, não deve ser confundida com problema inteiramente diverso respeitante ao efeito devolutivo do recurso especial (sobre o qual, v., infra, $\S 8^{\circ}$ ), delimitado pela causa de pedir (questão federal invocada) e pelo respectivo pedido (cassação ou reforma do julgado). O que se quer dizer, aqui, é que o juízo de admissibilidade do recurso especial pode enquadrar a situação narrada pelo recorrente em fundamento jurídico diverso daquele invocado erroneamente pela parte, à luz dos incisos do art. 105, III, CF.

\subsection{HiPÓTESES DE CABIMENTO}

Assim como ocorreu, a partir da Constituição de 1988, com o recurso extraordinário, o recurso especial tem as suas hipóteses de cabimento delineadas de forma integral no próprio texto constitucional. Isso impede que a legislação infraconstitucional e, a fortiori, disposições regimentais do Superior Tribunal de Justiça, ampliem ou restrinjam o cabimento do recurso, ${ }^{534}$ afastando-se a sistemática atual da orientação da Carta anterior, que permitia ao Supremo Tribunal Federal a estipulação de outros requisitos para admissão do extraordinário por meio de seu regimento interno (art. 119, §1 ${ }^{\circ}$ ). À legislação é

\footnotetext{
${ }^{532} C f$. BARBosa MoReIRA, "Considerações sobre a causa de pedir na ação rescisória", n. 7, p. 210-211 (tratando da rescisória, mas em lição inteiramente aplicável aos recursos excepcionais); CRUZ E TUCCI, $A$ 'causa petendi' no processo civil, n. 4.27, p. 286; EDUARDO RIBEIRO DE OLIVEIRA, "Recurso especial algumas questões de admissibilidade", n. 3, p. 188-189. No direito italiano, embora existam decisões da Corte de Cassação em sentido contrário, a doutrina dispensa a indicação específica do dispositivo ao qual se subsume o vício denunciado, quando este possa ser extraído das razões do recurso. Nesse sentido, v. ROBERTO POLI, "Il giudizio di cassazione dopo la riforma", n. 4, p. 14.

${ }^{533}$ Contra, Pontes de MiRanda, Comentários ao Código de Processo Civil (de 1973), t. VIII, p. 28, embora, em outra passagem, admita justamente que "deve o Supremo Tribunal Federal tomar conhecimento do recurso com o fundamento que é o próprio da espécie. Iura novit curia" (op. cit., p. 30); categoricamente, RODOlFo DE CAMARGO MANCUSO, Recurso extraordinário e recurso especial, n. 6.1, p. 314-315 e nota 174.

${ }^{534}$ Barbosa Moreira, Comentários ao Código de Processo Civil, 14. ed., Rio de Janeiro: Forense, 2008, v. 5, n. 319, p. 587; já POnTES De MIRANDA, Comentários ao Código de Processo Civil (de 1973), tomo VIII, p. 60-61.
} 
permitida somente a regulação de questões procedimentais, como o prazo ou a exigência de preparo; ao Regimento Interno do Superior Tribunal de Justiça, somente a regulamentação das matérias indicadas no art. $96, \mathrm{I}, a, \mathrm{CF}^{535}$

\subsubsection{AlíNEA "A"}

O cabimento pela letra $a$ - que permite a interposição do recurso quando a decisão "contrariar tratado ou lei federal, ou negar-lhes vigência" - não apresenta dificuldades teóricas ou práticas. Ainda que tenham havido intensas discussões sobre ela no passado, os três debates antigos sobre o cabimento pela alínea $a$ hoje não mais se colocam na pauta do dia. São eles, basicamente, I) a confusão entre admissibilidade e mérito do recurso, II) a natureza da violação à lei exigida para a sua interposição e III) o enunciado n. 400 da Súmula Supremo Tribunal Federal. Cabe, por isso, fazer apenas uma breve menção a esses temas.

I) Do ponto de vista da técnica de julgamento, parece ter sido definitivamente assentado - após repetidas manifestações doutrinárias do Prof. BARBOSA MOREIRA - que, apesar da redação da letra $a$ não descrever um tipo neutro (tal como as alíneas $b$ e $c$ ), juízo de admissibilidade e juízo de mérito não se confundem. Para superar a etapa preliminar consistente em conhecer do recurso, basta a alegação de violação à lei federal (somada, é claro, aos demais pressupostos de cabimento - gerais e específicos); a verificação efetiva de sua ocorrência integra já o juízo de mérito. O recurso, por isso, pode ser conhecido e desprovido, não sendo obrigatório, para admiti-lo, que se lhe dê provimento. ${ }^{536}$

\footnotetext{
${ }^{535}$ ARAKEN DE ASSIS, Manual dos recursos, n. 92, p. 776.

${ }^{536}$ Consultem-se, nesse sentido, as seguintes obras e ensaios do autor: Comentários ao Código de Processo Civil, vol. 5, n. 319, p. 588-589, n. 320, p. 592 e n. 336, p. 630-633; "Juízo de admissibilidade e juízo de mérito no julgamento do recurso especial", p. 163 e ss.; "Questões de técnica de julgamento nos Tribunais", n. 4, p. 290-293; Ver, ainda, NELSON NERY JR., "Aspectos da teoria geral dos recursos no processo civil”, n. 3, p. 157. Na doutrina estrangeira, apontando a relação de subordinação existente entre os dois juízos, Othmar JAUERnig, Direito processual civil, §72/IV, p. 362-3. Contra, por todos, OSMAR MENDES PAIXÃO CÔRTES, "O cabimento do recurso extraordinário pela alínea 'a' do art. 102, III, da Constituição Federal e a "causa de pedir aberta"”, n. 1, p. 246. Alguns autores (v.g., FLÁvio CHEIM JorGE, Teoria geral dos recurso cíveis, n. 4.2, p. 43-44 e, adiante, n. 6.3, p. 86-87) buscaram posições intermediárias - rechaçando a orientação criticada dos Tribunais Superiores, mas afirmando não ser suficiente a mera alegação de causa de pedir correspondente a um dos fundamentos legais do recurso para que o mesmo seja admitido -, destacando o "grau de cognição exercida pelo órgão julgador" como critério idôneo a diferenciar o juízo de admissibilidade e o juízo de mérito. ${ }^{536}$ Tal entendimento, entretanto, acaba por conduzir aos mesmos equívocos da orientação consagrada pelo enunciado da Súmula, ignorando que os juízos de admissibilidade e mérito se diferenciam do ponto de vista qualitativo, justamente porque têm objetos distintos, e não apenas
} 
II) Por sua vez, carece de sentido atual a discussão sobre o sentido das expressões "negar vigência" e "contrariar" lei federal. É irrelevante saber se o erro alegado decorre de negativa expressa de vigência (violação ao direito em tese) ou mera interpretação/aplicação incorreta da norma. ${ }^{537}$ Como coloca, de maneira muito simples e didática, o legislador alemão, "o direito é violado quando uma norma jurídica é aplicada incorretamente" (§ $546, \mathrm{ZPO})$.

III) Por fim, é certo haver sido superada a orientação contida no verbete n. ${ }^{\circ} 400$, Súmula/STF. Ela representava o paradigma então reinante a respeito da função do recurso extraordinário: não se buscava formular uma norma de alcance geral por meio de um precedente, escolhendo e fixando um dentre vários sentidos possíveis do texto legal, mas apenas controlar ex post a legalidade da específica decisão recorrida, tolerando-se, por isso, a interpretação razoável. ${ }^{538}$ Além do mais, o verbete era é uma clara resposta à "crise do Supremo", buscando um expediente para julgar de forma mais rápida uma série de recursos extraordinários versando questões de direito federal infraconstitucional, simplesmente inadmitindo os mesmos.

Por isso, o verbete 400 da Súmula não se concilia com a função dos Tribunais Superiores e, segundo a esmagadora maioria da doutrina, não foi recepcionada pela Constituição da República de $1988{ }^{539}$ A estes tribunais cabe justamente fixar o sentido dos textos legais (i.e, a norma jurídica), realizando uma obra de estabilização do Direito. Devese ter em mente a distinção entre a possível descrição da equivocidade semântica de um texto legal feita pela doutrina - que reconhece, então, a possibilidade de interpretar-se um dispositivo de diversas maneiras (interpretação dita cognoscitiva) - da escolha de uma de tais possibilidades pelo órgão judicial, que deve necessariamente solucionar a controvérsia

quantitativamente, ou seja, em relação à profundidade da cognição.

537 Já nesse sentido, v.g., José Frederico MARQUES, Manual de direito processual civil, vol. 3, n. 644, p. 178.

${ }^{538}$ MiChELE TARUFFO, El vértice ambiguo, introd., p. 16 (associando a interpretação razoável com a visão retrospectiva da nomofilaquia).

539 Algo nesse sentido, criticando a inadmissão de recursos extraordinários com base no argumento da interpretação razoável, já PONTES DE MIRANDA, Comentários ao Código de Processo Civil (de 1973), t. VIII, p. 40. Há certo consenso doutrinário em época recente, v.g., ARRUDA ALVIM, “O antigo recurso extraordinário e o recurso especial...", n. VI, p. 156 e ss.; CARlos MÁRIO VELloso, “O Superior Tribunal de Justiça competências originária e recursal", n. 5.4, p. 39-40; EDUARDO RIBEIRO DE OLIVEIRA, "Recurso especial algumas questões de admissibilidade", n. 1, p. 183; JOSÉ SARAIVA, Recurso especial e o STJ, n. 15.3, p. 197206. Mesmo um dos últimos opositores do abandono do emprego do enunciado sumular $\mathrm{n}^{\circ} 400$, considera-o hoje superado (ATHOS GUSMÃO CARNEIRO, Recurso especial, agravos e agravo interno, n. 19, p. 62-63). 
individual, decidindo-a à luz da norma eleita (interpretação dita, por isso mesmo, decisória). ${ }^{540}$

Ou seja, ainda que teoricamente possíveis diversas interpretações reputadas como razoáveis pela doutrina, a atividade jurisdicional - convocada a solucionar um caso e darlhe um desfecho preciso -, deve escolher uma único sentido, dentre os demais, como sendo verdadeiro ou adequado. Se isso é correto do ponto de vista dos litígios individuais, é intuitivo que, em nome do dever de igualdade e da segurança jurídica, deve prevalecer um mesmo entendimento para todos os casos que apresentem as mesmas propriedades jurídicas relevantes: essa uniformização da jurisprudência constitui precisamente a tarefa dos Tribunais Superiores. Não é que só pode haver uma interpretação correta (one right answer), mas que o sistema, em razão do postulado fundamental da igualdade, deve reservar a um órgão de cúpula uma estabilização hermenêutica.

Confirmando a orientação, tem-se afirmado, na Corte, que "a Súmula 400 STF é incompativel com a teleologia do sistema recursal introduzido pela nova Carta Magna", ${ }^{541}$ embora, excepcionalmente (e mesmo em tempos recentes, para perplexidade dos jurisdicionados), sejam encontradas decisões isoladas valendo-se do enunciado sumular superado. ${ }^{542}$

\subsubsection{ALÍNEA "B"}

O permissivo da letra $b$ dispõe, hoje, que cabe recurso especial contra a decisão que "julgar válido ato de governo local contestado em face de lei federal". No entanto, nem sempre foi assim. Antes da EC 45/04, a alínea contemplava também a hipótese da lei local que contrariasse lei federal. Com a modificação do texto da Constituição, foi ela transferida para o art. 102, III, c, CF, passando a integrar a competência do Supremo Tribunal Federal.

\footnotetext{
${ }^{540} C f$. RICCARDO GUASTINI, "Una teoría cognoscitiva de la interpretación”, esp. n. 1, p. 24.

${ }^{541}$ STJ, $2^{\text {a }}$ T., EDcl no REsp 475.378/SP, rel. Min. Francisco PeÇAnha Martins, j. em 25/10/2005, DJ 05/12/2005, p. 271.

${ }^{542}$ STJ, 4a T., AgRg no Ag 1037944/RJ, rel. Min. Fernando GonÇAlves, j. em 15/10/2009, DJe $09 / 11 / 2009$.
} 
A doutrina recente destacava, mesmo antes da modificação de competências operada pela EC 45/04, que a antiga letra $b$ ensejava, na verdade, uma questão constitucional, relativa à distribuição de competência legislativa entre os entes federados. ${ }^{543}$ Algo nesse sentido, PONTES DE MIRANDA afirmara, à luz do texto constitucional de 1967/69, que, na hipótese de decisão que "julga[sse] válida lei ou ato do govêrno local contestado em face da Constituição ou de lei federal”, a conferência seria "mediata, com indispensável questão prévia, que é a de se saber qual a entidade estatal que é competente para edictar, in casu, a regra jurídica". ${ }^{444}$ O problema de repartição de capacidade para legislar, como se sabe, é justamente o objeto das regras de competência prevista na Constituição; daí, em princípio, a natureza constitucional da questão.

A fim de ilustrar essas particularidades, diz-se que o atual permissivo do art. 102, III, $c$, CF (competência do Supremo Tribunal Federal, à luz da alteração promovida pela EC 45/04), envolve uma "questão constitucional complexa indireta". Constitucional, como já se viu, por depender da atribuição de poder por regras constitucionais de competência legislativa. Complexa, por reclamar um exame de compatibilidade entre normas (e não a mera interpretação de uma norma isoladamente). Indireta, por fim, já que o exame da conformidade ao texto constitucional é mediado pela distribuição de competências (e não efetuado diretamente entre o ato impugnado e a Constituição). ${ }^{545}$

Ainda que, em teoria, o conflito entre lei local e lei federal não envolva sempre uma questão puramente de distribuição de competências, o texto constitucional é claro em atribuir a hipótese ao Supremo Tribunal Federal.

Por sua vez, é de escassa relevância prática a hipótese de ato governo local contestado em face de lei federal. Entre os exemplos que podem ser apontados, destaca-se julgado em que se debateu conflito entre os poderes de polícia estadual e da União a respeito da fiscalização de experimentos com organismos geneticamente modificados. ${ }^{546}$

\footnotetext{
543 RoQUe CARRAZZA, "Do recurso extraordinário e do recurso especial”, n. 9, p. 56; CARLOS MÁRIO VELLOSO, "O Superior Tribunal de Justiça - competências originária e recursal”, n. 6, p. 40-42.

${ }^{544}$ Comentários ao Código de Processo Civil (de 1973), tomo VIII, p. 116.

${ }^{545}$ A construção é da doutrina argentina: veja-se AUGUSTO M. MORELLO, "Recursos extraordinarios: visión comparada brasileña y argentina”,n. 2.3, p. 14-15. Entre nós, reproduzem a lição JOSÉ MIGUEL GARCIA MEDINA, "Variações recentes sobre os recursos extraordinário e especial", n. 4, p. 1056; BRUNO DANTAS, Repercussão geral, n. 4.2.2.1.2, p. 166-167 (falando simplesmente em questões constitucionais indiretas).

${ }^{546}$ Lembrado por ARAKEN DE ASSIS, Manual dos recursos, n. 92.2.3, p. 790 (STJ, 1ª T., Resp 592.682/RS,
} 


\subsubsection{AlíneA “C"}

A alínea $c$ permite a interposição do recurso especial quando a decisão do tribunal de segundo grau "der a lei federal interpretação divergente da que lhe haja atribuido outro tribunal'. Ela visa, claramente, à uniformização da interpretação do direito federal infraconstitucional, buscando estabelecer precedentes para compor, a partir desse marco temporal, divergências surgidas nas instâncias a quo. Seus requisitos são, basicamente: I) o cotejo analítico entre as decisões contrastadas; II) a atualidade da divergência; III) a diversidade dos tribunais envolvidos, não se prestando o recurso especial a solucionar divergências internas (verbete . $^{\circ} 13$, Súmula/STJ).

Discute-se em doutrina se a alínea $c$ configura hipótese de cabimento autônoma, que possa ensejar a propositura do recurso especial por si só, ou se é dependente de alegação de violação à lei federal, nos termos da alínea $a$, da qual seria, então, apenas uma forma de demonstração ou um "reforço" argumentativo.

A maior parte da doutrina contemporânea entende - a meu ver, corretamente - que a alínea $c$ é apenas uma espécie particularizada de manifestação do cabimento pela letra $a$, havendo sobreposição entre os dois fundamentos. ${ }^{547-548}$ Aliás, já se manifestara nesse

rel. Min. Denise ARRUDA, j. em 06.12.2005, DJ 06.02.2006, p. 200).

547 ARAKen de Assis, Manual dos recursos, n. 92.2.4, p. 790; José Miguel Garcia Medina, Prequestionamento e repercussão geral, n. 2.3.3, p. 85-87; ID., "Variações recentes sobre os recursos extraordinário e especial", n. 4, p. 1057; DANILO KNIJNIK, $O$ recurso especial e a revisão da questão de fato..., n. 3.5.4, p. 202, nota 97; RAFAEL BICCA MACHADO, Recurso especial, cap. 3, n. 2, p. 93-94.

${ }^{548}$ São isoladas as vozes em contrário. GILBERTO BRUSCHI alega haver casos - de lacunas da lei - em que não se pode afirmar existir uma violação a dispositivo legal em qualquer das interpretações divergentes, o que inviabilizaria o exame pela letra $a$, por parte do STJ, da matéria. Em seguida, dá como exemplo a polêmica instaurada em torno do art. 475-J do CPC. Contudo, o próprio autor citado rotula uma das possíveis interpretações como equivocada, o que faz ruir a sua tese, demonstrando que o provimento do recurso pela alínea $c$ depende, em última análise, da constatação de contrariedade à lei federal no acórdão recorrido: "Defendendo a possibilidade de citação na pessoa do advogado do embargado estão alguns julgados, que, apesar de equivocados, não pode tal interpretação ser configurada em uma das situações elencadas na letra $a$ do permissivo constitucional" ("Recurso especial fundado em divergência jurisprudencial", n. 2, p. 115-116grifou-se). Mais adiante, o autor acaba por confirmar novamente a posição contrária ao admitir que, na configuração do dissídio, caberá ao recorrente sustentar "as razões pelas quais entende que a interpretação correta é a do acórdão divergente e não aquela proferida pelo tribunal a quo" (op. cit. n. 3, p. 118). Tal posicionamento não leva em conta o abandono das teorias exegéticas, que defendiam a existência de uma interpretação única e exata da lei, passível de mera dedução por parte do intérprete, que assim descobria um significado latente no texto. Sabendo-se que a interpretação deve ser amparada por boas razões e que não existe, a priori, uma reposta correta, perde relevância a argumentação no sentido de haver casos em que paira uma dúvida sobre o sentido de determinado dispositivo: nestas hipóteses, como em todas as outras, caberá ao Superior Tribunal de Justiça (em sede de legislação federal infraconstitucional) uniformizar a interpretação, 
sentido AlFREDo BuZAID, ao dizer que "não é legítimo invocar, como fundamento autônomo do recurso, a circunstância de haver outro tribunal dado interpretação diversa ao direito", devendo-se alegar sempre a violação, decorrendo daí que o recurso fundado na divergência "ou dá lugar a um recurso artificial ou se reconduz à hipótese da letra 'a"”. 549

LiEBMAN, por sua vez, afirmara que "a decisão errônea, e não a decisão divergente, é que se deve fulminar", ${ }^{550}$ querendo com isso indicar justamente o ponto aqui afirmado. E, em verdade, o permissivo em questão (letra $c$ ) sequer é idôneo a assegurar a uniformidade de decisões, na medida em que - sendo reconhecido que a decisão recorrida é acertada e o paradigma equivocado - este não será modificado ou extirpado do mundo jurídico. ${ }^{551}$

A conclusão apontada também se justifica pelo prisma histórico. Como foi visto (supra, $\S 2^{\circ}$ ), o surgimento do recurso por dissídio jurisprudencial, no direito brasileiro (com a Reforma de 1926), visou a permitir a interposição do recurso extraordinário fora da hipótese restrita de "negativa de vigência" da lei federal, tal como interpretada na época. E, se algum sentido teve, ulteriormente, na defesa da alínea $c$ como hipótese autônoma de cabimento nas Constituições anteriores - já que, então, o recurso teria de ser conhecido com base na divergência, independentemente da razoabilidade da interpretação adotada (refiro-me ao enunciado n. $^{\circ} 400$ da Súmula/STF) -, parece hoje ter perdido relevância a questão. $^{552}$

O próprio Supremo Tribunal Federal, logo após o início da vigência da Constituição de 1988 - texto que, como se sabe, reservou a menção ao dissídio jurisprudencial unicamente ao rol de hipóteses de cabimento do recurso especial, e não mais de recurso extraordinário -, já se pronunciou no sentido de que, não obstante não

escolhendo, dentre outros possíveis, o melhor sentido a ser atribuído à norma reconstruída a partir do texto legal.

549 “A crise do Supremo Tribunal Federal”, n. 22-23, p. 154-155. Também EDUARDO RIBEIRO DE OLIVEIRA manifestou-se nesse sentido, observando que consoante a largueza emprestada à letra $a$, o permissivo da alínea $c$ seria, na prática, por aquela absorvido ("Recurso especial - algumas questões de admissibilidade", n. 1, p. 177).

${ }^{550}$ Nas suas Notas a CHIOVENDA, Instituições de direito processual civil, vol. 3, § 80, n. 413, p. 297 , nota 1.

551 Alfredo BuZAID, "A crise do Supremo Tribunal Federal”, in Estudos de direito, São Paulo: Saraiva, 1972, v. 1, n. 23, p. 155-156.

552 Já nesse sentido, EDUARDO RIBEIRO DE OLIVEIRA, "Recurso especial - algumas questões de admissibilidade", n. 1, p. 184. 
constar no art. 102, III, CF, a alegação de dissídio de jurisprudência sobre o tema exclusivamente constitucional pode ser visto como reforço do fundamento pela letra "a". 553

Não obstante a irrelevância da letra $c$ como hipótese autônoma de cabimento, é certo que a divergência entre instâncias inferiores é um indicativo da importância da solução da questão pelo Tribunal de superposição. Contribui, no caso do recurso extraordinário, como argumento a favor do reconhecimento da repercussão geral da questão; acaso implantado semelhante filtro no âmbito do Superior Tribunal de Justiça, as mesmas considerações são válidas.

\subsubsection{COTEJO ANALÍTICO E "DISTINGUISHING"}

Impõe o art. 255, $\S 2^{\circ}$, do Regimento Interno da Corte que sejam mencionadas "as circunstâncias que identifiquem ou assemelhem os casos confrontados" (v. também o art. 541, parágrafo único, in fine, CPC). A exigência é comumente conhecida como o cotejo analítico entre a decisão recorrida e o paradigma invocado, sendo essencial ao conhecimento do recurso com base na letra "c".

A fim de realizar-se o cotejo analítico entre dois julgados, apontando a divergência entre eles existente na aplicação de teses jurídicas, deve-se demonstrar a semelhança relevante entre as situações fáticas subjacentes, às quais foram aplicadas duas normas jurídicas diversas, ou, o que dá no mesmo, duas interpretações diferentes acerca de um mesmo texto normativo.

O permissivo da letra “c”, assim, "introduz no debate a questão da pertinência da divergência", ou seja, dos critérios a serem utilizados na comparação entre os casos, através de uma operação de subsunção que permita enquadrá-los numa mesma classe. ${ }^{554}$ Trata-se de uma operação de subsunção especializadora, ou seja, de uma comparação que leva em conta traços comuns, de forma a permitir o agrupamento de eventos como pertencentes a um mesmo gênero, sem considerar a individualidade ou unicidade dos

\footnotetext{
${ }^{553}$ STF, Pleno, AI 131320 QO, rel. Min. MoreIRA ALVES, j. em 19/04/1989, DJ 28/04/1989, p. 6300.

554 Carlos Alberto Alvaro De Oliveira, “A semelhança no dissídio jurisprudencial para efeitos de recurso especial e embargos de divergência e a lógica”, n. 4, p. 133-4.
} 
acontecimentos. ${ }^{555}$ As particularidades que servem apenas para individualizar um conjunto de circunstâncias fáticas do ponto de vista histórico (ou seja, a utilização de dados de abrangência individual e concreta), são irrelevantes do ponto de vista da unificação do direito (enquanto categoria geral e abstrata) e por isso devem ser ignoradas.

Evidentemente, não se exige que os dois casos sejam idênticos, porquanto uma exata e única conjuntura fática não se repete, mas sim que sejam demonstradas as semelhanças relevantes que permitam assimilar um precedente ao outro, segundo regras de relevância (rules of relevance) ou, em sentido contrário, as justificativas convincentes para a diferença de tratamentos. É esta, aliás, a tarefa de uma teoria dos precedentes: selecionar, dentre as diversas categorizações possíveis para um conjunto de fatos, aquela que se apresentar juridicamente relevante para a solução de outros casos. ${ }^{556}$

Não basta, por isso, sob pena de tornar a questão algo estéril, a mera reafirmação da máxima formal de tratar igualmente os iguais e desigualmente os desiguais, sem indicar que categorias e com qual abrangência devem ser classificados os casos. ${ }^{557}$ Dentre os inúmeros aspectos e particularidades que envolvem cada um dos litígios, deve o intérprete selecionar aqueles relevantes para o desiderato aqui considerado, separando o joio do trigo e identificando, em síntese, se a mesma pergunta jurídica já foi feita e decidida de modo diferente. O crucial, portanto, será verificar a identidade do problema normativo tratado, de maneira diversa, pelo acórdão recorrido e pelo paradigma, critério que não pode ser aferido apenas a partir dos fatos das causas, lembrando que "a identidade dos fatos em si não pode nunca ser critério da identidade do problema". 558

O que interessa, portanto, é que se apresentem comparações entre "quadros fáticos congruentes", identificados então a partir de seus elementos jurídicos (da ratio decidendi ou da premissa maior do silogismo judicial), tendo em vista a finalidade da norma. ${ }^{559} \mathrm{Ou}$,

\footnotetext{
555 CARlos Alberto Alvaro De Oliveira, "A semelhança no dissídio jurisprudencial para efeitos de recurso especial e embargos de divergência e a lógica", n. 4, p. 135.

${ }^{556}$ Sobre isso, v. FredericK SCHAUER, "Precedent", p. 570-572; MELVIN A. EISENBERG, The nature of the common law, cap. 6, p. 65; NEIL DUXBURY, The nature and authority of precedent, cap. 5, n. 2, p. 174-175; Luiz GuILherme MARINONI, Precedentes obrigatórios, cap. 3, n. 2.9, p. 251-253; RoBert AleXY, Teoría de la argumentación jurídica, n. 2.5.1, p. 262; HORST-EBERHARD HENKE, La cuestión de hecho..., § 2(III), p. 25.

${ }^{557}$ FREDERICK SCHAUER, "Precedent", p. 596.

${ }^{558}$ CASTANHEIRA NEVES, $O$ instituto dos “assentos”..., cap. 2, p. 50-51.

559 CARlos Alberto Alvaro DE Oliveira, “A semelhança no dissídio jurisprudencial para efeitos de recurso especial e embargos de divergência e a lógica", n. 4, p. 136-138. É importante observar que a finalidade da norma, além de permitir a comparação da divergência para fins de admissibilidade recursal, será
} 
ainda, em outras palavras, determinar os elementos recorrentes, e não únicos, da condição humana, que possam interessar na medida em que permitam a generalização de uma regra jurídica. ${ }^{560}$

Equivocam-se, por isso, decisões do Superior Tribunal de Justiça que deixam de reconhecer a divergência diante de alterações fáticas irrelevantes entre os casos comparados. Além do mais, meras exigências (jurisprudenciais) ligadas à regularidade formal da peça recursal e de sua redação não devem frustrar a análise do mérito do recurso, se for possível, à luz da peça, vislumbrar a divergência relevante entre o acórdão recorrido e o paradigma invocado pelo recorrente. ${ }^{561}$

\subsection{QUESTÃo DE DIREITO E QUESTÃo DE FATO}

\subsubsection{ANÁLISE TEÓRICA}

\subsubsection{UMA DISTINÇÃO CONCEITUAL ARTIFICIAL}

A solução de uma controvérsia jurídica (de um caso ou de uma "causa", para utilizar a expressão empregada pela nossa Constituição) envolve sempre uma situação fática e uma regulação normativa, entrelaçadas justamente pelo problema específico que se coloca na forma de uma pergunta.

Nesse sentido, é evidente que um dado acontecimento da vida só se torna relevante para o Direito na medida em que notas correspondentes a algum (ou alguns) de seus aspectos sejam descritas como pressuposto da incidência de uma norma jurídica. Esta, por sua vez, depende do preenchimento concreto deste seu "suporte fático" (fattispecie, Tatbestand) para que incida, seja aplicada e produza seus efeitos programados (daí o aforisma ex facto oritur ius).

invocada também no juízo de mérito do recurso, como fator determinante da interpretação que deverá prevalecer (op. cit.. p. 139). No mesmo sentido, à luz dos recursos de casación por infração da doutrina legal do Tribunal Supremo ou divergência entre as Audiencias Provinciales, ver VicEnTE GIMENO SENDRA, Derecho procesal civil, vol. 1, n. 32(IV), p. 639.

${ }^{560}$ FREDERICK SCHAUER, "Precedent", n. 39, p. 602.

561 Trata-se de noção que encontra guarida na idéia-chave de colaboração no processo civil, aplicada especificamente ao direito recursal, $c f$. DANIEL MiTIDIERO, Colaboração no processo civil, p. 152. 
A teoria tridimensional do direito, tão difundida entre nós pela autoridade de Miguel ReAle, destaca justamente essa indissociabilidade dos elementos fático e normativo, realçando, ainda, o aspecto axiológico que governa a positivação da norma jurídica e a valoração das condutas humanas. Fato, valor e norma, nessa medida, "não existem separados um dos outros, mas coexistem numa unidade concreta". 562

Por isso, sabe-se que a representação tradicional do raciocínio jurídico através de um esquema subsuntivo mecânico - por meio do qual o juiz, diante da premissa menor (fatos) e da premissa maior (norma), seria levado a uma unívoca conclusão (decisão do caso) por meio de uma dedução quase que automática - é demasiadamente simplista, ignorando justamente o problema fundamental que se traduz na escolha das premissas indicadas. ${ }^{563}$ Quais fatos são relevantes? Qual é o texto legal aplicável ao caso? Quais são, ainda, o sentido e os efeitos programados da norma reconstruída a partir do texto? Todas essas perguntas - cuja importância não se pode negar - não encontram justificativa na estrutura singela do silogismo.

Sem adentrar a longa discussão que o tema propicia, é suficiente apontar que separar nitidamente os fatos (como objeto da premissa menor) e as normas concretamente aplicáveis (como componente da premissa maior) é operação que pode apresentar grande dificuldade - senão mesmo ser considerada impossível - do ponto de vista da metodologia jurídica e da teoria da decisão judicial. ${ }^{564}$ Ainda que se admita que a subsunção possa, em tese, retratar de maneira lógica e ordenada o desfecho do processo (como uma representação a posteriori ou ex post facto do raciocínio judicial), ela certamente não

\footnotetext{
${ }^{562}$ Miguel Reale, Lições preliminares de direito, 22. ed., São Paulo: Saraiva, 2005, cap. VI, p. 65. O autor, contudo, cede à tendência metodológica de empregar importância dogmática à dicotomia fato-direito, em especial para fins de qualificação do que seria "direito em tese" e do que seriam "questões de direito" passíveis de revisão em sede de recursos excepcionais (op. cit., cap. XVI, p. 207-208). A clássica obra de JOSÉ AFONSO DA SILVA contém um capítulo denominado justamente "fato, valor e norma no recurso extraordinário" (Do recurso extraordinário no direito processual brasileiro, n. 49-60, p. 115 e ss.), no qual se destaca que, "[em] verdade, não se pode separar fato e Direito, pois êste é, como vimos, objeto tridimensional, porque integrado de fato, valor e norma" (op. cit., n. 53, p. 125).

${ }^{563}$ Cf. Richard Posner, Problemas de filosofia do direito, esp. n. 1, p. 73 e n. 6, p. 271; CHAÏM PERELMAn, Ética e direito, n. 46, p. 572; AlEKSANDER PECZENIK, On law and reason, n. 1.3, p. 29; ALOIS TROLLER, Dos fundamentos do formalismo processual civil, § 2, p. 21; CASTANHEIRA NEVES, $O$ instituto dos 'assentos' e a função jurídica dos Supremos Tribunais, cap. 2, p. 183-185. Na doutrina brasileira, v. HUMBERTO ÁvILA, "Subsunção e concreção na aplicação do direito", n. 1, p. 421-429.

${ }^{564}$ Essa dificuldade já havia sido percebida, em larga medida, por CALAMANDREI, La casación civil, tomo III, esp. n. 103-105, p. 287-302 (ressaltando a complexidade da formação da sentença judicial através de uma cadeia de silogismos concatenados não uniformes, de modo que nem todo erro cometido na premissa maior poderia dizer-se de direito nem todo erro encontrado na premissa menor seria necessariamente de fato). Apesar dessa percepção, essa doutrina foi criticada como "formalista" e amesquinhadora da função do juiz por JoSÉ AFONSO DA SILVA, Do recurso extraordinário no direito processual brasileiro, n. 54, p. 128-129.
} 
demonstra o iter que conduz a essa solução. Deixa de lado, portanto, elementos fundamentais relacionados à interpretação/aplicação do Direito e à fundamentação das decisões judiciais, não considerando, v.g., as noções de pré-compreensão e de círculo hermenêutico (também dito espiral hermenêutico), todas elas etapas essenciais para a seleção dos aspectos "fáticos" e "jurídicos" relevantes ao caso. ${ }^{565}$

Fato e direito não são, portanto, dados indiferentes um perante o outro, mas elementos correlativos, entrelaçados de maneira indissolúvel num único problema jurídico. ${ }^{566}$ De um lado, a determinação dos aspectos fáticos relevantes, isto é, da porção do acontecimento histórico individual que deve ser analisada enquanto objeto de prova e decisão no processo, só é possível diante de uma norma que os singularize a partir de um ponto de vista jurídico (o processo não cuida de fatos brutos); de outro, a escolha e a determinação do sentido da norma passam necessariamente pelo acertamento dos fatos, na medida em que o ato de interpretar está indissociavelmente ligado à aplicação mesma da norma (o juiz não interpreta textos legais desvinculados de um caso). ${ }^{567-568}$

\footnotetext{
${ }^{565}$ A noção de círculo hermenêutico busca explicar as condições necessárias para a compreensão dos problemas jurídicos e pode manifestar-se de diversas maneiras. No que aqui interessa, o círculo hermenêutico refere-se, de um lado, à relação entre a pré-compreensão do intérprete (isto é, a hipótese de trabalho com que se aproxima do problema diante de suas inclinações e conhecimento pessoais) e o texto normativo, com destaque para a contribuição decisiva do sujeito que interpreta (postulado da reflexão); de outro, designa a recíproca consideração das características do fato e das características das possíveis normas correspondentes, num "ir e vir do olhar" (nos dizeres de ENGISCH) que prepara as premissas do silogismo judicial (postulado da completude). Sobre isso, v. ALEXY, "Interpretação jurídica", Direito, razão, discurso (trad. Luís Afonso Heck), Porto Alegre: Livraria do Advogado, 2010, p. 64-65. O autor indica, ainda, um terceiro tipo de círculo hermenêutico, concernente à relação recíproca entre normas individualmente consideradas e o sistema jurídico como um todo, objetivo da interpretação de cunho sistemático (postulado da coerência).
}

${ }^{566}$ Consoante aponta com clareza CERINO CANOVA: "La vita, è stato detto autorevolmente, si svolge senza soluzione di continuità, in una serie infinita di passaggi rigidamente concatenati, con una progressione di cui non è dato individuare l'inizio e la fine. Nemmeno gli abituali criteri di determinazione dello spazio e del tempo posseggono questa attitudine sceveratrice, poiché essi non sono nella reltà ma un modo esterno di contemplare la realtà ed anzi un modo estremamente flessibile, corrispondente agli atteggiamenti dell'osservatore. La realtà si concreta in fatti delimitati non per forza propria, ma in virtù della misura con cui la si riguarda e in particolare dell'interesse per cui la si studia. Sicché, se lo scopo è di formulare conseguenze giuridiche, il diritto è la misura della consistenza e della distinzione di ogni specifico evento" ("La domanda giudiziale ed il suo contenuto", Commentario del Codice di Procedura Civile (coord. Enrico Allorio), Torino: UTET, 1980, libro II, t. I, n. 21, p. 188-189 - grifei).

${ }^{567}$ A doutrina contemporânea é praticamente uníssona. Remete-se o leitor, primordialmente, às seguintes obras e ensaios para o trato aprofundado do tema: CASTANHEIRA NEVES, Questão-de-facto - questão de direito..., passim, mas esp. o $\S 1$, p. 42-45; ID., "A distinção entre a questão-de-facto e a questão-dedireito...", passim, mas esp. n. 1, p. 510-512, 517 e 521-522; ID., O instituto dos 'assentos'..., p. 45 e ss.; Michele TARUfFo, La prueba de los hechos, cap. II, esp. n. 2.1, p. 96-105; RonAlD J. AlleN - MichaEL S. PARDO, "The myth of the law-fact distinction", p. 1769 e ss. Na doutrina processual, ver SERGI GUASCH FERNÁNDEZ, El hecho y el derecho en la casación civil, passim, mas esp. p. 183; DANILO KNIJNIK, O recurso especial e a revisão da questão de fato..., esp. n. 1.2, p. 13-46; OvíDIO A. BAPTISTA DA SILVA, “QQuestão de fato’ em recurso extraordinário”, p. 499; CARLOS AlBerTo Alvaro DE OliveIRA, Do formalismo no processo civil, n. 20.3, p. 210; JOSÉ AFONSO DA SILVA, Do recurso extraordinário no direito processual brasileiro, n. 53, p. 125; ADOLFO GELSI BIDART, "Presentación comparativa de dos casaciones en Uruguay", 
Não obstante as observações antecedentes, a tradicional distinção metodológica entre questões fáticas e questões jurídicas é largamente empregada no discurso jurídico, inclusive (e principalmente) para delimitar o cabimento do recurso especial (e do recurso extraordinário) e as respectivas fronteiras da atividade cognitiva exercida pelo Superior Tribunal de Justiça (e pelo Supremo Tribunal Federal). Os Tribunais Superiores só se ocupam, ninguém ignora, de quaestiones iuris. A orientação, a par de sua acolhida em doutrina, é reafirmada pela jurisprudência e pela própria Súmula das respectivas Cortes de superposição (enunciados de n. ${ }^{\circ} 5$ e 7 do STJ; enunciados de n. 279 e 454 do STF), que consagram, assim, uma "metodologia lógico-conceitual", seguindo uma teoria antiga e tradicional na literatura sobre os Tribunais de cassação e revisão. ${ }^{569}$

Da dissociação entre discurso e prática resulta uma inevitável tensão. O critério de admissibilidade do recurso especial com base na summa divisio é, desta forma, altamente questionável, devendo ser rejeitadas explicações apriorísticas que procurem estabelecer uma diferenciação definitiva no âmbito ontológico (o que é "fato" e o que é "direito"), epistemológico (como conhecemos os "fatos" e o "direito") ou simplesmente de uma metodologia jurídica geral. ${ }^{570}$ A doutrina especializada destaca que a crença em uma

n. 28, p. 130-131. Embora a plena consciência da inviabilidade prática da distinção fato-direito seja premissa cuja aceitação generalizada é recente, cabe lembrar que nesse sentido já haviam se pronunciado, quando da adoção de uma Corte de Cassação no território de Lombardo-Veneto, em 1860, os defensores de um modelo de terceira instância, nos moldes do projeto então apresentado pela Comissão Cassinis ( $c f$. MiCHELE TARUFFO, El vértice ambiguo, $\S 1$, n. 4, p. 46-47). Mesmo aqueles juristas que defendem a possibilidade de distinguir, na lógica da decisão, a definição de "o que ocorreu" daquilo "que deve ser feito a esse respeito", assentando a distinção fato-direito sobre outros pares conceituais (ser-dever-ser, descrição-prescrição etc.), reconhecem que a distinção não pode explicar de maneira adequada a distribuição de competências para conhecer questões de fato e questões de direito, tal como ocorre na instituição do júri norte-americano; v.g., FREDERICK SCHAUER, Thinking like a lawyer, n. 11.1, p. 205.

${ }^{568}$ Contra, por todos, HORST-EBERHARD HeNKE, La cuestión de hecho..., § 5, p. 151 e ss.

569 DANILO KNIJNIK destaca a opção pelo "método lógico-conceitual" - cujo desenvolvimento se deve sobretudo a MANNHEIM e POHLE - feita pelo enunciado da Súmula, embora a praxis do Tribunal acabe desmentindo a suposta tomada de posição. A proposta conceitual, em verdade, é impraticável do ponto de vista da teoria hermenêutica e encontra obstáculo intransponível diante dos chamados conceitos indeterminados (ver, sobre isso, o seu $O$ recurso especial e a revisão da questão de fato..., n. 3.2.1, p. 116124).

${ }^{570}$ Para uma exposição profunda e detalhada dessas diversas perspectivas, ver, mais uma vez, CASTANHEIRA NEVES, "A distinção entre a questão-de-facto e a questão-de-direito...", n. 1, p. 483-523. O mesmo autor deixa clara a autonomia do problema do objeto do recurso excepcional em relação ao problema geral (lógico, metodológico, epistemológico) da questão-de-fato - questão-de-direito, afirmando que "o fundamento daquela delimitação [do objeto do recurso] ter-se-á de encontrar imediatamente, a apenas no fim institucional e na função jurídico-processual do recurso, e o seu critério unicamente também nos termos jurídico-positivos e processuais em que esse fim e função foram instituídos" (op. cit., n. 2, p. 524). 
suposta distinção de validade geral, a ser obtida a partir de uma investigação científica de enfoque unitário, é capaz apenas de conduzir a incertezas. ${ }^{571}$

Existem, evidentemente, casos em que a (im)possibilidade de revisão da questão como sendo, respectivamente, "de fato" ou "de direito" - não se discute, por serem hipóteses extremas e convencionalmente aceitas como tal. Assim, v.g., ninguém razoavelmente negará que a constatação de que "um automóvel trafegava a $100 \mathrm{~km}$ por hora" ou de que "chovia no momento do acidente" é uma questão "fática" (rectius, que não interessa ao reexame por um Tribunal Superior); por outro lado, é seguramente "jurídica" (rectius, passível de revisão por um Tribunal Superior) a afirmação de que, em princípio, "qualquer condutor está obrigado a obedecer aos limites máximos de velocidade sinalizados para a via”. Nessas hipóteses, há verdadeiro consenso doutrinário e jurisprudencial, e o problema, nessa medida, sequer chega a colocar-se. Mas o dilema logo reaparece se indagarmos acerca da natureza de uma questão nos moldes da seguinte: o automóvel guardava a "distância de segurança" em relação aos demais veículos, considerando "a velocidade e as condições do local, da circulação, do veículo e as condições climáticas" (cf. preconiza o art. 29, II, Código de Trânsito Brasileiro)? Nesse - e em inúmeros outros casos - a distinção convencional torna-se confusa e, mais do que isso, imprestável, de modo que a solução para o problema da admissibilidade do recurso especial deve ser buscada com base em outros critérios. Se isso é verdade, o que realmente interessa é a compreensão de quais sejam exatamente esses "outros critérios", e não a insistência num par conceitual - ainda que seja temperada a sua rigidez pela constatação de um grupo intermediário de questões (ditas mistas) - que não se presta a resolver as situações problemáticas. ${ }^{572}$

\footnotetext{
${ }^{571} C f$. CASTANHEIRA NEVES, “A distinção entre a questão-de-facto e a questão-de-direito...”, n. 1, p. 489-494, esp. nota 11; MAZZArella, Analisi del giudizio civile di cassazione, 3. ed., Padova: CEDAM, 2003, p. 83. Para RonAlD J. ALLEN - Michael S. PARDO ("The myth of the law-fact distinction", n. II, p. 1790-1797 e p. 1800), com argumentação bastante convincente, fato e direito são ontologicamente equivalentes, na medida em que este último seria, na verdade, uma manifestação fática, algo existente e passível de ser afirmado e submetido a uma verificação de verdade ou falsidade no discurso jurídico. O juiz que ignorasse o texto legal ou precedente pertinente cometeria, assim, um erro fático. Por essa perspectiva, por exemplo, seria correto afirmar que "é um fato" que não incide contribuição previdenciária sobre os valores pagos a título de aviso prévio indenizado, com base em decisões do Superior Tribunal de Justiça (STJ, $2^{\mathrm{a}}$ T., REsp 1198964/PR, rel. Min. MaUro CAMPBell MarQues, j. em 02/09/2010, DJe 04/10/2010).

572 Com essa afirmação, contudo, não se cai na conhecida "falácia" segundo a qual "se não podemos claramente distinguir uma coisa de outra em todos os casos, então a distinção é sem valor ou incoerente" (criticada por FREDERICK SCHAUER, Thinking like a lawyer, n. 8.2, p. 153, nota 15, com apoio em BERTRAND RUSSELL). Na suposta dicotomia "fato-direito", o grupo que se convencionou chamar "questões mistas" não pode ser comparado às hipóteses "limítrofes" de (in)determinação conceitual, como os exemplos repetidos pela doutrina de homens a respeito dos quais seria difícil determinar serem ou não carecas ou de ser o
} 
Uma coisa é, sem dúvida, certa: a indicação da dupla fato-direito não traz um critério seguro para a definição das hipóteses sujeitas à revisão por parte do Superior Tribunal de Justiça; traz, antes de mais nada, um problema de dificílima solução. ${ }^{573}$ Pior do que isso, acaba por mascarar as razões pragmáticas e funcionais que, em verdade, são e devem efetivamente ser sopesadas para admitir ou não a revisão in iure de determinada questão. A conceituação teórica nos diz pouco ou nada e, por isso, dificilmente poder-se-á duvidar do acerto de JOLOWICZ ao ponderar que, por essa perspectiva, "existe pouca, se alguma, diferença entre a afirmação 'a corte pode cuidar apenas de recursos sobre pontos de direito' e a afirmação 'um ponto de direito é um ponto de que pode cuidar um corte que não pode cuidar de recursos sobre pontos de fato"" 574 Gera-se, com essa circularidade, um estado de grave insegurança, em que o juízo de admissibilidade do recurso não dispõe de critérios racionais e intersubjetivamente controláveis, sendo, pelo contrário, dominado por uma "jurisprudência defensiva" errática, imprevisível e, algumas vezes, de aplicação retroativa. Dão conta desse quadro caótico não apenas as intermináveis discussões doutrinárias, mas também os inúmeros precedentes do Superior Tribunal de Justiça, ora

crepúsculo uma manifestação do dia ou da noite. Nesses casos, há apenas o problema da indeterminação segundo um único critério - a quantidade de cabelo ou a intensidade da luz solar, respectivamente. Se assim também fosse quanto ao problema da revisão pelo Superior Tribunal de Justiça, seria possível - em tese reenquadrar a questão mista como sendo "de fato" ou "de direito", o que é negado pela doutrina (v. DANILO KNIJNIK, O recurso especial e a revisão da questão de fato..., n. 3.4.2, p. 160). Antes, no problema da distinção entre "fático" e "jurídico", o que há é uma inadequação do próprio critério; a zona de indeterminação, portanto, não se coloca entre os polos "de fato" e "de direito", mas sim da generalização, repetibilidade e aptidão para a tomada de decisão acerca das questões envolvidas. Da correta afirmação de que "nesse caso [da questão mista], será necessário buscar um conceito jurídico-processual auxiliar, a fim de avaliar, cientificamente, a possibilidade de revisão da matéria em sede de recurso especial" (DANILO KNIJNIK, op. cit., n. 3.4.2, p. 160), já resulta claramente não se tratar esta de uma classificação unívoca das questões (de fato - mista - de direito), porquanto o novo critério importa, evidentemente, um novo modo de classificar. Daí as críticas que podem ser lançadas à teoria tricotômica.

${ }^{573}$ Nesse sentido, aduziu CASTANHEIRA NEVES que remeter o intérprete à distinção em tela é remetê-lo a um problema e, mais do que isso, a um problema sobre o qual pende uma "dúvida radical" ("A distinção entre a questão-de-facto e a questão-de-direito ...”, n. 1, p. 483 e p. 485, nota 1). O autor insistentemente demonstra a confusão gerada - em razão da adoção quase que generalizada de uma perspectiva unitária e reducionista de análise - entre os numerosos problemas diferentes (dogmático, epistemológico, metodológico etc.) que envolvem os pares conceituais fato - direito e questão-de-fato - questão-de-direito, quase sempre tratados “conjunta e indiscriminadamente" nas obras a respeito da cassação e revisão (op. cit., n. 1, p. 513-515). Ademais, demonstra que a distinção entre o fático e o jurídico não se deixa reduzir a um único problema e não pode ser pressuposta em relação a todos os institutos jurídicos específicos nos quais as contraposições entre fato e direito assumem relevo. Basta lembrar que, num sentido dogmático, a qualificação "de fato" é atribuída a relações nitidamente jurídicas, embora de constituição anômala, tais como as "sociedades de fato", para diferenciá-las daquelas relações jurídicas ditas "de direito", em que não se verifica descompasso entre o esquema legal e a prática. Pode-se pensar, ainda, na determinação do direito, enquanto objeto cultural normativo, em oposição ao que não é direito (e seria, nesse sentido, meramente "fático"). Esses pontos de vista são obviamente diversos daquele que se coloca em relação à definição da questão-de-fato - questão-dedireito, no qual a distinção assume um significado metodológico, ligado à estrutura do pensamento jurídico na solução de casos concretos (op. cit., n. 1, esp. p. 497-512).

${ }^{574}$ On civil procedure, cap. 15, p. 303. 
admitindo, ora rejeitando a mesma questão por entendê-la, respectivamente, como questão jurídica ou questão fática.

Não seria despropositado lembrar, a esta altura, que o direito estrangeiro também lida com tais dificuldades: nos Estados Unidos, em que o binômio law-fact apresenta enorme importância - repartindo a competência entre júri e juiz (de acordo com a Seventh Ammendment da Constituição) e delimitando quando e à luz de qual standard ("de novo" ou clearly erroneous) poderá haver revisão dos fatos e do direito por meio de recursos (regra 52(a) das F.R.C.P.) ${ }^{575}$-, a Suprema Corte não hesitou em afirmar que a distinção é, ao menos, "escorregadia", ${ }^{576}$ para não dizer que tem uma "natureza vexatória". ${ }^{777}$ No direito continental, são praticamente intermináveis os debates em torno do que seja "fato" e "diritto", "hecho" e "derecho", "fait" e "droit" etc.

Por isso, é precisa a observação de PETERs segundo a qual "a linha delimitativa entre o revisível e o irrevisível corre em termos inteiramente diferentes daqueles que sugere o par contraditório questão-de-direito - questão-de-fato". ${ }^{578}$

\subsubsection{O SENTIDO TELEOLÓGICO OU FUNCIONAL DA DISTINÇÃO}

A fim de que a distinção fato-direito possa ter algum valor operacional como critério de definição da competência recursal excepcional, é necessário pensá-la especificamente a partir da função exercida pelo Superior Tribunal de Justiça no julgamento do recurso especial, campo que delimita a sua aplicação e o seu valor. ${ }^{579}$ Daí

\footnotetext{
${ }^{575}$ Salvo exceções, a revisão das conclusões ditas fáticas alcançadas pelo júri ou por um juiz inferior, pela Corte ad quem, só pode ocorrer quando se entender que elas foram "claramente equivocadas", cf. a regra 52(a)(6) das Federal Rules of Civil Procedure: "Findings of fact, whether based on oral or other evidence, must not be set aside unless clearly erroneous, and the reviewing court must give due regard to the trial court's opportunity to judge the witnesses' credibility" (grifado). Sobre a regra e o modo pelo qual tem sido aplicada pela Supreme Court, ver JAMES - HAZARD - LEUBSDORF, Civil procedure, § 12.9, p. 770-774.

${ }^{576}$ Thompson v. Keoane, 516 U.S. 99, 111 (1995).

${ }^{577}$ Pullman-Standard v. Swint, 456 U.S. 273, 288 (1982).

578 Citado ("Tat-, Rechts- und Ermessensfragen in der Revisionsinstanz", in Zeitschr. f. d. gesamte Strafrechtswissenschaft, 1938, p. 39) por CASTANHEIRA NEVES, "A distinção entre a questão-de-facto e a questão-de-direito...", n. 2, p. 530.

${ }^{579} C f$., em profundidade, RonAld J. ALLEN - MiChAEl S. PARdo, "The myth of the law-fact distinction", p. 1806. Ver, entre nós, BARBOSA MOREIRA, que já cogitava de "tentar-se uma nova sistematização (...) com apoio em considerações teleológicas" ("Regras de experiência e conceitos jurídicos indeterminados”, n. 6, p. 72); DANILO KNIJNIK, O recurso especial e a revisão da questão de fato..., n. 3.5.4, p. 200; algo nesse sentido, DINAMARCO, "Admissibilidade do recurso especial ou extraordinário e as chamadas questões mistas”, n. 603, p. 895-896. Como se verá, já era essa a opinião, em largas linhas, de SCHWINGE - que defendia uma aproximação teleológica ou funcional ao problema do que deve e do que não deve ser
} 
por que, ao lado do insatisfatório método lógico-conceitual, desenvolveram-se, sobretudo na doutrina alemã, enfoques prático-processuais e teleológicos: ligados, respectivamente, às possibilidades cognitivas do Tribunal Superior e ao exame da questão pelo prisma da finalidade do recurso. ${ }^{580}$

Com efeito, a distinção entre o fático e o jurídico, para fins de delimitação do cabimento dos recursos excepcionais, coloca-se como um problema dogmático relacionado a um instituto específico e, portanto, como um problema institucional-processual, ou seja, como um dado a ser levado em conta apenas enquanto possa servir de parâmetro para a realização ótima da função acometida aos Tribunais Superiores. Em verdade, o que se deve fazer é substituir a equívoca distinção geral "fato-direito" por outra, a ser pensada a partir do papel institucional especifico dos Tribunais Superiores, ainda que se conserve a nomenclatura há muito consagrada - questão-de-fato-questão-de-direito - para designar, respectivamente, o que escapa ou ingressa na competência de tais órgãos jurisdicionais.

Devemos ter em mente que não é a busca por uma suposta pureza da distinção que deve nortear o trabalho da Corte, mas sim o escopo da concreção da unidade do direito por meio dos seus precedentes. Nessa medida, o Superior Tribunal de Justiça deverá conhecer o recurso sempre que sua atuação seja requerida à luz de tal função, "sem muita preocupação se a questão a ser considerada deve, estritamente falando, ser chamada uma questão de direito". 581

Seguindo essa linha de raciocínio, é importante perceber que o fato humano objeto de um problema jurídico apresenta-se sempre como um particular acontecimento histórico - único e irrepetível enquanto fato individual -, mas também, por outro ponto de vista, como uma manifestação de uma "estrutura coletiva" de interesse geral, cuja qualificação transcende aquela ocorrência específica e representa toda uma categoria de casos análogos. Por exemplo, uma coisa é averiguar se, em determinada ocasião específica, certa pessoa

examinado pelo Tribunal de Revisão, sob o prisma da generalização da questão - e de KUCHINKE, para quem, complementando o requisito da generalidade, se deve averiguar também a tipicidade do quadro fático e sua repetibilidade ou relevância para o futuro. Ver, sobre as teorias citadas, as respectivas resenhas críticas de HORST-EBERHARD HENKE, La cuestión de hecho..., § 2/III, p. 21 e ss. (Schwinge), com resumo de p. 30-31, e $\S 2 /$ III, p. 45 e ss. (Kuchinke). Entre nós, há uma descrição em DANILO KNIJNIK, O recurso especial e a revisão da questão de fato..., n. 3.2.2.1, p. 124-128 (Schwinge) e n. 3.2.2.2, p. 128-130 (Kuchinke).

${ }^{580}$ Ver, sobre isso, a ampla exposição dos três "métodos do direito de cassação" (lógico, das possibilidades de agir e teleológico) em HORST-EBERHARD HENKE, La cuestión de hecho..., § 2(I/III), p. 15-54.

${ }^{581}$ RENÉ DAVID, French law, p. 43. O autor cita, em nota de rodapé na mesma página (nota 28), lição de G. MARTY no mesmo sentido: “A Corte de Cassação deve intervir sempre que, em razão do caráter da decisão recorrida, seu julgamento possa ter um efeito geral e ajudar a evitar dificuldades futuras". 
transferiu ao patrimônio de outra um bem por mera liberalidade ou com o intuito de receber uma vantagem recíproca em dinheiro; outra, diversa, é saber se, diante da conclusão num ou noutro sentido para o problema anterior, está configurada uma doação ou uma compra e venda. No segundo caso, há uma classificação do problema sob uma categoria geral. Aos Tribunais Superiores - enquanto órgãos encarregados de conferir unidade ao Direito e, portanto, de buscar uniformizar soluções para situações com base em regras (i.e, prescrições gerais) - caberá, naturalmente, apenas o exame de tais estruturas coletivas. Na perfeita síntese de FERDINANDO MAZZARELLA, trata-se "de uma instituição positivamente organizada a não receber, e, portanto, a colocar de lado os aspectos particulares e individualizantes do juízo jurisdicional, e, correlatamente, a deixar filtrar somente a estrutura coletiva". 582

Em linhas amplas, pode-se dizer que a "questão de direito", para fins de recurso especial, deve ser entendida como aquela apta a individualizar uma categoria jurídica ou um problema de aplicação normativa. Esse, por sua vez, consiste num dado suscetível de repetir-se diante de outros casos análogos ao que se coloca diante do Tribunal no julgamento do recurso, na medida em que a norma aplicada, embora identificada apenas diante do caso concreto, deve prosseguir como um critério decisório de caráter geral para casos futuros. A tônica recai, assim, sobre os aspectos prospectivos da generalização e da repetibilidade da questão, em conformidade com a função objetiva da Corte. ${ }^{583} \mathrm{~A}$ contrario sensu, as questões ditas fáticas abrangem apenas os acontecimentos históricos particulares e individuais do caso, ${ }^{584}$ em relação aos quais a intervenção do Tribunal Superior seria

\footnotetext{
${ }^{582}$ Analisi del giudizio civile di cassazione, p. 84-85. Coerentemente, o autor sustenta que, no juízo de cassação, ocorre uma destorificazione do fato, uma redução à unidade das múltiplas particularidades do acontecimento real, de modo a reconhecer no caso uma categoria (op. cit., p. 86). MISABEL DERZI observa que "a questão individual do caso sub judice esconde sempre uma questão, um problema, uma pergunta geral" (Modificações da jurisprudência no direito tributário, cap. III, n. 10.1, p. 259).

583 Cf. Michele taruffo, La prueba de los hechos, cap. II, n. 2.1, p. 102; HenRy P. Monaghan, "Constitutional fact review", p. 235; WILLIAM C. WhITFORD, "The role of the jury (and the fact/law distinction) in the interpretation of written contracts", p. 932. Entre nós, também analisou o problema pelo ângulo da generalização da questão debatida BARBOSA MOREIRA: "Tem-se de considerar a atitude tomada pelo órgão a quo no puro plano das proposições gerais, dos enunciados suscetíveis de ser emitidos independentemente das características particulares daquele específico pleito" ("Mandado de segurança. Recurso especial", p. 353). Fala-se, por isso, numa "capacidade expansiva" das normas, que lhes possibilita a aplicação no futuro, ainda que distante ( $c f$. ALBERTO VIRGILIO, "La Corte di Cassazione (funzione di legittimità e stile delle sentenze)", n. 3, p. 344.

${ }^{584}$ Note-se que os "fatos" tanto podem dizer respeito ao objeto litigioso quanto ao processo em si mesmo considerado. Pode-se lembrar, como exemplo dessa segunda hipótese, a específica localização de um imóvel para determinação in concreto da competência forum rei sitae, ex art. 95, CPC. É equivocado, por isso, afirmar de maneira absoluta que, enquanto as questões jurídicas podem ser referidas ao mérito da demanda ou à relação jurídica processual, os fatos dizem respeito necessariamente àquele.
} 
predominantemente retrospectiva, algo que não se coaduna com a sua função e deve ser evitado, até porque aquela instância está em piores condições estruturais de proceder ao exame da prova. Tais critérios, observará o leitor atento, já apontam, grosso modo, no mesmo sentido da seleção dos recursos devido à sua importância ou à repercussão geral da questão debatida. E, efetivamente, na falta de um instrumental adequado, os Tribunais de superposição lançam comumente mão da distinção imprecisa entre fato e direito como sucedâneo dessa oportunidade de seleção, qualificando, prima facie, várias questões como sendo fáticas, mas delas conhecendo quando se coloca um problema normativo relevante.

A idéia de conferir destaque ao aspecto geral (ou generalizável) do caso, descartando como irrelevantes - do ponto de vista funcional - as particularidades referidas apenas à situação individual e concreta, era já defendida por SCHWINGE, para quem só seriam reexamináveis as conclusões que pudessem concretizar a unidade do direito e a uniformização da jurisprudência, mediante a edição de "julgamentos-pauta" para decisões futuras. Sua obra "deixa definitivamente de lado o critério da distinção entre questão-dedireito e questão-de-facto, para enunciar antes um critério definido pela distinção entre 'questões de princípio ou de relevo jurídico geral' (Richtlinienfrage $=$ rechtsgrundsätliche Frage) e 'questões do caso concreto' (Frage des Einzelfalls)". 585

Ademais, o critério da generalidade é reforçado pela idéia de uma alocação racional de competências, levando em conta as capacidades do órgão: o juiz inferior - colocado em contato imediato com a causa - está em melhores condições de decidir as particularidades do caso específico; já o Tribunal Superior, justamente por situar-se no vértice da estrutura judiciária, tem aptidão para conferir unidade ao Direito, uniformizando a jurisprudência a partir de seus precedentes. Devem ser sopesadas, assim, as vantagens de respeitar a margem de decisão do juiz com a possibilidade de desenvolvimento do Direito pelo Tribunal.

Não devem ser estranhadas as considerações pragmáticas dessa ordem. Elas são freqüentemente decisivas, no direito estadunidense, para a distribuição de atribuições e responsabilidades entre júri e juiz e para a fixação de standards de revisão recursal. A

\footnotetext{
${ }^{585} C f$. citações de CASTANHEIRA NEVES, “A distinção entre a questão-de-facto e a questão-de-direito...", n. 1, p. 494, nota 11; amplamente, e com visão crítica, HORST-EBERHARD HENKE, La cuestión de hecho..., § 2(III), p. 21-45. O conceito de pauta é de "uma norma geral, ou seja, aplicável a um número qualquer de casos, de direito judicial", tendo equivalência com "a premissa maior da forma silogística"; a questão singular, por sua vez, refere-se à valoração do caso concreto segundo as normas da pauta, guardando correspondência com a premissa menor do silogismo (op. cit., § 2(III), p. 28-29 e nota 66).
} 
credibilidade da testemunha, v.g., é avaliação deixada à discrição (discretion) dos jurados, em razão da importância das impressões colhidas direta e imediatamente à luz da crossexamination, sendo revisada apenas em casos excepcionais (deferential review). Já a fixação de punitive damages, justamente por depender de uma comparação de casos análogos para a melhor avaliação de seu impacto, pode ser revisada amplamante ("de novo" review). ${ }^{586-587}$

É, efetivamente, inevitável que o Superior Tribunal de Justiça acabe exercendo, nessa matéria, uma "autolimitação da competência". ${ }^{588}$ Deve ele optar por intervir para precisar o sentido e o alcance das normas jurídicas, bem como para tipificar - por meio de seus precedentes - grupos de casos e parâmetros de valores, deixando, por outro lado, de conhecer questões de menor alcance, relacionadas tão somente com a situação fática específica do caso. Assim, v.g., deve a Corte renunciar à revisão da questão invocada pelo recorrente quando ela repousar sobre conceitos indeterminados que dependam de regras de experiência e da apreciação de usos e costumes especificamente locais. Parece claro que tais noções dificilmente serão clarificados por uma decisão tomada por um Tribunal de âmbito nacional. ${ }^{589} \mathrm{Na}$ medida em que a ratio reconstruída a partir do texto legal - ainda que esse seja federal - terá aplicação específica diante de circunstâncias locais, não há, em alguma medida, o próprio pressuposto da questão jurídica federal a ser revisada.

\footnotetext{
${ }^{586}$ Ver, v.g., a decisão da Suprema Corte no caso Cooper, em que um dos argumentos utilizados para afirmar a possibilidade de revisão de novo dos valores fixados a título de punitive damages foi justamente ligado a considerações de que a competência institucional das Cortes de Apelação permite uma melhor comparação entre sanções aplicadas a diferentes tipos de casos, ressaltando a necessidade de uniformização [Cooper Indus., Inc. v. Leatherman Tool Group, Inc., 532 U.S. 424, 440 (2001)].

${ }^{587}$ Semelhantes considerações foram reunidas sob o rótulo da "teoria do rendimento ou das possibilidades de julgar" por DANILO KNIJNIK, O recurso especial e a revisão da questão de fato..., n. 3.2.3, p. 130-134. As soluções ali descritas, contudo, recomendam que o acesso à Corte seja reservado para o controle da "zona de certeza' (positiva ou negativa) dos conceitos jurídicos envolvidos", deixando de revisar decisões tomadas com base na margem de apreciação relativa aos casos situados na zona de penumbra dos conceitos. Trata-se de orientação que leva em consideração, em última análise, a gravidade ou evidência do erro como indício de sua revisibilidade. Tal ensinamento discrepa da orientação defendida no texto, desconsiderando que o Tribunal Superior tem como função a uniformização do Direito mesmo (ou ainda com maior razão) nos casos de indeterminação conceitual. Assim, considerações pragmáticas sobre a alocação de competência para decidir não excluem, antes recomendam que se analise também fatores ligados à aptidão para a comparação entre grupos de casos e à necessidade de uniformização e estabilidade do Direito. Ademais, o efeito de seleção dos casos litigados levaria a crer que os casos ditos "fáceis", situados na "zona de certeza", não seriam levados à apreciação dos Tribunais Superiores, o que diminuiria a utilidade prática da teoria.

${ }^{588}$ Expressão empregada por CHAÏM PERELMAN ao tratar do problema da distinção do fato e do direito à luz da atuação das Cortes de Cassação (Ética e direito, § 46, p. 579).

${ }^{589}$ A esse respeito, destacando as particularidades locais e a variedade de usos e costumes no Brasil, de modo a dificultar, por vezes, uma revisão pelos Tribunais Superiores, BARBOSA MOREIRA, "Regras de experiência e conceitos juridicamente indeterminados", n. 6, p. 72.
} 


\subsubsection{AS CHAMADAS “QUESTÕES MISTAS” (MIXED QUESTIONS OF LAW AND FACT): APRECIAÇÃO CRÍTICA DA TEORIA TRICOTÔMICA}

Em tese inovadora entre nós, DANILO KNIJNIK propôs que um modelo dicotômico (que separe apenas "fato" e "direito" como categorias contrapostas) seria impraticável, devendo-se admitir um grupo intermediário de questões ditas mistas (mixed questions of fact and law), em que fato e direito estão interligados de tal maneira que sua distinção naqueles moldes - não deve ser intentada. Os exemplos podem ser encontrados dentre as normas tipicamente vagas, tais como as cláusulas gerais, conceitos jurídicos indeterminados, standards, conceitos carecidos de um preenchimento valorativo etc. Nesses casos, a questão não seria reconduzida aos termos da distinção tradicional entre o fático e o jurídico, mas apenas admitida ou não como objeto de revisão in iure, segundo um regime jurídico próprio. O ponto crucial estaria em afastar um raciocínio binário ("fato" ou "direito") para introduzir, assim, um tipo intermediário ou misto ("fato", "direito" ou "fato $e$ direito"), em que a solução se orienta por outros parâmetros. ${ }^{590}$

Importou-se, assim, a categoria das mixed questions do direito norte-americano. Segundo definição jurisprudencial daquele país, questões mistas são aquelas em que "os fatos históricos são incontroversos ou acertados, a regra de direito é indisputada, e a questão é se os fatos satisfazem o 'standard' legal ou, para colocá-lo de outro modo, se a regra de direito, tal qual aplicada aos fatos acertados é ou não violada". ${ }^{591}$ No entanto, como bem destaca a doutrina daquele país, as próprias “Cortes federais estão divididas quanto ao standard apropriado para a revisão dessas questões mistas de direito e fato". 592

\footnotetext{
${ }^{590}$ O recurso especial e a revisão da questão de fato..., passim. Segundo o autor, "a característica fundamental da questão mista é a de não se fazer possível, nela, a distinção entre o fato e o direito, de modo que não se deve intentá-la. Conseqüentemente, tudo o que se poderá dizer a respeito de uma questão mista é que, por seu grau de indeterminação, ela poderá ou não ser objeto de uma revisão in jure e, não, que deve ser qualificada como questão de fato ou questão de direito" (op. cit., n. 3.5.2, p. 187). Aderindo à concepção, ARAKEN DE ASSIS, Manual dos recursos, n. 84.2, p. 716; CÂNDIDO DINAMARCO, “Admissibilidade do recurso especial ou extraordinário e as chamadas "questões mistas"”, p. 895 e ss. Antes, já CALAMANDREI havia utilizado categoria análoga, aludindo a erros "que não são estritamente nem de direito nem de fato", mas constituem "uma espécie de zona gris entre as outras duas categorias de erros" para referir-se ao emprego de máximas de experiência (La casación civil, tomo III, n. 104, p. 297)

${ }^{591}$ Pullman-Standard v. Swint, 456 U.S. 273, 288 (1982). No original: "questions in which the historical facts are admitted or established, the rule of law is undisputed, and the issue is whether the facts satisfy the statutory standard, or to put it another way, whether the rule of law as applied to the established facts is or is not violated"

592 JAMES - HAZARD - LEUBSDORF, Civil procedure, $§ 12.9$, p. 774.
} 
Por essa perspectiva, fato e direito são vistos como pólos de um espectro ou de um "continuum de experiência", de modo que alguns assuntos - situados no meio do caminho, no campo da aplicação de standards normativos gerais a circunstâncias específicas constituiriam questões mistas em que a distinção tradicional perderia sua relevância do ponto de vista analítico e o problema passaria a ser de alocação de competência. Logo, a pergunta não seria mais "questão de fato ou de direito?", mas algo como "quem deve decidir de maneira definitiva a questão?".593

Segundo a tese tricotômica, o controle das questões ditas mistas só se justifica se, ao fazê-lo, o Superior Tribunal de Justiça puder desenvolver o Direito, delimitando o alcance e o sentido da norma. Diz-se, assim, que o Tribunal deve ter condições de "corrigir a margem de decisão", isto é, ampliar as zonas de certeza (positiva e negativa) nas quais se pode seguramente afirmar que uma determinada situação fática se encaixa, ou não, na hipótese normativa. Na medida em que tais margens de decisão vão sendo gradativamente reduzidas por meio de sucessivas definições jurisprudenciais, as questões que - em razão de sua vagueza -, antes eram tidas como "mistas" (i.e., de "fato e direito") recebem uma interpretação determinada. A partir de então, a liberdade de apreciação dos juízes é diminuída e a decisão que violar a nova margem de decisão fará surgir uma "questão de direito". Diz-se, por isso, que as questões mistas são essencialmente transitórias, transmudando-se em questões jurídicas depois de decididas. ${ }^{594}$

Bem compreendidas as noções, o que se postula, no fundo, é o reconhecimento de um âmbito de apreciação discricionária ao órgão judicial de segunda instância. A afirmação não deve causar espanto, pois não são desconhecidos casos em que se atribui ao juiz o poder de escolher entre duas ou mais alternativas legais, ${ }^{595}$ nem pode ser ignorada a

\footnotetext{
${ }^{593}$ HenRy P. MONAGHAN, "Constitutional fact review”, p. 236-237; também WiLliam C. WhitForD, "The role of the jury (and the fact/law distinction) in the interpretation of written contracts", p. 932.

${ }^{594}$ DANILO KNIJNIK, O recurso especial e a revisão da questão de fato..., n. 3.5.4, p. 209-210. Antes, também o dissera CASTANHEIRA NEVES (“A distinção entre a questão-de-facto e a questão-de-direito...”, n. 2, p. 528), com base na doutrina alemã: "a questão do contrôle da aplicação dos 'conceitos indeterminados' e das decisões discricionárias, admitido em geral, e que se considera hoje apenas condicionado pela possibilidade processual de um efectivo controle".

${ }^{595}$ Cf. exemplos citados por BARBOSA MOREIRA (obs.: os dispositivos do Código Civil referem-se ao diploma antigo): "Incluem-se nesse âmbito, v.g., no terreno penal, a possibilidade do perdão judicial (ex.: receptação culposa, se o agente é primário - Código Penal, art. 180, $\S 3^{\circ}$ ), bem como a de escolher a pena entre duas ou mais alternativamente cominadas (ex.: violação de domicílio, punível com detenção, de um a três meses, ou multa, de trezentos a dois mil cruzeiros - Código Penal, art. 150, caput); no terreno civil, a adoção, pelo órgão judicial, da "medida que lhe pareça reclamada pela segurança do menor e seus haveres", na hipótese de abuso do pátrio poder (Código Civil, art. 394), a determinação da maneira pela qual se cumprirá a obrigação de prestar alimentos (Código Civil, art. 403, par. ún.), a fixação do rumo da passagem forçada em benefício do prédio encravado (Código Civil, art. 558, fine) etc" ("Regras de experiência e conceitos jurídicos
} 
criatividade inerente à aplicação de normas vagas. Nesse sentido, se o efeito devolutivo amplo da apelação transfere ao tribunal de segundo grau a possibilidade de realizar um segundo exame da causa, tendo este, por conseguinte, plena liberdade para inverter a opção efetuada em primeira instância, isso não ocorre na via excepcional. No recurso especial eventualmente interposto, o exame é restrito, limitado a verificar apenas se houve ou não erro no acórdão recorrido, ou seja, se ocorreu violação das "margens de decisão". Isso implica, segundo a concepção exposta, que dentro das "margens" reconhecidas, o Tribunal a quo, na prática, exerce o poder de definir a providência a ser adotada, sendo a sua decisão insuscetível de revisão pelo Superior Tribunal de Justiça. Mesmo aqueles casos duvidosos - i.e., as hipóteses em que não se pode seguramente afirmar se o julgado recorrido violou as "margens de decisão" estabelecidas previamente - "deverão ser resolvidos em favor do não conhecimento, visto que o reexame in jure tem natureza extrema". 596

Apresentada a tese, cumpre agora apreciá-la. Possui ela, em primeiro lugar, o grande mérito de acentuar a inadequação da distinção conceitual entre fato e direito, destacando, nesse sentido, justamente a necessidade de recorrermos a outros critérios para delimitar a atuação do Superior Tribunal de Justiça. Trata-se, sem dúvida, da mais profunda, completa e inovadora monografia sobre o tema no Brasil. Entretanto, no plano estritamente teórico, a tese não rompe abertamente com as premissas a que visa combater e, nessa medida, sujeita-se a algumas observações de conteúdo crítico.

Percebe-se, nesse sentido, que embora proclame como ponto de partida a impossibilidade da distinção entre questões de fato e questões de direito (retratada sobretudo pela chamada "causa hermenêutica"), a tese finda por reafirmá-la, ao menos em parte, no seu ponto de chegada. Isso porque conclui por separar - no plano ontológico fato e direito, apenas para inserir ulteriormente, numa "zona cinzenta" e problemática, a categoria híbrida das mixed questions of law and fact.

Portanto, a defesa das questões mistas acaba por ficar, por assim dizer, num "ponto de passagem" entre as teorias conceituais tradicionais - i.e., que distinguem ontologicamente fato e direito - e as teorias que preconizam uma aberta ruptura com essa posição - considerando apenas o sentido teleológico e a função institucional-processual da

indeterminados", n. 3, p. 65-66).

${ }^{596}$ DANILO KNIJNIK, O recurso especial e a revisão da questão de fato..., n. 3.5.4, p. 211. 
revisão como critérios metodologicamente válidos. ${ }^{597}$ Não por mera coincidência, nos casos problemáticos oferecidos pelas mixed questions, segundo a própria teoria tricotômica, o critério válido "só pode ser buscado nas funções nomofilácicas do Tribunal e na articulação que deve existir entre o interesse da parte, representado pela sucumbência, e o interesse assinado ao Superior Tribunal de Justiça, representado pela função jusunitária". 598 Mas um critério complementar, empregado para lidar apenas com os "casos problemáticos", era já também defendido pelas orientações mais modernas da teoria lógico-conceitual ${ }^{599}$

Em razão dessa postura, acabam sendo relegadas ao segundo plano - como meros "sintomas ou critérios auxiliares" - as análises da generalidade, da repetibilidade, do efeito exemplificativo da questão etc. ${ }^{600}$ E são justamente esses, como se viu, os critérios aptos a delimitar racionalmente o âmbito de cognição possível dos Tribunais Superiores. Em outras palavras, a baliza decisiva para aferição das questões passíveis de revisão pelo Superior Tribunal de Justiça deve ser buscada sempre a partir de uma perspectiva teleológica, que leve em conta a função institucional do órgão no quadro judiciário. Inevitável considerar o caráter geral e exemplar da questão, de modo que a sua solução possa servir à unidade do Direito e ao seu desenvolvimento por meio dos precedentes (i.e., aos escopos precípuos dos Tribunais Superiores). Melhor do que trabalhar com as questões mistas seria dizer abertamente, portanto, que a perspectiva funcional deve governar, de

${ }^{597}$ É interessante consultar, a esse respeito, o mapeamento doutrinário feito por CASTANHEIRA NEVES em relação ao problema dos limites da intervenção dos Tribunais Superiores ("A distinção entre a questão-defacto e a questão-de-direito...", n. 1, p. 492-494, nota 11). O autor divide a doutrina que trata do tema em três fases, sendo a primeira e a terceira contrapostas como teses antagônicas: enquanto aquela corresponde à "doutrina de orientação conceitualista tradicional" - que deduz a solução dogmática para os recursos excepcionais de uma diferenciação conceitual pressuposta (fato $v$. Direito) -, esta rompe com a posição tradicional, considerando apenas o sentido teleológico e a função institucional-processual da revisão como critério metodologicamente válido. "Num ponto de passagem" entre os dois extremos - e aqui parece situarse justamente a tese tricotômica - "encontram-se aqueles autores - a maioria - que, acentuando embora já a função jurídico-institucional da revista como critério autonomamente relevante na sua delimitação objectiva, nem por isso deixam de tratar promíscua e indiscriminadamente o problema desse recurso com o problema da distinção, na base ainda, apesar de tudo, de uma implícita unidade entre ambos - já porque o critério fundamental seria a distinção e o fim institucional só determinaria, quando muito, algumas particularidades ou alguns desvios excepcionais, já porque do fim institucional se deduziria sem mais a coincidência do objeto do recurso com as <<questões-de-direito>>”. A crítica é repetida adiante (op. cit., n. 1, p. 513-514).

${ }^{598}$ DANILO KNIJNIK, O recurso especial e a revisão da questão de fato..., n. 3.5.4, p. 200-201.

${ }^{599}$ Cf. HORST-EBERHARD HENKE, La cuestión de hecho..., § 2(I), p. 19.

${ }^{600}$ Ver, na obra citada de DANILO KNIJNIK (O recurso especial e a revisão da questão de fato...), os tópicos referentes à "causa hermenêutica" (n. 1.2, p. 13-46) - cuja leitura é complementada pela exposição feita em seguida da "causa dogmática" (n. 1.3, p. 46-62) - e ao papel atribuído à generalidade, repetibilidade etc. das questões, como meros "sintomas ou critérios auxiliares à definição sobre a possibilidade ou não de o Tribunal intervir no caso" (n. 3.5.6, p. 230-237). 
maneira constante e em todas as hipóteses, o juízo de admissibilidade dos recursos excepcionais. Ganhar-se-ia, com isso, em clareza e uniformidade de discurso.

Por fim, é possível colocar em xeque dois resultados alcançados pela teoria tricotômica em face da função dos Tribunais Superiores. Primeiramente, deve-se questionar a afirmação de que se necessita respeitar as margens de decisão do tribunal $a$ quo, ou seja, o "halo conceitual" ou a "zona de penumbra" dos conceitos. Como bem objetou HORST-EBERHARD HENKE, "se o juiz de cassação tivesse que abster-se de julgar quando a valoração é insegura, se excluiria sua influência precisamente ali onde resulta mais necessária", ${ }^{601}$ ou seja, no desenvolvimento e na estabilização do Direito. A tese ressuscitaria, sob outras roupagens, a antiga orientação do enunciado n. 400 da Súmula/STF, hoje definitivamente superada.

Em segundo lugar - e admitindo-se que essa transmudação seja teoricamente possível -, cabe perquirir em que medida é desejável a reclassificação das chamadas "questões mistas" como questões de direito, uma vez tenham sido elas julgadas em sede de recurso especial. Por óbvio, a sucessiva concretização de normas vagas, por essa perspectiva, acabará gerando um número cada vez maior de questões jurídicas, cuja apreciação - na falta de um filtro adequado, ponto que não é tocado pela tese -, seria obrigatória para a Corte. Esse fenômeno, ao que parece, antes de colaborar para que o foco de atuação do Superior Tribunal de Justiça seja canalizado para as questões mais importantes e para a produção de precedentes, acaba por ocupar a Corte com um controle retrospectivo sobre um número crescente de questões já resolvidas. Em outras palavras, antes de contribuir para a solução da crise funcional, acaba por agravá-la.

\subsubsection{ANÁLISE PRÁtICA}

\subsubsection{SiMPLES REEXAME DE PROVA (ENUNCIADO N.ํㄱ DA SÚMULA/STJ)}

Até aqui, as afirmações teóricas feitas são de alcance universal. Mas como é regulado o problema no direito brasileiro? No que de mais perto interessa, o item $\mathrm{n}^{\circ} 7 \mathrm{da}$ Súmula do Superior Tribunal de Justiça dispõe que "a pretensão de simples reexame de prova não enseja recurso especial". ${ }^{602}$ Lido adequadamente, o verbete corrobora a linha de

\footnotetext{
${ }^{601}$ Horst-EBERHARD HenKE, La cuestión de hecho..., § 2(I), p. 19.

${ }^{602}$ A fórmula repete o enunciado 279 da Súmula do STF: "Para simples reexame de prova não cabe recurso
} 
raciocínio até aqui desenvolvida. Com efeito, ele tem a virtude de colocar em evidência que apenas o "simples reexame" de prova não abre espaço ao recurso especial, permitindo, por outro lado, que outras questões, de cunho geral - ligadas à qualificação jurídica da situação concreta, à admissibilidade ou valoração legal da prova ou, ainda, à concretização de normas vagas e à padronização de valores -, sejam revisadas.

O conceito de simples reexame da prova está intimamente relacionado ao livre convencimento do magistrado a respeito das circunstâncias particulares do caso concreto (questões de fato, na terminologia usual). ${ }^{603}$ Tal juízo é desenvolvido em primeiro (de forma imediata) e segundo (de forma mediata) graus de jurisdição, em atenção à regra geral do duplo grau, que permite, assim, um amplo reexame "de fato" e "de direito" da causa. Liga-se aos recursos ordinários. Por isso mesmo, é tema estranho ao recurso especial. Ao Superior Tribunal de Justiça é vedado ingressar no espaço deixado às instâncias a quo representado pelo livre convencimento motivado, porquanto esse se refere aos aspectos individuais e particularizantes do caso específico, tema que obviamente não interessa à função prospectiva da Corte. A respeito desses, a instância superior deve "tomar emprestadas" as impressões colhidas e as conclusões tomadas pelo juízo a quo. ${ }^{604}$

Num esquema simplificado, pode-se considerar reexame da prova "tudo e somente aquilo que se refere à verificação da verdade ou falsidade dos fatos empíricos relevantes, salvo o que concerne à aplicação de normas relativas à admissibilidade e assunção das provas, ou de normas de prova legal"; a contrario sensu, são consideradas questões jurídicas passíveis de revisão por meio do recurso especial a seleção e a interpretação/aplicação da norma, a qualificação jurídica dada aos fatos e a determinação dos efeitos jurídicos previstos pela norma. ${ }^{605}$

Acrescenta ATHOS GUSMÃo CARNEIRO que "não constitui reexame da prova, a ponto de não permitir o conhecimento do recurso especial, a mera aferição da ocorrência

extraordinário".

${ }^{603}$ STJ, $1^{\text {a }}$ T., REsp 737797/RJ, rel. Min. LuIZ FUX, j. em 03/08/2006, DJ 28/08/2006, p. 226 (contendo motivação com exposição da doutrina a esse respeito).

${ }^{604}$ Elio FAZZALARI, Il giudizio civile di Cassazione, cap. 2, n. 7, p. 65. Também é assim no direito alemão, em que as conclusões do juízo a quo sobre os fatos são obrigatórias para a Corte de Revisão (art. 559.2, $\mathrm{ZPO})$.

${ }^{605}$ Cf. Michele TARUfFo, El vértice ambíguo, $\S 5$, n. 1 p. 168-9. 
de um determinado fato incontroverso e necessário ao julgamento da demanda, e que seja constatado pelo simples cotejo entre documentos". ${ }^{606}$

\subsubsection{QUALIFICAÇÃo JURÍDICA DE FATOS, ATOS E NEGÓCIOS JURÍDICOS}

Uma qualificação consiste, como se sabe, numa relação entre um conceito e um elemento. Por isso, quando qualifica juridicamente uma dada situação - seja para incluí-la, seja para excluí-la da categoria conceitual -, o Tribunal contribui para precisar o Direito, permitindo que, a partir de uma série de casos, possa ser induzida uma regra geral. ${ }^{607}$

Nessa medida, a qualificação jurídica da situação concreta é operação que escapa dos limites do mero reexame da prova. Evidentemente, se o juiz da causa tivesse o poder de qualificar e requalificar os fatos como bem entendesse, estaria, indiretamente, a modificar a norma jurídica e o seu campo de aplicação. ${ }^{608}$ Por isso, é necessário perceber que na construção dos limites do recurso especial, à semelhança do que se disse acerca da Revision alemã, o Tribunal deve preocupar-se não apenas "dos atentados, bastante raros, contra ius in thesi clarum, mas que também está obrigado a cuidar que não se subsumam nos conceitos jurídicos fatos que não são os que lhes correspondem". ${ }^{609}$

De modo correto, a doutrina brasileira, em sua grande maioria, procura caracterizar a qualificação dos fatos acertados pelo Tribunal local como questão jurídica passível de revisão por meio do recurso especial. ${ }^{610-611}$ Cabe revisar a subsunção efetuada na medida

\footnotetext{
${ }^{606}$ Athos GuSMÃo CARNEIRO, Recurso especial, agravos e agravo interno, 6. ed., Rio de Janeiro: Forense, 2009 , n. 13.1, p. 36 .

${ }^{607}$ Cf. CHAÏM PERELMAN, Ética e direito, § 46, p. 578; CASTANHEIRA NEVES, Questão-de-facto - questão-dedireito..., §9, n. 1, p. 178-179; ID., “A distinção entre a questão-de-facto e a questão-de-direito...”, n. 2, p. 525

${ }^{608} C f$., ainda, CHAÏM PERELMAN, Ética e direito, § 46, p. 576.

${ }^{609}$ FRIEDRICH STEIN, El conocimiento privado del juez, $\S 7$, p. 143. No mesmo sentido, CALAMANDREI, La casación civil, tomo III, n. 39, p. 95.

${ }^{610}$ Ver, v.g., Barbosa Moreira, Comentários ao Código de Processo Civil, v. 5, n. 324, p. 601-602; ID., “Alegação de compensação rejeitada no despacho saneador. Documento junto sem audiência da outra parte. Pedido de exibição de documento em poder de pessoa jurídica sediada no estrangeiro. Questão de qualificação jurídica: possibilidade de reexame mediante recurso extraordinário”, n. 22, p. 235; OvíDIO A. BAPTISTA DA SILVA, “QQuestão de fato’ em recurso extraordinário”, p. 499; ID., Curso de processo civil, vol. 1, n. 17.4.4.4, p. 435; JOSÉ AFONSO DA SILVA, Do recurso extraordinário no direito processual brasileiro, $\mathrm{n}$. 58, p. 152; ATHOS GUSMÃo CARNEIRO, Recurso especial, agravos e agravo interno, 6. ed., Rio de Janeiro: Forense, 2009, n. 13.2, p. 38; Luiz GuILHERMe MARINONI - SÉrgio C. Arenhart, Prova, n. 20.2, p. 338; TERESA ARRUDA ALVIM WAMBIER, Recurso especial, recurso extraordinário e ação rescisória, 12.2, p. 367375; AdA Pellegrini GrinOVER, "O controle do raciocínio judicial pelos Tribunais Superiores brasileiros", n. 8, p. 18; José Miguel Garcia Medina, Prequestionamento e repercussão geral, n. 3.2.3.3, p. 155; Gleydson De OliveIRA, Recurso especial, n. 2.5.8, p. 290-292; ClARA AZZONI, Recurso especial e
} 
em que as circunstâncias particulares do caso, tal como estabelecidas pelo Tribunal local, não o impeçam ${ }^{612} \mathrm{e}$, portanto, de forma que se possa daí extrair uma pauta geral.

A possibilidade de qualificação jurídica não diz respeito tão somente a um negócio isolado, compreendendo também a possibilidade de examinar eventual coligação contratual, ou seja, de qualificar as relações de dependência existentes entre contratos vinculados para extrair daí o regime aplicável à espécie. ${ }^{613}$

Naturalmente, também é quaestio iuris, para fins de cabimento dos recursos excepcionais, a determinação dos efeitos da norma, ou seja, das conseqüências da qualificação jurídica realizada, operação ulterior ao enquadramento da fattispecie.

\subsubsection{QUESTÕES JURÍDICAS DE DIREITO PROBATÓRIO}

Conforme já assinalado, o simples reexame de prova é vedado ao Superior Tribunal de Justiça, noção que remete ao princípio do livre convencimento motivado do magistrado a quo a respeito das provas adquiridas no processo. Exclui-se da revisão por meio do recurso especial a conviç̧ão do Tribunal de origem acerca das questões que digam respeito às particularidades e acontecimentos históricos ligados ao caso concreto individualmente considerado, o que costuma ser vislumbrado como "simples apreciação das provas", traduzida por operações mentais de peso, conta e medida soberanamente decididas pelas instâncias a quo. ${ }^{614}$

extraordinário, n. 4.1.2, p. 155; LUCIA PALMEIRO DA FONTOURA, Recurso especial, n. 5, p. 47 e ss.; José SARAIVA, Recurso especial e o STJ, n. 18.4.1, p. 326; JOÃo FrANCISCO NAVES DA FONSECA, Exame dos fatos nos recursos extraordinário e especial, n. 25, p. 88-90.

${ }^{611}$ Também é assim na doutrina estrangeira: para o direito italiano, FERDINANDO MAZZARELLA, Analisi del giudizio civile di cassazione, cap. 3, n. 1, p. 86; para o direito francês, cf. LOḮ CADIET - JACQUES NORMAND - SORAYA AMRANI MeKKI, Théorie générale du procès, n. 285, p. 945; o clássico é GABRIEL MARTY, La distinction du fait e du droit, p. 204 (referindo que "tout problème de qualification est question de droit"); para o direito alemão, OTHMAR JAUERNIG, Direito processual civil, § 74/VII, p. 385.

${ }^{612}$ FRIEDRICH STEIN, El conocimiento privado del juez, § 7, p. 146.

${ }^{613}$ V.g., STJ, $4^{\mathrm{a}}$ T., REsp 419.362/MS, rel. para acórdão Min. RuY RoSADO, j. em 17.06.2003. O mesmo acórdão é citado e comentado por obra que trata especificamente do tema dos contratos coligados, defendendo-se, naquela sede, a natureza de questão de direito (i.e., de questão passível de revisão pelo STJ) da qualificação jurídica de coligação contratual (Francisco PAULO DE CRESCEnzo MARINO, Contratos coligados no direito brasileiro, n. 21.4, p. 179-181.

${ }^{614}$ Nesse sentido: "(...) não procedem censuras a que nele se faça exame de provas. Quando fundado, por exemplo, na alegação de falta de justa causa, impõe-se sejam as provas verificadas. O que se veda em habeas corpus, semelhantemente ao que acontece no recurso especial, é a simples apreciação de provas, digamos, a operação mental de conta, peso e medida dos elementos de conviçção" (STJ, 6 $6^{\mathrm{a}} \mathrm{T}$., HC 150.608/CE, rel. Min. NILSON NAVES, j. em 24/08/2010, DJe 09/09/2010). Vale lembrar que, segundo o 
Ninguém ignora, contudo, a existência de hipóteses em que a valoração do material probatório deve pautar-se por critérios legais (prova legal). Ademais, o juízo de admissibilidade da prova, a espécie de meio de prova admitida para determinados procedimentos específicos, a repartição do encargo de provar e também os standards de convencimento judicial são regulados pelo direito processual. Nesses momentos, não se trata mais de um problema de mera convicção sobre a prova, mas de problemas jurídicos ligados ao direito probatório. ${ }^{615}$ Nessa linha, o Superior Tribunal de Justiça costuma diferenciar, de um lado, a revaloração da prova - enquanto operação admissível em sede de recurso especial - e, de outro, o seu mero reexame, cuja realização é vedada. ${ }^{616}$

Isso tudo sem falar no problema do controle da logicidade e completude da motivação das sentenças, bem como de sua adequação às regras de experiência, temas amplamente discutidos pela doutrina da cassação e que, excepcionalmente, podem justificar a intervenção dos Tribunais Superiores.

Com apoio em recente e completa sistematização da matéria, deve-se distinguir "reexame de prova de aferição: i) da licitude da prova; ii) da qualidade da prova necessária para a validade do ato jurídico; ou iii) para o uso de certo procedimento; iv) do objeto da convicção; v) da convicção suficiente diante da lei processual; e vi) do direito material; vii) do ônus da prova; viii) da idoneidade das regras de experiência e das presunções; ix) além de outras questões que antecedem a imediata relação entre o conjunto das provas e os fatos,

Superior Tribunal de Justiça, a cognição admitida em habeas corpus equivale àquele exercida no recurso especial.

${ }^{615}$ Diferenciando o simples reexame de prova da violação de normas sobre o direito probatório, ver, entre outros: Barbosa Moreira, Comentários ao Código de Processo Civil, v. 5, n. 324, p. 603; PONTES DE Miranda, Comentários ao Código de Processo Civil (de 1973), t. VIII, p. 31; José Afonso DA SiLva, Do recurso extraordinário no direito processual brasileiro, n. 58, p. 152; ATHOS GUSMÃo CARNEIRO, Recurso especial, agravos e agravo interno, n. 13.2, p. 36; GLEYDSON DE OLIVEIRA, Recurso especial, n. 2.5.8, p. 278 e 288; FREDIE Didier JR. - LEONARDo J. CARNEIRO DA CUNHA, Curso de direito processual civil, cap. VII, n. 3, p. 255; ClARA AZZONI, Recurso especial e extraordinário, n. 4.1.3, p. 156. No direito italiano, ELIO FAZZALARI, Il giudizio civile di Cassazione, cap. 2, n. 7, p. 66.

616 "Revaloração do conjunto probatório. Possibilidade. I - A revaloração da prova ou de dados explicitamente admitidos e delineados no decisório recorrido não implica no vedado reexame do material de conhecimento (Precedentes). II - Os fatos apontados no acórdão vergastado - direção de veículo automotor em alta velocidade e com as portas abertas - evidenciam a culpa do recorrido que, de forma imprudente, acabou por ceifar a vida do cobrador que, desequilibrado, veio a cair da "lotação" (...)" (STJ, $5^{\mathrm{a}}$ T., REsp 1129045/SP, rel. Min. FELIX FISCHER, j. em 09/03/2010, DJe 05/04/2010). A decisão segue uma já antiga orientação do Supremo Tribunal Federal (v.g., STF, 2 $2^{\mathrm{a}}$ T., RE 57420/GB, rel. Min. ANTONIO VILLAS BOAS, j. em 07/05/1965, DJ 26/05/1965). 
por dizerem respeito ao valor abstrato de cada uma das provas e dos critérios que guiaram os raciocínios presuntivo, probatório e decisório". 617

\subsection{SEGUE: JUÍZO DE ADMISSIBILIDADE DA PROVA}

A dinâmica da prova deixa desdobrar-se, via de regra, em quatro fases ou estágios: postulação, admissão, produção e valoração. O juízo de admissibilidade da prova deve realizar-se de acordo com as regras pertinentes. É etapa prévia que não se confunde com o livre convencimento do juiz. E, como é este último o âmbito da decisão a quo a ser preservado em sede de recurso especial, a admissão ou inadmissão da prova é questão passível de revisão in iure.

Ainda nesse tópico, é importante ter em consideração que a admissibilidade da prova é juízo preliminar em relação à sua valoração e, portanto, à formação do convencimento do juiz, não cabendo antecipar um prognóstico dessas conclusões do juízo fático para indeferir, a esse título, o meio de prova regulamente requerido. A admissão da prova deve ser guiada por critérios estritamente objetivos: além da sua licitude, consideram-se apenas a pertinência e a relevância do meio requerido em relação ao thema probandum (all relevant evidence is admissable). ${ }^{618}$

Por isso, retomando o fio da exposição, percebe-se que na condenação fundada em prova ilícita existe error iuris in procedendo, cabendo anular o acórdão recorrido para que, excluído o meio probatório censurado, equivocadamente admitido, outra decisão seja proferida na instância a quo. ${ }^{619}$ Há de ser advertido, todavia, que preponderam decisões em sentido contrário no Superior Tribunal de Justiça.

\footnotetext{
${ }^{617}$ MARINONI - ARENHART, A prova, São Paulo: RT, 2009, n. 20.1, p. 337. O texto desenvolvido no presente item segue, em larga medida, a exposição dos autores no capítulo 20 da obra citada (n. 20.1-20.20, p. 336$355)$.

${ }^{618}$ Cf. Michele TARUfFO, La prueba de los hechos p. 366 e ss.; FRIEDRICH STEIN, El conocimiento privado del juez, § 7, p. 142; DANILO KNIJNIK, A prova nos juízos cível, penal e tributário, n. 1.6, p. 19-24; DANIEL Mitidiero, Colaboração no processo civil, p. 130-133. Na jurisprudência: "O juízo de admissibilidade é de natureza objetiva, levando em conta a relevância e pertinência do meio requerido em relação ao deslinde do feito. Por isso, não se podem confundir os juizos de admissibilidade e de valoração da prova, antecipando-se um prognóstico sobre o resultado da instrução como fundamento para inadmitir os meios probatórios requeridos, sob pena de cerceamento de defesa (violação do direito fundamental à prova)" (TRE-SP, Recurso n. ${ }^{\circ} 33.189$, rel. PAulo HenRIQUe LuCON, j. em 16/03/2010, DJe 30/03/2010).

619 Já dissera FRIEDRICH STEIN que, em tais casos, a atividade do Tribunal de superposição restringe-se a determinar se a prova ilícita foi levada em consideração no juízo fático, porquanto "uma investigação acerca de se, desaparecido esse fundamento, o material restante haveria levado ao mesmo resultado não compete à jurisdição de cassação, pois seria impraticável. A influência que possa haver tido a circunstância concreta no
} 
Outro exemplo é o da prova pericial produzida por pessoa inabilitada (art. 145, CPC). Já se decidiu que, em tais casos, é "nula a perícia", fato que conduz à "nulidade absoluta da prova e do processo por ela contaminado".620

Na mesma linha, causa de pedir ligada a eventual cerceamento de defesa - i.e., à inadmissão de uma prova relevante requerida oportunamente pela parte e subseqüente julgamento a ela desfavorável, baseado justamente em insuficiente convicção quanto aos fatos alegados - é passível de revisão por meio do recurso especial, enquanto quaestio iuris. Há, em tais casos, violação ao art. 330, CPC. Assim, de fato, vinha decidindo corretamente o Tribunal; ${ }^{621}$ entretanto, em tempos mais recentes, parecem ser majoritárias as decisões em sentido contrário. ${ }^{622}$

resultado total não é suscetível de ser exposta isoladamente. A apreciação da prova não é nenhum problema aritmético" (El conocimiento privado del juez, § 7, p. 137). É difícil compreender, por isso, a conclusão a que chega GLEYDSON DE OLIVEIRA, no sentido de que "caso, na decisão recorrida, haja manifestação acerca da avaliação da prova tida por inadmissível, como é, na instância excepciona, vedada a avaliação de fato ou de prova, o tribunal superior, ao reformar a decisão recorrida, deve adotar a conclusão retratada no acórdão recorrido, de forma que ocorre o efeito substitutivo. Do contrário, se, na decisão recorrida, inexistir avaliação acerca da prova tida como inadmissível, como o tribunal superior não pode, originariamente, avaliar prova (...), deve haver invalidação do acórdão recorrido, a fim de que o tribunal local profira outra decisão, avaliando os fatos e as provas" (Recurso especial, n. 2.5.8, p. 285-286).

${ }^{620}$ STJ, $2^{\text {a }}$ T., REsp 1127949/SP, rel. Min. ELIANA CALMON, j. em 03/11/2009, DJe 17/11/2009

${ }^{621}$ STJ, 4a T., REsp 107276/MG, rel. Min. RuY Rosado DE AgUiAR, j. em 09/06/1998, DJ 21/06/1999, p. 158.

${ }^{622}$ V.g., "Cerceamento de defesa - ofensa aos arts. 330, I e 333, II, do CPC. A pretensão esbarra na Súmula 7/STJ, pois foi com base na prova dos autos que o Tribunal a quo entendeu ser despiciendo determinar a continuidade da instrução probatória, oportunidade em que julgou antecipadamente a lide" (STJ, $2^{\mathrm{a}} \mathrm{T}$., REsp 970.361/RO, rel. Min. CASTRO MEIRA, j. em 21/10/2010, DJe 10/11/2010); "1. O Recurso Especial não é servil ao exame de questões que demandam o revolvimento do contexto fático-probatório dos autos, em face do óbice erigido pela Súmula 07/STJ. 2. In casu, o Tribunal local analisou a questão de acordo com as provas juntadas aos autos. Consoante se infere do voto condutor do acórdão hostilizado, destaca-se, à luz do contexto fático-probatório engendrado nos autos, in verbis: '(...) Tendo em conta esse entendimento, constata-seque a autora não comprovou que assumiu o ônus financeiro do tributo, não lhe sendo dado, a teor do disposto no art. 6 o do Código de Processo Civil, pleitear direito alheio em nome próprio, salvo quando autorizados em lei, o que não é o caso dos autos, caracterizando-se, pois, a ilegitimidade para pleitear a devolução ou o creditamento pleiteado.' 3. O poder instrutório do juiz, a teor do que dispõem os arts. 130 e 330 do Código de Processo Civil, permite-lhe o indeferimento de provas que julgar inúteis. 4. A aferição acerca da necessidade ou não de realização de provas, impõe o reexame do conjunto fático exposto nos autos, o que é defeso ao Superior Tribunal de Justiça, face do óbice erigido pela Súmula 07/STJ, porquanto não pode atuar como Tribunal de Apelação reiterada ou Terceira Instância revisora. Precedentes jurisprudenciais desta Corte: AG 683627/SP, desta relatoria, DJ 29.03.2006, RESP 670.852/PR, desta relatoria, DJ de 03.03.2005 e RESP 445.340/RS, Relator Ministro José Delgado, DJ de 17.02.2003" (STJ, ${ }^{\text {a }}$ T., AgRg no Ag 1297324/SP, rel. Min. LuIZ FuX, j. em 19/10/2010, DJe 04/11/2010). 


\subsection{SEGUE: VALOR DA PROVA EM ABSTRATO}

Por vezes, o juízo fático fica sujeito a vínculos formais, previstos abstratamente nas normas legais. É o que ocorre quando a lei impõe determinado meio de prova ou, em sentido oposto, exclui certo meio probatório para a verificação de determinados fatos.

No primeiro caso, tem-se uma prova considerada essencial à própria configuração do ato jurídico. Ela é dita, por isso, uma prova da "substância do ato" ou ad solemnitatem. ${ }^{623}$ Nesse sentido, v.g., dispõe genericamente o art. 366, CPC, que "quando a lei exigir, como da substância do ato, o instrumento público, nenhuma outra prova, por mais especial que seja, pode suprir-lhe a falta".

$\mathrm{Na}$ segunda hipótese, trata a lei de excluir certos meios de prova em relação a determinados fatos jurídicos. Assim, v.g., "a prova exclusivamente testemunhal só se admite nos contratos cujo valor não exceda o décuplo do maior salário mínimo vigente no país, ao tempo em que foram celebrados" (art. 401, CPC; art. 227, CC), embora o "começo de prova por escrito" (art. 402, I, CPC) ou a impossibilidade moral ou material de obter a prova escrita da obrigação (art. 402, II, CPC) tornem a prova oral admissível.

Essa averiguação do valor abstrato da prova pode também referir-se à sua compatibilidade com determinado procedimento. Violaria tais normas, por exemplo, a admissão de prova diversa da documental em sede de mandado de segurança, writ vocacionado apenas para a tutela de direitos líquidos e certos (i.e, comprovados previamente por meio de documentos). ${ }^{624}$

Em todos esses casos, a verificação da prova regulada pela lei (prova legal) é também quaestio iuris possível de ser invocada perante o Superior Tribunal de Justiça, pois pode aferir-se à luz de regras claramente positivadas na lei processual e não envolve qualquer valoração in concreto (i.e., convencimento) dos fatos probandos.

\subsection{SEGUE: ÔNUS DA PROVA}

A repartição do ônus da prova é, antes de tudo, uma decorrência da vedação do non liquet. Ao final da instrução, ainda que persista dúvida quanto aos fatos, o juiz deve

\footnotetext{
${ }^{623}$ CHIOvENDA, Instituições de direito processual civil, vol. 3, § 62, n. 345, p. 128.

${ }^{624}$ Luiz Guilherme Marinoni - SÉrgio C. Arenhart, Prova, n. 20.4, p. 339. Sobre o tema do começo de prova escrita, v. op. cit., n. 20.12, p. 347
} 
necessariamente julgar, acolhendo ou rejeitando a demanda. Para tanto, atua a disciplina da distribuição do encargo de provar como meio de afastar os inconvenientes da incerteza fática, estabelecendo regras de julgamento (Entscheidungsnormen, regole di giudizio) a serem seguidas em tais casos pelo juiz, de modo a repartir os riscos do insucesso da instrução entre as partes. ${ }^{625}$

O Código de Processo Civil regula a matéria no art. 333 e seus incisos. Atribui ao autor o ônus de provar o fato constitutivo de seu direito, narrado como causa de pedir; ao réu, os fatos modificativos, impeditivos ou extintivos porventura alegados como defesa indireta de mérito. A violação dessas regras constitui, a toda evidência, uma questão de direito e nenhuma dúvida se coloca quanto à possibilidade de sua revisão.

Por outro lado, existem casos especiais em que a normativa geral do Código, apriorística e estática, é preterida. Isso pode ocorrer, v.g., diante de autorização legal para uma inversão ope iudicis do ônus da prova, tal como previsto pelo Código de Defesa do Consumidor (art. $6^{\circ}$, VIII, CDC). No entanto, mesmo na falta de dispositivo, tem sido admitida a dinamização do ônus da prova (teoría de las cargas dinamicas), pela qual a produção da prova a respeito de um fato é atribuída ao sujeito que se encontra em melhor situação para fazê-lo, superando-se o desenho legal. A aplicação de tais mecanismos - que devem encontrar limites, sob pena de violarem a igualdade das partes no processo e a dimensão subjetiva das regras sobre ônus da prova ${ }^{626}$ - também pode ser controlada na instância superior, excluídas, é claro, as particularidades objeto do livre convencimento do tribunal a quo (v.g., se em tal ou qual circunstância específica e particular, cabia reconhecer a maior dificuldade de produzir a prova por uma das partes). Nesse sentido, tanto em relação à inversão em favor do consumidor quanto a respeito da repartição dinâmica do ônus da prova, há julgados do Superior Tribunal de Justiça conhecendo de recursos. $^{627}$

\footnotetext{
${ }^{625} C f$., entre muitos outros, KARL ENGISCH, Introdução ao pensamento jurídico, cap. 3, p. 102-105; BARBOSA MOREIRA, "Julgamento e ônus da prova", esp. p. 75; LeO ROSENBERG, La carga de la prueba p. 7; PONTES DE MIRANDA, Comentários ao Código de Processo Civil (de 1973), tomo IV, p. 228. Na doutrina de common law, WEINSTEIN - MANSFIELD -ABRAMS - BERGER, Evidence, p. 1089.

${ }^{626}$ Em resumo, pode-se dizer que a dinamização (ou a inversão ope legis fundada no Código de Defesa do Consumidor) deve: I) ocorrer por meio de decisão que permita a efetiva produção da prova pela parte onerada ( v.g., na audiência preliminar), não se permitindo inversão tardia feita somente na sentença; II) não pode impor uma prova reversa impossível (probatio diabolica). Nesse sentido, DANILO KNIJNIK, "As (perigosíssimas) doutrinas do "ônus dinâmico da prova"...", p. 948; DANIEL MitidiERo, Colaboração no processo civil, p. 127-130.

${ }^{627}$ Versando a inversão em favor do consumidor, v.g.: STJ, $3^{\text {a }}$ T., REsp 974.994/SP, rel. Min. NANCY ANDRIGHI, j. em 05/06/2008, Inf. 358; STJ, $3^{\text {a }}$ T., REsp 915.599/SP, rel. Min. NANCY ANDRIGHI, j. em
} 


\subsection{SEGUE: "STANDARDS" DE CONVENCIMENTO JUDICIAL}

O livre convencimento do juiz não se confunde com a sua íntima convicção. A delegação de liberdade na apreciação dos fatos pelo órgão judicial é, em boa dose, uma medida necessária, mas de nenhuma forma pode ser encarada como uma carta branca ao arbítrio. ${ }^{628}$ Trata-se, acima de tudo, de um convencimento racional. Por isso, buscando impregnar o juízo fático com certa objetividade, devem ser previamente aferidos e determinados standards de convencimento judicial, i.e., graus de suficiência da prova exigidos para embasar as conclusões do juízo fático, tendo em vista o objeto litigioso do processo.

O direito norte-americano costuma referir o problema da sufficiency of evidence ou measure of persuasion, descrito, de maneira bastante pragmática, como a questão concernente a saber "quanta prova" deve ser produzida para que seja satisfeito o ônus probatório que recai sobre a parte. Nos litígios civis, segundo a Suprema Corte, o juiz (ou o júri, instruído então pelo magistrado) deve contentar-se com uma "preponderância da prova" (preponderance of evidence) em favor de uma das partes. ${ }^{629}$ No outro extremo, as condenações penais dependem de prova além da dúvida razoável (beyond reasonable doubt). Para casos intermediários, existe o standard da "prova clara e convincente" (clear and convincing) ou da prova que seja "clara, precisa e inequívoca" (clear, precise and indubitable). ${ }^{630}$

No Brasil, tais idéias foram desenvolvidas extensamente em mais uma monografia precursora de DANILO KNIJNIK, autor que destacou - seguindo a experiência estadunidense - três "modelos de constatação", correspondentes à preponderância da prova, à prova clara e convincente e à prova além da dúvida razoável. No que de mais perto interessa ao presente estudo, cabe constatar que, a fim de submeter o juízo fático a um controle intersubjetivo, tais modelos de constatação devem ser previamente definidos pelo julgador e submetidos ao contraditório entre as partes. Trata-se, assim, de uma questão jurídica e,

21/08/2008, Inf. 364; STJ, $1^{\text {a }}$ T., REsp 737797/RJ, rel. Min. LuIz FuX, j. em 03/08/2006, DJ 28/08/2006, p. 226. Tratando especificamente da teoria das cargas dinâmicas, STJ, $4^{\mathrm{a}}$ T., REsp 69309/SC, rel. Min. RuY ROSADO DE AGUIAR, j. em 18/06/1996, DJ 26/08/1996, p. 29688.

${ }^{628}$ Carlos Alberto Alvaro de Oliveira, Do formalismo no processo civil, n. 20.5, esp. 219-221.

${ }^{629}$ O leading case recente é Grogan v. Garner, 498 U.S. 279 (1991).

${ }^{630}$ Cf. JAMES - HAZARD - LEUBSDORF, Civil procedure, $\S \S 7.14-7.15$, p. 416-417. 
portanto, de problema passível de ser enfrentado pelo Superior Tribunal de Justiça no âmbito do recurso especial. ${ }^{631}$

É verdade que a jurisprudência do Superior Tribunal de Justiça ignora semelhantes discussões. Normalmente, entende que verificar o parâmetro da suficiência da prova é operação ligada à valoração dos elementos de convicção e, por isso, a ele interditada à luz do enunciado n. ${ }^{\circ}$, Súmula/STJ. ${ }^{632}$ No entanto, há alguma menção ao tema na jurisprudência brasileira. Cabe lembrar e destacar cinco julgados pioneiros do Tribunal Regional Eleitoral de São Paulo, relatados pelo juiz e professor PAUlo HENRIQUE DOS SANTOS LUCON, em que o controle sobre o juízo fático foi realizado explicitamente sobre as bases dos standards probatórios ou modelos de constatação. ${ }^{633}$

\subsection{SEGUE: PRESUNÇÕES E MÁXIMAS DE EXPERIÊNCIA}

O objeto litigioso do processo compreende, necessariamente, a alegação da ocorrência de um fato ou de um conjunto de fatos jurídicos (isto é, fatos previstos no suporte fático ou fattispecie de uma norma), pedindo-se, como conseqüência desta causa petendi, o reconhecimento de certos efeitos normativos pretendidos pelo demandante. Em regra, o objeto de uma prova será precisamente a demonstração direta do fato jurídico (também dito "fato principal", "fato com transcendência jurídica", "fato essencial”, "fato primário" etc.). Há casos, entretanto, em que a verificação da ocorrência ou não de tal fato não será feita de forma direta, mas por meio da demonstração de outros fatos (ditos por isso fatos "acessórios", "não dotados de transcendência jurídica", "não essenciais", "secundários" etc.) que permitam formar a convicção do órgão julgador sobre a ocorrência daquele fato essencial.

São essas diferentes relações funcionais entre o objeto da prova concretamente produzida e o fato principal da causa que permitem traçar com nitidez a conhecida

\footnotetext{
${ }^{631}$ DANILO KNIJNIK, A prova nos juizos civel, penal e tributário, n. 1.5-1.6, p. 16-24 (destacando a importância dos modelos e sua natureza de quaestio iuris) e n. 2.2-2.4, p. 31-45 (desenvolvendo os três modelos).

${ }^{632}$ STJ, $1^{\text {a }}$ T., REsp 859.388/RJ, rel. Min. LuIZ FuX, j. em 02/10/2008, Inf. 370.

${ }^{633}$ TRE-SP, Recurso no 33286, rel. PAULO HENRIQUE LuCON, j. em 08/06/2010, DJe 22/06/2010; TRE-SP, Recurso ${ }^{\circ} 32513$, rel. PAUlo HenRIQUe LuCON, j. em 27/05/2010, DJe 08/06/2010; TRE-SP, Recurso ${ }^{\circ}$ 33160, rel. PAUlo HeNRiQue LuCON, j. em 27/05/2010, DJe 10/06/2010; TRE-SP, Recurso no 33465, rel. Paulo HenRiQue LuCon, j. em 15/04/2010, DJe 29/04/2010; TRE-SP, Recurso n. ${ }^{\circ}$ 2053, rel. PaUlo HENRIQUE LUCON, j. em 29/09/2009, DOE 06/10/2009, p. 20.
} 
distinção entre prova direta e prova indireta: a prova será direta quando o meio de prova empregado for abstratamente idôneo a demonstrar a ocorrência do próprio fato jurídico relevante ao caso, em si mesmo considerado; será, por sua vez, indireta quando o objeto da prova for fato diverso deste, embora, a partir de sua comprovação, por meio de um raciocínio probabilístico, possa-se considerar existente o fato jurídico probando. ${ }^{634}$

O raciocínio por meio de presunções permite justamente a inferência de um fato desconhecido (fato probando) a partir de um fato conhecido (indício), calcada na constatação de uma relação de causalidade entre os dois fatos, segundo o que normalmente acontece (id quod plerumque accidit). A prova indiciária (circumstancial evidence), portanto, é aquela em que se parte de um fato provado (indício) para que se chegue, por meio de uma inferência calcada em uma probabilidade indutiva, ao fato probando (factum probandum). ${ }^{635}$

As presunções são comumente classificadas em legais (estabelecidas previamente pelo legislador) e simples (ou hominis, resultantes do raciocínio do julgador por meio do emprego de regras de experiência comum). As primeiras, por sua vez, podem ser relativas (iuris tantum) ou absolutas (iuris et de iure), conforme admitam ou não, respectivamente, prova em contrário, ou seja, comprovação de que o fato probando na verdade não ocorreu. Costuma-se, aludir, ainda, a presunções mistas ou intermédias, para designar tipos presuntivos em que somente alguns meios de contraprova, especialmente previstos em lei, são admitidos. ${ }^{636}$

Por óbvio, a aplicação das presunções ditas legais é uma questão de direito, já que sua aplicação vem detalhada em regras jurídicas. Não há dúvida, v.g., de que na esfera tributária, diante dos princípios da legalidade, tipicidade e capacidade contributiva, o uso de presunções é sensivelmente restringido, ${ }^{637}$ dando ensejo à revisão de sua aplicação por meio do recurso especial. Nas presunções absolutas, em verdade, há "uma equiparação de

\footnotetext{
${ }^{634}$ Por todos, Michele TARUfFo, La prueba de los hechos, n. VI/2.1, p. 453 e ss.

${ }^{635}$ ElENA CATALANO, "Prova indiziaria, probabilistic evidence e modelli matematici di valutazione", p. 517.

${ }^{636}$ Ver, sobre isso, MOACYR AMARAL SANTOS, Prova judiciária no cível e comercial, vol. 5, p. 426-429.

${ }^{637}$ CASALTA NABAIS, O dever fundamental de pagar impostos, esp. n. 18, p. 498 e ss.
} 
eficácia", por meio da qual a lei "atribui efeitos iguais a diferentes esquemas de fato", de maneira semelhante ao que ocorre com as ficções. ${ }^{638}$

O que se questiona, portanto, é a possibilidade de revisar o emprego de presunções simples, nas quais desponta o papel desempenhado pelas regras de experiência comum.

As regras de experiência (Erfahrungssätze) distinguem-se de outras formas de conhecimento privado juiz - tal como os fatos notórios ou impressões por ele diretamente colhidas -, porquanto apresentam, ao contrário daqueles, "caráter de generalidade e abstração", ${ }^{639}$ representando máximas daquilo que, por definição, ordinariamente acontece.

Exercem funções distintas, segundo sejam utilizadas para a concretização de conceitos indeterminados e cláusulas gerais ou para embasar o raciocínio presuntivo no terreno probatório. ${ }^{640}$ De acordo com essa dualidade, a tendência será: I) admitir a revisão das regras de experiência quando sirvam ao propósito de interpretar/aplicar normas jurídicas e de II) rechaçá-la quando a máxima estiver à base do convencimento do juiz acerca das provas. ${ }^{641}$

É verdade que, nesse segundo caso, se reduzindo, para efeitos didáticos, o raciocínio judicial a um silogismo, a regra de experiência também vai situada como a premissa maior do esquema. ${ }^{642} \mathrm{O}$ próprio Superior Tribunal de Justiça por vezes invoca

\footnotetext{
${ }^{638} C f$., com muita clareza, BARBoSA MOREIRA, "As presunções e a prova”, n. 5 , p. 64 e ss.; v., ainda, PONTES DE MIRANDA, Comentários ao Código de Processo Civil (de 1973), tomo IV, p. 234-236.

${ }^{639}$ BARBosa Moreira, "Regras de experiência e conceitos jurídicos indeterminados", n. 1, p. 61-62; também CALAMANDREI, La casación civil, tomo III, n. 104, p. 296.

${ }^{640}$ Sobre o tema, amplamente, FRIEDRICH STEIN, El conocimiento privado del juez, § 3, p. 41-58. Entre nós, BARBOSA MOREIRA, "Regras de experiência e conceitos jurídicos indeterminados", n. 4, p. 66-67; antes, na doutrina italiana, CALAMANDREI, La casación civil, tomo III, n. 104, p. 297.

${ }^{641}$ Trata-se de uma solução intermediária cunhada pela doutrina alemã, tal como apontou CALAMANDREI, $L a$ casación civil, tomo III, n. 104, p. 298. Este autor, por sua vez, nega, prima facie, o controle das máximas de experiência, embora admita os resultados da teoria intermediária apontada: nesses casos, contudo, "a cassação terá lugar não porque haja sido violada em si uma máxima de experiência, mas porque a violação da mesma constitui em substância um erro de direito contra a norma jurídica em integração da qual a máxima havia sido utilizada" (op. cit., n. 104, p. 300; veja-se também a síntese em n. 105, p. 302). Noutro sentido, ALEJANDRO BuENDÍA CÁNOVAS, La casación civil, cap. IV, p. 325-326 e LUCIA PALMEIRO DA FONTOURA, Recurso especial, n. 5.1, p. 51 e ss. (ambos defendendo a revisibilidade das máximas de experiência em todos os campos, na medida em que se apresentam, sempre, como premissas gerais do raciocínio jurídico).
}

${ }^{642}$ AlfRedo BuZAID, "Nova conceituação do recurso extraordinário na Constituição do Brasil", n. 13, p. 194-195; Id., "Máximas de experiência", n. 16, p. 142-143, embora o autor, nesse último estudo, vislumbre a possibilidade de controle relativo ao emprego de máximas de experiência apenas por violação aos limites impostos pelo art. 335, CPC, dada a "rigidez constitucional" do conceito de lei federal. Já adiantara, 
máximas de experiência em seus julgamentos; a ementa de um acórdão diz textualmente que "as máximas da experiência demonstram, mulher de rurícola, rurícola é", repousando sobre essa assertiva a sua ratio decidendi. ${ }^{643}$

Veja-se um exemplo formulado na doutrina: "Em geral, o crime é cometido pela pessoa que possuía a arma adequada; ora, a pessoa que possuía a arma adequada é o réu; logo, o crime deve ter sido cometido pelo réu".

De modo algum, contudo, pode-se dizer que a regra de experiência substitui uma norma de decisão, a ser ulteriormente aplicada às circunstâncias presumidas pelo juiz. ${ }^{644}$ Daí a excepcionalidade do controle sobre o raciocínio fundado em presunções hominis, tema que se liga preponderantemente às particularidades do caso e que somente em raras ocasiões poderá servir ao fim jus-unitário; em alguma medida, o tema deve ser visto como o controle - também excepcional(íssimo) - sobre a motivação dos julgados.

Em resumo, na sede do recurso especial, há pouco espaço para o controle do uso de máximas de experiência no terreno probatório. Por óbvio, não será jamais possível reexaminar a convicção da instância a quo diante da ocorrência ou não do fato indiciário. Entretanto, e apenas na medida em que se possa daí extrair uma pauta geral, será possível controlar a regra de experiência utilizada para alcançar a conclusão quanto ao fato probando. ${ }^{645}$

\subsection{SEGUE: CONTROLE SOBRE A MOTIVAÇÃO}

Problema delicado é o do controle sobre a motivação dos julgados. Por certo, é esta uma garantia importante do devido processo legal, prevista tanto no altiplano constitucional quanto a nível infraconstitucional (art. 93, IX, CF; art. 458, II, CPC). No entanto, é também verdadeiro que o controle desse erro de procedimento em sede de

entretanto, que "não repugna a idéia de que, a bem da inteireza do direito, venha o Supremo Tribunal Federal a modificar a sua jurisprudência, sob o fundamento de que a regra de experiência comum, adotada por um tribunal, se contrapõe à regra de experiência comum, adotada por outro tribunal" (op. e loc. cit.).

${ }^{643}$ STJ, $6^{\text {a }}$ T., REsp 210.935/SP, rel. Min. LuIZ ViCEnTE CernicChiARo, j. em 30/06/1999, DJ 23/08/1999, p. 175.

${ }^{644} \mathrm{O}$ exemplo citado no parágrafo anterior, em sua literalidade, e as constatações dele advindas, são devidos a BARBOSA MOREIRA, "As presunções e a prova", n. 8, p. 68-70.

${ }^{645}$ Luiz Guilherme MARINONI - SÉrgio C. ARenhart, Prova, n. 20.11, p. 339-340. 
recurso excepcional não pode ser ampliado a ponto de desnaturar a função dos Tribunais Superiores.

Na Itália, o controverso motivo inserido no art. 360, 5, c.p.c., permite um controle sobre a motivação da sentença, em sede de cassação, quando houver omissão, contradição ou ilogicidade acerca de um fato decisivo. ${ }^{646}$

Também no direito alemão - embora o BGH seja obrigado, em princípio, a aceitar a versão dos fatos narrada pelo Tribunal de origem - o juízo fático pode ser objeto de censura quando contrarie "os processos de argumentação razoável, as leis da natureza ou conhecimento científico estabelecido". 647

$\mathrm{Na}$ França, costuma-se distinguir, nesse campo, os vícios de défaut de motifs e manque de base légale. O primeiro representa um vício de forma, violação ao art. 455, NCPC, dispositivo que impõe a fundamentação das decisões, podendo traduzir-se na ausência total, falta de resposta a pedido ou contradição insuperável entre motivos. $\mathrm{O}$ segundo configura-se quando a motivação é insuficiente para permitir um controle sobre a aplicação das normas jurídicas pela Cassation. ${ }^{648}$

Segundo AdA Pellegrini GrinOver, pode (e deve) ser controlado o defeito de motivação pelos Tribunais de superposição, embora esses não tenham demonstrado "sensibilidade para com o problema"; "assim, é muito tênue, na prática, o controle sobre o raciocínio do juiz (...) limitando-se aos casos em que cometa ele erros graves ou omita o exame de uma questão essencial". 649

E parece que deve ser assim. O controle sobre a motivação, quando exercido com muita liberdade, pode levar a distorções da função do Superior Tribunal de Justiça. A Corte de Cassação italiana tem sido alvo de constantes críticas nesse sentido. ${ }^{650}$ MiCHELE

\footnotetext{
${ }^{646}$ Claudio Consolo, Il processo di primo grado e le impugnazioni..., p. 507-508.

${ }^{647}$ Peter L. MURRAY - ROLF STÜRNER, German civil justice, cap. 10(E)(2), p. 392

${ }^{648}$ GUINCHARD - FERRAND - CHAINAIS, Procédure civile, n. 1807-1809, p. 1264-1266.

${ }^{649}$ ADA PELLEGRINI GRINOVER, “O controle do raciocínio judicial pelos Tribunais Superiores brasileiros”, n. 7, p. 17-18; também assim na cassação italiana, $c f$. MiCHELE TARUFFO, El vértice ambiguo, introd., p. 28 (ajuris, 1990, vol. 50).

${ }^{650}$ A Corte de Cassação italiana tem sido criticada justamente por "abusar" do controle sobre a motivação das sentenças. Ver, nesse sentido, RACHEL ANNE FENTON, "Separating law from facts: the difficulties faced by the Italian Corte di Cassazione in an appeal for illogicality of reasoning", p. 709 e ss., passim. O ensaio critica amplamente uma decisão da Corte de Cassação (6 nov. 1998 - 10 fev. 1999, n. ${ }^{\circ} 1.636$ ), em que esta afirmou - dentre outros argumentos utilizados para revisar amplamente os fatos da causa e afastar uma condenação por estupro - como sendo dado comum da experiência o fato de que, diante da dificuldade em remover calças tipo jeans, esse resultado implica a colaboração ou o consentimento da pessoa que as veste
} 
TARUFFO já demonstrou como a motivação deve ser vista como uma "argumentação justificativa", não se confundindo com o procedimento decisório ou heurístico. Assim, sob a rubrica do controle de motivação deve ser averiguada a validade da justificação, e não um reexame do juízo fático. ${ }^{651}$

Isso compreende, por exemplo, a sua plenitude (ou completude), sendo necessárias justificativas adequadas para adotar um entendimento contrário ao resultado de uma prova científica. A omissão em considerar um fato relevante provado nos autos (v.g., o resultado concludente de uma prova pericial ou um documento autêntico) representa vício grave de motivação, pois falta à fundamentação a justificativa para uma de suas premissas. Afrontase o preceito do art. 131, CPC, no sentido de que o juiz deverá julgar com base na prova dos autos. Serão raros os casos em que essa particularmente grave incompletude (Unvollständigkeit) do juízo fático ocorrerá, na medida em que a hipótese não se confunde com a valoração negativa da prova em questão (caso em que não há omissão) e exige, ademais, uma relação causal direta entre o fato ignorado e o desfecho da causa. ${ }^{652}$ Entretanto, não se pode afastar a possibilidade. Imagine-se, v.g., uma ação renovatória de locação comercial a que é oposta, pelo locador, a exceção de descumprimento do contrato, vindo o pagamento de aluguéis a menor ser comprovado pela perícia judicial e, por isso, a ação julgada improcedente em primeiro grau. O Tribunal de Justiça não poderá, em grau de apelação, desconsiderar o resultado da prova pericial sem justificativa para tanto, renovando o contrato sem refutar o pagamento a menor dos locativos, sob pena de ofender, a um só tempo, o art. 131, CPC e o art. 71, II, Lei n. ${ }^{\text { } 8.245 / 91 .}{ }^{653}$ Caberá, portanto, recurso especial.

Em resumo, define OvíDIO BAPTISTA DA SILVA, aos Tribunais Superiores "a tarefa que lhes é pertinente de comprovar se a fundamentação dos respectivos julgados não se mostra insuficiente, equivocada ou contraditória, tornando-se portanto arbitrária, com ofensa, especialmente, aos preceitos dos arts. 131 e 458 do Código de Processo Civil,

em retirá-las ("Deve poi rivelarsi che è un dato di comune esperienza che è quasi impossibile sfilare anche in parte i jeans ad una persona senza la sua fattiva collaborazione, poiché trattasi de una operazione che è già assai difficoltosa per chi li indossa"). O caso ganhou enorme notoriedade na mídia, inclusive estrangeira, e ficou conhecido como o "jeans alibi ruling".

${ }^{651}$ El vértice ambiguo, $\S 6$, p. 191-219.

${ }^{652}$ FRIEDRICH STEIN, El conocimiento privado del juez, § 7, p. 138-139.

${ }^{653} \mathrm{Na}$ medida em que, consoante julgados do Superior Tribunal de Justiça, "a comprovação do integral cumprimento da avença locatícia, (...) é indispensável para a propositura da renovatória. Precedentes." (STJ, 5 T., REsp 278.648/SP, rel. Min. FELIX FISCHER, j. em 14/11/2000, DJ 04/12/2000, p. 103). 
pilares de uma jurisdição compatível com um Estado Democrático de Direito, de modo a impedir que o inevitável arbítrio de decisões judiciais, carentes de fundamentação, violem a Constituição ou alguma norma de direito infraconstitucional". ${ }^{654}$ Por isso, os Tribunais Superiores, ao exercerem o controle sobre a motivação, não devem perder de vista a sua função objetiva e, portanto, não devem - a pretexto de controlar a racionalidade da justificação da decisão tomada - reexaminar as particularidades e acontecimentos históricos específicos da causa, exercendo uma autolimitação na matéria.

\subsubsection{NORMAS TIPICAMENTE VAGAS (CLÁUSULAS GERAIS, "STANDARDS" E CONCEITOS INDETERMINADOS)}

É também pelo ângulo da função do Tribunal Superior que devem ser analisadas as cláusulas gerais, standards e conceitos indeterminados. Deve-se ter em mente que esses são exemplos de uma técnica legislativa utilizada no intuito de delegar maior liberdade de decisão ao juiz e, por isso mesmo, particularmente sensíveis aos detalhes do caso concreto (v., supra, $\S 4^{\circ}$ ). A doutrina tradicional costuma referir-se a questões de direito "speciali, in hypothesi", em contraposição às "questões de direito gerais". ${ }^{65}$ Para a tese tricotômica, já apreciada, são típicas mixed questions of law and fact.

Sendo a norma, em tais casos, uma manifestação acentuadamente jurisprudencial, para que a aplicação de cláusulas gerais, standards e conceitos jurídicos indeterminados seja consistente, é enorme a importância do estudo de casos. Seu desenvolvimento ocorre, assim, sobretudo por meio de um raciocínio tópico, e não por um pensamento axiomáticodedutivo, já que o texto legal, por si só, diz pouco ao julgador. No entanto, a partir da análise de problemas concretos, vão sendo tomadas decisões que concretizam, pouco a pouco, as normas vagas, de acordo com os valores a que elas remetem. A partir daí, cabe comparar as rationes decidendi dos precedentes pertinentes, podendo-se induzir regras que vão progressivamente delimitando os contornos da cláusula. ${ }^{656}$

Assim, no campo das normas vagas (conceitos jurídicos indeterminados, cláusulas gerais etc.), é fundamental o papel dos precedentes - sobretudo daqueles produzidos por

\footnotetext{
${ }^{654}$ OvíDIO A. BAPTISTA DA SILVA, “"Questão de fato’ em recurso extraordinário”, p. 500.

${ }^{655}$ CALAMANDREI, La casación civil, tomo III, n. 39, p. 95 e ss.

${ }^{656}$ Sobre o tema, JUdith MARTINS-CostA, A boa-fé no direito privado, n. 4.4, p. 355 e ss. (explicando a aplicação das cláusulas gerais mediante recurso à tópica jurídica e o impacto desse modo de raciocínio sobre o conceito de sistema).
} 
Tribunais Superiores -, a fim de concretizar o seu sentido e reduzir o âmbito de incerteza na sua aplicação, ${ }^{657}$ por meio de uma "tipificação de casos" ${ }^{658}$ que conduza a uma mais detalhada "elaboração" da norma. ${ }^{659}$ Normas que imponham certos standards de comportamento, v.g., devem ser revisadas a fim de fixar-se uma "subnorma", que preenche e detalha aquele conceito. ${ }^{660}$

Enquanto Cortes de precedentes, é de primeira grandeza o papel desempenhado pelos Tribunais Superiores na aplicação das normas vagas, justamente porque, para que uma pauta útil seja estabelecida, é necessário que a ratio decidendi do caso concreto possa ser generalizada, servindo como exemplo para outros casos. Trata-se de missão difícil: se, por um lado, o Tribunal deve concretizar um endereço jurisprudencial para casos futuros (i.e, um topos ou locus argumentativo), por outro, não deve abstrair excessivamente as características relevantes do caso, de modo a formular uma regra demasiadamente ampla, com o que enrijeceria a aplicação e anularia a desejável flexibilidade da norma vaga. ${ }^{661}$

Sendo assim - e lembrando novamente que as razões de uma decisão anterior reduzem a liberdade do respectivo Tribunal ao julgar casos futuros -, o Superior Tribunal de Justiça deve atuar apenas quando possa contribuir para a clarificação ou para o desenvolvimento do Direito. Inversamente, se não for viável estabelecer - em razão da especial relevância das particularidades da controvérsia para o seu desfecho - um topos

\footnotetext{
${ }^{657}$ Ver, v.g., HORST-EBERHARD HENKE, La cuestión de hecho..., § 4(II), p. 115 e ss., p. 338; HUMBERTO ÁvILA, "Subsunção e concreção na aplicação do direito", Faculdade de direito da PUCRS: o ensino jurídico no limiar do novo século, Porto Alegre: EDIPUCRS, 1997, n. 2.1.2.4, p. 441; DANILO KNIJNIK, O recurso especial e a revisão da questão de fato..., n. 1.3.1, p. 53 e n. 3.5.4, p. 205; JOÃO FRANCISCO NAVES DA FONSECA, Exame dos fatos nos recursos extraordinário e especial, n. 25, p. 92.

${ }^{658}$ GIUSEPPE CAMPEIS - ARRIGO De PAULI, Il giudizio di Cassazione: le novità della riforma, n. 1.1, p. 17.

${ }^{659}$ HeNRY P. MONAGHAN, “Constitutional fact review”, p. 237.

${ }^{660}$ Nesse sentido, GIOVANNI VERDE, "In difesa dello jus litigatoris...", n. 7, p. 14 (exemplificando que, da norma que impõe a diligência dos médicos, a Corte di Cassazione fixou uma subnorma prevendo sua responsabilização pela não realização de parto cesáreo diante de determinadas condições específicas).

${ }^{661}$ Parece ser esta a idéia central da "objeção decisiva" (em boa medida injusta) formulada à teoria de SCHWINGE por HENKE, no sentido de que "o método teleológico de Schwinge negligencia o efeito exemplificador que dimana do julgamento do caso concreto, embora os exemplos de subsunções sejam imprescindíveis para entender e aplicar as pautas, formuladas freqüentemente de maneira indeterminada e por isso difíceis de apreciar em seus alcances" (La cuestión de hecho..., § 2(III), p. 36). Diz o autor, em síntese, que no método teleológico haveria uma supervalorização das possibilidades de criação de pautas gerais, ao mesmo tempo em que seriam subestimadas a importância da subsunção concreta para a aclaração e exame de tais pautas, bem como para o procedimento de comparação de casos (op. cit., § 2(III), p. 42). A crítica parece, como dito, em boa medida injusta, porquanto embora seja certo que somente a análise do caso concreto permite abstrair, a partir dos seus elementos jurídicos relevantes, uma pauta geral, o estabelecimento desta orientação será feito somente nos limites dessa possível abstração, sem que se criem precedentes excessivamente amplos em relação ao problema a ser resolvido. Levando em conta tais considerações, não se faz ruir a teoria de SCHWINGE ou, ao menos, o desenvolvimento que a partir de suas idéias centrais pode-se construir.
} 
adequado para casos futuros, sem incorrer em excessiva generalização, a função de orientação (guidance function) do Tribunal não pode ser cumprida. $\mathrm{O}$ critério funcional exclui a revisibilidade da questão em tais hipóteses.

\subsection{SEgUE: CASUÍSTICA}

A fim de ilustrar o raciocínio tópico descrito no item antecedente, cabe referir a casuística. Pouco adiantaria persistir em considerações teóricas e abstratas, já que o raciocínio axiomático-dedutivo é pouco útil nessa sede.

Dentre as normas vagas, os conceitos ligados aos elementos da responsabilidade civil aquiliana, em especial, têm sido bastante desenvolvidos pelo Superior Tribunal de Justiça. No que tange à imputação da responsabilidade por negligência, a Corte já entendeu, v.g.: I) haver negligência do médico que não presta assistência pós-cirúrgica à paciente que apresenta agravamento do estado de saúde após intervenção, preferindo encaminhá-la a terceiros; ${ }^{662}$ II) ser responsável o Banco pelo lançamento indevido de débito na conta-corrente do cliente; ${ }^{663}$ III) ter agido de maneira negligente o comerciante que não identifica o portador do cartão de crédito, possibilitando o uso de cartões clonados; $\left.{ }^{664} \mathrm{IV}\right)$ haver culpa in vigilando da administração pública pela morte de filho ocorrida dentro de uma cela de unidade prisional em razão do agir de outros detentos. ${ }^{665}$

Também assim quanto ao nexo causal, que é usualmente considerado um "elemento lógico-normativo" na imputação de responsabilidade civil. ${ }^{666}$ Nesse sentido, v.g., já se afastou o nexo causal e a responsabilidade do Estado que daí adviria em hipótese em que menor foragido que deveria cumprir medida sócio-educativa em regime de semiliberdade efetuou disparo com arma de fogo e a "bala perdida" veio a atingir terceiro, porquanto não haveria "causa direta e imediata" entre a omissão estatal e o tiroteio. ${ }^{667}$ Segundo o Superior Tribunal de Justiça, não é igualmente responsável o prestador de serviço de transporte por fato totalmente estranho, considerado então como de "força maior", tal como o disparo

\footnotetext{
${ }^{662}$ STJ, $4^{\text {a }}$ T., REsp 914.329/RJ, rel. Min. JOÃO OTÁVIO dE NORONHA, j. em 19/08/2008, Inf. 364. ${ }^{663}$ STJ, $4^{\text {a }}$ T., REsp 437.222/MG, rel. Min. ALdir PASSARINHO JR., j. em 15/04/2008, Inf. 352.

${ }^{664}$ STJ, $4^{\text {a }}$ T., REsp 945.154/RN, rel. Min. JOÃO OtÁVIO DE NoRONHA, j. em 08/04/2008, Inf. 351.

${ }^{665}$ STJ, $1^{\text {a }}$ T., REsp 936.342/ES, rel. p/ ac. Min. LuIZ FuX, j. em 11/11/2008, Inf. 376.

${ }^{666}$ STJ, $4^{\mathrm{a}}$ T., REsp 325.622/RJ, rel. Min. conv. CARLOS FernANDO MATHIAS, j. em 28/10/2008, Inf. 374.

${ }^{667}$ STJ, $1^{\text {a }}$ T., REsp 858.511/DF, rel. p/ ac. Min. TEORI ZAVASCKI, j. em 26/08/2008, Inf. 365.
} 
vindo de outro veículo que atinge o passageiro; ${ }^{668}$ entretanto, ele responde pelo furto de automóvel no estacionamento, não cabendo alegar força maior no caso. ${ }^{669}$

Causas supervenientes de alteração ou resolução dos contratos são freqüentemente objeto de atenção. Assim, por exemplo, já se defendeu em sede doutrinária quanto ao desequilíbrio da equação econômico-financeira (decorrente de fato imprevisível) de contrato administrativo. ${ }^{670}$ É também do Superior Tribunal de Justiça julgado em que se fixou o entendimento de que, em contrato de venda e compra de safra futura por preço certo, não há onerosidade excessiva quando o fato que alterou a cotação do produto no mercado internacional não era imprevisível. ${ }^{671}$ Por outro lado, vícios de vontade como a coação têm sido relegados à categoria de questões fáticas, sem que se conheçam os correspondentes recursos. ${ }^{672}$

O Superior Tribunal de Justiça tem também controlado a aplicação de sanções por ato de improbidade administrativa, adequando-as proporcionalmente aos fatos, tal como acertados pela instância $a$ quo. ${ }^{673}$ Já se excluiu, em dada ocasião, condenação por ato de improbidade administrativa (ex art. 11, Lei ${ }^{\circ}{ }^{8} 8.429 / 92$ ) ao argumento de que o tribunal local havia qualificado erroneamente a conduta praticada pelo agente, na medida em que a mera negligência reconhecida não se subsumiria a um tipo doloso. ${ }^{674}$

\subsubsection{INTERPRETAÇÃO DE CLÁUSULAS DE NEGÓCIOS JURÍDICOS}

A doutrina, em sua grande maioria, enxerga na interpretação de cláusula contratual um "mero desdobramento" do gênero das questões de fato. Perquirir o teor das declarações de vontade corresponderia a averiguar a intenção dos contraentes e, portanto, como as circunstâncias particulares do caso se passaram, sem que se pudesse, aí, vislumbrar uma

\footnotetext{
${ }^{668}$ STJ, $4{ }^{\text {a }}$ T., REsp 589.629/RJ, rel. Min. FERnANDO GONÇALVES, j. em 02/10/2008, Inf. 370. ${ }^{669}$ STJ, 4a T., REsp 503.208/SP, rel. Min. ALDIR PASSARINHO JR, j. em 26/05/2008, Inf. 357.

${ }^{670}$ Sobre esse tema, v. o parecer de CÂNDIDO DINAMARCO, “Admissibilidade do recurso especial ou extraordinário e as chamadas questões mistas”, esp. n. 616, p. 915-916.

${ }^{671}$ STJ, $4{ }^{\text {a }}$ T., REsp 679.086/GO, rel. Min. FernANDO GONÇALVES, j. em 10/06/2008, Inf. 359.

${ }^{672}$ STJ, $3^{\text {a }}$ T., EDcl no AgRg no Ag 1295506/DF, rel. Min. VASCO DELla GiUstina j. em 21/10/2010, DJe 03/11/2010; STJ, REsp 229.601/SP, 4a T., rel. Min. Aldir PASSARINHO JUNIOR, j. em 14/12/2004, DJ 14/03/2005, p. 339.

${ }^{673}$ STJ, $2^{\mathrm{a}}$ T., EDcl no REsp 1.021.851, rel. Min. EliAnA CALMON, j. em 23/06/2009, Inf. 400.

${ }^{674}$ STJ, $1^{\text {a }}$ T., REsp 875.163, rel. Min. DENISE ARRUDA, j. em 19/05/2009, Inf. 395.
} 
questão de direito. ${ }^{675}$ A jurisprudência endossa o entendimento, tendo inclusive versado a matéria em enunciados das Súmulas (n. ${ }^{\circ}$, Súmula/STJ; antes, n. ${ }^{\circ} 454$, Súmula/STF).

O entendimento referido é, prima facie, acertado. Entretanto, a maior parte da doutrina vê algo diferente na interpretação da cláusula contratual para que se qualifique o contrato. $^{676}$

Há hipóteses, ademais, em que pode ocorrer violação à lei federal que regula os cânones da interpretação contratual. ${ }^{677}$ Em tais casos, à semelhança do que ocorre no direito alemão ${ }^{678}$ e na dénaturation do direito francês, ${ }^{679}$ é defensável a possibilidade de revisar a correta aplicação das normas legais. Tenha-se em mente, por exemplo, a necessidade de interpretar os contratos de acordo com a boa-fé (art. 422, CC).

Por outro lado, em contratos que tenham alcance geral ou sejam de aplicação freqüente, haverá um interesse público em fixar pautas sobre a interpretação de suas cláusulas, que pode justificar a intervenção do Tribunal Superior. São exemplos: contratos padronizados do comércio internacional ou contratos adesivos, em que falta, na verdade, uma vontade individual e, portanto, não se perquire uma intenção particular. ${ }^{680}$

675 Nesse sentido, BARBOSA MOREIRA, “Alegação de compensação rejeitada no despacho saneador. Documento junto sem audiência da outra parte. Pedido de exibição de documento em poder de pessoa jurídica sediada no estrangeiro. Questão de qualificação jurídica: possibilidade de reexame mediante recurso extraordinário", n. 21, p. 235; ARRUDA ALVIM, "Recurso extraordinário", p. 158 e 163 e ss. (entendendo que a qualificação de um contrato administrativo como de permissão ou concessão é quaestio facti).

${ }^{676}$ BARBOSA MOREIRA, “Alegação de compensação rejeitada no despacho saneador. Documento junto sem audiência da outra parte. Pedido de exibição de documento em poder de pessoa jurídica sediada no estrangeiro. Questão de qualificação jurídica: possibilidade de reexame mediante recurso extraordinário", esp. n. 25-26, p. 238-239; ATHOS GUSMÃO CARNEIRO, Recurso especial, agravos e agravo interno, 6. ed., Rio de Janeiro: Forense, 2009, n. 13.4, p. 40; FREDIE DIDIER JR. - LEONARDO J. CARNEIRO DA CUNHA, Curso de direito processual civil, 8. ed., Salvador: JusPodivm, 2010, cap. VII, n. 5, p. 258; ClARA AzZONI, Recurso especial e extraordinário, n. 4.1.4, p. 162-163. Na doutrina estrangeira, já FRIEDRICH STEIN (El conocimiento privado del juez, § 7, p. 155-156), que vai, em verdade, além e reconhece a possibilidade de serem interpretadas as declarações de vontade das partes, quando estas representam o suporte fático direto e relevante de uma conseqüência jurídica, caso em que a interpretação é, na verdade, uma determinação da eficácia jurídica (Rechtssetzung), operação de natureza subsuntiva (op. cit., § 7, p. 158-161).

${ }^{677}$ LeOnidas Cabral AlbuQuerque, Admissibilidade do recurso especial, Porto Alegre: SAFe, 1996, n. 4.1.1.1, p. 96.

${ }^{678}$ Cf. Peter GotTwAld, "Review appeal to the German Federal Supreme Court after the reform of 2001", n. IV, p. 97 (dando como exemplos violações aos $\S \S 133$ e 157 do Código Civil alemão, que tratam, respectivamente, da necessidade de se perquirir a intenção das partes, e não o significado literal das palavras, e de interpretar os contratos de acordo com a boa-fé e com os costumes e párticas negociais).

${ }^{679}$ GUINCHARD - FERRAND - CHAINAIS, Procédure civile, n. 1809, p. 1266-1267 (apontando o art. 1.134 do Código Civil francês, que remete à força de lei do contrato entre as partes e à boa-fé).

${ }^{680}$ Cf. FRIEDRICH STEIN, El conocimiento privado del juez, § 7, p. 161; RAFAEL BICCA MACHADO, Recurso especial, p. 50-54. 
Nesse sentido, a doutrina alemã considera que "a interpretação de fórmulas de contratos alemães e condições gerais de venda é questão de direito e, por isso, susceptível de revista [i.e, Revision], se as condições são aplicáveis para lá da circunscrição dum OLG (BGHZ 126, 328)". ${ }^{681} \mathrm{O}$ mesmo, diga-se de passagem, ocorre com o direito francês, em que os "convênios coletivos de trabalho, os contratos tipo e as condições gerais dos contratos" podem ser objeto de recurso de cassação. ${ }^{682} \mathrm{Na}$ Itália, o art. 360, 3, c.p.c, prevê que podem ser impugnadas as decisões que violarem normas previstas em contratos e acordos coletivos nacionais de trabalho. ${ }^{683}$ É a generalidade, mais uma vez, a governar a distinção entre fato e direito.

\subsubsection{PADRONIZAÇÃo de VAlORES (DANOS MORAIS E HONORÁRIOS DE ADVOGADO)}

A extensão do dano sofrido por uma pessoa é, via de regra, uma questão ligada aos contornos específicos de um evento individual e irrepetível, tema que, nos moldes da distinção aqui proposta, configuraria uma "questão de fato" (i.e, questão não passível de revisão pelo Superior Tribunal de Justiça). Por outro lado, colocando essa premissa em xeque, CHAÏM PERELMAn já pusera a seguinte pergunta: “os montantes concedidos pelo juiz, a título de reparação do dano moral, na medida em que tendem para a elaboração de tarifas jurisprudenciais, não contribuem para a objetivação daquilo que, à primeira vista, se apresenta como uma pura questão de fato, deixada à discrição do juiz da causa"? ${ }^{684}$

A resposta é certamente positiva, coadunando-se com a função objetiva da Corte, ao estabelecer parâmetros gerais na quantificação de valores que se seguem de acontecimentos padronizados ou massificados. ${ }^{685}$ Tendo isso em vista, o Superior Tribunal de Justiça, "com base em contundentes razões pragmáticas" 686 - razões que, tem-se

\footnotetext{
${ }^{681}$ OTHMAR JAUERNIG, Direito processual, §74, VII, p. 386.

${ }^{682}$ LOÏC CADIET, "El sistema de la casación francesa", Los recursos ante Tribunales Supremos en Europa (coord. Manuel Ortells Ramos), Madrid: Difusión Jurídica, 2008, n. II/1, p. 32.

${ }^{683}$ No original: "Le sentenze pronunciate in grado d'appello o in unico grado possono essere impugnate con ricorso per cassazione (...) per violazione o falsa applicazione di norme di diritto e dei contratti e accordi collettivi nazionali di lavoro".

${ }^{684}$ CHAÏM PERELMAN, Ética e direito, § 46, p. 578.

${ }^{685}$ Nesse sentido, parte da doutrina reconhece na previsão da indenização do dano moral (sobretudo, ex art. 186, CC), uma espécie de norma jurídica aberta, a ser necessariamente completada pelo juiz no caso ( $v . g$., JOÃO FRANCISCO NAVES DA FONSECA, Exame dos fatos nos recursos extraordinário e especial, n. 27, p. 95).

${ }^{686}$ ATHOS GUSMÃo CARNEIRO, Recurso especial, agravos e agravo interno, 6. ed., Rio de Janeiro: Forense, 2009, n. 13.3, p. 38-39; no mesmo sentido, aludindo à uma opção política da Corte, CLARA AZZONI, Recurso
} 
insistido, em verdade nada mais fazem senão retratar a verdadeira natureza do problema da admissibilidade dos recursos excepcionais, tradicionalmente formulado sobre as bases equívocas do par conceitual fato-direito - tem admitido revisar valores abusivos ou irrisórios fixados a título de dano moral ou honorários de advogado. ${ }^{687}$ A dedicação do Superior Tribunal de Justiça ao tema pode ser visualizada em face dos diversos enunciados da sua Súmula a esse respeito, v.g., nn. $37,227,387$ e 388.

Alguns julgados ressaltam ser essa uma "excepcional intervenção", justificada pelo princípio da razoabilidade na fixação do dano moral. ${ }^{688}$ Nesse diapasão, a jurisprudência da Corte dispensa uma prova concreta do dano (que seria, é claro, diabólica), demonstrando que a fixação de tarifas, em verdade, pouco tem a ver com o reexame das particularidades do indivíduo lesado.

Não se busca, por meio de tais decisões, questionar o acontecimento específico objeto de prova nos seus contornos, algo já apreciado devidamente nas instâncias inferiores, mas sim verificar a aptidão de tal categoria de episódios a ensejar danos morais indenizáveis, bem como, sendo a primeira resposta afirmativa, a extensão razoável do quantum correspondente. Reconheceram-se, v.g. os danos morais: I) resultantes da distribuição de placebos por empresa fabricante de anticoncepcionais, frustrando a escolha da mulher quanto ao momento de ter filhos; ${ }^{689}$ II) em razão de revista íntima excessiva realizada em estabelecimento prisional; ${ }^{690} \mathrm{III}$ ) decorrentes de manutenção em unidade prisional sem condições mínimas, afastando-se a alegação do princípio da reserva do possível; ${ }^{691} \mathrm{IV}$ ) como resultado da divulgação, em noticiário de rádio, de nome e endereço de vítima de estupro, sobrepondo-se, no caso, o direito à intimidade à liberdade de imprensa. ${ }^{692}$ Por outro lado, foram afastados danos morais, v.g.: I) quando - e embora seja

especial e extraordinário, n. 4.1.3, p. 160.

${ }^{687}$ Didático, nesse sentido, o seguinte precedente: "(...) III - O valor da indenização por dano moral sujeitase ao controle do Superior Tribunal de Justiça, sendo certo que, na fixação da indenização a esse titulo, recomendável que o arbitramento seja feito com moderação, proporcionalmente ao grau de culpa, ao nível sócio-econômico dos autores e, ainda, ao porte econômico dos réus, orientando-se o juiz pelos critérios sugeridos pela doutrina e pela jurisprudência, com razoabilidade, valendo-se de sua experiência e do bom senso, atento à realidade da vida e às peculiaridades de cada caso (...)" (STJ, 4a T., REsp 145358/MG, rel. Min. SÁlVIO de FigueIREDO TEIXEIRA, j. em 29/10/1998, DJ 01/03/1999, p. 325).

${ }^{688}$ Nesse sentido, v.g., STJ, 4a T., REsp 623776/SC, rel. Min. LUIS FELIPE SALOM̃̃O, j. em 25/05/2010, DJe $08 / 06 / 2010$

${ }^{689}$ STJ, $3^{\mathrm{a}}$ T., REsp 1.096.325/SP, rel. Min. NANCY ANDRIGHI, j. em 09/12/2008, Inf. 380.

${ }^{690}$ STJ, $2^{\mathrm{a}}$ T., REsp 856.360/AC, rel. Min. EliANA CALMON, j. em 19/08/2008, Inf. 364.

${ }^{691}$ STJ, $1^{\mathrm{a}}$ T., REsp 1.051.023/RJ, rel. p/ ac. Min. TEORI ZAVASCKI, j. em 11/11/2008, Inf. 376.

${ }^{692}$ STJ, $3^{\text {a }}$ T., REsp 896.635/MT, rel. Min. NANCY ANDRIGHI, j. em 26/02/2008, Inf. 346. 
dever da entidade cadastral de débitos comunicar a respectiva inclusão ao obrigado (n. 350, Súm./STJ) - há inequívoca ciência da dívida pelo devedor ou cadastramento efetuado a partir de dados públicos, tais como o registro de ajuizamento de execuções ou lavratura de protesto, ${ }^{693}$ ou, ainda, II) quando a existência da dívida não é questionada, a despeito da ausência de comunicação; ${ }^{694}$ Por vezes, o Tribunal invoca o enunciado n. ${ }^{\circ} 7$ da Súmula, mas adentra mesmo assim a discussão sobre a ocorrência de dano moral indenizável: afirmando, por exemplo, não constituir o fato de soar o alarme na saída do consumidor de estabelecimento comercial, por si só, mais do que um dissabor ou contratempo; ${ }^{695}$ ou, embora não conhecendo o recurso, afirmando que o ajuizamento de ação penal representa exercício regular de um direito, sem que a improcedência acarrete danos morais ao réu absolvido. $^{696}$

A atuação da Corte é semelhante em relação ao controle dos honorários advocatícios fixados pela instância a quo. Poderá o Tribunal inferior cometer, desde logo, equívoco evidente na aplicação das normas pertinentes, desrespeitando, v.g., os limites porcentuais previstos para a fixação da verba (piso de dez e teto de vinte) em casos submetidos ao regime do art. 20, $\S 3^{\circ}$, CPC. A revisão in iure aí é inquestionável. Com maiores restrições devem ser encaradas as hipóteses em que não se atropelam os limites legais, discutindo-se, em verdade, a apreciação das circunstâncias arroladas nas alíneas $a, b$ e $c$ do dispositivo. Segundo o enunciado n. 389 da Súmula do Supremo Tribunal Federal, esse exame seria vedado em recurso extraordinário. Por outro caminho, entretanto, andou a jurisprudência do Superior Tribunal de Justiça, permitindo, à semelhança do que já foi destacado em relação aos danos morais, a revisão de valores manifestamente irrisórios ou excessivos. $^{697}$

O mesmo raciocínio será aplicável ao arbitramento ex art. $20, \S 4^{\circ}$, CPC. Nesses casos, a fixação está a reclamar apreciação eqüitativa do juiz, mas deve respeitar uma "lógica do razoável" ${ }^{698}$ A fórmula é sem dúvida obscura, podendo-se dizer apenas haver

\footnotetext{
${ }^{693}$ STJ, $4^{\text {a }}$ T., REsp 1.038.272/RS, rel. Min. ALDIR PASSARINHO JR., j. em 17/06/2008, Inf. 360.

${ }^{694}$ STJ, 4 a T., REsp 997.456/RS, rel. Min. ALDIR PASSARINHO JR., j. em 11/03/2008, Inf. 348.

${ }^{695}$ STJ, $4^{a}$ T., REsp 470.694/PR, rel. Min. ALDIR PASSARINHO JR, j. em 07/02/2008, Inf. 343.

${ }^{696}$ STJ, $4{ }^{\text {a }}$ T., REsp 691.210/PB, rel. Min. Aldir PASSARINHO JR, j. em 07/10/2008, Inf. 371.

${ }^{697} \mathrm{~V} . g$, “(...) O reexame da verba honorária no âmbito do recurso especial só se dá em situações verdadeiramente excepcionais, em que ela é arbitrada de modo manifestamente irrisório ou excessivo -o que ficou evidenciado na espécie (...)" (STJ, $3^{\mathrm{a}}$ T., AgRg no Ag 619962/MG, rel. Min. ARI PARGENDLER, j. em 04/12/2007, DJ 01/02/2008, p. 1).

${ }^{698}$ Por último, STJ, 4a T., REsp 813.652/MA, rel. Min. CesAR Asfor RochA, j. em 03/04/2007, DJ
} 
uma baliza geral; nesse sentido, afirma-se "não se pode[r] fixá-los [os honorários] em quantia estratosférica ou insignificante, considerado o parâmetro do valor do bem da vida em discussão no processo". ${ }^{699}$

\subsubsection{ACERTAMENTo das CirCUnStÂnCias fáticas Relativas a vício de PROCEDIMENTO COMETIDO NO ACÓRDÃO RECORRIDO}

A invocação de errores in procedendo como causa de pedir recursal traz consigo peculiaridades se comparada à hipótese em que o recorrente fundamenta sua irresignação em um error in iudicando. Tal distinção repercute também sobre os problemas da distinção "fato-direito" e do âmbito de cognição reservado ao Superior Tribunal de Justiça no julgamento do recurso especial.

Evidentemente, o vício de procedimento consiste na violação de uma norma processual e exige, para que se configure, uma atuação concreta em desconformidade com a previsão normativa, do que resulta a invalidade de um ato (e daqueles que dele são dependentes) ou, ainda, do procedimento considerado como um todo. Portanto, para que se reconheça um error in procedendo, é necessário averiguar determinadas circunstâncias fáticas relativas à atividade do juiz a quo e das partes no próprio processo (houve ou não publicação de pauta de acordo com o art. $552, \S 1^{\circ}, \mathrm{CPC}$; decidiu ou não o julgado além do pedido da parte etc.).

Contudo, não se trata aqui de um juízo fático no sentido estrito do termo, isto é, de um autêntico juízo probatório (referente a um fato passado que foi objeto de prova), mas tão-somente do acertamento de uma situação objetivamente presente no processo em curso. ${ }^{700}$ Por isso, o Superior Tribunal de Justiça poderá “valorar os fatos" sobre os quais se apóia a alegação do recorrente - i.e, verificar a ocorrência de situações particulares do processo - a partir do material documentado nos autos, sem que isso importe violação ao enunciado n. 7 da Súmula. ${ }^{701}$

04/06/2007, p. 365.

${ }^{699}$ BRUNO LOPES, Honorários advocatícios no processo civil, n. 48, p. 204 (sobre os parâmetros para o arbitramento por eqüidade, v. n. 38, p. 155 e ss.).

${ }^{700}$ Por todos, Ferdinando MazZArella, Analisi del giudizio civile di cassazione, cap. 2, n. 7, p. 72.

${ }^{701}$ Nesse sentido, Barbosa Moreira, Comentários ao Código de Processo Civil, v. 5, n. 324, p. 601. Também é assim quanto ao juízo de cassação italiano e à revisão alemã, $c f$., respectivamente, LIEBMAN, Manual de derecho procesal civil, p. 504; FRIEDRICH STEIN, El conocimiento privado del juez, § 7, p. 127; 


\subsubsection{CONCLUSÕES PARCIAIS}

A distinção conceitual entre fato e direito é inviável do ponto de vista metodológico. Em razão disso, a insistência no par conceitual, antes de trazer uma solução, remete o intérprete a um problema sobre o qual pende, nas palavras de CASTANHEIRA NEVES, uma "dúvida radical". 702

Na prática, a distinção fato e direito é usada pelo Superior Tribunal de Justiça (e por outras Cortes Supremas) como sucedâneo de um mecanismo de seleção calcado na importância da questão, com a desvantagem de não deixar essa opção às claras, tornando-a intersubjetivamente incontrolável.

É necessário, por isso, substituir o paradigma "questão-de-fato-questão-de-direito" por uma abordagem estritamente funcional ou teleológica da admissibilidade dos recursos excepcionais, ainda que mantida a nomenclatura tradicional. O Superior Tribunal de Justiça pode intervir nos casos em que se apresente um problema normativo ou uma discussão sobre uma estrutura coletiva (ou quaestio iure), sendo a ele vedada a análise de particularidades e acontecimentos relacionados específica e tão-somente ao caso individual (ou quaestio facti). Em favor dessa solução falam não somente a função prospectiva dos Tribunais Superiores, mas também a sua capacidade institucional e a alocação racional de competências entre instâncias inferior e superior. É esse, portanto, o significado a ser atribuído ao "simples reexame de prova", tal como cristalizado no verbete n. 7 da Súmula/STJ.

A defesa da categoria das mixed questions of law and fact, por essa perspectiva, não é justificada como a melhor opção. Essa teoria renuncia ao desenvolvimento do Direito nos casos de indeterminação (nos quais não se possa seguramente corrigir as margens de decisão) e, ao transformar questões mistas - uma vez julgadas - em questões jurídicas, olvida o problema do acúmulo de serviço dos Tribunais Superiores. Ao invés de promover a função prospectiva da Corte, favorece uma atuação retrospectiva do controle de legalidade das decisões, própria de uma acepção particularista e analítica da nomofilaquia.

Ao fim e ao cabo, semelhantes considerações apontam seguramente no sentido da superação da equívoca distinção entre fato e direito pela instituição de um filtro dos recursos a serem julgados, baseado na importância da questão neles debatida, idéia

OTHMAR JAUERnig, Direito processual civil, § 74/VII, p. 384.

702 “A distinção entre a questão-de-facto e a questão-de-direito ...”, n. 1, p. 483 e p. 485, nota 1. 
consentânea com a função prospectiva de orientação que deve ser atribuída aos Tribunais Superiores. 


\section{§ 8 - JULGAMENTO DO RECURSO ESPECIAL E SEUS EFEITOS}

\subsection{EFEITO DEVOLUTIVO}

\subsubsection{CONCEITO}

A expressão "efeito devolutivo" tem origem na remota noção de que o Rei, ou outra autoridade superior, delegava poder jurisdicional aos juízes de primeiro grau. Desse modo, a interposição de recurso acabava por devolver a jurisdição ao seu natural titular. ${ }^{703}$

No direito brasileiro, todos os recursos (exceção feita aos embargos declaratórios e aos embargos infringentes na execução fiscal de pequeno valor) são dotados de efeito devolutivo. Parece carente de significação prática a discussão acerca da necessidade de se transferir a um órgão judiciário de hierarquia superior o reexame da causa ou do incidente para que se tenha verdadeiro efeito devolutivo; sendo outro o órgão do Poder Judiciário provocado por meio da impugnação a manifestar-se, há transferência e, portanto, devolução. ${ }^{704}$

Entre nós, não é corrente ademais a noção de que o efeito devolutivo se manifesta apenas quando transfira ao órgão ad quem o reexame de todas as questões relativas ao mérito da causa. Por isso, é possível falar de recursos com efeito devolutivo limitado. É este, de fato, o caso do recurso especial, meio de impugnação estritamente in iure, no âmbito do qual as questões fáticas (rectius: questões ligadas às particularidades históricas do caso) e as questões jurídicas de direito local não podem ser revisadas.

$\mathrm{O}$ efeito devolutivo pode ser analisado em dois planos: horizontal e vertical. $\mathrm{O}$ primeiro diz respeito à sua extensão, delimitada pela pretensão recursal deduzida pela parte à luz de uma causa de pedir. O segundo refere-se à profundidade da cognição exercida dentro dos limites fixados, ou seja, ao material - jurídico e fático - com que o órgão $a d$ quem pode trabalhar. ${ }^{705}$

\footnotetext{
${ }^{703}$ Cf. JuAn Montero ArocA - José Flors MatíES, El recurso de casación civil, cap. 1, p. 21.

${ }^{704}$ Cf. Alcides DE MENDONÇA LIMA, Introdução aos recursos cíveis, 2. ed., São Paulo: RT, 1976, n. 186, p. 285-288; LuIZ MACHADO GUIMARÃES, “Efeito devolutivo da apelação”, n. I, p. 216.

${ }^{705}$ Barbosa Moreira, Comentários ao Código de Processo Civil, vol. 5, n. 237, p. 430.
} 
Cumpre destacar que, para designar a possibilidade, em alguns casos, de cognição ex officio de matérias de ordem pública, parcela da doutrina utiliza a expressão efeito translativo, como manifestação, em sede recursal, do princípio inquisitório. ${ }^{706}$ Trata-se, no fundo, de projeção do efeito devolutivo em seu sentido vertical.

\subsubsection{PRINCíPIO DisPositivo E LIMITAÇÃo do OBJETO do RECURSO ESPECIAL À QUESTÃO FEDERAL INVOCADA}

Como corolário inevitável do princípio dispositivo em sentido material (Dispositionsprinzip ou, de maneira mais exata, Verfügungsgrundsatz; principle of dispositive election), o objeto do recurso especial será fixado pelo recorrente, de tal sorte que o Tribunal não poderá apreciar outras causae petendi que não aquelas declinadas (tantum devolutum quantum appellatum).

A causa de pedir do recurso especial consiste na alegação de uma violação ao direito federal, ou seja, na alegação da solução incorreta de uma questão jurídica. Por isso, a primeira e mais elementar limitação ao efeito devolutivo refere-se ao reexame da prova $\left(\mathrm{v}\right.$, supra, $\left.\S 7^{\circ}\right)$.

Mas não é só. É preciso perceber que, embora o núcleo do fundamento do recurso seja uma questão normativa, o tratamento a ela dispensado é, tal como o de toda causa de pedir, o de uma quaestio facti. Isso ocorre porque "questões concernentes à causa petendi são consideradas, em qualquer caso, questões de fato, jamais questões de direito", submetendo-se, portanto, à disciplina daquelas. ${ }^{707}$ Daí estar o objeto do recurso estritamente limitado à violação apontada.

A premissa é importantíssima para que se possa compreender o efeito devolutivo limitado do recurso especial, que exclui do objeto do recurso questões não préquestionadas ou alegadas pelas partes, ainda quando elas sejam matéria de ordem pública.

\footnotetext{
${ }^{706}$ Por todos, NeLSON NeRY JR., Teoria geral dos recursos, n. 3.5.4, p. 482 e ss.

${ }^{707}$ BARBOSA MOREIRA, “Considerações sobre a causa de pedir na ação rescisória”, n. 3, p. 207. No mesmo sentido, afirma CRUZ E TUCCI que "cada fundamento invocado em um destes meios de impugnação [refere-se ao recurso extraordinário e ao recurso especial], apesar de seu respectivo núcleo versar matéria de direito (afronta a texto legal expresso; divergência de orientação jurisprudencial...), constitui a situação fática concreta apta a autorizar, em tese, o processamento do recurso" ( $A$ 'causa petendi' no processo civil, n. 4.27, p. 285).
} 
O âmbito do julgamento pelo Superior Tribunal de Justiça coincide, portanto, com o juízo de admissibilidade por ele mesmo efetuado. Com efeito, impugnando-se apenas parte do julgado a quo, a devolução ao Superior Tribunal de Justiça a esta estará limitada. ${ }^{708}$ Nesse sentido, "caso o acórdão recorrido se haja pronunciado sobre questão preliminar, mesmo de mérito (rejeitando, por exemplo, a argüição de prescrição), o recurso interposto no concernente à questão principal não estende seu efeito à preliminar. A menos que se recorra igualmente no que a esta diz respeito, não será lícito ao tribunal ad quem reexaminá-la, ainda que para tanto exista fundamento"; surge, daí, a necessidade de interposição de recurso adesivo condicional para a parte vencedora na questão principal, mas derrotada na preliminar. ${ }^{709}$

Já foi objetado que não há possibilidade de interpor um recurso adesivo condicional (i.e, sem que exista sucumbência efetiva), por faltar interesse ao litigante. Mas a alegação é inconsistente. Os próprios autores que a afirmam reconhecem, ao mesmo tempo, que o Superior Tribunal de Justiça - justamente por uma necessidade prática - deve conhecer das outras questões. Ora, se a Corte pode conhecê-las de ofício, com muito maior razão poderá delas conhecer por provocação da parte potencialmente afetada pelo julgamento.

Por fim, cabe lembrar que, por vezes, o julgamento positivo do recurso deixará questões que não haviam sido resolvidas pela instância de origem (porque prejudicadas) em aberto. Se o recurso volta-se contra o acolhimento de uma preliminar (v.g., prescrição) e esta é rechaçada pelo Superior Tribunal de Justiça, em regra, será necessário o reenvio para tratar de questões subordinadas ou para produzir novas provas. ${ }^{710}$ É óbvio, v.g., que havendo inversão do ônus da prova, devem os autos ser remetidos ao juízo de primeiro grau para que se realize instrução. ${ }^{711}$ Essa solução, como se viu, é prestigiada pelos Tribunais Superiores de diversos países, e não somente por aqueles que adotam um sistema de cassação (supra, $\S 3^{\circ}$ ). O Superior Tribunal de Justiça deverá rejulgar a causa apenas

\footnotetext{
${ }^{708}$ Nesse sentido, Pontes de Miranda, Comentários ao Código de Processo Civil (de 1973), t. VIII, p. 28; OvídIO A. BAPTISTA DA SILVA, Curso de processo civil, vol. 1, n. 17.4.6.3, p. 441.

709 Barbosa Moreira, Comentários ao Código de Processo Civil, v. 5, n. 324, p. 605; ID., "Recurso especial. Exame de questão de inconstitucionalidade de lei pelo Superior Tribunal de Justiça. Recurso extraordinário sob condição", n. 12, p. 267; PONTES DE MIRANDA, Comentários ao Código de Processo Civil (1973), tomo VIII, p. 169; OvíDIO A. BAPTISTA DA SILVA, Curso de processo civil, vol. 1, n. 17.4.6.3, p. 442.

${ }^{710}$ Contra, entendendo não haver, em nosso direito, a possibilidade de reenvio, diante da ausência de regra expressa nesse sentido, JOÃO FRANCISCO NAVES DA FONSECA, Exame dos fatos nos recursos extraordinário e especial, n. 24, p. 84. O autor, contudo, acaba por admitir excepcionalmente essa providência quando forem necessárias provas ainda não produzidas ( $o p$. e loc. cit.).

${ }^{711}$ STJ, $3^{\text {a }}$ T., REsp 915.599/SP, rel. Min. NANCY ANDRIGHI, j. em 21/08/2008, Inf. 364.
} 
quando forem desnecessários ulteriores esclarecimentos fáticos, sendo possível, à luz dos fatos já acertados, aplicar o direito à espécie. O enunciado n. 456 da Súmula/STF e considerações ligadas à economia processual não devem levar ao atropelamento de requisitos e garantias das partes nem à desnaturação da função objetiva da Corte.

\subsubsection{TESE CONTRÁRIA: EFEITO DEVOLUTIVO AMPLO}

Deve-se mencionar, entretanto, a posição contrária de boa parte da doutrina. Com efeito, muitos autores defendem a possibilidade de os Tribunais de superposição conhecerem de matérias de ordem pública (i.e, de objeções) não alegadas previamente pelas partes ou pré-questionadas, sendo condição necessária e suficiente para tanto a admissão do recurso por outros fundamentos. São variados os argumentos, que nem sempre são empregados em conjunto. A título de síntese, todavia, pode-se dizer, de acordo com os partidários da tese, que isso seria: I) possível diante do enunciado da Súmula do Supremo Tribunal Federal de n. 456 e do efeito translativo dos recursos; II) útil em face da possibilidade do manejo de ulterior ação rescisória (o que tornaria contraproducente a atuação do Superior Tribunal de Justiça que não levasse em consideração a causa de rescindibilidade); III) recomendável à luz da atual postura metodológica de um "processo civil de resultados", refletida, v.g., por reformas como aquela responsável pela introdução do art. 515, § $3^{\circ}, \mathrm{CPC}$; IV) desejável em razão da importância das matérias de ordem pública no quadro do devido processo legal. ${ }^{712}$ Tal amplitude valeria, em especial, para os

\footnotetext{
${ }^{712}$ Para uma visão geral dos argumentos, ver, sobretudo, PAUlO HENRIQUE DOS SANTOS LUCON, "Recurso especial: ordem pública e prequestionamento", n. 8.2, p. 739; em sentido assemelhado, RUY ROSADO DE AGUIAR JR., "Recurso especial: questão de ordem pública. Prequestionamento", n. 14, p. 287; RODOLFO DE CAMARgo MANCUSO, Recurso extraordinário e recurso especial, n. 6.1, p. 311-312; JosÉ MigUEL GARCIA MEDINA, Prequestionamento e repercussão geral, n. 2.4.1, p. 95-97 e n. 3.2.2.6, p. 137-141; GLEYDSON KLEBER LOPES DE OliveIRA, "Recursos de efeito devolutivo restrito e a possibilidade de decisão acerca de questão de ordem pública sem que se trate da matéria impugnada", n. 7, p. 267-268; RoGÉRIO LICASTRO TORRES DE MELLO, "Recurso especial e matéria de ordem pública: desnecessidade de prequestionamento", n. 8, p. 238-9; ID., Atuação de ofício em grau recursal, n. 6.9-6.10, p. 251-254; PATRÍCIA TORRES BARRETO COSTA CARVALHO, "Efeito translativo nos recursos excepcionais", n. 4, p. 279-280; FRANCISCO NAVES DA FONSECA, Exame dos fatos nos recursos extraordinário e especial, n. 10, p. 44; FERNANDO RUBIN, $A$ Preclusão na dinâmica do processo civil, n. 1.5.2.6, p. 157;VITO ANTÔNIO BocCuZZI NeTO, "Recursos excepcionais - o prequestionamento e a matéria de ordem pública”, n. 7, p. 446-447; ANDRÉA CHEREM FABRÍCIO DE MELO, "O prequestionamento e as matérias de ordem pública nos recursos extraordinário e especial", n. 4, p. 28. Com opinião conforme, FREDIE DIDIER JR. sintetiza a posição: "Para fins de impugnação (efeito devolutivo), somente cabe recurso extraordinário/especial se for previamente questionada, pelo tribunal recorrido, determinada questão jurídica. Para fins de julgamento (efeito translativo), porém, uma vez conhecido o recurso extraordinário/especial, poderá o tribunal examinar todas as matérias que possam ser examinadas a qualquer tempo, inclusive a prescrição, decadência e as questões de ordem pública de que trata o $\S 3^{\circ}$ do art. 267 do CPC", acrescentando, como argumento derradeiro, a
} 
pressupostos processuais e condições da ação, matérias arroladas pelo art. $267, \S 3^{\circ}, \mathrm{CPC}$, como sendo daquelas que o juiz "conhecerá de ofício, em qualquer temo e grau de jurisdição, enquanto não proferida a sentença de mérito", bem como indicadas no art. 301, $\S 4^{\circ} .713$

Argumenta-se, ainda, que em abono da tese "falam as Súmulas ns. 528 e 292 do Supremo Tribunal Federal que, aplicáveis também ao Superior Tribunal de Justiça, reconhecem a unidade do julgamento perante aqueles tribunais e autorizam que a admissão do extraordinário ou do especial por um fundamento, ou relativamente a uma parte autônoma do acórdão recorrido, enseje o exame do recurso pelos demais fundamentos ou com respeito aos demais capítulos do acórdão". 714

Para outros autores, na fase de julgamento da causa, não haveria qualquer limitação à matéria impugnada ou decidida, independentemente de tratar-se ou não de matéria de ordem pública. ATHOS GUSMÃo Carneiro afirma que "ao 'aplicar o direito à espécie', $a$ Turma não fica jungida ao pressuposto do prequestionamento, por certo importantíssimo no alusivo ao 'conhecimento' do recurso especial, mas inoperante quando já se cuida da etapa sucessiva, de 'julgamento' da causa, de reconhecer o direito ao seu legítimo titular, jus suum cuique tribuere". 715

É substancialmente igual a posição defendida por FREDIE DIDIER JR. e LEONARDO CunHA, para quem o requisito do pré-questionamento só diria respeito à admissibilidade recursal, sendo possível, por isso, uma vez conhecido o recurso por outro fundamento, que o Superior Tribunal de Justiça conhecesse de ofício de todas as questões de ordem pública ou, ainda, de todas aquelas "relacionadas ao capítulo decisório objeto do recurso extraordinário, mesmo que não tenham sido enfrentadas no acórdão recorrido". A

indesejável possibilidade de ajuizamento de ulterior ação rescisória caso não admitida a providência (“Alegação de prescrição e decadência em recurso extraordinário: notas ao Código Civil de 2002", n. 2, p. 119-121).

713 ADA PELLEGRINI GRINOVER, "Litisconsórcio necessário e efeito devolutivo do recurso especial", n. 2.3, p. 32-33, ressaltando que a "presença dos pressupostos processuais é antecedente lógico do julgamento do mérito e, nessa medida, tais pressupostos são também antecedente lógico do julgamento do mérito dos recursos pelo Supremo Tribunal Federal e Superior Tribunal de Justiça", conclusão que estende às condições da ação; HeITOR SicA, Preclusão processual civil, n. 8.3.7, p. 223 (aduzindo não haver restrição na profundidade do efeito devolutivo).

${ }^{714}$ ADA PELLEGRINI GRINOVER, "Litisconsórcio necessário e efeito devolutivo do recurso especial”, n. 2.3, p. 34

${ }^{715}$ Recurso especial, agravos e agravo interno, n. 31-A, p. 103. 
profundidade do efeito devolutivo - afirmam - não sofre qualquer restrição e não tem qualquer peculiaridade no recurso especial. ${ }^{716}$

Para NELSON NERY JR., embora fazendo ressalva do juízo de mérito bipartido, alega que, sendo positivo o iudicium rescindens (etapa em que a devolução é restrita), o Tribunal poderia, por ocasião do iudicium rescissorium, inclusive reexaminar provas, exercendo as funções de um verdadeiro tribunal de apelação ao apreciar todos os aspectos da causa (de fato e de direito). O autor invoca, a esse propósito, a experiência da Revision germânica. ${ }^{717-}$ 718

Passada em revista a doutrina, que juízo fazer do último ponto de vista mencionado? Em face do que se expôs no item antecedente, deve ele ser rechaçado. Com efeito, ao admiti-lo anular-se-iam os limites impostos pelo princípio dispositivo. Além disso, a posição traz riscos de ofensa ao contraditório e de julgamento com surpresa para as partes, desconsidera o pré-questionamento e obriga o Superior Tribunal de Justiça a uma análise particularista de todos os pontos da causa (inclusive fáticos), transformando-o em

\footnotetext{
${ }^{716}$ Curso de direito processual civil, cap. VII, n. 8, p. 280-283.

717 “Para que possa proferir adequada e corretamente o juízo de revisão, o tribunal superior deverá ingressar livremente no exame da prova dos autos, funcionando como verdadeiro tribunal de apelação, podendo, inclusive, corrigir injustiça. No juízo de revisão, porque exerce funções de tribunal de apelação (segundo grau de jurisdição), pode o tribunal superior examinar pela primeira vez as questões de ordem pública, que devem ser examinadas em qualquer grau ordinário de jurisdição (CPC $267 \S 3^{\circ}$ e $301 \S 4^{\circ}$ ), circunstância decorrente do efeito translativo dos recursos" (NELSON NERY JR., "Questões de ordem pública e o julgamento do mérito dos recursos extraordinário e especial: anotações sobre a aplicação do direito à espécie (STF 456 e RISTJ 257)", n. 3, p. 968). Do mesmo autor, Teoria geral dos recursos, n. 3.5.1.5, p. 442. No mesmo sentido, ressalvando, no entanto, a vedação ao reexame de provas, JOÃO FRANCISCO NAVES DA FONSECA. Este autor, embora admitindo o julgamento da causa "com base em todos os elementos de prova constantes dos autos, ainda que não mencionados no acórdão recorrido", procura traçar limites a essa atuação do Tribunal. De um lado, diz, é imprescindível garantir o efetivo direito à prova, possibilitando a sua produção quando isso for relevante para o novo julgamento, o que obriga ao reenvio; de outro, há vinculação da instância superior aos fatos já apreciados, tal como foram acertados pelo juízo a quo. Admite, por isso, que em casos excepcionais ocorra o reenvio ao tribunal de apelação (Exame dos fatos nos recursos extraordinário e especial, n. 24, esp. p. 81).

718 Nesse sentido, o seguinte julgado do Superior Tribunal de Justiça: "Agravo regimental - fraude à execução - averiguação da existência de prova da insolvência pelo credor - tarefa afeta à instância a quo retorno dos autos à origem - necessidade - agravo improvido. 1. O Superior Tribunal de Justiça deve, em um primeiro momento, debruçar-se sobre a matéria de direito trazida no recurso especial, a fim de uniformizar a jurisprudência pátria acerca da interpretação da legislação federal. 2. Afastado o fundamento jurídico do acórdão a quo, cumpre a esta Corte Superior julgar a causa, aplicando, se necessário, o direito à espécie, nos termos do art. 257 do RISTJ e da Súmula n. 456/STF. 3. Ao aplicar o direito à espécie, o Superior Tribunal de Justiça poderá mitigar o requisito do prequestionamento ao valer-se de questões não apreciadas diretamente pela Instância de origem nem ventiladas no apelo nobre. 4. Quando, porém, a aplicação do direito à espécie reclamar o exame do acervo probatório dos autos, convirá o retorno dos autos à Corte de origem para a ultimação do procedimento de subsunção do fato à norma. 5. Agravo regimental improvido" (STJ, 3 ${ }^{a}$ T., AgRg nos EDcl no Ag 961528/SP, rel. Min. MASSAMI UYEDA, j. em 21/10/2008, DJe 11/11/2008).
} 
um terceiro grau ordinário de jurisdição, o que é incompatível com a sua função prospectiva de Corte de precedentes. Cabe refutar, um a um, os argumentos enumerados.

É certo que o ônus do recorrente de indicar a questão federal - isto é, a causa de pedir - sobre a qual se funda o recurso não pode ser suprido pelo Superior Tribunal de Justiça: "Para tomar posição entre a alternativa [colocada pela questão federal invocada], não tem o Superior Tribunal de Justiça de cogitar de eventual infração de qualquer outra norma. Por mais evidente que se lhe afigure, ex hypothesi, a ocorrência de tal infração, nenhuma conseqüência estará o Superior Tribunal de Justiça autorizado a tirar disso". ${ }^{719}$ E, como a questão federal, por ser causa de pedir, recebe o mesmo tratamento dispensado aos fatos constitutivos, de modo algum poderia a Corte transgredir os limites impostos pelo objeto do recurso. Violaria, com isso, os arts. $2^{\circ}, 128$ e 460, todos do CPC. Não se trata de mero capricho acadêmico: do desrespeito ao princípio dispositivo resulta possível ofensa ao contraditório. Há uma inegável necessidade de evitar a surpresa aos litigantes, ${ }^{720}$ o que impede, no juízo rescisório, a adoção de ratio decidendi ligada a questão (ainda que de ordem pública) não debatida anteriormente pela partes. Citando mais uma vez o Prof. BARBOSA MoreIRA, “em última análise, acrescentando nova razão às invocadas pelo recorrente, o que faria o Superior Tribunal de Justiça era nada mais, nada menos que interpor ex officio, ele mesmo, recurso especial contra o acórdão a quo". "721 É essa também a posição de ARAKEN DE ASSIS: "veda-se a apreciação de questões não impugnadas". ${ }^{722}$

Também a exigência de pré-questionamento não pode ser atropelada no julgamento do recurso especial. O enunciado n. ${ }^{\circ} 456$, Súmula/STF, não tem o condão de ampliar - seja no plano horizontal, seja no plano vertical - o efeito devolutivo dos recursos excepcionais. E não poderia mesmo fazê-lo. O cabimento de tais impugnações está todo previsto na Constituição. Esta, por meio de uma regra específica de competência, atribui ao Superior Tribunal de Justiça o poder de "julgar, em recurso especial, as causas decididas (...)" por Tribunais de segunda instância. Não faz qualquer ressalva quanto ao ponto: refere-se ao

\footnotetext{
${ }^{719}$ BARBOSA MOREIRA, "Mandado de segurança. Recurso especial”, p. 350.

${ }^{720}$ Sobre isso, v. CARLOS Alberto Alvaro DE Oliveira, “A garantia do contraditório", n. 4, p. 237; ID., Do formalismo no processo civil, n. 20.6, p. 225-226; também CRUZ E TUCCI, A 'causa petendi' no processo civil, n. 4.16, p. 211; JoSÉ ROBERTO DOS SANTOS BEDAQUE, "Os elementos objetivos da demanda analisados à luz do contraditório", n. 1.6, p. 38-42. A exigência de prévio debate, mesmo no que toca a questões cognoscíveis de ofício pelo órgão judicial, é hoje reconhecida expressamente por diversas legislações: art. 3.3, CPC português; § 139, ZPO alemã; art. 16, NCPC francês; art. 384, c.p.c. italiano.

721 "Mandado de segurança. Recurso especial”, p. 353.

${ }^{722}$ Manual dos recursos, n. 85.1, p. 728.
} 
julgamento, e não à admissão. A distinção pretendida - no sentido de que o préquestionamento operaria tão somente em relação ao juízo de admissibilidade, mas não em relação ao mérito do recurso - não encontra, portanto, qualquer amparo no texto da Constituição. A locução "causas decididas" - da qual se extrai o fundamento constitucional do pré-questionamento - constitui, assim, o próprio objeto que circunscreve o julgamento pelo Superior Tribunal de Justiça. ${ }^{723}$

O verbete sumular, adicione-se, reflete simplesmente a natureza dos Tribunais de superposição brasileiros como Cortes de revisão (e não de cassação), que julgam sem reenvio, mas não amplia o objeto do julgamento. ${ }^{724}$ Essa orientação é antiga no Supremo Tribunal Federal e está à base dos precedentes que originaram o enunciado, dos quais não se pode extrair fundamento para a ampliação da devolução recursal. ${ }^{725-726}$ Aliás, já na Lei n. $221 / 1894$, dizia-se que a decisão no recurso extraordinário, “(...) quer confirme, quer reforme a sentença recorrida, será restrita à questão federal controvertida, sem se estender a qualquer outra porventura compreendida no julgado".

Os julgados ulteriores da Corte que trataram do assunto não discrepam. Suscitada questão de ordem acerca do âmbito do julgamento a ser proferido, uma vez afastada a preliminar, esta foi resolvida para fixar entendimento no sentido de que não se deveria ir adiante para julgar o restante da causa, i.e, para apreciar a ocorrência ou não do descumprimento do encargo e suas conseqüências. Motivou-se que não era dado à Corte

\footnotetext{
${ }^{723}$ Correto, quanto ao ponto, CASSIO SCARPINELla Bueno, Curso sistematizado..., vol. 5, cap. 11, n. 11, p. 305 .

${ }^{724}$ ANGÉLICA ARRUdA ALVIM - EdUARDo ARRUdA AlVIM, “Aspectos inerentes ao prequestionamento no recurso especial", n. 7, p. 1166.

${ }^{725}$ Assim, v.g., em STF, Pleno, RE 56323, rel. Min. Victor NUNES, j. em 01/10/1964, DJ 24/12/1964, p. 1006. A referência nele feita ao julgamento da causa é apenas e tão-somente a seguinte: “(...) É certo que $o$ Tribunal Regional afirmou a existência da fraude, mas o Tribunal Superior do Trabalho, conhecendo da revista, decidiu de modo contrário, julgado a causa. Tinha poder para isso (...), como procede o Superemo Tribunal Federal quando conhece do recurso extraordinário". Não se distanciou, contudo, dos limites da causa de pedir do recurso. Muito pelo contrário, limitou sua própria competência: "No recurso extraordinário contra decisões do Tribunal Superior do Trabalho, não devemos exercer rígida tutela sôbre a maneira como a Justiça especializada exerce a sua jurisdição, sob pena de frustramos a sua finalidade constitucional".

${ }^{726}$ É a conclusão à luz de STF, 2a T., AI 23.496/MG, rel. Min. VICTOR NUNES, j. em 11.07.1961. Nesse caso, o Supremo Tribunal Federal negou provimento ao agravo de instrumento, sequer conhecendo do recurso extraordinário, na medida em que o agravantes visava ao reexame de prova. Limitou-se a afirmar que "Supremo Tribunal não entra no exame das provas, para apreciar o cabimento do recurso, mas tão sòmente, depois que conhece do recurso, para julgar a questão federal controvertida". A parte final - mero obiter dictum, diga-se de passagem -, como se pode ver, está ligada antes à qualificação jurídica dos fatos tidos por existentes nos autos do que a qualquer outro tema. Seja como for, de modo algum pode-se extrair daí a ilação de que aos Tribunais Superiores, uma vez conhecido o recurso, seria possível julgar questões estranhas à impugnação das partes.
} 
julgar questões não apreciadas pelo Tribunal local ou ingressar no exame dos fatos (ainda que, no caso, tivessem essas circunstâncias sido analisadas pela sentença em primeiro grau). ${ }^{727}$

O próprio art. $267, \S 3^{\circ}, \mathrm{CPC}$, lido a partir de perspectiva adequada, corrobora essa conclusão. $\mathrm{O}$ dispositivo permite o conhecimento das matérias ali elencadas, em qualquer tempo e grau de jurisdição, enquanto não proferida a sentença de mérito. Ora, sentença de mérito quer significar, aí, a última decisão tomada pelas instâncias ordinárias, o que afasta, portanto, as instâncias excepcionais. ${ }^{728}$

De sua vez, o argumento baseado na possibilidade de intentar-se ulterior ação rescisória contra o acórdão do Superior Tribunal de Justiça que deixa de conhecer da matéria de ordem pública prova demais. Com efeito, fosse isso relevante, não haveria necessidade de pré-questionamento diante da alegação de qualquer violação a dispositivo literal de lei (art. 485, V, CPC), porquanto o cabimento de rescisória, a toda evidência, não é restrito às hipóteses de ausência pressupostos processuais ou condições da ação.

Como foi dito, costuma-se invocar também o enunciado n. 528 da Súmula/STF para defender a cognição ex officio de matérias de ordem pública. O enunciado é o seguinte: "se a decisão contiver partes autônomas, a admissão parcial, pelo Presidente do Tribunal 'a quo', de recurso extraordinário que sobre qualquer delas se manifestar, não limitará apreciação de todas pelo Supremo Tribunal Federal, independentemente de interposição de agravo de instrumento". O que se lê, no verbete, é mera explanação do juízo bipartido de admissibilidade dos recursos excepcionais: quer ele dizer que, sendo admitido - ainda que apenas por uma causa de pedir - o recurso extraordinário (ou especial) na origem, não será necessário interpor o agravo ex art. 544, CPC, em relação a eventuais fundamentos inadmitidos. A conclusão é mesmo óbvia: o Tribunal ad quem,

\footnotetext{
${ }^{727}$ STF, $2^{\text {a }}$ T., RE 67284, rel. Min. THOMPSON FlORES, j. em 29/09/1969, DJ 27-02-1970. Em recurso extraordinário no qual se discutia a questão referente à necessidade ou não de interpelação para constituir em mora o devedor que descumpre obrigação de abstenção, a Corte, decidindo afastar a preliminar acolhida pelo Tribunal local, foi confrontada justamente com o problema referente à possibilidade de julgar o restante do mérito da causa. Tratava-se de ação de revogação de doação modal à qual havia dado provimento o juiz em primeiro grau, entendendo desnecessária a interpelação e existente descumprimento de encargo negativo apto a ensejar os efeitos pretendidos pelos demandantes. Em segundo grau, como se disse, o Tribunal de Justiça havia, em sentido contrário, acolhido a questão prévia suscitada pelos demandados, rejeitando, com base nela, a demanda.

${ }^{728}$ BOTELHO DE MESQUITA et al, "Questões de ordem pública: revisíveis ad inifinitum", esp. n. 1.2.3, p. 1524 e n. 6.2-6.3, p. 1530-1532 (diferenciando, ainda, conhecer de matérias e decidir questões, considerando contra legem a jurisprudência majoritária em sentido contrário).
} 
recebendo os autos, efetuará novamente e de maneira integral o juízo de admissibilidade, já que não está vinculado ao juízo efetuado na origem. Seria despropositado e inútil o agravo contra a decisão de admissão parcial; daí ser possível, nos termos do verbete, a apreciação de todo o recurso "independentemente de interposição de agravo de instrumento".

Por fim, a extensão da cognição do Superior Tribunal de Justiça ao exame dos fatos, ainda que no juízo rescisório, também não se coaduna com a sua função. Evidentemente, a restrição da devolutividade do recurso especial às questões de direito não é regra que opera apenas no plano da admissibilidade. ${ }^{729}$ Essa alternativa, além de conformar-se à função do Superior Tribunal de Justiça (enquanto órgão preocupado com a unidade do Direito e a uniformidade da jurisprudência) e à limitação de sua atividade cognitiva, atribui a apreciação dos fatos da causa a órgão que, de acordo com o sistema do duplo grau de jurisdição, está em melhores condições de fazê-lo. Do ponto de vista institucional, portanto, duas razões recomendam a solução: os poderes limitados de que dispõe o Tribunal Superior e a necessidade de uma racional alocação de competências.

\subsubsection{INAPLICABILIDADE DO ART. $515, \S 3^{\circ}, \mathrm{CPC}$}

Havendo error in procedendo, poderá o Superior Tribunal de Justiça, desde logo, ao prover o recurso especial por esse fundamento, julgar o mérito da controvérsia, nos termos do que dispõe o art. 515, $\S 3^{\circ}, \mathrm{CPC}$ ? Parcela da doutrina ${ }^{730}$ e julgados esparsos do próprio Tribunal, embora de maneira tímida, entendem que sim. Várias razões, contudo, levam à resposta negativa. Primeira: o dispositivo em questão (enquanto parágrafo do caput) refere-se especificamente à apelação, levando em conta, portanto, o seu amplo efeito devolutivo, no que diverge radicalmente dos recursos excepcionais. ${ }^{731}$ Segunda: para

\footnotetext{
${ }^{729}$ Algo nesse sentido, TERESA ARRUDA ALVIM WAMBIER, Recurso especial, recurso extraordinário e ação rescisória, n. 12.4 , p. 383 , embora ressalve, adiante (op. cit., n. 12.4, p. 386), que talvez outra fosse a "solução ideal" para o problema, em que o rejulgamento da causa não contasse com os limites do enunciado sumular n. 7 do Superior Tribunal de Justiça.

730 "No recurso especial e no extraordinário é mais problemática a operacionalização da técnica permitida por esse parágrafo, dada sua sujeição a pressupostos de admissibilidade muito precisos e conseqüente estreiteza da devolução possível. Mesmo assim, quando satisfeitos aqueles requisites e os do próprio $\S 3^{\circ}$ do art. 515 do Código de Processo Civil, não deixa de ser razoável que também o Supremo Tribunal Federal e o Superior Tribunal da Justiça pratiquem o que ele preconiza" (CÂNDIDO DINAMARCO, "O efeito devolutivo da apelação e de outros recursos", n. 88, p. 174).

${ }^{731}$ Parece ser esta também a opinião de BARBosa MoreIRA, Comentários ao Código de Processo Civil, v. 5 , n. 324 , p. 606 , nota 60 .
} 
que tenha operacionalidade, a norma pressupõe que o órgão ad quem possa examinar e formar um juízo autônomo sobre os fatos, poder que falta ao Superior Tribunal de Justiça. Terceira: se, diante de error in procedendo, no julgamento do recurso especial, se passasse desde logo ao mérito da causa, não se terá observado o requisito do pré-questionamento, o que contraria a função do Tribunal Superior (que deve emitir um metajuízo) e prejudica o contraditório entre as partes.

Clara Azzoni posiciona-se contra o uso do art. 515, $\S 3^{\circ}, \mathrm{CPC}$, no domínio do Superior Tribunal de Justiça, excluídos apenas os casos em que o error in procedendo invocado refira-se a julgamento extra ou ultra petita pelo Tribunal a quo. ${ }^{732}$ A ressalva feita pela autora, contudo, em verdade é estranha ao problema, configurando uma "falsa exceção" que apenas confirma a regra: ao anular o capítulo excedente do julgamento, a instância revisora circunscreve-se a cassar ou rescindir aquilo que não corresponde ao objeto litigioso do processo, ainda que mantenha, de outro lado, a parte hígida da decisão recorrida. Assim sendo, não há como falar, nessa hipótese, de "julgamento imediato da lide", nos termos do art. 515, $\S 3^{\circ}, \mathrm{CPC}$, mas tão-somente de eliminação da parte do julgado que violou o princípio dispositivo em sentido material, sem qualquer substituição nesse âmbito. Seja como for, a vedação ao reexame de provas pelo Superior Tribunal de Justiça torna, na prática, inviável a aplicação do art. $515, \S 3^{\circ}, \mathrm{CPC} .^{733}$

Diferente é a situação em que o Tribunal local, embora incidindo em error in procedendo (acolhendo, v.g., preliminar de não cabimento do recurso de apelação, por ser adequado o agravo de instrumento) - o que normalmente deveria conduzir à mera anulação do acórdão - manifesta-se também sobre a matéria de fundo (pronunciando-se sobre o mérito do recurso supostamente não conhecido). Nesse caso, segundo o Superior Tribunal de Justiça, está atendido o requisito do pré-questionamento, ensejando uma "causa madura", i.e, passível de juízo rescisório (e não apenas rescindente). ${ }^{734} \mathrm{O}$ que se tem, no entanto, não é propriamente invocação do art. $515, \S 3^{\circ}, \mathrm{CPC}$, mas o reconhecimento de

\footnotetext{
732 Clara MoReira Azzoni, Recursos especial e extraordinário, n. 4.4.2, p. 258-259. Vale notar que o exemplo imaginado de julgamento extra petita é justamente o de "extrapolação", de modo que, além do pedido, seja concedida outra providência não pleiteada.

733 JOÃo FRANCISCO NAVES DA FONSECA, Exame dos fatos nos recursos extraordinário e especial, n. 23, p. 77-78.

${ }^{734}$ STJ, $3^{\text {a }}$ T., REsp 337094/MG, rel. Min. Humberto Gomes De BARROS, j. em 29/11/2005, DJ 19/12/2005, p. 393 .
} 
que o acórdão recorrido, embora formalmente não conhecendo do recurso, em verdade adentrou no mérito das questões invocadas, cometendo verdadeiro error in iudicando.

\subsection{EFEITO SUBSTITUTIVO}

Interposto recurso especial calcado em error in procedendo do acórdão pronunciado pelo Tribunal local, a atividade do Superior Tribunal de Justiça será meramente rescindente. A exigência constitucional de uma "causa decidida" (caput do art. 105, III, CF) obsta o emprego do art. 515, $\S 3^{\circ}, \mathrm{CPC}$, no âmbito dos Tribunais de superposição, não havendo devolução de questões estranhas ao que foi pré-questionado. Desse modo, em nenhum caso o recurso interposto exclusivamente com base nesse motivo levará à substituição do acórdão recorrido: sendo positivo o juízo de mérito, o julgado será simplesmente anulado, com reenvio dos autos à instância inferior para novo julgamento; ocorrendo desprovimento, não há o que substituir, por não haver coincidência entre o objeto das duas decisões. ${ }^{735}$

Por outro lado, é lição corrente na doutrina a de que, uma vez conhecido o recurso calcado em error in iudicando, o pronunciamento ad quem substitui a decisão recorrida (à luz do art. 512, CPC). Essa substituição ocorreria mesmo na hipótese de desprovimento do recurso, ou seja, quando a decisão fosse "confirmada" pela instância superior. As conseqüências práticas, como se sabe, são muito relevantes: basta lembrar que, havendo substituição da decisão recorrida, o título executivo será o acórdão da instância superior e dela será a competência para apreciar eventual ação rescisória.

A lição reproduzida no parágrafo antecedente é certamente válida em relação aos recursos ordinários, cujo efeito devolutivo compreende um verdadeiro reexame da causa. Assim, mesmo quando o Tribunal de apelação apenas "confirma" a sentença de primeiro grau "por seus próprios fundamentos", o acórdão que não dá provimento ao recurso terá a mesma natureza do próprio pronunciamento recorrido, substituindo-o na extensão do que houver sido impugnado.

\footnotetext{
735 Barbosa Moreira, Comentários ao Código de Processo Civil, vol. 5, n. 222, p. 397-398; contra, sustentando substitutividade também nos casos de desprovimento de recurso fundado em vício de procedimento, a meu ver sem razão, NELSON NERY JR., Teoria geral dos recursos, n. 3.5.5, p. 488-489.
} 
A opinião geral acaba por estender tais noções aos recursos excepcionais, sustentando que, uma vez admitido recurso especial fundado em error in iudicando, a competência para julgar a respectiva ação rescisória será da instância superior; ou seja, conhecido o recurso, haverá sempre substituição do acórdão recorrido, ainda que não se tenha dado provimento à irresignação, pouco importando, portanto, o seu resultado no mérito. ${ }^{736}$ Por sua vez, o enunciado n. ${ }^{\circ} 249$ da Súmula/STF (em alguma medida complementado pelo enunciado n. 515 da mesma Súmula) - que tem sido observado também pelo Superior Tribunal de Justiça - afirma ser competente para eventual rescisória o próprio Tribunal quando, "embora não tendo conhecido do recurso extraordinário (...), tiver apreciado a questão federal convertida". Trata-se de orientação jurisprudencial que não atende, evidentemente, à boa técnica, baralhando etapas do julgamento, mas que reconhece o que se denominou ironicamente de "substituição à brasileira". ${ }^{737}$ Por isso, abstraídas as diferenças terminológicas entre a doutrina e a jurisprudência, logo se vê que as opiniões coincidem: ingressando no mérito (pouco importando que se dê, formalmente, esse nome ou não ao juízo acerca da causa petendi do recurso), haverá sempre substituição do acórdão e, conseqüentemente, fixação da competência para ação rescisória no órgão $a d$ quem, mesmo nos casos em que não se vislumbre a violação apontada no julgado recorrido.

Parece-me, contudo, que as coisas se passam de modo diferente em relação aos recursos excepcionais, e que o tópico merece ser repensado. Como já foi visto (supra, $\S$ $1^{\circ}$ ), o recurso especial é do tipo rescidente, de modo que, uma vez admitido, se procede a um juízo de mérito bipartido: preliminarmente, realiza-se uma censura da própria decisão recorrida, cujo desfecho, se positivo, acarretará a sua rescisão (ius rescindens); somente se procedente a etapa anterior, caberá o rejulgamento do capítulo cassado, com substituição do acórdão impugnado naquela parte (ius rescissorium). Disso resulta que - adiantando já a conclusão -, se desprovido o recurso (i.e., não rescindido o acórdão do Tribunal local), a decisão recorrida permanece intacta, não se podendo falar na sua substituição.

\footnotetext{
${ }^{736}$ Barbosa MoreIRA, Comentários ao Código de Processo Civil, vol. 5, n. 324, p. 604-605; Nelson NERY JR., Teoria geral dos recursos, n. 3.4, p. 270; José Miguel GarCiA MedinA, Prequestionamento e repercussão geral, n. 2.1.2, p. 68; ClARA MOREIRA AZZONI, Recurso especial e extraordinário, n. 4.4.1, p. 255.

${ }^{737}$ A significativa expressão deve-se a CÂNDIDO DINAMARCO, "Ação rescisória, incompetência e carência de ação", n. 142, p. 274-276.
} 
Não se quer, com isso, negar a nítida e lógica distinção entre juízo de admissibilidade e juízo de mérito no âmbito do recurso especial. Esta, como se sabe, foi muitas vezes ignorada, sem boa técnica de julgamento, pela jurisprudência: os acórdãos “deixavam de conhecer" o recurso, não obstante, em realidade, tivessem desempenhado incursão no seu mérito. Os Tribunais de superposição viam-se, então, obrigados a discernir - não sem uma boa combinação de má técnica, confusão e artificialidade - entre os diferentes efeitos ligados ao não-conhecimento "com" ou "sem" exame do mérito, respectivamente (tal como, entre outros exemplos, no já apontado verbete n. 249 da Súmula/STF). ${ }^{738}$ Evidentemente, o recurso será conhecido sempre que presentes, objetivamente, os seus requisitos de admissibilidade - hipótese em que também será conhecido eventual recurso especial adesivo. Ausente, de iure condito, qualquer filtro para o recurso especial, isso significa bastar a mera afirmação de violação à lei federal somada, é claro, aos demais pressupostos (gerais e específicos) - para que ele seja conhecido. A verificação da procedência ou não da alegação do recorrente, por sua vez, será realizada tão-somente em momento ulterior representado pelo juízo de mérito, cuja valoração não se pode antecipar para negar conhecimento ao recurso.

O que se quer demonstrar é a insuficiência do mero conhecimento para dar ensejo ao efeito substitutivo da decisão recorrida, diante da particular estrutura do recurso especial. Explico: enquanto meio de impugnação de fundamentação vinculada voltado contra a própria decisão atacada, em si mesmo considerada (daí por que, coerentemente, se pode exigir o pré-questionamento da matéria), o recurso especial não devolve ao Superior Tribunal de Justiça, num primeiro momento, o reexame da causa, tal como efetuado pelo juízo a quo. Este reexame ocorrerá tão-somente se for constatada, preliminarmente, a violação alegada pelo recorrente, ou seja, se for dado provimento ao recurso para cassar o capítulo impugnado. Apenas nesses últimos casos seguir-se-á ao juízo rescindente a fase rescisória de "aplicação do direito à espécie".

\footnotetext{
${ }^{738}$ V.g., ao decidir: “(...) RE adesivo: admissibilidade quando não conhecido o RE principal. Não obsta, em principio, à admissão do RE adesivo, que o recurso extraordinário ou especial principal, interposto pela letra ' $a$ ', segundo a terminologia do STF, não seja conhecido, porque se repute inexistente a contrariedade à Constituição ou à lei federal, conforme o caso. Precedentes" (STF, 1ª T., RE 196430/RS, rel Min. Sepúlveda Pertence, j. em 09/09/1997, DJ 21/11/1997, p. 60600). Respeitada que fosse a boa técnica e a distinção entre admissibilidade e mérito, a questão concernente ao recurso adesivo seria facilmente resolvida pela constatação de que, embora conhecido o recurso principal - não havendo, portanto, impedimento à admissão do recurso subordinado a este título -, este fora desprovido, podendo, contudo, a impugnação adesiva eventualmente merecer sorte diferente no mérito.
} 
Voltando novamente os olhos para a relação entre o julgado do Tribunal local e o acórdão de desprovimento do respectivo recurso especial, é fácil perceber ser diverso o objeto de cognição dos dois pronunciamentos: a decisão recorrida examina a própria causa; a decisão que enjeita o recurso especial no mérito limita-se a negar a ocorrência do motivo de cassação, considerando simplesmente infundada a censura específica dirigida ao acórdão recorrido, sem, contudo, adentrar no exame da causa. É sabido, por outro lado, que não pode projetar-se o efeito substitutivo do recurso na falta de coincidência da atividade cognitiva realizada pelas duas instâncias. ${ }^{739}$ A conclusão, à luz das premissas, é simples: a decisão que nega provimento ao recurso especial não tem a mesma natureza do acórdão recorrido, sendo qualitativamente diversa e, portanto, inidônea a substituí-lo; logo, só haverá substituição se, conhecido o recurso (é algo óbvio), este for provido.

Além de justificar-se pela análise coerente da estrutura do recurso especial no quadro maior da teoria dos recursos, negar efeito substitutivo ao recurso especial desprovido contribui também para a delimitação adequada da competência do Superior Tribunal de Justiça à luz de sua função específica. Evita-se, assim, que a ele sejam dirigidas ações rescisórias versando matérias decididas efetivamente pelas instâncias locais.

Em síntese: o conhecimento do recurso, juízo neutro a ser realizado preliminarmente e sem adentrar o mérito das alegações do recorrente, é suficiente para que seja admitida eventual impugnação adesiva; entretanto, somente com o provimento do recurso - i.e., com juízo de mérito positivo - será cassado e (no mais das vezes) substituído o capítulo impugnado, hipótese em que o Superior Tribunal de Justiça será competente para eventual ação rescisória desse seu julgado.

\footnotetext{
${ }^{739}$ A lição é de Barbosa Moreira (Comentários ao Código de Processo Civil, vol. 5, n. 222, p. 397-398), embora, a meu ver, não a tenha aplicado coerentemente aos recursos excepcionais.
} 


\section{§ 9 - COORDENAÇÃO DO RECURSO ESPECIAL COM O RECURSO EXTRAORDINÁRIO}

\subsection{A BIPARTIÇÃO DOS RECURSOS EXCEPCIONAIS E SUAS COMPLICAÇÕES}

Já se comparou a gênese "traumática" do recurso especial ao ato bíblico de criação da mulher: "assim foi iniciado o caminho que conduziria à expulsão dos jardins do Éden", com o que teve começo, também, “a tensão inseparável do ato de fazer, de um, dois, que nunca mais terminou, tornando difícil, sob sua influência, o desenvolvimento da nova criatura". Diante dos acontecimentos, nem Adão, nem o Supremo Tribunal Federal, voltaram a ser os mesmos. ${ }^{740}$

A alegoria divina feita por Botelho DE MESQuita tem a virtude de colocar em devido destaque um problema complexo. Desde a criação do Superior Tribunal de Justiça e, portanto, da duplicação dos recursos excepcionais cabíveis contra a mesma decisão de segundo grau - assentada que esteja em duplo fundamento (constitucional e de direito federal comum) -, a doutrina salientou os intrincados problemas que surgiriam (a começar por questões de direito intertemporal) e que surgem, de fato, a todo momento, na coordenação do recurso extraordinário com o recurso especial. ${ }^{741}$ As complicações não passaram despercebidas, igualmente, aos Ministros da Corte e à Comissão de Regimento do Superior Tribunal de Justiça, ${ }^{742}$ sem que se chegasse, contudo, a uma solução adequada. As dificuldades, como se disse, são as mais variadas: não se limitam a especulações teóricas ligadas ao princípio da unirrecorribilidade, que na hipótese é mutilado; projetamse, sobretudo, no plano prático. ${ }^{743}$

\footnotetext{
${ }^{740}$ BOTELHO DE MESQUITA, "Recurso extraordinário e recurso especial: contrastes e confrontos”, p. 358.

${ }^{741}$ Nesse sentido, entre outros, já NELSON LUIZ PINTO, Recurso especial para o Superior Tribunal de Justiça, n. III.IV, p. 61 e ss.. Trata-se do ponto central do trabalho monográfico de JOSÉ THEOPHILO FLEURY, Recursos especial e extraordinário, n. 2, p. 52.

${ }^{742}$ Referida Comissão enviou à Câmara dos Deputados sugestão - não acolhida, como é sabido - para acrescentar, no capítulo referente ao recurso especial, dispositivo do seguinte teor: "Se a decisão recorrida contiver controvérsia constitucional e de direito comum, a parte, na petição de interposição do recurso especial, para que não preclua a matéria constitucional, protestará pela apresentação do recurso extraordinário, se for o caso, após o julgamento do recurso especial".

${ }^{743} \mathrm{~A}$ demonstrar que o desfecho insatisfatório dessa opção não poderia mesmo ser diferente, cabe citar a complicada experiência análoga do direito espanhol, em que a competência para conhecer recursos de cassação também é bipartida (lembrando, além do que será exposto, a existência do Tribunal Constitucional):
} 
Logo de início, já se coloca a preocupação de determinar, com um mínimo de clareza, o que seja, de um lado, violação à Constituição, a ensejar recurso extraordinário, e o que configura mera contrariedade ao direito infraconstitucional, cognoscível por meio de recurso especial, de outro. A situação é agravada pelo caráter particularmente analítico da Constituição brasileira, cujas disposições são freqüentemente repetidas pela legislação comum: surge, então, séria dificuldade quando o acórdão recorrido tem um fundamento que contrarie, ao mesmo tempo, norma constitucional e infraconstitucional. Criaram-se, na tentativa de contornar o problema, teorias tão complexas quanto artificiais acerca de violações "diretas" ou "reflexas" ao texto constitucional, não raro sendo discrepantes as posições adotadas por um e por outro Tribunal de superposição, com flagrante prejuízo para as partes litigantes e para o desempenho da função institucional jus-unitária das Cortes.

Cabe lembrar, ainda pela perspectiva do conteúdo da decisão recorrida, ser indispensável, em alguns casos - i.e., quando o julgado contiver duplo fundamento suficiente, sendo cada um deles, isoladamente considerado, idôneo a sustentar de forma autônoma o (respectivo capítulo do) dispositivo do acórdão -, a interposição simultânea de ambos os recursos, sob pena de seu indeferimento ( $c f$. o enunciado . $^{\circ} 126$, Súmula/STJ). É natural, portanto, que as partes e seus advogados - receosos de terem seus recursos inadmitidos - sejam levados a interpor, na maior parte das vezes, as duas impugnações da mesma decisão, com duplicação de trabalho e de custos para todos.

Em segundo lugar, coloca-se um problema de atribuição de poderes: possui o Superior Tribunal de Justiça a capacidade de declarar, incidenter tantum, a inconstitucionalidade de lei federal? Ou estará ele obrigado a aplicar a lei que considera

se fundado em preceito constitucional ou de direito privado comum, será do Tribunal Supremo; acaso invocadas normas de direito privado especial ou foral de uma Comunidade (leia-se, direito local), será do respectivo Superior Tribunal de Justicia. Diante desse desenho institucional, surgem dúvidas quando a fundamentação do recurso esteja escorada em norma de direito civil local mas, ao mesmo tempo, "se cite de modo tangencial e complementar um preceito constitucional". Em tais casos, a jurisprudência cuida de afirmar a competência dos Superiores Tribunales ( $c f$. julgados colacionados por JUAN MONTERO AROCA JosÉ FlORSMATÍES, El recurso de casación civil, cap. 3, p. 294 e ss.), o que se distingue da "verdadeira alegação de preceito constitucional”, em que a competência é mesmo do Tribunal Supremo (op. cit., cap. 3, p. 300). Pode ver-se, desde logo, a dificuldade na distinção pelos próprios termos usados: o que há de ser uma alegação "verdadeira" de norma da Constituição? Há, ainda, a possibilidade de cabimento simultâneo de dois recursos quando concorrem normas de direito civil comum e de direito civil local, hipótese em que se terá como não interposta a cassação destinada ao Tribunal Supremo, tendo primazia o recurso autonómico - i.e, dirigido ao Superior Tribunal de Justicia da respectiva Comunidad (op. cit., cap. 3, p. 301-302). Com relação ao Tribunal Constitucional, ao menos, o problema não se coloca: a cassação constitui uma via recursal prévia de tutela também a direitos de status constitucional, havendo um princípio de subsidiariedade a governar a atuação daquele ( $c f$. VICENTE GIMENO SENDRA, Derecho procesal civil, vol. 1, n. 32(IV), p. 635). 
inconstitucional, sob pena de invadir a competência do Supremo Tribunal Federal? Tratase de tema importante, que tem suscitado numerosos debates na doutrina e oscilações na jurisprudência dos Tribunais de superposição.

Em terceiro lugar, o próprio processamento dos dois recursos - simultaneamente interpostos - apresenta-se complicado e ineficiente. Eventuais discussões e desencontros sobre a ordem dos julgamentos - à luz da possível relação de prejudicialidade existente entre as questões alegadas num e noutro recurso (em face das regras previstas no art. 543, CPC, e seus parágrafos) -, conspiram contra a duração razoável do processo (art. $5^{\circ}$, LXXVIII, CF). Problemas surgem também em relação à verificação do efeito substitutivo da decisão recorrida, quando esta assentar em "duplo fundamento suficiente": exige-se, para tanto, o conhecimento ou o provimento de ambos os recursos? A quem caberá apreciar eventual ação rescisória? Como se não bastasse, essa sistemática deu ensejo à implementação de jurisprudência defensiva criadora de verdadeiras armadilhas para o recorrente. Lembre-se, v.g., o ônus diabólico de comprovar o protocolo do agravo de instrumento contra a decisão de inadmissão de recurso extraordinário para que seja conhecido o agravo referente ao recurso especial, nos casos em que a interposição simultânea das duas impugnações é indispensável (ex verbete n. ${ }^{\circ} 126$, Súmula/STJ). ${ }^{744}$

Ainda no plano procedimental, cabe recordar as dificuldades decorrentes do juízo bipartido de admissibilidade exercido em relação aos recursos excepcionais: como proceder quando as duas irresignações são inadmitidas na origem e ambos os respectivos agravos são manejados? E se for negado seguimento a somente o recurso especial? Ou, ainda, apenas ao recurso extraordinário? As soluções sugeridas, como não poderia deixar de ser, são tão variadas quanto as combinações que se podem imaginar. ${ }^{745}$

\footnotetext{
${ }^{744}$ Orientação com a qual se negou conhecimento a vários agravos de instrumento em recursos especiais; v.g. "1. A interposição simultânea dos Recursos Extraordinário e Especial impõe, rejeitados ambos na origem, ao agravante demonstrar a irresignação contra ambas as inadmissões em face do entendimento pacífico de que, fundando-se o acórdão recorrido em matéria constitucional e infraconstitucional, indispensável o oferecimento dos dois meios de impugnação (inteligência do Enunciado 126 da Súmula do STJ). 2. É do agravante a responsabilidade pela correta formação do instrumento" (STJ, 6 a T., AgRg no Ag 967.794/BA, rel. Min. Celso Limongi, j.em 15/09/2009, DJe 28/09/2009). Felizmente, em embargos de divergência, a formalidade despropositada e de difícil observância foi abandonada: v. STJ, 1 a Seção, EAg 1099496/SP, rel. Min. Hamilton CARVALHIDO, j. em 22/09/2010, DJe 13/10/2010.

${ }^{745}$ Ver, a esse respeito, as ponderações de ATHOS GUSMÃO CARNEIRO, Recurso especial, agravos e agravo interno, n. 5, p. 18-19; NeLSON LUIZ PINTO, Recurso especial para o Superior Tribunal de Justiça, n. III.IV, p. 65-66; amplamente, JosÉ THEOPHILO FLEURY, Recursos especial e extraordinário, cap. 4, p. 71 e ss.
} 
Por fim, às inúmeras perplexidades já existentes, veio acrescentar-se uma nova, decorrente da instituição do requisito da repercussão geral para a admissão do recurso extraordinário: como compatibilizar o conhecimento do recurso especial com a eventual ausência de repercussão geral da questão constitucional, nos casos em que a decisão recorrida possui duplo fundamento (constitucional e comum), sendo, por isso, obrigatória a interposição simultânea?

Nada mais precisa ser dito para que se chegue à inequívoca conclusão de que o balanço crítico pesa claramente em desfavor do sistema bipartido criado pela Constituição de 1988. A opção constitucional gera complicações procedimentais e debates acadêmicos desnecessários, impõe perda de tempo (e dinheiro) das partes e dos juízes e não contribui nem para superar a crise do Supremo nem para favorecer a função jus-unitária. Afigura-se correta, portanto, a opinião de que teria sido melhor evitar a dualidade de recursos, restringindo o cabimento do recurso extraordinário às decisões tomadas pelo Superior Tribunal de Justiça em sede de recurso especial ${ }^{746}$ (tal como ocorre, aliás, nas Justiças Especiais Eleitoral e do Trabalho e seus respectivos Tribunais Superiores). ${ }^{747}$

Entretanto - em que pese ser essa, de lege ferenda, indiscutivelmente a melhor solução -, o direito posto obriga o intérprete a buscar explicações e mecanismos a ele adequados, procurando emprestar alguma racionalidade ao caos. É o que se tentará fazer no presente capítulo.

\footnotetext{
${ }^{746}$ V.g., CARLoS MÁRIO Velloso, "O Superior Tribunal de Justiça - competências originária e recursal", n. 8, p. 45; PAUlo RoBerto da COSTA Leite, "Recurso especial: admissibilidade e procedimento", p. 194. É verdade que, adiante no texto ( $o p$. e loc. cit.), este último autor entende que "aquela solução, tida como ideal, não se justifica na prática. Diante da pletora de feitos, além de não fazer sentido o trânsito pelo Superior Tribunal de Justiça de causa que contenha apenas o contencioso constitucional, com a instituição de uma quarta instância, apenas se mudaria o endereço da crise que se instalou no Supremo Tribunal Federal. Brevemente estariam sobrecarregadas as pautas de julgamento da nova Corte, com o conseqüente retardo da prestação jurisdicional". Como é sabido por todos, a repartição de competências entre os dois Tribunais não impediu que se instalasse, em breve termo, a crise decorrente do número elevadíssimo de recursos interpostos; pior do que isso, a crise atingiu ambas as Cortes. Ademais, é rara a hipótese em que uma causa "contenha apenas o contencioso constitucional", sem qualquer discussão situada no plano do direito federal comum. Dessa forma, parece difícil justificar-se - seja no plano ideal, seja mesmo na prática - a dualidade recursal.

${ }^{747}$ Ponto que diferencia, segundo NeLSON RodRIGUES NetTo, o recurso especial da revista e do recurso especial eleitoral (Interposição conjunta..., n. 5, p. 26-27).
} 


\title{
9.2. CABIMENTO DE UM OU DE OUTRO RECURSO
}

Prepondera no Superior Tribunal de Justiça a orientação segundo a qual não se deve conhecer de recurso especial calcado em norma infraconstitucional que meramente reproduz o texto constitucional. Constituem, segundo a jurisprudência da Corte, exemplos dessa espécie de fundamento a argüição de violação: aos arts. 480 a 482 do CPC (que reproduzem a norma do art. 97, CF), que determinam a reserva de plenário para a declaração de inconstitucionalidade pelos Tribunais, ${ }^{748}$ ao art. 97, CTN (reproduzindo o art. 150, I, CF), que impõe a edição de lei para a definição do fato gerador de tributo; ${ }^{749}$ ao art. 54, ECA (equivalente ao art. 208, IV, CF), norma que consagra o dever positivo do Estado de prestar serviço de educação infantil; ${ }^{750}$ ao art. 49, CTN (de teor igual ao art. 153, $\S 3^{\circ}$, II, CF), tendo como questão a sistemática de compensação e não cumulatividade do IPI. $^{751}$

\footnotetext{
${ }^{748}$ Nesse sentido, v.g., "Processual civil. Cláusula de plenário. Argüição de inconstitucionalidade. Tema constitucional. 1. A controvérsia acerca da cláusula de reserva de plenário escapa do âmbito de apreciação do recurso especial, porquanto os dispositivos legais tidos como contrariados reproduzem o que está consignado no artigo 97 da Constituição Federal. Precedente desta Turma. 2. A verificação, no âmbito desta Corte, de eventual omissão pelo Tribunal a quo na análise de matéria constitucional importaria na usurpação da competência reservada ao STF" (STJ, $2^{\mathrm{a}}$ T., REsp 853563/RJ, rel. Min. CASTRO MEIRA, j. em 01/03/2007, DJ 13/03/2007, p. 332)
}

\begin{abstract}
${ }^{749}$ Nesse sentido, v.g., "1. É inadmissivel recurso especial interposto contra acórdão decidido sob enfoque essencialmente constitucional, sob pena de usurpar-se competência da Suprema Corte. (...) 3. A interpretação do art. 97 do CTN, que reproduz norma encartada no art. 150, I, da CF/88, implica apreciação de questão constitucional, inviável em recurso especial. (...) 5. A admissibilidade do recurso especial não depende, exclusivamente, da matéria tratada, mas do enfoque dado pela Corte de origem, pois um mesmo tema pode ser examinado sob perspectivas constitucional ou infraconstitucional, o que vai determinar a admissão dos recursos dirigidos a esta Corte e ao Supremo. Assim, embora dois recursos discutam a mesma matéria, não se pode dizer que o destino de ambos seja o mesmo" (STJ, 2a T., AgRg no REsp 1154339/RS, rel. Min. CASTRO MEIRA, j. em 17/08/2010, DJe 26/08/2010)

${ }^{750}$ Nesse sentido, v.g., "1. O acórdão recorrido assenta sobre fundamentação de índole eminentemente constitucional, razão pela qual, estando a competência do STJ, delimitada pelo art. 105, III, da Constituição, restrita à uniformização da legislação infraconstitucional, é inviável o conhecimento do recurso especial. 2. Não houve emissão de juízo pelo acórdão do Tribunal de origem sobre as normas contidas nos dispositivos cuja violação se aponta no especial, um dos quais (art. 54 do ECA) praticamente reproduz a disposição do art. 208, IV, da Constituição - circunstância que torna ainda mais evidente a indole constitucional do tema em debate, e a impossibilidade de seu tratamento pelo STJ" (STJ, $1^{\mathrm{a}}$ T., REsp 613.206/SP, rel. p/ acórdão Min. TEORI ALBINO ZAVASCKI, j. em 11/05/2004, DJ 23/08/2004, p. 141).
\end{abstract}

${ }^{751}$ Nesse sentido, v.g., "(...) 3. Não se conhece de recurso especial quando a decisão atacada baseou-se, como fundamento central, em matéria de cunho eminentemente constitucional. Apesar de haver fundamento infraconstitucional e dissídio jurisprudencial a respeito, não prevalecem estes em detrimento da abordagem central de natureza constitucional. 4. O dispositivo legal tido por ofendido (art. 49 do CTN) reproduz, a grosso modo, a dicção expressa do art. 153, § $3^{\circ}$, II, da Carta Política. Nesse sentido, já se decidiu que 'se o dispositivo tido por violado não passa de mera reprodução de norma constitucional, que o absorve totalmente, é do STF a competência exclusiva para dispor sobre a temática controvertida' (STJ - RT 698/198). Da mesma forma quando a reprodução é parcial ou mitigada (RSTJ 55/132). 5. O fato de este Tribunal já ter apreciado questão idêntica à dos presentes autos não indica que, necessariamente, tenha que se analisar todas que ingressem nesta Corte, visto que muitas delas, como a presente, envolvem debate 
O entendimento, contudo, não é unânime. A exigência de reserva de plenário para declaração incidental de inconstitucionalidade de lei pelos Tribunais, v.g., já foi apreciada no julgamento do mérito recursal pelo Superior Tribunal de Justiça. ${ }^{752}$ Outrossim, a delicada e importante questão concernente à apreciação de recurso especial em que se discuta direito adquirido - garantia que encontra guarida tanto no art. $6^{\circ}$, caput e $\S 2^{\circ}$, LICC, quanto no art. 5 XXXVI, CF - foi debatida pela Corte Especial, que decidiu, em apertadíssima maioria, pela afirmativa, ${ }^{753}$ não sendo raros, contudo, julgados ulteriores de Turmas em sentido contrário. ${ }^{754}$

O problema, como se disse, é particularmente agravado diante de teses por vezes antagônicas adotadas pelos Tribunais de superposição, verificando-se, então, um "verdadeiro impasse": o Supremo Tribunal Federal, invocando a doutrina da "ofensa direta", 755 entende que a questão é de índole infraconstitucional, enquanto o Superior Tribunal de Justiça sustenta justamente o oposto, e a matéria acaba não sendo enfrentada. $^{756}$

A solução parece ser admitir tanto um quanto outro recurso nesses casos. Nada obsta que um mesmo instituto seja regulado, ao mesmo tempo, no texto constitucional e também na lei, de modo que cabíveis, respectivamente, o recurso extraordinário e/ou o recurso especial. Daí a possibilidade de ser discutido o polêmico instituto do direito adquirido também pela ótica constitucional. ${ }^{757}$ A adoção de postura contrária implicaria

eminentemente constitucional, o que, provavelmente, não ocorreu quando daquele julgamento" (STJ, $1^{\mathrm{a}} \mathrm{T}$., AgRg no Ag 734.483/MG, rel. Min. José DELGADO, j. em 20/04/2006, DJ 22/05/2006, p. 157).

${ }^{752}$ STJ, $1^{\text {a }}$ Seção, REsp 747487/RJ, rel. Min. Eliana CALMON, j. em 08/08/2007, DJ 27/08/2007, p. 181.

753 STJ, Corte Especial, REsp 274.732/SP, rel. Min. JosÉ ARNALDO DA FONSECA, j. em 25/03/2004, DJ 06/12/2004, p. 183.

754 Nesse sentido, v.g., "É pacífica a orientação desta Corte Superior no sentido de que os princípios contidos na LICC - direito adquirido, ato jurídico perfeito e coisa julgada - apesar de estarem previstos em norma infraconstitucional, não podem ser analisados em sede de recurso especial, pois são institutos de natureza eminentemente constitucional (art. 5', inc. XXXVI, da CR/88). Precedentes" (STJ, $2^{\mathrm{a}}$ T., REsp 1166681/RJ, rel. Min. Mauro CAMPBell MARQues, SEGUNDA TURMA, j. em 28/09/2010, DJe 25/10/2010)

755 Ver, sobre isso, BURNO DANTAS, Repercussão geral, n. 4.2.2.1.3, p. 170 e ss. (defendendo que, dependendo da intensidade da ofensa reflexa, o recurso constitucional deve ser conhecido).

${ }^{756}$ EDUARDO RIBEIRO DE OLIVEIRA, "Norma constitucional e infraconstitucional de igual conteúdo - recurso especial e extraordinário", n. 7, p. 908.

757 STF, Pleno, RE 226855, rel. Min. Moreira Alves, j. em 31/08/2000, DJ 13/10/2000, p. 20, RTJ 174/916.Para GILMAR MENDES, referindo-se a esse exato julgamento do Supremo Tribunal Federal,"tivesse prevalecido entendimento contrário (...) muito provavelmente, a garantia do art. $5^{\circ}$, XXXVI, teria desaparecido enquanto direito de hierarquia constitucional" (Curso de direito constitucional, cap. 6, n. III.3, p. 463). 
manifesta contrariedade aos arts. 102, III, e 105, III, da Constituição ${ }^{758}$ e renunciaria à função jus-unitária em temas que, de tão importantes, recebem a atenção do constituinte e do legislador ordinário. Assim, acaso interpostos simultaneamente ambos os recursos contra o acórdão do Tribunal local, devem ser observadas as regras usuais sobre o seu processamento: remetem-se os autos, primeiramente, ao Superior Tribunal de Justiça e, na eventualidade de julgamento desfavorável, ao Supremo Tribunal Federal. Essa interposição conjunta, entretanto, de modo algum pode ser considerada obrigatória, não se confundindo com a hipótese tratada pelo enunciado n. 126 da Súmula/STJ, em que há dois fundamentos autônomos suficientes, isoladamente, para sustentar o acórdão recorrido. Por isso, desprovido o recurso especial, não há como excluir o cabimento do recurso extraordinário contra a própria decisão do Superior Tribunal de Justiça, alegando-se, v.g., que a interpretação dada à norma não está em conformidade com a Constituição. Definida então a questão pelo Supremo Tribunal Federal, o precedente, no ponto, deve vincular a todos os demais órgãos judiciários, inclusive o Superior Tribunal de Justiça. Com maior razão, o eventual provimento do recurso especial enseja a interposição de recurso extraordinário ao recorrido.

\subsection{INTERPOSIÇÃO CONJUNTA DOS RECURSOS ESPECIAL E EXTRAORDINÁRIO}

A interposição conjunta dos recursos especial e extraordinário é regulada, muito genericamente, pelo art. 543, §§, CPC. Dizem os dispositivos que os autos serão remetidos primeiramente ao Superior Tribunal de Justiça, para que seja julgado o recurso especial, e, num segundo momento, ao Supremo Tribunal Federal, se ainda houver utilidade no julgamento do recurso extraordinário. ${ }^{759}$ Caso a matéria constitucional seja considerada prejudicial, abre-se exceção: recebidos os autos pelo Superior Tribunal de Justiça, o Ministro relator, em decisão irrecorrível, sobrestará o seu julgamento e remeterá os autos ao Supremo Tribunal Federal. Nesta sede, de duas uma: ou há concordância e, ato contínuo, procede-se ao julgamento do recurso extraordinário, ou, discordando-se, os autos

\footnotetext{
${ }^{758}$ Nesse sentido, EDUARDO RIBEIRO DE OLIVEIRA, "Norma constitucional e infraconstitucional de igual conteúdo - recurso especial e extraordinário", n. 8, p. 910.

${ }^{759}$ Segundo NELSON RODRIGUES NETTO, “a interpretação pretoriana realizada pelo Supremo Tribunal Federal foi consolidando a regra da preferência no julgamento do recurso especial em face do recurso extraordinário, tornando-a norma de procedimento, devendo o conhecimento e julgamento do recurso especial preceder a apreciação do recurso extraordinário" (Interposição conjunta..., n. 7, p. 46), o que passou à legislação extravagante (Lei n. $\left.{ }^{\circ} 8.038 / 90\right)$ e ao Código de Processo Civil.
} 
serão remetidos novamente ao Superior Tribunal de Justiça, que deverá, então, necessariamente apreciar a respectiva impugnação (recurso especial).

Duas ordens de problemas podem ser suscitados à luz dessa sistemática. Primeiro: é necessário determinar quando a interposição simultânea é necessária, enquanto requisito de admissibilidade dos recursos (enunciado n. 126, Súmula/STJ), e quando representará mera faculdade do recorrente. Segundo: é preciso compreender a relação existente entre a repercussão geral da questão constitucional (requisito de admissibilidade do recurso extraordinário, ex art. 543-A, CPC) e o juízo de admissibilidade do recurso especial nas hipóteses de interposição concomitante.

I) Com a expressão "interposição simultânea” dos recursos, não se quer indicar a obrigatoriedade de seu protocolo no mesmo dia. Não há, aqui, preclusão consumativa pela apresentação de um recurso em relação ao outro, tal como ocorre, v.g., entre contestação e reconvenção (ex art. 299, CPC). A doutrina chama atenção para o ponto, salientando ser preferível falar, em nome da boa técnica, em interposição conjunta, e não simultânea dos recursos extraordinário e especial. ${ }^{760}$ No entanto, devido à consagrada terminologia - e feito o aparte -, seguir-se-á referindo o fenômeno indistintamente.

De acordo com jurisprudência uníssona (enunciado n. ${ }^{\circ}$ 126, Súmula/STJ; verbete n. 283 , Súmula/STF), ${ }^{761}{ }^{762}$ será obrigatória a interposição de ambos os recursos quando,

\footnotetext{
${ }^{760}$ Nesse sentido, NELSON RODRIGUES NETTO, Interposição conjunta de recurso extraordinário e especial, $\mathrm{n}$. 9.1, p. 72-73; ARAKEN DE ASSIS, Manual dos recursos, n. 86.1.1.2, p. 738-739.

761 Ressalve-se, contudo, o entendimento contrário de BOTELHO DE MESQUITA (Recurso extraordinário e recurso especial: contrastes e confrontos", p. 359-363, passim). Para ele, "este entendimento, aparentemente lógico, só é lógico quando os dois fundamentos se referem a um só recurso, caso em que, havendo fundamento suficiente inatacado, carecerá o recurso do indispensável interesse processual; mas não é nada lógico quando os dois fundamentos se prendem a dois recursos diferentes". Partindo da premissa de que os fundamentos não transitam em julgado (de fato, como já visto, eles não transitam), o autor afirma que, "na pendência do recurso especial, se não interposto simultaneamente o recurso extraordinário, não haverá trânsito em julgado nem da conclusão da sentença recorrida, nem, muito menos, do fundamento de direito constitucional". O exemplo que utiliza é didático: o acórdão do tribunal de apelação julgara procedentes embargos à execução fiscal, sob o duplo fundamento da inconstitucionalidade da lei e da inocorrência do fato gerador. Como se pode facilmente identificar, ambos os motivos dão sustento ao mesmo (e único) capítulo de mérito. A Fazenda interpõe apenas recurso especial, deixando inatacada a questão da incompatibilidade da lei fiscal com a Constituição. À luz do caso hipotético, são diferenciadas, então, duas hipóteses, às quais o autor atribui soluções diversas: a de inadmissão do recurso especial e a de seu julgamento no mérito. Na primeira (juízo negativo de admissibilidade), não ocorreria substituição pelo acórdão do Superior Tribunal de Justiça e, portanto, remanesceria intacta a decisão recorrida, sendo intempestivo eventual recurso endereçado apenas então ao Supremo Tribunal Federal. Nas suas próprias palavras, "o que se terá serão duas decisões isoladas, separadas entre si por um intervalo de tempo, maior que o do prazo para interposição do recurso extraordinário contra a primeira, [de modo que] não existirão condições atuais que permitam a interposição do recurso extraordinário"; a previsão legal da interposição simultânea de ambos os recursos seria, nessa medida, uma "facul[dade] da lei", instituída justamente para prevenir esse risco. Na segunda (juízo positivo
} 
no acórdão de origem, o dispositivo da sentença assentar em mais de um fundamento constitucional e infraconstitucional -, cada um suficiente para manter o desfecho alcançado.

O exemplo mais claro (e freqüente) é o do acórdão em que se discute, como questão prévia, a (in)constitucionalidade da lei. Nesse caso, há o motivo constitucional, ligado à análise da compatibilidade do ato normativo com a Constituição, e a questão infraconstitucional, ligada à interpretação/aplicação do texto legal ao caso concreto. Assim, v.g., ocorre com o acórdão que acolhe embargos à execução fiscal declarando tanto a

de admissibilidade), o novo acórdão toca o mérito do recurso e substitui a decisão recorrida; isso ocorreria, segundo o pensamento do autor, tanto com a confirmação da conclusão do juízo a quo (desprovimento) quanto com a sua reforma (provimento). Em ambos os casos, alega o Professor BOTELHO DE MESQUITA, "não have[ria] nenhum obstáculo [a impedir o Superior Tribunal de Justiça] de pronunciar-se sobre a inconstitucionalidade incidentemente reconhecida pela decisão recorrida, do mesmo modo que não estaria impedido o tribunal de apelação em face da sentença de primeiro grau". Por isso, seguindo ainda o seu raciocínio, contra o acórdão (mesmo de desprovimento) do Superior Tribunal de Justiça que julga o mérito do recurso especial, "voltam a estar presentes, portanto, todos os pressupostos para a interposição do recurso extraordinário, que não configurará recurso contra o acórdão do tribunal de apelação, que já não mais existirá, mas contra o novo acórdão que o substituiu, proferido pelo STJ". Seja como for, para o autor, "a interposição de ambos os recursos não é obrigatória", mas apenas um "ônus da parte", a ser cumprido na medida em que se queira evitar o risco de não conhecimento do recurso especial interposto sozinho. A teoria - que se espera ter descrito fielmente, recorrendo-se para tanto à transcrição literal dos vários trechos do ensaio - é engenhosa e sedutora. Entretanto, não resiste a um exame aprofundado. De início, como já se teve oportunidade de sustentar, não parece acertada, à luz da peculiar estrutura dos recursos excepcionais, a afirmação genérica de que, "uma vez conhecido o recurso, há necessária substituição da decisão recorrida". Isso somente ocorre diante (e nos limites) de decisão de mérito positiva (i.e, de provimento do recurso). Ainda que não fosse assim, as conclusões do insigne Professor BOTELHO DE MESQUITA não podem ser acolhidas por outras razões, na medida em que contrariam a distribuição de competências entre os dois Tribunais de superposição. Veja-se que, por um lado, se o acórdão no julgamento do recurso especial negar provimento à pretensão recursal, confirmando, no exemplo adotado, que o fato gerador não foi mesmo praticado pelo contribuinte - e admitindo-se, pelo argumento, que se opere a substituição da decisão recorrida também nessa hipótese -, eventual recurso extraordinário contra tal decisão é inútil. Isso porque, de acordo com as regras de competência adotadas pela Constituição (arts. 102, III, e 105, III), não será possível ao Supremo Tribunal Federal revisar o entendimento do Superior Tribunal de Justiça acerca da lei federal. Cabe a este - e não àquele - dar a última palavra acerca do direito federal infraconstitucional. Sendo assim, a interposição do único recurso cabível (o extraordinário), pela Fazenda, deixaria de abranger um fundamento suficiente para a manutenção do dispositivo favorável ao contribuinte: ainda que se declarasse constitucional a lei tributária, persistiria intacto o ponto definido pelo Superior Tribunal de Justiça no sentido de que a regra-matriz do tributo não incidiu aos fatos praticados. E, como é reconhecido pelo próprio autor citado, em passagem já transcrita, "é lógico [que], quando os dois fundamentos se referem a um só recurso [...], havendo fundamento suficiente inatacado, carecerá o recurso do indispensável interesse recursal”. Por outro lado, na hipótese de provimento do recurso especial, para que se mantenha coerência com o argumento do amplo efeito devolutivo, será necessário admitir que, por meio do recurso extraordinário, o Supremo Tribunal Federal poderá revisar não somente a questão da (in)constitucionalidade da lei, mas também o enquadramento da conduta praticada pelo contribuinte no conceito do fato gerador. Novamente, no entanto, há transgressão das regras de competência e o resultado não parece compatibilizar-se com o texto da Constituição.

762 Sintetizada na seguinte passagem: "pela sistemática do art. 541, CPC, a parte vencida tem o ônus processual de interpor ambos os recursos, especial e extraordinário, concomitantemente, em peças distintas, no prazo de 15 (quinze) dias da intimação do acórdão do Tribunal a quo. Não pode, por isso mesmo, pretender atacar o fundamento constitucional do acórdão do Tribunal local, tão-somente quando da decisão do STJ" (ARRUDA ALVIM, "Recurso especial - fundamentacão vinculada", n. 1.3.2, p. 34). 
inconstitucionalidade da lei fiscal quanto a falta de enquadramento do fato praticado pelo contribuinte ao fato gerador previsto. Parece evidente que, nessa hipótese, a discussão constitucional é prejudicial ao tema infraconstitucional, de modo que, na prática, interpostos ambos os recursos, os autos devem ser remetidos ao Supremo Tribunal Federal em primeiro lugar.

Ainda nesse tema, são comuns as afirmações doutrinárias no sentido de que o fundamento não impugnado pelo respectivo recurso estaria coberto pela autoridade da coisa julgada, sendo esse o motivo pelo qual, em alguns casos, seria imperiosa a interposição simultânea dos recursos especial e extraordinário. A asserção, à luz do nosso direito positivo, é manifestamente equivocada: por expressa determinação da lei, os fundamentos da sentença não transitam em julgado (art. 469, I, CPC).

Novamente, cabe distinguir as diferentes situações a fim de compreender bem o problema. Havendo I) capítulos diversos, cada um dos quais apoiado em fundamento de índole normativa também diversa (i.e, constitucional e infraconstitucional, respectivamente), e não sendo impugnado um deles, ocorre, de fato, o trânsito em julgado. A coisa julgada, todavia, atinge o capítulo (i.e, a parte correspondente do dispositivo sentencial) $^{763}$ que se deixou de impugnar, mas não os motivos à sua base (ou quaisquer outros motivos), ainda que uma fragmentação da motivação em partes distintas seja necessária para compreender cada uma das questões jurídicas como uma causa petendi diversa do recurso especial. ${ }^{764}$ Deixada essa última questão de lado, o que se tem, na hipótese descrita, é um corolário óbvio do efeito devolutivo, no sentido horizontal, dos recursos (tantum devolutum quantum appellatum). Se, ao contrário, há II) dupla fundamentação para o mesmo capítulo, a parte que deixa de interpor um dos recursos, segundo o entendimento pacífico dos Tribunais Superiores (verbete n. ${ }^{\circ} 126$, Súmula/STJ; enunciado n. ${ }^{\circ} 283$, Súmula/STF), carecerá de interesse, na medida em que o provimento hipotético de uma das impugnações, por si só, não será idôneo a reformar o acórdão recorrido. A conseqüência inevitável é a inadmissão do único recurso interposto, por faltarlhe utilidade (art. $3^{\circ}, \mathrm{CPC}$ ). Nem por isso, entretanto, serão alterados os limites objetivos da coisa julgada; essa autoridade recairá somente sobre o dispositivo, e não sobre um fundamento específico. Em resumo, o problema da dupla fundamentação do acórdão - seja

\footnotetext{
${ }^{763}$ Sobre o conceito, ver CÂNDIDO DINAMARCO, Capítulos de sentença, esp. n. 11-17, p. 31 e ss. ${ }^{764}$ Algo nesse sentido, NeLSON RodRIGUES NETTO, n. 10.3, p. 86-87.
} 
em relação a um único capítulo, seja em relação a capítulos diversos - nada tem a ver com a formação da coisa julgada.

II) Problema mais diretamente relacionado à função dos Tribunais de superposição é o da influência da repercussão geral (requisito ligado ao recurso extraordinário) sobre o juízo de admissibilidade do recurso especial. Se, com efeito, nas hipóteses abarcadas pelo verbete n. ${ }^{\circ} 126$, Súmula/STJ, não se preencher o requisito da repercussão geral, em princípio caberia inadmitir o recurso especial, por ausência de interesse.

Diante de tal situação, parte da doutrina entende que deveria ser dispensada a interposição do recurso extraordinário. ${ }^{765}$ Haveria, então, uma "ampliação da competência do Superior Tribunal de Justiça, que examinaria não apenas questões federais infraconstitucionais, mas, também, questões constitucionais". ${ }^{766}$ A conclusão corrobora, em alguma medida, a premissa de que a bipartição dos recursos excepcionais é artificial e que melhor teria sido evitá-la. Ao Superior Tribunal de Justiça, de qualquer maneira, cabe interpretar o ordenamento infraconstitucional de acordo com a Constituição da República. No entanto, falta o passo decisivo de reservar ao Supremo Tribunal Federal apenas uma competência subsidiária em relação aos julgados de todos os Tribunais Superiores, inclusive do Superior Tribunal de Justiça.

\subsection{Limites do CONTROLE DE CONSTITUCIONALIDAde REAlizado PELO SuPERIOR Tribunal de JustiçA}

Questão diretamente relacionada à função do Superior Tribunal de Justiça, na esteira do tema tratado no último parágrafo do tópico anterior, é saber se a Corte pode conhecer de questões constitucionais no julgamento de recursos especiais.

Parte da doutrina nega que a Corte tenha o poder de declarar a inconstitucionalidade das leis. Alega-se, nesse sentido, que a cláusula de reserva de plenário não estabeleceria a competência de todos os Tribunais para a declaração de inconstitucionalidade da norma; apenas regularia, dentro dos Tribunais a quem coubesse

\footnotetext{
${ }^{765}$ Clara AzzONi, Recurso especial e extraordinário, n. 2.2.5, p. 50.

${ }^{766}$ José Miguel Garcia MedinA, Prequestionamento e repercussão geral, n. 1.2.6, p. 59.
} 
tal controle (de maneira "interna") - rol do qual estaria excluído o Superior Tribunal de Justiça -, a repartição de juízos segundo a matéria versada. ${ }^{767}$

$\mathrm{O}$ argumento não convence. $\mathrm{O}$ controle de constitucionalidade (difuso) é conferido a todos os Tribunais e juízes. O fato do direito brasileiro ter incorporado o modelo norteamericano já o comprova - nos EUA, como se sabe, o judicial review não está expressamente previsto na Constituição, tendo resultado de decisão da própria Suprema Corte, ${ }^{768}$ que consagrou, dessa forma, "uma indispensável, implícita característica de uma Constituição escrita". ${ }^{769}$ Ademais, o argumento sob análise, acaso procedente, provaria em demasia, porquanto, se fosse verdade que o art. 97 da Constituição apenas estabelece uma repartição interna de competência para a declaração de inconstitucionalidade das normas, dependendo de outra regra que outorgasse "externamente" poder aos órgãos do Poder Judiciário para tanto, não se poderia igualmente afirmar a competência dos juízes de primeiro grau. E semelhante conclusão, além de ofender a tradição judiciária de nosso país (em que o controle por todos os juízes e tribunais da constitucionalidade das leis é previsto, ao menos, desde o art. 13, $\S 10$, da Lei 221 de 20 de novembro de $1894^{770}$ ), contrasta com doutrina pacífica. ${ }^{771}$

Ao Superior Tribunal de Justiça, portanto, é atribuído também o poder de declarar a inconstitucionalidade de leis e atos normativos, no âmbito de sua competência, com a restrição genericamente imposta pelos tribunais pelo art. 97 da Constituição. ${ }^{772}$ Assim já decidiu, corretamente, o Supremo Tribunal Federal. ${ }^{773}$ Isso é confirmado tanto pelo

${ }^{767}$ LEONARDO CASTANHO MENDES, O recurso especial e o controle difuso de constitucionalidade, n. 3.2.2, p. 185-186. No entanto, adiante, o próprio autor acaba por admitir o controle de constitucionalidade em algumas hipóteses, o que faz ruir o argumento exposto no texto (n. 3.3.3, p. 232 e ss.).

${ }^{768}$ Trata-se da célebre decisão proferida por JOHN MARSHALL em Marbury v. Madison, I Cranch 137 (1803)

${ }^{769}$ FELIX FRANKFURTER, "Marshall and the judicial function”, p. 219.

${ }^{770}$ Assim redigido: "Os juízes e tribunais apreciarão a validade das leis e regulamentos e deixarão de aplicar aos casos ocorrentes as leis manifestamente inconstitucionais e os regulamentos manifestamente incompatíveis com as leis e com a Constituição".

771 José AfOnso DA SILVA, Curso de direito constitucional positivo, p. 51; Luís RoBerto BARROSO, O controle de constitucionalidade no direito brasileiro, p. 47; PAULO BONAVIDES, Curso de direito constitucional, , p. 326-327.

${ }^{772}$ BARBOSA MOREIRA, "Recurso especial. Exame de questão de inconstitucionalidade de lei pelo Superior Tribunal de Justiça. Recurso extraordinário sob condição”, n. 5, p. 256-257; ATHOS GUSMÃO CARNEIRO, Recurso especial, agravos e agravo interno, n. 4, p. 16; BOTELHO DE MESQUITA, "Recurso extraordinário e recurso especial: contrastes e confrontos", p. 362; ROQUE CARRAZZA, "Do recurso extraordinário e do recurso especial", n. 9, p. 56.

${ }^{773} \mathrm{~V}$. Informativo-STF n ${ }^{\mathrm{o}} 316$, publicado em agosto de 2003. 
exercício de competências originárias da Corte quanto pela ausência de qualquer restrição constitucional ao conhecimento de tais questões. Ademais, o próprio RISTJ consagra, nos arts. 199 e 200, incidente de argüição de inconstitucionalidade. O problema, nessa medida, não é sobre se o Superior Tribunal de Justiça pode apreciar a constitucionalidade das leis, mas sobre quando poderá fazê-lo.

Para CÂNDIDo DinAmARCO, o Superior Tribunal de Justiça pode e deve verificar a constitucionalidade da lei federal cuja violação, em razão de sua aplicação pelo Tribunal local, é alegada pelo recorrente. Nesses casos, constatada a incompatibilidade, deve-se negar provimento ao recurso especial, tendo em vista inconstitucionalidade da lei. O que não poderia ser feito - sob pena de usurpar-se competência privativa do Supremo Tribunal Federal (ex art. 102, III, $b, \mathrm{CF}$ ) - é declarar-se a incompatibilidade da lei aplicada com a Constituição (ou, inversamente, negar-se a inconstitucionalidade reconhecida na instância a quo) a fim de prover o recurso especial. ${ }^{774}$ Nas palavras do autor, "dar provimento ao recurso especial com fundamento na Constituição Federal constitui invasão da esfera reservada ao recurso extraordinário e à competência do Supremo Tribunal Federal", 775

Com efeito, cabe lembrar a distinção já feita entre duas espécies de situações. A primeira é aquela em que o litigante tem sua pretensão rejeitada, no Tribunal local, tanto com base na Constituição quanto a nível infraconstitucional, repousando o acórdão sobre essa dupla fundamentação, em que cada um dos fundamentos é suficiente, por si só, para manter a conclusão da decisão. Nesse caso, a parte sucumbente deverá interpor, desde logo, tanto o recurso extraordinário quanto o recurso especial, sob pena, inclusive, de inadmissibilidade dos recursos excepcionais (enunciado n. ${ }^{\circ}$ 283, Súmula/STF; verbete n. ${ }^{\circ}$ 126, Súmula/STJ). Isso porque, havendo fundamentos autônomos e suficientes, o ataque contra um só e único deles não basta para que se modifique o acórdão recorrido, fato que revela ausência de interesse recursal da parte. São relativos a esses casos os precedentes do Supremo Tribunal Federal e do Superior Tribunal de Justiça - que afirmam, por vezes sem especificar devidamente o seu âmbito de aplicação, a inviabilidade de controle de constitucionalidade em sede de recurso especial. ${ }^{776}$

\footnotetext{
774 "Recurso especial provido por fundamento constitucional e reclamação ao Supremo Tribunal Federal", n. 624, p. 927-928.

775 CÂNDIDO DINAMARCO, "Recurso especial provido por fundamento constitucional e reclamação ao Supremo Tribunal Federal”, n. 625, p. 929.

$776 C f$. rigorosa análise de JosÉ CARLOS BARBosA MOREIRA, "Recurso especial. Exame de questão de
} 
Diferente é o caso em que a parte tem a sua pretensão acolhida com base em argumento de índole infraconstitucional, mas rejeitada a argüição preliminar de ilegitimidade da lei sob a ótica da Constituição. Nessa hipótese, em que não há sucumbência a legitimar a interposição de recurso (isto é, em que a parte não foi vencida, mas vencedora), poderá ela reiterar a questão nas contra-razões a eventual recurso especial interposto pelo seu adversário, devolvendo a discussão ao Superior Tribunal de Justiça, que, na verdade, já poderia dela conhecer de ofício. Reconhecida a inconstitucionalidade nesta sede, caberá recurso extraordinário. ${ }^{777}$

A discussão, em verdade, gira sobre um falso problema. O que se deve distinguir são as hipóteses em que um mesmo litigante é vencido tanto em relação ao fundamento constitucional quanto infraconstitucional daquelas em que, rejeitado o argumento ligado à Constituição, é acolhido o argumento infraconstitucional. Na primeira hipótese, surgem, no aresto local, tanto a causa de pedir constitucional quanto a infraconstitucional, o que exige a interposição simultânea dos dois recursos excepcionais: extraordinário ao Supremo Tribunal Federal; especial ao Superior Tribunal de Justiça. O mesmo litigante deve impugnar a rejeição dupla (constitucional e infraconstitucional) da mesma pretensão, valendo-se de dois recursos. Em suma, "a impossibilidade de discutir a inconstitucionalidade de lei em recurso especial se manifesta quando o recorrente tenta utilizá-lo como uma sorte de sucedâneo do extraordinário, em vez de interpor este último em separado" 778

No segundo caso, a situação é diversa. Como a parte recorrida não sucumbiu, tendo obtido praticamente tudo que pedira, não pode, teoricamente, manejar qualquer recurso desde logo. Contudo, é possível que, devolvida ao Superior Tribunal de Justiça a questão infraconstitucional, esta seja resolvida favoravelmente ao recorrente, hipótese em que o recorrido teria inegável interesse em discutir o fundamento de índole constitucional. Então, de duas uma: ou se admite o controle de constitucionalidade pelo Superior Tribunal de

inconstitucionalidade de lei pelo Superior Tribunal de Justiça. Recurso extraordinário sob condição", n. 8-9, p. 258-262; no mesmo sentido, CASSIO SCARPINELla BUENO, Curso sistematizado..., vol. 5, cap.11, n. 10, p. 304.

777 BARBOSA MOREIRA, "Recurso especial. Exame de questão de inconstitucionalidade de lei pelo Superior Tribunal de Justiça. Recurso extraordinário sob condição, n. 10, p. 262-263; EDUARDO RIBEIRO DE OLIVEIRA, "Norma constitucional e infraconstitucional de igual conteúdo - recurso especial e extraordinário", n. 8, p. 909.

${ }^{778}$ BARBOSA MOREIRA, "Recurso especial. Exame de questão de inconstitucionalidade de lei pelo Superior Tribunal de Justiça. Recurso extraordinário sob condição", n. 9, p. 261. 
Justiça à luz de contra-razões ofertadas pela parte (ou mesmo de ofício), ou se admite a interposição de recurso extraordinário condicionado (v., supra, $\S 8^{\circ}$ ). Alguns falam, nessa sede, de um "recurso excepcional adesivo cruzado", 779 mecanismo que seria aplicável tanto à hipótese em que o vencedor quer garantir a discussão do outro fundamento (constitucional ou infraconstitucional) quanto ao caso em que houver sucumbência recíproca.

779 Pedro Miranda de Oliveira, "Recurso excepcional adesivo 'cruzado"', n. 5, p. 631-633. Contra, inadmitindo semelhante recurso "cruzado" SERGIO BERMUDES, "O procedimento dos recursos extraordinário e especial no juízo recorrido", n. 6, p. 203. 


\section{$\S 10$ - CONCLUSÕES}

Seria despropositado recordar, a essa altura, todas as conclusões específicas alcançadas ao longo do trabalho. A título de desfecho, melhor será reafirmar a premissa metodológica e as linhas gerais do estudo.

Para entender o recurso especial, é preciso antes averiguar o porquê do Superior Tribunal de Justiça no ordenamento judiciário brasileiro. Somente com a devida compreensão da função da Corte (perspectiva analítico-funcional) pode-se reconstruir a estrutura dogmática do meio de impugnação.

Viu-se que a jurisprudência desempenha um papel complementar e constitutivo no desenvolvimento e estabilização do Direito. À luz disso, os Tribunais Superiores devem exercer, a fim de assegurar princípios inerentes ao Estado de Direito (igualdade, segurança jurídica e devido processo legal), uma função de orientação acentuadamente prospectiva.

Da investigação comparada, algumas tendências e valorações conclusivas puderam ser extraídas. A principal delas é que, para que uma Corte Suprema realize de maneira eficiente sua função de orientação, é necessário que possa controlar o número de recursos por ela decididos, levando em consideração a importância da questão invocada pelo recorrente e tendo em vista a oportunidade para estabelecer um precedente.

É hoje ultrapassada, por isso, a idéia de realizar uma nomofilaquia "particularista e analítica", garantindo-se um acesso irrestrito à Corte e a sua intervenção compreensiva em todos os casos em que se suscite um error iuris. Uma defesa da equivalência ou prevalência do ius litigatoris na conformação dos recursos excepcionais tem como conseqüência a anulação da função pública do Tribunal Superior e, por paradoxal que possa parecer, também o sacrifício do interesse das próprias partes. Ao fim e ao cabo, os interesses dos indivíduos são muito melhor servidos por uma Corte de precedentes do que por um Tribunal de controle da legalidade das decisões inferiores.

Tudo isso é aplicável ao Superior Tribunal de Justiça. Em alguns pontos, a Corte caminha no rumo certo, procurando empregar maior autoridade aos seus precedentes, sendo um bom exemplo disso a sistemática de julgamento dos recursos repetitivos (ainda 
que, por vezes, mal utilizada). No entanto, o passo decisivo ainda não foi dado. Consiste ele na adoção (por meio de reforma constitucional) de um mecanismo de seleção de recursos com base na sua importância (análogo à repercussão geral da questão constitucional prevista para o recurso extraordinário). Sem isso, não há como racionalizar o trabalho da Corte e ela não pode cumprir a sua função prospectiva de orientação de maneira ótima.

A falta de adoção de um mecanismo de seleção de recursos traz efeitos colaterais altamente indesejáveis. Com efeito, nasce da sobrecarga de trabalho a "jurisprudência defensiva", tentativa excessivamente formalista e muito pouco transparente de tentar limitar a atuação da Corte. A fim de produzir bons resultados, tornar o juízo de admissibilidade intersubjetivamente controlável e garantir a participação das partes e da opinião pública no processo, é preciso superar tais práticas.

Outras críticas podem ser dirigidas ao Superior Tribunal de Justiça. Primeiramente, à prática (de origem autoritária) dos enunciados da Súmula, por variadas razões, deve preferir-se uma teoria do precedente, cuja cultura ainda está por formar-se. Em segundo lugar, como reflexo desta última constatação, o Superior Tribunal de Justiça é ainda marcado pela enorme falta de estabilidade e incoerência de sua própria jurisprudência. Sem consistência interna, não há como esperar que os precedentes da Corte sirvam adequadamente como endereços normativos para os outros juízes e para os indivíduos em geral.

À luz de tais considerações, deve ser repensado o recurso especial nos seus aspectos dogmáticos (distinção entre fato e direito, pré-questionamento, efeitos do seu julgamento e coordenação com o recurso extraordinário). A função prospectiva de orientação atrai e polariza esses elementos, de modo a articulá-los com o funcionamento racional do Superior Tribunal de Justiça em nome dos princípios formais e procedimentais do Estado de Direito. 


\title{
BIBLIOGRAFIA
}

\begin{abstract}
$-\mathbf{A}-$
AARNIO, Aulis. "Precedent in Finland", Interpreting precedents: a comparative study (coord. Neil MacCormick - Robert Summers), Aldershot: Dartmouth Pub., 1997.

ABBuD, André de albuquerque Cavalcanti. "A repercussão geral dos recursos extraordinários e o julgamento por amostragem...", As novas reformas do CPC e de outras normas processuais (org. Maurício Giannico - Vítor Monteiro), São Paulo: Saraiva, 2009.
\end{abstract}

Afonso DA SILVA, José. Do recurso extraordinário no direito processual brasileiro, São Paulo: RT, 1963.

. Curso de direito constitucional positivo, 27. ed., São Paulo: Malheiros, 2006.

Aguiar JR., Ruy Rosado. "Recurso especial: questão de ordem pública. Prequestionamento", Revista de Processo, 2006, vol. 132.

Albuquerque, Leonidas Cabral. Admissibilidade do recurso especial, Porto Alegre: Sergio Antonio Fabris, 1996.

ALEXY, Robert. Teoria de la argumentación jurídica: la teoría del discurso racional como teoría de la fundamentación jurídica (trad. Manuel Atienza), Madrid: Centro de Estudios Constitucionales, 1989.

. "Interpretação jurídica”, Direito, razão, discurso (trad. Luís Afonso Heck), Porto Alegre: Livraria do Advogado, 2010.

; DREIER, Ralf. "Precedent in the Federal Republic of Germany", Interpreting precedents: a comparative study (coord. Neil MacCormick - Robert Summers), Aldershot: Dartmouth Pub., 1997.

Allen, Ronald J.; PARDO, Michael S. "The myth of the law-fact distinction", Northwestern University Law Review, 2002-2003, vol. 97.

Alvaro de Oliveira, Carlos Alberto. Do formalismo no processo civil, 4. ed., São Paulo: Saraiva, 2010.

. "A semelhança no dissídio jurisprudencial para efeitos de recurso especial e embargos de divergência e a lógica", in Meios de impugnação ao julgado civil - estudos em homenagem a José Carlos Barbosa Moreira (coord. Adroaldo Furtado Fabrício), Rio de Janeiro: Forense, 2008.

. "A garantia do contraditório", in Do formalismo no processo civil, 2. ed., São Paulo: Saraiva, 2004

; Mitidiero, Daniel. Curso de processo civil, São Paulo: Atlas, 2010, vol. 1. 
. “'O formalismo-valorativo no confronto com o formalismo excessivo", Leitura complementares de processo civil (coord. Fredie Didier Jr.), 8. ed., Salvador: Juspodivm, 2010 .

AraúJo CINTRA, Antônio Carlos de. "Apontamentos sobre os fatos da causa e a apelação", Meios de impugnação ao julgado civil - estudos em homenagem a José Carlos Barbosa Moreira (coord. Adroaldo Furtado Fabrício), Rio de Janeiro: Forense, 2008.

Arruda Alvim, Angélica; ArRudA Alvim, Eduardo. "Aspectos inerentes ao prequestionamento no recurso especial", Direito civil e processo - estudos em homenagem ao Prof. Arruda Alvim (coord. Araken de Assis et al), São Paulo: RT, 2007.

Arruda Alvim Netto, José Manoel de. "O recurso especial na Constituição Federal de 1988 e suas origens", Aspectos polêmicos e atuais do recurso especial e do recurso extraordinário, São Paulo: RT, 1997.

. "O antigo recurso extraordinário e o recurso especial...", Recursos no Superior Tribunal de Justiça (coord. Sálvio Teixeira), São Paulo: Saraiva, 1991.

. "O Estado-de-Direito e a função jurisdicional", Revista do Instituto de Pesquisas e Estudos, 1966, vol. 1.

" “A EC n. 45 e o instituto da repercussão geral", A Reforma do Judiciário (obra coletiva), São Paulo: RT, 2005.

. "Recurso extraordinário", Direito processual civil - vol. 2, São Paulo: RT, 2002.

. "Recurso especial - fundamentação vinculada", Direito processual civil - vol. 2, São Paulo: RT, 2002.

Assis, Araken de. Manual dos recursos, 2. ed., São Paulo: RT, 2008.

. "Introdução aos sucedâneos recursais", Aspectos polêmicos e atuais dos recursos $\overline{\text { cíveis e }}$ de outras formas de impugnação às decisões judiciais (coord. Nelson Nery Jr. e Teresa Arruda Alvim Wambier), São Paulo: RT, 2002.

ASSUMPÇÃO, Helcio Alves. "Recurso extraordinário: requisitos constitucionais de admissibilidade", Meios de impugnação ao julgado civil - estudos em homenagem a José Carlos Barbosa Moreira (coord. Adroaldo Furtado Fabrício), Rio de Janeiro: Forense, 2008.

Ávila, Humberto. Teoria dos princípios: da definição à aplicação dos princípios jurídicos. 10. ed. São Paulo: Malheiros, 2009.

. "Subsunção e concreção na aplicação do direito", Faculdade de direito da PUCRS: o ensino jurídico no limiar do novo século, Porto Alegre: EDIPUCRS, 1997.

. "Neoconstitucionalismo': entre a 'Ciência do Direito' e o 'Direito da Ciência'”, Vinte anos da Constituição Federal de 1988 (coord. Cláudio Neto - Daniel Sarmento - 
Gustavo Binenbojm), Rio de Janeiro: Lumen Juris, 2009.

. Teoria da igualdade tributária, São Paulo: Malheiros, 2008.

. “O que é ‘devido processo legal'?”, Revista de processo, 2008, vol. 163.

Azzoni, Clara Moreira. Recurso especial e extraordinário: aspectos gerais e efeitos, São Paulo: Atlas, 2009.

\section{-B-}

BAHIA, Alexandre Gustavo Melo Franco. "Os recursos extraordinários e a co-originalidade dos interesses público e privado no interior do processo: reformas, crises e desafios à jurisdição desde uma compreensão procedimental do Estado Democrático de Direito", Constituição e processo: a contribuição do processo ao constitucionalismo democrático brasileiro (coord. Felipe Machado - Marcelo de Oliveira), Belo Horizonte: Del Rey, 2009.

. Recursos extraordinários no STF e no STJ: conflito entre interesses público e

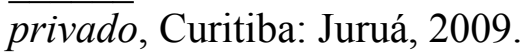

BAnKowski, Zenon; MacCormick, Neil; Marshall, GeOFfrey. "Precedent in the United Kingdom", Interpreting precedents: a comparative study (coord. Neil MacCormick Robert Summers), Aldershot: Dartmouth Pub., 1997.

Baptista da Silva, Ovídio Araújo. Processo e ideologia - o paradigma racionalista, 2. ed., Rio de Janeiro: Forense, 2006.

. "Questão de fato' em recurso extraordinário", Meios de impugnação ao julgado civil - estudos em homenagem a José Carlos Barbosa Moreira (coord. Adroaldo Furtado Fabrício), Rio de Janeiro: Forense, 2008.

. Curso de processo civil, 7. ed., Rio de Janeiro: Forense, 2005, vol. 1.

Barbosa Moreira, José Carlos. Comentários ao Código de Processo Civil. 14. ed., Rio de Janeiro: Forense, 2008, vol. 5.

."Questões de técnica de julgamento nos Tribunais", Temas de direito processual Nona série, São Paulo: Saraiva, 2007.

. "Súmula, jurisprudência, precedente: uma escalada e seus riscos", Temas de direito processual - Nona série, São Paulo: Saraiva, 2007.

. "Mandado de segurança. Recurso especial", Direito aplicado II - pareceres, 2. ed., Rio de Janeiro: Forense, 2005.

- "Considerações sobre a causa de pedir na ação rescisória", Temas de direito processual - Quarta série, São Paulo: Saraiva, 1989.

. "O neoprivatismo no processo civil", Temas de direito processual - Nona série, São Paulo: Saraiva, 2007. 
. O novo processo civil brasileiro, 27. ed., Rio de Janeiro: Forense, 2009.

. "A importação de modelos jurídicos", Temas de direito processual - Oitava série, São Paulo: Saraiva, 2004.

. "O processo civil brasileiro entre dois mundos", Temas de direito processual Oitava série, São Paulo: Saraiva, 2004.

. "As presunções e a prova", Temas de direito processual, São Paulo: Saraiva, 1977.

Saraiva, 1977.

"As bases do direito processual civil", Temas de direito processual, São Paulo:

- "Regras de experiência e conceitos jurídicos indeterminados", Temas de direito processual-Segunda série, São Paulo: Saraiva, 1980.

. "Juízo de admissibilidade e juízo de mérito no julgamento do recurso especial", Recursos no Superior Tribunal de Justiça (coord. Sálvio Teixeira), São Paulo: Saraiva, 1991.

. "Alegação de compensação rejeitada no despacho saneador. Documento junto sem audiência da outra parte. Pedido de exibição de documento em poder de pessoa jurídica sediada no estrangeiro. Questão de qualificação jurídica: possibilidade de reexame mediante recurso extraordinário", Temas de direito processual - Segunda série, São Paulo: Saraiva, 1980.

. "Julgamento e ônus da prova", Temas de direito processual - segunda série, São Paulo: Saraiva, 1980.

. "A Suprema Corte norte-americana: um modelo para o mundo?", Temas de direito processual - Oitava série, São Paulo: Saraiva, 2004.

BARroso, Luís Roberto. O controle de constitucionalidade no direito brasileiro, 2. ed., São Paulo: Saraiva, 2006.

BAUM, Lawrence. The Supreme Court, 10. ed., Washington: CQ Press, 2010.

BeDaque, José Roberto dos Santos. "Os elementos objetivos da demanda analisados à luz do contraditório", in Causa de pedir e pedido no processo civil (coord. J. R. Cruz e Tucci e J. R. dos Santos Bedaque), São Paulo: RT, 2002.

. "Discricionariedade judicial”, Revista Forense, 2001, vol. 354.

BELVEDERE, Andrea. "Linguaggio giuridico", Digesto delle discipline privatistiche Sezione civile (aggiornamento), 4. ed., Torino: UTET, 2000.

BENETI, Sidnei Agostinho. "Assunção de competência e fast track recursal", Estudos em homenagem à Prof. Ada Pellegrini Grinover (coord. Flávio Yarshell e Marício Zanoide de Moraes), São Paulo: DPJ, 2005. 
Bergholtz; Gunnar; PeCZenIK, Aleksander. "Precedent in Sweden", Interpreting precedents: a comparative study (coord. Neil MacCormick - Robert Summers), Aldershot: Dartmouth Pub., 1997.

BERMUdES, Sergio. Introdução ao processo civil, 5. ed., Rio de Janeiro, Forense, 2010.

. "O procedimento dos recursos extraordinário e especial no juízo recorrido", Recursos no Superior Tribunal de Justiça (coord. Sálvio Teixeira), São Paulo: Saraiva, 1991.

BEZERRA, Márcia Fernandes. "O cabimento do recurso extraordinário contra acórdão que defere medida liminar e a súmula 735 do STF", Os poderes do juiz e o controle das decisões judiciais - estudos em homenagem à Prof. Teresa A. A. Wambier (coord. José Miguel Garcia Medina et al.), São Paulo: RT, 2008.

BIDART, Adolgo Gelsi. "Presentación comparativa de dos casaciones en Uruguay", Revista de Processo, 1980, vol. 17.

BoBeK, Michal. "Quantity or quality? Reassessing the role of Supreme Jurisdictions in Central Europe", American Journal of Comparative Law, 2009, vol. 57.

BocCuZZI Neto, Vito Antônio. "Recursos excepcionais - o prequestionamento e a matéria de ordem pública", in Aspectos polemicos e atuais dos recursos cíveis e assuntos afins (coord. Nelson Nery Jr. e Teresa Arruda Alvim Wambier), São Paulo: RT, 2007, vol. 11.

Bonavides, Paulo. Curso de direito constitucional, 13. ed., São Paulo: Malheiros, 2003.

Botelho De Mesquita, José Ignácio. “A nova lei de recursos (lei 8.038/90)”, Teses, estudos e pareceres de processo civil, São Paulo: RT, 2005, vol. 2.

. "A súmula da jurisprudência predominante no Supremo Tribunal Federal", Teses, estudos e pareceres de processo civil, São Paulo: RT, 2005, vol. 2.

. "Recurso extraordinário e recurso especial: contrastes e confrontos", in Meios de impugnação ao julgado civil - estudos em homenagem a José Carlos Barbosa Moreira (coord. Adroaldo Furtado Fabrício), Rio de Janeiro: Forense, 2008.

; et al. "Questões de ordem pública: revisíveis ad inifinitum", Direito civil e processo - estudos em homenagem ao Prof. Arruda Alvim (coord. Araken de Assis et al), São Paulo: RT, 2007.

BRUSCHI, Gilberto G. "Recurso especial fundado em divergência jurisprudencial", in Recurso especial e recurso extraordinário: repercussão geral e atualidades (coord. Rogério Licastro Torres de Mello), São Paulo: Método, 2007.

Bulygin, Eugenio. “Los jueces crean derecho?”, Revista Isonomía, 2003, vol. 18.

BUZAID, Alfredo. "Nova conceituação do recurso extraordinário na Constituição do Brasil", Estudos de direito, São Paulo: Saraiva, 1972, vol. 1. 
1972, vol. 1.

“A crise do Supremo Tribunal Federal”, Estudos de direito, São Paulo: Saraiva, . "Máximas de experiência", Estudos e pareceres de direito processual civil (com notas de Ada Pellegrini Grinover - Flávio L. Yarshell), São Paulo: RT, 2002.

\section{$-\mathbf{C}-$}

CABral, Antonio do Passo. "Il principio del contraddittorio come diritto d'influenza e dovere di dibattito", Rivista di diritto processuale, 2005(2).

CAdiet, Loïc; Normand, Jacques; MeKki, Soraya Amrani. Théorie générale du procès, Paris: PUF, 2010.

- "El sistema de la casación francesa", Los recursos ante Tribunales Supremos en $\overline{\text { Europa }}$ (coord. Manuel Ortells Ramos), Madrid: Difusión Jurídica, 2008

Calamandrei, Piero. La casación civil (trad. Santiago Sentís Melendo). Buenos Aires: El Foro, 1945, tomos I, II e III.

; FuRno, Carlo. "Cassazione civile", in Novissimo Digesto Italiano, Torino: UTET, 1957, vol. 2, p. 1053-1104.

. "Sulla distinzione fra $<<$ error in iudicando $>>$ ed $<<$ error in procedendo $>>$ ", Opere giuridiche, Napoli: Morano, 1979, vol. VII.

. "La certeza del derecho y las responsabilidades de la doctrina", Los estudios de derecho procesal en Italia (trad. Sentís Melendo), Buenos Aires: EJEA, 1959.

CÂmara, Alexandre Freitas. Lições de direito processual civil, 10. ed., Rio de Janeiro: Lumen Juris, 2005, vol. 2.

CAMPeIS, Giuseppe; De PAul, Arrigo. Il giudizio di Cassazione: le novità della riforma, Kluwer, 2006.

CAnivet, Guy. "Activisme judiciaire et prudance interprétative", Arch. Phil. Droit, 2006, vol. 50, p. 9-31.

Canotilho, J. J. Gomes. Direito constitucional e teoria da Constituição, 7. ed., Coimbra: Almedina, 2003.

CAPpelletti, Mauro. Juizes legisladores? (trad. Carlos Alberto Alvaro de Oliveira), Porto Alegre: Sergio Antonio Fabris, 1993.

- "Parere iconoclastico sulla riforma del processo civile italiano", Giustizia e società, Milano: Ed. di Comunità, 1977.

CARmona, Carlos Alberto. "O sistema recursal brasileiro: breve análise crítica", Aspectos polêmicos e atuais dos recursos (coord. Eduardo Arruda Alvim, Nelson Nery Jr., Teresa 
Wambier), São Paulo: RT, 2000.

CARneIRO, Athos Gusmão. Recurso especial, agravos e agravo interno, 6. ed., Rio de Janeiro: Forense, 2009.

. "Os embargos de declaração e a Súmula 281 do Supremo Tribunal Federal",

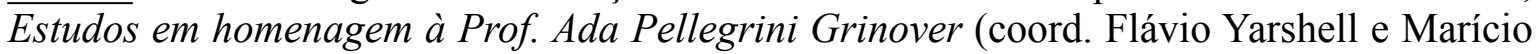
Zanoide de Moraes), São Paulo: DPJ, 2005.

CARPI, Federico. "Una novità francese per frenare i ricorsi in Cassazione dilatori", Studi in onore di Vittorio Denti, Padova: CEDAM, 1994, vol. 2.

CARRAZZA, Roque A. "Do recurso extraordinário e do recurso especial", Justitia, 1994, vol. 56(167).

"Segurança jurídica e eficácia temporal das alterações jurisprudenciais competência dos Tribunais Superiores para fixá-la - Questões conexas", Efeito "ex nunc" e as decisões do STJ (obra coletiva), Barueri: Manole, 2008.

Carvalho, Patrícia Torres Barreto Costa. "Efeito translativo nos recursos excepcionais", Revista de Processo, 2009, vol. 171.

Casalta Nabais, José. $O$ dever fundamental de pagar impostos, Coimbra: Almedina, 2009 (reimp.).

CastanheIRA Neves, A. O instituto dos <<assentos $>>$ e a função jurídica dos Supremos Tribunais, Coimbra: Coimbra, 1983.

. “A distinção entre a questão-de-facto e a questão-de-direito e a competência do Supremo Tribunal de Justiça como Tribunal de $<<$ revista $>>$ ", Digesta - escritos acerca do direito, do pensamento jurídico, da sua metodologia e outros, Coimbra: Coimbra, 1995.

- Questão-de-facto - questão-de-direito ou o problema metodológico da juridicidade, Coimbra: Almedina, 1967.

CATAlano, Elena Maria "Prova indiziaria, probabilistic evidence e modelli matematici di valutazione", Rivista di diritto processuale, 1996.

CERINo CANOva, Augusto. "La domanda giudiziale ed il suo contenuto", Commentario del Codice di Procedura Civile (coord. Enrico Allorio), Torino: UTET, 1980, libro II, t. I.

Chiarloni, Sergio. "Un singolare caso di eterogenesi dei fini, irrimediabile per via di legge ordinaria: la garanzia costituzionale del ricorso in cassazione contro le sentenze", $O s$ poderes do juiz e o controle das decisões judiciais - estudos em homenagem à Prof. Teresa A. A. Wambier (coord. José Miguel Garcia Medina et al.), São Paulo: RT, 2008.

. "La Cassazione e le norme”, in Rivista di diritto processuale, 1990, p. 982-1000.

Chiovenda, Giuseppe. Instituições de direito processual civil. São Paulo: Saraiva, 1965, 
vol. 3 .

CoHn, Ernst J. "Precedents in Continental Law", The Cambridge Law Journal, 1933-1935, vol. 5, p. 366-370.

COLEMAN JR., William T. "The Supreme Court of the United States: managing its caseload to achieve its constitutional purposes", Fordham Law Review, 1983.

Costa LeITE, Paulo Roberto Saraiva da. "Recurso especial: admissibilidade e procedimento", Recursos no Superior Tribunal de Justiça (coord. Sálvio Teixeira), São Paulo: Saraiva, 1991.

CRISAFUlli, Vezio. "Disposizione (e norma)", Enciclopedia del diritto, Milano: Giuffrè, 1964, vol. XIII.

Cross, Rupert; Harris, J. W. Precedent in English law, Oxfored: Clarendon, 1991.

CRUZ e Tucci, José Rogério. A 'causa petendi' no processo civil, 3. ed., São Paulo: RT, 2009.

. "Recentes orientações em tema de prequestionamento", Questões práticas do processo civil, São Paulo: Atlas, 1997.

. Precedente judicial como fonte de direito. São Paulo: RT, 2004.

- “A 'repercussão geral' como pressuposto de admissibilidade do recurso extraordinário", in Meios de impugnação ao julgado civil - estudos em homenagem a José Carlos Barbosa Moreira (coord. Adroaldo Furtado Fabrício), Rio de Janeiro: Forense, 2008.

CunHA, Leonardo José Carneiro da. "Meios processuais para concessão de efeito suspensivo a recurso que não o tem", Aspectos polêmicos e atuais dos recursos cíveis e outros meios de impugnação às decisões judiciais - vol. 8 (coord. Nelson Nery Jr. e Teresa Arruda Alvim Wambier), São Paulo: RT, 2005.

\section{-D-}

DAMAŠKA, Mirjan. The faces of Justice and State authority: a comparative approach to the legal process, New Haven: Yale University Press, 1986.

DANTAS, Bruno. Repercussão geral: perspectivas histórica, dogmática e de direito comparado, São Paulo: RT, 2008.

DAVID, René. French law - its structure, sources and methodology (trad. Michael Kindred), Baton Rouge: Lousiana State University, 1972.

DÁvila Millán, M. Encarnación. Litisconsorcio necesario - concepto y tratamiento procesal, 2. ed., Barcelona: Bosch: 1992. 
DENTI, Vittorio. "The Court of Cassation as a court on the merits", in Italian Yearbook of Civil Procedure (org. Elio Fazzalari), Milano: Giuffrè, 1993, vol. 2.

DERZI, Misabel. Modificações da jurisprudência no direito tributário, São Paulo: Noeses, 2009.

DIDIER JR., Fredie. “Alegação de prescrição ou decadência em recurso extraordinário: notas ao Código Civil de 2002", Aspectos polêmicos e atuais dos recursos cíveis e de outros meios de impugnação às decisões judiciais (coord. Nelson Nery Jr. e Teresa Arruda Alvim Wambier), São Paulo: RT, 2005, vol. 8.

. Cunha, Leonardo José Carneiro da. Curso de direito processual civil, 8. ed., Salvador: JusPodivm, 2010, vol. 3.

DinAmARCO, Cândido Rangel. "Superior Tribunal de Justiça e acesso à ordem jurídica justa", Recursos no Superior Tribunal de Justiça (coord. Sálvio Teixeira), São Paulo: Saraiva, 1991.

. A instrumentalidade do processo, 12. ed., São Paulo: Malheiros, 2005.

. Capitulos de sentença. São Paulo: Malheiros, 2004.

. "Fundamento constitucional da exigência de prequestionamento", Fundamentos do processo civil moderno, 6. ed., São Paulo: Malheiros, 2010.

- "A função das Cortes Supremas na América Latina", Fundamentos do processo civil moderno, 5. ed., São Paulo: Malheiros, 2002, t. II.

2004.

. "Os efeitos dos recursos", Nova era do processo civil, São Paulo: Malheiros,

. "O efeito devolutivo da apelação e de outros recursos", Nova era do processo civil, São Paulo: Malheiros, 2004.

- "Admissibilidade do recurso especial ou extraordinário e as chamadas questões mistas", Processo civil empresarial, São Paulo: Malheiros, 2010.

. "Processo civil comparado", Fundamentos do processo civil moderno, 6. ed., São Paulo: Malheiros, 2010, t. I.

. "O futuro do processo civil brasileiro", Fundamentos do processo civil moderno, 6. ed., São Paulo: Malheiros, 2010, t. I.

“Ação rescisória, incompetência e carência de ação", Nova era do processo civil, São Paulo: Malheiros, 2004.

DUXBURY, Neil. The nature and authority of precedent, Cambridge: Cambridge, 2008. 
EISENBERG, Melvin Aron. The nature of the common law, Cambridge: Harvard Univ., 1991.

ENG, Svein. "Precedent in Norway", Interpreting precedents: a comparative study (coord. Neil MacCormick - Robert Summers), Aldershot: Dartmouth Pub., 1997.

EnGISCH, Karl. Introdução ao pensamento jurídico (trad. J. Baptista Machado), 9. ed., Lisboa: Calouste Gulbenkian, 2004.

\section{$-\mathbf{F}-$}

FABRÍciO, Adroaldo Furtado. "Embargos de declaração: importância e necessidade de sua reabilitação", Meios de impugnação ao julgado civil - estudos em homenagem a José Carlos Barbosa Moreira (coord. Adroaldo Furtado Fabrício), Rio de Janeiro: Forense, 2008.

FALLON JR., Richard H. "'The Rule of Law' as a concept in constitutional discourse", Columbia Law Review, 1997, vol 97.

FAIRÉN GUILLÉN, Victor. "La recepción en España del recurso de casación francés (18121813)", in Temas del ordenamiento procesal, Madrid: Tecnos, 1969, tomo I.

. "La doctrina legal y el control de los hechos em la Casación civil y laboral española", in Temas del ordenamiento procesal, Madrid: Tecnos, 1969, tomo II.

FALCÃo, Djaci. “O Poder Judiciário e a nova Carta Constitucional”, Revista de Processo, 1989, vol. 53.

FAZZALARI, Elio. Il giudizio civile di Cassazione, Milano: Giuffrè, 1960.

."Ricorso per cassazione nel diritto processuale civile", Digesto delle disc. priv. (sez. civ.), Torino: UTET, 1998, vol. XVII, p. 580 e ss.

. "Rescissionary rulings from the Court of Cassation", in Italian Yearbook of Civil Procedure (org. Elio Fazzalari), Milano: Giuffrè, 1993, vol. 2.

. "La cassazione civile: stato atuale e possibili misure", Rivista di diritto processuale, 1999(3). vol. 35 .

"Procedimento (teoria generale)", Enciclopedia del diritto, Milano: Giuffrè, 1985,

."Processo e giurisdizione", Rivista di diritto processuale, 1993(1).

FENTON, Rachel Anne. "Separating law from facts: the difficulties faced by the Italian Corte di Cassazione in an appeal for illogicality of reasoning", International \& Comparativa Law Quarterly, 2000, vol. 49.

FERNANDES, Luís Eduardo Simardi. Embargos de declaração: efeitos infringentes, prequestionamento e outros aspectos polêmicos, São Paulo: RT, 2003. 
FERRAZ JR., Tércio Sampaio. "Irretroatividade e jurisprudência judicial", Efeito "ex nunc" e as decisões do STJ (obra coletiva), Barueri: Manole, 2008.

FLACH, Daisson. A verossimilhança no processo civil e sua aplicação prática, São Paulo: RT, 2009.

FLEURY, José Theophilo. Recurso especial e extraordinário: interposição simultânea, fundamentos suficientes e prejudicialidade, Curitiba: Juruá, 2008.

FIUZA, Ricardo Arnaldo Malheiros. "Superior Tribunal de Justiça: 'guardião do direito federal comum"”, Recursos no Superior Tribunal de Justiça (coord. Sálvio Teixeira), São Paulo: Saraiva, 1991.

FonseCA, João Francisco Naves da. Exame dos fatos nos recursos extraordinário e especial, Dissertação apresentada à Faculdade de Direito da Universidade de São Paulo (USP), 2010.

Frankfurter, Felix. "Marshall and the judicial function", Harvard Law Review, 19551956, vol. 69.

FuldA, Carl H. "Prospective overruling of court decisions in Germany and the United States", The American Journal of Comparative Law, 1964, vol. 13 (3).

FuX, Luiz. "A desistência recursal e os recursos repetitivos", BDJur, Brasília, DF, 10 fev. 2010. Disponível em: < http://bdjur.stj.jus.br/dspace/handle/2011/27102>

\section{-G-}

Gagarin, Michael. Early greek law, Berkeley-Los Angeles-London: University of California, 1989.

GALIČ, Aleš. "The role of the Supreme Court in creating precedents in Slovenian civil procedure", Los recursos ante Tribunales Supremos en Europa (coord. Manuel Ortells Ramos), Madrid: Difusión Jurídica, 2008

GALVÃO, Ilmar Nascimento. "Poder Judiciário. Reforma de 1988. O recurso especial no Superior Tribunal de Justiça", Recursos no Superior Tribunal de Justiça (coord. Sálvio Teixeira), São Paulo: Saraiva, 1991.

GARCÍA DE ENTERRÍA, Eduardo. Revolución francesa y administración contemporanea. Madrid: Civitas, 1994.

GeEroms, Sofie M. "Comparative law and legal translation: why the terms cassation, revision and appeal should not be translated", in American Journal of Comparative Law, 2002, vol. 50 .

Gimeno Sendra, Vicente. Derecho procesal civil (El proceso de declaración. Parte general), 3. ed., Madrid: Colex, 2010, vol. 1. 
GIOIA, Gino. "Lo sviluppo storico del ricorso per cassazione, tra necessità e abusi", Rivista di diritto processuale, 2007(4), p. 921-944.

GOODHART, Arthur L. "The ratio decidendi of a case", The Modern Law Review, 1959, vol. 22.

GOMES DA CRUZ, José Raimundo. "Admissibilidade dos recursos e efetividade do processo civil", Estudos sobre o processo e a Constituição de 1988, São Paulo: RT, 1993, p. 187202.

GotTwald, Peter. "Comparative civil procedure”, Ritsumeikan Law Review, 2005, vol. 22. . "Review appeal to the German Federal Supreme Court after the reform of 2001", Los recursos ante Tribunales Supremos en Europa (coord. Manuel Ortells Ramos), Madrid: Difusión Jurídica, 2008.

GRAU, Eros Roberto. Ensaio e discurso sobre a interpretação/aplicação do Direito, São Paulo: Malheiros, 2002.

GRECO, Leonardo. "Paradigmas da Justiça contemporânea e acesso à justiça", Revista de direito da Unigranrio, 2008, vol. 1.

GrINOVER, Ada Pellegrini. "Litisconsórcio necessário e efeito devolutivo do recurso especial”, Revista da Procuradoria Geral do Estado de São Paulo, 2003, vol. especial.

. "O controle do raciocínio judicial pelos Tribunais Superiores brasileiros", Revista da Ajuris, 1990, vol. 50.

GUASCH FERNÁNDEZ, Sergi. El hecho y el derecho en la casación civil, Barcelona: Bosch, 1998.

GUASTINI, Riccardo. "Se i giudice creino diritto", La ciencia del derecho procesal constitucional: estudios en homenaje a Héctor Fix-Zamudio en sus cincuenta años como investigador del derecho - tomo V: Juez e sentencia constitucional, México: UNAM, 2008.

. “Una teoría cognoscitiva de la interpretación”, Revista Isonomía, 2008, vol. 29.

Guinchard, Serge; Ferrand, Frederique; Chainais, Cécile. Procédure civile - Droit interne et Droit communautaire, 29. ed., 2008.

\section{$-\mathrm{H}-$}

HART, H. L. A. The concept of law, Oxford: Clarendon, 1979.

HAZARD JR,, Geoffrey C.; TARUFFO, Michele. American civil procedure - an introduction, New Heven: Yale University, 1993.

HENKE, Horst-Eberhard. La cuestión de hecho: el concepto indeterminado en el derecho civil y su casacionabilidad (trad. Tomas A. Banzhaf), Buenos Aires: EJEA, 1979. 
JAMES JR., Fleming; HAZARD JR, Geoffrey C.; LEUBSDORF, John. Civil procedure, 5. ed., New York: Foundation Press, 2001

JAUERNIG, Othmar. Direito processual civil $\left(25^{\mathrm{a}}\right.$ edição, totalmente refundida, da obra criada por FRIEDRICH LENT - trad. de F. Silveira Ramos), Coimbra: Almedina, 2002.

Jolowicz, J. A. "Appeal and review in comparative law: similarities, differences and purposes", in Melbourne University Law Review, 1986, vol. 15.

JoRGE, Flávio Cheim. Teoria geral dos recursos cíveis, 4. ed., São Paulo: RT, 2009.

\section{$-\mathbf{K}-$}

KNIJNIK, Danilo. O recurso especial e a revisão da questão de fato pelo Superior Tribunal de Justiça. Rio de Janeiro: Forense, 2005.

. A prova nos juizos cível, penal e tributário, Rio de Janeiro: Forense, 2007.

. "As (perigosíssimas) doutrinas do "ônus dinâmico da prova" e da "situação de senso comum" como instrumentos para assegurar o acesso à justiça e superar a probatio diabolica", Processo e Constituição - estudos em homenagem ao Prof. José Carlos Barbosa Moreira (coord. Luiz Fux - Nelson Nery Jr. - Teresa Wambier), São Paulo: RT, 2006, p. 942-951.

KozIKoski, Sandro Marcelo. Manual dos recursos cíveis - teoria geral e recursos em espécie, 4. e.d, Curitiba: Juruá, 2007.

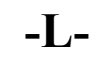

LACERDA, Galeno. "Críticas ao prequestionamento", in Revista dos Tribunais, 1998, vol. 758.

LARENZ, Karl. Metodologia da ciência do direito (trad. port. da $6^{\mathrm{a}}$ ed. alemã por José Lamego), 3. ed., Lisboa: Calouste Gulbenkian, 1997.

LASPRO, Oreste Nestor de Souza. Duplo grau de jursdição no direito processual civil. São Paulo: RT, 1995.

LEMMENS, Paul. "Guidance by Supreme courts to lower courts on the requirements of the ECHR", Reforming the European Convention on Human Rights: a work in progress, Strasbourg: Council of Europe, 2009.

LEVADA, Cláudio Antônio Soares. "A súmula 203 do STJ", Recurso especial e recurso extraordinário: repercussão geral e atualidades (coord. Rogério Licastro Torres de Mello), São Paulo: Método, 2007.

LiEBMAN, Enrico Tullio. "Institutos de direito comum no processo civil brasileiro", Revista Forense, 1953, vol. 147. 
. "A força criativa da jurisprudência e os limites impostos pelo texto da lei" (trad. Teresa Wambier), Revista de Processo, 1986, vol. 43.

. "Limiti ed effetti della 'correzione in diritto' della sentenza in sede di cassazione", Problemi del processo civile, Napoli: Morano, 1962. EJEA, 1980.

Manual de derecho procesal civil, trad. Santiago Sentis Melendo, Buenos Aires:

LiMA, Alcides de Mendonça. Introdução aos recursos cíveis, 2. ed., São Paulo: RT, 1976. 1989, vol. 56.

. "O recurso extraordinário na Constituição Federal de 1988", Revista de Processo,

- "Recurso extraordinário e recurso especial", Recursos no Superior Tribunal de $\overline{\text { Justiça }}$ (coord. Sálvio Teixeira), São Paulo: Saraiva, 1991.

LiNDBLOM, Henrik "The role of the Supreme Courts in Scandinavia", Scandinavian Studies in Law (Stockholm Institute for Scandianvian Law), 2000, vol. 39.

LoBo DA CosTA, Moacyr. A revogação da sentença: gênese e genealogia. São Paulo: Ícone, 1995.

LOPES, Bruno Vasconcelos Carrilho. Honorários advocatícios no processo civil, São Paulo: Saraiva, 2008.

LuCON, Paulo Henrique dos Santos. "Recurso especial: ordem pública e prequestionamento", Estudos em homenagem à Prof. Ada Pellegrini Grinover (coord. Flávio Yarshell e Marício Zanoide de Moraes), São Paulo: DPJ, 2005.

Eficácia das decisões e execução provisória. São Paulo: RT, 2000.

; Recena Costa, Guilherme. "O processo de perda do mandato em razão de desfiliação sem justa causa: a infidelidade partidária à luz da Resolução n. 22.610/TSE", n. 6.1, p. 92-95.

. "Devido processo legal substancial", Leituras complementares de processo (coord. Fredie Didier Jr.), $3^{\text {a }}$ ed., Salvador: JusPodium, 2007.

\section{-M-}

MACCORMICK; Neil; SUMMERS, Robert. "Further general reflections and conclusions", Interpreting precedents: a comparative study (coord. Neil MacCormick - Robert Summers), Aldershot: Dartmouth Pub., 1997.

Machado, Rafael Bicca. Recurso especial - doutrina, jurisprudência e prática. São Paulo: Quartier Latin, 2005.

Machado Guimarães, Luiz. "Efeito devolutivo da apelação", Estudos de direito processual, Rio de Janeiro: Jurídica Universitária, 1969 
MACIEL, Adhemar Ferreira. "Restrição à admissibilidade de recursos na Suprema Corte dos Estados Unidos e no Supremo Tribunal Federal do Brasil", in Meios de impugnação ao julgado civil - estudos em homenagem a José Carlos Barbosa Moreira (coord. Adroaldo Furtado Fabrício), Rio de Janeiro: Forense, 2008.

Mancuso, Rodolfo de Camargo. Recurso extraordinário e recurso especial, 10. ed., São Paulo: RT, 2007.

. "A realidade judiciária brasileira e os Tribunais da Federação - STF e STJ: inevitabilidade de elementos de contenção dos recursos a ele dirigidos", Processo $e$ Constituição - estudos em homenagem ao Prof. José Carlos Barbosa Moreira (coord. Luiz Fux - Nelson Nery Jr. - Teresa Wambier), São Paulo: RT, 2006.

MARINo, Francisco Paulo de Crescenzo. Contratos coligados no direito brasileiro, São Paulo: Saraiva, 2009.

MarinOnI, Luiz Guilherme. Precedentes obrigatórios, São Paulo: RT, 2010.

; AREnharT, Sérgio Cruz. Prova. São Paulo: RT, 2009.

; Arenhart, Sérgio Cruz. Processo de conhecimento (Curso de processo civil vol. 2), 8. ed., São Paulo: RT, 2010.

- "Aproximação crítica entre as jurisdições de civil law e de common law e a necessidade de respeito aos precedentes no Brasil", Revista de Processo, 2009, vol. 172.

; Mitidiero, Daniel. O projeto do CPC: críticas e propostas, São Paulo: RT, 2010.

; MitidiERo, Daniel. Repercussão geral no recurso extraordinário, 2. ed., São Paulo: RT, 2008.

MARQueS, José Frederico. Manual de direito processual civil, São Paulo: Saraiva, 1976, vol. 3.

Martins-Costa, Judith. A boa-fé no direito privado, São Paulo: RT, 1999.

MARTY, Gabriel. La distinction du fait e du droit, Paris: Sirey, 1929.

Matos PeiXoto, José Carlos de. Recurso extraordinário. Rio de Janeiro: Freitas Bastos, 1935.

Mattirolo. Tratatto di diritto giudiziario civile italiano, 5. ed., Torino: Fratelli Bocca, 1902, vol. 1.

MAtTEI, Ugo. "Precedente giudiziario e stare decisis", Digesto delle discipline privatistiche - Sezione civile, Torino: UTET, 1997, vol. XIV.

; RusKola, Teemu; GIDI, Antonio. Schlesinger's Comparative Law (cases-text- 
materials), 7. ed., New York: Foundation Press, 2009.

MazZarella, Ferdinando. Analisi del giudizio civile di cassazione, 3. ed., Padova: CEDAM, 2003.

Treccani, 2007.

"Cassazione: i) diritto processuale civile", Enciclopedia giuridica, Roma:

Medina, José Miguel Garcia. Prequestionamento e repercussão geral (e outras questões relativas aos recursos especial e extraordinário), 5. ed., São Paulo: RT, 2009.

. "Variações jurisprudenciais recentes sobre a dispensa do prequestionamento", Aspectos polêmicos e atuais dos recursos cíveis e outros meios de impugnação às decisões judiciais - vol. 8 (coord. Nelson Nery Jr. - Teresa Wambier), São Paulo: RT, 2005.

"Variações recentes sobre os recursos extraordinário e especial", Processo e Constituição - estudos em homenagem ao Prof. José Carlos Barbosa Moreira (coord. Luiz Fux - Nelson Nery Jr. - Teresa Wambier), São Paulo: RT, 2006.

Melo, Andréa Cherem Fabrício de. "O prequestionamento e as matérias de ordem pública nos recursos extraordinário e especial”, Revista de Processo, 2006, vol. 132.

MENDES, Gilmar Ferreira. "Limitação de efeitos no sistema difuso e a aplicação do art. 27 da Lei 9.868/99: algumas notas", Constituição e processo: a contribuição do processo ao constitucionalismo democrático brasileiro (coord. Felipe Machado - Marcelo de Oliveira), Belo Horizonte: Del Rey, 2009.

; et al. Curso de direito constitucional, 2. ed., São Paulo: Saraiva, 2008.

MENDES, Leonardo Castanho. $O$ recurso especial e o controle difuso de constitucionalidade, São Paulo: RT, 2006.

Mengoni, Luigi. "Diritto vivente", Digesto delle discipline privatistiche - sezione civile, Torino: UTET, 2002, vol. VI.

Merryman, John Henry; PÉrez-Perdomo, Rogelio. The civil law tradition: an introduction to the legal systems of Europe and Latin America, 3. ed., Stanford Univ. Press, 2007.

Monaghan, Henry P. "Constitutional fact review”, Columbia Law Review, 1985, vol. $85(2)$.

Moniz de Aragão, Egas Dirceu. "Pré-questionamento", in Revista Forense, 1994, vol. 328.

MonTEIRO, Vitor José de Mello. "Julgamento por amostragem do recurso especial (lei n. 11.672/08)", As novas reformas do CPC e de outras normas processuais (org. Maurício Giannico - Vítor Monteiro), São Paulo: Saraiva, 2009.

Montero ArocA, Juan; Flors MatíEs, José. El recurso de casación civil, Valencia: Tirant 
lo Blanch, 2009.

Montesano; Luigi; Arieta, Giovanni. Diritto processuale civile II - la cognizione contenziosa di rito ordinario, 2. ed., Torino: Giappichelli, 1997.

MORAWSKI, Lech; ZIRK-SADOWSKI, Marek; "Precedent in Poland", Interpreting precedents: a comparative study (coord. Neil MacCormick - Robert Summers), Aldershot: Dartmouth Pub., 1997.

Morello, Augusto Mario. La nueva etapa del recurso extraordinario - el 'certiorari', Buenos Aires: Abeledo-Perrot, 1990.

Processo, vol. 79.

. "Recursos extraordinarios: visión comparada brasileña y argentina", Revista de

Murray, Peter L.; StÜRner, Rolf. German civil justice, Durham: Carolina Academic Press, 2004.

\section{$-\mathbf{N}-$}

NERY JR., Nelson. "Ainda sobre o prequestionamento - os embargos de declaração prequestionadores", Aspectos polêmicos e atuais dos recursos cíveis e de outras formas de impugnação às decisões judiciais - vol. 4 (coord. Nelson Nery Jr. e Teresa Arruda Alvim Wambier), São Paulo: RT, 2001

. Teoria geral dos recursos, 6. ed., São Paulo: RT, 2004.

1988, vol. 51.

"Aspectos da teoria geral dos recursos no processo civil", Revista de Processo,

. "Questões de ordem pública e o julgamento do mérito dos recursos extraordinário e especial: anotações sobre a aplicação do direito à espécie (STF 456 e RISTJ 257)", Os poderes do juiz e o controle das decisões judiciais - estudos em homenagem à Prof. Teresa Wambier (coord. José Miguel Garcia Medina et al), São Paulo: RT, 2008.

- "Boa-fé objetiva e segurança jurídica - eficácia da decisão judicial que altera jurisprudência anterior do mesmo Tribunal Superior", Efeito "ex nunc" e as decisões do STJ (obra coletiva), Barueri: Manole, 2008.

NetTo, Nelson Rodrigues. Interposição conjunta de recurso extraordinário e de recurso especial, São Paulo: Dialética, 2005.

NiEva Fenoll, Jordi. "La relevancia social de la casación: la importancia del ius litigatoris", Revista de processo, 2007, vol. 147.

O'HARE, John; Browne, Kevin. Civil litigation, 14. ed., London: Sweet \& Maxwell, 2009. 
OliveIRA, Gleydson Kleber Lopes de. Recurso especial, São Paulo: RT, 2002.

- "Recursos de efeito devolutivo restrito e a possibilidade de decisão acerca de questão de ordem pública sem que se trate da matéria impugnada", Aspectos polêmicos e atuais dos recursos (coord. Eduardo Arruda Alvim, Nelson Nery Jr., Teresa Wambier), São Paulo: RT, 2000.

Oliveira, Pedro Miranda de. "Recurso excepcional adesivo cruzado", Aspectos polêmicos e atuais dos recursos cíveis e de outros meios de impugnação às decisões judiciais - vol. 8 (coord. Teresa Wambier e Nelson Nery Jr.), São Paulo: RT, 2005.

OLIVEIRA, Eduardo Ribeiro de. "Recurso especial - algumas questões de admissibilidade", Recursos no Superior Tribunal de Justiça (coord. Sálvio Teixeira), São Paulo: Saraiva, 1991.

" Norma constitucional e infraconstitucional de igual conteúdo - recurso especial e extraordinário", Os poderes do juiz e o controle das decisões judiciais - estudos em homenagem à Prof. Teresa A. A. Wambier (coord. José Miguel Garcia Medina et al.), São Paulo: RT, 2008.

\section{-P-}

PAlmeIro DA FonTOURA, Lucia Helena Ferreira. Recurso especial: questão de fato/questão de direito, Porto Alegre: Sergio Antonio Fabris, 1993.

PAIXÃO CÔRTES, Osmar Mendes. Recurso extraordinário - origem e desenvolvimento no direito brasileiro, 2. ed., Rio de Janeiro: Forense, 2006.

. "As nulidades acolhidas pelos Tribunais Superiores em recursos de natureza extraordinária - necessidade ou formalismo?", Os poderes do juiz e o controle das decisões judiciais - estudos em homenagem à Prof. Teresa A. A. Wambier (coord. José Miguel Garcia Medina et al.), São Paulo: RT, 2008.

- “O cabimento do recurso extraordinário pela alínea 'a' do art. 102, III, da Constituição Federal e a "causa de pedir aberta", in Aspectos polêmicos e atuais dos recursos cíveis e assuntos afins (coord. Nelson Nery Jr. e Teresa Arruda Alvim Wambier), São Paulo: RT, 2007, vol. 11.

PeCZENIK, Aleksander. On law and reason, Dordrecht: Kluwer, 1989.

. "The binding force of precedent", Interpreting precedents: a comparative study (coord. Neil MacCormick - Robert Summers), Aldershot: Dartmouth Pub., 1997.

PEKELIS, Alexander. "The case for a jurisprudence of welfare: possibilities and limitations", Lawyers Guild Review, 1946, vol. 6.

Perelman, Chaïm. Ética e direito (trad. M. Galvão), São Paulo: Martins Fontes, 2005.

De Plácido e Silva. Comentários ao Código de Processo Civil, 4. ed., Rio de Janeiro: Forense, 1956, vol. 5. 
PICARDI, Nicola. "Notas sobre o precedente judicial", Jurisdição e processo (trad. Carlos Alberto Alvaro de Oliveira), Rio de Janeiro: Forense, 2008 [original: "Appunti sul precedente giudiziario", Rivista Trimestrale di Diritto e Procedura Civile, 1985, p. 201208].

. "A vocação do nosso tempo para a jurisdição", Jurisdição e processo [trad. Carlos Alberto Alvaro de Oliveira), Rio de Janeiro: Forense, 2008 (original: "La vocazione del nostro tempo per la giurisdizione", Rivista Trimestrale di Diritto e Procedura Civile, 2004].

. "Introdução ao Code Louis (ordonnance civile, 1667)", Jurisdição e processo (trad. Carlos Alberto Alvaro de Oliveira), Rio de Janeiro: Forense, 2008 [original: "Introduzione al Code Louis (Ordonnance Civile, 1667)", in Testi e documenti per la storia del processo (coord. Picardi - Giuliani), Code Louis, Milano: Giuffrè, 1996].

PINTO, Nelson Luiz. Recurso especial para o Superior Tribunal de Justiça: teoria geral e admissibilidade, São Paulo: Malheiros, 1992.

Pizzorusso, Alessandro. "Le sentenze dei giudici costituzionali tra diritto giurisprudenziale e diritto legislativo", La ciencia del derecho procesal constitucional: estudios en homenaje a Héctor Fix-Zamudio en sus cincuenta años como investigador del derecho - tomo V: Juez e sentencia constitucional, México: UNAM, 2008.

. “Corte di Cassazione”, Enciclipedia giuridica Treccani, Roma, 2007.

Poli, Roberto. "Il giudizio di cassazione dopo la riforma", Rivista di diritto processuale, 2007(1).

Pontes de Miranda, F. C. Comentários ao Código de Processo Civil. Rio de Janeiro: Forense, 1975, tomos IV e VIII.

. Tratado da ação rescisória das sentenças e de outras decisões, 5. ed. Rio de Janeiro: Forense, 1976.

. Tratado de direito privado, 4. ed., São Paulo: RT, 1983, tomo I.

Posner, Richard. Problemas de filosofia do direito (trad. J. Camargo), São Paulo: Martins Fontes, 2007.

Proto PisAni, Andrea. Lezioni di diritto processuale civile, 2. ed., Napoli: Jovene, 1996.

. "Crisi della Cassazione: la (non più rinviabile) necessitá di una scelta", Revista de Processo, 2008, vol. 157.

PRÜTTING, Hans. “A admissibilidade do recurso aos Tribunais alemães superiores”, Revista de Processo, 1978, vol. 9. 
. "Estudio introductorio al Código Procesal Civil alemán", Código Procesal Civil $\overline{\text { alemán }}$ (coord. e trad. Pérez Ragone - Ortiz Pradillo), Berlin: Konrad-Adenauer-Stiftung, 2006.

\section{$-\mathbf{R}-$}

RADBRUCH, Gustav. "El fin del derecho", Los fines de derecho: bien comun, justicia, seguridad (trad. Daniel Breña), México: UNAM, 1975.

RAWLS, John. A theory of justice, rev. ed., Cambridge: Harvard Univ. Press, 1999.

REALE, Miguel. Lições preliminares de direito, 22. ed., São Paulo: Saraiva, 2005.

RECENA Costa, Guilherme. "Entre função e estrutura: passado, presente e futuro da tutela de urgência no Brasil", Tutelas de urgência e cautelares - estudos em homenagem a Ovídio A. Baptista da Silva (coord. Donaldo Armelin), São Paulo: RT, 2010.

RIBEIRO, Eduardo. "Prequestionamento", Aspectos polêmicos e atuais dos recursos cíveis de acordo com a Lei 9.756/98 (coord. Teresa Wambier e Nelson Nery Jr.), São Paulo: RT, 1999.

RICCI, Edoardo. "La cassazione civile italiana e il divieto di pronuncia sul caso concreto", Rivista di diritto processuale, 1968(4), p. 708-729.

Rosenberg, Leo. La carga de la prueba (trad. Ernesto Krotoshin), Buenos Aires: EJEA, 1996.

Rubin, Fernando. A Preclusão na dinâmica do processo civil. Porto Alegre: Livraria do Advogado, 2010.

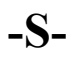

SANChES, Sidney. "O Supremo Tribunal Federal na nova Constituição", Revista de Processo, 1989, vol. 55.

SANTOS, Cláudio. "Recurso especial - visão geral", Inf. juríd. Bibl. Min. Oscar Saraiva, 1989, vol. 1(2).

SAntos, Moacyr Amaral. Prova judiciária no cível e comercial, São Paulo: Max Limonad, 1952, vol. 5.

SASSANI, Bruno. "Tra 'consapevolezza culturale' e 'buona volotà organizzativa': considerazione sparse sulla deprecata funzione nomofilattica della Corte di Cassazione", Stato di diritto e garanzie processuali - atti delle II Giornate Internazionale di Diritto processuale civile (coord. Franco Cipriani), Napoli: Edizioni Scientifiche Italiane, 2008.

SARAIVA, José. Recurso especial e o STJ, São Paulo: Saraiva, 2002.

SCARPINElla Bueno, Cassio. "Duas 'novidades' em torno dos recurso extraordinários em sentido lato", Revista de Processo, 1996, vol. 84. 
. "De volta ao preqüestionamento - duas reflexões sobre o RE 298.695-SP", Aspectos polêmicos e atuais dos recursos cíveis e de outros meios de impugnação às decisões judiciais (coord. Nelson Nery Jr. e Teresa Arruda Alvim Wambier), São Paulo: RT, 2005, vol. 8.

. "Prequestionamento - reflexões sobre a súmula 211 do STJ", Aspectos polêmicos e atuais dos recursos (coord. Eduardo Arruda Alvim, Nelson Nery Jr., Teresa Wambier), São Paulo: RT, 2000.

. Curso sistematizado de direito processual civil, São Paulo: RT, 2008, vol. 5.

SCHAUER, Frederick. Thinking like a lawyer. Cambrigde: Harvard University, 2009. . "Precedent", Stanford Law Review, 1986-1987, vol. 39.

73. . "Do cases make bad law?", The Univerisity of Chicago Law Review, 2006, vol. . "Giving reasons", Stanford Law Review, 1994-1995, vol. 47.

SHERwIN, Emily. "Judges as rulemakers", The University of Chicago Law Review, 2006, vol. 73.

SiCA, Heitor Vitor Mendonça. Preclusão processual civil, 2. ed., São Paulo: Atlas, 2008.

SILVESTRI, Elisabetta. "La selezione dei ricorsi in Cassazione: um problema per la riforma del processo civile", Rivista di diritto processuale, 1984(3).

StEIN, Friedrich. El conocimiento privado del juez (trad. Andrés de la Oliva Santos), 2. ed., Bogotá: Temis, 1999.

SuMMERS, Robert S. "The principles of the rule of law", Notre Dame Law Review, 19981999, vol. 74. 2000. . "A formal theory of the rule of law", Essays in legal theory, Dordrecht: Kluwer, . "The argument from ordinary meaning in statutory interpretation", Essays in legal theory, Dordrecht: Kluwer, 2000.

\section{$-\mathbf{T}-$}

TANIGUCHI, Yasuhei. "The 1996 Code of Civil Procedure of Japan - a procedure for the coming century?", American Journal of Comparative Law, 1997, vol. 45

TARUFFO, Michele. El vértice ambíguo - ensayos sobre la Casación civil (trad. Juan J. M. Palacios e Juan F. M. Gálvez), Lima: Palestra, 2005.

. "Precedente e giurisprudenza", La ciencia del derecho procesal constitucional: estudios en homenaje a Héctor Fix-Zamudio en sus cincuenta años como investigador del derecho - tomo V: Juez e sentencia constitucional, México: UNAM, 2008. 
"Institutional factors influencing precedents", Interpreting precedents: a comparative study (coord. Neil MacCormick - Robert Summers), Aldershot: Dartmouth Pub., 1997.

- "Las funciones de las Cortes Supremas", Reforma procesal civil (coord. Eduardo Oteiza), Buenos Aires: Rubinzal-Culzoni, 2010, n 1, p. 649-650.

. La prueba de los hechos (trad. Jordi Ferrer Beltrán), Madrid: Trotta, 2002.

. "Una reforma de la casación civil?", Proceso civil: hacia uma nueva justicia civil (coord. Andrés de la Oliva Santos - Diego Vélez), Santiago: Ed. Jurídica de Chile, 2007.

TARZIA, Giuseppe. "Le impugnazoni civili tra disfunzioni e riforme", Problemi del processo civile di cognizione, Padova: Cedam, 1989.

Theodoro JR., Humberto. "O novo artigo 543-C do Código de Processo Civil (Lei $\mathrm{n}^{\mathrm{o}}$. 11.672, de 08.05.2006)", Revista IOB de Direito Civil e Processual Civil, 2008, vol. 53, p. 64-5.

; Dierle NunES - AlEXANDRE BAHIA, "Breves considerações sobre a politização do Judiciário e sobre o panorama de aplicação no direito brasileiro - análise da convergência entre o civil law e o common law e dos problemas da padronização decisória”, Revista de Processo, 2010, vol. 189.

TorRes DE Mello, Rogério Licastro. "Recurso especial e matéria de ordem pública: desnecessidade de prequestionamento", in Recurso especial e recurso extraordinário: repercussão geral e atualidades (coord. Rogério Licastro Torres de Mello), São Paulo: Método, 2007.

. Atuação de ofício em grau recursal, São Paulo: Saraiva, 2010.

Trocker, Nicoló. Processo civile e costituzione: problemi di diritto tedesco e italiano, Milan: Giuffrè, 1974.

Troller, Alois. Dos fundamentos do formalismo processual civil (trad. Carlos Alberto Alvaro de Oliveira), Porto Alegre: Sergio Antonio Fabris, 2009.

TROPER; Michel; GRZEGORCZYK, Cristophe. "Precedent in France", Interpreting precedents: a comparative study (coord. Neil MacCormick - Robert Summers), Aldershot: Dartmouth Pub., 1997.

Tunc, André. "La Cour suprême idéale", Revue internationale de droit comparé - La cour judiciaire suprême. Enquête comparative, 1978, vol. 30(1), p. 433-471.

van CAenegem, R. C. Juízes, legisladores e professors (trad. Luís Carlos Borges), Rio de Janeiro: Elsevier, 2010. 
VÁSQUEZ SoTElo, José Luiz. "El modelo español de casación (configuración histórica y evolución legislativa)", Scritti in onore di Elio Fazzalari, Milano: Giuffrè, 1993, vol. 3.

Velloso, Carlos MÁRio. "O Superior Tribunal de Justiça - competências originária e recursal”, Recursos no Superior Tribunal de Justiça (coord. Sálvio Teixeira), São Paulo: Saraiva, 1991.

VERDE, Giovanni. "In difesa dello jus litigatoris (sulla Cassazione come è e come si vorrebbe che fosse)", in Rivista di diritto processuale, 2008, vol. 1, p. 1-20.

. Profili del processo civile, Napoli: Jovene, 1996, vol. 2.

Vigoriti, Vincenzo. "Sul metodo comparativo", Estudos em homenagem à Prof. Ada Pellegrini Grinover (coord. Flávio Yarshell e Marício Zanoide de Moraes), São Paulo: DPJ, 2005.

VIRGILIO, Alberto. "La Corte di Cassazione (funzione di legittimità e stile delle sentenze)", Scritti in onore di Elio Fazzalari, Milano: Giuffrè, 1993, vol. 3.

VOn Mehren, Arthur Taylor; Gordley, James Russell. The civil law system: an introduction to the comparative study of law, 2. ed., Boston: Little, Brown and Co., 1977.

\section{$-\mathbf{W}-$}

WALDRON, Jeremy. "The concept and the Rule of Law", Georgia Law Review, 2008, vol. 43(1).

WAMBIER, Teresa Arruda Alvim. "Estabilidade e adaptabilidade como objetivos do direito: civil law e common law", Revista de Processo, 2009, vol. 172.

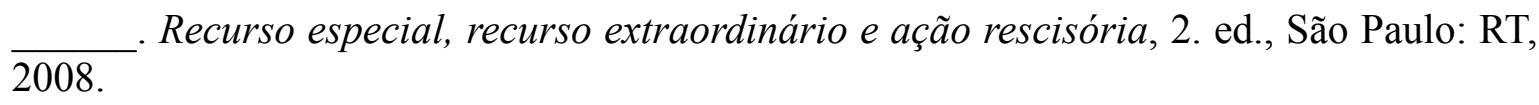

Weinstein, Jack; MANSFIEld, John; Abrams, Norman; Berger, Margaret. Evidence, 9.ed. Westbury: Foundation, 1997, p. 1089

WHITFORD, William C. "The role of the jury (and the fact/law distinction) in the interpretation of written contracts", Winsconsin Law Review, 2001.

WRÓBLEWSKY, Jerzy. "Problems of judicial reasoning in civil law and common law systems - some reflections on Julis Stone's approach", Bulletin of the Australian Society of Legal Philosophy, 1986, vol. 10.

\section{$-\mathbf{Y}-$}

YARSHELl, Flávio Luiz. Ação rescisória: juizos rescindente e rescisório, São Paulo: Malheiros, 2005. 